\title{
IMPACTO DA PROSPECÇÃO GEOLÓGICA NA OTIMIZAÇÃO DO PROCESSO DE PRODUÇÃO DE CIMENTO PORTLAND NA FÁBRICA DE CIMENTO VOTORAN, VOTORANTIM, SP
}

\author{
HÉLIO SHIMADA
}

Orientador: Prof. Dr. Jorge Kazuo Yamamoto

\author{
TESE DE DOUTORAMENTO
}

COMISSÃO JULGADORA

Nome

Presidente: Prof. Dr. Jorge Kazuo Yamamoto

Examinadores:

Dr. Cláudio Sbrighi Neto

Prof. Dr. João Carlos Biondi

Dr. Valdir Aparecido Zampieri

Prof. Dr. Yushiro Kihara

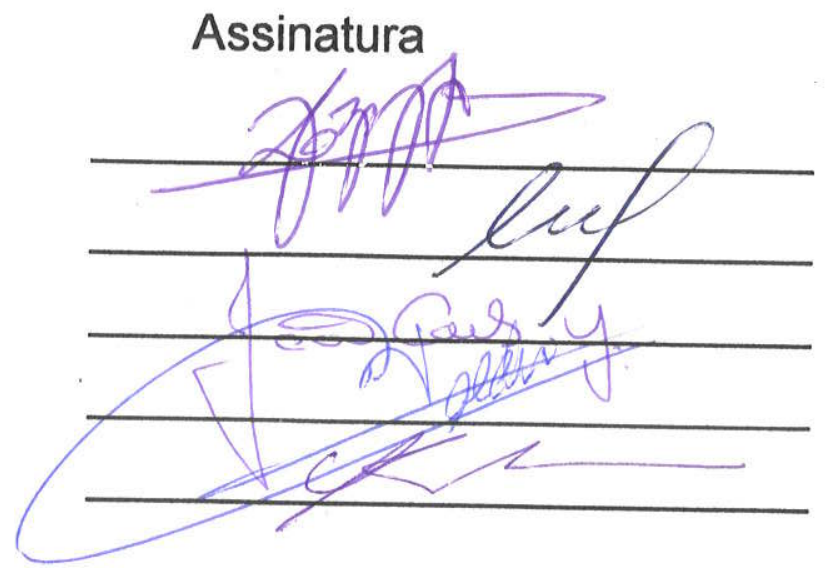

SÃO PAULO

1999 
UNIVERSIDADE DE SÃO PAULO

INSTITUTO DE GEOCIÊNCIAS

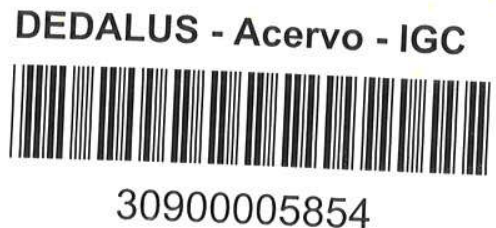

\section{IMPACTO DA PROSPECÇÃO GEOLÓGICA NA OTIMIZAÇÃO DA PRODUÇÃO DE CIMENTO PORTLAND NA FÁBRICA DE CIMENTO VOTORAN, VOTORANTIM, SP}

Hélio Shimada

Orientador: Prof. Dr. Jorge Kazuo Yamamoto

TESE DE DOUTORAMENTO

Programa de Pós-Graduação em Recursos Minerais e Hidrogeologia 
Dedico este trabalho à memória do meu pai, Hideaki Shimada que, apesar da sua pouca escolaridade, era um estudioso que valorizava muito a cultura e soube, muito sabiamente, transmitir-me o gosto pela Ciência e, à minha mãe, Yasuko Shimada, que foi capaz de imensos sacrifícios para a formação dos filhos. 


\section{AGRADECIMENTOS}

O desenvolvimento do estudo aqui apresentado não teria sido possível sem a valiosa ajuda de pessoas $e$ instituições, às quais expresso a minha mais sincera gratidão.

Agradeço inicialmente ao Instituto Geológico, da Secretaria do Meio Ambiente do Estado de São Paulo, pela oportunidade de realizar o aperfeiçoamento, ao Instituto de Geociências da Universidade de São Paulo, pela acolhida no curso de pós-graduação e à S. A. Indústrias Votorantim pela autorização da pesquisa e pelo apoio técnico e material durante o desenvolvimento dos trabalhos.

Agradeço especialmente aos docentes do IG-USP, Prof. Dr. Jorge Kazuo Yamamoto, pela orientação durante o desenvolvimento da maior parte do estudo; ao Prof. Dr. Jorge Silva Bettencourt pela orientação inicial e pelas relevantes contribuições, e ao Prof. Dr. Yushiro Kihara, também da ABCP - Associação Brasileira de Cimento Portland, pelas valiosa colaboração na avaliação dos resultados do estudo.

Agradecimentos também especiais aos seguintes funcionários da Fábrica de Cimento Votoran, que me dedicaram amizade e não mediram esforços na ajuda ao desenvolvimento dos estudos: Sr. Antonio Alacir Noronha Moreira, Gerente da Divisão de Mineração, e Geólogos Roberto Tadanobu Nakamura, Marcos de Araújo Pinto e Alexandre Vergani, pela enorme colaboração durante todas as etapas do estudo; Engenheiro de Minas Cláudio Silveira Faria, pela ajuda nas simulações computacionais; Engenheiro Químico Fábio Augusto Silva, pelos esclarecimentos e frutiferas discussões a respeito do processo de fabricação do cimento; Airton Donizetti Simão, pela valiosa ajuda nos trabalhos de campo; Sakae Kawamoto, Antônio Carlos Gomes e Roberto Uillians Lopes dos Santos, pelos levantamentos topográficos; Ayrton Alves dos Santos, pelo apoio logístico na mina Pastinho, e Técnica Química Janete Rosa, pela grande ajuda nas questões laboratoriais.

Aos seguintes docentes do IG-USP pelas contribuições durante os estudos: Profa. Dra. Lília Mascarenhas Sant' Agostino, na caracterização dos materiais estudados; Profa: Dra. Sônia Maria Barros de Oliveira, nas discussões e esclarecimentos a respeito do processo de lateritização; Prof. Dr. Ginaldo Ademar da Cruz Campanha, no esclarecimento de aspectos estruturais relacionados às minas 
estudadas, e Prof. Dr. Paulo César Fonseca Giannini, na identificação de minerais pesados.

Aos seguintes pesquisadores do Laboratório de Caracterização Tecnológica do Departamento de Engenharia de Minas da Escola Politécnica - USP pela colaboração durante os estudos: Prof. Dr. Henrique Kahn, na caracterização dos materiais estudados; Química Dra. Giuliana Ratti nas questões analíticas, Geóloga Gabriela Fronzaglia na execução e na interpretação de difratogramas de raios-X, Geóloga Sandra Garcia Gabas na microscopia eletrônica de varredura, e graduanda de Geologia Izabel A. A. Santos, nas análises granulométricas instrumentais.

Aos seguintes funcionários do IG-USP, pela valiosa colaboração em diversas etapas dos estudos: Geóloga M.Sc. Rita Parisi Conde e Márcia Cristina da Ponte, da Seção de Informática; Físico M.Sc. Flávio Machado de Souza Carvalho, do Laboratório de Difração de Raios-X; Engenheiro Metalurgista Isaac Jamil Sayeg, do Laboratório de Microscopia Eletrônica de Varredura; Elaine Aparecida da Silva Sinfrônio, do Laboratório de Sedimentologia, e Silvio Luiz Pereira, do Laboratório de Preparação de Amostras.

À Géologa M.Sc. Maria Heloísa Barros de Oliveira Frascá, da Divisão de Geologia do Instituto de Pesquisas Tecnológicas do Estado de São Paulo S.A. - IPT, pela coloração e descrição das lâminas delgadas de rochas carbonáticas.

Aos docentes do Instituto de Geociências e Ciências Exatas da UNESP Campus de Rio Claro: Prof. Dr. Marcos Aurélio Farias de Oliveira, Prof. Dr. Peter Christian Hackspacher, Prof. Dr. Antônio Saad, Prof. Dr. José Alexandre de Jesus Perinotto e Prof. Dr. Antônio Misson Godoy, pelos esclarecimentos e discussões a respeito da geologia da área de estudo.

Aos colegas e amigos do Instituto Geológico, Geográfa Dra. Luci Hidalgo Nunes, pela revisão do abstract; Geólogo M.Sc. José Maria de Azevedo Sobrinho, pela ajuda na descrição de lâminas petrográficas e de minerais pesados; Geóloga M.Sc. Sônia Aparecida Abissi Nogueira, Geólogo Dr. Tarcísio José Montanheiro, Geólogos M.Sc. Antonio Luiz Teixeira, Francisco de Assis Negri e Silvio Takashi Hiruma pelas contribuições e pelo apoio constante durante os estudos; Geógrafo Dr. José Antonio Ferrari e Geóloga M.Sc. Márcia Maria Nogueira Pressinotti pela ajuda na revisão 
bibliográfica, e Geólogo M.Sc. Paulo César Fernandes da Silva, pelas contribuições e discussões sobre a geologia da área de estudo.

Aos então graduandos de Geologia Carlos Alberto da Silva, Carlos César de Araújo e Tati de Almeida, pela grande ajuda nos trabalhos de campo.

À Karin Eiko Camilo e à Raquel Negrini Siqueira, estagiárias do Laboratório de Microscopia Eletrônica de Varredura do IG-USP, pela ajuda na preparação das amostras e na operação do equipamento.

Ás Sras. Ana Paula Cabanal Pentagna e Magali Poli Fernandes Rizzo, da Secretaria de Pós-Graduação do IG-USP; Denise Cristina Manegon Cristovam e Luzia Sônia Candeo e ao Sr. João Victor Maschi, da Secretaria do Departamento de Geologia Sedimentar e Ambiental, pelo apoio administrativo durante os estudos.

À Maristela Prestes Severino, da Biblioteca do IG-USP, pela revisão das referências bibliográficas.

Ao CNPq - Conselho Nacional de Pesquisa Científica e à CAPES - Coordenação de Aperfeiçoamento do Pessoal de Nivel Superior, pela concessão das bolsas de pósgraduação.

Finalizando, peço desculpas pelas eventuais omissões e agradeço imensamente a todos que direta ou indiretamente contribuíram para a realização do estudo. 


$\begin{array}{lc} & \text { Página } \\ \text { DEDICATÓRIA } & \mathrm{i} \\ \text { AGRADECIMENTOS } & \mathrm{ii} \\ \text { SUMÁRIO } & \mathrm{v} \\ \text { LISTA DE FIGURAS } & \text { ix } \\ \text { LISTA DE TABELAS } & \mathrm{xii} \\ \text { LISTA DOS QUADROS } & \text { xiv } \\ \text { LISTA DOS ANEXOS } & \text { xiv } \\ \text { RESUMO } & \mathrm{xv} \\ \text { ABSTRACT } & \text { xvi }\end{array}$

CAPITULOO 1 - INTRODUÇÃO

1.1 LOCALIZAÇÃO E GEOMORFOLOGIA DA ÁREA DE ESTUDO 3

1.1.1 Localização 3

1.1.2 Geomorfologia 5

1.2 JUSTIFICATIVA DA ESCOLHA DO TEMA 6

$\begin{array}{lll}1.3 & \text { OBJETIVOS } & 7\end{array}$

1.4 SÍNTESE DA METODOLOGIA

CAPÍTULO 2 - O CIMENTO PORTLAND 9

2.1 BREVE HISTÓRICO 9

2.2 CIMENTO NO BRASIL E NO MUNDO 13

2.3 A FABRICAÇÃO DO CIMENTO PORTLAND 16

2.3.1 As matérias-primas $\quad 16$

2.3.2 A farinha de clinquer $\quad 19$

2.3.3 Componentes menores da farinha 21

2.3.4 O clínquer Portland $\quad 22$

2.4 TIPOS DE CIMENTO PORTLAND FABRICADOS NO BRASIL 26

CAPÍTULO 3 - GEOLOGIA REGIONAL 27

3.1 LITOLOGIAS 29

3.2 ESTRATIGRAFIA 31 
Página

3.3 METAMORFISMO

3.4 ESTRUTURAS

3.5 EVOLUÇÃO GEOLÓGICA

CAPITUULO 4 - A ALTERAÇÃO SUPERFICIAL DAS ROCHAS

4.1CONCEITOS GERAIS

4.1.1 As soluções aquosas superficiais e suas ações intempéricas

4.1.2 Transformação e neoformação de minerais no perfil de intemperismo

4.1.3 Comportamento do ferro e do alumínio no intemperismo

4.1.4 Dissolução da sílica

4.2 INTEMPERISMO EM CONDIÇÕES TROPICAIS LATERITIZAÇÃO

4.2.1 Definição e classificação das lateritas

4.2.2 Mecanismo de formação das lateritas

4.2.3 Perfis lateríticos

4.2.4 Influência do clima e do tempo de exposição na lateritização

4.2.5 Importância econômica das lateritas

4.2.6 Lateritas no Brasil

CAPÍTULO 5 - MATERIAIS E MÉTODOS

5.1 IDENTIFICAÇÃO DO PROBLEMA

5.2 REVISÃO BIBLIOGRÁFICA

5.3 DEFINIÇÃO DO MODELO GEOLÓGICO E DOS CRITÉRIOS DE PROSPECÇÃO

5.3.1 Definição do modelo geológico

5.3.2 Estabelecimento de critérios prospectivos e seleção de 58
prospectos

5.4 PLANEJAMENTO DOS TRABALHOS DE CAMPO
5.5 PREPARAÇÃO DE BASES CARTOGRÁFICAS E AEROFOTOGRÁFICAS

5.5.1 Bases cartográficas

5.5.2 Bases aerofotográficas 
Página

\subsection{AMOSTRAGEM}

5.6.1 Amostragem de solo e de rocha alterada (amostragem de superfície)

5.6.2 Amostragem de rocha nas minas

5.6.3 Amostragem de subsuperfície

5.6.4 Outros tipos de amostragem

5.7 PROCEDIMENTOS LABORATORIAIS

5.7.1 Análise química

5.7.2 Análise petrográfica e mineralógica

5.7.3 Microscopia eletrônica de varredura (MEV)

5.7.4 Análises físicas

5.7.5 Determinação aproximada do teor de sílica livre

5.8 PROCESSAMENTO COMPUTACIONAL DE DADOS

5.8.1 Cartografia digital

5.8.2 Cálculo preliminar de reserva mineral

5.8.3 Diagramas triangulares

5.8.4 Simulações computacionais da composição da farinha

5.9 TESTE DE PRODUÇÃO DO CLÍNQUER PORTLAND

CAPÍTULO 6 - AS MINAS PASTINHO, DO LAGO E BALTAR 75 SUBTERRÂNEA

6.1 MINA PASTINHO

6.1.1 Análise química de amostras de rocha 75

6.1.2 Análise petrográfica $\quad 85$

6.3 MINA BALTAR SUBTERRÂNEA

6.4 MINA DO LAGO 88

CAPITULO 7 - PROSPECÇÃO 90

7.1 PROSPECÇÃO ESTRATÉGICA: RECONHECIMENTO
GEOLÓGICO E AMOSTRAGEM PRELIMINAR

7.1.1 Prospecto 1 - Metabásica de Alumínio 91

7.1.2 Prospecto 2 - Setor do Maciço Granítico São Francisco 96

7.1.3 Prospecto 3 - Cobertura sedimentar avermelhada 101 
Página

7.1.4 Prospecto 4 - Sienito de Piedade

7.2 PROSPECÇÃO TÁTICA

7.2.1 Sondagem

7.2.2 Caracterização dos materiais amostrados

7.2.3 Identificação de alvos para detalhamento - cálculo preliminar de reservas

CAPÍTULO 8 - TESTES DE PRODUÇÃO DE CLÍNQUER

8.1 LAVRA EXPERIMENTAL

8.2 SIMULAÇÕES COMPUTACIONAIS DA COMPOSIÇÄO DA FARINHA

8.3 TESTES DE PRODUÇÃO DE CLÍNQUER

CAPÍTULO 9 - AVALIAÇÃO DOS RESULTADOS

9.1 AVALIAÇÃO TÉCNICA

9.1.1 Vida útil da reserva de laterita 139

9.1.2 Resultados dos testes de produção de clínquer 139

9.1.3 Moabilidade da farinha e do clínquer 149

9.1.4 Consumo de metadolomito de alto cálcio da mina Pastinho e da cálcio-silicatada xistosa da mina Baltar subterrânea

9.2 AVALIAÇÃO ECONÔMICA

CAPITULLO 10 - CONCLUSÕES 


\section{LISTA DAS FIGURAS}

Página

Figura 1.1 Localização da área de estudo 4

Figura 2.1 Forno de cimento de Aspdin, em Northfleet, Kent, Inglaterra, fotografado por M. A. Swayze em 1938

Figura 2.2 Evolução da produção e da importação de cimento no Brasil (1953-1997)

Figura 2.3 Evolução do consumo aparente per capita de cimento no Brasil (1953-1997)

Figura 2.4 Posições relativas dos 10 maiores produtores mundiais de cimento

Figura 2.5 Consumo per capita de cimento em alguns dos países desenvolvidos

Figura 2.6 Fluxograma ilustrado da fabricação do cimento Portland na FC V -1

Figura 2.7 llustrações fotográficas das etapas de fabricação do cimento

Figura 2.8 Seqüência de reações que ocorrem nas zonas de um forno de via seca (modificado de Wolter 1985)

Figura 2.9 Intervalos de temperatura de estabilidade dos diferentes compostos no forno

Figura 3.1 Mapa geológico regional

Figura 4.1 Variação da natureza dos minerais neoformados em função das condições climáticas e hídricas

Figura 4.2 Solubilidade da sílica amorfa, do quartzo, do ferro e do aluminio em função do $\mathrm{pH}$

Figura 4.3 Distribuição global do fenômeno da lateritização

Figura 4.4 Diagrama triangular para a classificação de lateritas

Figura 4.5 Perfil esquemático de alteração das rochas em clima tropical 
Figura 4.6 Estrutura micronodular da laterita, feita da assembléia de hematita, caulinita e quartzo, porosa e caracterizada pela drenagem rápida.

Figura 5.1 Distribuição espacial da pluviosidade média no período 1972-1991 na região de Sorocaba

Figura 5.2 Localização dos prospectos selecionados

Figura 6.1 Vista aérea de Santa Helena: FCV-1 e minas de metacalcário e filito

Figura 6.2 Mapa geológico de Santa Helena e do seu entorno

Figura 6.3 Mina Baltar subterrânea: A) Projeção da mina na superficie do terreno; B) Perfil longitudinal; C) Detalhe de salão de lavra

Figura 6.4 Mapa de pontos de observação/amostragem na mina Pastinho

Figura 6.5 Mapa geológico da mina Pastinho

Figura 6.6 Perfil geológico da mina Pastinho

Figura 6.7 llustrações fotográficas da mina Pastinho

Figura 6.8 llustrações fotográficas de detalhes geológicos da mina Pastinho

Figura 6.9 Fotomicrografias de rochas da mina Pastinho

Figura 6.10 Fotomicrografias de rochas das minas Pastinho e Baltar subterrânea

Figura 6.11 Difratograma de raios- $X$ do filito intemperizado da mina do Lago

Figura 7.1 Mapa geológico e de pontos de descrição/amostragem no prospecto 1 - Metabásica de Alumínio

Figura 7.2 Difratogramas de raios- $X$ das amostras MB-01 (alteração do filito); MB-14 (alteração do metassiltito) e MB-16 (alteração da metabásica)

Figura 7.3 Mapa geológico do prospecto 2 - Setor do Maciço Granítico São Francisco 
Figura 7.4 Mapa de pontos de observação/amostragem no prospecto 2 - Setor do Maciço Granítico São Francisco

Figura 7.5 Mapa de pontos de observação/amostragem superficial e de furos de trado no prospecto 3

Figura 7.6 Mapa geológico da área do prospecto 3 - Cobertura sedimentar avermelhada

Figura 7.7 Localização dos furos de trado e das amostras superficiais no extremo NW da Mina 1 - Salto de Pirapora

Figura 7.8 Difratogramas de raios-X das amostras 01 a 04 do furo TA-01, na cobertura sedimentar avermelhada

Figura 7.9 Ilustrações fotográficas dos prospectos 1 e 3

Figura 7.10 llustrações fotográficas do prospecto 2

Figura 7.11 Perfis geológicos e de teores de $\mathrm{SiO}_{2}, \mathrm{Al}_{2} \mathrm{O}_{3}$ e $\mathrm{Fe}_{2} \mathrm{O}_{3}$ do furo GSF $35 T$

Figura 7.12 Mapa de localização dos furos de trado e dos alvos para detalhamento no prospecto 2 - Setor do Maciço Granítico São Francisco

Figura 7.13 Perfis geológicos do prospecto 2 - Setor do Maciço Granítico São Francisco

Figura 7.14 Fotografia aérea do Alvo 1 do prospecto 2: Fazenda Ventania

Figura 7.15 llustrações fotográficas do prospecto 2 - Setor do Maciço Granítico São Francisco

Figura 7.16 A - Posições das amostras da área de estudo no diagrama de Schellmann (1981)

B - Evolução geoquímica da lateritização no prospecto 2

Figura 7.17 Difratogramas de raios-X das amostras do furo GSF 36 T

Figura 7.18 Fotomicrografias de concentrados de minerais pesados

Figura 7.19 Imagens de microscopia eletrônica de varredura das amostras GSF 29T5, 29T4, 31T4 e 42T 
Figura 7.20 Imagens de microscopia eletrônica de varredura (elétrons secundários), de grãos de quartzo do saprolito do granito e da laterita do prospecto 2

Figura 7.21 Triângulos considerados no cálculo de reserva do Alvo 1 Fazenda Ventania

Figura 8.1 Área da lavra experimental no Alvo 1

Figura 8.2 Difratogramas de raios-X das farinhas FN-01 (normal), FT-01 e FT-02A (com a laterita do Alvo 1 - Fazenda Ventania).

Figura 8.3 llustrações fotográficas do Alvo 1, da lavra experimental e dos testes de produção de clínquer

Figura 9.1 Fotomicrografias de clínquer produzido sem o uso da laterita da Fazenda Ventania

Figura 9.2 Fotomicrografias de clínquer produzido com o uso da laterita da Fazenda Ventania

Figura 9.3 Fotomicrografias de clínquer produzido com o uso da laterita da Fazenda Ventania

Figura 9.4 Imagens de microscopia eletrônica de varredura (MEV) de amostra do clínquer do Teste 1 com o uso da laterita

Figura 9.5 Digratogramas de raios- $X$ de amostras dos clínqueres CN1A (sem o uso da laterita), CT1A (teste $1 \mathrm{com}$ a laterita e CT-02 (teste $2 \mathrm{com}$ a laterita).

\section{LISTA DAS TABELAS}

Página

$\begin{array}{llll}\text { Tabela 2.1 } & \begin{array}{l}\text { Classificação das rochas carbonáticas segundo } \\ \text { Bigarella (1956) }\end{array}\end{array}$

Tabela 2.2 Principais parâmetros químicos utilizados na indústria 20 cimenteira

Tabela 2.3 Limites ideais para os componentes menores do clínquer

Tabela 2.4 Principais fases cristalinas do clínquer Portland 
Tabela 2.5 Proporções ponderais dos principais componentes do clínquer

Tabela 2.6 Tipos de cimento Portland fabricados no Brasil

Tabela 5.1 Relação das cartas topográficas 1:50.000 do IBGE utilizadas no estudo

Tabela 5.2 Relação das cartas topográficas 1:10.000 da SEPLAN

Tabela 5.3 Relação das fotografias aéreas utilizadas

Tabela 6.1 Teores médios, em \%, das amostras da mina Pastinho

Tabela 7.1 Teores médios das amostras MB-01 a 17 do prospecto 1 , analisadas por via úmida

Tabela 7.2 Teores médios das amostras MB-18 a 52 do prospecto 1 , analisadas por espectrofotometria de plasma ICP

Tabela 7.3 Resultados analíticos médios dos furos de trado GSF 1T a GSF $5 T$

Tabela 7.4 Resultados analíticos das amostras dos furos TA-01 e TA-02

Tabela 7.5 Resultados analíticos das amostras de saprolito do Granito São Francisco

Tabela 8.1 Dados médios dos furos GSF 40T, 50T, 51T e 52T

Tabela 8.2 Síntese da simulação da composição da farinha para o Teste 1 de produção de clínquer

Tabela 8.3 Síntese da simulação da composição da farinha para o Teste 2 de produção de clínquer

Tabela 9.1 Granulometria dos clínqueres dos testes 1 e 2

Tabela 9.2 Síntese dos resultados analíticos e de resist6encia do cimento do Teste 1

Tabela 9.3 Síntese dos resultados analíticos e de resist6encia do cimento do Teste 2

Tabela 9.4 Porcentagem dos componentes dos clínqueres calculados pela microscopia quantitativa

Tabela 9.5 Resistência à compressão dos cimentos CP \|-32 e CP II-40 a 3,7 e 28 dias, no período de janeiro setembro/99 


\section{LISTA DOS QUADROS}

Página

Quadro 3.1 Propostas de subsdivisão estratigráfica dos grupos São Roque e Serra do Itaberaba

Quadro 4.1 Mecanismos físico-químicos de ataque em função das características das soluções naturais

Quadro 4.2 Comportamento da sílica, do alumínio e das bases, e tipos de lateritas resultantes em função da intensidade da hidrólise

Quadro 4.3 Depósitos de bauxita laterítica do Estado de São Paulo (incluindo parte de Minas Gerais)

\section{LISTA DOS ANEXOS}

Página

Anexo 1 Resultados analíticos de rochas da mina Pastinho

Anexo 2 Resultados analíticos das amostras superficiais da prospecção estratégica

Anexo 3 Resultados analíticos dos furos de trado no extremo NE da Mina 1

Anexo 4 Resultados analíticos dos furos de trado no prospecto 2

Anexo 5 Resultados da determinação do teor de areia por elutriação

Anexo 6 A - Curva granulométrica da amostra GSF 35T2

B - Curva granulométrica de amostra composta do furo GSF 35T

203

C - Granulometria das partículas acima de $1 \mathrm{~mm}$ nas amostras do furo GSF $42 T$

$D$ - Curvas granulométricas instrumentais das amostras do furo GSF 42T (fração abaixo de $1 \mathrm{~mm}$ )

Anexo 7 Resumo do cálculo preliminar de reserva do Alvo 1 Fazenda Ventania

Anexo 8 Curvas granulométricas instrumentais das amostras de farinha FN-01 (sem o uso da laterita) e FT-01 (Teste 1) 


\section{RES U M O}

Materiais cimentícios são conhecidos pelo Homem desde a remota antigüidade. Os romanos utilizavam um cimento primitivo, considerado o precursor do cimento atual, constituído por uma mistura de cal e cinza vulcânica. O cimento Portland, patenteado em 1824 pelo inglês J. Aspdin, é obtido a partir do clínquer, produto da reação, sob alta temperatura, de uma mistura finamente moída de calcário e argila. As proporções dos componentes são definidas pelos parâmetros químicos Fator de Saturação de Cal, Módulo de Alumina e Módulo de Sílica, relacionados às quantidades de $\mathrm{CaO}, \mathrm{SiO}_{2}$, $\mathrm{Al}_{2} \mathrm{O}_{3}$ e $\mathrm{Fe}_{2} \mathrm{O}_{3}$. O clínquer, moido com aditivos como gesso, escória e pozolanas, resulta no cimento Portland.

A Unidade 1 da Fábrica de Cimento Votoran opera desde 1936 em Santa Helena, município de Votorantim. O metacalcário utilizado tem elevada pureza; porém, a argila local, um filito sericitico intemperizado, pobre em $\mathrm{Al}_{2} \mathrm{O}_{3}$ e $\mathrm{Fe}_{2} \mathrm{O}_{3}$, demanda a adição de bauxita e minério de ferro como corretivos, elevando o custo de produção.

No estudo desenvolvido, realizou-se a prospecção de argila alternativa que permitisse a minimização ou a eliminação dos corretivos, além de obedecer a outros condicionantes: o material deveria ser inconsolidado; a distância da fábrica deveria ser a menor possível; a área da jazida deveria estar livre de títulos minerários de terceiros; deveriam ser evitadas áreas com possibilidades de conflitos da mineração com outros usos do solo; o volume de material deveria garantir um mínimo de 25 anos de vida útil e, finalmente, a lavra não deveria interferir em áreas de proteção ambiental. Quatro prospectos foram selecionados, reconhecidos e/ou amostrados em superficie e por sondagem a trado. Um depósito laterítico promissor, Alvo 1 - Fazenda Ventania, foi mais detalhadamente sondado, para caracterização do material e uma avaliação preliminar do seu volume, tendo sido objeto de lavra experimental em seguida.

Paralelamente, estudou-se também a possibilidade da otimizar a lavra do metacalcário de alta pureza através da mistura com parte de suas encaixantes: metadolomitos, filitos carbonáticos e rochas cálcio-silicáticas. Simulações computacionais da composição da farinha mostraram que é possível a utilização dos materiais estudados. Testes de produção do clínquer em escala piloto segundo a melhor alternativa simulada foram realizados, e a avaliação dos resultados demonstrou o impacto técnico-econômico positivo do uso das matérias-primas consideradas. 
Varied cementitious materials are known since remote times. A primitive cement made of a mix of lime and volcanic ash, considered the forerunner of the present cement, was used by the Romans. The Portland cement, patented by the English $\mathrm{J}$. Aspdin in 1824, is made from the clinker, that results from the reaction between a finely ground mix of limestone and clay in high temperature. The proportion of the raw mix components are ruled by chemical parameters Lime Saturation Factor, Alumina Modulus and Silica Modulus, related to the quantities of $\mathrm{CaO}, \mathrm{SiO}_{2}, \mathrm{Al}_{2} \mathrm{O}_{3}$ and $\mathrm{Fe}_{2} \mathrm{O}_{3}$. The Portland cement is made by grinding of clinker with additives as gipsum, slag and pozolanic materials.

The Unity 1 of the Fábrica de Cimento Votoran operates since 1936 in Santa Helena, in the neighborhood of Votorantim city. A highly pure metalimestone is used in the raw mix, but the clay, a weathered phyllite, is deficient in $\mathrm{Al}_{2} \mathrm{O}_{3}$ and $\mathrm{Fe}_{2} \mathrm{O}_{3}$, demanding the addition of bauxite and iron ore as correctives, wich increases the production cost.

The goal of this study was an exploration to find out an alternative clay aiming the minimization or the entire substitution of the correctives, besides other conditioning factors: the material should be unconsolidated; the distance from the factory should be as short as possible; the area should be free of third part's mining claims; the areas with possible conflicts with other land uses should be avoided; the volume of the material should guarantee a minimum of twenty five years of mining and, finally, the mining should not interfere with environmental protection areas. Four exploration areas were selected and sampled on surface and by auger drilling. A promising lateritic deposit, Target 1 - Fazenda Ventania, was sampled by further auger drilling for preliminary volume and quality evaluation. Then, an experimental mining was made.

It was additionally studied the possibility of the mining optimization of the metalimestone by blending with part of its host rocks, metadolomites, carbonaceous phyllites and calcio-silicatic rocks. Computer simulations of the raw mix have shown that it is possible to use the studied materials. Clinker production tests were then performed and their results have demonstrated the positive technical and economical impact of the use of the studied raw materials. 


\section{CAPÍTULO 1}

\section{INTRODUÇÃO}

Materiais cimentícios variados são conhecidos pelo Homem desde a remota antigüidade. Os romanos utilizavam um cimento primitivo, considerado o precursor do cimento Portland, constituído por uma mistura de cal e cinza vulcânica. Esse tipo de material cimentício foi gradualmente esquecido após o final do Império Romano, reaparecendo somente no século 14 , sendo retomado com mais vigor somente na primeira metade do século 19. Veio a ser conhecido como cimento Portland em 1824, através da patente do inglês Joseph Aspdin.

O cimento Portland é obtido a partir do clínquer, resultante da reação, sob alta temperatura, de uma mistura finamente moída de calcário e material argiloso em proporções definidas. Os componentes da mistura, farinha ou cru no vocabulário da indústria cimenteira, têm suas proporções definidas em função de parâmetros químicos, basicamente relacionados às relações entre as quantidades de cal $(\mathrm{CaO})$, silica $\left(\mathrm{SiO}_{2}\right)$, alumina $\left(\mathrm{Al}_{2} \mathrm{O}_{3}\right)$ e óxido de ferro $\left(\mathrm{Fe}_{2} \mathrm{O}_{3}\right)$. São denominados Fator de Saturação de Cal (FSC), Módulo de Alumina (MA) e Módulo de Sílica (MS), podendo variar seus valores dentro de estreitos limites. A farinha demanda a adição de substâncias conhecidas como corretivos quando o calcário elou o material argiloso apresentam deficiência de um ou mais elementos químicos, não permitindo a satisfação dos citados parâmetros.

O clínquer, moído com aditivos como gesso e escória siderúrgica, resulta no cimento Portland. O seu endurecimento se processa através da hidratação dos seus principais minerais componentes: alita $\left(\mathrm{Ca}_{3} \mathrm{SiO}_{5}\right)$, belita $\left(\mathrm{Ca}_{2} \mathrm{SiO}_{4}\right)$, aluminato tricálcico $\left(\mathrm{Ca}_{3} \mathrm{Al}_{2} \mathrm{O}_{6}\right)$ e brownmillerita ou ferrita $\left(\mathrm{Ca}_{4} \mathrm{Al}_{2} \mathrm{Fe}_{2} \mathrm{O}_{10}\right)$. Na indústria cimenteira, as fórmulas químicas desses minerais são respectivamente simplificadas como $\mathrm{C}_{3} \mathrm{~S}, \mathrm{C}_{2} \mathrm{~S}$, $\mathrm{C}_{3} \mathrm{~A}$ e $\mathrm{C}_{4} \mathrm{AF}$, conforme designação de Thörnebohm em 1897 (Duda, 1985).

A Unidade 1 da Fábrica de Cimento Votoran (FCV-1), do grupo S. A. Indústrias Votorantim (SAIV), opera desde 1936 em Santa Helena, município de Votorantim. $\mathrm{Na}$ composição da sua farinha, utiliza um calcário metamórfico de elevada pureza; porém, o material argiloso utilizado, um filito sericítico intemperizado, é deficiente em óxidos de $\mathrm{Al}$ e $\mathrm{Fe}$, demandando a adição de bauxita e minério de ferro como corretivos, influindo negativamente no custo de produção. 
$\mathrm{Na}$ pesquisa desenvolvida, foi realizada a prospeç̧ão de material argiloso alternativo que, pelas suas propriedades físico-químicas, permitisse a minimização ou a eliminação do uso dos corretivos. A prospecção foi também condicionada por outros fatores: o material deveria ser inconsolidado; a distância da fábrica deveria ser a menor possivel; a área da jazida deveria estar livre de títulos minerários de terceiros; deveriam ser evitadas áreas com possibilidades de conflitos da mineração com outros usos do solo; o volume de material deveria garantir um mínimo de vinte e cinco anos de vida útil e, finalmente, a lavra do depósito não deveria interferir em áreas de proteção ambiental.

A prospecção teve início com o estudo do processo de fabricação do clínquer Portland, da geologia regional e dos processos geoquímicos superficiais que, tendo atuado nas rochas da região, pudessem ter dado dar origem ao material buscado. $A$ partir desse conhecimento e dos fatores condicionantes já descritos, foi estabelecido um modelo geológico para o tipo de material buscado, a partir do qual foram definidos critérios prospectivos, que permitiram a escolha de áreas exploratórias preferenciais na região.

As áreas assim identificadas foram objeto de reconhecimento geológico e amostragem preliminar. Em função dos resultados analíticos e das informações de campo, foram selecionados alvos, amostrados por sondagem a trado, para melhor conhecimento dos materiais em profundidade. O depósito que apresentou materiais com propriedades físicas e químicas mais promissoras foi amostrado mais detalhadamente, visando a caracterização do material $e$, também, a verificação preliminar do seu potencial volumétrico.

Com o conjunto de dados de campo e de laboratório, foram realizadas simulações computacionais da composição da farinha. Paralelamente, estudou-se também a possibilidade de otimizar a utilização das reservas de metacalcário de alta pureza, através da sua mistura com parte de suas encaixantes, metadolomitos, filitos carbonáticos e hornfels cálcio-silicáticos, que constituem o material estéril removido na lavra.

Após as simulações computacionais, decidiu-se, em acordo com a direção da FCV-1, através da sua Divisão de Mineração, pela realização de testes de produção do clínquer em escala piloto segundo a melhor alternativa simulada. Os testes foram realizados com a manutenção dos parâmetros operacionais normais de produção, 
sendo os resultados avaliados segundo os procedimentos usualmente aplicados na FCV-1, com base nas normas técnicas da ABNT e dentro dos parâmetros estabelecidos pela certificação ISO 9002.

O presente texto apresenta uma síntese dos estudos desenvolvidos, descrevendo os métodos e materiais aplicados, seus resultados, bem como uma avaliação do impacto dos mesmos na otimização do processo de fabricação do cimento Portland na FCV-1, considerando os aspectos técnicos e econômicos envolvidos.

\subsection{LOCALIZAÇÃO E GEOMORFOLOGIA DA ÁREA DE ESTUDO}

\subsubsection{Localização}

A área de estudo localiza-se a sudoeste da cidade de São Paulo, numa região que abrange os municipios de Sorocaba, Votorantim, Salto de Pirapora, Brigadeiro Tobias, Alumínio, Mairinque e Piedade. Situa-se no entorno próximo das Unidades 1 (FCV-1, Votorantim) e 2 (FCV-2, Salto de Pirapora). A Figura 1.1 ilustra a localização da área.

Há duas alternativas de acesso à mesma a partir da Capital:

- através das rodovias Castello Branco (SP-280) e Senador José Ermírio de Morais ("Castelinho"), tomando-se esta rumo a Sorocaba. Atravessa-se a cidade no rumo sul e toma-se a rodovia Sorocaba - Piedade (SP-079), passando por Votorantim e chegando-se à FCV-1, em Santa Helena, num percurso total de cerca de $110 \mathrm{~km}$. Desta, chega-se à FCV-2 num percurso de $10 \mathrm{~km}$. O restante da área é acessado por estradas municipais e vicinais diversas;

- através da rodovia Raposo Tavares (SP-270) até Sorocaba. Desta, toma-se a rodovia Sorocaba - Piedade (SP-079), sendo o restante do percurso o mesmo da primeira alternativa.

As estradas municipais e vicinais da região, numerosas e não pavimentadas em sua maioria, oferecem, salvo raras exceções, boas condições de tráfego durante o ano inteiro. 


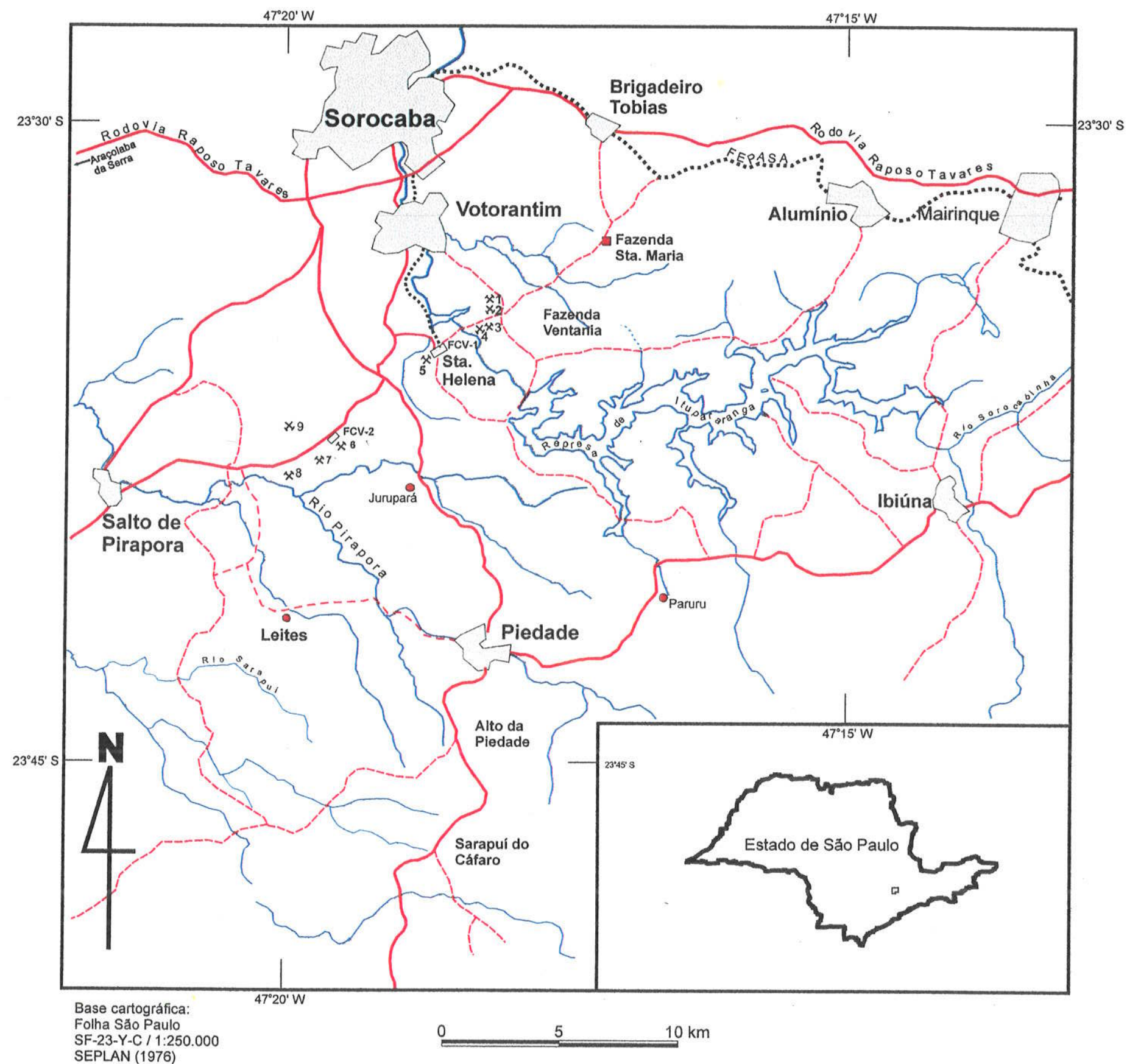

LEG E N D A

XMinas ativas: 1 - Pastinho

3 - Baltar subterrânea

5 - Mina do Lago (filito)

6 - Mina 1 - Salto de Pirapora

7 - Superbrita

8 - Minercal

Fábrica de cimento da S.A.

FCV-1 Indústrias Votorantim
X Minas inativas: 2 - Placa

4 - Baltar céu aberto

9 - Ponte Alta

Estrada pavimentada

....... Estrada não pavimentada

.***...* Estrada de ferro

Figura 1.1 - Localização da área de estudo. 


\subsubsection{Geomorfologia}

Segundo a subdivisão geomorfológica de Ross \& Moroz (1997), as porções centro, sul e sudeste da área de estudo situam-se no Planalto de Ibiúna/São Roque, um setor do Planalto Atlântico, por sua vez inserido na unidade morfoestrutural denominada Cinturão Orogênico do Atlântico. Na sua parte noroeste, a área insere-se na Depressão Paranapanema, setor da Depressão Periférica Paulista.

O relevo caracteriza-se, no Planalto de Ibiúna/São Roque, por morros altos apresentando formas de topos convexos. Escarpas ocorrem de maneira isolada. As altitudes estão geralmente acima dos $800 \mathrm{~m}$, chegando a $1.100 \mathrm{~m}$ nos domínios das rochas graníticas. As declividades predominantes estão acima de $20 \%$, podendo chegar localmente a mais de $40 \%$. As formas de dissecação são médias a altas, apresentando vales entalhados e densidade de drenagem média a alta, com padrão dendrítico dominante e alguns trechos subordinados às estruturas.

Na Depressão Paranapanema, caracterizada pelas rochas da Bacia Sedimentar do Paraná, o relevo apresenta colinas com topos convexos, altitudes de 600 a $700 \mathrm{~m}$ e declividades entre 10 e $20 \%$. As formas de dissecação são baixas, com vales pouco entalhados e baixa densidade de drenagem.

Quanto à drenagem, a área situa-se no divisor de águas entre as bacias dos altos cursos dos rios Piracicaba e Paranapanema. Na primeira, destaca-se o rio Sorocaba, cujas cabeceiras situam-se na área de estudo. Na segunda, destacam-se os rios Pirapora e Sarapuí, que também nascem na área e correm no sentido sudestenoroeste na parte sudoeste da área (Figura 1.1).

Os solos dominantes são classificados segundo intervalos de altitudes e os domínios geomorfológicos. No Planalto de Ibiúna/São Roque, entre 800 e $900 \mathrm{~m}$ predomina Latossolo Vermelho-Amarelo e, entre 900 e 1.100m, predomina o Podzólico Vermelho-Amarelo. $\mathrm{Na}$ Depressão Paranapanema, predominam os latossolos Vermelho-Amarelo e Amarelo Médio Grosso. 


\subsection{JUSTIFICATIVA DA ESCOLHA DO TEMA}

Dados do SNIC - Sindicato Nacional da Indústria do Cimento (1998) mostram que, após a implantação do Plano Real e da conseqüente estabilidade da moeda nacional no período 1994-1998, ocorreu rápido aumento da demanda interna de cimento, fazendo a produção saltar de 25,2 milhões de toneladas em 1994 para 38,1 milhões em 1997. Um incremento de $51 \%$ no período considerado.

Esse aumento da demanda é devido, principalmente, aos pequenos consumidores, representados pelas camadas de mais baixa renda da população, fazendo com que alguns fabricantes passassem a comercializar, paralelamente aos tradicionais, de $50 \mathrm{~kg}$, cimento em sacos de $25 \mathrm{~kg}$, mais adaptados ao novo perfil de consumo.

Por outro lado, o consumo per capita brasileiro de cimento, de aproximadamente $240 \mathrm{~kg}$ em 1997, situa-se, segundo dados de SNIC (1998), bastante aquém daqueles de países desenvolvidos como Japão $(654 \mathrm{~kg})$ e Itália $(584 \mathrm{~kg})$ e, também, de alguns países em desenvolvimento, como China $(388 \mathrm{~kg})$, Tailândia $(621 \mathrm{~kg})$ e Coréia do Sul $(1.326 \mathrm{~kg})$. Apesar de $\circ$ Brasil ser $\circ 6^{\circ}$ produtor mundial, o consumo per capita nacional ainda não está entre os 20 maiores do mundo, indicando que o Brasil apresenta potencial para aumento significativo da demanda de cimento.

O acentuado aumento da demanda e a consciência do potencial de crescimento fizeram com que muitas fábricas operassem no limite máximo da capacidade produtiva, obrigando alguns fabricantes a realizar projetos de expansão em ritmo acelerado.

Dentro desse panorama, a SAIV também colocou em marcha seus projetos de expansão da capacidade produtiva em algumas de suas fábricas, cujas unidades paulistas responderam por $70,25 \%$ da produção estadual de 8.077 .765 toneladas em 1997. Os projetos de ampliação representam investimentos da ordem de centenas de milhões de reais, motivo pelo qual as suas fábricas passam atualmente por um processo de modernização técnico-administrativa, visando a melhora da produtividade e a redução de custos.

Nessa conjuntura, a FCV-1, responsável por $30,77 \%$ da produção estadual no mesmo período, não foi exceção. Entre vários itens, identificou-se a necessidade de reduzir os custos relativos às matérias-primas minerais do clínquer. A análise setorial 
dos custos dentro da Divisão de Mineração da FCV-1 indicou, além dos ajustes operacionais nas diversas etapas de produção, a minimização da utilização dos corretivos e a otimização da lavra de metacalcário como prioritários no programa de redução de custos.

Desta maneira, o estudo justifica-se como uma aplicação de conhecimentos e procedimentos científicos na solução de problema tecnológico e econômico numa indústria. Esta, fabricante de um produto de enorme importância social. Ao mesmo tempo, justifica-se também por evidenciar o potencial de utilização dos materiais geológicos estudados e da aplicação dos métodos em situações similares.

\subsection{OBJETIVOS}

O presente estudo teve por objetivo o estudo da utilização de materiais argilosos alternativos, prospectados dentro de um raio econômico ${ }^{1}$ de $50 \mathrm{~km}$ em torno da fábrica e, paralelamente, o aproveitamento parcial das rochas encaixantes do metacalcário. Os materiais argilosos foram estudados considerando as características mineralógicas, químicas e físicas que permitissem a minimização ou a eliminação do uso dos corretivos na composição da farinha.

Na mina Pastinho, foi estudada a possibilidade de aproveitamento, ainda que parcial, do metadolomito e do filito carbonático do setor sudeste (capa), desmontado como estéril na operação de aprofundamento da cava. Na mina subterrânea do Baltar, onde se encontra em desenvolvimento $\circ 2^{\circ}$ painel de lavra, inferior, foram consideradas as rochas cálcio-silicáticas, que constituem o estéril na abertura de rampas de acesso e galerias de desenvolvimento.

Essas rochas, misturadas ao metacalcário em proporções adequadas, poderiam proporcionar parâmetros aceitáveis na composição da farinha. Esse aproveitamento considerou a participação do novo material argiloso e a redução do volume de metacalcário lavrado, racionalizando-se a lavra como um todo e prolongando a vida útil da jazida. Adicionalmente, a redução do volume de material a ser descartado em pilhas de estéril (bota-fora) tem implicações ambientais positivas.

\footnotetext{
'Distância na qual o custo da extração + transporte do material argiloso se igualaria ao da aquisiçăo da bauxita.
} 


\subsection{SÍNTESE DA METODOLOGIA}

Os estudos foram realizados através da seguinte seqüência metodológica:

* - identificação do problema, através de contatos iniciais com a equipe da Divisão de Mineração da FCV-1, à qual foi então submetido um plano de trabalho;

- revisão bibliográfica, para conhecimento da geologia regional, do processo de fabricação do clínquer Portland e dos processos geoquímicos superficiais;

- estabelecimento de modelo geológico para a prospecção e definição de critérios prospectivos, através da análise de informações geológicas, fisiográficas e climáticas;

- preparação de bases cartográficas e fotográficas;

- trabalhos de campo para amostragem das minas: o metacalcário da mina Pastinho, suas encaixantes e o filito intemperizado da mina do Lago; análises laboratoriais para a caracterização petrográfica, mineralógica e química;

- reconhecimento geológico regional e trabalhos iniciais de campo para amostragem superficial preliminar;

- análise dos dados iniciais de campo e de laboratório, identificando-se as áreas promissoras e planejando-se nova etapa de campo;

- amostragem semi-detallhada nas áreas selecionadas, através de sondagem a trado, acompanhada de mapeamento superficial e cartografia digital; caracterização laboratorial dos materiais amostrados; identificação de alvos para pesquisa;

- análise e integração dos dados obtidos, cálculo preliminar de reserva, simulações computacionais das alternativas de composição da farinha com a participação dos materiais estudados;

- planejamento e execução de ensaios industriais de fabricação do clínquer Portland com os materiais estudados;

- interpretação, discussão e avaliação dos resultados obtidos. 


\section{CAPÍTULO 2 \\ O CIMENTO PORTLAND}

\subsection{BREVE HISTÓRICO}

A sintese histórica do cimento aqui apresentada foi elaborada com base nas informações encontradas, principalmente, em Candlot (1906), Bogue (1947), Lea (1970), Gomà (1979), Von Landsberg (1992), Centurione (1993), Zampieri (1993), Pliskin (1993), e também na Internet, nos sites http://www.portcement.org/indhist.htm da PCA - Portland Cement Association, que congrega os fabricantes dos Estados Unidos e do Canadá, http://www.olemiss.edu/courses/engr313/engr314/, do Laboratório de Ciência dos Materiais da Universidade do Mississipi, E.U.A.; http://edison.rutgers.edu/patente5.htm, da Universidade de Rutgers, também nos E.U.A; http://www.cimfra.fr, do grupo produtor Ciments Français, e http://www.abcp.org.br, da Associação Brasileira de Cimento Portland.

Desde os primórdios da civilização humana, foram buscados materiais ligantes que unissem os blocos rochosos nas construções. Os Assírios e Babilônios usaram argila ou betume para esse fim. Os Egipcios avançaram da argila misturada à palha até a argamassa de gesso e areia. Segundo Pliskin (1993), já conheciam os mesmos a produção da cal pela calcinação de rochas carbonáticas. A preferência pelo gesso teria sido em razão da escassez de combustivel para a calcinação a temperaturas próximas de $700^{\circ} \mathrm{C}$. A gipsita, embora menos abundante do que os calcários no Egito, podia ser desidratada em temperaturas entre $100^{\circ}$ e $150^{\circ} \mathrm{C}$.

Os gregos usavam material cimentício baseado na cal e, segundo alguns autores, transmitiram esse conhecimento aos romanos. Estes, utilizavam uma mistura de cal e cinza vulcânica denominada pozzuolana, extraída na região do Monte Pozzuoli. Este material deu origem ao nome pozolana, referente aos materiais naturais ou artificiais silicosos ou sílico-aluminosos que, não sendo por si só cimentícios, podem reagir com a cal na presença de umidade e à temperatura ambiente, resultando em compostos com propriedades cimentícias. As proporções da mistura eram variáveis de acordo com as necessidades, tendo sido utilizados aditivos como gordura animal, leite e até mesmo sangue. 
Após a queda do Império Romano, esse conhecimento sobre o cimento ficou esquecido, voltando os materiais pozolânicos a ser utilizados somente no século 14; porém, com evolução lenta até o início do século 18. Em 1756, o inglês John Smeaton, na reconstrução do farol de Eddystone, chegou ao cimento hidráulico constituído por uma mistura homogênea de cal hidráulica e tufo vulcânico italiano em proporções iguais. Smeaton chegou também à conclusão de que as melhores cales resultavam de calcinação de calcários impuros, argilosos. $\mathrm{Na}$ época, ele comparou as propriedades de seu cimento às das melhores pedras de Portland, itha de onde eram extraídos blocos de calcário para construção.

Depois de Smeaton, diversos estudiosos, como Bry Higgins, James Parker, James Frost, Canvas White, John Tickell, Abrahan Chambers, Maurice St. Leger, Henri Le Chatelier e Louis Vicat, entre outros, dedicaram-se à pesquisa de materiais cimentícios. Parker, por exemplo, chegou ao então bem aceito "cimento de Parker" ou "cimento Romano" através da calcinação de calcário impuro contendo nódulos de argila.

Nas bem sucedidas experiências do francês Vicat, entre 1812 e 1813, as rochas calcárias impuras deram lugar à mistura artificial de calcário e materiais argilosos, que podia ser feita em proporções ideais, resultando em cimento de boa e constante qualidade. Algumas fontes consultadas, como Pliskin (1993), consideram Vicat como o inventor do cimento Portland. Pouco depois, em 1822, o inglês James Frost preparou um cimento hidráulico similar ao de Vicat, denominando-o "cimento Britânico".

Em 1824, Joseph Aspdin, construtor inglês de Leeds, patenteou o "cimento Portland". Entretanto, muitos autores contestam o crédito dado a Aspdin como o inventor do mesmo porque ele teria apenas utilizado os conhecimentos adquiridos pelos seus antecessores, chegando a um produto que diferia pouco, por exemplo, do cimento de Vicat. Até mesmo o nome já havia surgido 68 anos antes, nos comentários de John Smeaton. A Figura 2.1 apresenta uma fotografia do forno de Aspdin.

Nos anos seguintes, a utilização do cimento aumentou gradualmente, até ser amplamente utilizado nas construções no final do século 19, e fábricas foram construídas em outros países. Em 1871, David O. Saylor fundou, em Coplay, Pensilvânia, a primeira fábrica de cimento Portland nos EUA, que o importava da Inglaterra desde 1868. 


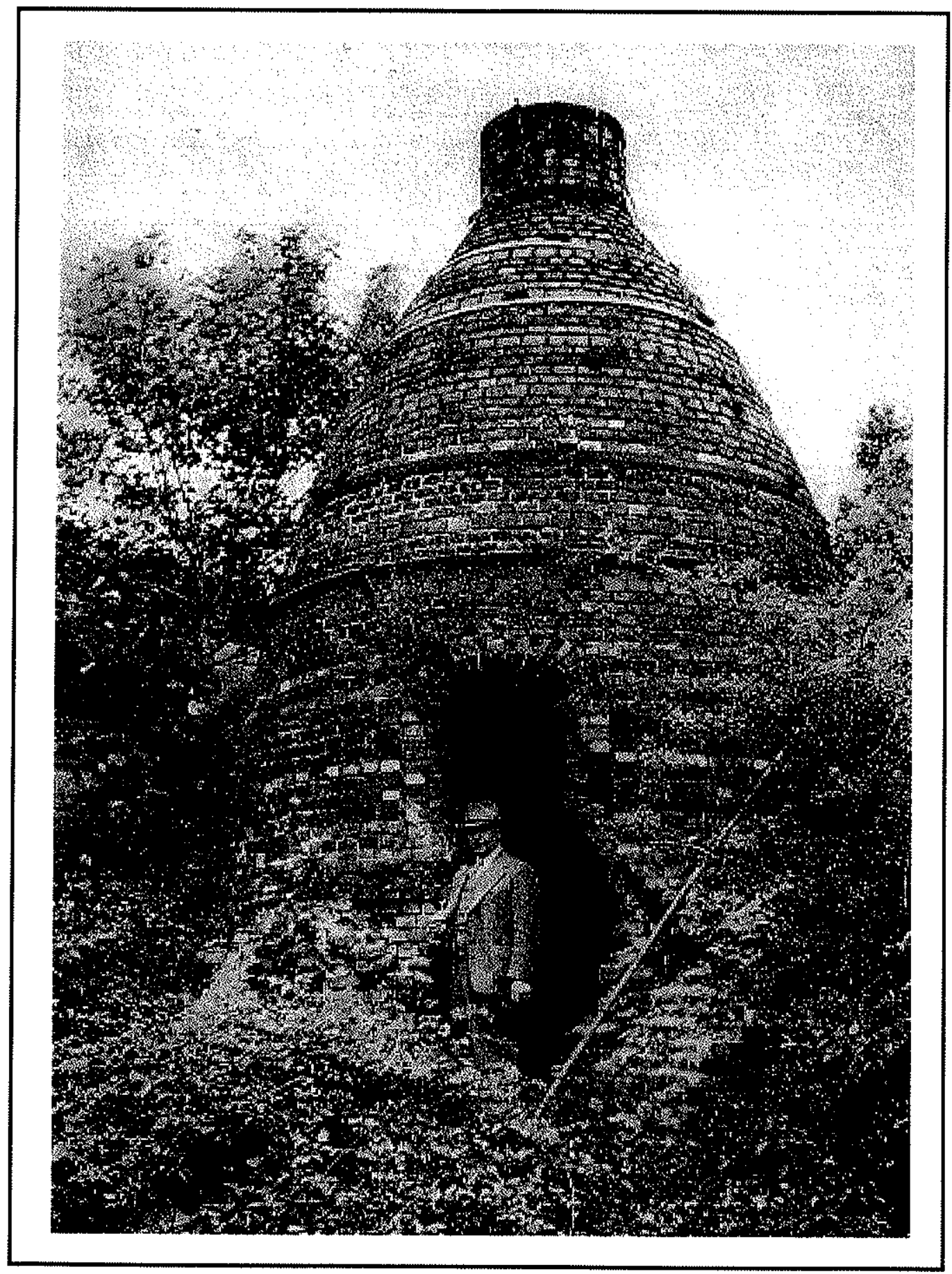

Fonte: Bogue (1947)

Figura 2.1 - Forno de cimento de Aspdin, em Northfleet, Kent, Inglaterra, fotografado por M. A. Swayze em 1938. 
A crescente importância do cimento nos mais diversos tipos de construção fez aumentar rapidamente o seu consumo; porém, a produção em fornos fixos, de processo descontínuo, necessitava de modificações para atender ao acelerado crescimento da demanda. No início da década de 1870, Thomas Millen e seus dois filhos, norte americanos de South Bend, Indiana, produziram cimento Portland queimando a farinha numa peça de tubulação de esgoto e moendo o clínquer num moinho de café. Esse equipamento improvisado foi, talvez, o primeiro forno rotatório experimental na América.

Em 1885, o Engenheiro inglês $F$. Ransome patenteou um pequeno forno levemente inclinado e rotatório, com chama de gasogênio, que permitia ao material, introduzido seco em seu interior, mover-se de um extremo ao outro, num processo contínuo. Porém, segundo Candlot (1906), a qualidade do cimento produzido nesse forno deixava muito a desejar. O empresário Navarro, de New York, adquiriu a patente de Ransome e aperfeiçoou o equipamento com a ajuda do francês P. Giron. O novo equipamento, conhecido como forno de Giron, tinha $10 \mathrm{~m}$ de comprimento por $1,5 \mathrm{~m}$ de diâmetro, já contando com maçarico a óleo e ar comprimido. O material entrava semi seco no forno, para que não fosse carreado pela corrente de gás.

Paralelamente aos progressos tecnológicos nos equipamentos, avançavam também os conhecimentos sobre a química do cimento. Em 1887, o francês Henri Le Chatelier estabeleceu razões de óxidos para o preparo da correta quantidade de cal para a fabricação do cimento, nomeando os componentes: alita (silicato tricálcico), belita (silicato bicálcico) e celita (aluminoferrita tetracálcica).

O forno rotatório, tornado de uso corrente já no final do século passado, passou por sucessivos desenvolvimentos tecnológicos praticados por pesquisadores renomados. Por exemplo, Thomas Alva Edison, fundador da Edison Portland Cement Company, obteve cinco patentes do equipamento entre 1904 e 1914.

Em 1906, já existiam fábricas de cimento na Inglaterra, França, Alemanha, Bélgica, Rússia, Dinamarca, Suécia, Portugal, Romênia, Japão e Estados Unidos. A produção mundial anual da época era estimada em cerca de 13 milhões de toneladas.

Em 1916, foi fundada nos EUA a PCA - Portland Cement Association e, no ano seguinte, o USBS - United States Bureau of Standards e a ASTM - American Society for Testing Materials estabeleceu uma fórmula padrão para o cimento Portland. Seguiram- 
se entidades normativas em outros países produtores e o cimento Portland consagrouse como material cimentício.

\subsection{CIMENTO NO BRASIL E NO MUNDO}

Desde a implantação, em 1926, da primeira fábrica bem sucedida no Brasil, a Companhia Brasileira de Cimento Portland, em Perus, a indústria cimenteira brasileira teve notável desenvolvimento. Atualmente, o Brasil conta com 60 fábricas em operação, das quais 10 são unidades de moagem. A Figura 2.2 mostra a evolução da produção e das importações brasileiras de cimento no período 1953 - 1997.

Dados do SNIC (1998) e do SFIC - Syndicat Français de I'Industrie Cimentière (1998) mostram que, após a implantação do Plano Real, ocorreu rápido aumento da demanda interna de cimento, que passou de 25.229.609 t em 1994 para 38.096.043 em 1997, fazendo o Brasil saltar do $13^{\circ}$ para $\circ 6^{\circ}$ lugar entre os maiores produtores mundiais, superando países como a Alemanha, Itália e Espanha. Em 1998, o Brasil produziu 39,7 milhões de toneladas de cimento, mantendo-se no $6^{\circ}$ lugar.

A Figura 2.3 mostra a evolução do consumo aparente ${ }^{2}$ per capita brasileiro no período 1953-1997. Apesar do aumento recente e acentuado, o consumo per capita brasileiro é inferior ao dos países desenvolvidos e até mesmo de alguns países em desenvolvimento, como visto em 1.2. Dados de SIFC (1998) e SNIC (1998) mostram que o consumo per capita de alguns países em desenvolvimento como a Tailândia e a Coréia do Sul superam aqueles dos paises desenvolvidos, evidenciando a aceleração da atividade econômica nesses países. A comparação do consumo desses países com - brasileiro mostra claramente que o Brasil apresenta potencial para crescimento significativo da indústria de cimento.

A produção mundial de cimento, em 1997, foi de aproximadamente 1,516 bilhão de toneladas, com a produção brasileira representando $2,51 \%$ desse total (SFIC 1998). As Figura 2.4 e 2.5 mostram, respectivamente, os dez maiores produtores mundiais em 1997 e o consumo per capita de 10 países entre os maiores consumidores no mesmo ano. A figura 2.5 permite concluir que o consumo de cimento é bastante variável mesmo entre os países desenvolvidos.

\footnotetext{
${ }^{2}$ Consumo aparente per capita $=($ despachado-exportado+importado)/população recenseada e projetada.
} 


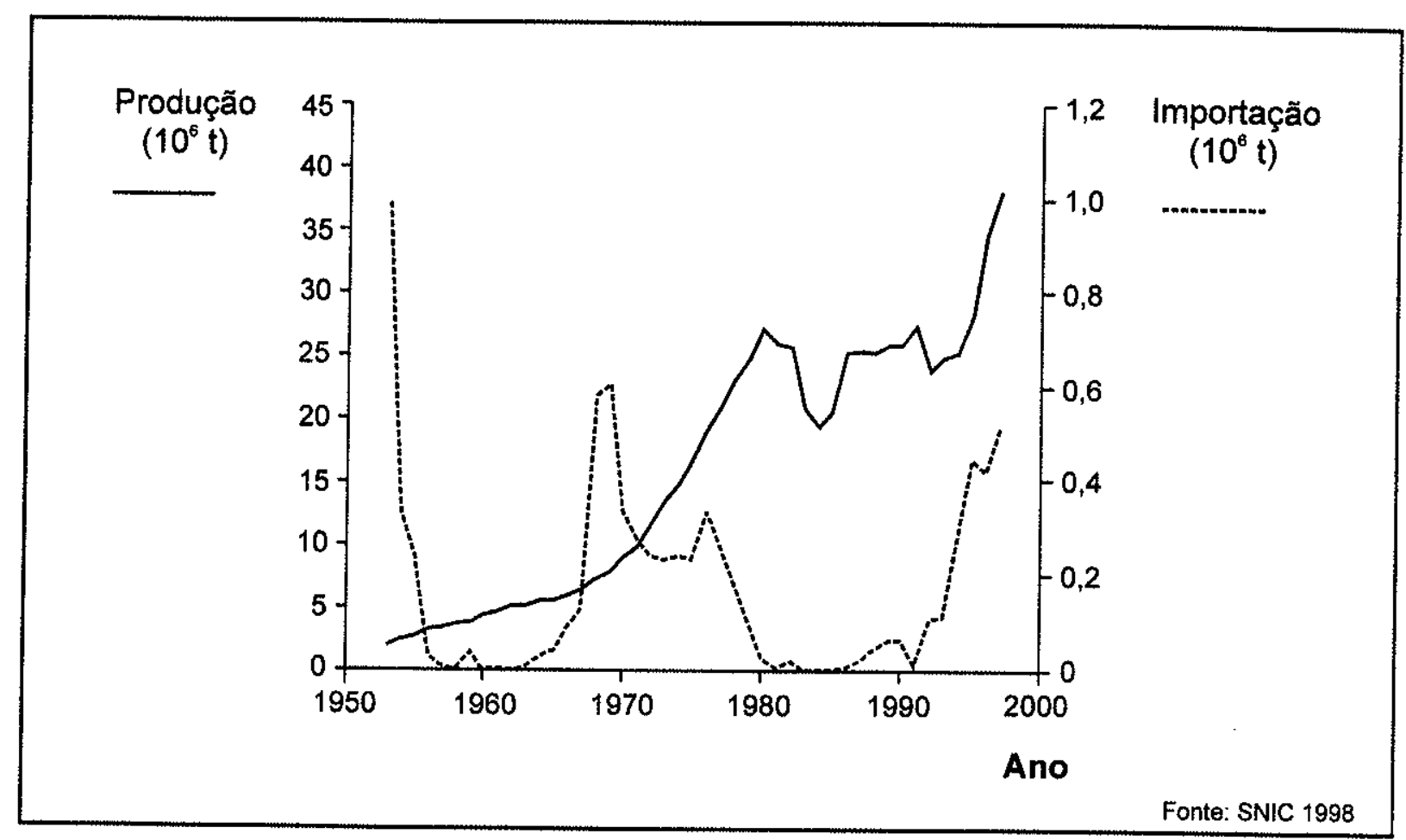

Figura 2.2 - Evolução da produção e da importação de cimento no Brasil (1953 - 1997).

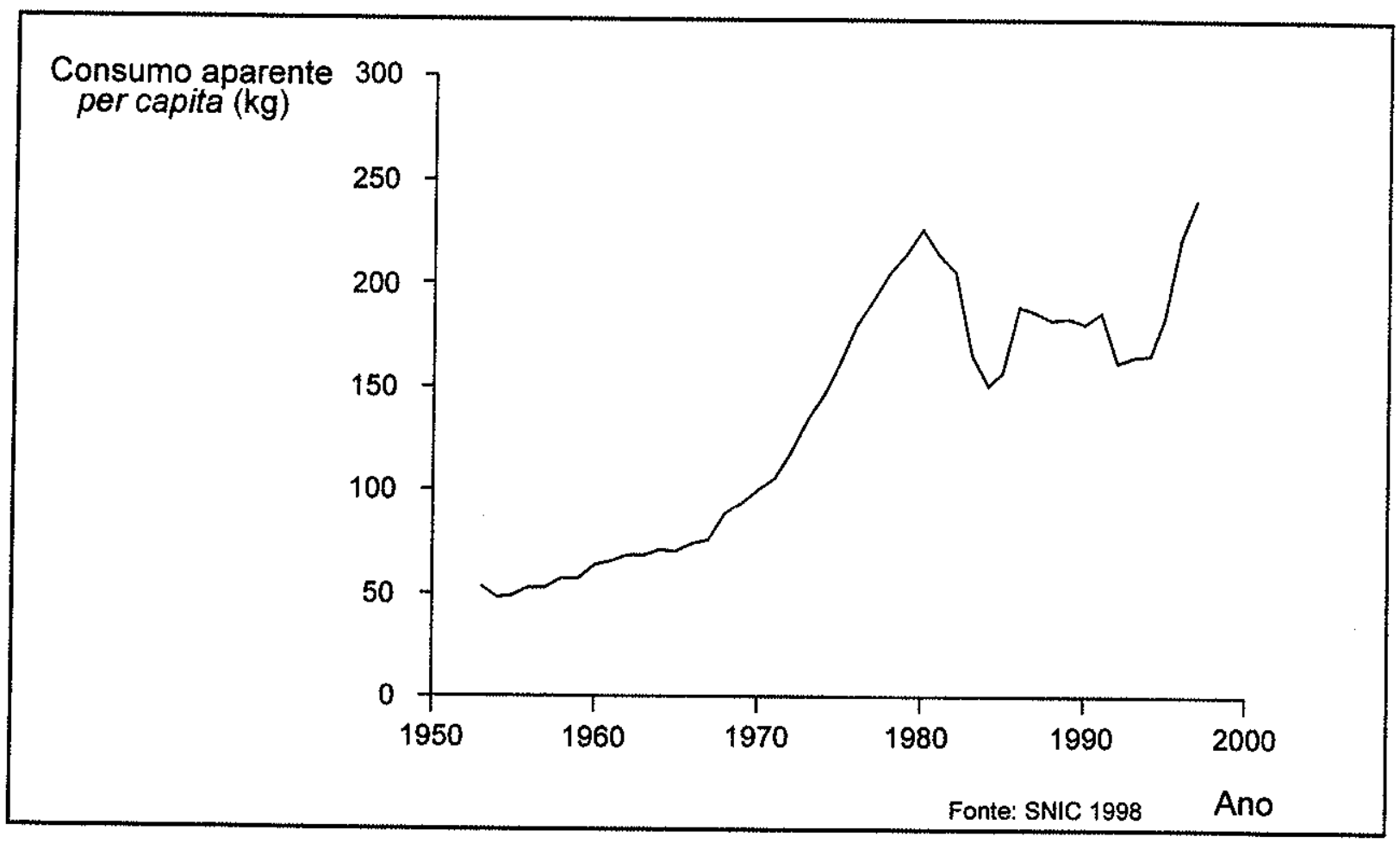

Figura 2.3 - Evolução do consumo aparente per capita de cimento no Brasil (1953-1997). 


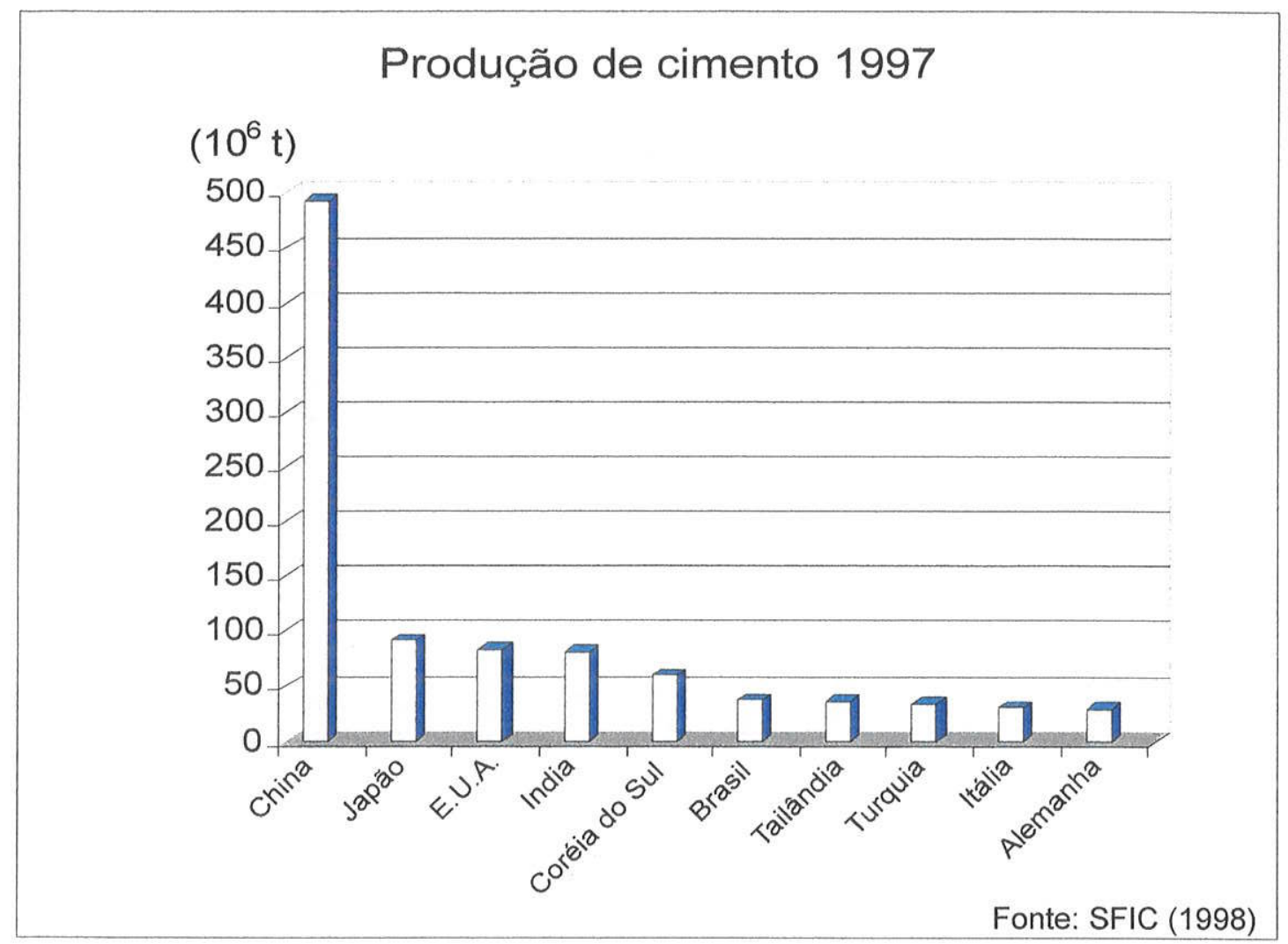

Figura 2.4 - Posições relativas dos 10 maiores produtores mundiais de cimento.

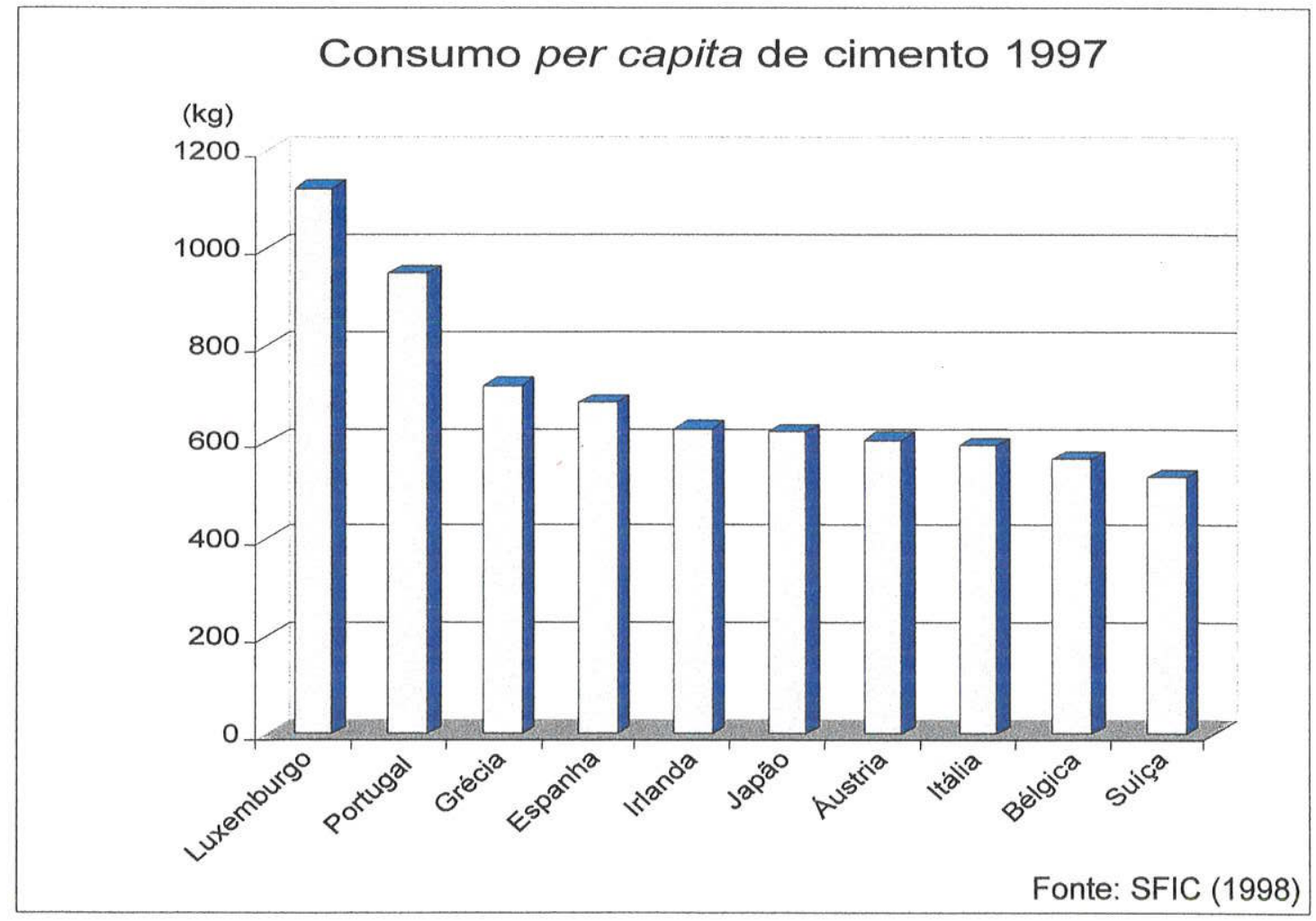

Figura 2.5 - Consumo per capita de cimento em alguns países desenvolvidos. 


\subsection{A FABRICAÇÃO DE CIMENTO PORTLAND}

O cimento Portland é fabricado a partir de uma mistura de rocha carbonática e argila. Essa mistura, finamente moída, é submetida ao forno em temperaturas que chegam próximas de $1450^{\circ}$ C. O processo envolve calcinação, sinterização e peletização, no qual reações químicas transformam os minerais das matérias-primas em outros, dando origem ao clínquer Portland. O cimento é então obtido através da moagem do clínquer com aditivos como gesso, escória siderúrgica, pozolanas e o próprio calcário. As proporções clínquer-aditivos são variáveis em função dos tipos de cimento Portland. As etapas de fabricação podem apresentar algumas diferenças em função das características das matérias-primas, das particularidades operacionais de cada fábrica, e dos equipamentos utilizados. A Figura 2.6 mostra o fluxograma ilustrado do processo de fabricação de cimento na FCV-1. As Figuras $2.7 \mathrm{~A}$ a $2.7 \mathrm{H}$ ilustram fotograficamente parte das etapas da fabricação.

\subsubsection{As matérias - primas}

A rocha carbonática deve conter um mínimo de $42 \%$ de $\mathrm{CaO}$ e máximos de $4 \%$ de $\mathrm{MgO}$ e $10 \%$ de $\mathrm{SiO}_{2}$ (CPRM 1972). Pliskin (1993) indica teor mínimo de $78,5 \%$ de $\mathrm{CaCO}_{3}$ (aproximadamente $44 \%$ de $\mathrm{CaO}$ ) e $\mathrm{MgO}$ inferior a $2 \%$ na farinha. Bigarella (1956) classifica as rochas calcárias (Tabela 2.1) e, segundo o mesmo, apenas os calcários calcíticos e magnesianos são utilizáveis na fabricação. Os mais magnesianos podem, eventualmente, ser misturados aos mais calciticos, desde que a farinha não tenha $\mathrm{MgO}$ acima de aproximamente $3 \%$, variável segundo as condições de fabricação. Acima desse teor o $\mathrm{MgO}$ passa a ser um constituinte nocivo que, expresso sob a forma de periclásio $(\mathrm{MgO})$ no clínquer, pode sofrer expansão lenta dentro do concreto.

Tabela 2.1 - Classificação das rochas calcárias segundo Bigarella (1956)

\begin{tabular}{|l|c|}
\hline Denominação & $\mathrm{MgO}(\%)$ \\
\hline Calcário calcitico & $0,0-1,1$ \\
\hline Calcário magnesiano & $1,1-4,3$ \\
\hline Calcário dolomítico & $4,3-10,5$ \\
\hline Dolomito calcítico & $10,5-19,1$ \\
\hline Dolomito & $19,1-22,0$ \\
\hline
\end{tabular}




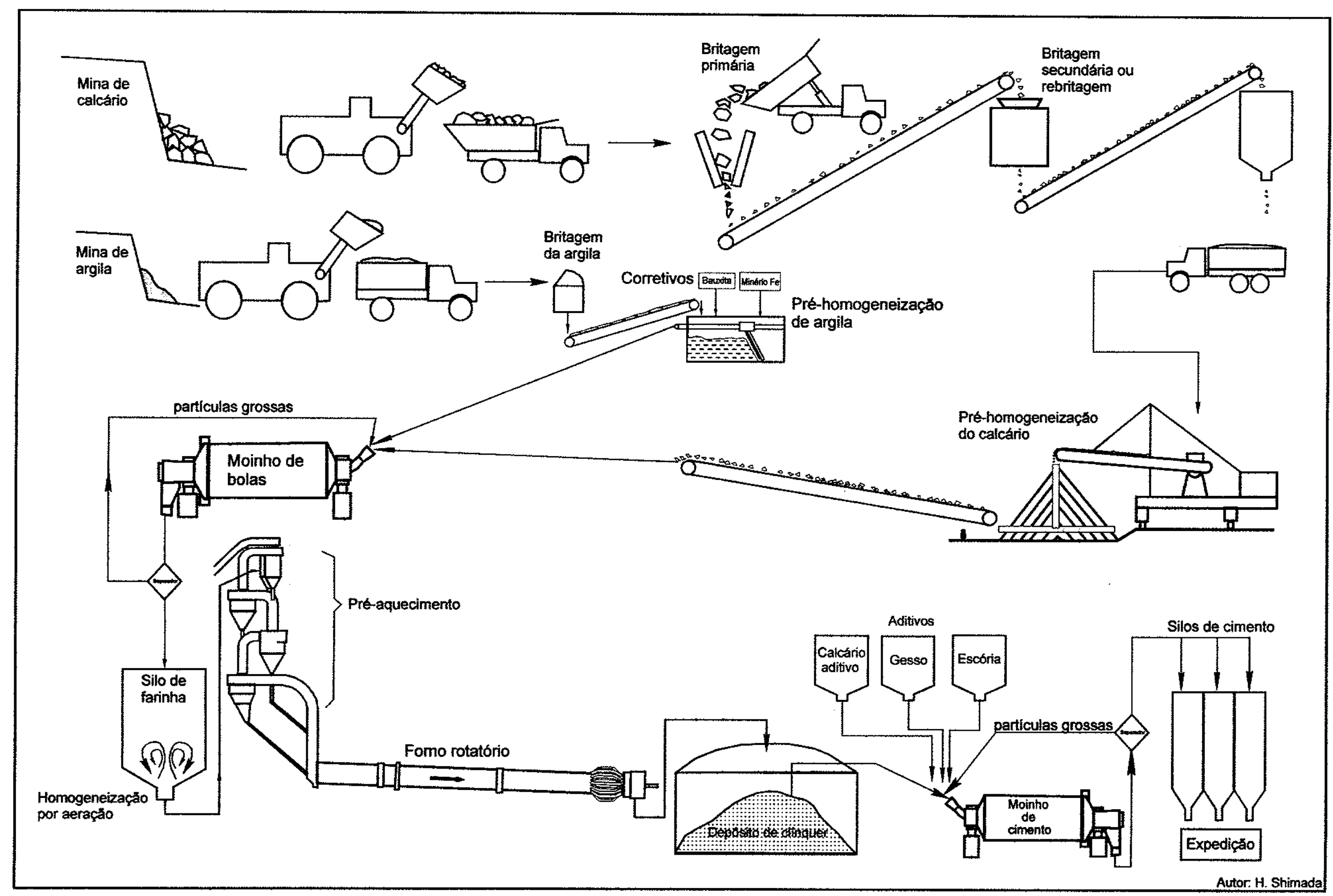

Figura 2.6 - Fluxograma ilustrado da fabricação de cimento portland na FCV-1 (Fornos 1"e 3). 


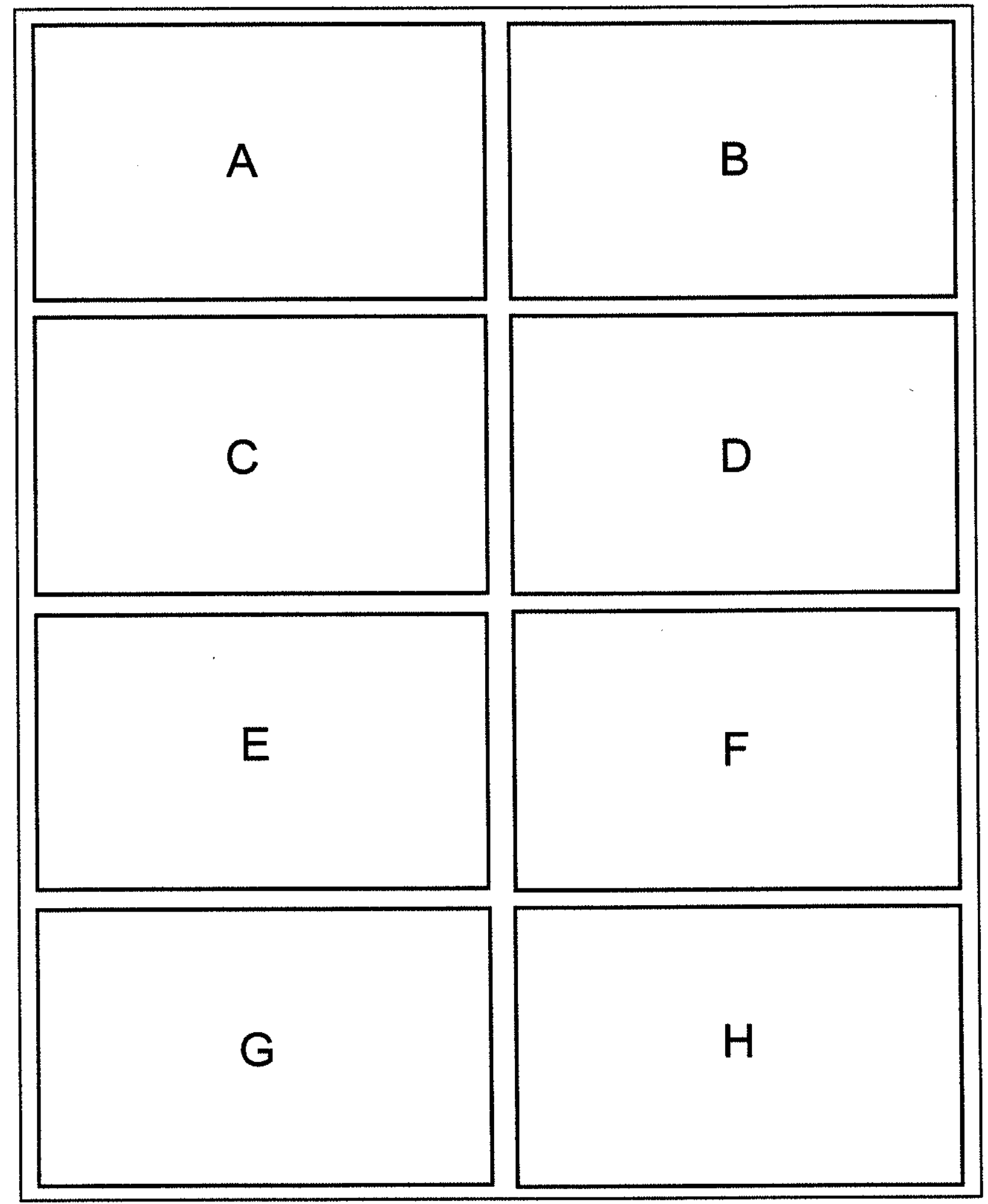

Figura 2.7 - A) Desmonte de metacalcário na mina Pastinho; B) Vista geral da mina do Lago; C) Entrada de metacalcário na britagem primária; D) Britagem secundária, com pilha de abastecimento em primeiro plano; E) Pré-homogeneização de metacalcacário, com retomada em segundo plano; F) Préhomogeneização de argila (retomada); G) Vista parcial do forno $n^{\circ} 2$ da FCV $-1 ; H)$ Vista geral da fábrica de cimento FCV-1. 

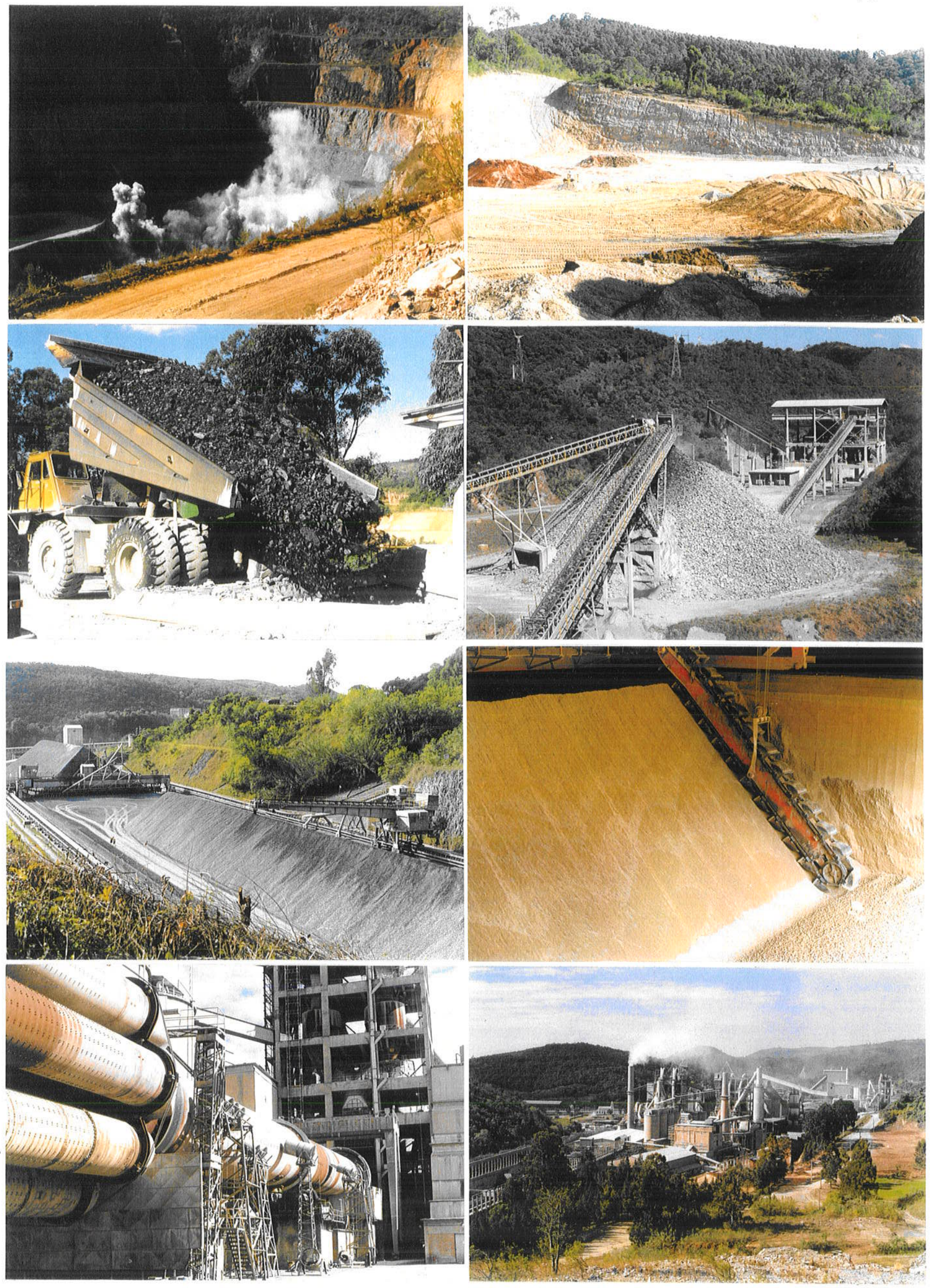

Figura 2.7 - Ilustrações fotográficas das etapas de fabricação do cimento. 
A argila deve também obedecer a especificações químico-mineralógicas. Ideaimente, a argila deve conter $\mathrm{SiO}_{2}, \mathrm{Al}_{2} \mathrm{O}_{3}$ e $\mathrm{Fe}_{2} \mathrm{O}_{3}$ em teores que permitam a satisfação dos parâmetros químicos exigidos para a farinha, com o menor conteúdo possivel de quartzo e $\mathrm{Na}_{2} \mathrm{O}<3,0 \%$ e $\mathrm{K}_{2} \mathrm{O}<4,0 \%$. Os grãos de quartzo, se presentes em excesso, dificultam a moagem, implicam em maior consumo energético no processo e, quando grossos, dificultam a reação de formação de alita a partir da belita (Christensen 1981).

\subsubsection{A farinha de clínquer}

A farinha é obtida pela fina moagem da mistura de matérias-primas, em moinhos de tipos variados: de bolas, vertical ou de rolos horizontais. Quanto mais fina a farinha, mais facilmente se processarão as reações químicas no interior do forno; porém, uma moagem ultra-fina seria inviável em termos de custo, mesmo considerando a redução no consumo energético do forno.

A granulometria ou finura da farinha refere-se aos grãos de calcário e de quartzo, visto que as partículas de argila são naturalmente finas. Centurione (1993), ao estudar detalhadamente a influência das características das matérias-primas no processo de sinterização do clínquer Portiand, considerou grossos os grãos de quartzo acima de 45 $\mu \mathrm{m}$ (malha 325) e os de calcário acima de $125 \mu \mathrm{m}$ (malha 120). Pliskin (1993) refere-se à moagem até a obtenção de cru com 1,0 a $1,5 \%$ de retenção na peneira de abertura $160 \mu \mathrm{m}$. Verifica-se que as especificações variam entre os autores.

A homogeneidade da farinha é de grande importância, favorecendo a combinação do $\mathrm{CaO}$ no clínquer e resultando em clínquer com composição uniforme. Segundo Kihara et al. (1983), as farinhas com homogeneidade deficiente não apresentam composição química constante, demandando maiores temperaturas e tempo de queima, implicando em maior consumo de energia, resultando em clínquer nem sempre com as qualidades esperadas.

A capacidade da farinha de se transformar em clínquer de boa qualidade é denominada aptidão à clinquerização. As composições química e mineralógica, a granulometria e o grau de homogeneização são os principais fatores que condicionam a aptidão à clinquerização de uma farinha. Um dos procedimentos práticos na indústria é a avaliação posterior da aptidão, medindo-se o conteúdo de $\mathrm{CaO}$ não combinado no clínquer (CaO livre), por métodos químicos ou ópticos (Kihara 1973; Miller 1981; ABCP 
1984; Theisen 1992; Centurione 1993). O conteúdo de cal livre remanescente de um clínquer, comparado ao de um clínquer resultante de uma matéria-prima padrão, submetida às mesmas condições de queima e resfriamento, define a queimabilidade (burnability) (Theisen 1992), medida através do Índice de Queimabilidade:

$$
\begin{aligned}
& I Q=A / B \times 3,73 \quad \text { onde: } \\
& A=C L 1+C L 2+2 C L 3+3 C L 4 \\
& B=(C L 1 / C L 4)^{1 / 4}
\end{aligned}
$$

Sendo: $\quad C L 1-\%$ de cal livre a $1350^{\circ} \mathrm{C}$

CL2 - \% de cal livre a $1400^{\circ} \mathrm{C}$

CL3 - \% de cal livre a $1450^{\circ} \mathrm{C}$

CL4 - \% de cal livre a $1500^{\circ} \mathrm{C}$

A queimabilidade depende não somente das características químicas e mineralógicas da farinha, mas também dos parâmetros operacionais do processo de queima. A indústria cimenteira controla a qualidade da farinha através de parâmetros químicos relacionados aos seus óxidos principais, mostrados na Tabela 2.2. Os limites dos parâmetros podem sofrer pequenas variações de acordo com as condições de fabricação.

Tabela 2.2 - Principais parâmetros químicos utilizados na indústria cimenteira

\begin{tabular}{|l|l|c|}
\hline \multicolumn{2}{|c|}{ PARÂMETRO } & FÓRMULA \\
\hline FSC & $\begin{array}{l}\text { Fator de Saturação } \\
\text { de Cal } \\
(90-100)^{3}\end{array}$ & $\frac{100 \mathrm{CaO}}{2,8 \mathrm{SiO}_{2}+1,18 \mathrm{Al}_{2} \mathrm{O}_{3}+0,65 \mathrm{Fe}_{2} \mathrm{O}_{3}} \quad$ (\%) \\
\hline MS & $\begin{array}{l}\text { Módulo de Sílica } \\
(2,2-2,6)^{3}\end{array}$ & $\frac{\mathrm{SiO}_{2}}{\mathrm{Al}_{2} \mathrm{O}_{3}+\mathrm{Fe}_{2} \mathrm{O}_{3}}$ \\
\hline MA & $\begin{array}{l}\text { Módulo de Alumina } \\
(1,5-2,5)^{3}\end{array}$ & $\frac{\mathrm{Al}_{2} \mathrm{O}_{3}}{\mathrm{Fe}_{2} \mathrm{O}_{3}}$ \\
\hline
\end{tabular}

Modificado de Centurione (1993)

O FSC está estreitamente relacionado às proporções de cal livre, alita e belita no clínquer. O aumento do FSC, com o teor de cal livre fixo, implicam no aumento do conteúdo de alita e diminuição da belita, com o aumento da resistência mecânica à

${ }^{3}$ Limites usuais dos parâmetros, com pequenas variações entre autores e fabricantes. 
compressão do cimento, principalmente em relação às resistências iniciais, de 3 e 7 dias. Porém, para FSC acima de 100\%, forma-se excesso de cal livre, causando o decréscimo da resistência. $O$ aumento de FSC implica também em maior consumo de combustível devido à maior demanda energética para a descarbonatação do $\mathrm{CaCO}_{3}$.

Sintetizando as informações de Duda (1985), Johansen (1977), Gouda (1978), Long (1982) e Pliskin (1993), o valor de MS, numa dada temperatura, é inversamente proporcional ao conteúdo da chamada fase líquida e diretamente proporcional ao conteúdo de alita e belita. A primeira favorece a reação de consumo de $\mathrm{CaO}$, com formação da alita e, também, a formação da colagem protetora sobre os tijolos refratários do forno. Assim, um valor baixo de MS é favorável ao processo de clinquerização. Por outro lado, a elevação do MS é acompanhada do aumento da temperatura máxima, significando maior consumo energético.

Ainda segundo Kihara et al. (1983), o MA, também conhecido como módulo de fundente, controla a composição e a viscosidade da fase líquida, com importante influência na temperatura e no processo de clinquerização.

Os óxidos $\mathrm{Al}_{2} \mathrm{O}_{3}$ e $\mathrm{Fe}_{2} \mathrm{O}_{3}$ agem como fundentes, proporcionando economia no consumo energético. Quando o MgO estiver em teores normais, seu valor ideal é 1,63, no qual todo o conteúdo desses óxidos entra em fusão à temperatura aproximada de $1300^{\circ} \mathrm{C}$ (Johansen 1977; Miller 1981; Taylor 1997).

\subsubsection{Componentes menores da farinha}

Além dos quatro óxidos principais, a farinha contém vários outros elementos ou compostos químicos, contidos nos diversos minerais. Alguns desses compostos, como $\mathrm{Na}_{2} \mathrm{O}, \mathrm{TiO}_{2}, \mathrm{CaF}_{2}$, conhecidos como mineralizadores, atuam como fundentes em pequenas quantidades, facilitando a clinquerização; porém, causam diversos problemas se presentes em quantidades maiores. Outros, podem causar combinações químicas indesejáveis, como a formação de $\mathrm{CaSO}_{4}$ pelo excesso de $\mathrm{SO}_{3}$. Chatterjee (1979a; 1979b) estudou a interferência dos componentes menores, e apresenta os intervalos ideais de teores para alguns componentes, conforme mostrado na Tabela 2.3. Porém, esses limites podem sofrer pequenas variações entre os fabricantes em função das características das matérias-primas e das condições operacionais. 
Tabela 2.3 - Limites ideais para os teores de componentes menores do clínquer.

\begin{tabular}{|c|c|}
\hline Componente & Limites ideais para os teores (\%) \\
\hline $\mathrm{Cr}_{2} \mathrm{O}_{3}$ & $0,3-0,5$ \\
\hline $\mathrm{SO}_{3}$ & $0,5-2,0$ \\
\hline $\mathrm{Na}_{2} \mathrm{O}$ & $0,2-0,3$ \\
\hline $\mathrm{BaO}$ & $0,5-1,0$ \\
\hline $\mathrm{TiO}_{2}$ & $1,5-2,0$ \\
\hline $\mathrm{P}_{2} \mathrm{O}_{5}$ & $<\sim 1,0$ \\
\hline $\mathrm{F}^{-}$ & $<\sim 1,0$ \\
\hline $\mathrm{Cl}^{-}$ & $0,3-0,5$ \\
\hline
\end{tabular}

Modificado de Chatterjee (1979b)

\subsubsection{0 clínquer Portland}

O clínquer de cimento Portland pode ser definido como uma rocha artificial, resultante de um conjunto de reações sofridas pela fina mistura de calcário, argila e eventuais corretivos silicosos, aluminosos e/ou ferriferos, com a formação de novos minerais. As reações ocorrem em estado sólido, com fusão parcial dos componentes, num processo de calcinação em temperaturas próximas de $1450^{\circ} \mathrm{C}$, seguida de sinterização e peletização (Braga 1973; Kihara et al. 1990; Centurione 1993; Pliskin 1993).

Segundo Kihara \& Valarelli (1975), o processo, com reações por difusão iônica, é semelhante à anatexia, sendo comparável ao metamorfismo de alto grau de rochas calcárias e argilosas finamente divididas. Nessas reações, os carbonatos, silicatos e óxidos que compõem a farinha são essencialmente transformados em quatro fases cristalinas: os silicatos bi e tricálcicos, o aluminato tricálcico e o ferroaluminato tetracálcico ou brownmillerita.

Os componentes do clínquer são mostrados na Tabela 2.4. A Tabela 2.5 mostra as proporções ponderais de cada componente do clínquer. A Figura 2.8 ilustra a seqüência de reações que ocorrem no interior de um forno de clínquer e a Figura 2.9 mostra os intervalos de estabilidade dos componentes em função da temperatura. 


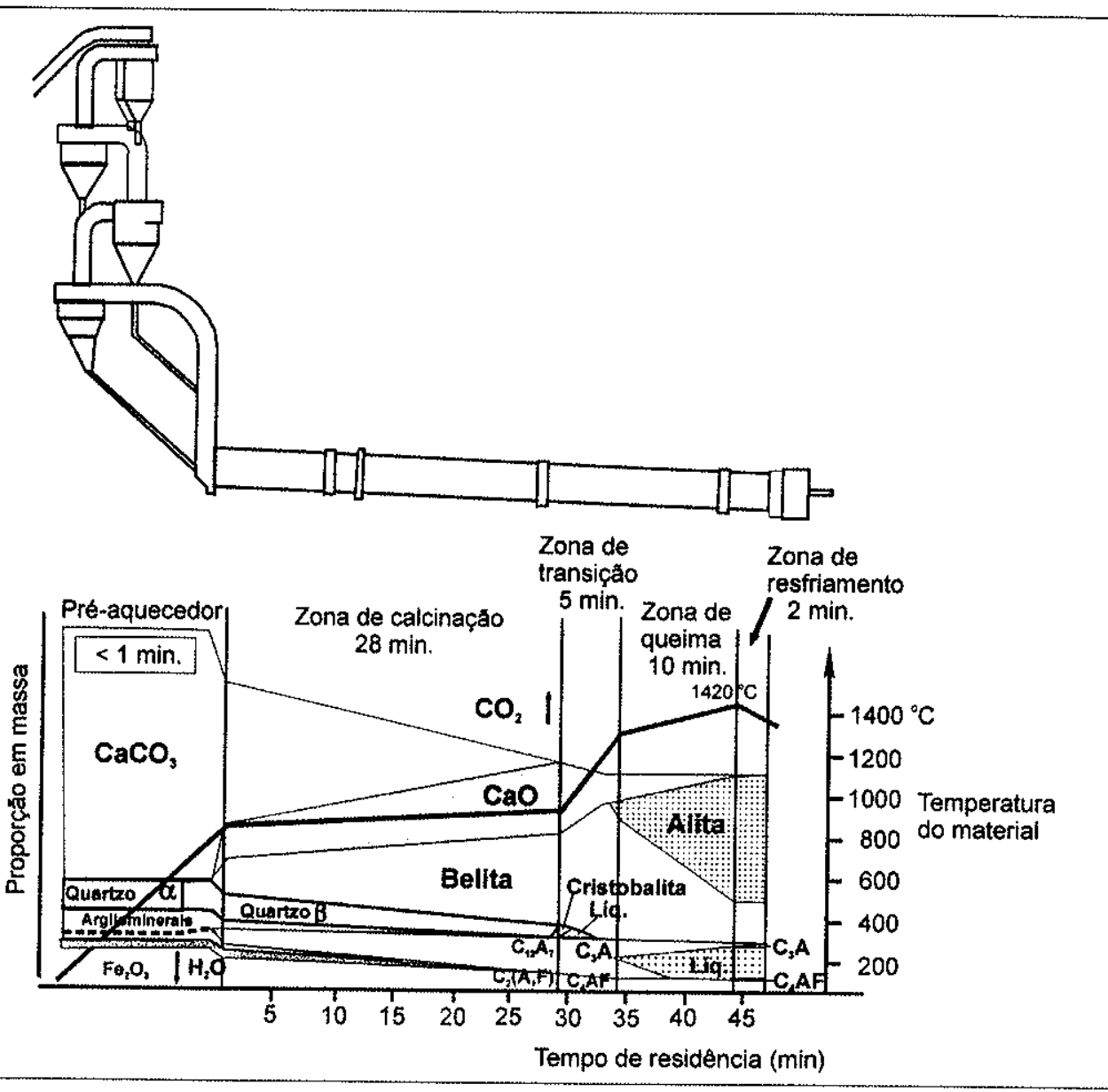

Figura 2.8 - Sequência de reações que ocorrem nas zonas de um forno de via seca (modificado de Wolter 1985).

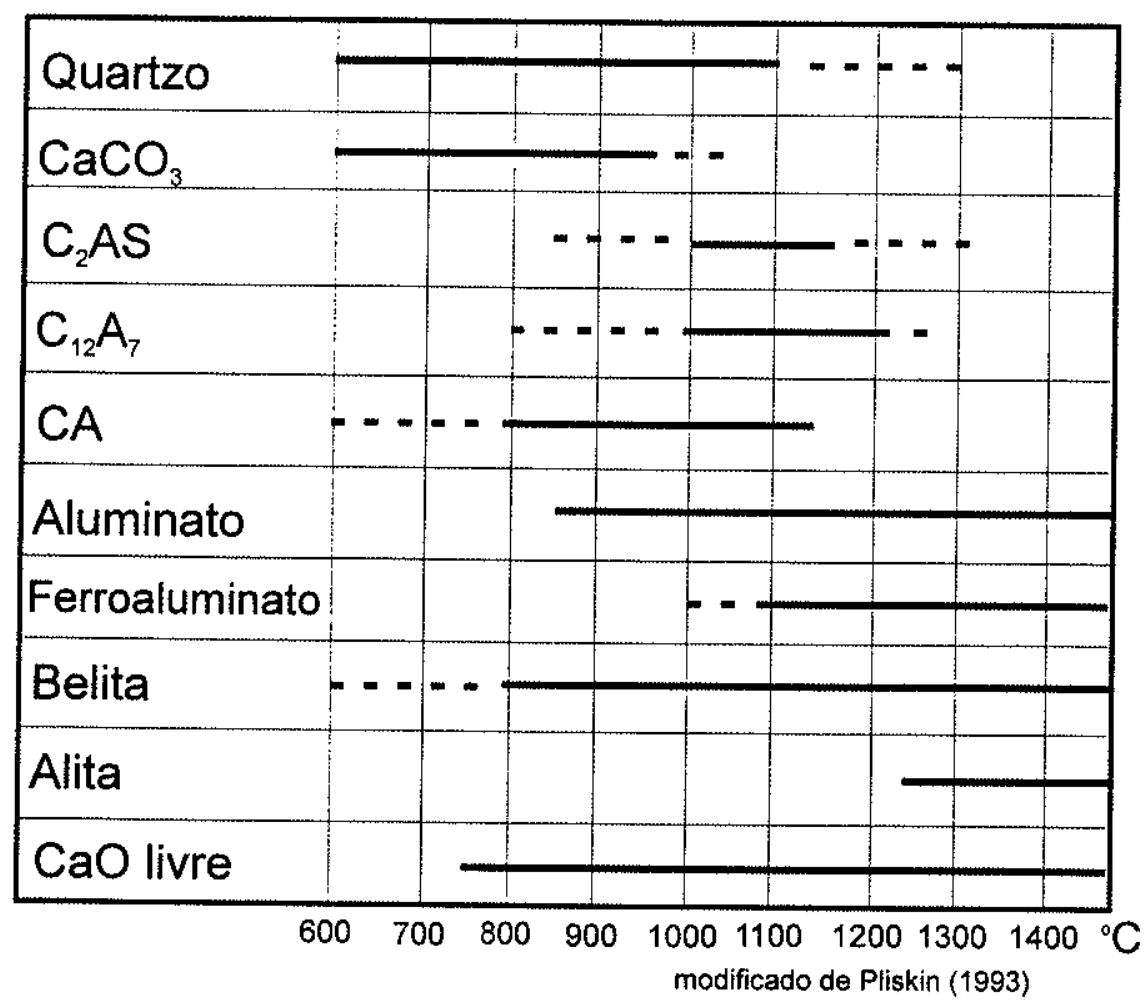

Figura 2.9 - Intervalos de temperatura de estabilidade dos diferentes compostos no forno. 
Tabela 2.4 - Principais fases cristalinas do clínquer Portland.

\begin{tabular}{|c|l|l|}
\hline Notação & \multicolumn{1}{|c|}{ Nome } & \multicolumn{1}{|c|}{ Fórmula química } \\
\hline $\mathrm{C}_{3} \mathrm{~S}$ & Silicato tricáicico ou alita & $3 \mathrm{CaO} . \mathrm{SiO}_{2}$ \\
\hline $\mathrm{C}_{2} \mathrm{~S}$ & Silicato bicálcico ou belita & $2 \mathrm{CaO} . \mathrm{SiO}_{2}$ \\
\hline $\mathrm{C}_{3} \mathrm{~A}$ & Aluminato tricálcico & $3 \mathrm{CaO} \cdot \mathrm{Al}_{2} \mathrm{O}_{3}$ \\
\hline $\mathrm{C}_{4} \mathrm{AF}$ & $\begin{array}{l}\text { Ferroaluminato tetracálcico ou } \\
\text { brownmillerita }\end{array}$ & $4 \mathrm{CaO} \cdot \mathrm{Al}_{2} \mathrm{O}_{3} \cdot \mathrm{Fe}_{2} \mathrm{O}_{3}$ \\
\hline
\end{tabular}

Modificado de Pliskin (1993)

Tabela 2.5 - Proporções ponderais dos principais componentes do clínquer.

\begin{tabular}{|c|c|c|c|c|}
\hline $\begin{array}{c}\text { Composição } \\
\text { (\% peso) }\end{array}$ & $\mathrm{C}_{3} \mathrm{~S}$ & $\mathrm{C}_{2} \mathrm{~S}$ & $\mathrm{C}_{3} \mathrm{~A}$ & $\mathrm{C}_{4} \mathrm{AF}$ \\
\hline Teor minimo & 40 & 0 & 2 & 0 \\
\hline Teor médio & 60 & 15 & 8 & 8 \\
\hline Teor máximo & 70 & 30 & 15 & 15 \\
\hline
\end{tabular}

Os principais constituintes mineralógicos do clínquer são:

Alita: nome dado às diferentes formas do silicato tricálcico $\left(C_{3} S\right)$. É formada pela reação sólido-sólido entre cristais de cal livre e belita. É um nesossilicato artificial, com estrutura definida por tetraedros independentes de $\mathrm{SiO}_{4}$ unidos por ions intersticiais de cálcio, formando cristais geralmente tabulares, compactos e idiomórficos, com seção hexagonal. Pode ter pequenas inclusões de óxidos estranhos como $\mathrm{MgO}, \mathrm{Al}_{2} \mathrm{O}_{3}, \mathrm{Fe}_{2} \mathrm{O}_{3}$, $\mathrm{TiO}_{2}, \mathrm{P}_{2} \mathrm{O}_{5}, \mathrm{SO}_{3}, \mathrm{Na}_{2} \mathrm{O}, \mathrm{K}_{2} \mathrm{O}$ e outros. Desempenha importante papel no endurecimento e na resistência mecânica do cimento.

Belita: nome dado à solução sólida envolvendo o silicato bicálcico $\left(C_{2} S\right)$. em suas diferentes formas polimórficas, estabilizadas pela presença de óxidos estranhos como $\mathrm{MgO}, \mathrm{Al}_{2} \mathrm{O}_{3}, \mathrm{Fe}_{2} \mathrm{O}_{3}, \mathrm{TiO}_{2}, \mathrm{P}_{2} \mathrm{O}_{5}, \mathrm{SO}_{3}, \mathrm{Na}_{2} \mathrm{O}, \mathrm{K}_{2} \mathrm{O}, \mathrm{Cr}_{2} \mathrm{O}_{3}, \mathrm{Mn}_{2} \mathrm{O}_{3}, \mathrm{BaO}$ e outros. É importante para a resistência mecânica a longo prazo do cimento. Quando o teor de belita supera $50 \%$, o cimento recebe o nome de clínquer belítico, produzido com menor consumos energético, porém, com diminuição das características hidráulicas. Os cristais têm estrutura semelhante à da alita, mas apresentam-se comumente em formas arredondadas ao microscópio. 
Aluminato tricálcico: abreviado como $\mathrm{C}_{3} \mathrm{~A}$, é um dos componentes do clínquer formado a partir da cristalização do material que se funde durante o processo de clinquerização (fase líquida). Seu sistema cristalino é o cúbico e a sua estrutura admite óxidos estranhos como $\mathrm{MgO}, \mathrm{SiO}_{2}, \mathrm{Al}_{2} \mathrm{O}_{3}, \mathrm{Fe}_{2} \mathrm{O}_{3}, \mathrm{TiO}_{2}, \mathrm{Na}_{2} \mathrm{O}, \mathrm{K}_{2} \mathrm{O}$ e outros em proporções de até $10 \%$ em massa.

Brownmillerita: também chamado de ferroaluminato tetracálcico ou ferrita. Dá a cor acinzentada ao cimento devido à presença do ferro, sendo praticamente ausente nos clínqueres brancos, e inferior a $15 \%$ nos demais. Correspondente a um termo da solução sólida entre os extremos $\mathrm{C}_{2} \mathrm{~F}$ (ou $\mathrm{Ca}_{2} \mathrm{Fe}_{2} \mathrm{O}_{5}$ ) e o "hipotético" $\mathrm{C}_{2} \mathrm{~A}$ (ou $\mathrm{Ca}_{2} \mathrm{Al}_{2} \mathrm{O}_{5}$ ), sendo basicamente representada pelo $C_{2} A F$. $A$ forma mais estável, usada para representar a solução sólida, aparenta ser a $\mathrm{C}_{4} \mathrm{AF}\left(\mathrm{Ca}_{4} \mathrm{Al}_{2} \mathrm{Fe}_{2} \mathrm{O}_{10}\right)$. Cristaliza-se também a partir da fase intersticial fundida, formando cristais irregulares nos interstícios dos silicatos. Tem estrutura complexa, com camadas de octaedros $\left(\mathrm{FeO}_{6}\right.$ ou $\left.\mathrm{AlO}_{6}\right)$ intercaladas por cadeias de tetraedros $\left(\mathrm{FeO}_{4}\right.$ Ou $\left.\mathrm{AlO}_{4}\right)$. Os vazios na estrutura são preenchidos por íons $\mathrm{Ca}$ e podem incorporar, também, elementos como $\mathrm{Mg}, \mathrm{Si}, \mathrm{Ti}$, $\mathrm{Mn}$ e $\mathrm{Cr}$. Embora tenha baixa reatividade hidráulica, esta fase caracteriza-se por conferir resistência à corrosão química do cimento.

Além desses componentes principais, o clínquer Portland apresenta os seguintes constituintes mineralógicos secundários:

Cal livre: apresenta-se na proporção média de $1 \%$. É considerada indesejável a partir de $2 \%$, podendo provocar, durante a hidratação, a formação de Portlandita $[\mathrm{Ca}(\mathrm{OH}) 2)]$, causando a expansão do cimento. Seu excesso reflete condições inadequadas no processo de clinquerização, e a porcentagem de cal livre é usada como parâmetro para a avaliação das condições do processo, conforme mostrado em 2.3.2.

Periclásio: típico de clínqueres ricos em MgO. Quando o teor de Mgo for superior a aproximadamente $2 \%$, ○ material excedente cristaliza como periclásio $(\mathrm{MgO})$. Este, é praticamente inerte no processo de hidratação, mas o seu excesso é indesejável porque sofre lenta expansão no concreto.

Todos esses constituintes podem ser estudados por microscopia de luz refletida, em seçס̄es polidas atacadas com reagentes como $\mathrm{KOH}+$ sacarose e $\mathrm{HNO}_{3}$, para ressaltar determinadas feições. 


\subsection{TIPOS DE CIMENTO PORTLAND FABRICADOS NO BRASIL}

Segundo informações da $A B C P$, via Internet, os tipos de cimento Portland fabricados no Brasil são os constantes da Tabela 2.6 a seguir:

Tabela 2.6 - Tipos de cimento Portland fabricados no Brasil

\begin{tabular}{|c|c|c|c|c|c|c|}
\hline \multicolumn{7}{|c|}{ TIPOS } \\
\hline \multicolumn{7}{|c|}{ CIMENTO PORTLAND COMUM (NBR 5732) } \\
\hline $\begin{array}{l}\text { CIMENTO PORTLA } \\
\text { CP II-E - Cimentc } \\
\text { CP H-Z - Cimentc } \\
\text { CP II-F - Cimentc }\end{array}$ & $\begin{array}{l}\text { D COMP } \\
\text { Portland } \\
\text { Portland } \\
\text { Portland }\end{array}$ & $\begin{array}{l}\text { TTO (NBI } \\
\text { mposto c } \\
\text { mposto c } \\
\text { mposto c }\end{array}$ & $\begin{array}{l}578) \\
\text { Escória } \\
\text { Pozolane } \\
\text { Filer }\end{array}$ & & & \\
\hline \multicolumn{7}{|c|}{ CIMENTO PORTLAND DE ALTO-FORNO: CP III (NBR 5735) } \\
\hline \multicolumn{7}{|c|}{ CIMENTO PORTLAND POZOLÂNICO: CP IV (NBR 5736) } \\
\hline \multicolumn{7}{|c|}{$\begin{array}{l}\text { CIMENTO PORTLAND BRANCO (NBR 12989) } \\
\text { CPB Cimento Portland Branco (Não Estrutural e Estrutural) }\end{array}$} \\
\hline \multicolumn{7}{|c|}{ CIMENTO PORTLAND DE ALTA RESISTÉNCIA INICIAL: CP V-ARI (NBR 5733) } \\
\hline \multicolumn{7}{|c|}{$\begin{array}{l}\text { CIMENTO PORTLAND RESISTENTE A SULFATOS (NBR 5737) } \\
\text { São designados pela sigla original de seu tipo acrescida de RS } \\
\text { Por exemplo: CP I-S-32 RS, CP III-32 RS, CP V-ARI RS }\end{array}$} \\
\hline \multicolumn{7}{|c|}{ CLASSES } \\
\hline & & \multicolumn{5}{|c|}{ Resistência à Compressão } \\
\hline Cimento & Classe & $\begin{array}{r}1 \mathrm{dia} \\
\text { (MPa) }\end{array}$ & $\begin{array}{l}3 \text { dias } \\
(\mathrm{MPa}) \\
\end{array}$ & $\begin{array}{l}7 \text { dias } \\
\text { (MPa) }\end{array}$ & $\begin{array}{c}28 \text { dias } \\
(\mathrm{MPa})\end{array}$ & $\begin{array}{l}91 \text { dias } \\
(\mathrm{MPa})\end{array}$ \\
\hline $\mathrm{CPI}$ & 25 & - & $\geq 8,0$ & $\geq 15,0$ & $\geq 25,0$ & - \\
\hline CPI-S & $\begin{array}{l}32 \\
40\end{array}$ & & $\begin{array}{l}\geq 10,0 \\
\geq 15,0\end{array}$ & $\begin{array}{l}\geq 20,0 \\
\geq 25,0\end{array}$ & $\begin{array}{l}\geq 32,0 \\
\geq 40,0\end{array}$ & \\
\hline$C P \|-E$ & 25 & - & $\geq 8,0$ & $\geq 15,0$ & $\geq 25,0$ & - \\
\hline$C P \|-Z$ & 32 & & $\geq 10,0$ & $\geq 20,0$ & $\geq 32,0$ & \\
\hline$C P \|-F$ & 40 & & $\geq 15,0$ & $\geq 25,0$ & $\geq 40,0$ & \\
\hline CP III & 25 & - & $\geq 8,0$ & $\geq 15,0$ & $\geq 25,0$ & $\geq 32,0^{(1)}$ \\
\hline & 32 & & $\geq 10,0$ & $\geq 20,0$ & $\geq 32,0$ & $\geq 40,0^{(1)}$ \\
\hline & 40 & & $\geq 12,0$ & $\geq 23,0$ & $\geq 40,0$ & $\geq 48,0^{(1)}$ \\
\hline CPIV & 25 & - & $\geq 8,0$ & $\geq 15,0$ & $\geq 25,0$ & $\geq 32,0^{(1)}$ \\
\hline (NBR 5736) & 32 & & $\geq 10,0$ & $\geq 20,0$ & $\geq 32,0$ & $\geq 40,0^{(1)}$ \\
\hline CPB-E (estrutural) & 25 & - & $\geq 8,0$ & $\geq 15,0$ & $\geq 25,0$ & - \\
\hline & 32 & & $\geq 10,0$ & $\geq 20,0$ & $\geq 32,0$ & \\
\hline & 40 & & $\geq 15,0$ & $\geq 25,0$ & $\geq 40,0$ & \\
\hline CP V-ARI & & $\geq 14,0$ & $\geq 24,0$ & $\geq 34,0$ & - & - \\
\hline
\end{tabular}

(1) Ensaio Facultativo (1 MPa (megapascal) $=10,1977 \mathrm{kgf} / \mathrm{cm}^{2}$ ). 


\section{CAPÍTULO 3}

\section{GEOLOGIA REGIONAL}

A geologia da região caracteriza-se, fundamentalmente, pelas rochas metassedimentares e metabasitos proterozóicos do Grupo São Roque. Essa seqüência acha-se parcialmente sotoposta, em sua parte NNW, às rochas sedimentares permocarboníferas do Subgrupo Itararé, da Bacia Sedimentar do Paraná. Rochas granitóides, formando batólitos e stocks, acham-se intrudidas nas rochas do Grupo São Roque. Ocorrem também na região intrusões de rochas alcalinas datadas do Cretáceo Inferior, sendo o exemplo mais notável a de Ipanema. São observáveis, ainda, evidências de sills e diques de diabásio possivelmente juro-cretácicos. Localmente, são observadas coberturas sedimentares provavelmente cenozóicas, ainda pouco estudadas, e aluviões recentes. A leste e a sudeste da região ocorrem litologias do Complexo Embu, representadas por rochas metassedimentares migmatizadas.

A presente síntese resulta da pesquisa efetuada nas obras de autores que abordaram diferentes aspectos da geologia da região e adjacências, como Knecht (1943a, 1944,1950, 1960), Coutinho (1972,1980), Franco (1958), Cordani et al. (1963), Setzer (1960), Cordani et al. (1967), Amaral et al. (1967), Hennies et al. (1967), Flicíssimo Jr. (1967), Hasui et al. (1969), Hasui \& Hama (1972), Hasui \& Sadowski (1976), Wernick et al. (1976), Hasui et al. (1978), Hasui et al. (1980), Hasui et al. (1981), Ulbrich e Gomes (1981), Figueiredo et al. (1982), Petri \& Fúlfaro (1983), Couto (1984), Carneiro et al. (1984), Hasui \& Oliveira 1984, Tassinari et al. (1985), Campos Neto (1985), Van Schumus et al. (1986), Wernick e Galembeck (1986), Bergmann (1988, 1992), Soares (1988), Godoy (1989), Campos Neto et al. (1990), Instituto Geológico-SMA (1990a; 1990b), Frascá (1992), Hackspacher et al. (1992a, 1992b, 1992c), Oliveira et al. (1992), Hackspacher (1994), Juliani \& Beljavskis (1995), Silva (1997) e Souza (1997), e outros citados no decorrer do texto.

A Figura 3.1 apresenta o mapa geológico regional, obtido a partir dos dados de CPRM (1998), no qual foram agrupadas as subdivisões da Formação Piragibu. 
LEGENDA DO MAPA GEOLÓGICO REGIONAL

(Figura 3.1)

\section{CENOZÓICO}

Qa Aluviöes recentes

\section{PALEOZÓICO / MESOZÓICO \\ BACIA DO PARANÁ}

Ap Rochas alcalinas

\section{Subgrupo Itararé}

ItI Lamitos

Ita Arenitos

\section{PROTEROZÓICO - EOPALEOZÓICO \\ DOMÍNIO SÃO ROQUE}

\section{Rochas ígneas e metamórficas de contato}

Maciços granitóides

$\gamma_{\text {So Sorocaba }}$

$\gamma_{\text {Sf Säo Francisco }}$

$\gamma_{\mathrm{Pr}}$ Pirapora

$\gamma_{\text {Lv Lavras Velhas }}$

$\gamma_{\text {Sr Säo Roque }}$

\section{Grupo São Roque}

Bt Formação Boturuna: Metarenitos / metarcóseos

Pg Formação Piragibu

Rochas metassedimentarea ritmicas mais ou menos arcoseanas

Formação Pirapora do Bom Jesus

Metacalcários e metadolomitos; calcio-silicáticas subordinadas

Pj2 Filitos com intercalações de calciofilitos, mármores e quarztitos

Pj3 Calcio-silicáticas, mármores impuros, calciofilitos e calciarenitos

\section{Grupo Serra do Itaberaba}

Pp Formação Pedra Preta

Micaxistos, hornfels xistosos e xistos migmatizados

\section{DOMÍNIO AÇUNGUI}

Granada-muscovita-biotita-xistos finos a médios

\section{DOMÍNIO EMBU}

Rochas igneas granitóides

$\gamma_{\mathrm{SI}}$ Granito Serra do Lopes $\gamma_{\mathrm{Ib}}$ Granito Ibiúna

$\gamma_{\mathrm{Pi}}$ Suite Granitóide Piedade $\gamma_{\mathrm{Sb}}$ Granitóides São Sebastião

\section{Complexo Embu}

Rochas metapelíticas: biotita-quarzto-muscovita xistos e

granada-biotita xistos migmatizados 


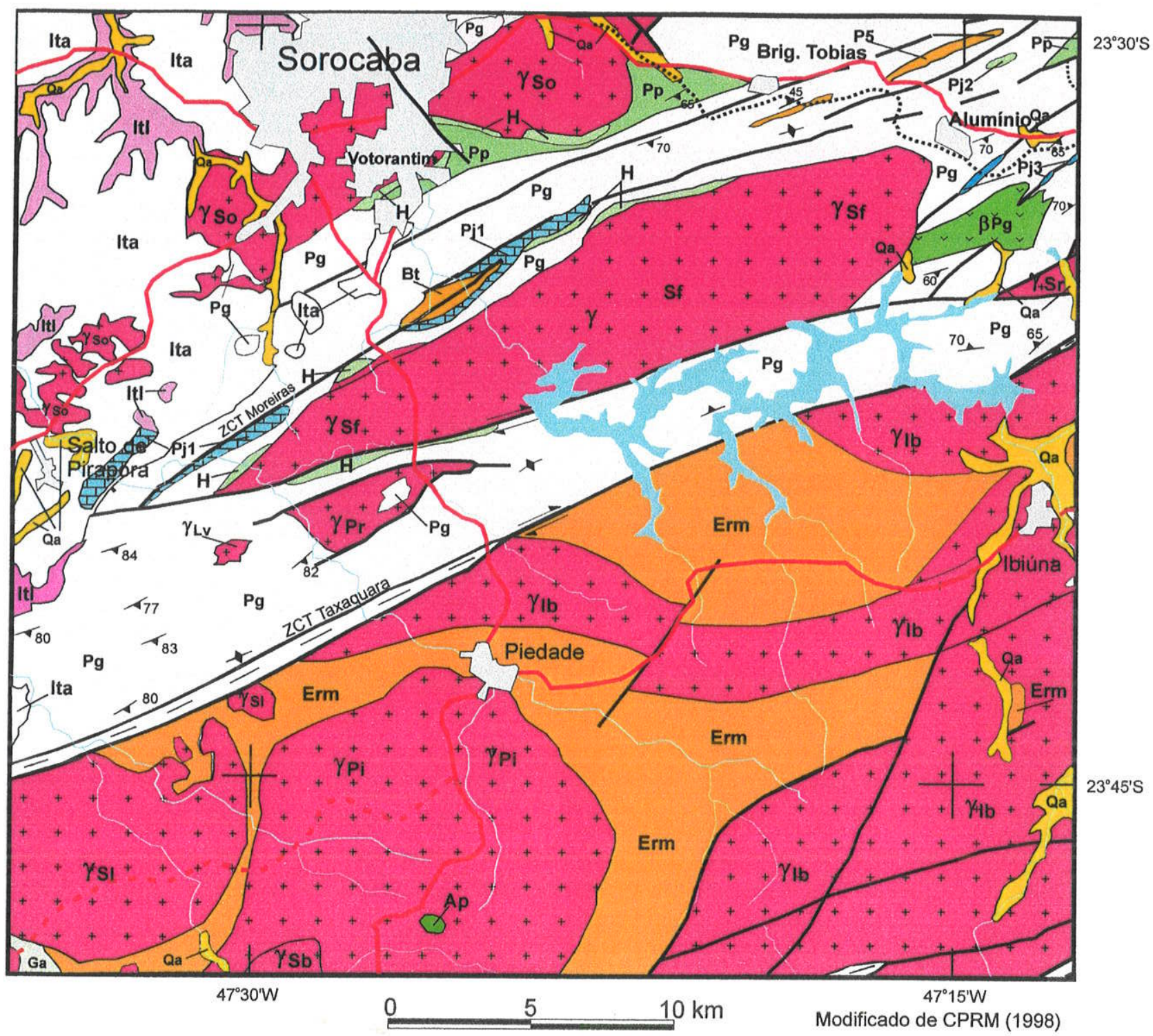

C O N VEN Ç Õ ES

$\sim$ Contato litológico

Falha ou fratura

Falha ou zona de cisalhamento com movimentação relativa indicada

Zona de rochas miloníticas

Foliação tectônica principal com mergulho medido

* Foliação tectônica principal com mergulho vertical $\square$ Cidade

.......** Estrada de ferro

Estrada pavimentada

Estrada não pavimentada

Drenagem

Reservatório

Lineamento

Figura 3.1 - Mapa geológico regional. 


\subsection{LITOLOGIAS}

Os epimetamorfitos do Grupo São Roque são principalmente representados por quartzitos e filitos sericíticos e grafitosos. Subordinadamente, ocorrem metacalcários, metadolomitos, metabasito, itabirito e metaconglomerado oligomítico. O conjunto é considerado originariamente vulcano-sedimentar marinho. Essas rochas, penetradas por batólitos e stocks graníticos, desenvolveram auréolas de metamorfismo de contato, nas quais ocorrem gnaisses, micaxistos feldspáticos, hornfels cálciossilicáticos, anfibolitos, quartzitos feldspáticos e mármore com biotita.

Os metapelitos, principalmente filitos, são as litologias mais abundantes. São comumente de cor acinzentada, essencialmente constituídos por quartzo e sericita. Ocasionalmente, podem conter carbonatos, transicionando para filitos carbonáticos, metamargas e mesmo calcários metamórficos.

As rochas carbonáticas ocorrem sob a forma de corpos lenticulares alongados segundo NE-SW. As rochas calcárias mais escuras correspondem a metacalcários e metacalcários magnesianos $e$, as mais claras, a metacalcários dolomíticos, metadolomitos calcíticos e metadolomitos. Constituem-se essencialmente de carbonatos em grãos mais ou menos equidimensionais, compondo um mosaico granoblástico. Os minerais acessórios são: quartzo, matéria carbonosa fina, muscovita, biotita e clorita. A quantidade de quartzo e de muscovita é às vezes elevada, constituindo os chamados filitos calcários. Às vezes, predomina o quartzo, constituindo quartzitos calcários ou calcários quartzosos. Associam-se a hornfels cálcio-silicáticos bordejando o Maciço de São Francisco desde a Serra de Inhaíba até a região de Salto de Pirapora.

As rochas psamíticas são representadas por corpos lenticulares de metarenitos e quartzitos, também orientados segundo NE-SW. Na região de Votorantim, camadas de quartzito apresentam quantidades expressivas de feldspato, merecendo designações de quartzito feldspático e metarcóseo. Os feldspatos são microclínio pertítico e oligoclásio.

Um corpo de metabasito ocorre na borda SE do Maciço Granítico de São Francisco. Esse corpo exibe, em sua parte leste, rochas de granulação fina a média, cor verde escura, constituídas por labradorita sódica, quase totalmente saussuritizada, em arranjo sem orientação preferencial. O máfico presente é actinolita-tremolita 
poiquiloblástica, também alongada e sem orientação. Junto ao contato com o granitóide, a rocha se constitui de oligoclásio, em grãos subédricos e anédricos, mais ou menos equidimensionais, entre prismas de hornblenda, às vezes poiquiloblástica e sem orientação. Os acessórios são titanita, clorita, biotita, apatita, opacos e quartzo.

Os granitóides são representados pelos batólitos de Sorocaba, São Francisco, São Roque e Piedade, com composição variando de granítica a monzonítica. As rochas de granulação mais fina também apresentam variação semelhante, mas podem ser mais básicas, de natureza até quartzo-diorítica. Nos maciços de Sorocaba e São Francisco, aparecem ocasionalmente massas de dezenas a centenas de metros de extensão de metamorfitos como xenólitos.

A intrusão alcalina de Ipanema, com cerca de $13 \mathrm{~km}^{2}$ de área, é constituída por um núcleo de glimerito com veios tardios de aegirinito e sovito, contornado por um expressivo halo fenítico, em cuja porção interna ocorrem veios de glimerito e apatita. Diques de shonkinito cortam encaixantes e demais alcalinas. O corpo alcalino atravessa metamorfitos fenitizados do Grupo São Roque e arenitos do Subgrupo Itararé. Apresenta superficie profundamente intemperizada, com acúmulo residual de blocos de magnetita e silexito, e apatita disseminada em laterita. A sua idade minima, obtida em biotita do shonkinito, é de $123 \mathrm{Ma}$.

A cerca de $10 \mathrm{~km}$ a SSW de Piedade, ocorre uma intrusão alcalina elíptica (sienito) com cerca de $0,25 \mathrm{~km}^{2}$, alongada segundo $E-W$ e encaixada no Granito Piedade. Na superfície, só se observam produtos de alteração como magnetita, silexito, barita e apatita. Pouco a $W$ do corpo, um dique de shonkinito pórfiro corta as rochas granitóides do Batólito de Ibiúna. A datação K-Ar do shonkinito forneceu idade de $120 \mathrm{Ma}$.

As rochas permo-carboníferas do Subgrupo Itararé são representadas na região por arenitos predominantes, lamitos, folhelhos e conglomerados flúvio-glaciais e lacustrino-glaciais.

Os sedimentos finos e avermelhados, presumidamente terciários, têm ocorrências restritas e irregulares, tendo sido pouco estudados na região. Aparentemente, estão associados a pequenas bacias relacionadas a movimentos neotectônicos. Silva (1997) os relaciona a possíveis restos de sills de diabásio, assim como Setzer (1960). Possivelmente, são correlacionáveis aos sedimentos cenozóicos 
descritos por Bjornberg et al. (1971), Fúlfaro \& Suguio (1974), Melo \& Ponçano (1983) e Melo (1995) em outras regiões do Estado. Segundo estes autores, esses sedimentos estariam relacionados a basculamentos tectônicos de blocos, dentro de um contexto neotectônico.

Aluviões recentes associam-se aos cursos d'água atuais, geralmente de forma descontínua e irregular.

\subsection{ESTRATIGRAFIA}

Embora não se pretenda, na presente pesquisa, analisar o mérito das propostas de subdivisão estratigráfica do Grupo São Roque, foram levantadas as mais recentes propostas em relação à mesma. A subdivisão estratigráfica do Grupo São Roque é muito dificultada pela intensa deformação das rochas, imbricando as litologias em várias escalas e colocando lado a lado, por empilhamento tectônico, unidades que não apresentam continuidade estratigráfica. Bergmann (1988) propôs, em estudos realizados na região de Pirapora do Bom Jesus, subdividir o Grupo São Roque em três formações, da base para o topo:

-Formação Pirapora: pilha de rochas metavulcânicas e sub-vulcânicas de caráter básico toleítico e rochas piroclásticas subordinadas, com um Membro Carbonático a cálciofilitos e metadolomitos a estromatólitos;

-Formação Estrada dos Romeiros: em contato transicional com a anterior, com um membro arenoso na base e um membro pelítico no topo;

-Formação Boturuna: Formação Boturuna: em contato brusco com a precedente, apresentando dois membros vulcânicos e dois membros arenosos.

A mesma autora considerou essas unidades como depositadas em ambiente associado a calhas rasas, do tipo rift intracontinental, numa provável margem continental passiva, com vulcanismo associado ao início de sua evolução. A sedimentação teria ocorrido no Proterozóico Inferior e o metamorfismo no Proterozóico Médio ou Superior.

Bergmann (1992) publicou revisão da litoestrafigrafia e do paleoambiente do Grupo São Roque na mesma região, definindo três unidades litoestratigráficas, nomeando-as Unidade Vulcano-sedimentar Basal, Unidade Clástica Turbiditica Superior e Unidade Clástica Alóctone. 
Hackspacher et al. (1992b), em estudos na mesma região, posicionaram na base do Grupo São Roque a Formação Estrada dos Romeiros, com siltitos e metaritmitos pelíticos, seguida pelos quartzitos e metassiltitos da Formação Boturuna, e pela Formação Pirapora, composta por rochas básicas toleíticas e calcários. Os mesmos autores consideram essas unidades depositadas no Proterozóico Inferior, com metamorfismo no Proterozóico Médio ou Superior.

Considerando essa subsidivisão, a área das minas da FCV-1 estaria incluída na Formação Pirapora, em contato possivelmente tectônico com a Formação Estrada dos Romeiros. As metabásicas, incluídas na última, são de ocorrência restrita na região de Santa Helena.

Juliani \& Beljavskis (1995), numa revisão, propuseram para a faixa São Roque/Serra do Itaberaba a separação de uma unidade metavulcanossedimentar, denominando-a Grupo Serra do Itaberaba, antes definida por Juliani (1993), subdividindo-a, da base para o topo, nas formações Morro da Pedra Preta, vulcanosedimentar e basal; Nhanguçu, superior e essencialmente composta por metapelitos com andaluzita ou manganesíferos com lentes subordinadas de rochas carbonáticas e cálcio-silicáticas; e Pirucaia, predominantemente quartzítica, possivelmente correspondente a litofácies depositada nas margens da bacia sedimentar, podendo ser cronocorrelata às duas citadas formações, particularmente à Nhanguçu.

No Grupo São Roque, os mesmos autores reconheceram as formações Piragibu, metapelítica, com raras lentes de metavulcânicas e metaconglomerados na sua base; Pirapora do Bom Jesus, predominantemente vulcânica e vulcanoclástica, com biohermas e cálcio-filitos; Estrada dos Romeiros, com metapelitos e metarenitos rítmicos; e Boturuna, essencialmente metarenítica/arcoseana.

CPRM (1998), em sua Carta Geológica 1:250.000, Folha de São Paulo (SF 23Y-C), subdivide o Grupo São Roque, na região do presente estudo, nas seguintes formações: Pirapora do Bom Jesus, basal, com rochas carbonáticas e cálcio-silicáticas; Piragibu, intermediária, com rochas metassedimentares rítmicas mais ou menos arcoseanas e metabasitos; e Estrada dos Romeiros, superior, com metapelitos e metarenitos rítmicos. Os micaxistos e hornfels xistosos junto à borda SE do Maciço Granítico Sorocaba foram posicionados na Formação Pedra Preta, unidade basal do 
Grupo Serra do Itaberaba. O Quadro 3.1 a seguir sintetiza as propostas de subdivisão estratigráfica dos grupos São Roque e Serra do Itaberaba.

Quadro 3.1 - Propostas de subdivisão estratigráfica dos grupos São Roque e Serra do Itaberaba.

\begin{tabular}{|c|c|c|c|c|c|}
\hline & $\begin{array}{l}\text { Bergmann } \\
(1988)\end{array}$ & $\begin{array}{l}\text { Bergmann } \\
(1992)\end{array}$ & $\begin{array}{l}\text { Hackspacher } \\
\text { et al. (1992b) }\end{array}$ & $\begin{array}{c}\text { Juliani e } \\
\text { Beljavskis } \\
(1995) \\
\end{array}$ & $\begin{array}{l}\text { CPRM } \\
(1998)\end{array}$ \\
\hline \multirow{3}{*}{$\begin{array}{l}\text { Grupo } \\
\text { Sæa } \\
\text { Roque }\end{array}$} & \begin{tabular}{|l|} 
Formaçăo \\
Boturuna \\
\end{tabular} & $\begin{array}{l}\text { Unicade clástica } \\
\text { alóctone }\end{array}$ & Formação Pirapora & \begin{tabular}{|l|} 
Formação \\
Boturuna \\
\end{tabular} & $\begin{array}{l}\text { Fm. Estrada } \\
\text { dos Romeiros }\end{array}$ \\
\hline & \begin{tabular}{|l|} 
Formação \\
Estrada dos \\
Romeiros
\end{tabular} & $\begin{array}{l}\text { Unidade clástica } \\
\text { turbidítica } \\
\text { Superior }\end{array}$ & Formação Boturuna & \begin{tabular}{|l|} 
Fomação \\
Pirapora do \\
Bom Jesus
\end{tabular} & Fm. Piragibu \\
\hline & $\begin{array}{l}\text { Formação } \\
\text { Pirapora }\end{array}$ & $\begin{array}{l}\text { Unidade vulcano } \\
\text { sedimentar basal } \\
\end{array}$ & $\begin{array}{l}\text { Formação Estrada } \\
\text { dos Romeiros }\end{array}$ & $\begin{array}{l}\text { Formação } \\
\text { Piragibu } \\
\end{array}$ & $\begin{array}{l}\text { Fm. Pirapora } \\
\text { do Bom Jesus }\end{array}$ \\
\hline $\begin{array}{l}\text { Grupo } \\
\text { Serra do } \\
\text { Itaberaba }\end{array}$ & & & & $\begin{array}{l}\text { Fm. Nhanguçu } \\
\text { Fm. Pirucaia } \\
\text { Fm. Morro da } \\
\text { Pedra Preta } \\
\end{array}$ & \begin{tabular}{|l|} 
Fm. \\
Nhanguçu \\
Fm. Morro da \\
Pedra Preta \\
\end{tabular} \\
\hline
\end{tabular}

Nota: O alinhamento horizontal das unidades geológicas năo significa, necessariamente, a correlaçăo lito-estratigráfica entre as mesmas.

\subsection{METAMORFISMO}

Os epimetamorfitos do Grupo São Roque são regionalmente metamorfizados na fácies xisto verde (Turner 1981). Litologias de fácies anfibolito são observadas apenas nas periferias de granitóides intrusivos. Nas rochas de fácies anfibolito, são comuns as associações mineralógicas em desequilíbrio, como biotita-clorita, plagioclásio com borda albítica ou saussuritizado, zoicita-clinozoisita, granada-clorita e sillimanitamuscovita. Essas associações são indicativas de um processo retrometamórfico em condições físicas bastante atenuadas.

Nas rochas carbonáticas mais puras e de granulação fina, evidências de metamorfismo são pouco visiveis. A pequena quantidade de quartzo provavelmente contribuiu para o escasso rearranjo mineral. A recristalização parcial da rocha é a evidência mais observável da ação metamórfica. Às vezes, nota-se a presença de talco nas fraturas, que podem exibir também carbonatos e quartzo recristalizados. Segundo Frascá (1992), a presença de abundantes romboedros de dolomita em algumas rochas carbonáticas poderia sugerir uma dolomitização secundária pela percolação de soluções magnesianas através de zonas de fraqueza.

Nas zonas de contato dos corpos granitóides com as rochas metassedimentares, desenvolveram-se auréolas de metamorfismo de contato, onde 
são também observados fenômenos pneumatolíticos e hidrotermais, como turmalinização, pegmatitos e presença de fluorita e de pirita.

Associado às zonas de cisalhamento, ocorreu o metamorfismo cataclástico, com o desenvolvimento de produtos variando do cataclasito ao ultramilonito. Tais zonas chegam a ter largura quilométrica em alguns setores.

\subsection{ESTRUTURAS}

Estruturalmente, a região faz parte da organização das áreas pré-cambrianas de São Paulo e Paraná, caracterizada pela segmentação em blocos por uma intensa rede de zonas de cisalhamento (ZCTs), que são as feições estruturais mais marcantes da região, com orientação predominante NE-SW e alto ângulo de mergulho. São zonas de comportamento dúctil-rúptil, com movimentação lateral dextral em regime não coaxial. Ao longo das mesmas, desenvolveu-se marcante foliação milonítica. As ZCTs mais importantes são as de Taxaquara, Pirapora, Mairinque, Araçariguama e Caucaia. As áreas das minas Placa, Pastinho e Mina 1 de Salto de Pirapora são afetadas pela ZCT secundária denominada Moreiras.

As rochas metassedimentares do Grupo São Roque, quando não afetadas pelas ZCTs, exibem o acamamento reliquiar So, acompanhado por uma foliação paralela a subparalela $\mathrm{S} n+1$. Essas estruturas são deformadas por conjuntos de dobras $D n+2$ e $\mathrm{Dn}+3$, com orientações predominantemente em torno de NE. O conjunto $\mathrm{Dn}+3$ exibe clivagem empinada nas proximidades das ZCTs. O auge metamórfico teria sido contemporâneo à fase Dn+3 (Oliveira et al. 1992).

As estruturas reliquiares observáveis são a estratificação plano-paralela, a laminação/estratificação cruzada, estrutura gradual e estrutura rítmica. A xistosidade apresenta direção regional NE-SW, com mergulhos variáveis para NW e SE. Crenulação e transposição são observáveis nos metapelitos, introduzindo ondulações adicionais visíveis em escala de afloramento ou microscópica.

As dobras observáveis em afloramentos são centimétricas a decamétricas, isoclinais ou cerradas, com planos axiais subverticais, com xistosidade também planoaxial. Apresentam adelgaçamento de flancos e espessamento de ápices. Quando há intercalação restrita de rochas mais competentes, como quartzitos, em pacotes de metapelitos, os últimos exibem padrões mais complexos de dobramento. No caso 
metapelitos, os últimos exibem padrões mais complexos de dobramento. No caso inverso, os metapelitos mostram dobras de arrasto ou parasiticas. Dobras maiores, em escala regional, apresentam-se com eixos NE-SW.

Juntas são observáveis em quatro ou cinco sistemas bem desenvolvidos:

- um sistemà subvertical e subtransversal à xistosidade;

- dois sistemas subverticais e obliquos à xistosidade, com a obliqüidade em torno de $50^{\circ}$

- um ou dois sistemas subhorizontais, com menos de $40^{\circ}$ de inclinação. Quando isoladamente observados nos afloramentos, aparentam tratar-se de juntas de alívio de carga, mas, quando observados em conjunto, apresentam-se opostamente inclinados, evidenciando relação com o mesmo regime de esforços causador dos anteriores.

\subsection{EVOLUÇÃO GEOLÓGICA}

Autores como Soares (1988) e Magalhães et al. (1995), interpretam a evolução geológica da porção leste do sul-sudeste brasileiro em estreita associação com a colisão de blocos crustais, com base na Teoria das Placas e apoio em evidências obtidas através de métodos geofísicos.

Para a região que compreende as áreas de estudo da presente pesquisa, teria ocorrido a colisão do chamado bloco Vitória, situado a ENE, com o bloco São Paulo, situado a WSW do primeiro e, em cuja borda teria ocorrido a sedimentação das rochas que hoje compõem o Grupo São Roque. A colisão, obliqua e de baixo ângulo, teria resultado no cavalgamento do bloco Vitória sobre o São Paulo (subducção do tipo A), provocando, em estado plástico, a desarticulação, o imbricamento e a lenticularização das unidades rochosas. Esse evento teria imposto às rochas uma primeira foliação (S1), do tipo milonítica, com direção geral ENE-WSW, com mergulhos baixos para SSE e paralela à sutura dos blocos colisionais. Devido à obliqüidade do movimento de cavalgamento, a lineação de estiramento (L1) apresenta direção EW.

A evolução dos eventos deformativos teria ocorrido não em fases isoladas no tempo, mas de maneira progressiva. Dentro desse princípio, numa etapa posterior, os maciços teriam se tornado progressivamente mais arrefecidos. Assim, o transporte de massas rochosas, que estaria ocorrendo de $E$ para $W$ em rampa oblíqua de baixo 
ângulo, teria sido gradativamente impedido, induzindo o aparecimento de diversas zonas de cisalhamento dúctil a dúctil-rúptil de alto ângulo de direção ENE-WSW. A foliação $S 1$ teria então sido verticalizada ou gerou uma nova foliação (S2), com o aparecimento de outra lineação de estiramento (L2). As zonas de cisalhamento de Taxaquara, Cubatão, Pirapora e outras seriam exemplos desse evento. A maioria dessas zonas tem direção NE-SW e caráter transcorrente dextral, compativel com 0 movimento de E para W do bloco Vitória. Segundo Magalhães et al. (1995), a ZCT de Moreiras, que afeta as regiões das Mina 1 de Salto de Pirapora e da mina Pastinho, enquadra-se nesse contexto.

As idades dos eventos deformativos e mesmo das unidades rochosas são ainda objeto de controvérsias. A sedimentação é atribuída, por autores como Hackspacher et al. (1992b) e Bergmann (1988), ao Proterozóico Inferior, com metamorfismo no Proterozóico Médio ou Superior. As grandes zonas de transcorrência teriam se desenvolvido no Proterozóico Superior - Eo-Cambriano. Juliani \& Beljavskis (1995) atribuem idade proterozóica média ao Grupo Serra do Itaberaba e superior ao Grupo São Roque.

No Fanerozóico, parte da região foi coberta pelos sedimentos do Supegrupo Itararé, da Bacia Sedimentar do Paraná. No Mezozóico, diques e sills de rochas básicas cortaram as rochas pré-existentes. No Cenozóico, basculamentos tectônicos de blocos teriam proporcionado a sedimentação das coberturas inconsolidadas. 


\section{CAPÍTULO 4}

\section{A ALTERAÇÃO SUPERFICIAL DAS ROCHAS}

\subsection{CONCEITOS GERAIS}

A superfície terrestre exposta é coberta, em grande parte, por produtos originários da destruição das rochas sob ação dos agentes atmosféricos e biológicos. $A$ transferência de matéria na epiderme dos continentes caracteriza o chamado ciclo supérgeno, que envolve intemperismo, pedogênese, erosão e sedimentação. Seus mecanismos fundamentais são a subtração e a adição de constituintes móveis durante o processo, cujas reações são controladas por três variáveis principais: as rochas, as águas meteóricas e os gases dissolvidos, principalmente $\mathrm{O}_{2}$ e $\mathrm{CO}_{2}$.

A água é o principal agente do intemperismo, promovendo a dissolução dos sais solúveis (de $\mathrm{Na}^{+}, \mathrm{K}^{+}, \mathrm{Mg}^{2+}, \mathrm{Ca}^{2+}$ e outros), a hidratação de certos íons ( $\mathrm{Fe}$ ) e sobretudo a hidrólise, que provoca o colapso das estruturas cristalinas pela retirada de cátions do edifício cristalino dos minerais (Nahon 1991; Melfi 1993).

Sendo a água é o agente intempérico mais importante, é evidente a importância das chuvas. Tardy (1986) apresenta $74,6 \mathrm{~mm}$ como média de precipitação anual nas áreas expostas, embora ocorram grandes variações segundo as diversas zonas climáticas. Segundo Melfi (1993), os extremos chegam a $12.400 \mathrm{~mm}$ na Índia e menos de $2 \mathrm{~mm}$ em algumas regiöes desérticas. Tardy (1986), comparando as porcentagens da precipitação que evapora com aquela que percola através do solo ou escoa na superficie, estimou em apenas $36 \%$ do total precipitado $(26,8 \mathrm{~mm})$ a quantidade média de água "efetiva", que participa como agente do intemperismo químico.

\subsubsection{As soluções aquosas superficiais e suas ações intempéricas}

Segundo Birot (1981), mesmo a água pura possui ação agressiva, dissociandose espontaneamente em íons $\mathrm{H}^{+}$e $\mathrm{OH}^{-}$e permitindo as reações de hidrólise. Em presença de sais, de ácidos ou de bases fortes, a ação de suas moléculas é suficiente para afastar os íons constitutintes (por exemplo, $\mathrm{NaCl} \Rightarrow \mathrm{Na}^{+}+\mathrm{Cr}$ ). As águas carregadas de substâncias orgânicas ácidas ou de $\mathrm{CO}_{2}$ são ainda mais agressivas aos minerais (Campy \& Macaire 1989). As características das soluções variam conforme a natureza dos materiais dissolvidos e de suas concentrações, definindo o mecanismo 
físico-químico de ataque aos minerais. Segundo Melfi (1993), essa relação pode ser resumida como mostrado no Quadro 4.1 a seguir.

Quadro 4.1 - Mecanismos físico-químicos de ataque em função das características das soluções naturais.

\begin{tabular}{|c|c|c|c|}
\hline $\begin{array}{c}\text { Mecanismo } \\
\text { Físico- } \\
\text { químico }\end{array}$ & \multicolumn{1}{|c|}{$\begin{array}{c}\text { Características gerais das } \\
\text { soluções superficiais }\end{array}$} & $\begin{array}{c}\mathrm{pH} \mathrm{da} \\
\text { solução }\end{array}$ & $\begin{array}{c}\text { Zona } \\
\text { climática }\end{array}$ \\
\hline Acidólise & $\begin{array}{l}\text { Águas ricas em ácidos orgânicos } \\
\text { hidrossolúveis (pk<pk Al) }\end{array}$ & $4-4,5$ & Fria \\
\hline Hidrólise & $\begin{array}{l}\text { Águas puras e carregadas em } \\
\mathrm{CO}_{2} \text { ou ainda reativos cujo pk }> \\
\text { pk Al }\end{array}$ & $5-6$ & Temperada \\
\hline Salinólise & $\begin{array}{l}\text { Águas carregadas em sais de } \\
\text { ácidos fortes (cloretos, sulfatos,...) }\end{array}$ & $>7$ & Desértica \\
\hline Alcalinólise & $\begin{array}{l}\text { Águas carregadas em sais de } \\
\text { ácidos fracos (carbonatos) }\end{array}$ & $5-6$ & Tropical \\
\hline
\end{tabular}

- $\mathrm{pk}=$ constante ácida dos elementos químicos $=-\log \mathrm{K}$, onde $\mathrm{K}=$ constante de ionização

Modificado de Melfi (1993)

Segundo Melfi (1993), os mecanismos de ataque aos minerais primários, citados no Quadro 4.1, diferem entre si pela maneira como os vários elementos participantes do processo aparecem na superficie, conforme descrição a seguir:

Acidólise: as soluções de ataque contêm reagentes ácidos ( $\mathrm{pk}<5$ ), podendo salificar

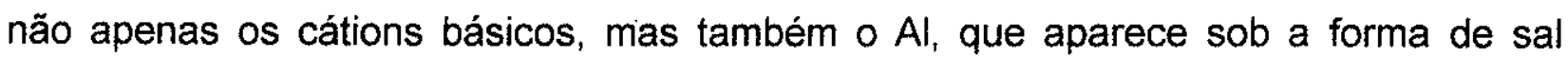
solúvel, dissociado em maior ou menor extensão.

Hidrólise: promove a extração e individualização do Al na forma de compostos insolúveis e fracamente ionizados, seja como hidróxidos livres ou sais básicos hidroxi aluminossilicatados. Sílica e cátions básicos permanecem em solução no estado de ácido não dissociado ou de bases altamente ionizadas.

Salinólise: típica de soluções mais concentradas, formadas por sais de ácidos e bases fortes. O tipo de evolução é semelhante à hidrólise. O cátion básico aparece como sal solúvel. 
Alcalinólise: as soluções contêm reagentes básicos (pk >9,6), conduzindo à individualização da sílica e do alumínio, liberados na forma de aluminatos e silicatos (ânions), que podem ser neutralizados pelos cátions básicos externos (da solução).

\subsubsection{Transformação e neoformação de minerais no perfil de intemperismo}

Segundo Campy \& Macaire (1989), o movimento dos íons no interior das alteritas se caracteriza pela formação dos chamados "complexos de alteração", constituídos pelos minerais argilosos, óxidos e hidróxidos, através de dois processos:

- transformação progressiva da estrutura e modificação do quimismo dos minerais primários, como é o caso dos filossilicatos;

- neoformação, através da cristalização de minerais a partir de elementos menos móveis em solução, com passagem eventual por um estado amorfo intermediário (gel).

A cinética da destruição dos minerais primários e a composição do "complexo de alteração" depende, acima de tudo, do clima. Os trabalhos de Pedro $(1964,1969)$, McFarlane (1976), Tardy et al. (1991), Tardy \& Roquin (1992), Tardy (1993) e outros pesquisadores resultaram no reconhecimento de domínios de alteração segundo as condições climáticas:

Alteração nula: nos climas frios das regiões polares ou quentes e secos dos desertos, os minerais primários praticamente não evoluem, predominando a desagregação física das rochas.

Bissialitização (hidrólise parcial): nos climas temperados e úmidos, os minerais são moderadamente afetados, dando origem a filossilicatos variados, sobretudo do tipo $2 / 1$, caracterizados por cela unitária com duas camadas de tetraedros de $\mathrm{SiO}_{4}$ e uma camada de octaedros de $\mathrm{Al}_{2}(\mathrm{OH})_{6}$, principalmente representados pela ilita, vermiculita, e esmectita (Santos 1992).

Monossialitização (hidrólise parcial): no clima tropical, quente e úmido, ocorre forte alteração dos minerais; o empobrecimento da alterita em sílica, mais solúvel do que $\mathrm{Al}$ e $\mathrm{Fe}$, leva à formação prefencial de filossilicatos $1 / 1$, com cela unitária de uma camada de tetraedros de $\mathrm{SiO}_{4}$ e uma camada de octaedros de $\mathrm{Al}_{2}(\mathrm{OH})_{6}$, principalmente representados pela caulinita e haloisita.

Alitização (hidrólise total): sob clima equatorial, muito quente e úmido, a alteração chega ao extremo, com a destruição total dos minerais primários e a eliminação quase 
completa da sílica, restando somente alguns acessórios resistentes. Somente os óxidos de Al e Fe permanecem próximos à superficie.

A Figura 4.1 ilustra a variação da natureza dos minerais neoformados em função das condições climáticas e hídricas.

A gênese dos minerais secundários é freqüentemente induzida por uma "evolução inicial" nos minerais originais, como albitização, sericitização e cloritização, que podem ser de origem superficial; porém, mais comumente de origem profunda (retrodiagênese ou alteração hidrotermal).

\subsubsection{Comportamento do ferro e do alumínio no intemperismo}

O ferro, que ocupa o quarto lugar entre os elementos mais abundantes da crosta continental ( $5 \%$ em peso), tem a sua solubilidade bastante reduzida na sua forma férrica $\left(\mathrm{Fe}^{3+}\right)$, no intervalo natural de $\mathrm{pH}(3,5$ a 9,5$)$, sendo praticamente insolúvel em pH acima de 6 (Melfi 1993; Thomas 1994). Esse comportamento do ferro é mostrado no gráfico de solubilidade comparada da $\mathrm{SiO}_{2}$ amorfa, do quartzo, do Al e do $\mathrm{Fe}$ em função do $\mathrm{pH}$ da Figura 4.2.

Diferentemente do alumínio, o Fe não se integra tão facilmente ao retículo cristalino dos filossilicatos argilosos, apresentando-se com freqüencia sob a forma de óxidos ou hidróxidos criptocristalinos ou cristalizados, como hematita, limonita, goethita, lepidocrocita e outros, à exceção da magnetita. A goethita e a hematita são os mais importantes, juntamente com amorfos.

O alumínio, mais abundante do que o ferro ( $8 \%$ em peso) apresenta, segundo Thomas (1994), comportamento similar ao do $\mathrm{Fe}$ como $\mathrm{Al}^{3+}$; entretanto, em $\mathrm{pH}$ acima de 8 , passa a $\mathrm{Al}(\mathrm{OH}) 4^{-}$e tem a sua solubilidade aumentada. $\mathrm{Com}$ pH nas condições de hidrólise, o $\mathrm{Al}$ assume a forma $\mathrm{Al}^{3+}$, menos solúvel, formando óxidos e hidróxidos; porém, Fe e Al têm suas solubilidades aumentadas na presença de ácidos orgânicos

Segundo Schwertmann (1983), o alumínio pode substituir o ferro nos óxidos mais comuns, sendo melhor observado na goethita, mas tem sido constatada em hematita, lepidocrocita e até mesmo em magnetita. 


\section{ZONALIDADE MINERALÓGICA LATITUDINAL Influência das condições hidroclimáticas}

Aumento da pluviosidade e da velocidade de infiltração

$\begin{array}{ll}\text { Zona } & \text { Zona } \\ \text { árida } & \text { tropical úmida }\end{array}$

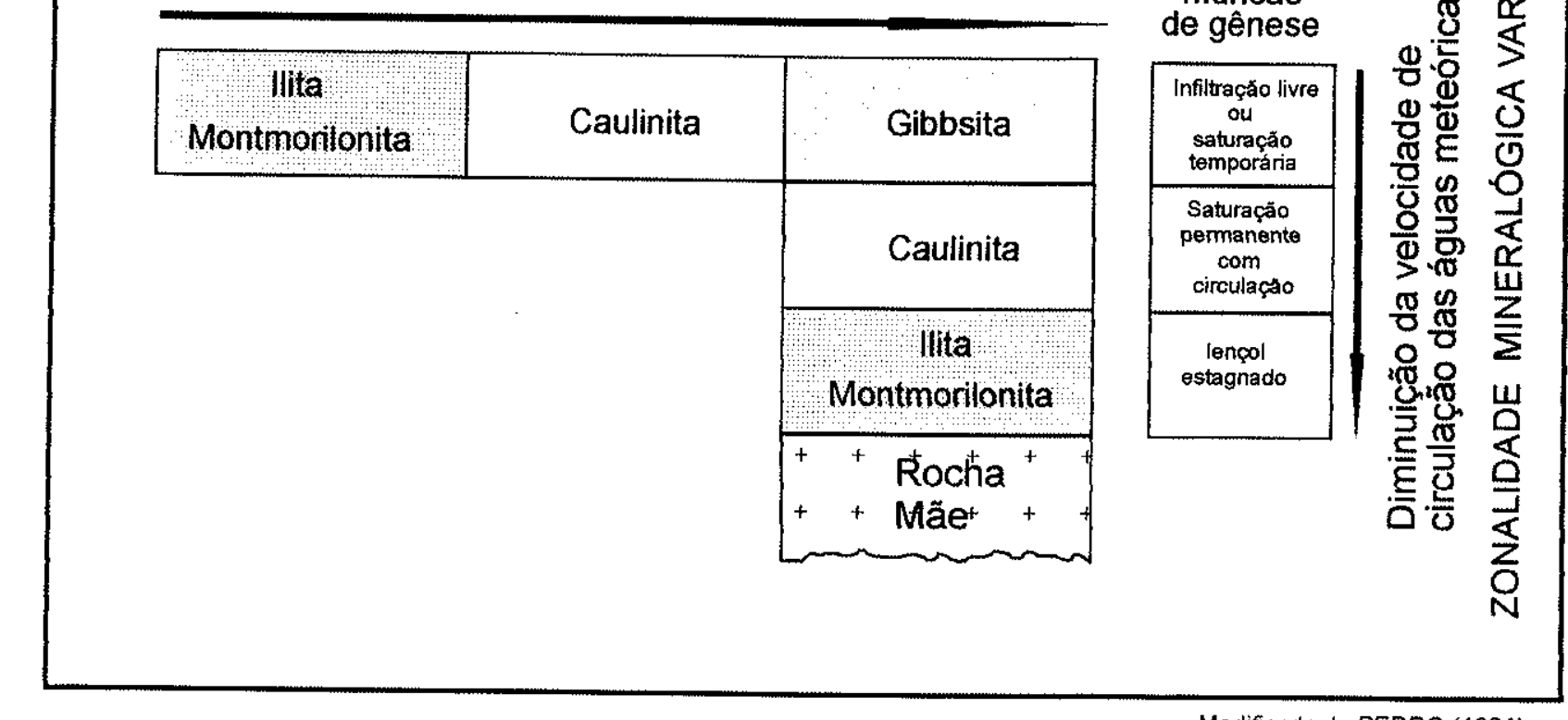

Montmorilonita

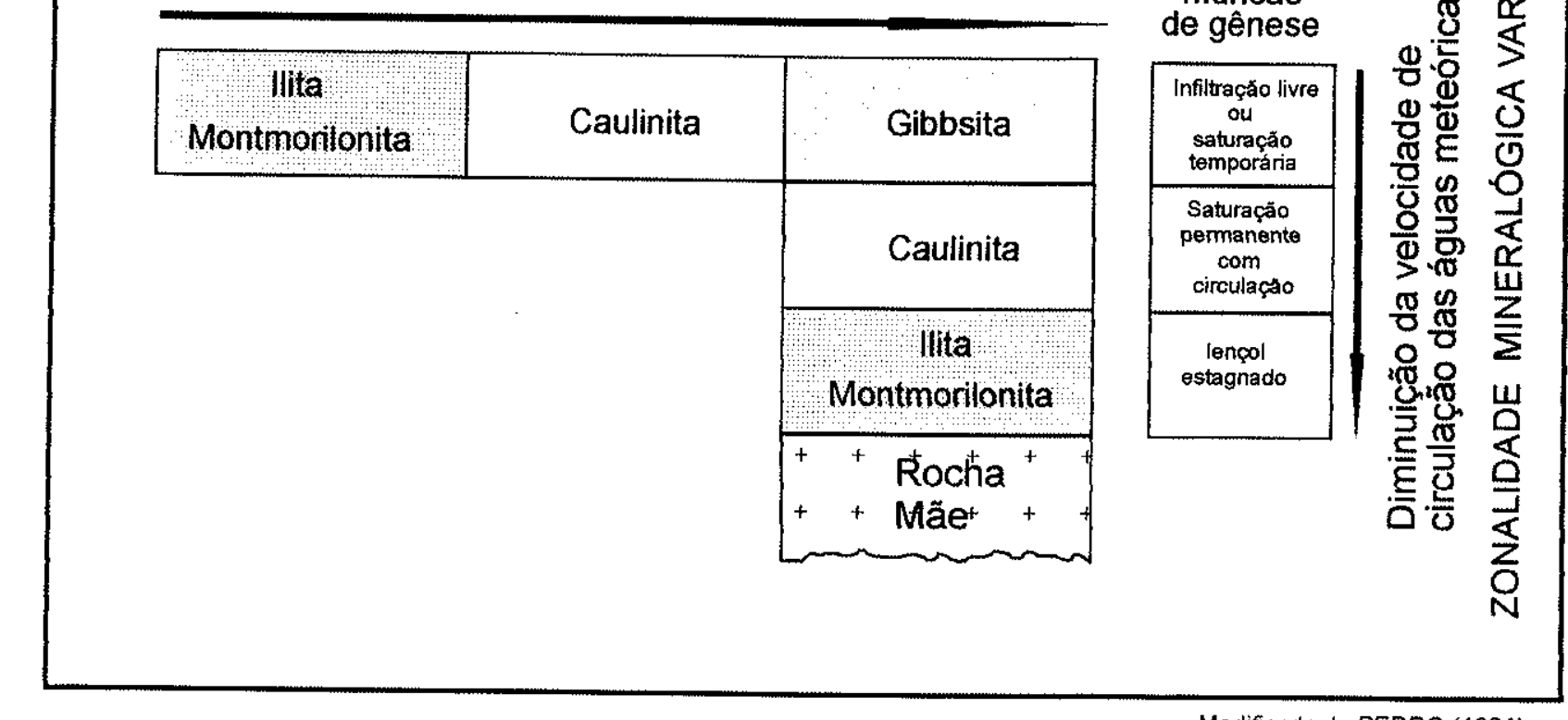

Exemplos

das condiçōes

hidricas
de gênese

Modificado de PEDRO (1964)

Figura 4.1 - Variação da natureza dos minerais neoformados em função das condições climáticas e hídricas.

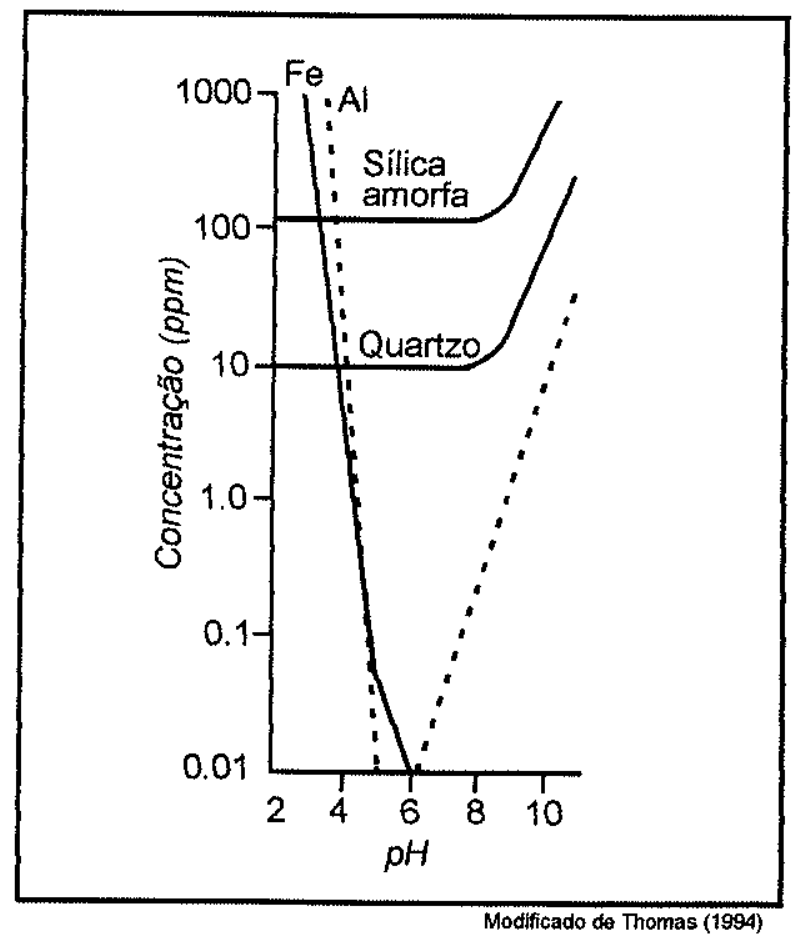

Figura 4.2 - Solubilidade da sílica amorfa, do quartzo, do ferro e do alumínio em função do $\mathrm{pH}$. 


\subsubsection{Dissolução da sílica}

A sílica pode se apresentar em diferentes graus de cristalinidade na natureza, variando do quartzo, a forma mais ordenada, à sílica amorfa, passando por tipos intermediários como a opala. A solubilidade da sílica é inversamente proporcional à sua cristalinidade (Krauskopf 1972; Birot 1981; Melfi 1993).

A dissolução da sílica se processa por hidrólise, segundo a reação:

$$
\mathrm{SiO}_{2}+2 \mathrm{H}_{2} \mathrm{O} \Leftrightarrow \mathrm{H}_{4} \mathrm{SiO}_{4} \quad \text { (despolimerização) }
$$

(ácido silícico)

O ácido silícico, embora muito mais fraco, apresenta analogias com o ácido carbônico $\left(\mathrm{H}_{2} \mathrm{CO}_{3}\right)$, exceto pelo fato de a sua molécula conter uma molécula adicional de água. $\mathrm{Em} \mathrm{pH}$ acima de 9, dissocia-se em:

$$
\mathrm{H}_{4} \mathrm{SiO}_{4} \Leftrightarrow H^{+}+\mathrm{H}_{3} \mathrm{SiO}_{4}
$$

O teor de sílica dissolvida nas águas superficiais é de aproximadamente $13 \mathrm{ppm}$, saturada em relação ao quartzo, cuja saturação a $25^{\circ} \mathrm{C}$, termodinamicamente calculada, é de cerca de 6 ppm. Os teores mais elevados de sílica nas águas superficiais resultam da alteração dos silicatos, geralmente mais solúveis.

Segundo Birot (1981), os grãos de quartzo que se encontram dentro, por exemplo, de um granito fresco, apresentam uma película externa de sílica "amorfa", onde os íns perderam a estrutura regular, podendo chegar à espessura de $1 \mu \mathrm{m}$, quando começa a desagregação granular. A origem dessa película é controversa. Poderia representar uma desestabilização do quartzo ao contato com as águas estagnadas nos poros; porém, algumas dessas películas têm a forma de uma cascata que cobre o grão a partir da sua parte superior, levando a crer que se trata de um depósito vindo da parte superior do solo. Nas regiões tropicais úmidas, pode-se observar, ao microscópio eletrônico de varredura, partes do mesmo grão cobertas pela película e, outras, com feições de corrosão.

Segundo o mesmo autor, nos horizontes pedológicos, onde não está presente a película "amorfa", as águas levemente ácidas não retiram mais do que 1 a $2 \mathrm{mg} / \mathrm{lde}$ sílica por litro de drenagem anual, com cerca de 6 meses de contato. 


\subsection{INTEMPERISMO EM CONDIÇÕES TROPICAIS - LATERITIZAÇÃO}

\subsubsection{Definição e classificação das lateritas}

Para a gênese do material argiloso enfocado na pesquisa, enriquecido em alumínio e ferro, o mecanismo de intemperismo mais favorável é o da lateritização, sobre o qual apresenta-se a seguir uma síntese, cujo conhecimento norteou os trabalhos prospectivos durante os estudos.

Extensas área das regiões tropicais são cobertas por espessos mantos de alteração de cor avermelhada, conhecidos como laterita, em cuja composição predominam óxidos de ferro, alumínio e silício.

O termo laterita vem do latim later (ladrilho). O primeiro autor a se referir à laterita foi Buchanan (1807 apud Pedro \& Melfi 1983), descrevendo um material suficientemente mole para ser cortado em blocos, mas que endurecia quando exposto ao ar, transformando-se em excelente material para construção. $O$ mesmo autor denominou de brickstone a um material que já era encontrado endurecido no solo.

Posteriormente, surgiram controvérsias sobre a definição de laterita. Alguns autores passaram a considerar laterita somente os materiais endurecidos (couraças ferruginosas). Outros utilizaram o termo também para os materiais inconsolidados. No início do século, a cor avermelhada foi adotada como critério para a definição de laterita por Walther (1916 apud McFarlane 1976), levando os estudiosos a considerar laterita qualquer material vermelho, independentemente da dureza. Essas controvérsias perduraram por décadas.

Segundo Tardy (1992), evidenciam-se atualmente duas posições:

- a dos pesquisadores que consideram laterita todos os tipos de produtos de intemperismo em ambiente tropical;

- a dos estudiosos que adotam o termo para designar produtos de intemperismo ricos em ferro e alumínio, geralmente formados sob condições tropicais, duros ou que endurecem sob exposição alternada entre umidade e ressecamento. Esta definição, derivada de conclusões resultantes de encontros internacionais visando a uniformização de critérios, exclui caulinita moldável, saprolitos finos e solos ferralíticos não endurecidos. 
Schellmann (1983) apresentou, como resultado de estudos realizados por grupos de trabalho, a moderna definição de laterita: "acumulações superficiais ou subsuperficiais de produtos provenientes do intenso intemperismo de rochas, desenvolvidos sob condições favoráveis a uma maior mobilidade dos elementos alcalinos, alcalino - terrosos e sílica e imobilização de ferro e de alumínio". Tais materiais possuem uma paragênese mineral relativamente simples, caracterizadas pela predominância de argilominerais do grupo da caulinita e de óxidos e hidróxidos de ferro e de alumínio, além do quartzo que, apesar da sua resistência, também pode ser parcialmente destruído e removido durante o processo.

A lateritização é favorecida pela combinação de temperatura e umidade elevadas, condição que caracteriza as regiões tropicais, delimitadas por uma faixa situada entre as latitudes $30^{\circ} \mathrm{N}$ e $30^{\circ} \mathrm{S}$. A Figura 4.3 mostra a distribuição global do fenômeno da lateritização, segundo Bardossy \& Aleva (1990).

Foram feitas várias tentativas de classificação dos diferentes tipos de laterita ao longo do tempo. Schellmann (1981), apresentou uma proposta que abrange todos os tipos. Este autor utilizou-se de base químico - mineralógica representada em diagrama triangular, considerando os teores de $\mathrm{SiO}_{2}, \mathrm{Al}_{2} \mathrm{O}_{3}$ e $\mathrm{Fe}_{2} \mathrm{O}_{3}$, em função dos minerais presentes: quartzo, caulinita, hematita - goethita e gibbsita. No diagrama da Figura 4.4, pode-se constatar a existência de cinco tipos de lateritas: silicosa (rica em quarzto), ferruginosa, aluminosa, caulinítica e laterita sensu strictu. A laterita sensu strictu é caracterizada pela paragênese mineral mais comum dos solos tropicais: caulinita associada a quantidades variáveis de hematita, goethita e gibbsita.

\subsubsection{Mecanismo de formação das lateritas}

Segundo Pedro \& Melfi (1983), a gênese das lateritas é geoquimicamente entendida como uma total desalcalinização da rocha-mãe, com a individualização de argilas cauliniticas e hidróxidos, puros (Al: gibbsita; Fe: hidratos amorfos, hematita, goethita) ou mistos (goethita e hematita aluminosas).

A sílica também é mobilizada, embora em velocidade menor se comparada aos elementos alcalinos, podendo combinar-se com o alumínio que permanece in situ, dando origem aos argilominerais. 


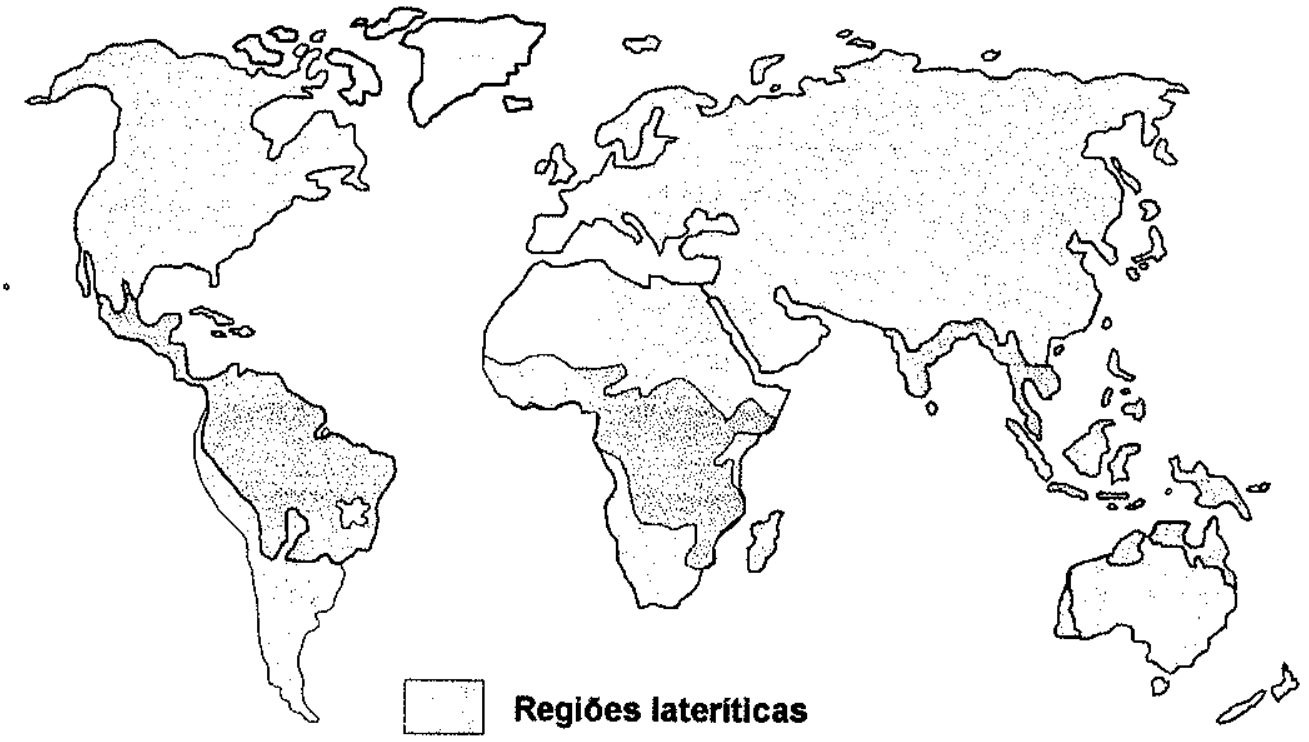

Modificado de Bardossy \& Aleva (1990)

Figura 4.3 - Distribuição global do fenômeno de lateritização.

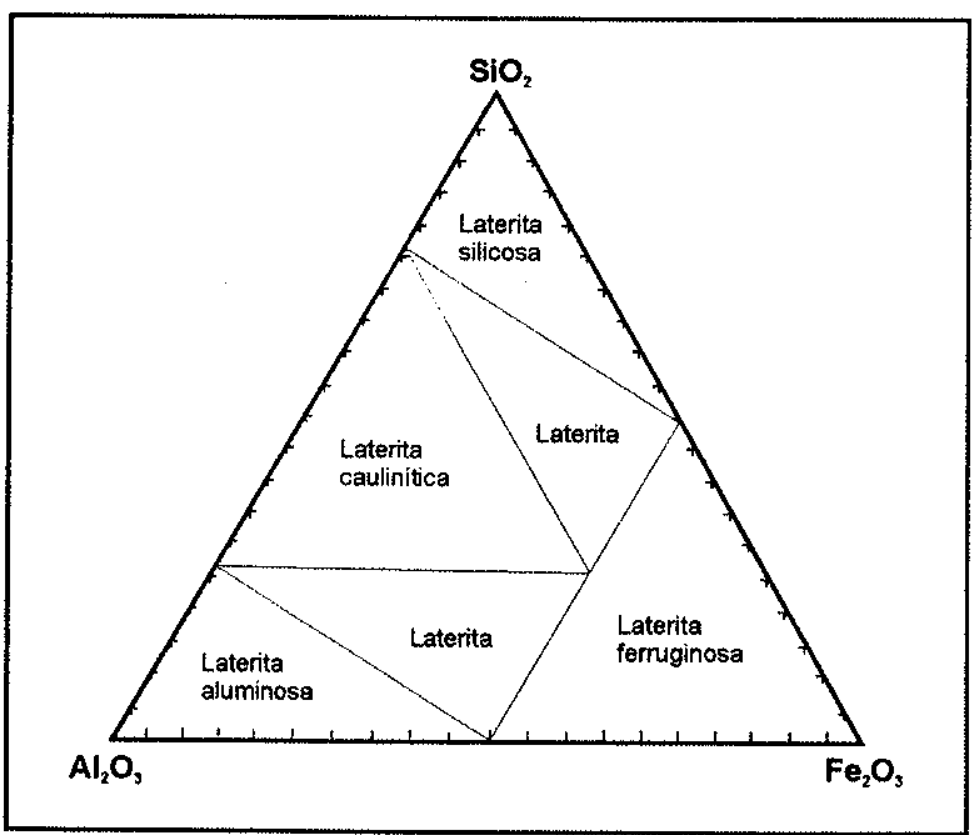

Modificado de Scheilmann (1981)

Figura 4.4 - Diagrama triangular para a classificação de lateritas. 
Embora formadas por um único processo, as lateritas podem abranger vários tipos de produtos, caracterizados não somente pelas diferenças composicionais, mas principalmente por variadas organizações estruturais, visto que a intensidade do processo, os materiais de origem e o tempo de atuação do processo podem variar segundo a posição geográfica.

A intensidade da hidrólise é, em grande parte, responsável pela constituição mineralógica das lateritas. A influência do grau de hidrólise na natureza dos seus produtos é mostrada no Quadro 4.2.

Quadro 4.2 - Comportamento da sílica, do alumínio e das bases, e tipos de lateritas resultantes em função da intensidade da hidrólise.

\begin{tabular}{|c|c|c|c|}
\hline & \multicolumn{3}{|c|}{ Grau da hidrólise } \\
\hline & Hidrólise total & \multicolumn{2}{|c|}{ Hidrólise parcial } \\
\hline \multirow{2}{*}{$\begin{array}{c}\text { Geoquimica } \\
\text { da } \\
\text { Dessilicificação }\end{array}$} & Dessilicificação total & \multicolumn{2}{|c|}{ Dessilicificação parcial } \\
\hline & Alitização & \multicolumn{2}{|c|}{ Sialitização } \\
\hline \multirow{2}{*}{$\begin{array}{l}\text { Caracterização } \\
\text { cristaloquímica }\end{array}$} & Hidróxido de alumínio & \multicolumn{2}{|c|}{ Silicatos argilosos } \\
\hline & Gibbsita & $\begin{array}{l}\text { Tipo } 1 / 1 \\
\text { Caulinita } \\
\end{array}$ & $\begin{array}{c}\text { Tipo } 2 / 1 \\
\text { Esmectitas } \\
\end{array}$ \\
\hline Processo de alteração & Alitização & Monossialitização & Bissialitização \\
\hline $\begin{array}{c}\text { Geoquímica da } \\
\text { desalcalinização }\end{array}$ & \multicolumn{2}{|c|}{ Desalcalinização total } & $\begin{array}{c}\text { Desalcalinização } \\
\text { parcial } \\
\end{array}$ \\
\hline Tipos de lateritas & $\begin{array}{l}\text { Lateritização sensu } \\
\text { strictu } \\
\text { (ultraferralitização) }\end{array}$ & $\begin{array}{l}\text { Lateritização sensu } \\
\qquad \text { latu }\end{array}$ & Sialferralitização \\
\hline $\begin{array}{c}\text { Paragênese } \\
\text { característica do perfil } \\
\text { de alteração }\end{array}$ & $\begin{array}{c}\text { Gibbsita - hidratos } \\
\text { férricos } \\
\text { (tipo óxido) }\end{array}$ & $\begin{array}{c}\text { Caulinita - hidratos } \\
\text { férricos } \\
\text { (tipo caulinitico) }\end{array}$ & $\begin{array}{c}\text { Esmectitas } \\
(\mathrm{Al}-\mathrm{Fe})\end{array}$ \\
\hline
\end{tabular}

Modificado de Pedro \& Melfi (1983)

\subsubsection{Perfís lateríticos}

Segundo Melfi (1993, 1994), nos climas quentes e úmidos da zona intertropical, a alteração afeta a maioria dos minerais primários, que desaparecem rapidamente dos horizontes intempéricos, levando à formação de espessos perfis essencialmente 
constituídos por minerais secundários, com pedogênese limitada aos horizontes superiores.

A Figura 4.5 apresenta o perfil esquemático da alteração das rochas em clima tropical, onde são identificados dois grandes conjuntos: a alterita e o solum. A primeira é formada pelos horizontes de alteração e o segundo caracteriza os horizontes de evolução pedológica. A Figura 4.6 mostra um detalhe do perfil latossólico.

O solum contém acumulações de argilominerais, óxidos e hidróxidos. Os últimos podem formar couraças ou carapaças contínuas, ou nódulos ou pisólitos. Estruturas reliquiares da rocha são raramente preservadas. Os horizontes observados a partir da rocha fresca caracterizam-se pela diminuição progressiva de densidade aparente e pelo aumento da porosidade. Segundo Melfi (1994), os volumes originais da rocha fresca são geralmente preservados no interior da alterita (alteração isovolumétrica), apesar das perdas de matéria por dissolução, que chega a $80 \%$ no caso das rochas ultramáficas.

Minerais primários podem ser integralmente substituídos por minerais secundários, mantendo a estrutura original da rocha (pseudomorfose). Óxi-hidróxidos de $\mathrm{Fe}$ e Al e argilominerais, formados no início do processo na periferia dos minerais primários (minerais ferro-magnesianos e feldspatos), passam a constituir paredes ou cercas, que sustentam a estrutura original mesmo com a progressão da alteração e da conseqüente saída de matéria. As transferências iônicas nessa escala podem ser intracristalinas, intercristalinas, ou mesmo em escalas maiores, em nível de horizonte ou da paisagem. Processo análogo ocorre com o ferro em minerais como olivinas, piroxênios, anfibólios e biotitas, com a formação de paredes ou cercas goethíticas. A goethita e a gibbsita das lateritas podem, segundo Tardy et al. (1991), transformar-se em hematita e bohemita quando desidratadas, formando estruturas nodulares e pisoliticas.

Grubb (1983) estudou, no Zimbabwe, a formação de perfís lateriticos e bauxíticos a partir de granitos, observando que ocorre substancial dissolução do granito mesmo próximo à rocha fresca, com a formação de gibbsita nos primeiros estágios do intemperismo, passando por uma fase argílica. Pouca gibbsita se formaria posteriormente, predominando a remobilização e a recristalização da mesma no perfil. 


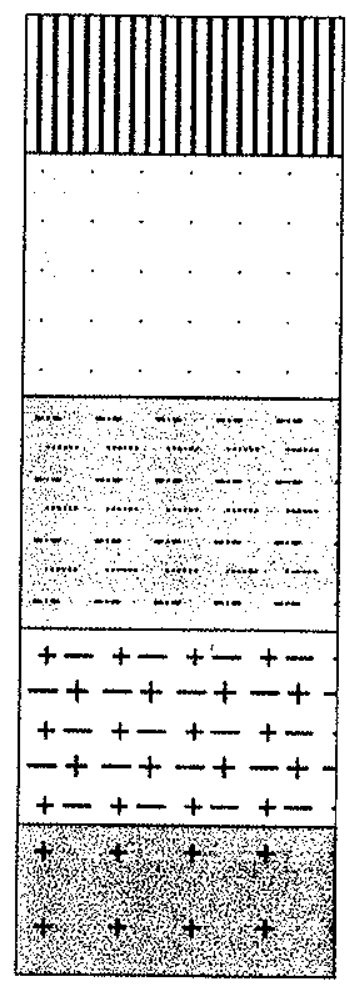

Solo

SOLUM

Alterita com estrutura

modificada

Alterita com estrutura ALTERITA

conservada

Rocha alterada

compacta

Rocha fresca

Modificado de Melfi (1994)

Figura 4.5 - Perfil esquemático de alteração das rochas em clima tropical.
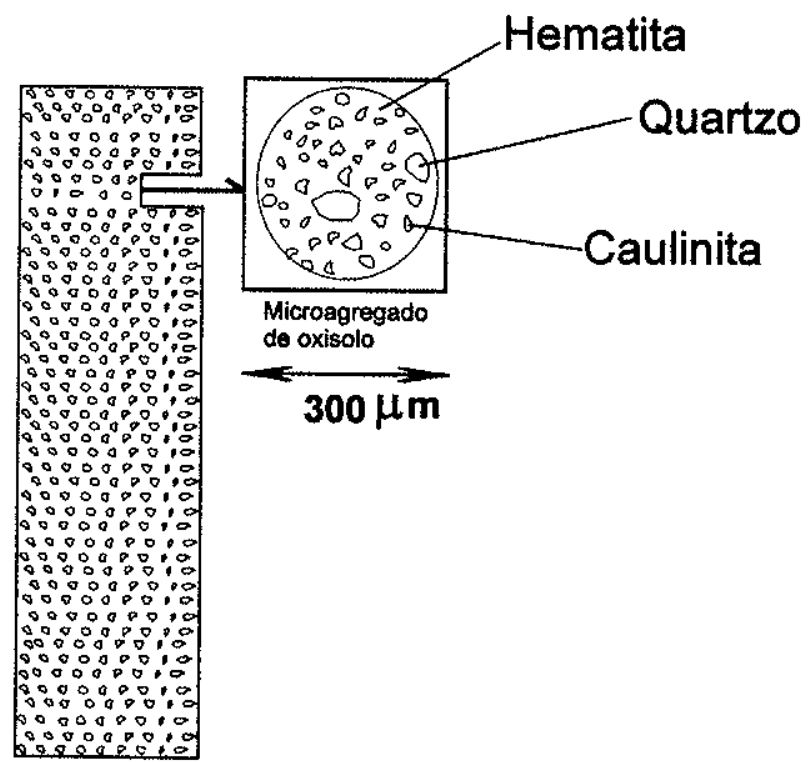

Modificado de Chauvel (1977 apud TARDY 1992)

Figura 4.6 - Estrutura micronodular da laterita, feita da assembléia de hematita, caulinita e quarzto, porosa e caracterizada pela drenagem rápida. 
Logo após a fase de formação da gibbsita, ocorre significativa dissolução do quartzo, com a redução do tamanho dos grãos.

\subsubsection{Influência do clima e do tempo de exposição na lateritização}

Segundo McFarlane (1976), é amplamente aceita a idéia de que as lateritas não podem se formar em ambientes extratropicais; porém, existem divergências entre os autores quanto ao papel do calor no processo. Tais divergências decorrem da dificuldade de definir se uma determinada laterita está ou não se formando atualmente. Assim, lateritas formadas em condições paleoclimáticas diferentes das atuais podem induzir a erros de interpretação.

Segundo Tardy \& Roquin (1992), os ferricretes, concentrações ferruginosas comuns em ambientes de lateritização, desenvolvem-se principalmente em zonas tropicais úmidas com precipitação média anual em torno de $1.500 \mathrm{~mm}$, estação seca de 5 meses e temperatura média anual entre $25^{\circ}$ e $30^{\circ} \mathrm{C}$.

Grubb (1983) estabeleceu como guia exploratório para zonas altamente lixiviadas, com potencial para depósitos lateríticos ou bauxíticos, as áreas delimitadas pela pluviosidade acima de $1.000 \mathrm{~mm} /$ ano e altitudes acima de $1.200 \mathrm{~m}$.

Bardossy \& Aleva (1990), resumem as condições climáticas para a formação de bauxitas: temperatura média anual acima de $22^{\circ} \mathrm{C}$ e precipitação anual superior a 1.200 mm, distribuida em 9 a 11 meses chuvosos e 1 a 3 meses relativamente mais secos. Tal fato não significa, segundo os mesmos autores, que os depósitos encontrados dentro dessa faixa sejam atuais, podendo as suas formações terem se iniciado há milhões de anos, continuando a se formar nos locais onde encontram presentemente condições favoráveis. Depósitos situados fora dessa faixa favorável de temperatura e de precipitação seriam testemunhos de condições climáticas pretéritas adequadas.

Ferrari (1996) simulou, através de dados paleoclimáticos e paleomagnéticos dos últimos $100 \mathrm{Ma}$, a sucessão paleoclimática associada à deriva continental e calculou o tempo de exposição das bauxitas lateríticas da África e da América do Sul às condições de lateritização. Concluiu que a maioria dos depósitos localiza-se em zonas que estiveram expostas por muito tempo, chegando a $100 \mathrm{Ma}$. Mostrou, também, que as bauxitas africanas abandonaram os ambientes favoráveis ao desenvolvimento há mais tempo do que as sul americanas, posicionando-se em ambientes mais favoráveis à 
formação de ferricretes, motivo pelo qual teriam teor mais elevado de $\mathrm{Fe}_{2} \mathrm{O}_{3}$ do que as da América do Sul. Para os depósitos brasileiros, o tempo de exposição teria sido superior a $17 \mathrm{Ma}$, com a última exposição há 1 milhão de anos. Em seu estudo, o autor não considerou os depósitos do sudeste brasileiro.

Samama (1986), apresenta tempos bastante variáveis para a formação de depósitos de bauxita: 2 Ma ou menos para rocha-mãe pobre em quartzo e ferro; 10 mil anos no Havaí e 60 Ma na Índia, para rochas pobres em quartzo e ricas em ferro (como os basaltos); 2 Ma no Escudo das Guianas e 50 Ma no norte da Austrália, para as rochas quartzosas.

Pedro \& Melfi (1983) apresentam as situações mais freqüentes em relação à drenagem:

- meio úmido e permanentemente percolado: as condições de hidrólise são privilegiadas, podendo desenvolver latossolos e materiais ricos em gibbsita;

- meio úmido, saturado ou não, correspondendo à zona de oscilação do nível hidrostático: essa alternância de meio livre e saturado leva à formação de concreções ferruginosas na zona de oscilação;

- meio com alternância entre condições de umidade e ultra-seco: situação comum em regiões tropicais, onde o solo é muito ressecado na estiagem, podendo formar perfis com solos encouraçados.

Nos casos extremos da primeira situação, pode ocorrer a formação de depósitos de bauxita. Segundo Samama (1986), mesmo rochas silicosas, com mais de $90 \%$ de quartzo, como os arenitos arcoseanos, podem dar origem a depósitos aluminosos, chegando até mesmo a bauxíticos. Como exemplo, pode ser citada a jazida de bauxita de Porto Trombetas, no Pará, formada a partir de arenitos arcoseanos e siltitos argilosos (Boulangé \& Carvalho 1997; Hernalsteens \& Lapa 1988). Ainda como exemplo, no alto rio Cachorrinho (NW do Pará), existem de espessos perfis lateríticos desenvolvidos sobre platôs graníticos, com mais de $15 \mathrm{~m}$ espessura, enriquecidos em gibbsita abaixo de um horizonte superior argiloso e couraça ferruginosa nos niveis inferiores (observação pessoal deste autor). 


\subsubsection{Importância econômica das lateritas}

Além da bauxita, os depósitos lateríticos podem apresentar concentrações economicamente importantes, por exemplo, de níquel (quando originários de rochas ultramáficas), manganês, ouro e outros elementos, conforme descritos por Samama (1986) e Melfi et al. (1988).

Nas condições de lateritização, até mesmo um elemento estável como o ouro, contido na estrutura cristalina de minerais da rocha-mãe ou disseminado em partículas microscópicas, é solubilizado, migra e precipita ao encontrar variações das condições físico-químicas, dando origem às concentrações secundárias, caracterizadas por partículas grossas, como aquelas conhecidas nas regiões de Cuiabá (MT) e Barro Alto (GO) (Shimada 1983). Em Chapada (GO), ocorre espesso manto laterítico sobre depósito sulfetado de cobre e ouro, no qual o último, contido na estrutura da calcopirita no minério primário, ocorre sob a forma de partículas de metal nativo na laterita, suficientemente grossas para permitir a separação gravimétrica (constatação pessoal deste autor).

\subsubsection{Lateritas no Brasil}

O Brasil, segundo Melfi (1994) é um país essencialmente laterítico, com mais de $60 \%$ da sua superfície recoberta por diferentes materiais lateríticos. Os mais comuns são os materiais argilo-ferruginosos friáveis, que dão origem, por pedogênese, aos latossolos, solos muito finos e pulverulentos, com microagregação característica.

Segundo Melfi (1997), todos os depósitos brasileiros de bauxita são de origem laterítica, formados através do intenso intemperismo de diferentes tipos de rocha e essencialmente constituídos de gibbsita. Ainda segundo o mesmo autor, são observadas variações mineralógicas regionais em relação aos óxidos nas lateritas brasileiras. As diferenças mineralógicas são, sobretudo, reflexo de variações paleoclimáticas, tendo o clima atual pouco afetado estas formações.

$\mathrm{Na}$ Amazônia, a cobertura laterítica é essencialmente constituída por geothita e gibbsita, sendo a hematita subordinada ou ausente. Destacam-se na região as grandes jazidas de bauxita, como a de Porto Trombetas. 
Na região Centro-Oeste, são encontradas extensas áreas de laterita ferruginosa, nodular ou localmente formando crostas ou carapaças. Observa-se a associação de goethita, hematita e gibbsita.

No Nordeste, são também comuns as lateritas, cobrindo várias litologias e formando freqüentemente espessas couraças abaixo de um nivel nodular, como ocorre no vale do rio Paramirim, na região de Macaúbas, Bahia (observadas por este autor). A goethita é o mineral ferrífero predominante, não ocorrendo gibbsita ou hematita.

$\mathrm{Na}$ Província Mantiqueira Central, no Quadrilátero Ferrifero e no Sudeste são conhecidos depósitos bauxíticos relacionados à lateritização de diversos tipos de rocha: filitos no Quadrilátero Ferrífero; gnaisses em Cataguases (MG); anfibolitos em Nazaré Paulista; metadiabásio em Curucutu (SP); granito em Mogi das Cruzes; rochas alcalinas em Resende, Rio Bonito, Piraí e Macacu (RJ), e Poços de Caldas e Passa Quatro (MG). Além dos depósitos bauxíticos, a lateritização é observada sobre variadas litologias, principalmente sobre os basaltos da Bacia Sedimentar do Paraná, onde a goethita desaparece nas lateritas, com a hematita passando a principal constituinte (Melfi 1997).

O depósito bauxítico situado mais a sul no Brasil é o de Lages (SC), associado a rochas do Distrito Alcalino de Lages, principalmente fonólitos (Formoso et al. 1997).

Ainda segundo Melfi (1994), os depósitos lateríticos brasileiros distribuem-se de acordo com as posições que ocupam no relevo. Relevo este que resulta de uma evolução iniciada no Cretáceo superior, com o soerguimento do continente sul americano. A seguir, estabeleceu-se um longo período de erosão, nivelando as paisagens brasileiras sob a forma de um imenso peneplano, a Superfície Sul-Americana (King 1956). As imensas coberturas lateríticas formaram-se no Terciário Inferior por ação da alteração meteórica, durante a fase de agradação desta superfície.

No Terciário Superior, ocorreu novo soerguimento, com novo ciclo erosivo, o ciclo Velhas, no qual a Superfície Sul-Americana foi, em grande parte, erodida e desmantelada. Porém, ainda é possivel encontrar grandes e bem preservados testemunhos desse peneplano no interior do País, onde os mesmos formam a essência do Planalto Central Brasileiro, com altitudes variando de 500 a $1.000 \mathrm{~m}$.

A alteração retomou a sua progressão sobre os testemunhos da Superfície SulAmericana. Sobre a Superfície Velhas, inferior e embutida na primeira, iniciou-se nova 
fase de lateritização. As lateritas friáveis da Superfície Velhas apresentam-se compartimentadas em grandes setores que correspondem, aproximadamente, às bacias hidrográficas brasileiras: Amazônia, Araguaia - Tocantins, São Francisco e algumas bacias de rios do sudeste, em posições topográficas mais baixas.

Retomadas de erosão sub-atual (Ciclo Paraguaçu) e atual causaram o entalhamento dessas superfícies e deram origem a um novo conjunto de paisagens rejuvenescidas.

\section{Lateritas no Estado de São Paulo}

No Estado de São Paulo, são conhecidos vários depósitos lateríticos gibbsíticos, formando concentrações de bauxita, em Mogi das Cruzes, Curucutu (região sul da Capital), Lavrinhas, Nazaré Paulista e na região de Santo Antônio do Pinhal, SapucaíMirim e Camanducaia, na divisa com o Estado de Minas Gerais.

Esses depósitos originaram-se a partir de litologias variadas, envolvendo rochas alcalinas, metabasitos/metaultrabasitos, gnaisses, migmatitos e granitos. Essa litoindependência evidencia a importância das condições climáticas e topográficas na gênese dos mesmos. Mesmo rochas bastante silicosas podem sofre forte lixiviação da sílica, resultando em concentrações bauxíticas.

Knecht (1960) descreveu produtos de alteração de rochas alcalinas em Piedade e Toledo-Groke \& Melfi (1982) estudaram os aspectos micromorfológicos associados às bauxitas desenvolvidas sobre rochas básicas e alcalinas no Estado de São Paulo.

Segundo Oliveira \& Toledo (1997), os depósitos de bauxita da Província Costeira Sudeste são derivados de rochas ígneas e metamórficas em condições de alta temperatura e pluviosidade. A distribuição da bauxita é controlada no relevo pelas condições de drenagem, ocorrendo preferencialmente nos topos e nas encostas superiores bem drenadas.

O Quadro 4.3 a seguir apresenta uma síntese das informações sobre os depósitos de bauxita do Estado de São Paulo. 
Quadro 4.3 - Depósitos de bauxita laterítica do Estado de São Paulo (incluindo parte de Minas Gerais).

\begin{tabular}{|c|c|c|c|c|c|}
\hline Depósito & $\begin{array}{c}\text { Natureza da rocha- } \\
\text { mãe }\end{array}$ & Altitude (m) & $\begin{array}{c}\text { Recursos }(\mathrm{t}) \mathrm{e} \\
\text { teores médios }(\%)\end{array}$ & $\begin{array}{c}\begin{array}{c}\text { Teores na rocha- } \\
\text { mãe }\end{array} \\
\end{array}$ & $\begin{array}{l}\text { Referências } \\
\text { bibliográficas }\end{array}$ \\
\hline Nazaré Paulista & $\begin{array}{c}\text { Anfibolito } \\
\text { (metabásica) }\end{array}$ & $930-1.000$ & $\begin{array}{l}5,6 \times 10^{6} \mathrm{t} \\
\mathrm{SiO}_{2}=7,7 \% \\
\mathrm{Al}_{2} \mathrm{O}_{3}=35,0 \% \\
\mathrm{Fe}_{2} \mathrm{O}_{3}=29,0 \% \\
\mathrm{TiO}_{2}=1,9 \%\end{array}$ & $\begin{array}{l}\mathrm{SiO}_{2}=48,8 \% \\
\mathrm{Al}_{2} \mathrm{O}_{3}=14,0 \% \\
\mathrm{Fe}_{2} \mathrm{O}_{3}=16,4 \% \\
\mathrm{TiO}_{2}=1,4 \%\end{array}$ & $\begin{array}{l}\text { Beljavskis (1981); } \\
\text { Beljavskis et al. (1984); } \\
\text { Silva \& Oliveira (1989); } \\
\text { Oliveira \& Toledo (1997) }\end{array}$ \\
\hline $\begin{array}{l}\text { Lavrinhas } \\
\text { (coluvial) }\end{array}$ & Nefelina sienito & $500-1.330$ & $\begin{array}{l}5,5 \times 10^{6} \mathrm{t} \\
\mathrm{SiO}_{2}=1,67 \% \\
\mathrm{Al}_{2} \mathrm{O}_{3}=58,20 \% \\
\mathrm{Fe}_{2} \mathrm{O}_{3}=6,62 \% \\
\mathrm{TiO}_{2}=1,36 \%\end{array}$ & $\begin{array}{l}\mathrm{SiO}_{2}=54,20 \% \\
\mathrm{Al}_{2} \mathrm{O}_{3}=21,00 \% \\
\mathrm{Fe}_{2} \mathrm{O}_{3}=2,06 \% \\
\mathrm{TiO}_{2}=0,62 \%\end{array}$ & $\begin{array}{l}\text { Sigolo (1979, 1988); } \\
\text { Sigolo \& Boulangé (1997) }\end{array}$ \\
\hline Mogi das Cruzes & $\begin{array}{l}\text { Gnaisses e } \\
\text { migmatitos }\end{array}$ & $820-830$ & $\begin{array}{l}120.000 t \\
\mathrm{SiO}_{2}=19,2 \% \\
\mathrm{Al}_{2} \mathrm{O}_{3}=52,1 \% \\
\mathrm{Fe}_{2} \mathrm{O}_{3}=3,0 \% \\
\mathrm{TiO}_{2}=0,6 \%\end{array}$ & $\begin{array}{l}\mathrm{SiO}_{2}=63,5 \% \\
\mathrm{Al}_{2} \mathrm{O}_{3}=24,3 \% \\
\mathrm{Fe}_{2} \mathrm{O}_{3}=1,9 \% \\
\mathrm{TiO}_{2}=0,6 \% \\
\text { (na caulinita associada) }\end{array}$ & $\begin{array}{l}\text { Knecht (1943b); Knecht } \\
\text { (1950); Gomes (1956); } \\
\text { Toledo-Groke (1981); } \\
\text { Oliveira \& Toledo (1997) }\end{array}$ \\
\hline Curucutu & $\begin{array}{c}\text { Metabásicas e } \\
\text { metaultrabásicas }\end{array}$ & $800-900$ & $\begin{array}{l}72.000 \mathrm{t} \\
\mathrm{SiO}_{2}=1,94 \% \\
\mathrm{Al}_{2} \mathrm{O}_{3}=41,98 \% \\
\mathrm{Fe}_{2} \mathrm{O}_{3}=19,82 \% \\
\mathrm{TiO}_{2}=1,82 \% \\
\end{array}$ & $\begin{array}{l}\mathrm{SiO}_{2}=50,94 \% \\
\mathrm{Al}_{2} \mathrm{O}_{3}=11,90 \% \\
\mathrm{Fe}_{2} \mathrm{O}_{3}=9,81 \% \\
\mathrm{TiO}_{2}=1,00 \% \\
\text { (metadiabásio) } \\
\end{array}$ & $\begin{array}{l}\text { Gomes (1956); Toledo- } \\
\text { Groke (1981); Oliveira \& } \\
\text { Toledo (1997) }\end{array}$ \\
\hline $\begin{array}{l}\text { Santo Antônio do } \\
\text { Pinhal, Sapucaí- } \\
\text { Mirim e } \\
\text { Camanducaia }\end{array}$ & Granitos e anfibolitos & $1.500-1.700$ & Não quantificado & Não quantificado & Goraieb et al. (1998) \\
\hline
\end{tabular}




\section{CAPÍTULO 5}

\section{MATERIAIS E MÉTODOS}

\subsection{IDENTIFICAÇÃO DO PROBLEMA}

O problema referente às matérias-primas, citado em 1.2, foi identificado através de contatos iniciados pelos Professores Doutores Jorge Silva Bettencourt e Jorge Kazuo Yamamoto com a direção da Divisão de Mineração da FCV-1. Com o avanço das conversações, foi apresentado um plano de trabalho, elaborado por este autor $e$ aprovado pela FCV-1.

Já nesta etapa, simulações computacionais da composição da farinha, realizadas segundo o método descrito em 5.6.3, mostraram que a composição de uma argila hipotética, que substituisse integralmente a argila em uso, dispensando os corretivos, teria como composição aproximada $55,20 \%$ de $\mathrm{SiO}_{2}, 22 \%$ de $\mathrm{Al}_{2} \mathrm{O}_{3}$ e $10 \%$ de $\mathrm{Fe}_{2} \mathrm{O}_{3}$. Uma segunda argila hipotética que, adicionada à argila em uso, substituísse apenas os corretivos (bauxita e minério de ferro), teria como composição aproximada $40 \%$ de $\mathrm{SiO}_{2}, 32 \%$ de $\mathrm{Al}_{2} \mathrm{O}_{3}$ e $12 \%$ de $\mathrm{Fe}_{2} \mathrm{O}_{3}$. Constituintes menores, como $\mathrm{MgO}, \mathrm{K}_{2} \mathrm{O}, \mathrm{Na}_{2} \mathrm{O}$, deveriam ter teores baixos, da ordem de 0,1 a $0,3 \%$. Esses dados indicaram como materiais a prospectar aqueles de composição de lateritas cauliníticas, segundo a classificação de Schellmann (1981).

\subsection{REVISÃO BIBLIOGRÁFICA}

A revisão bibliográfica abrangeu a geologia regional, a fabricação do cimento Portland e os processos geoquímicos superficiais, particularmente aqueles envolvidos na gênese de materiais lateriticos.

Foram realizadas pesquisas nas bibliotecas do IG-USP, do IG-SMA, da ABCP, do Instituto de Geociências e Ciências Exatas da UNESP (Rio Claro, SP), do Departamento de Geologia da Universidade Federal do Paraná (Curitiba, PR), do Centro de Energia Nuclear na Agricultura-USP (Piracicaba, SP) e do Instituto Agronômico de Campinas. Além das bibliotecas, foram realizadas buscas na Internet, tendo sido consultados os sites já mencionados em 2.1. 


\subsection{DEFINIÇÃO DO MODELO GEOLÓGICO E DOS CRITÉRIOS PROSPECTIVOS}

\subsubsection{Definição do modelo geológico}

A análise do problema da FCV-1 mostrou que o material argiloso buscado deveria ser inconsolidado, com as características químicas citadas em 5.1, típicas de materiais lateríticos. Assim, as condições para a formação de depósitos lateríticos, já citadas em 4.2.2, 4.2.3 e 4.2.4, foram somadas aos dados climáticos da região para uma análise conjunta.

Embora o clima atual possa não estar influindo na formação de depósitos lateríticos na região, foram levantados os dados de Tavares (1997), que compilou, analisou, e definiu tendências dos dados climáticos da região de Sorocaba. Segundo esse autor, as áreas a centro-sul, sul e sudeste da cidade de Sorocaba apresentam, no período 1972-1991, as médias pluviométricas mais elevadas da região, variando de 1.400 a $2.000 \mathrm{~mm}$ anuais. Mesmo nos anos mais secos, não caiu abaixo de $1.000 \mathrm{~mm}$. No inverno, cai bruscamente, chegando a menos de $50 \mathrm{~mm}$, apresentando o contraste favorável à lateritização. A Figura 5.1 mostra a distribuição da pluviosidade média na região no período considerado. Nota-se média superior a $1.400 \mathrm{~mm}$ a SSE de Sorocaba.

Quanto aos dados de temperatura, o mesmo autor estudou somente aqueles medidos na Fazenda Ipanema, em Araçoiaba da Serra, na parte NW da sua área de estudo. O período abrangido pelas medidas foi de 1950-1991. Segundo suas interpretações, a média das máximas decresceu ligeiramente nesse período, indo de $27,9^{\circ} \mathrm{C}$ a $26,7^{\circ} \mathrm{C}$. A média das mínimas, por outro lado, apresentou acréscimo de $1,6^{\circ}$ $\mathrm{C}$ no mesmo periodo, variando de $13,8^{\circ} \mathrm{C}$ a $15,4^{\circ} \mathrm{C}$. A média absoluta apresentou variação positiva de $0,7^{\circ} \mathrm{C}$, indo de $19,3^{\circ} \mathrm{C}$ a $20^{\circ} \mathrm{C}$.

A análise dos dados levantados permitiu concluir que havia a possibilidade de existência de depósitos lateríticos na região, com distribuição restrita e dependente das condições topográficas, à semelhança dos demais depósitos do paulistas.

Desta maneira, definiu-se o seguinte modelo geológico: depósitos lateríticos cauliniticos, desenvolvidos a partir de litologias variadas, através da lixiviação parcial da silica e acumulação do ferro e do alumínio, em condições de elevada pluviosidade e temperatura, em terreno bem drenado, preferencialmente em altos topográficos. 


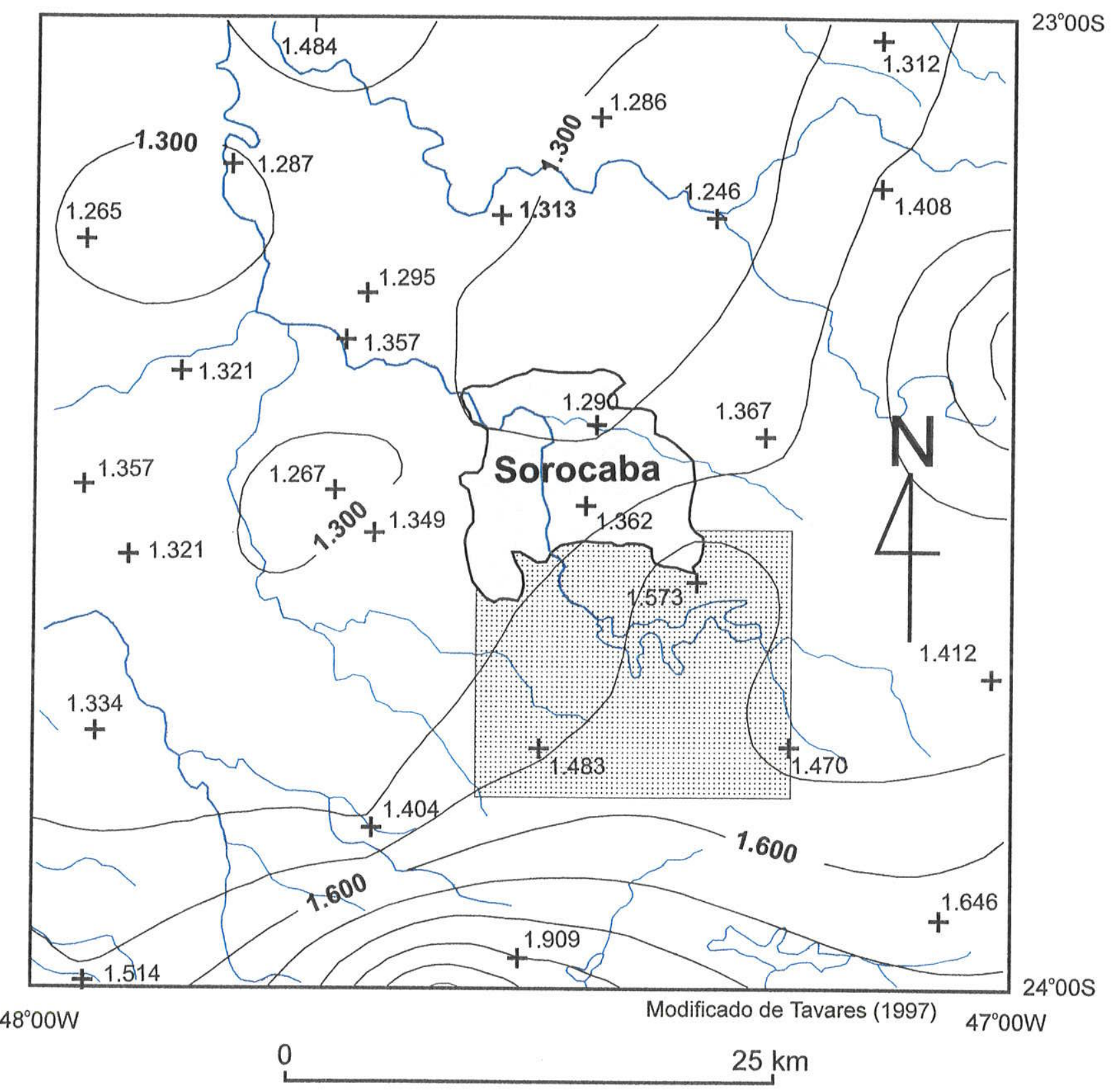

LEGENDA

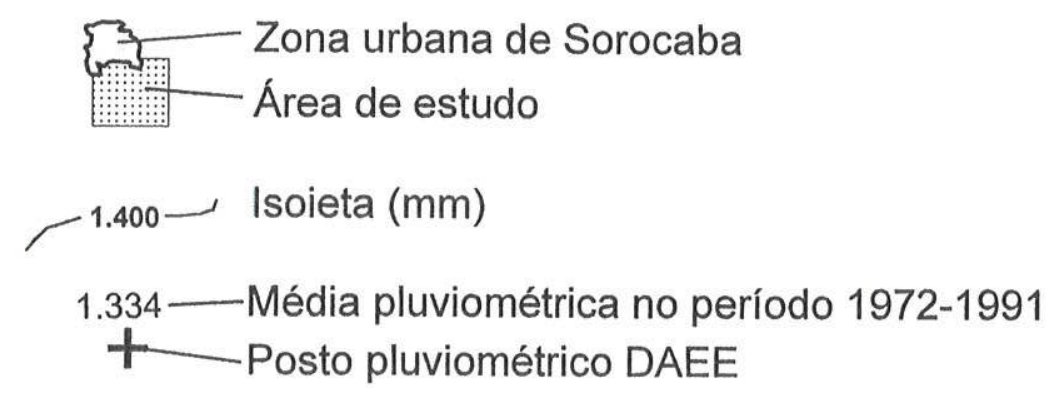

Figura 5.1 - Distribuição espacial da pluviosidade média no período 1972 -1991 na região de Sorocaba. 


\subsubsection{Estabelecimento de critérios prospectivos e seleção de prospectos}

Estabelecido o modelo, partiu-se para a definição dos critérios prospectivos que norteariam os trabalhos de campo. Sabia-se que as lateritas não ocorrem de maneira generalizada na região, manifestando-se em setores restritos, de pequena expressão superficial, sendo necessário selecionar as sub-áreas ou prospectos mais favoráveis com base nesses critérios.

Uma rocha-mãe pobre em sílica seria uma condição favorável à lateritização, consideradas constantes as demais condições. Seria o caso das rochas metabásicas e alcalinas da região, como ocorre nos depósitos de Nazaré Paulista e Curucutu. Assim, as metabásicas e as alcalinas foram, em princípio, consideradas as litologias mais favoráveis, sem desprezar a fato de a lateritização poder afetar litotipos variados, inclusive os mais silicosos, como os granitos, como ocorre em Mogi das Cruzes.

Os parâmetros geológicos e fisiográficos associados aos depósitos lateríticos, descritos na literatura consultada, somados aos condicionantes econômicos, legais, sociais e ambientais, permitiram chegar aos seguintes critérios:

- posicionamento em altos topográficos, freqüentemente relacionados a testemunhos da Superfície Sul-Americana, em cotas entre 500 e 1000 m ou mais;

- distância rodoviária máxima de $50 \mathrm{~km}$ a partir da FCV-1, com boas condições de acesso;

- área isenta de títulos minerários de terceiros;

- área isenta de outros usos do solo potencialmente conflitantes com a futura lavra, como loteamentos e áreas de proteção ambiental, incluindo áreas de mata secundária desenvolvida.

Além dos critérios acima, foram consideradas as ocorrências conhecidas de materiais inconsolidados avermelhados, indicativos da presença de ferro.

Os títulos minerários incidentes sobre a região foram levantados através do SICOM-Sistema de Controle Minerário do DNPM-Departamento Nacional da Produção Mineral, que permite a consulta informatizada através de janelas delimitadas por coordenadas, por município, por substância ou por tipo de título. 
A aplicação dos critérios resultou na seleção de 4 sub-áreas dentro da área de estudo, denominadas prospectos (Figura 5.2):

Prospecto 1 - Metabásica de Aluminio: abrangendo o corpo metabásico e seu entorno próximo, a sul da referida cidade, foi considerado prioritário devido à natureza da rocha, favorável à gênese de materiais intempéricos ricos em alumínio e ferro, aliada às altitudes da ordem de $900 \mathrm{~m}$.

Prospecto 2 - Setor do Macico Granítico São Francisco: embora situado em área de rochas mais silicosas, foi selecionado pelas condições fisiográficas, com amplos altos topográficos acima de $950 \mathrm{~m}$, em terreno bem drenado, além da sua proximidade da FCV-1.

Prospecto 3 - Zona de ocorrência da cobertura sedimentar avermelhada: embora em situação topográfica desfavorável, de colinas suaves com altitudes em torno de $700 \mathrm{~m}$, foi selecionado devido à presença conhecida de materiais inconsolidados avermelhados, indicativos de concentração de ferro.

Prospecto 4 - Sienito de Piedade: foi também selecionado em razão da litologia favorável e das condições topográficas, com cotas acima de $1.000 \mathrm{~m}$.

\subsection{PLANEJAMENTO DOS TRABALHOS DE CAMPO}

Primeiramente, foram planejados estudos nas minas Pastinho, Baltar subterrânea e do Lago, para um melhor conhecimento geológico, principalmente da primeira, com caracterização das litologias, particularmente do metadolomito de alto cálcio da capa (setor SE da mina). Na mina Pastinho, foi realizado através da descrição/amostragem de pontos numerados e levantados pela equipe de topografia, além de amostragem mais detalhada do metadolomito da capa. O número de pontos não foi previamente estabelecido, optando-se por defini-los de acordo com o andamento da atividade.

Para os 4 prospectos de materiais argilosos, foram planejados trabalhos de campo divididos em duas etapas:

Prospecção estratégica: teve como objetivo o conhecimento dos aspectos da geologia regional descritos na literatura ou fotointerpretados, assim como de realizar uma amostragem preliminar, nos prospectos, dos produtos de intemperismo considerados 


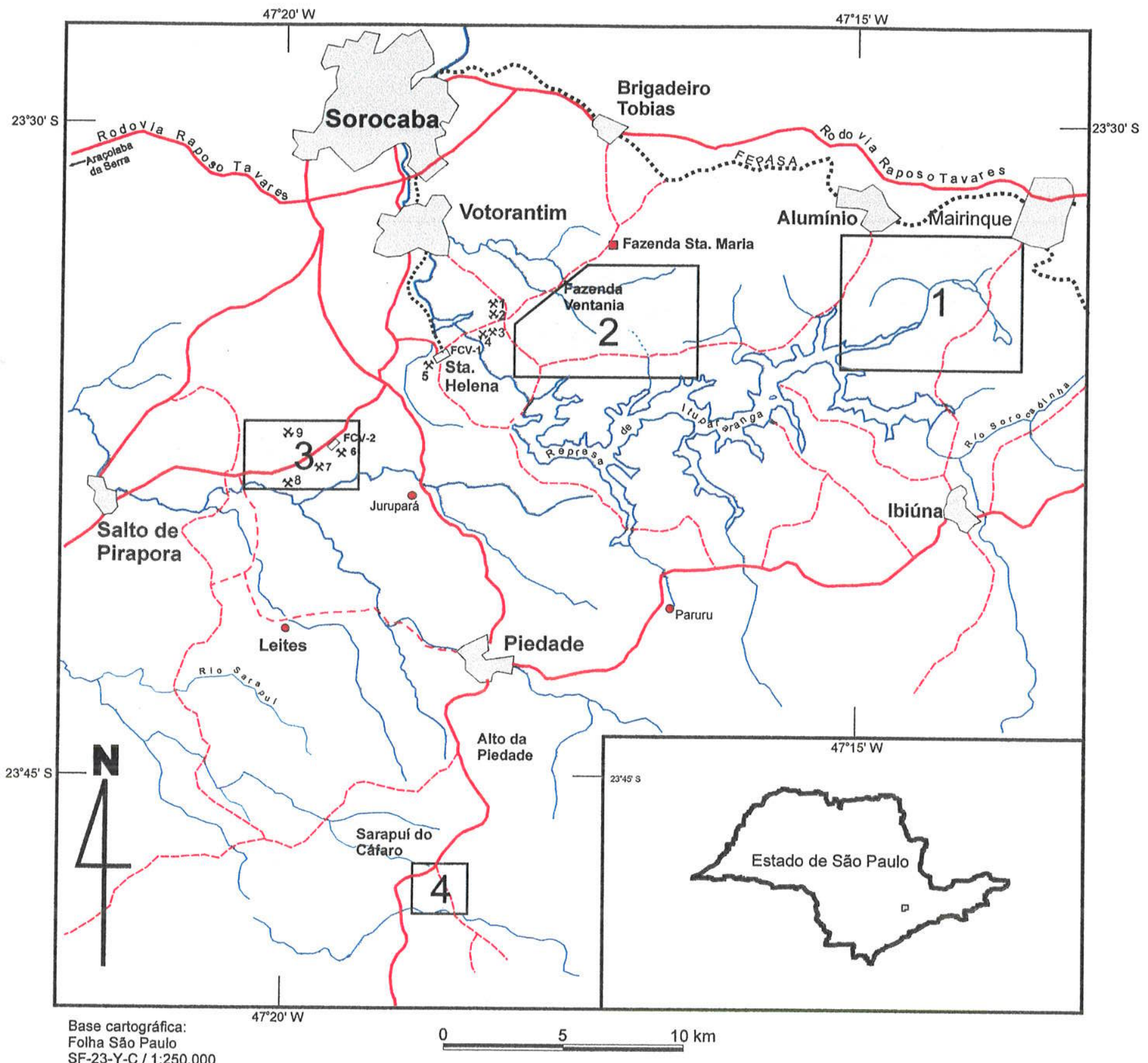

LEGEN D A

Prospectos

1

2

3

4
Metabásica de Alumínio

Maciço Granítico São Francisco

Cobertura sedimentar avermelhada

Sienito de Piedade
X Minas ativas: 1 - Pastinho

3 - Baltar subterrânea

5 - Mina do Lago (filito)

6 - Mina 1 - Salto de Pirapora

7 - Superbrita

8 - Minercal

$X$ Minas inativas: 2 - Placa

4 - Baltar céu aberto

9 - Ponte Alta

Estrada pavimentada

_-... Estrada não pavimentada

.* **...* Estrada de ferro

Figura 5.2 - Localização dos prospectos selecionados. 
interessantes. A amostragem foi predominantemente superficial e não sistemática, com alguma investigação em subsuperfície. Em função das dimensões da área a percorrer, cerca de $900 \mathrm{~km}^{2}$, e da malha viária existente, os caminhamentos foram todos rodoviários.

Prospecção tática: sucedendo a estratégica, visou o detalhamento dos trabalhos nos alvos selecionados dentro dos prospectos. Teve como objetivos a caracterização física e química preliminar do material e a avaliação preliminar de reservas, através de amostragem em subsuperfície. Nesta etapa, foram definidos os alvos para a pesquisa sistemática posterior, a ser realizada pela equipe da Divisão de Mineração da FCV-1, com execução de malha regular de amostragem e modelamento através de métodos geoestatísticos.

\subsection{PREPARAÇÃO DE BASES CARTOGRÁFICAS E AEROFOTOGRÁFICAS}

\subsubsection{Bases cartográficas}

As bases cartográficas utilizadas durante os estudos são divididas em:

- carta 1:250.000 - utilizou-se a folha de São Paulo, editada em 1976 pela Secretaria de Economia e Planejamento do Estado de São Paulo - SEPLAN, para a visão conjunta da área de estudo;

- cartas topográficas na escala 1:50.000 do IBGE-Instituto Brasileiro de Geografia e Estatística, disponíveis no acervo do Instituto Geológico-SMA, conforme a Tabela 5.1;

- cartas topográficas na escala 1:10.000 da SEPLAN, editadas em 1979 e adquiridas sob a forma de cópias heliográficas no IGC-Instituto Geográfico e Cartográfico, conforme a Tabela 5.2:

Tabela 5.1 - Relação das cartas topográficas 1:50.000 do IBGE utilizadas no estudo.

\begin{tabular}{|l|c|c|}
\hline \multicolumn{1}{|c|}{ Folha } & Código de identificação & Ano de edição \\
\hline Jurupará & SF-23-Y-C-V-3 & 1973 \\
\hline Salto de Pirapora & SF-23-Y-C-IV-2 & 1971 \\
\hline São Roque & SF-23-Y-C-V-2 & 1973 \\
\hline Sorocaba & SF-23-Y-C-V-1 & 1973 \\
\hline
\end{tabular}


Tabela 5.2 - Relação das cartas topográficas 1:10.000 da SEPLAN.

\begin{tabular}{|l|l|}
\hline \multicolumn{1}{|c|}{ Folha } & Código de identificação \\
\hline Bairro Cafezal de Baixo & SF-23-Y-C-V-3-NO-A \\
\hline Bairro do Arado & SF-23-Y-C-V-1-NO-E \\
\hline Bairro Miguel Russo & SF-23-Y-C-V-3-NO-C \\
\hline Bairro Pirapora & SF-23-Y-C-IV-2-NE-E \\
\hline Bairro Utinga & SF-23-Y-C-IV-2-NE-F \\
\hline Brigadeiro Tobias II & SF-23-Y-C-V-1-NE-A \\
\hline Fazenda Santa Maria & SF-23-Y-C-V-1-NE-C \\
\hline Fazenda São Marcos & SF-23-Y-C-IV-2-NE-D \\
\hline Jundiaquara & SF-23-Y-C-IV-2-NE-C \\
\hline Mairinque I & SF-23-Y-C-V-1-NE-D \\
\hline Mairinque II & SF-23-Y-C-V-2-NO-C \\
\hline Piraporinha & SF-23-Y-C-IV-2-SE-B \\
\hline Represa de Itupararanga & SF-23-Y-C-V-1-NE-F \\
\hline Salto de Pirapora & SF-23-Y-C-IV-2-SE-A \\
\hline Santa Helena & SF-23-Y-C-V-1-NO-F \\
\hline Serra de São Francisco & SF-23-Y-C-V-1-NE-D \\
\hline Serrote do Paiol Velho & SF-23-Y-C-V-1-NE-E \\
\hline Vila Ėlvio & SF-23-Y-C-V-3-NO-D \\
\hline Vila Industrial & SF-23-Y-C-V-1-NE-B \\
\hline Votorantim II & SF-23-Y-C-V-1-NO-C \\
\hline Votorantim III & SF-23-Y-C-V-1-NO-D \\
\hline
\end{tabular}

As cartas, algumas com mais de 20 anos após a edição, apresentam a malha viária desatualizada, causando problemas na localização em campo, motivo pelo qual se utilizou um receptor GPS-Global Positioning System, marca Trimble, modelo Ensign, cedido pelo então Departamento de Geologia Econômica e Geofísica Aplicada (DGE) do Instituto de Geociências-USP (IG-USP). Como foi utilizado somente um receptor GPS, não houve correção do erro induzido, mas, os desvios foram minimizados através de amarração com pontos próximos bem definidos.

\subsubsection{Bases aerofotográficas}

Para a fotointerpretação geológica, foram utilizadas fotografias aéreas na escala 1:25.000, elaboradas pela BASE S.A. na obra O-590 URBES (1995) e cedidas pela Divisão de Mineração da FCV-1.

Como equipamento para a fotointerpretação, foram utilizados um estereoscópio de espelho Wild e um estereoscópio de bolso DFV. A tabela 5.3 mostra as faixas e a numeração das fotografias utilizadas. 
Tabela 5.3 - Relação das fotografias aéreas utilizadas.

\begin{tabular}{|c|l|}
\hline Faixa & \multicolumn{1}{|c|}{ Fotografias } \\
\hline 02 & 16,17 \\
\hline 03 & $16,17,18$ \\
\hline 04 & $15,16,17$ \\
\hline 05 & $13,14,15$ \\
\hline 06 & $14,15,16,17$ \\
\hline 07 & $5,6,7,8,13,14,15,16$ \\
\hline 08 & $5,6,7,8$ \\
\hline
\end{tabular}

\subsection{AMOSTRAGEM}

A localização dos pontos de amostragem foi realizada, no campo, nas cartas 1:10.000 relacionadas na Tabela 5.2, com apoio do GPS nas ocasiões em que a desatualização das cartas causava dúvidas. No alvo da Fazenda Ventania, no setor oeste do prospecto 2 (Granito São Francisco), onde a amostragem foi mais detalhada, as posições dos furos de trado foi posteriormente levantada com precisão centimétrica pela equipe de topografia da FCV-1, através de uma estação total a infravermelho marca Topcon.

Nos trabalhos na mina Pastinho, os pontos descritos/amostrados foram levantados pela mesma equipe de topografia e lançados em planta 1:1.000.

Os procedimentos de amostragem variaram conforme a natureza dos materiais amostrados e, também, em função da etapa dos trabalhos de campo. A seguir, são resumidamente descritos os métodos adotados.

\subsubsection{Amostragem de solo e de rocha alterada (amostragem de superfície)}

As amostras superficiais de solo e rocha alterada, dos prospectos, foram preferencialmente coletadas em cortes de estrada, com raspagem e descarte do material exposto à superficie. Cada amostra representou uma canaleta vertical da altura do corte. A quantidade de material foi de aproximadamente $1 \mathrm{~kg}$ por amostra.

\subsubsection{Amostragem de rocha nas minas}

Na mina Pastinho, foi realizada através de coleta de fragmentos (chip samples) de rocha para análise química, em pontos escolhidos, posteriormente levantados pela 
equipe de topografia da FCV-1 e numerados dentro de uma seqüência já estabelecida na mina. A quantidade de material foi de aproximadamente $0,5 \mathrm{~kg}$ por amostra. Além dos fragmentos para análise química, foram coletadas amostras das litologias mais representativas para estudos petrográficos.

O metadolomito de alto cálcio, o estéril que seria desmontado em maior volume na abertura da cava para SE, foi amostrado numa série das chamadas canaletas, com amostragem contínua de fragmentos em intervalos de $3 \mathrm{~m}$ entre dois pontos numerados e topograficamente levantados, sempre na base dos taludes. Inicialmente, pensou-se em amostrar malhas regulares nos taludes do metadolomito; porém, mostrou-se a mesma impraticável por motivo de segurança. Alternativas de amostragem foram estudadas com base nas informações de Annels (1991), optando-se pela amostragem horizontal na base dos taludes através das canaletas, com complementações futuras, na ocasião dos desmontes, por amostragens de pó de perfuratriz e de blocos desmontados.

$\mathrm{Na}$ mina Baltar subterrânea, foram apenas coletadas amostras das rochas descritas como cálcio-silicáticas pelos Geólogos da FCV-1, para estudos petrográficos.

Na mina do Lago, foram coletadas amostras do filito são e intemperizado, para estudos mineralógicos e petrográficos.

\subsubsection{Amostragem de subsuperfície}

As amostras de subsuperfície, tanto na prospeç̧ão estratégica como na tática, foram coletadas através de sondagem a trado. Inicialmente, foi utilizado o trado modelo IPT, de 4 polegadas de diâmetro, substituído pelo trado mecanizado de mesmo diâmetro, cedido pela FCV-1. Este, revelou-se bastante problemático na sua operação pelos seguintes motivos:

- demanda, no mínimo, um técnico e dois auxiliares, elevando o custo operacional;

- embora perfure mais rapidamente do que o trado manual, as manobras, a cada $30 \mathrm{~cm}$ de avanço, demandam muito tempo devido ao sistema de junção de hastes por roscas e luvas;

- apresenta freqüentes problemas mecânicos, sendo também pesado e ruidoso; 
Devido a esses inconvenientes, o trado mecanizado foi utilizado somente nos furos rasos, de até $3 \mathrm{~m}$, destinados à delimitação da área de ocorrência de material laterítico do prospecto 2 .

Os furos de trado mais profundos, de até $10,5 \mathrm{~m}$, na fase de prospecção tática, foram executados com trado manual marca Eijekelcamp, de fabricação holandesa e cedido pelo DGE / IG - USP. Este equipamento mostrou-se o mais adequado ao tipo de trabalho, devido à leveza do conjunto e à operação muito facilitada pela junção das hastes por luvas e encaixes, proporcionando rendimento superior ao do trado mecanizado. Em profundidades de até $5 \mathrm{~m}$, pode ser operado por apenas uma pessoa.

\subsubsection{Outros tipos de amostragem}

Inserem-se nesta categoria as amostras para controle de teores e determinação de peso específico do material argiloso, assim como de farinha e de clínquer Portland.

Amostragem para controle de teores: foram coletadas nas pilhas de material argiloso da mina do Lago e da Fazenda Ventania, destinadas aos ensaios de produção de clínquer. Várias amostras foram coletadas em diferentes pontos das pilhas, resultando em amostra compostas.

Amostragem para a determinação dos pesos específicos in situ e a seco da laterita da Fazenda Ventania: foram coletadas nos cortes abertos pela lavra experimental, na forma de blocos aproximadamente cúbicos, de dimensões variadas, cujos volumes foram medidos no campo, sendo então encaminhados aos laboratório da FCV-1 em embalagens herméticas.

Amostragem de farinha: foi realizada através dos amostradores automáticos instalados na saída dos moinhos, segundo procedimentos usuais na FCV-1.

Amostragem de clínquer Portland: destinada à obtenção de amostras representativas do mesmo, foram realizada através do peneiramento de cerca de $3 \mathrm{~kg}$ do material in natura em peneiras com abertura de $19 \mathrm{~mm}, 9,5 \mathrm{~mm}, 4,8 \mathrm{~mm}, 2,4 \mathrm{~mm}$ e $0,3 \mathrm{~mm}$. As frações retidas foram manualmente fragmentadas e novamente peneiradas, sendo as porções passantes na peneira $2,4 \mathrm{~mm}$ e retidas na $0,6 \mathrm{~mm}$ compostas, para formar $50 \mathrm{~g}$ de amostra. Este procedimento foi realizado no laboratório da FCV-1. 


\subsection{PROCEDIMENTOS LABORATORIAIS}

\subsubsection{Análise química}

$\mathrm{Na}$ análise química das amostras do estudo, foram utilizados os seguintes métodos:

Análise química clássica (via úmida): realizada no laboratório da FCV-1, foi utilizada nas primeiras amostras de materiais argilosos dos prospectos (24 do prospecto 1, 44 do prospecto 2, 10 do prospecto 3 e 2 do prospecto 4). Devido à morosidade na execução, este método foi substituído pela análise instrumental. Foi também utilizado para a calibração da análise instrumental via fluorescência de raios- $X$. com a laterita do prospecto 2 .

Espectrofotometria de plasma ICP (Ratti 1994): realizada no laboratório Nomos Análises Minerais, do Rio de Janeiro, foi utilizada em grande parte das amostras de material argiloso (28 do prospecto 1,122 do prospecto 2 e 7 do prospecto 3 ).

Fluorescência de raios-X (Ratti 1994): foi realizada através do espectrômetro Phillips PW 1606 do laboratório da FCV-1. Foi utilizada nas amostras de rocha das minas Pastinho e do Lago, na bauxita, no minério de ferro, na farinha, no clínquer, e nas amostras da laterita do prospecto 2 após a calibração do instrumento para o material, já na fase de ensaios de produção de clínquer. As amostra foram preparadas sob a forma de pastilhas prensadas após moagem abaixo da malha 150. Este método é aplicado na rotina diária de análises na FCV-1.

\subsubsection{Análise petrográfica e mineralógica}

Análise petrográfica em lâminas delgadas: foi realizada em amostras de rochas da mina Pastinho (15), da metabásica de Alumínio (1), da mina Baltar subterrânea (3) e da mina do Lago (1). As 20 lâminas foram confeccionadas na Seção de Laminação do IG-USP. Para verificar a distribuição de calcita e dolomita, uma lâmina do metacalcário e três do metadolomito da capa foram coloridas por alizarina com a colaboração da Geóloga M.Sc. Maria Heloisa Barros de Oliveira Frascá, do IPT, segundo método utilizado por Frascá (1992). A análise petrográfica foi realizada no Laboratório de Petrografia do IGSMA e no Laboratório de Microscopia do IG-USP, com a colaboração do Geólogo M.Sc. José Maria de Azevedo Sobrinho e do Prof. Dr. Francisco Dias Alves, do IG-USP. 
Identificação microscópica de minerais pesados: os minerais pesados de algumas amostras do saprolito do Granito São Francisco, da laterita sobrejacente e da cobertura sedimentar avermelhada foram separados e identificados ao microscópio, após concentração por bateamento manual, separação da fração magnética por ímã manual e separação fina por bromofórmio. As lâminas, em sua maioria, foram montadas de forma provisória, com líquido de imersão, sendo apenas as mais representativas montadas de forma definitiva, com bálsamo do Canadá. A identificação dos minerais foi realizada nos mesmos laboratórios acima citados, com a colaboração do Prof. Dr. Paulo César Fonseca Giannini, do IG-USP e do Geólogo M.Sc. José Maria de Azevedo Sobrinho do IG-SMA.

Microscopia de clínquer Portland: teve o objetivo de avaliar a qualidade do clínquer obtido nos ensaios. As amostras de clínquer, obtidas conforme descrito em 5.3.4, foram montadas em seções polidas em enxofre (análise qualitativa) e resina (análise quantitativa) e estudadas ao microscópio de luz refletida quanto à mineralogia e aos aspectos físicos dos componentes. A descrição foi realizada no laboratório da FCV-1, pela Técnica Quimica Janete Rosa, com a participação deste autor. As seções foram examinadas no estado natural e após ataque com $\mathrm{KOH}+$ sacarose em solução aquosa a $10 \%, \mathrm{KOH}+$ álcool e $\mathrm{HNO}_{3}$, destinados a ressaltar determinadas feições ou minerais.

difratometria de raios-X: foi realizada no Laboratório de Difratometria de Raios-X do IG USP (difratômetro Siemens D-500) e no LCT - EPUSP (difratômetro Phillips MPD 1880 - PW 1710). Foi realizada em amostras selecionadas dos materiais argilosos, da farinha de clínquer, do clínquer e de algumas rochas, como complemento à análise petrográfica. As amostras foram reduzidas abaixo da malha 150 e manualmente prensadas em suporte adequado. Para a interpretação dos resultados, foram utilizados os programas Difrac AT da Siemens e ldent da Phillips.

\subsubsection{Microscopia Eletrônica de Varredura (MEV)}

Amostras selecionadas do saprolito do Granito São Francisco, da laterita da Fazenda Ventania e do clínquer Portland, convencional e produto do ensaio, foram examinadas nos microscópios eletrônicos de varredura (MEV) LEO-4401, do Instituto de Geociências - USP, e LEO-S440 do LCT-EPUSP. 
$\mathrm{Na}$ laterita, visou o conhecimento da morfologia dos minerais constituintes na fração argila e, também, dos grãos de quartzo, para comparação com o quartzo do saprolito do granito. As amostras, já separadas na fração argila ou como grãos isolados de quartzo obtidos por lavagem, foram montadas nos suportes (stubs) espalhadas sobre fita de carbono, sendo metalizadas com carbono e ouro.

No clínquer procurou-se comparar a morfologia dos cristais dos componentes dos clínqueres convencional e produzido no ensaio, como parte do processo de avaliação da qualidade do último. As amostras, na forma de fragmentos, foram montadas sobre os stubs coladas à fita de carbono, tendo sido recobertas somente com ouro, o que privilegia a obtenção das imagens.

Para o estudo pontual e qualitativo da composição química das amostras, utilizou-se o recurso do MEV denominado Detetor de Energia Dispersiva (EDS em inglês), cuja aplicação é mais adequada em amostras recobertas com carbono.

\subsubsection{Análises físicas}

Granulometria: inicialmente, 5 amostras do prospecto 2 foram submetidas à análise granulométrica pelo método da pipetagem descrito em Suguio (1973), mas, devido à lentidão do mesmo, foi adotada a análise instrumental, realizada em 30 amostras selecionadas de material argiloso, nas frações abaixo de $1 \mathrm{~mm}$, utilizando-se o analisador a laser Mastersizer Microplus Ver. 2.17, marca Malvern, do LCT- EPUSP. A fração acima de $1,00 \mathrm{~mm}$ foi estudada por peneiramento convencional, utilizando-se as peneiras Tyler de aberturas $4 \mathrm{~mm}(5 \#), 2,38 \mathrm{~mm}(8 \#)$ e $1,68 \mathrm{~mm}(10 \#)$ e 1,00 mm (16 $\#$ \#.

Peso específico in situ e seco: foi determinado em amostras da laterita da Fazenda Ventania. Os blocos aproximadamente cúbicos do material, coletados na área de lavra experimental do Alvo 1 - Fazenda Ventania, foram medidos, acondicionados em embalagem hermética e enviados ao laboratório da FCV-1, onde foram pesados, submetidos a secagem por 24 horas a $60^{\circ} \mathrm{C}$, e novamente pesados. No material escavado, foram também determinados os pesos específicos úmido e seco, através da pesagem em tambores de volume conhecido. Este procedimento prestou-se, também, ao cálculo do fator de empolamento. 


\subsubsection{Determinação aproximada do teor de sílica livre}

Para o conhecimento aproximado do conteúdo de sílica livre, principalmente sob a forma de gräos de quartzo, amostras selecionadas dos materiais argilosos foram tratadas pelo processo conhecido como elutriação (Yamamoto, no prelo), no Laboratório de Preparação de Amostras do DGE/IG-USP.

Neste processo, uma massa conhecida de amostra, previamente desagregada em meio aquoso, é colocada num funil de vidro cuja base está conectada a uma torneira através de uma mangueira. Controlando-se a vazão da água, é possível eliminar as partículas mais finas, que saem pela parte superior, restando em seu interior as partículas grossas, entre elas os grãos de quartzo.

Evidentemente, o método separa outros grãos minerais juntamente com quartzo, motivo pelo qual, ao fornecer o teor de areia, permite conhecer apenas o teor aproximado de quartzo. Porém, após exame visual, admitiu-se como desprezível a massa desses minerais em relação à do quartzo. Foi também desconsiderada a eventual massa de grãos muito finos de quartzo eliminados com as demais partículas finas. Estas, submetidas à análise granulométrica instrumental no analisador a laser Mastersizer Microplus Ver. 2.17, marca Malvern, do LCT- EPUSP, revelaram a média de $44 \mu \mathrm{m}$ para o limite com a fração grossa.

No tratamento das amostras, deu-se ênfase àquelas dos furos de trado do Alvo 1-Fazenda Ventania e dos furos dos Alvos 2 e 3 do prospecto 2 (92), tratando-se também amostras da "argila ferruginosa" (5), do saprolito do Granito São Francisco (5) e da cobertura sedimentar avermelhada (7).

\subsection{PROCESSAMENTO COMPUTACIONAL DE DADOS}

Para o tratamento do grande volume de dados, recorreu-se ao processamento computacional, tanto para as informações gráficas como para os cálculos. Foram aplicadas as seguintes técnicas:

\subsubsection{Cartografia digital}

Para a digitalização das cartas topográficas nas áreas de interesse, foi utilizado o programa Autocad (Autodesk 1997), na sua versão R14. Como equipamento, foi 
utilizada uma mesa digitalizadora Summagraphics formato A0, acoplada a um microcomputador Pentium $166 \mathrm{MHz}$.

Além do Autocad R14, foram utilizados programas computacionais desenvolvidos e/ou adaptados ao presente estudo, como Coord, para conversão de sistemas de coordenadas de geográficas para UTM e vice-versa, e Isopoly5, para conversão de arquivos .DWG em .DXF para exportação e uso em outros programas. Esses programas foram respectivamente desenvolvidos e colocados à disposição dos usuários, em 1996, pelo Geofísico Otávio Coaracy Brasil Gandolfo e pelo Geógrafo Dr. José Antonio Ferrari; o primeiro, pós-graduando do IAG-USP e, o segundo, Pesquisador do Instituto Geológico-SMA .

Os arquivos gerados através do Autocad R14 foram a base de todos os mapas e perfis aqui apresentados, embora a maioria tenha sido editada em suas versões finais em programas como o Corel Draw 7.0 (Corel Corporation 1997).

\subsubsection{Cálculo preliminar de reserva mineral}

Para o cálculo preliminar da reserva de material argiloso no Alvo 1 - Fazenda Ventania, do prospecto 2, utilizou-se o método clássico dos triângulos (Popoff 1966), onde a reserva é resultante da soma dos volumes de primas de base triangular, definida por triângulos formados por furos de sonda posicionados em seus vértices.

O teor médio de cada prisma é obtido pela média dos teores dos furos, ponderada pelas espessuras. O teor médio da reserva é obtido pela ponderação dos teores dos prismas pelos respectivos volumes.

Os cálculos foram realizados com o uso da planilha do Excel 97 (Microsoft Corporation 1997), também utilizada para os demais cálculos, tabulações de dados e confecção de gráficos.

\subsubsection{Diagramas triangulares}

Os diagramas triangulares dos dados de análise química foram obtidos através do programa Triplot $2.0^{4}$, e editados através do Corel Draw 7.0 para apresentação final.

\footnotetext{
${ }^{4}$ Programa computacional elaborado por S. J. Baedke \& T. A. Thompson (1993), Bloomington, Indiana.
} 


\subsubsection{Simulações computacionais da composição da farinha}

Uma vez obtidos os resultados da campanha prospectiva e definido um alvo promissor, foram realizadas simulações da composição da farinha com os diversos componentes, visando a definição da melhor alternativa de combinação dos mesmos. $O$ cálculo da composição da mistura ideal de componentes é realizado através da solução do sistema de equações abaixo, exemplificado para quatro componentes:

$$
\begin{aligned}
& X_{1} S_{1}+X_{2} S_{2}+X_{3} S_{3}+X_{4} S_{4}=T_{1} \\
& X_{1} A_{1}+X_{2} A_{2}+X_{3} A_{3}+X_{4} A_{4}=T_{2} \\
& X_{1} F_{1}+X_{2} F_{2}+X_{3} F_{3}+X_{4} F_{4}=T_{3} \\
& X_{1} C_{1}+X_{2} C_{2}+X_{3} C_{3}+X_{4} C_{4}=T_{4}
\end{aligned}
$$

onde:

$X_{1}, X_{2}, X_{3}, X_{4}=$ proporção de cada óxido nos componentes $1,2,3$ e 4

$S_{1}, S_{2}, S_{3}, S_{4}=$ teores de $\mathrm{SiO}_{2}$ dos componentes $1,2,3$ e 4

$A_{1}, A_{2}, A_{3}, A_{4}=$ teores de $\mathrm{Al}_{2} \mathrm{O}_{3}$ dos componentes $1,2,3$ e 4

$F_{1}, F_{2}, F_{3}, F_{4}=$ teores de $\mathrm{Fe}_{2} \mathrm{O}_{3}$ dos componentes $1,2,3$ e 4

$C_{1}, C_{3}, C_{4}, C_{5}=$ teores de $\mathrm{CaO}$ dos componentes $1,2,3$ e 4

$T_{1}, T_{2}, T_{3}, T_{4}=$ teores de $\mathrm{SiO}_{2}, \mathrm{Al}_{2} \mathrm{O}_{3}, \mathrm{Fe}_{2} \mathrm{O}_{3}$ e $\mathrm{CaO}$ na farinha (objetivos)

$T_{1}, T_{2}, T_{3}$ e $T_{4}$ são estabelecidos de forma a obedecer aos limites ideais dos parämetros químicos exigidos: Módulo de Sílica (MS), Módulo de Alumina (MA) e Fator de Saturação de Cal (FSC), mostrados na Tabela 2.2.

As equações do sistema podem ser representadas sob a forma de matrizes, como mostrado a seguir:

$$
Q X=T
$$

onde Q é a matriz: $\left|\begin{array}{cccc}S_{1} & S_{2} & S_{3} & S_{4} \\ A_{1} & A_{2} & A_{3} & A_{4} \\ F_{1} & F_{2} & F_{3} & F_{4} \\ C_{1} & C_{2} & C_{3} & C_{4}\end{array}\right|$ 
Xé a matriz: $\left|\begin{array}{c}x_{1} \\ x_{2} \\ x_{3} \\ x_{4}\end{array}\right|$ e Té a matriz: $\left|\begin{array}{c}T_{1} \\ T_{2} \\ T_{3} \\ T_{4}\end{array}\right|$

A variação de $1 \%$ em $T_{1}$, com $T_{2}, T_{3}$ e $T_{4}$ constantes, corresponde a certas variações, positivas ou negativas, na proporção de cada um dos quatro componentes. Essas variações são designadas $\Delta S_{1}, \Delta A_{1}, \Delta F_{1}, \Delta C_{1}$ e definidas como objetivos incrementais. Analogamente, uma variação de $1 \%$ em $T_{2}$ corresponde a objetivos incrementais $\Delta S_{2}, \Delta A_{2}, \Delta F_{2}, \Delta C_{2}$, e assim por diante.

Cada um dos quatro conjuntos de $\Delta$ s pode ser obtido através da solução do problema da mistura com os quatro conjuntos de objetivos, como mostrado na matriz 1 a seguir:

\section{MATRIZ 1}

Quatro conjuntos de objetivos incrementais, expressos em porcentagem:

$1^{\circ}$ conjunto de $2^{\circ}$ conjunto de $3^{\circ}$ conjunto de $4^{\circ}$ conjunto de objetivos objetivos objetivos objetivos incrementais incrementais incrementais incrementais

\begin{tabular}{l|llll|}
$\mathrm{SiO}_{2}$ & 1,00 & 0,00 & 0,00 & 0,00 \\
$\mathrm{Al}_{2} \mathrm{O}_{3}$ & 0,00 & 1,00 & 0,00 & 0,00 \\
$\mathrm{Fe}_{2} \mathrm{O}_{3}$ & 0,00 & 0,00 & 1,00 & 0,00 \\
$\mathrm{CaO}$ & 0,00 & 0,00 & 0,00 & 1,00
\end{tabular}

Uma vez obtidos os $\Delta \mathbf{s}$, podem os mesmos ser arranjados para formar a matriz inversa da composição. Sendo a matriz de composição representada pela matriz 2 , pode-se obter a matriz inversa da composição ( matriz 3 ). 
MATRIZ 2

matriz de composição

Componente 1 Componente 2 Componente 3 Componente 4

\begin{tabular}{l|llll}
$\mathrm{SiO}_{2}$ & $S_{1}$ & $S_{2}$ & $S_{3}$ & $S_{4}$ \\
$\mathrm{Al}_{2} \mathrm{O}_{3}$ & $A_{1}$ & $A_{2}$ & $A_{3}$ & $A_{1}$ \\
$\mathrm{Fe}_{2} \mathrm{O}_{3}$ & $F_{1}$ & $F_{2}$ & $F_{3}$ & $F_{4}$ \\
$\mathrm{CaO}$ & $C_{1}$ & $C_{2}$ & $C_{3}$ & $C_{4}$
\end{tabular}

MATRIZ 3

Matriz inversa da composição

$1 \% \mathrm{SiO}_{2} \quad 1 \% \mathrm{Al}_{2} \mathrm{O}_{3} \quad 1 \% \mathrm{Fe}_{2} \mathrm{O}_{3} \quad 1 \% \mathrm{CaO}$

\begin{tabular}{l|cccc}
$\mathrm{SiO}_{2}$ & $\Delta \mathrm{S}_{1}$ & $\Delta \mathrm{S}_{2}$ & $\Delta S_{3}$ & $\Delta S_{4}$ \\
$\mathrm{Al}_{2} \mathrm{O}_{3}$ & $\Delta A_{1}$ & $\Delta A_{2}$ & $\Delta A_{3}$ & $\Delta A_{4}$ \\
$\mathrm{Fe}_{2} \mathrm{O}_{3}$ & $\Delta F_{1}$ & $\Delta F_{2}$ & $\Delta F_{3}$ & $\Delta F_{4}$ \\
$\mathrm{CaO}$ & $\Delta C_{1}$ & $\Delta \mathrm{C}_{2}$ & $\Delta C_{3}$ & $\Delta C_{4}$
\end{tabular}

Cada elemento da matriz inversa é calculado de tal forma que:

$$
\mid \text { MATRIZ } 2|\times| \text { MATRIZ } 3|=| \text { MATRIZ } \mid
$$

Onde a matriz l é:

$\left|\begin{array}{llll}1 & 0 & 0 & 0 \\ 0 & 1 & 0 & 0 \\ 0 & 0 & 1 & 0 \\ 0 & 0 & 0 & 1\end{array}\right|$


Uma vez obtidos os objetivos incrementais da matriz 3, são os mesmos multiplicados pelos objetivos estabelecidos $T_{1}, T_{2}, T_{3}$ e $T_{4}$ para se chegar às proporções $X_{1}, X_{2}, X_{3}$ e $X_{4}$ dos óxidos de cada componente, conforme mostrado na matriz 4.

MATRIZ 4

$$
\mathrm{T}_{1} \% \mathrm{SiO}_{2} \quad \mathrm{~T}_{2} \% \mathrm{Al}_{2} \mathrm{O}_{3} \quad \mathrm{~T}_{3} \% \mathrm{Fe}_{2} \mathrm{O}_{3} \quad \mathrm{~T}_{4} \% \mathrm{CaO}
$$

\begin{tabular}{c|cccc} 
Componente 1 & $T_{1} \times \Delta S_{1}$ & $T_{2} \times \Delta S_{2}$ & $T_{3} \times \Delta S_{3}$ & $T_{4} \times \Delta S_{4}$ \\
Componente 2 & $T_{1} \times \Delta A_{1}$ & $T_{2} \times \Delta A_{2}$ & $T_{3} \times \Delta A_{3}$ & $T_{4} \times \Delta A_{4}$ \\
Componente 3 & $T_{1} \times \Delta F_{1}$ & $T_{2} \times \Delta F_{2}$ & $T_{3} \times \Delta F_{3}$ & $T_{4} \times \Delta F_{4}$ \\
Componente 4 & $T_{1} \times \Delta C_{1}$ & $T_{2} \times \Delta C_{2}$ & $T_{3} \times \Delta C_{3}$ & $T_{4} \times \Delta C_{4}$
\end{tabular}

O resultado é a matriz a seguir, cujos elementos são as proporções buscadas para cada componente:

\begin{tabular}{l|l} 
Componente 1 & $x_{1}$ \\
Componente 2 & $x_{2}$ \\
Componente 3 & $x_{3}$ \\
Componente 4 & $x_{4}$
\end{tabular}

Nas simulações, foram utilizados os programas computacionais FARINHA.PAS, desenvolvido pelo orientador desta pesquisa, e FARINHA.EXE, desenvolvido pela SAIV.

\subsection{TESTE DE PRODUÇÃO DE CLÍNQUER PORTLAND}

Após as simulações da composição da farinha, os dados da melhor alternativa, incluindo as opções de mistura das rochas encaixantes com o metacalcário, foram utilizadOs para a realização de testes de produção de clínquer em escala industrial nos fornos 1 e 2 da FCV-1. A alternativa de testes em escala de laboratório foi abandonada por recomendação da própria indústria, devido à dificuldade de realização dos mesmos na fábrica. Seus técnicos de processo julgaram os resultados das simulações suficientemente confiáveis para a realização de testes em escala industrial. 


\section{CAPÍTULO 6}

\section{AS MINAS PASTINHO, DO LAGO E BALTAR SUBTERRÂNEA}

Antes dos trabalhos de prospecção, foram realizados estudos para o conhecimento geologia das minas e das matérias-primas minerais em utilização na FCV-1. Na mina Pastinho, foram estudados os principais litotipos: metacalcário calcítico, metadolomito de alto cálcio, metadolomito silicoso, filito carbonático e metarenito. Na mina do Lago, foram estudadas amostras do filito são e intemperizado. A Figura 6.1 mostra, em vista aérea, a localização das minas Pastinho, do Lago, Baltar subterrânea, Baltar céu aberto e Placa, sendo as duas últimas paralisadas. A Figura 6.2 mostra o mapa geológico de Santa Helena.

※ão foram realizados estudos na mina Baltar subterrânea (Figura 6.3) devido aos problemas operacionais para a realização dos trabalhos subterrâneos. O seu metacalcário é muito semelhante ao da mina Pastinho, e foram apenas coletadas amostras de rochas cálcio-silicáticas para estudos petrográficos. Os dados químicos referentes às litologias da mina foram fornecidos pela Divisão de Mineração da FCV-1. Esta, realiza mapeamento geológico-estrutural da mina subterrânea na escala 1:500 e monitora rigorosamente as deformações do maciço rochoso através de uma rede de extensômetros. Nesta mina, o volume de estéril a ser removido é inferior ao da mina a céu aberto, limitando-se ao material removido nos trabalhos de desenvolvimento e nas poucas intercalações no minério.

\subsection{A MINA PASTINHO}

\subsubsection{Análise química de amostras de rocha}

Foram descritos 321 pontos, coletadas 290 amostras pontuais e 107 amostras de canaleta. Deste total, 85 amostras foram do metadolomito de alto cálcio. $O$ trabalho representou um refinamento do mapeamento geológico da FCV-1, com um maior detalhamento das informações sobre as propriedades químicas e mineralógicas das rochas. As análises das amostras da mina foram realizadas no laboratório da FCV-1, por fluorescência de raios- $X$ e parcialmente por via úmida, dentro de uma rotina já bem estabelecida na fábrica. Os resultados analíticos são mostrados no Anexo 1. 


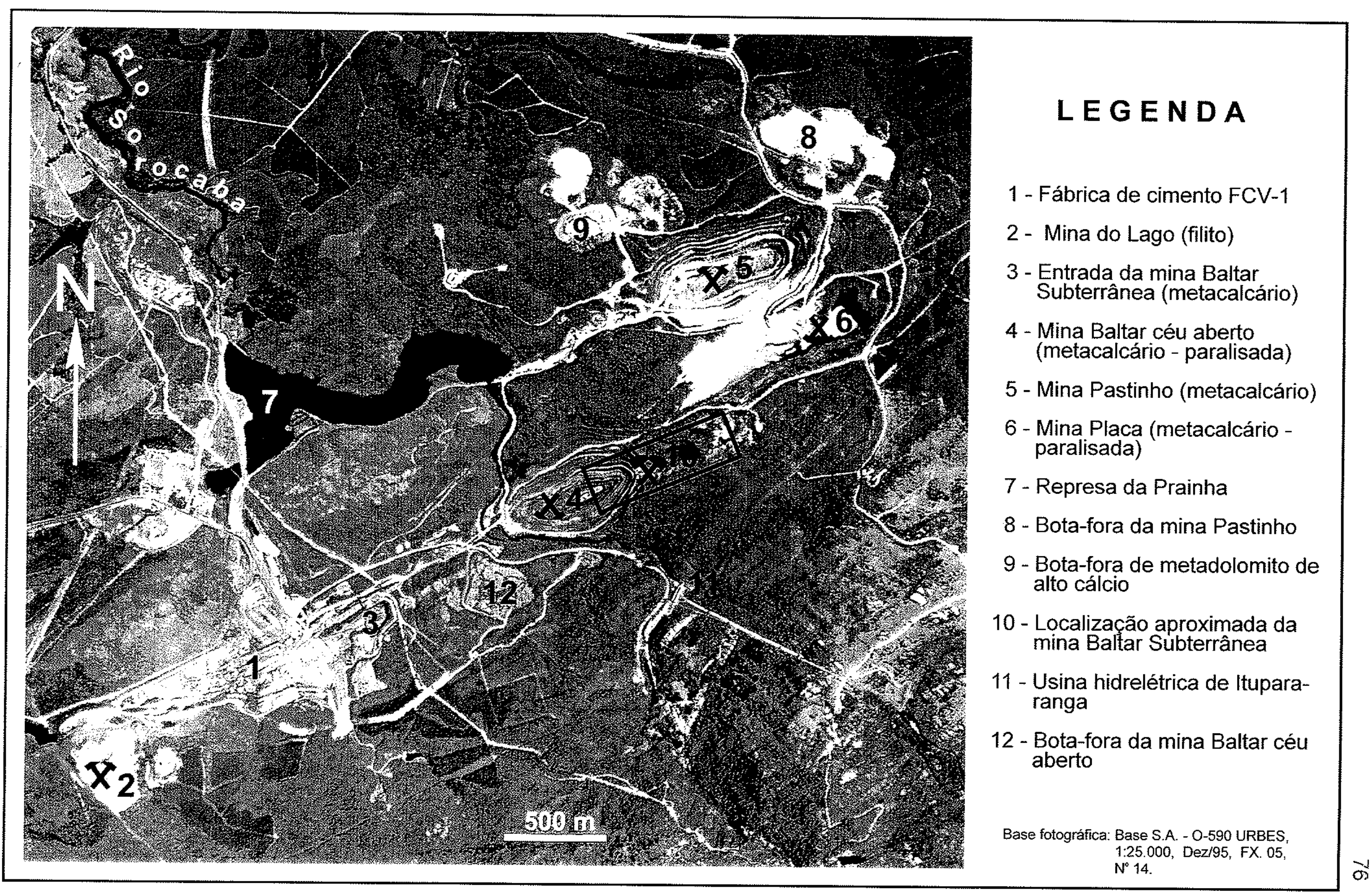

Figura 6.1 - Vista aérea de Santa Helena: FCV-1 e minas de metacalcário e filito. 


\section{CONVENÇÕES}
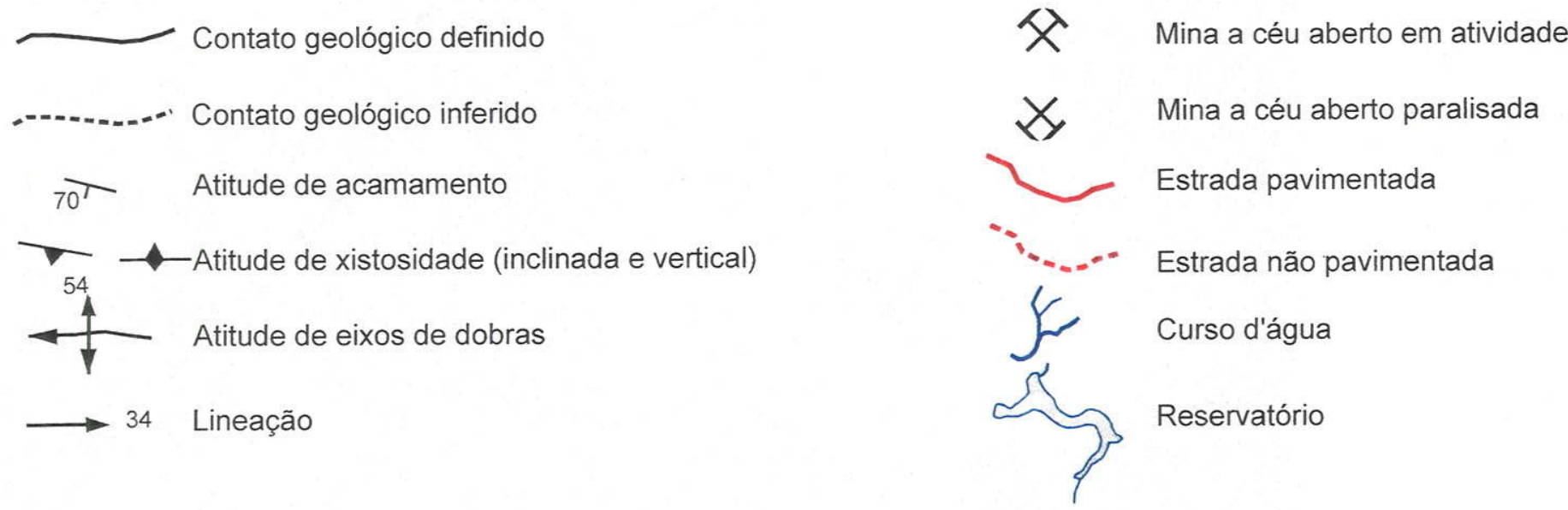


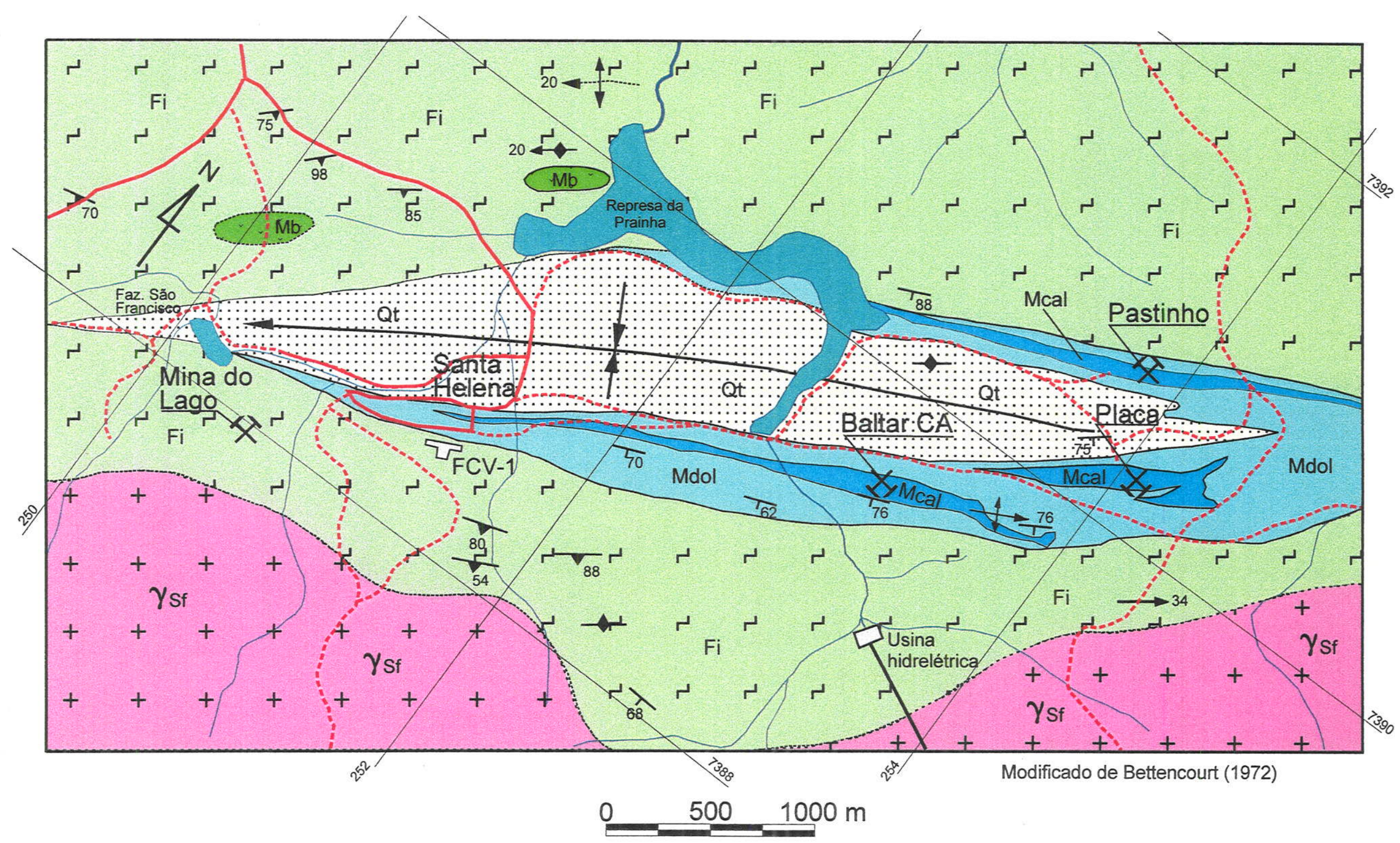

Figura 6.2 - Mapa geológico de Santa Helena e do seu entorno. 

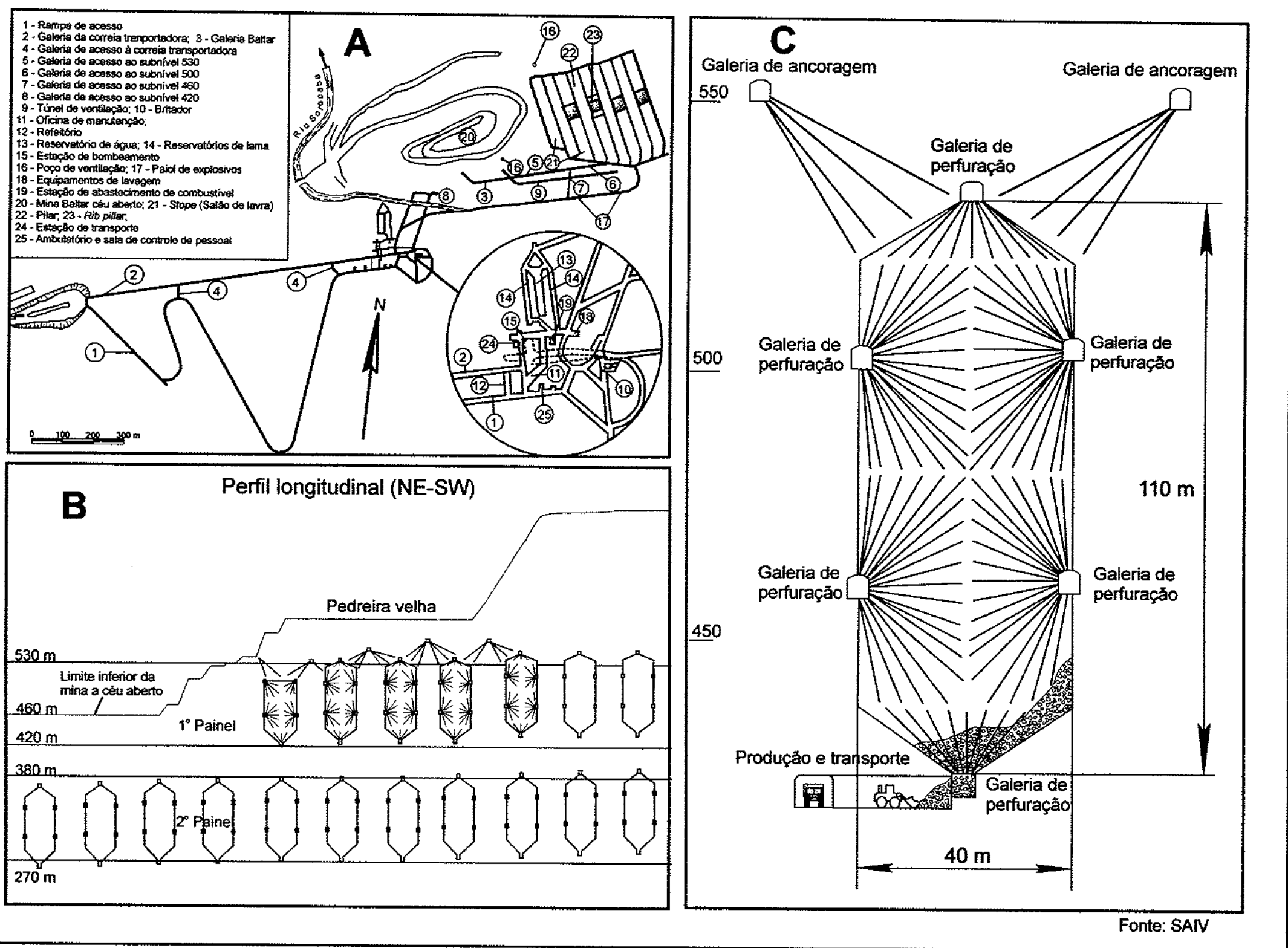

Figura 6.3 - Mina Baltar Subterrânea: A) Projeção da mina na superfície do terreno; B) Perfil longitudinal; C) Detalhe de salão de lavra. 
Os resultados analíticos das amostras da mina Pastinho são mostrados no Anexo 1. A Figura 6.4 mostra os pontos numerados de descrição/amostragem da mina Pastinho, e as Figuras 6.5 e 6.6 mostram, respectivamente, o mapa geológico da mina e o perfil geológico da mesma.

O filito carbonático, do qual foram coletadas 16 amostras, incluindo um lote de 10 posteriormente coletadas pela equipe da FCV, tem ocorrência restrita na mina, em faixas delgadas, com pequena expressão volumétrica. $O$ metadolomito silicoso, com 85 amostras, não será mais desmontado no setor NW da mina (lapa), estando os taludes e bermas desse flanco da cava já em configuração final. A Figura 6.7A e B mostram a cava da minas Pastinho. A Figura 6.7C mostra um modelo geológico digital da mina Pastinho. A Figura 6.7D mostra uma vista aérea das minas Baltar Céu Aberto, Pastinho e Placa. A Figura 6.7E mostra o desmonte do metadolomito e do filito carbonático no setor SE da mina Pastinho. As Figuras 6.8A a $6.8 \mathrm{H}$ mostram detalhes macroscópicos dos litotipos da mina Pastinho.

Para o metacalcário calcítico (115 amostras), o metadolomito de alto cálcio do setor SE da mina (capa), o filito carbonático e o metadolomito silicoso, foram obtidas as médias para os teores, conforme apresentados na Tabela 6.1 a seguir:

Tabela 6.1 - Teores médios, em \%, das amostras de rocha da mina Pastinho.

\begin{tabular}{|l|c|c|c|c|c|}
\hline \multicolumn{1}{|c|}{ Litologia } & $\mathrm{CaO}$ & $\mathrm{SiO}_{2}$ & $\mathrm{Al}_{2} \mathrm{O}_{3}$ & $\mathrm{Fe}_{2} \mathrm{O}_{3}$ & $\mathrm{MgO}$ \\
\hline $\begin{array}{l}\text { metacalcário } \\
\text { calcítico }\end{array}$ & 51,93 & 3,28 & 0,50 & 0,41 & 0,80 \\
\hline $\begin{array}{l}\text { metadolomito } \\
\text { de alto cálcio }\end{array}$ & 31,73 & 3,45 & 1,11 & 0,84 & 17,94 \\
\hline $\begin{array}{l}\text { filito } \\
\text { carbonático }\end{array}$ & 15,07 & 49,44 & 10,09 & 3,66 & 7,16 \\
\hline $\begin{array}{l}\text { metadolomito } \\
\text { silicoso }\end{array}$ & 23,55 & 23,51 & 3,31 & 2,06 & 12,83 \\
\hline
\end{tabular}

Os teores de $\mathrm{K}_{2} \mathrm{O}$ e $\mathrm{Na}_{2} \mathrm{O}$ foram determinados em apenas 32 amostras devido à falta de disponibilidade do laboratório da FCV para a execução das análises via úmida, motivo pelo qual não foram incluidos seus valores médios na Tabela 6.1. Nas amostras analisadas, apresentam-se baixos, chegando $\circ \mathrm{K}_{2} \mathrm{O}$ a mais de $2,0 \%$ apenas nas amostras do filito carbonático. 


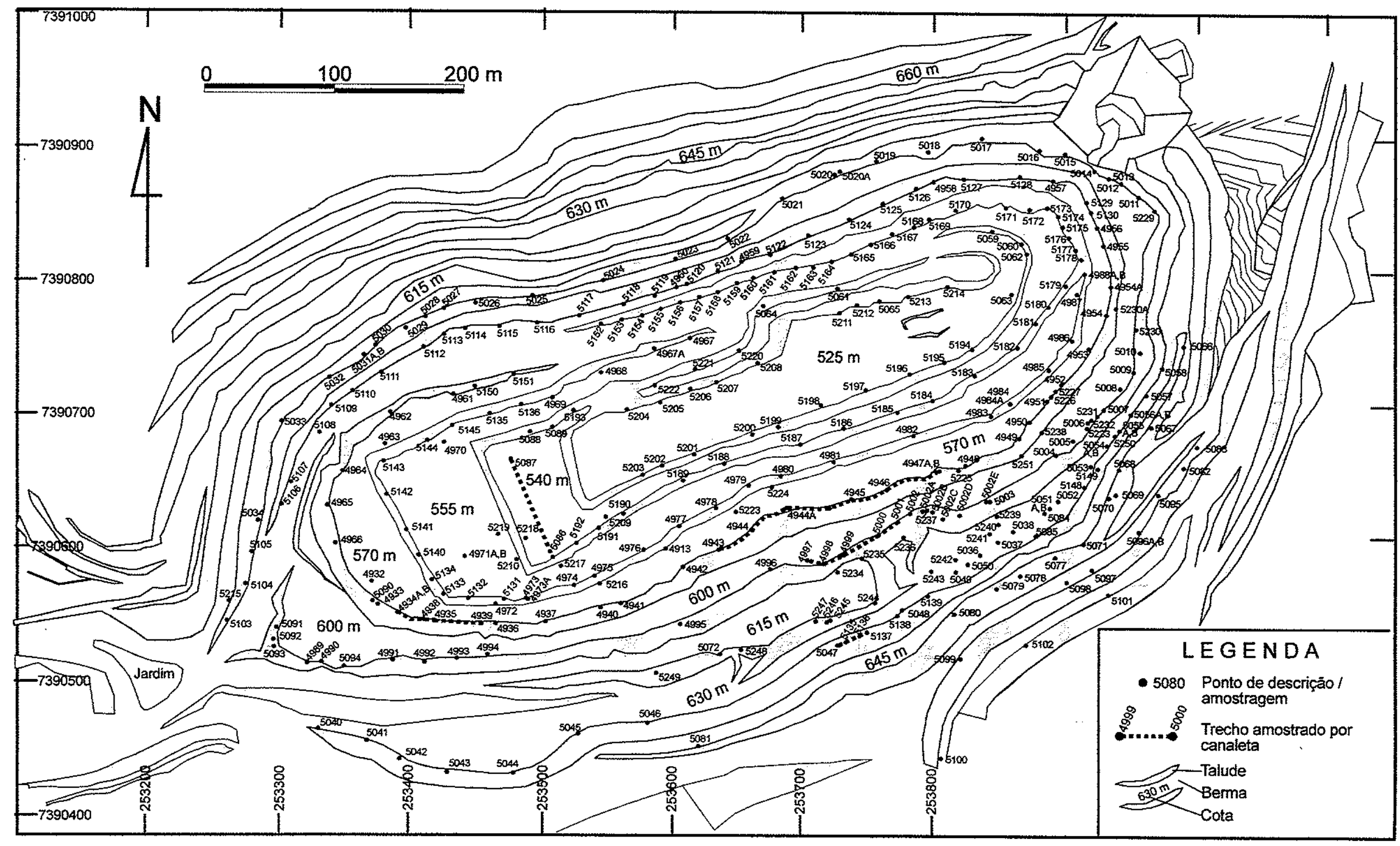

Figura 6.4 - Mapa de pontos de observação / amostragem na mina Pastinho. 
LEGENDA DA FIGURA 6.5

Ei Filito

Mds Metadolomito silicoso

Mcc Metacalcário calcítico

Mcd Metacalcário dolomítico

Fc Filito carbonático

Mdc Metadolomito de alto cálcio (capa)

Màs: Metarenito silicificado

Mair: Metarenito com intercalações de metassiltitos

_ـ Contato geológico definido

....... Contato geológico inferido

80 Atitude de foliação

570 Cota em metros 


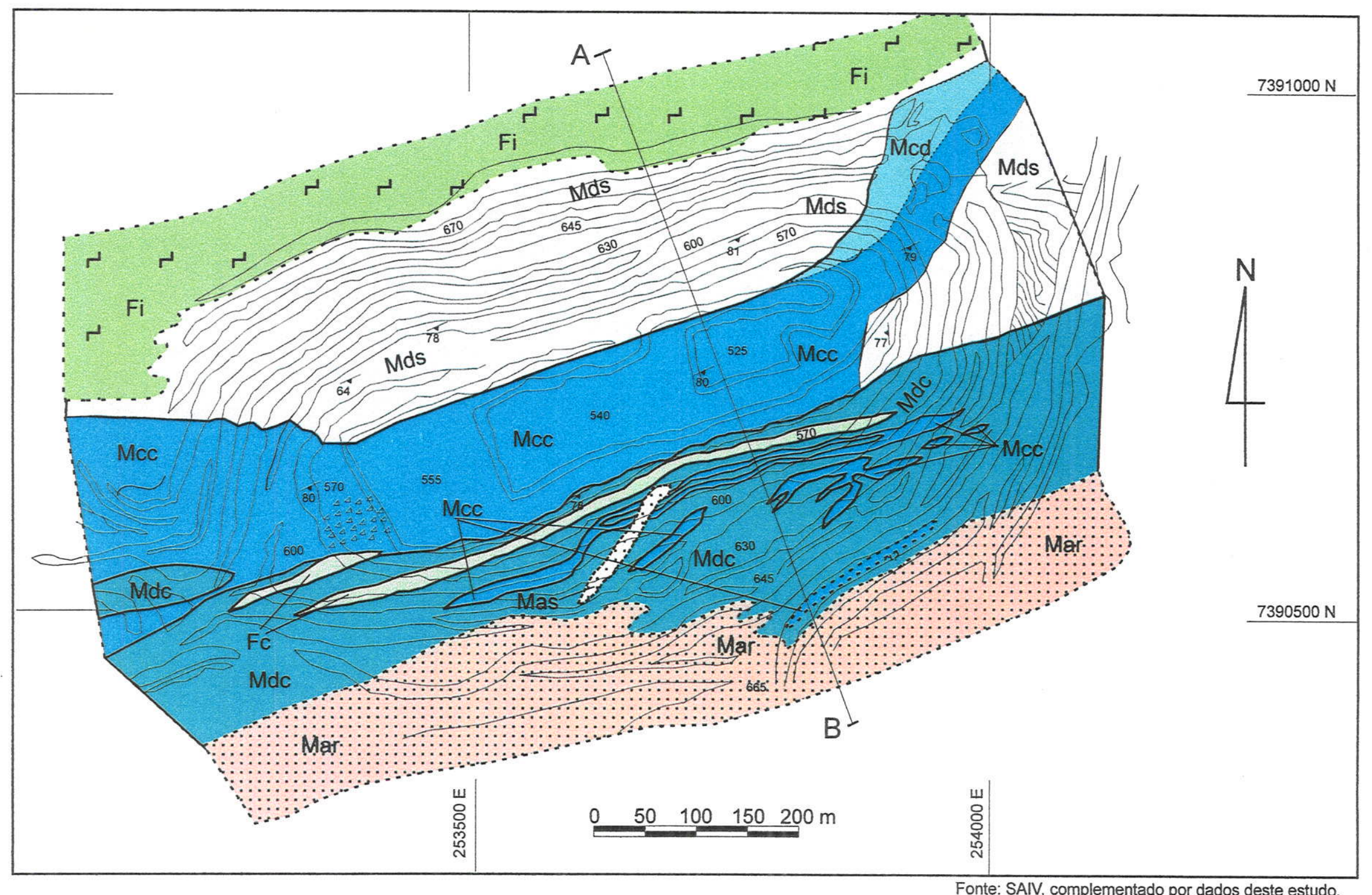

Figura 6.5 - Mapa geológico da mina Pastinho. 


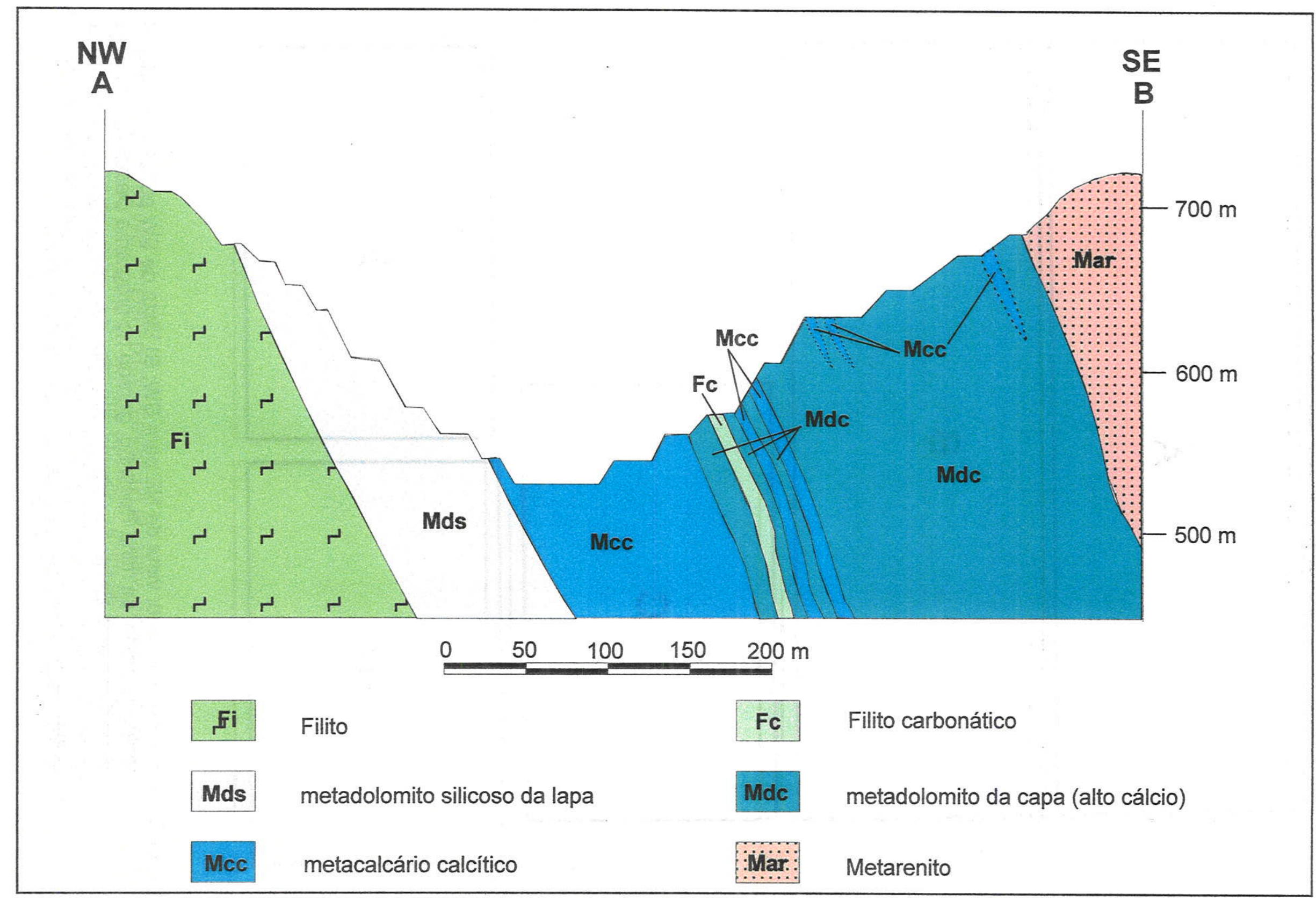

Figura 6.6 - Perfil geológico da mina Pastinho. 


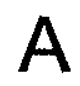

B
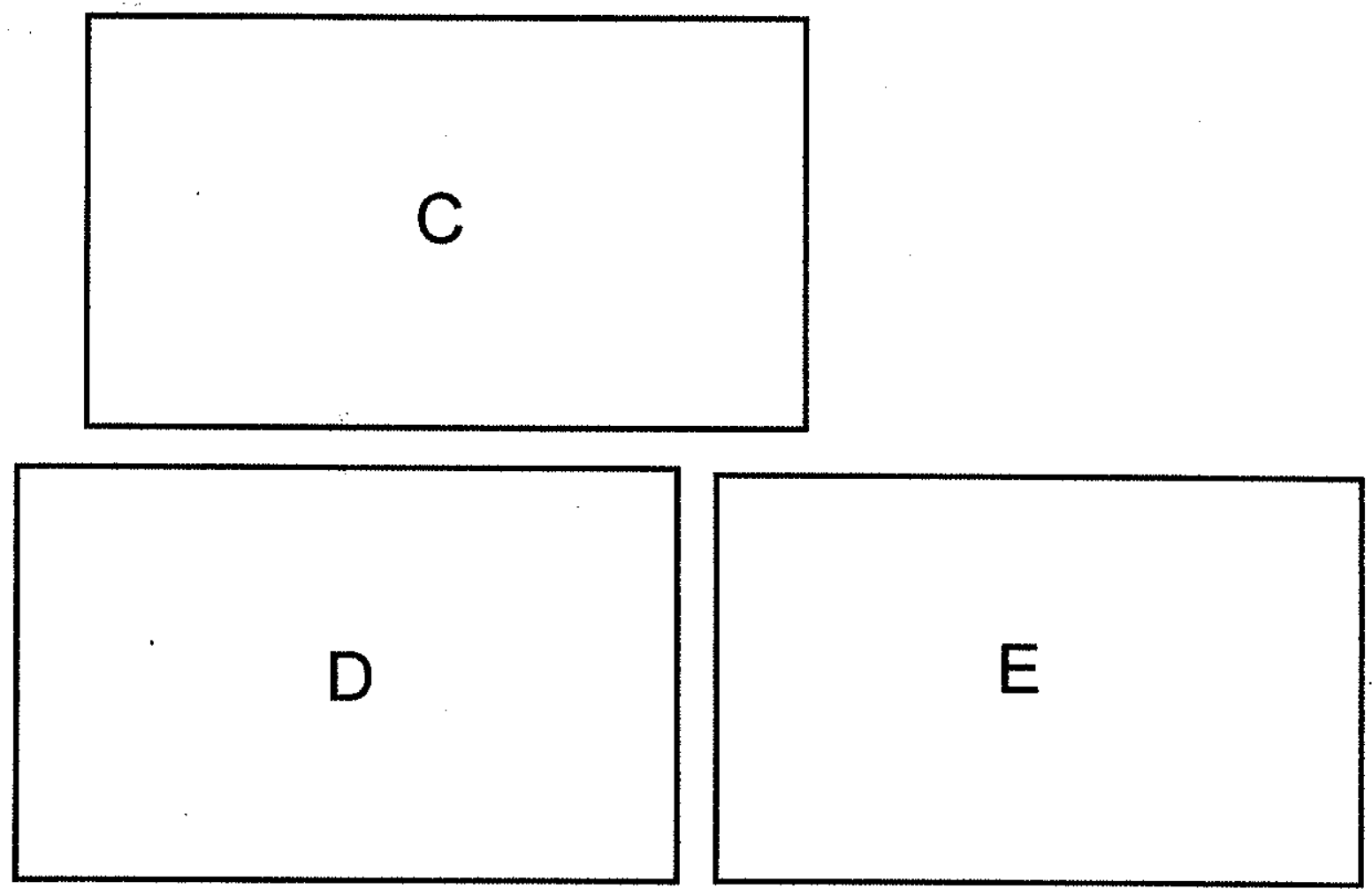

Figura 6.7 - A) Mina Pasrinho: vista de NE para SW; B) Vista de SW para NE; C) Modelo geológico digital da mina Pastinho, gerado no programa Datamine; D) Vista aérea das minas Baltar céu aberto (em primeiro plano), Pastinho (no alto, à esquerda, e Placa (inundada); E) Desmonte do metadolomito de alto cálcio e do filito carbonático no setor SE na mina Pastinho (capa). 

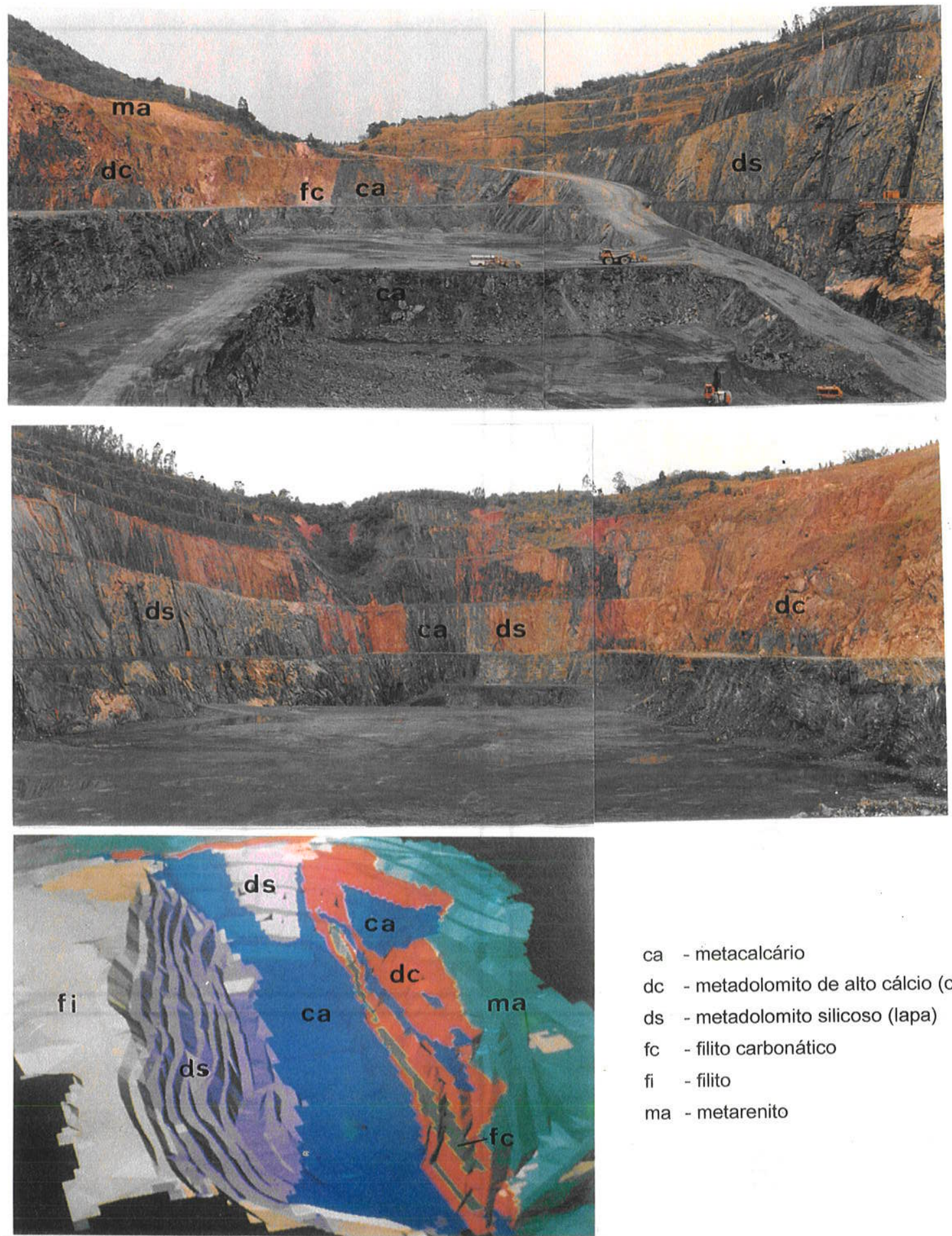

$$
\begin{array}{ll}
\text { ca } & \text { - metacalcário } \\
\text { dc } & \text { - metadolomito de alto cálcio (capa) } \\
\text { ds } & \text { - metadolomito silicoso (lapa) } \\
\text { fc } & \text { - filito carbonático } \\
\text { fi } & \text { - filito } \\
\text { ma } & \text { - metarenito }
\end{array}
$$
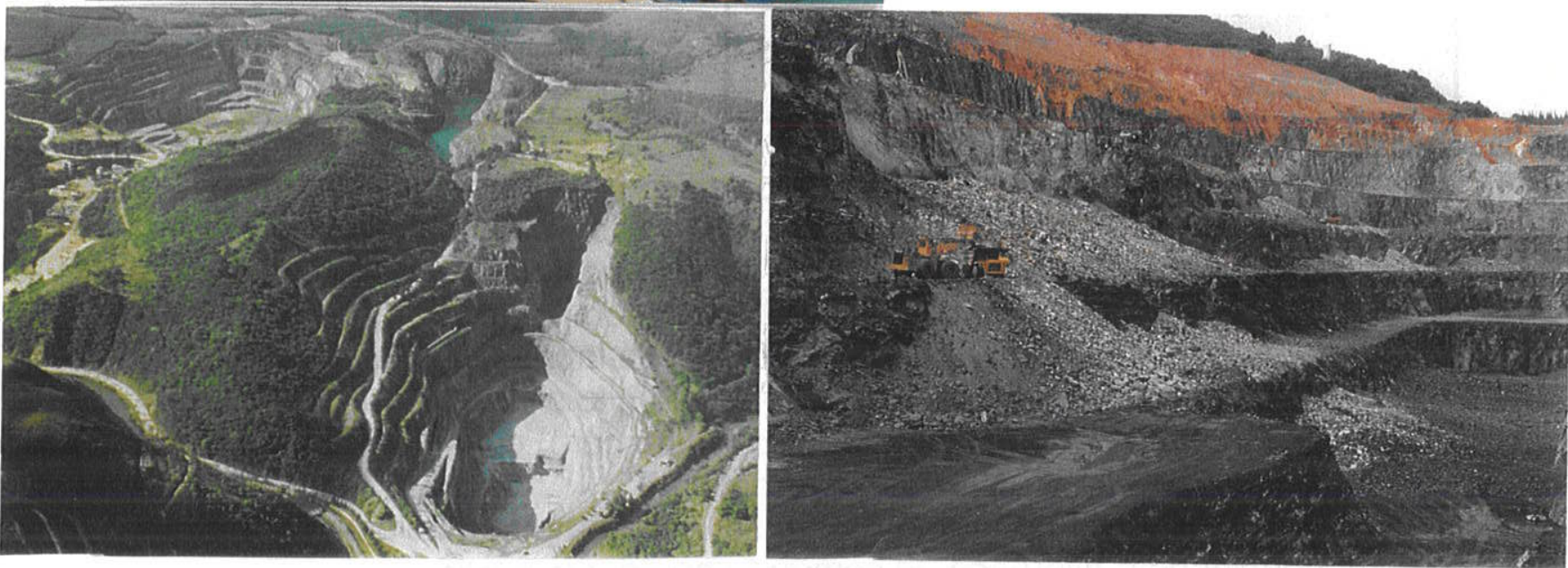

Figuras 6.7A a E - Ilustrações fotográficas gerais da mina Pastinho. 

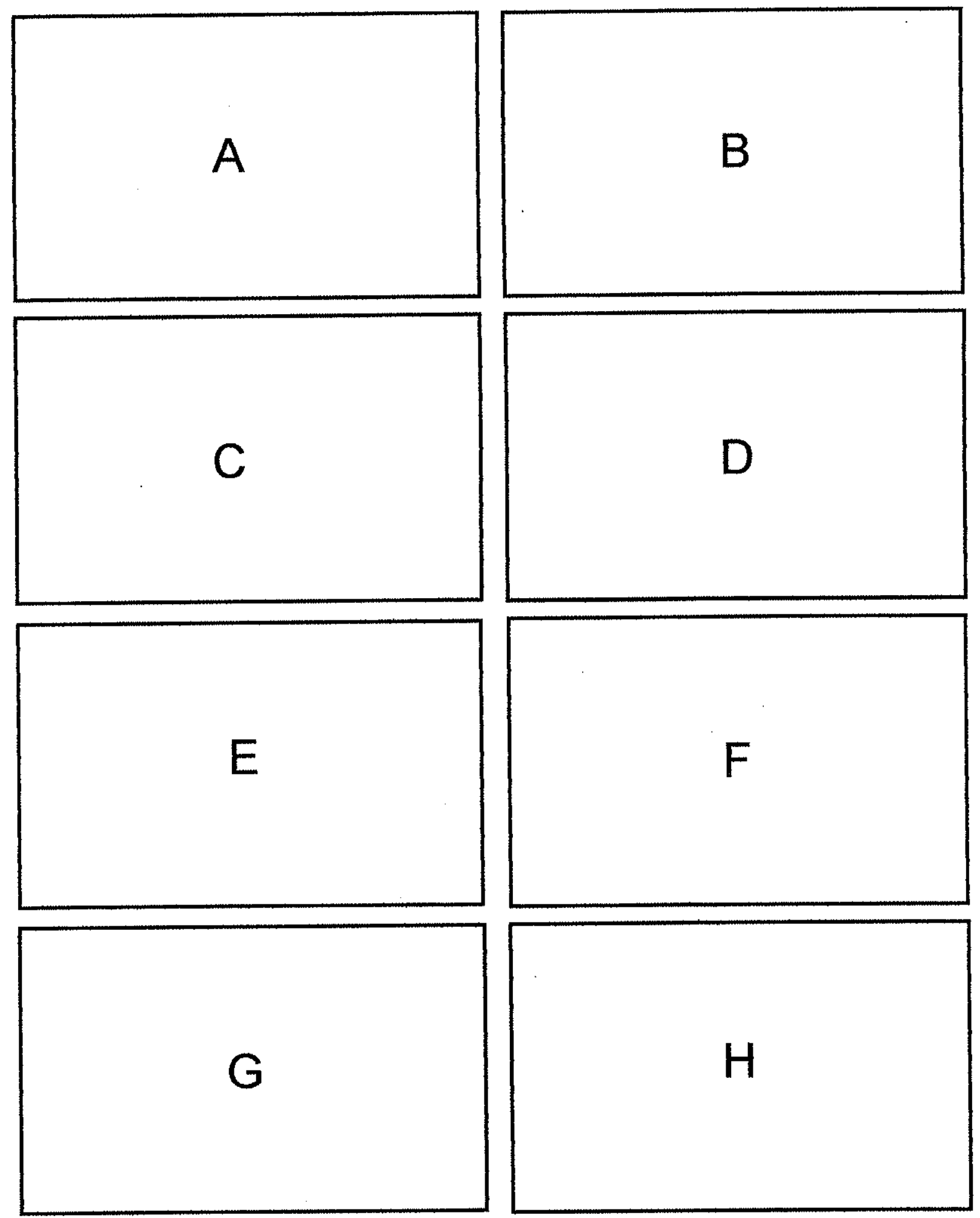

Figura 6.8 - A) Zona brechada com cimento calcítico no metacalcário da mina Pastinho;

B) Aspecto foliado do metacalcário da mina Pastinho;

C) Intercalação de metacalcário (escuro) no dolomito de alto cálcio (capa);

D) Aspecto venulado e não foliado do dolomito de alto cálcio da mina Pastinho;

E) Aspecto foliado do dolomito silicoso da lapa (setor NW da mina Pastinho);

F) Venulas paralelas de quartzo no dolomito silicoso da lapa;

G) Contado por falha do metacalcário (escuro) com o dolomito silicoso em atitude discordante (setor NE da mina Pastinho);

H) Deformação do metacalcário se amoldando ao dolomito maciço da capa, evidenciando a diferença de comportamento mecânico. 

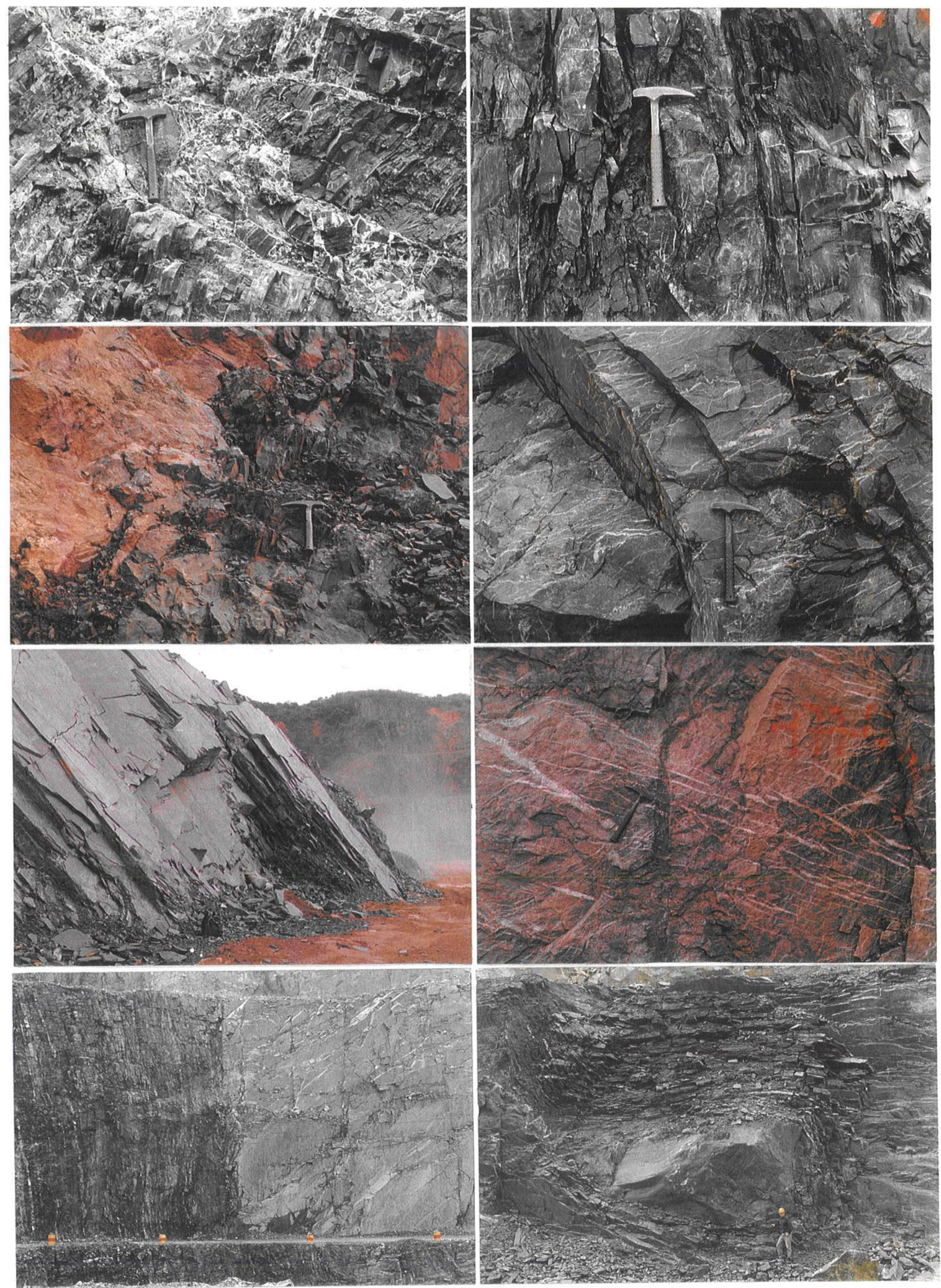

Figuras 6.8A a H - llustrações fotográficas de detalhes geológicos da mina Pastinho. 


\subsubsection{Análise petrográfica}

Foram realizados estudos petrográficos em 15 lâminas delgadas das litologias da mina Pastinho (amostras 4933A ${ }^{5}, 4933 B, 4934 A, 4934 B, 4936,4941,4944,4948,4954$, 4956A, 4956B, 4958, 4965, 5002 e 5188).

As descrições petrográficas foram realizadas no Laboratório de Microscopia do Instituto Geológico - SMA, com o auxilio do Geólogo M.Sc. José Maria de Azevedo Sobrinho. A nomenclatura das rochas carbonáticas foi baseada nos critérios estabelecidos por Dunhan (1962) em sua proposta de classificação de acordo com a textura deposicional. Segundo essa classificação, as rochas carbonáticas muito finas da mina Pastinho são mudstones carbonáticos.

As Figuras $6.9 \mathrm{~A}$ a $6.9 \mathrm{H}$ e $6.10 \mathrm{~A}$ a $\mathrm{D}$ apresentam fotomicrografias e descrições dos litotipos mais representativos da mina Pastinho.

Em lâminas delgadas, as evidências de metamorfismo, nas rochas das minas Pastinho e Baltar são típicas do fácies xisto verde. No metacalcário e no metadolomito de alto cálcio, a quase ausência de minerais além dos carbonatos não propiciou a formação de minerais metamórficos. O pouco quartzo presente contribuiu para algum rearranjo mineral, mas são as recristalizações parciais e a intensa venulação, no caso dos metadolomitos, que indicam fenômenos metamórficos.

Nota-se, tanto em escala macroscópica como microscópica, que as rochas encontram-se localmente deformadas em conseqüência dos esforços relacionados ao cisalhamento transcorrente da ZCT de Moreiras (Magalhães et al. 1995; Silva 1997), que se estende de Salto de Pirapora, afetando as minas Mina 1, Pastinho, Placa e prolongando-se para NE até juntar-se à ZCT de Pirapora.

Rochas contendo minerais micáceos, como o filito carbonático, mostram uma foliação oblíqua à laminação mais evidente. Nota-se a mesma foliação oblíqua no metadolomito silicoso da lapa.

\subsection{MINA BALTAR SUBTERRÂNEA}

Como anteriormente exposto, os trabalhos nesta mina limitaram-se à coleta e estudo petrográfico de amostras das rochas cálcio-silicáticas, respectivamente

\footnotetext{
${ }^{5}$ As letras após o número do ponto identificam amostram em duplicata do mesmo ponto ou amostras coletadas em ambos os lados de contatos geológicos.
} 


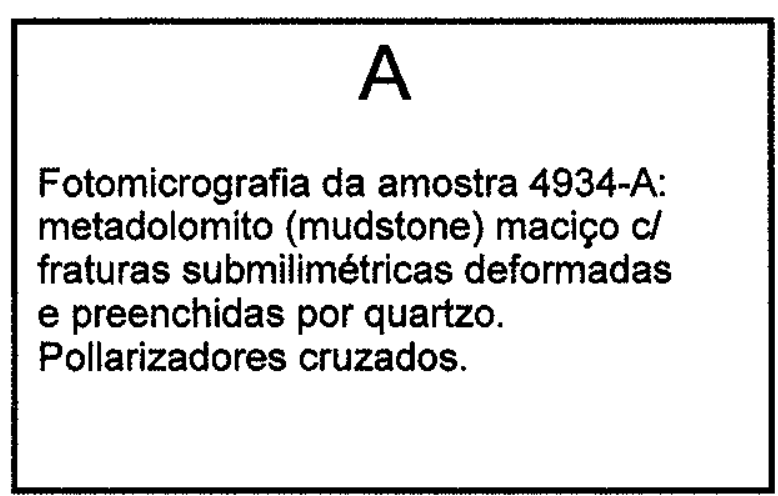

\section{C}

Fotomicrografia da amostra 4941: metadolomito da capa com granulação média e textura granoblástica tendendo à poligonizaçăo, cortado por veio carbonático de espessura submilimétrica.

Polarizadores cruzados.

\section{E}

Fotomicrografia da amostra 4956-A: metacalcário (mudstone deformado) com veio calcítico dobrado.

Polarizadores cruzados.

\section{G}

Fotomicrografia da amostra 4956-A: metacalcário (mudstone) com veios calcíticos deformados paralelamente à foliaçẫo e carbonatos de granulação mais grossa formando augens.

Polarizadores cruzados.

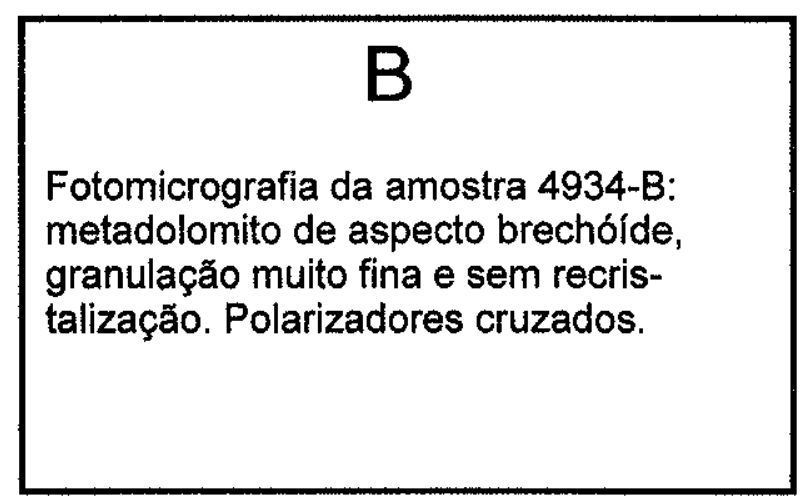

\section{D}

Fotomicrografia da amostra 4954: metadolomito silicoso (mudstone foliado) com foliação marcada por filmes de opacos. Fraturas subcentimétricas preenchidas por carbonatos e quartzo xenomófico a idiomórfico. Polarizadores cruzados.

\section{5}

Fotomicrografia da amostra 4956-B: metadolomito maciço com filmes de opacos marcando a presença de estilólitos.

Polarizadores paralelos.

\section{$\mathrm{H}$}

Fotomicrografia da amostra 4965: metacalcário (mudstone) parcialmente recristalizado com filmes de opacos dobrados e transpostos. Polarizadores cruzados. 


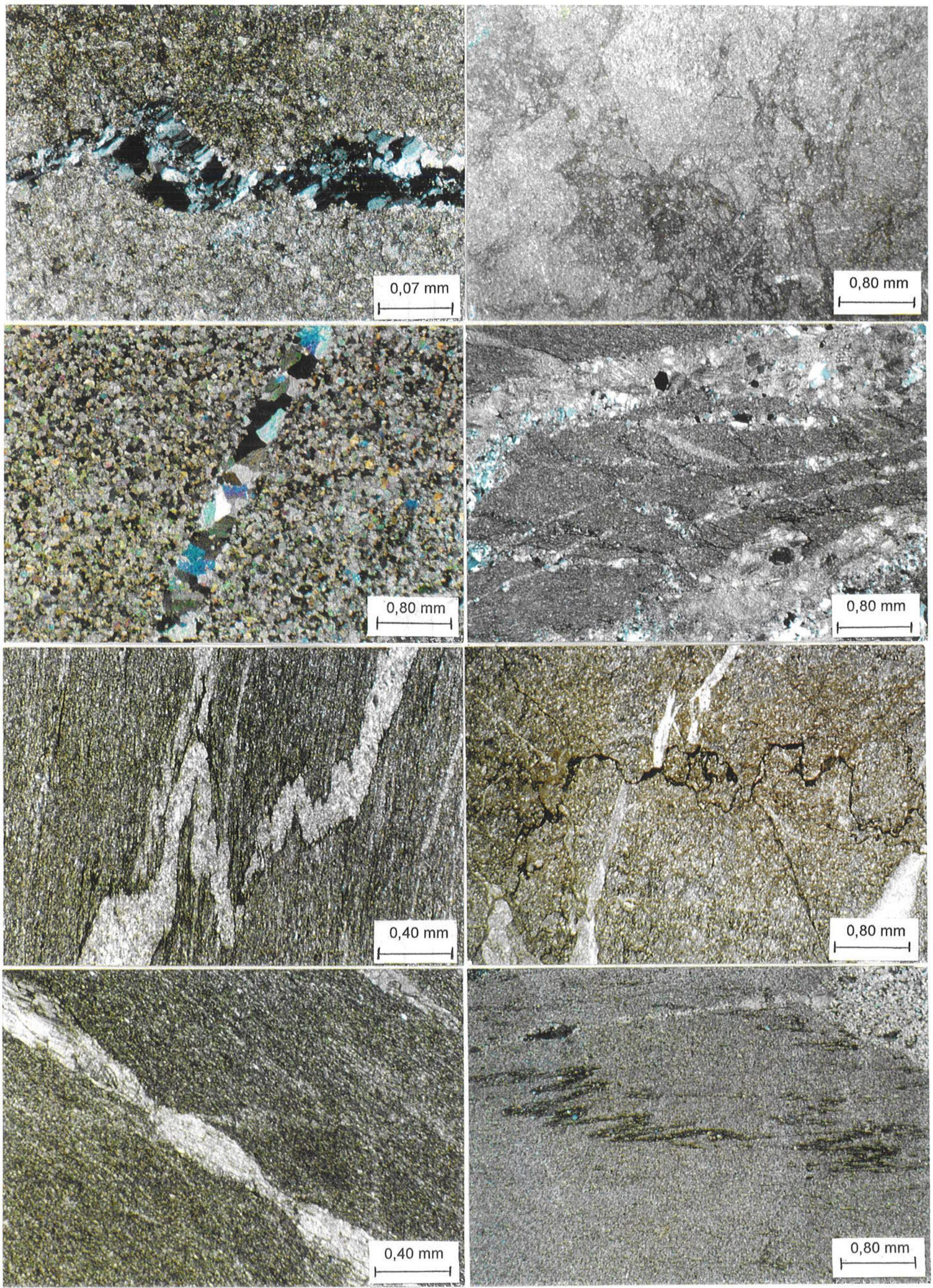

Figuras 6.9A a H - Fotomicrografias de rochas da mina Pastinho. 


\section{$\mathrm{A}$ \\ Fotomicrografia da amostra 5002: metadolomito da capa da mina Pastinho, com vênulas de carbonato e quartzo cor- tando a massa dolomítica. \\ Polarizadores cruzados e tratada com alizarina, para coloração da calcita.}

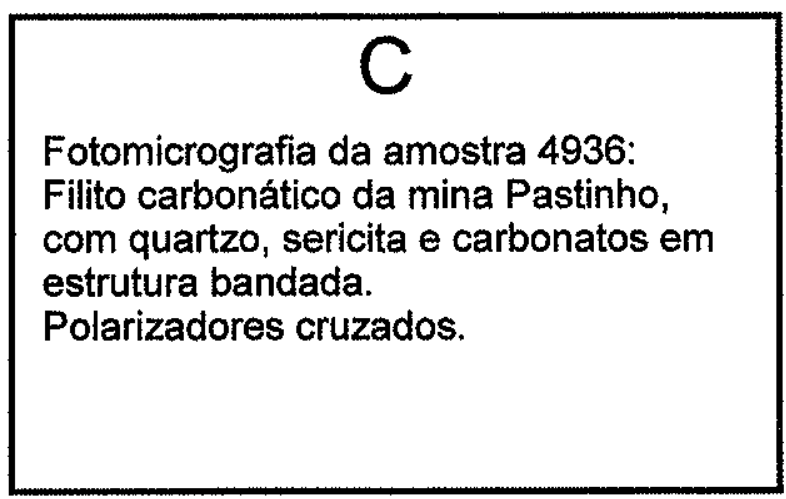

\section{$E$}

Fotomicrografia da amostra CSX-01:

Cálcio-silicática bandada da mina Baltar subterrânea, com bandas formadas por quartzo, acinolita-tremolita, carbonatos e opacos. Microfalhas provocaram dobras de arrasto na xistosidade.

Polarizadores cruzados.

\section{G}

Fotomicrografia da amostra CSB-01: Cálcio-silicática bandada da mina Baltar subterrânea, exibindo banda rica em quartzo à esquerda, cristal de vesuvianita no centro e banda rica em actinolitatremolita à direita.

Polarizadores cruzados.

\section{B}

Fotomicrografia da amostra 4944:

metadolomito da capa mina Pastinho, com grãos de calcita coloridos por alizarina e dispersos ao longo de fratura.

Polarizadores paralelos.

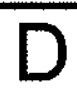

Fotomicrografia da amostra 4936:

Filito carbonático da mina Pastinho, exibindo banda mais rica em carbonatos, com sericita e quartzo.

Polarizadores cruzados.

\section{$\mathrm{F}$}

Fotomicrografia da amostra CSM-01:

Cálcio-silicática maciça da mina Baltar subterrânea, exibindo estrutura xistosa, com biotita e quartzo como constituintes essenciais e carbonatos acessórios.

Polarizadores paralelos.

\section{$\mathrm{H}$}

Fotomicrografia da amostra CSB-01: detalhe de cristal de vesuvianita.

Polarizadores paralelos. 

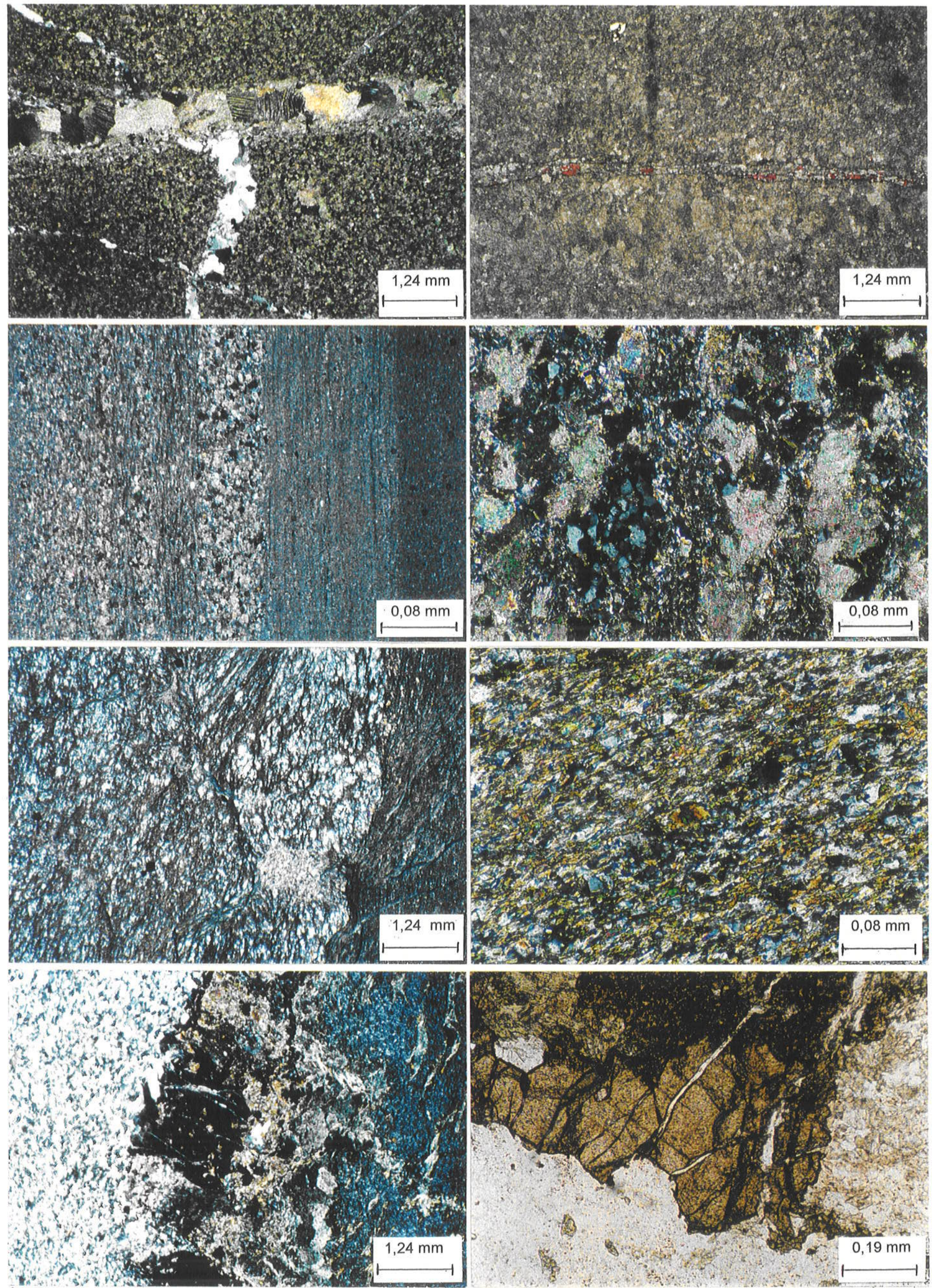

Figuras 6.10A a H - Fotomicrografias de rochas da mina Pastinho e Baltar subterrânea. 
denominadas maciça (CSM-01), bandada (CSB-02) e xistosa (CSX-01) pelos Geólogos da FCV-1. A primeira apresenta-se xistosa, contendo como minerais essenciais biotita e quartzo, comparecendo os carbonatos como acessórios. A segunda apresenta-se em bandas centimétricas de grãos de quartzo e de material constituído por actinolitatremolita, carbonatos e cristais zonados de vesuvianita. A última mostra-se bem xistosa, contendo actinolita-tremolita, quartzo, carbonatos e opacos, com microfalhas cortando a xistosidade e provocando pequenas dobras de arrasto (drag folds) (Figuras 6.10E a $6.10 \mathrm{H})$. A litologia que apresenta interesse para a mistura com o metacalcário é a cálcio-silicática xistosa, que ocorre intercalada no. metacalcário, cuja análise típica, fornecida pela FCV-1, é apresentada abaixo:

\begin{tabular}{ccccc}
$\mathrm{SiO}_{2}$ & $\mathrm{Al}_{2} \mathrm{O}_{3}$ & $\mathrm{Fe}_{2} \mathrm{O}_{3}$ & $\mathrm{MgO}$ & $\mathrm{K}_{2} \mathrm{O}$ \\
\hline 47,40 & 5,94 & 6,15 & 2,50 & 0,98
\end{tabular}

\subsection{A MINA DO LAGO}

A mina do Lago foi objeto de um rápido reconhecimento geológico, com a coleta de amostras da rocha intemperizada e fresca para análise mineralógica. $O$ filito intemperizado da mina do Lago (amostra FL-01) foi submetido à difração de raios-X, apresentando como minerais essenciais quartzo, mica e caulinita no difratograma (Figura 6.11). Nota-se que o material apresenta heterogeneidade mineralógica em função da presença de blocos de rocha semi-intemperizada.

A rocha fresca (amostra FL-02) apresenta-se macroscopicamente com coloração cinza e bem foliada. Microscopicamente, revela como constituintes essenciais sericita e quartzo. Como acessórios, notam-se grãos muito finos de zircão, turmalina e apatita.

Os dados de análise química da mina do Lago foram fornecidos pela FCV-1, que a realiza rotineira e sistematicamente por fluorescência de raios- $X$, para controle de enchimento dos depósitos de argila. Apresenta-se a seguir uma análise típica do filito intemperizado:

\begin{tabular}{ccccc}
$\mathrm{SiO}_{2}$ & $\mathrm{Al}_{2} \mathrm{O}_{3}$ & $\mathrm{Fe}_{2} \mathrm{O}_{3}$ & $\mathrm{MgO}$ & $\mathrm{K}_{2} \mathrm{O}$ \\
\hline 63,12 & 18,00 & 7,33 & 1,13 & 2,68
\end{tabular}




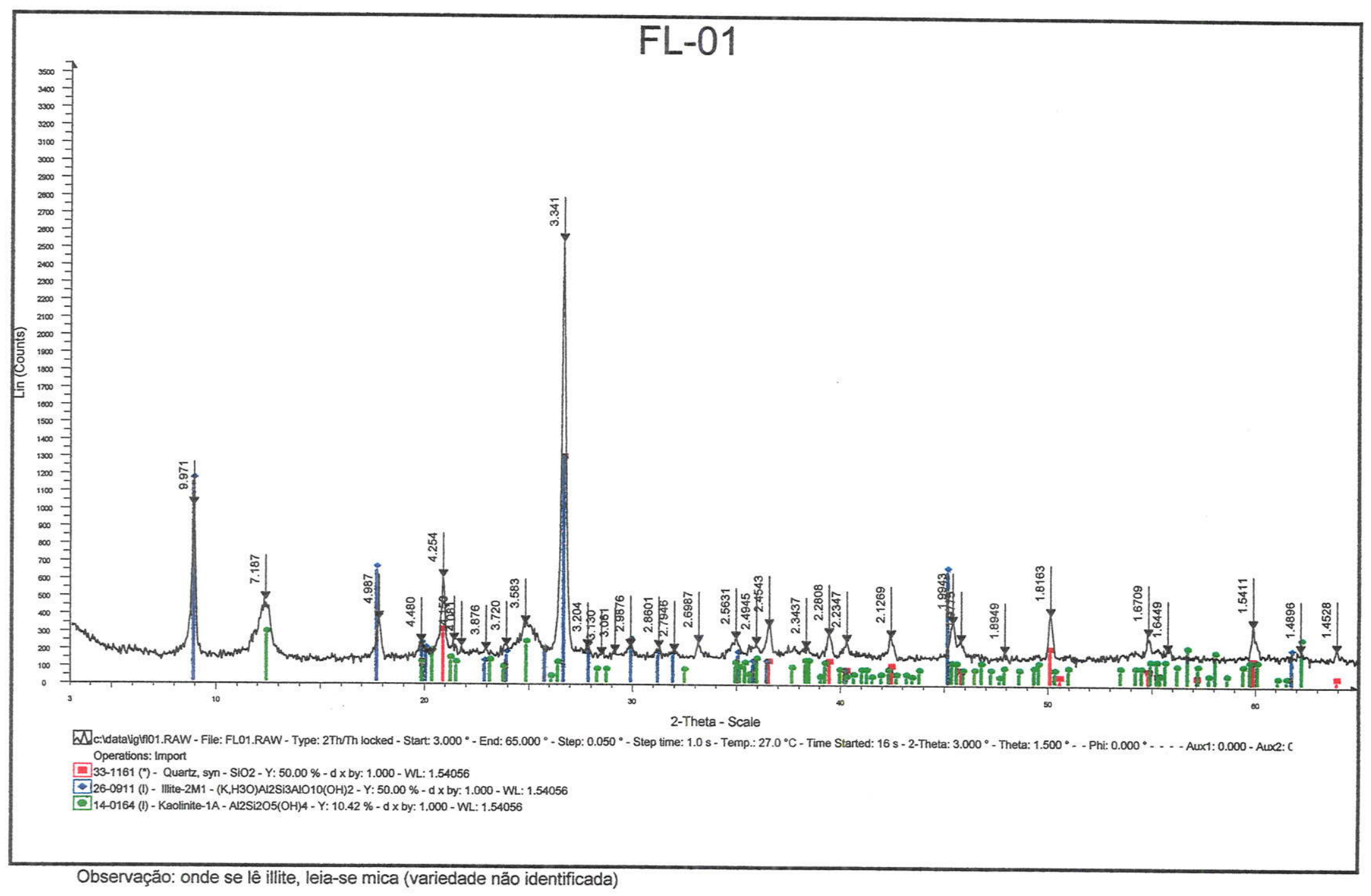

Figura 6.11 - Difratograma de raios-X do filito intemperizado da mina do Lago. 


\section{CAPÍTULO 7}

\section{PROSPECÇÃO}

\subsection{PROSPECÇÃo ESTRATÉGICA: RECONHECIMENTO GEOLÓGICO E AMOSTRAGEM PRELIMINAR}

$\mathrm{Na}$ primeira etapa de campo, iniciada em outubro/98, foi realizado um reconhecimento geral de campo, na área da Figura 1.1, para conhecimento das unidades geológicas regionais, abrangendo suas litologias, estruturas e relações de campo. Paralelamente, realizou-se a amostragem preliminar. Estas atividades somaram 5 etapas não contínuas de 4 dias cada.

Os trabalhos desta etapa contaram com a participação parcial dos Geólogos Marcos de Araújo Pinto, da Divisão de Mineração da FCV-1, e Paulo César Fernandes da Silva, do Instituto Geológico, além do graduando do curso de Geologia do IG-USP, Carlos Alberto da Silva. O primeiro contribuiu substancialmente durante todo o desenvolvimento do estudo com o seu amplo conhecimento da geologia das minas da SAIV e das particularidades da mistura das matérias-primas do clínquer. O segundo, que então realizava os trabalhos de campo de seu projeto de Mestrado (Silva 1997), colaborou com importantes informações e discussões sobre os aspectos geológico estruturais regionais. $O$ último auxiliou nos trabalhos de amostragem.

A área abrangida pelo reconhecimento é limitada a leste por Mairinque, a oeste por Salto de Pirapora, a norte por Sorocaba e a sul por Piedade. Procurou-se cobrir uma extensão territorial que contivesse as principais unidades geológicas regionais, dentro do raio econômico estabelecido pela FCV-1. Particular atenção foi dada às áreas do prospectos descritos em 5.3.2.

Na porção a norte e a oeste de Sorocaba, esse raio foi reduzido devido à predominância de litologias arenosas do Subgrupo Itararé, da Bacia Sedimentar do Paraná, com cotas abaixo de $700 \mathrm{~m}$ e altos topográficos pouco pronunciados, desfavoráveis aos fins prospectivos propostos. Lamitos intercalados aos arenitos seriam fontes potenciais de argila; porém, a única exposição expressiva, próxima ao pedágio da "Castelinho", encontra-se em aproveitamento por uma indústria cerâmica. 
A intrusiva alcalina da Serra de Ipanema, a NW de Sorocaba, embora apresentasse dimensões e fatores geológicos e geomorfológicos favoráveis (litologias com baixo teor de sílica e alto topográfico bem drenado), além da conhecida lateritização em seus altos, foi descartada devido à sua total cobertura por títulos minerários de terceiros, principalmente de empresas concorrentes da SAIV, como Holdercim e Cia. de Cimento Ipanema.

Os conflitos potenciais com outros usos do solo nos prospectos seriam verificados durante os trabalhos de campo. A região que engloba os prospectos tem seus limites aquém dos $50 \mathrm{~km}$ de distância rodoviária da FCV-1.

\subsubsection{Prospecto 1 - Metabásica de Alumínio}

$\mathrm{Na}$ área da metabásica de Alumínio, de provável origem basáltica segundo Souza (1997), notou-se que ocorrem solos avermelhados, argilosos; porém verificou-se, também, que a rocha alterada está praticamente exposta em muitos dos pontos mais elevados do relevo, com capeamento centimétrico de solo. Este, apresenta-se freqüentemente como acumulações coluviais nas encostas ou no sopé das elevações, levando a crer que ocorreram processos erosivos após a formação do solo, possivelmente em conseqüência de movimentação neotectônica. A rocha encontra-se profundamente intemperizada, mantendo a estrutura original e apresentando coloração amarelada a avermelhada.

Os perfis de alteração têm, freqüentemente, altura decamétrica até a rocha fresca. Nas partes inferiores dos perfis, são comuns os blocos com núcleos de rocha semi-intemperizada. Em altos topográficos próximos ao contato com o Maciço São Francisco, foram notados, na superfície do terreno, blocos arredondados da metabásica, com esfoliação esferoidal e núcleo de rocha fresca. Ferricretes não são comuns na área. O relevo da metabásica encontra-se ligeiramente abaixo do Maciço São Francisco, com altitudes entre 900 e 950 m. A Figura 7.1 apresenta o mapa geológico e de pontos de observação/amostragem da área da metabásica de Alumínio.

Materiais avermelhados foram observados e amostrados também sobre as os filitos, metassiltitos e granitos, encaixantes da metabásica. Foram coletadas 52 amostras de materiais de alteração no total, sendo 23 da metabásica, 14 do filito, 11 do metassiltito e 4 do granito. 


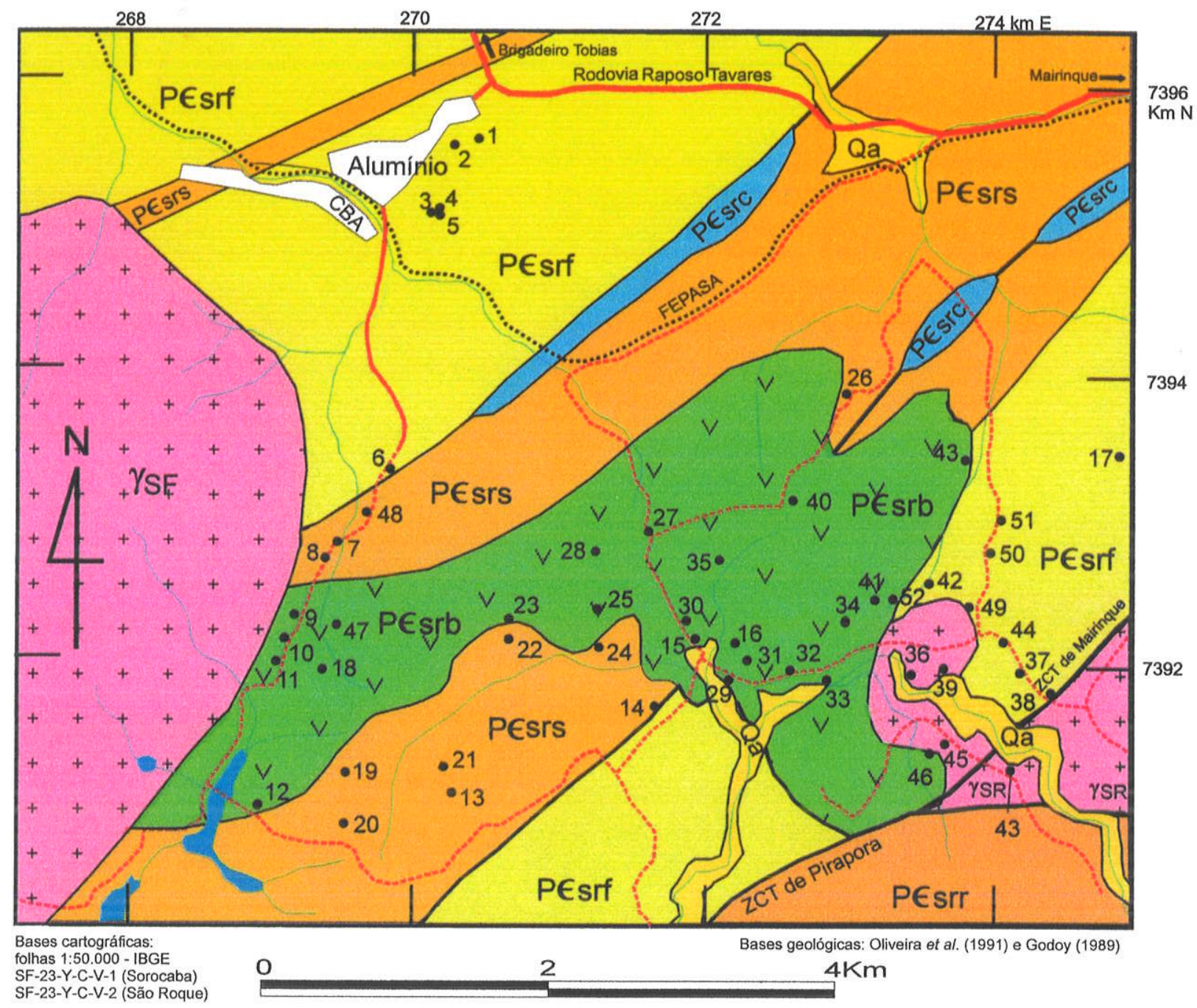

LEGENDA

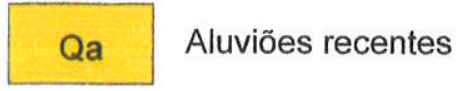

Rochas granitóides

${ }^{+} \gamma_{S}^{+}{ }^{-} \quad$ Maciço São Francisco

${ }^{+} \gamma S^{\dagger} R$

Maciço São Roque

\section{Grupo São Roque}

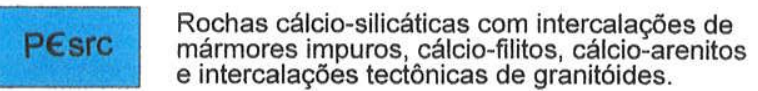
PEsrs $\begin{aligned} & \text { Metassiltitos esbranquiçados, passando localmente } \\ & \text { para quartzitos finos. }\end{aligned}$ PEsrr $\begin{aligned} & \text { Metarritmitos psamo-pelíticos, marcados com niveis } \\ & \text { alternados de espessuras centimétricas/milimétricas. }\end{aligned}$ PEsrf $\begin{aligned} & \text { Sericita filitos laminados, com intercalações locais } \\ & \text { de quartzitos finos. }\end{aligned}$

PEsrb Metabasitos foliados, compostos essencialmente por plagioclásio e hornblenda.
- 20 Ponto de amostragem/descrição

Contato geológico

Estrada pavimentada

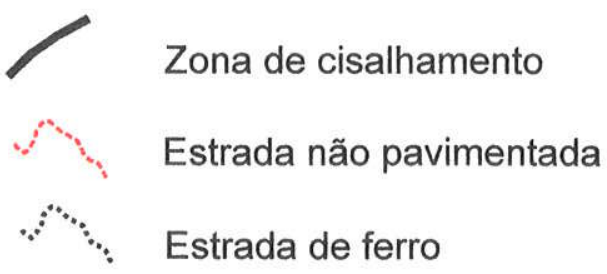

Zona de cisalhamento

Estrada não pavimentada

$\because \because$ Estrada de ferro

Figura 7.1 - Mapa geológico e de pontos de descrição/amostragem do prospecto 1 metabásica de Alumínio. 
Das amostras do prospecto 1, as 24 primeiras foram analisadas no laboratório da FCV-1, por via úmida, visto que a via instrumental (fluorescência de raios-X) não estava calibrada para o tipo de material. Foram analisados $\mathrm{SiO}_{2}, \mathrm{Al}_{2} \mathrm{O}_{3}, \mathrm{Fe}_{2} \mathrm{O}_{3}, \mathrm{CaO}$ e $\mathrm{MgO}$. Devido à sobrecarga do laboratório e da lentidão da análise não instrumental, as 28 amostras restantes foram analisadas, por espectrofotometria de emissão atômica por plasma de acoplamento induzido (ICP), no laboratório Nomos Análises Minerais, do Rio de Janeiro, contemplando também $\mathrm{CrO}_{2}, \mathrm{CrO}, \mathrm{K}_{2} \mathrm{O}, \mathrm{MnO}_{2}, \mathrm{P}_{2} \mathrm{O}_{5}, \mathrm{TiO}_{2}, \mathrm{ZrO}_{2}$, e perda ao fogo (PF). Os resultados analíticos das amostras encontram-se no Anexo 1.

As médias dos teores (\%) das amostras analisadas por via úmida e por espectrofotometria de plasma ICP são respectivamente apresentadas nas Tabela 7.1 e 7.2 a seguir:

Tabela 7.1 - Teores médios das amostras MB-01 a 17 do prospecto 1, analisadas por via úmida.

\begin{tabular}{|l|c|c|c|c|c|}
\hline \multicolumn{1}{|c|}{ Amostras } & $\mathrm{SiO}_{2}$ & $\mathrm{Al}_{2} \mathrm{O}_{3}$ & $\mathrm{Fe}_{2} \mathrm{O}_{3}$ & $\mathrm{CaO}$ & $\mathrm{MgO}$ \\
\hline Alteração da metabásica & 39,44 & 19,58 & 21,98 & 0,41 & 0,17 \\
\hline Alteração do filito & 51,37 & 20,16 & 12,92 & 0,76 & 0,20 \\
\hline Alteração do metassiltito & 51,65 & 19,81 & 13,00 & 0,60 & 0,14 \\
\hline
\end{tabular}

Tabela 7.2 - Teores médios das amostras MB-18 a 52 do prospecto 1, analisadas por espectrofotometria de plasma ICP.

\begin{tabular}{|c|c|c|c|c|c|c|c|c|c|c|c|c|}
\hline & $\mathrm{SiO}_{2}$ & $\mathrm{Al}_{2} \mathrm{O}_{3}$ & $\mathrm{Fe}_{2} \mathrm{O}_{3}$ & $\mathrm{CaO}$ & $\mathrm{MgO}$ & $\mathrm{CrO}_{2}$ & $\mathrm{~K}_{2} \mathrm{O}$ & $\mathrm{MnO}_{2}$ & $\mathrm{P}_{2} \mathrm{O}_{5}$ & $\mathrm{TiO}_{2}$ & $\mathrm{ZrO}_{2}$ & $\mathrm{PF}$ \\
\hline 1$)$ & 41,48 & 21,18 & 18,20 & 0,88 & 1,19 & 0,02 & 0,85 & 0,23 & 0,22 & 1,73 & 0,06 & 13,34 \\
\hline 2$)$ & 46,16 & 23,61 & 13,27 & 0,25 & 0,46 & 0,02 & 1,29 & 0,18 & 0,16 & 1,12 & 0,06 & 12,83 \\
\hline 3$)$ & 55,97 & 15,76 & 15,00 & 0,30 & 0,34 & 0,01 & 1,10 & 0,22 & 0,28 & 1,31 & 0,10 & 9,16 \\
\hline 4$)$ & 50,73 & 21,90 & 8,65 & 1,01 & 0,77 & 0,01 & 0,68 & 0,11 & 0,20 & 1,62 & 0,13 & 13,65 \\
\hline
\end{tabular}

Nota: 1) Alteração da metabásica; 2) Do filito; 3) Do metassiltito; 4) Do granito

Segundo cálculos realizados a partir dos dados de Souza (1997), a metabásica fresca de Alumínio apresenta os seguintes teores médios: $48,76 \% \mathrm{SiO}_{2}, 13,75 \% \mathrm{Al}_{2} \mathrm{O}_{3}$ e $10,12 \% \mathrm{Fe}$ total $\left(\mathrm{Fe}_{2} \mathrm{O}_{3}+\mathrm{FeO}\right)$. Comparando esses teores com aqueles obtidos para 
os materiais de alteração da mesma rocha, verifica-se que houve remoção não muito acentuada da sílica e acumulação do alumínio e do ferro. Para as demais litologias, não há resultados de análise de rocha sã para comparação.

A composição mineralógica dos materiais amostrados foi estudada, em caráter preliminar, através da difratometria de raios-X. A Figura 7.2 apresenta os difratogramas das amostras MB-01 (alteração do filito), MB-14 (alteração do metassiltito) e MB-16 (alteração da metabásica). Nota-se pelos mesmos que a mineralogia dos materiais é semelhante, essencialmente representada por quartzo, caulinita e goethita. Nas amostras MB-01 e MB-14, nota-se também a presença secundária de mica e gibbsita.

Simulações computacionais da composição da farinha com os dados médios das Tabelas 7.1 e 7.2 mostram que nenhum dos materiais estudados poderia substituir integralmente a mistura argila da mina do Lago + bauxita + minério de ferro, podendo atuar apenas como substituto parcial dos corretivos, dispensando o uso do minério de ferro e reduzindo o consumo da bauxita. Utilizando os produtos de alteração da metabásica, do filito, do metassiltito e do granito, as reduções no consumo de bauxita seriam, respectivamente, de $39,02 \%, 12,20 \%, 26,83 \%$ e $17,07 \%$.

Em relação aos demais fatores condicionantes, descritos em 5.3.2, a área do prospecto 1 apresenta a seguinte situação:

- o material que aparenta ter o melhor potencial volumétrico é a alteração da metabásica;

- a ocupação da superfície do terreno é principalmente caracterizada por dezenas de pequenas e médias propriedades rurais (sítios, pequenas fazendas e haras, incluindo propriedades da SAIV), além de condomínios residenciais de luxo e bolsões de habitações de população de baixa renda;

- títulos minerários de terceiros, em fases diversas de tramitação junto ao DNPM, cobrem cerca de $60 \%$ da área;

- ocorrem manchas de vegetação secundária desenvolvida na área;

Apesar da indicação desfavorável do conjunto de dados levantados, a direção da SAIV considerou o prospecto potencialmente interessante, decidindo pelo requerimento de pesquisa da áreas ainda livres de títulos minerários, principalmente sobre a metabásica. 


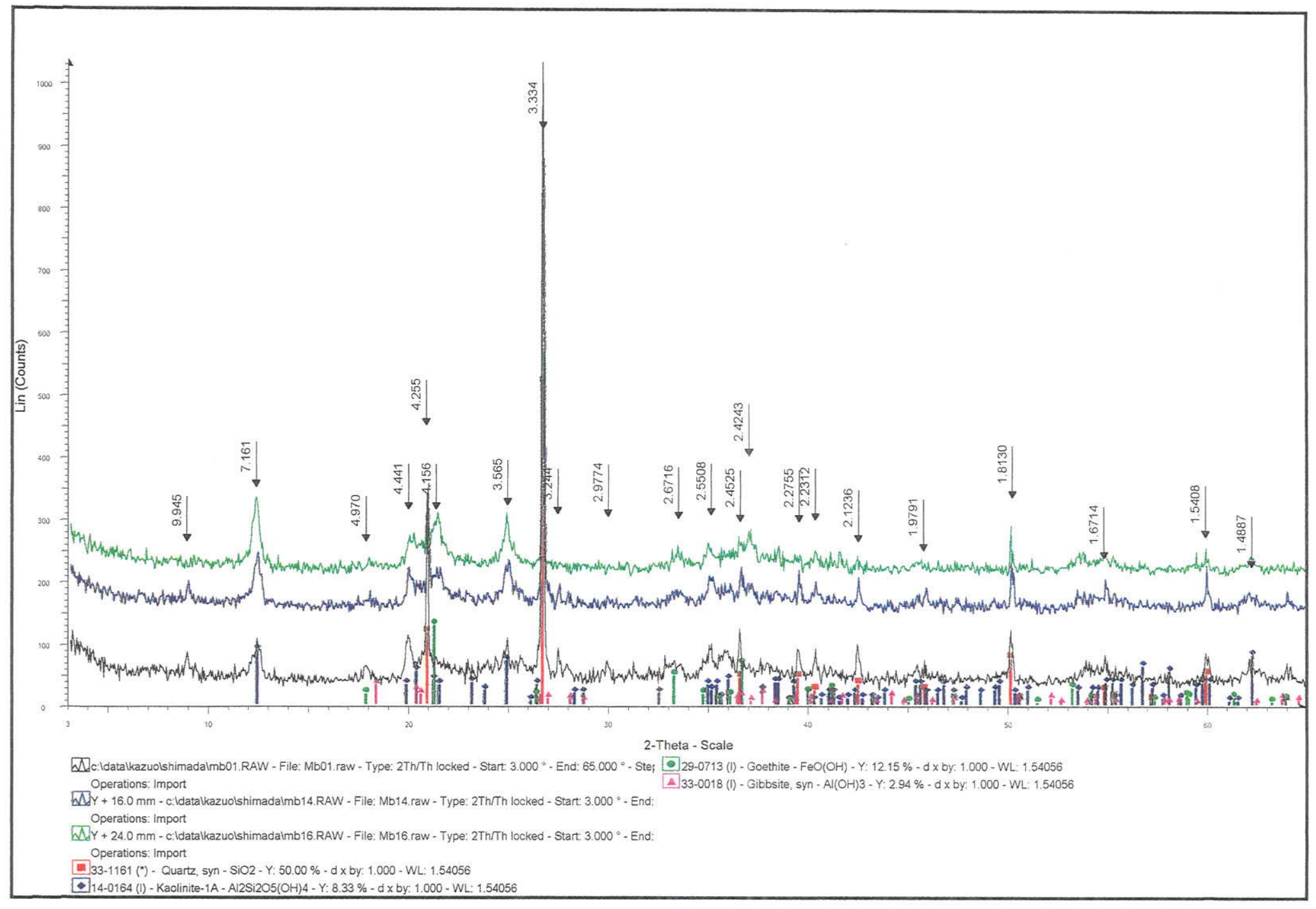

Figura 7.2 - Difratogramas de raios-X das amostras MB-01 (alteração do filito); MB-14 (alteração do metassiltito) e MB-16 (alteração da metabásica). 


\subsubsection{Prospecto 2 - Setor do Maciço Granítico São Francisco}

No prospecto 2, observa-se que o granito apresenta afloramentos em profusão na maioria de seus altos e encostas, formando lajes com centenas de metros quadrados, além da presença constante de matacões; porém, notou-se que alguns dos seus pontos mais elevados não apresentam afloramentos, com as suas características superficiais mascaradas por reflorestamentos de eucaliptos, indicativos da presença de solo desenvolvido.

As fotografias aéreas da área mostram um sistema principal de fraturamento $\mathrm{N} 45^{\circ} \mathrm{W}$, com maior densidade na zona próxima ao contato com os filitos do Grupo São Roque, na porção NW do prospecto. Observa-se também um padrão secundário aproximadamente $\mathrm{N} 60^{\circ} \mathrm{E}$. Esse dois sistemas são os principais condicionadores das drenagens locais, estando presentes também em escala de afloramento, provavelmente favorecendo a permeabilidade do maciço rochoso e dando boas condições de drenagem ao terreno.

No reconhecimento de geológico, cruzando o prospecto 2 no sentido SW-NE através da estrada municipal não pavimentada, foram notadas pequenas exposições de couraças (ferricretes) ou nódulos ferruginosos nos pontos 1, 20, 21 e 26. Nos pontos 1 , 21 e 26 são observados nódulos ferruginosos, com maior expressão no ponto 21 , onde apresentam-se como uma camada de cerca de $1 \mathrm{~m}$ de espessura no corte de estrada. No ponto 20 , ocorre couraça silicosa com pequena expressão superficial e espessura inferior a $1 \mathrm{~m}$. As Figuras 7.3 e 7.4 mostram, respectivamente, o mapa Geológico e de pontos de observação/amostragem no prospecto 2 .

Verificou-se os altos topográficos do Maciço São Francisco dentro do prospecto 2 exibem, nos cortes de estrada, um solo avermelhado, argiloso, diferenciado do solo arenoso típico do granito das áreas mais baixas, geralmente abaixo de $950 \mathrm{~m}$. Esse tipo de solo avermelhado foi observado nos cortes de estrada, nos pontos $1,3,4,5,8,9$, $12,15,16,19,32,33,4456,57,61$ e 62 . Entretando, o solo superficial argiloso desses altos exibe coloração amarelada a marrom na maioria dos leitos das estradas, mascarando o substrato. Apesar desse inconveniente, foi possivel identificar a presença de material avermelhado no subsolo através da observação de formigueiros, onde saúvas trazem o material à superfície. Nesses locais, o material contém geralmente abundantes grãos angulosos milimétricos de quartzo. 


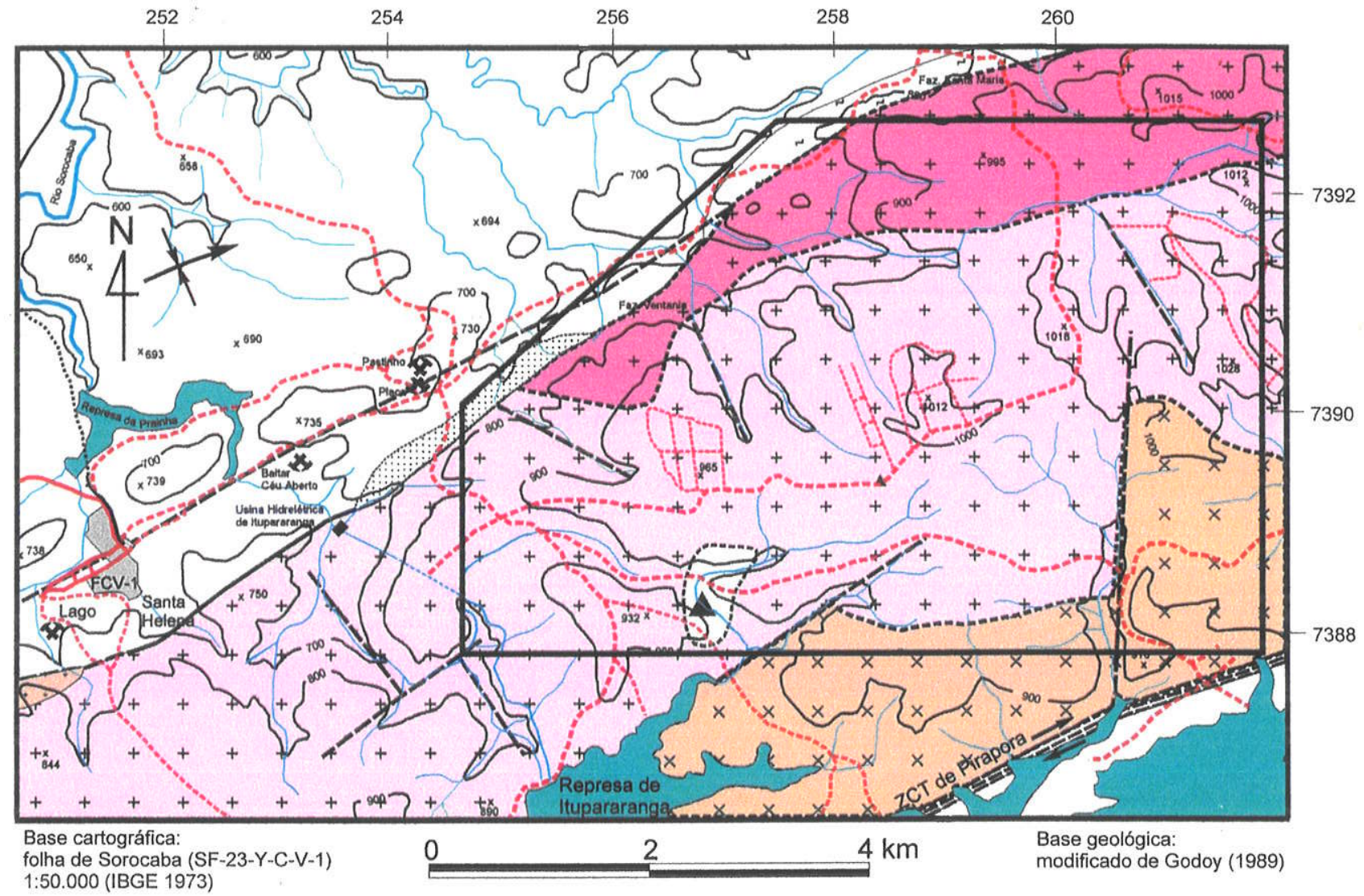

\section{EGENDA}

\section{Maciço Granítico São Francisco}

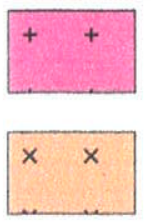

Monzogranitos porfiróides róseos, com texturas rapakivi e anti-rapakivi locais

Sienogranitos equigranulares róseos, holo a leucocráticos, de granulação média a grossa

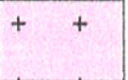

Sienogranitos porfiróides róseos,com texturas rapakivi e anti-rapakivi

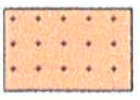

Sienogranitos e monzogranitos porfiríticos, inequigranulares com textura rapakivi

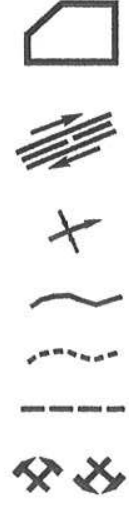

Área de prospecção

Zona de cisalhamento com indicação do sentido de movimento

Sinforme

Contato geológico definido

Contato geológico inferido

Falha / fratura inferida

\' Mina em operação / paralisada
Hornfels - rochas do Grupo São Roque afetadas por metamorfismo de contato

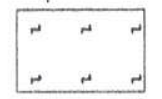

Rochas miloníticas e/ou cataclásticas

Grupo São Roque - rochas metassedimentares e metaígneas indiferenciadas

A Enclaves - ocorrências de xenólitos maiores

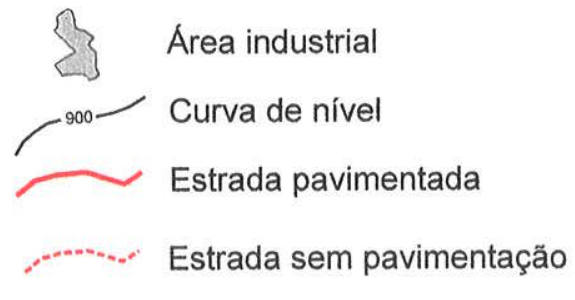

Estrada de ferro

Drenagem

Reservatório

Figura 7.3 - Mapa geológico do prospecto 2 - Setor do Maciço Granítico São Francisco. 


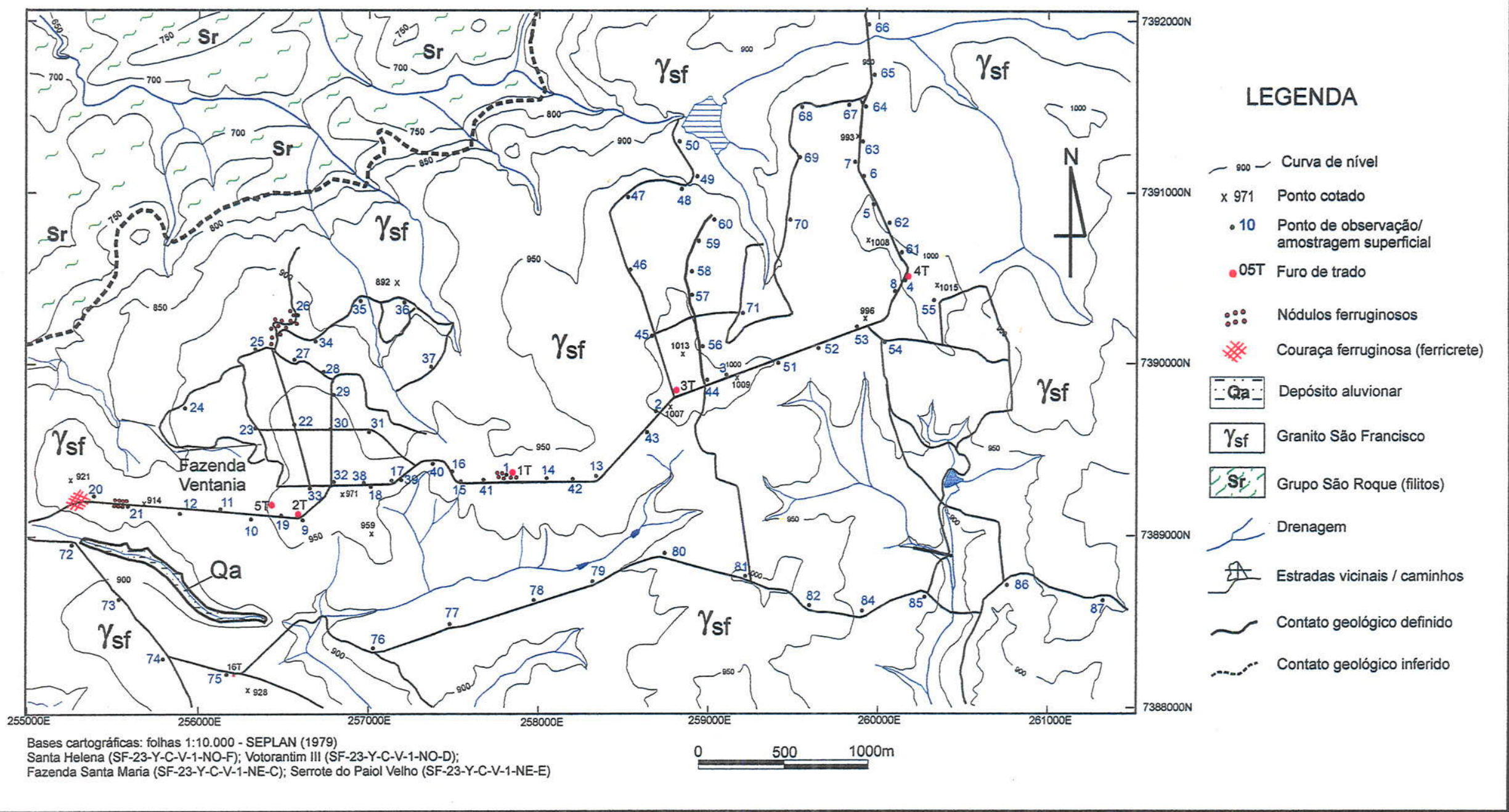

Figura 7.4 - Mapa pontos de observação/amostragem no prospecto 2 - Setor do Maciço Granítico São Francisco. 
$\mathrm{Na}$ área do Maciço Granítico São Francisco, foram inicialmente coletadas e analisadas amostras superficiais de 10 pontos, cujos resultados analíticos constam do Anexo 2, onde são identificadas como GSF 01 a GSF 10. O pequeno número de amostras analisadas nesta etapa dos trabalho deve-se à lentidão da análise via úmida. As médias dos teores de $\mathrm{SiO}_{2}, \mathrm{Al}_{2} \mathrm{O}_{3}$ e $\mathrm{Fe}_{2} \mathrm{O}_{3}$ para essas 10 amostras são:

\begin{tabular}{ccc}
$\mathrm{SiO}_{2}(\%)$ & $\mathrm{Al}_{2} \mathrm{O}_{3}(\%)$ & $\mathrm{Fe}_{2} \mathrm{O}_{3}(\%)$ \\
\hline 40,37 & 25,06 & 15,47
\end{tabular}

Além das amostragem superficial, foram executados 5 furos de trado para reconhecimento do material avermelhado em subsuperfície. Foram furos rasos, com profundidades variando de 1 a 5 metros. Apenas os furos GSF 1T e $5 T$ atingiram o saprolito do granito. Observou-se que o material é argiloso e plástico até a profundidade aproximada de $2 \mathrm{~m}$, tornando-se gradualmente menos plástico em profundidades maiores, com aspecto granulado e cor vermelha intensa. Nódulos ferruginosos milimétricos e grãos angulosos de quartzo, isolados ou formando agregados, são observáveis nos nesses níveis inferiores. O saprolito apresenta-se amarelado ou avermelhado, com manchas cauliníticas brancas e abundância de grãos angulosos de quartzo.

Os resultados analíticos dos furos encontram-se também no Anexo 2. A Tabela 7.3 a seguir apresenta os teores médios de $\mathrm{SiO}_{2}, \mathrm{Al}_{2} \mathrm{O}_{3}, \mathrm{Fe}_{2} \mathrm{O}_{3}, \mathrm{CaO}$ e $\mathrm{MgO}$ para os 5 furos.

Tabela 7.3 - Resultados analíticos médios dos furos de trado GSF 1T a GSF 5T.

\begin{tabular}{|l|c|c|c|c|c|c|c|}
\hline Furo & Prof. (m) & $\mathrm{SiO}_{2}(\%)$ & $\mathrm{Al}_{2} \mathrm{O}_{3}(\%)$ & $\mathrm{Fe}_{2} \mathrm{O}_{3}(\%)$ & $\mathrm{CaO}(\%)$ & $\mathrm{MgO}(\%)$ & $\mathrm{Ki}(1)$ \\
\hline GSF 1T & 3 & 45,57 & 16,37 & 22,73 & 0,60 & 0,02 & 2,78 \\
\hline GSF 2T & 1,5 & 25,66 & 34,89 & 13,50 & 0,01 & 0,09 & 0,74 \\
\hline GSF 3T & 1 & 35,94 & 28,35 & 5,99 & 0,45 & n.d. (2) & 1,27 \\
\hline GSF 4T & 2 & 36,95 & 28,65 & 12,40 & 0,37 & 0,04 & 1,29 \\
\hline GSF 5T & 5 & 48,73 & 22,93 & 10,51 & 0,66 & 0,04 & 2,12 \\
\hline Médias & & 38,66 & 26,49 & 13,69 & 0,47 & 0,05 & 1,46 \\
\hline
\end{tabular}

(1) $\mathrm{Ki}=\mathrm{SiO}_{2} / \mathrm{Al}_{2} \mathrm{O}_{3} \quad$ (2) n.d. = não detectado

Os teores de $\mathrm{SiO}_{2}, \mathrm{Al}_{2} \mathrm{O}_{3}$ e $\mathrm{Fe}_{2} \mathrm{O}_{3}$, em algumas amostras superficiais e de trado, apresentam valores próximos do material que substituiria os corretivos, conforme 
descrito em 5.1 e, se comparados aos teores do saprolito e do granito fresco, mostrados a seguir, apresentam nítido contraste, com teor de sílica acentuadamente menor e teores maiores de alumina e de óxido férrico.

\begin{tabular}{lccc} 
& $\mathrm{SiO}_{2}(\%)$ & $\mathrm{Al}_{2} \mathrm{O}_{3}(\%)$ & $\mathrm{Fe}_{2} \mathrm{O}_{3}(\%)$ \\
\hline Saprolito do granito & 68,55 & $20 ., 15$ & 2,15 \\
Granito fresco & 76,66 & 12,24 & 2,39
\end{tabular}

Os teores no saprolito foram obtidos pelas médias de 5 amostras analisadas $e$, no granito fresco, foram calculados a partir dos dados de Godoy (1989).

Adicionalmente, os valores de $\mathrm{Ki}$ apresentam-se inferiores a 1,8 em várias amostras, indicando que houve, segundo o conceito de Harrassowitz (1926 apud Pedro \& Melfi 1983), condições para a lateritização, com a formação de gibbsita. Assim, os dados obtidos indicaram que o material seria resultado de um processo de lateritização, com considerável lixiviação da sílica e acumulação de $\mathrm{Al}_{2} \mathrm{O}_{3}$ e $\mathrm{Fe}_{2} \mathrm{O}_{3}$.

Quanto à mineralogia do material amostrado no prospecto 2, não foram feitos difratogramas nesta etapa dos trabalhos em problemas operacionais e de disponibilidade do equipamento, tendo sido adiados para a etapa de prospecção tática.

Embora as extensões superficiais das ocorrências do material laterítico não fossem ainda conhecidas com precisão, tornou-se claro que ocorrem em três altos topográficos, com cotas máximas variando de 971 a $1.015 \mathrm{~m}$ e alongados segundo a direção NW-SE, conforme ilustrado na Figura 7.4.

Outros dados levantados indicaram aspectos positivos quanto aos demais condicionantes:

- cerca de $80 \%$ da área do prospecto pertencem à SAIV;

- igual porcentagem situa-se dentro dos limites de títulos minerários (concessões de lavra) da SAIV;

- não há mata nativa ou secundária desenvolvida nos altos topográficos amostrados;

- inexistem habitações ou outras construções nesses altos, e o uso do solo limita-se ao plantio de eucaliptos da CBA, uma empresa controlada pela SAIV;

- a área não pertence a unidade de conservação ambiental; 
Os dados analíticos e de campo expostos permitiram escolher o prospecto 2 como merecedor de trabalhos prospectivos adicionais para melhor caracterização física, química e mineralógica do material, assim como para determinação de seu potencial volumétrico, visto que as reservas do material argiloso alternativo devem garantir o consumo da FCV-1 pelo período mínimo de 25 anos.

\subsubsection{Prospecto 3 - Cobertura sedimentar avermelhada}

Nos taludes e bermas do extremo NE da mina de metacalcário da FCV-2, conhecida como Mina 1, em Salto de Pirapora, havia sido recentemente exposto um material avermelhado, aparentando ser uma cobertura sedimentar inconsolidada, denominado de "argila ferruginosa" pelos técnicos das FCVs 1 e 2. Trata-se de material argilo-arenoso fino, sem estruturas ou horizontes diferenciados, contendo grãos submilimétricos e subarredondados de quartzo numa matriz argilosa vermelha, com presença constante de grãos milimétricos de magnetita e espessura máxima superior a $10 \mathrm{~m}$. Pelo seu aspecto ferruginoso e argiloso, o material foi considerado potencialmente interessante para os objetivos do estudo.

$\mathrm{Na}$ área a NNW da Mina 1, principalmente a norte da estrada Votorantim-Salto de Pirapora, foram também observadas algumas exposições de cobertura sedimentar avermelhada, verificando-se que a mesma ocorre predominantemente em topos e em meia encosta, cobrindo litologias do Grupo São Roque e do Subgrupo Itararé. É um material argiloso, de coloração avermelhada, semelhante ao material da Mina 1, com presença freqüente de fragmentos milimétricos de magnetita, embora aparente ser mais argiloso.

A Figura 7.5 apresenta o mapa de pontos de observação/amostragem da área da cobertura sedimentar avermelhada. A Figura 7.6 apresenta o mapa geológico da área, que mostra envoltórias das zonas de ocorrência da cobertura, visto que a mesma apresenta grande irregularidade nos seus limites, demandando trabalhos de campo muito detalhados, com o apoio de sondagem, para o traçado preciso dos mesmos.

Foram coletadas 10 amostras superficiais da cobertura sedimentar avermelhada a NNW da Mina 1 (amostras CSA) e 5 da "argila ferruginosa" do NE da Mina 1 (amostras AFE). Em relação à amostragem de subsuperfície, a equipe da DM/FCV-1 executou uma malha de 17 furos de trado na chamada "argila ferruginosa", na tentativa 


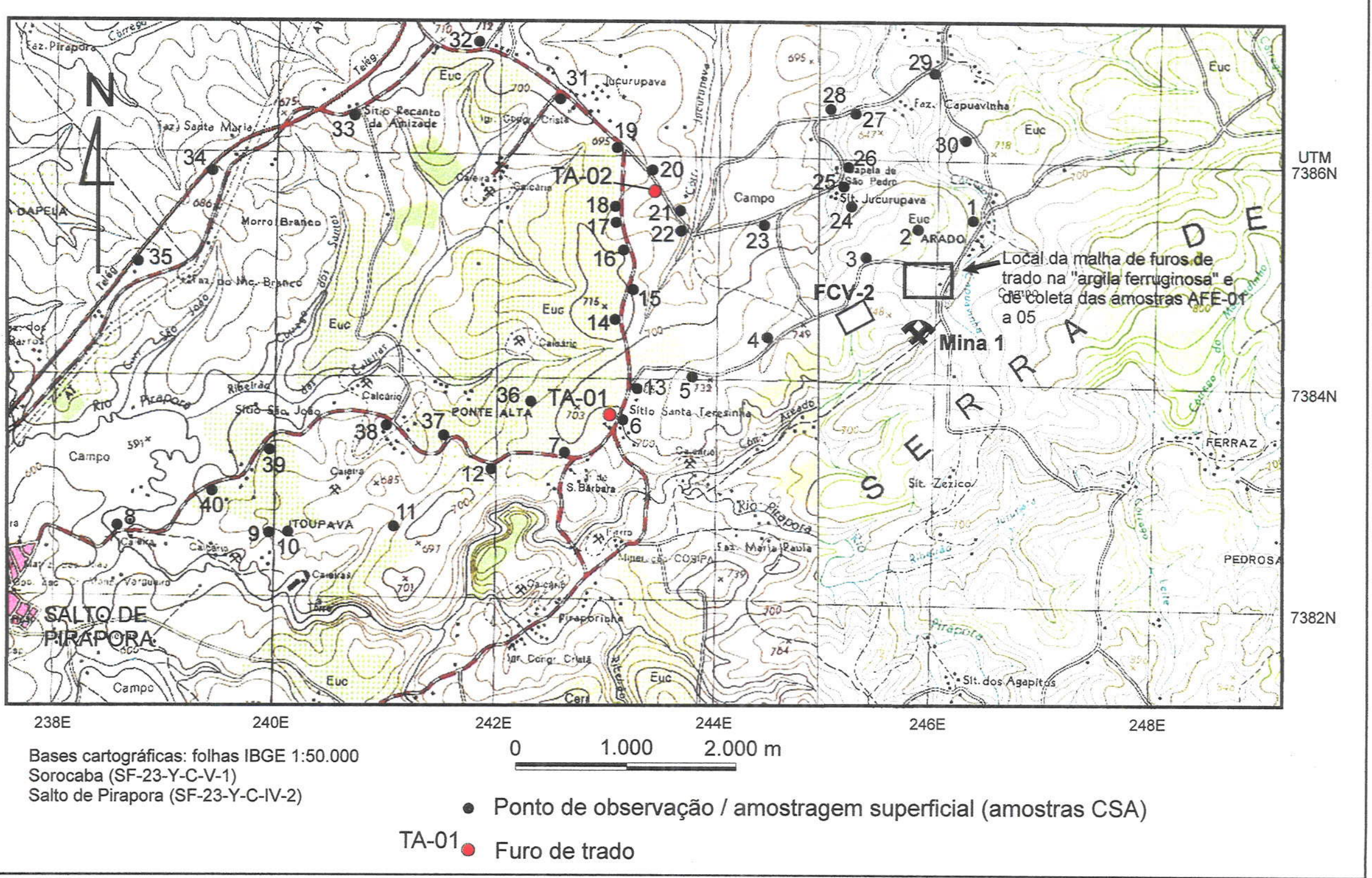

Figura 7.5 - Mapa de localização dos pontos de observação / amostragem superficial e de furos de trado no prospecto 3. 


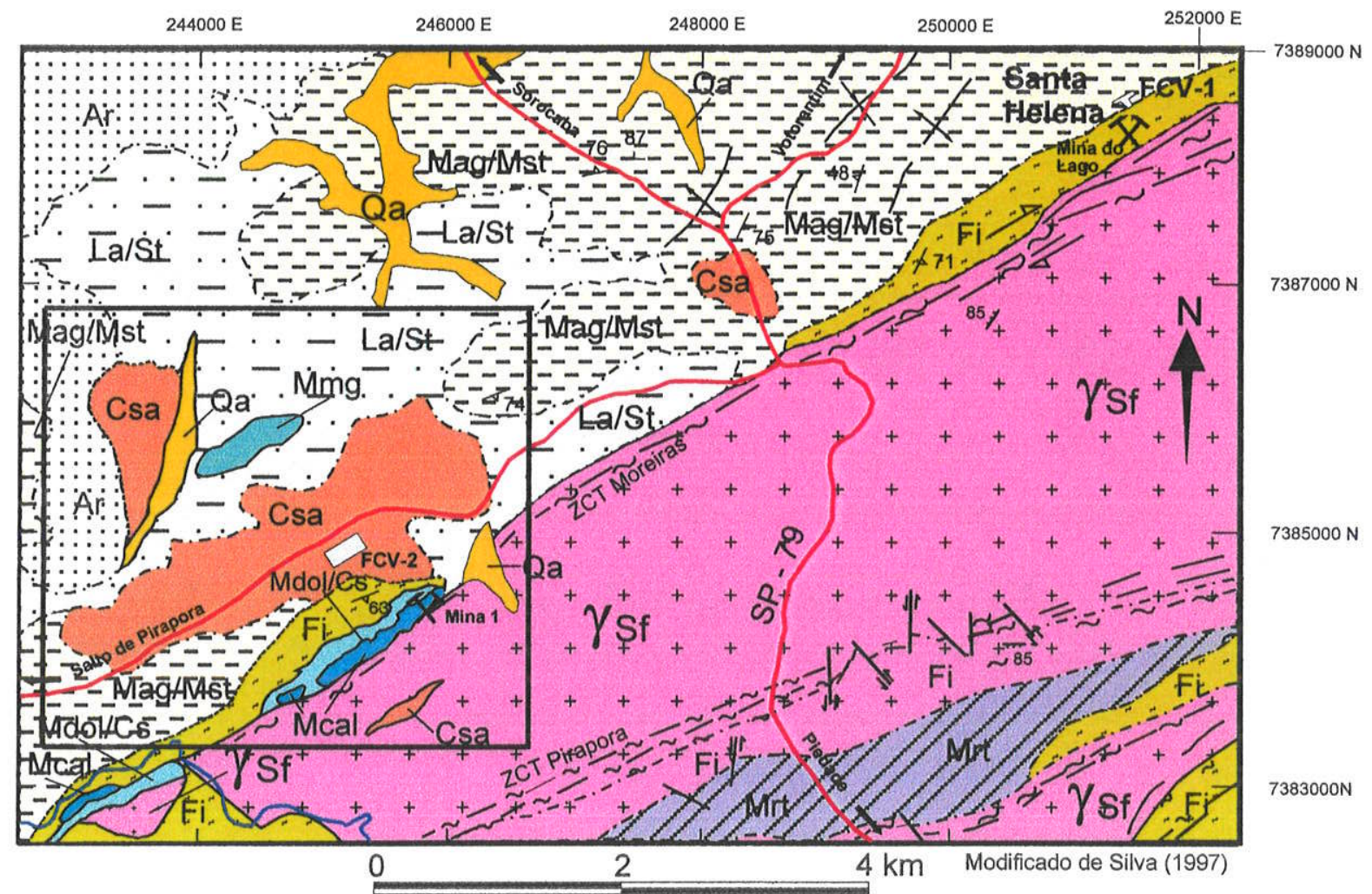

\section{LEGENDA}

Unidades cenozóicas

Subgrupo Itararé

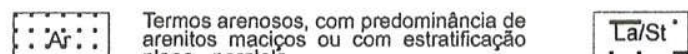
plano - paralela.

Granitóides

丹 Sf + Maciço São Francisco: cinza - róseo a cinza escuro esverdeado, com vários termos texturais.
Foliado nas bordas do corpo.

\section{Grupo São Roque}

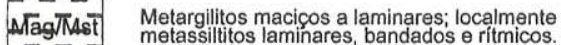

\begin{tabular}{|c|l}
\hline Mmg & $\begin{array}{l}\text { Metamargas laminares ou bandadas, com alternåncia de } \\
\text { niveis milimétricos a decimétricos de material carbonático } \\
\text { e clástico - pelítico. Localmente filitos carbonáticos }\end{array}$ \\
MdoVCs & $\begin{array}{l}\text { Metadolomitos e metacalcilutitos (dolomíticos a calcíticos), } \\
\text { geralmente bandados a laminares com estruturas sedimen- }\end{array}$
\end{tabular}

C1 Metarritmitos, compostos por alternância de nito muito fino $\theta$ metapelitos. tares. Localmente maciço ou brechóide.

Fi. Filitos sericiticos; localmente quartzo filitos, dosianos e carbonáticos. Metacalcários calcíticos, predominatemente maciços.
Localmente laminares ou bandados.

Area do prospecto 3

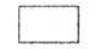

Instalações industriais SAIV

Rodovia pavimentada

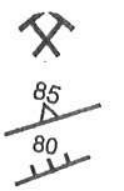

Mina a céu aberto

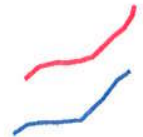

Drenagem

Contato geológico observado em operação

Foliação tectônica Sn

Foliação milonítica $(\mathrm{Sm})$ ou cliivagem $\mathrm{Sn+1}$

Antiforma

-. _. Contato geológico inferido

45 Acamamento sedimentar So

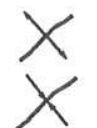

Sinforma

Planos de falha com indicação da direção do movimento.

בก๊

Faixas cataclásticas / miloníticas relacionadas às zonas de cisalhamento transcorrente (ZCT)

Traços de fraturas mapeáveis

Figura 7.6 - Mapa geológico da área do prospecto 3 - Cobertura sedimentar avermelhada. 
de viabilizar a utilização da argila alternativa em curto prazo. Os furos, todos com $10 \mathrm{~m}$ de profundidade, foram concentrados numa pequena área, de aproximadamente $100 \mathrm{~m}$ por $160 \mathrm{~m}$, mostrada na Figura 7.7, que ilustra também a localização das amostras AFE-01 a 05 As amostras de 9 furos foram analisadas em intervalos de $1 \mathrm{~m}$ e os resultados encontram-se no Anexo 3 . Os teores médios (\%) das 89 amostras analisadas são:

\begin{tabular}{ccccc}
$\mathrm{SiO}_{2}$ & $\mathrm{Al}_{2} \mathrm{O}_{3}$ & $\mathrm{Fe}_{2} \mathrm{O}_{3}$ & $\mathrm{CaO}$ & $\mathrm{MgO}$ \\
\hline 60,56 & 15,21 & 12,44 & 0,43 & 0,15
\end{tabular}

Confirmando as observações de campo, a "argila ferruginosa" mostrou-se bastante silicosa, sendo uma parte expressiva dessa sílica representada por grãos de quartzo (cerca de $32 \%$ da massa total do material, estimada por separação física dos grãos).

A equipe da DM/FCV-1 realizou simulações computacionais e teste de forno com a utilização conjunta da argila da Mina do Lago e da "argila ferruginosa". Os resultados não foram promissores, motivo pelo qual não foram realizados estudos adicionais no local.

Nas amostras superficiais CSA-01, 01, 05, 06, 07, 13, 14, 18, 19 e 20 e AFE-01 a 05, as médias (\%) de $\mathrm{SiO}_{2}, \mathrm{Al}_{2} \mathrm{O}_{3}, \mathrm{Fe}_{2} \mathrm{O}_{3}, \mathrm{CaO}$ e $\mathrm{MgO}$ são:

\begin{tabular}{lccccc} 
Amostras & $\mathrm{SiO}_{2}$ & $\mathrm{Al}_{2} \mathrm{O}_{3}$ & $\mathrm{Al}_{2} \mathrm{O}_{3}$ & $\mathrm{CaO}$ & $\mathrm{MgO}$ \\
\hline CSA (10 amostras) & 47,42 & 27,12 & 12,24 & 0,70 & 0,26 \\
AFE (5 amostras) & 61,91 & 15,61 & 11,79 & 0,42 & 0,18
\end{tabular}

Na cobertura sedimentar a NNW da mina 1, foram realizados dois furos de trado, TA-01 e TA-02, atravessando todo o perfil do material.

O furo TA-01, situado à cota aproximada de $700 \mathrm{~m}$, com $4 \mathrm{~m}$ de profundidade, partiu de um solo avermelhado e argiloso-arenoso na superfície, mantendo-se homogêneo até $3,70 \mathrm{~m}$, quando passou a lamito do Subgrupo Itararé, de coloração mais clara, amarelada. 


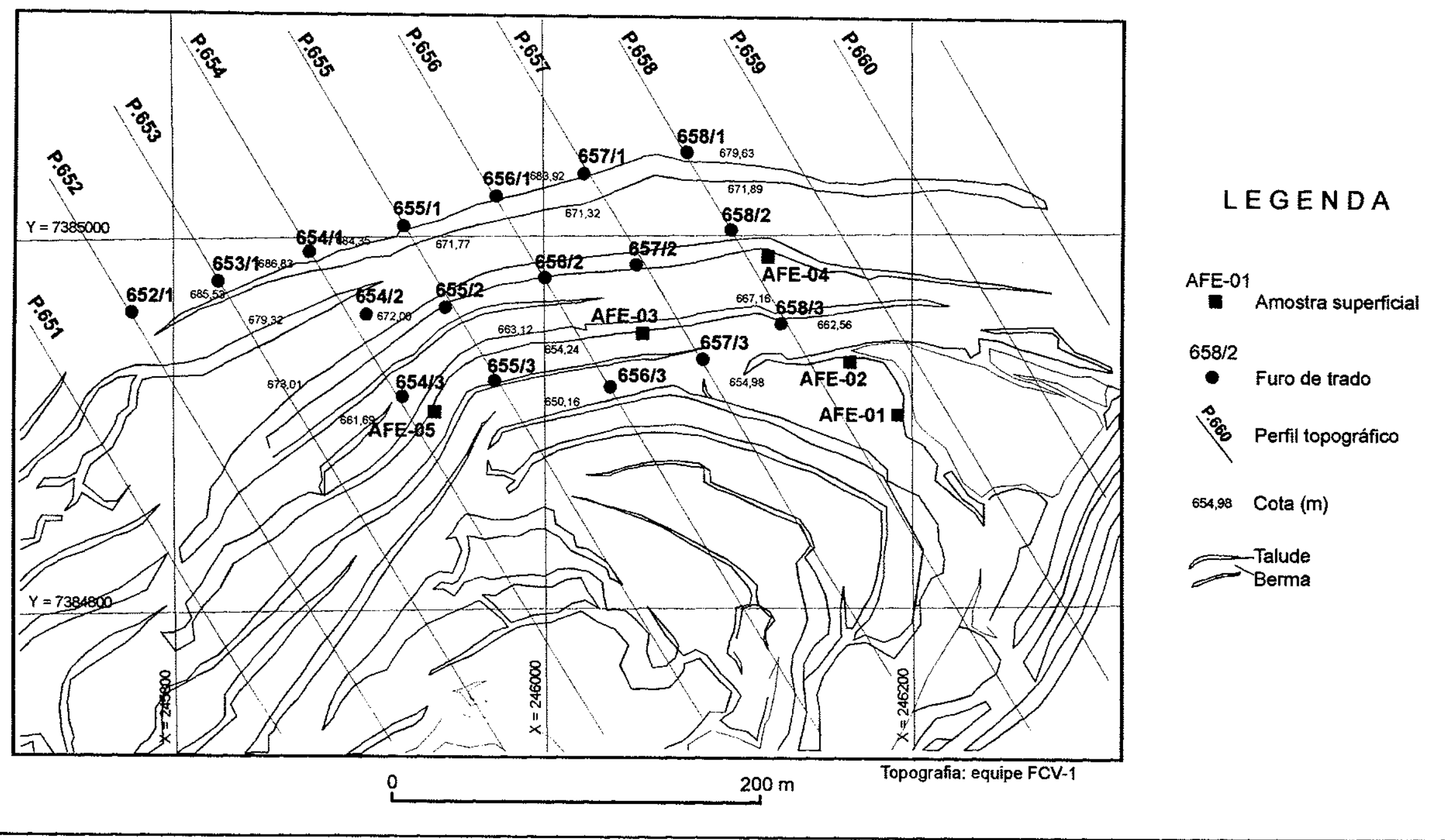

Figura 7.7 - Localização dos furos de trado e das amostras superficiais no extremo NE da Mina 1 - Salto de Pirapora. 
O furo TA-02, com $3 \mathrm{~m}$ de profundidade, foi feito a cerca de $2 \mathrm{~km}$ a NE do primeiro, numa altitude de cerca de $655 \mathrm{~m}$. Este, apresentou material semelhante ao primeiro nos dois metros iniciais e, a partir de $2 \mathrm{~m}$, passou a um material marrom, plástico, passando a rosado com manchas brancas a partir de 2,3 m. Aparentemente, trata-se de uma alteração do siltito do Subgrupo Itararé.

A ocorrência da cobertura sedimentar não é contínua no intervalo entre os dois furos, restringindo-se a setores de meia-encosta de elevações. Seus limites são bem visiveis no terreno e em fotografias aéreas quando o terreno está exposto; porém, em caso de haver vegetação nativa ou cultivada, suas características ficam inteiramente mascaradas.

As amostras foram analisadas no laboratório da FCV-1, via úmida, e a tabela 7.4 a seguir apresenta os resultados dos furos TA-01 e 02 (\%):

Tabela 7.4 - Resultados analíticos das amostras dos furos TA-01 e TA-02.

\begin{tabular}{|c|c|c|c|c|c|c|c|c|}
\hline Amostra & Intervalo $(\mathrm{m})$ & $\mathrm{Ki}$ & $\mathrm{SiO}_{2}$ & $\mathrm{Al}_{2} \mathrm{O}_{3}$ & $\mathrm{Fe}_{2} \mathrm{O}_{3}$ & $\mathrm{MgO}$ & $\mathrm{CaO}$ & $\mathrm{PF}$ \\
\hline $\mathrm{TA}-01 / 1$ & $0-1$ & 1,18 & 43,72 & 37,10 & 11,12 & 0,00 & 0,58 & 13,39 \\
\hline $\mathrm{TA}-01 / 2$ & $1-2$ & 1,39 & 46,28 & 33,20 & 10,88 & 0,00 & 1,14 & 12,31 \\
\hline $\mathrm{TA}-01 / 3$ & $2-3$ & 1,59 & 45,28 & 28,54 & 9,99 & 0,00 & 0,72 & 12,92 \\
\hline $\mathrm{TA}-01 / 4$ & $3-4$ & 1,93 & 50,16 & 25,94 & 9,94 & 0,19 & 0,66 & 22,36 \\
\hline Médias & & 1,49 & 46,36 & 31,20 & 10,48 & 0,05 & 0,78 & 15,25 \\
\hline TA-02/1 & $0-1$ & 1,88 & 50,44 & 26,80 & 8,79 & 0,00 & 0,86 & 12,50 \\
\hline TA-02/2 & $1-2$ & 1,96 & 48,46 & 24,72 & 10,36 & 0,00 & 0,79 & 10,94 \\
\hline TA-02/3 & $2-3$ & 2,92 & 60,18 & 20,64 & 8,16 & 0,14 & 0,74 & 22,36 \\
\hline Médias & & 2,20 & 53,03 & 24,05 & 9,10 & 0,05 & 0,80 & 15,27 \\
\hline
\end{tabular}

Os resultados mostram que os materiais situados em cotas mais elevadas (furo TA-01) encontram-se possivelmente mais lixiviados, apresentando $\mathrm{Ki}$ mais baixo e maiores conteúdos de $\mathrm{Al}_{2} \mathrm{O}_{3}$ e $\mathrm{Fe}_{2} \mathrm{O}_{3}$.

Nota-se que a "argila ferruginosa" da Mina 1 e a cobertura sedimentar avermelhada são materiais quimicamente distintos, embora sejam macroscopicamente semelhantes. A primeira é, provavelmente, resultante da alteração das rochas cálciosilicáticas subjacentes, com algum transporte e contribuição das rochas do Subgrupo Itararé. Tal suposição baseia-se no fato de que a magnetita, observada na cálciosilicática alterada, ser constante na "argila ferruginosa" e a assembléia de minerais 
pesados, com zircão, sillimanita, turmalina e acessórios como monazita, epidoto e rutilo ser indicativa de origem metassedimentar. Por outro lado, os grãos subarredondados de quartzo, abundantes, levam a crer em contribuição de sedimentos arenosos do Subgrupo Itararé. A cobertura sedimentar avermelhada apresenta assembléia de minerais pesados mais relacionada a granitos, com zircão, turmalina, rutilo, cassiterita e monazita, em grãos subarredondados. A presença de grãos arredondados de quartzo indica que houve também a possível contribuição dos sedimentos do Subgrupo Itararé.

Mineralogicamente, a cobertura sedimentar tem como constituintes principais quartzo, caulinita, gibbsita e hematita, conforme mostrado nos difratogramas de raios- $X$ das amostras 01 a 04 do furo TA-01 (Figura 7.8). A "argila ferruginosa" da Mina-1 apresenta composição mineralógica similar, com prováveis diferenças nas proporções dos componentes, principalmente do quartzo, mais abundante nesta última. A magnetita, embora freqüentemente visivel nos dois materiais, não foi detectada nos difratogramas, possivelmente por comparecer em quantidade inferior a $5 \%$ dos minerais.

Os resultados obtidos no prospecto 3 mostraram que a cobertura sedimentar avermelhada possui características físicas e químicas favoráveis à substituição dos corretivos, principalmente no furo TA-01. Em relação aos demais fatores condicionantes, foram levantados os seguintes dados:

- cerca de $40 \%$ da área do prospecto pertencem à SAIV;

- cerca de $50 \%$ da área situa-se dentro dos limites de títulos minerários (concessões de lavra) da SAIV, havendo áreas não oneradas nos limites do prospecto;

- o material aparenta ter bom potencial volumétrico, embora a sua espessura não seja expressiva nos pontos observados, não passando de $4 \mathrm{~m}$;

- há manchas de mata secundária desenvolvida dispersas na área;

- o uso do solo é caracterizado por pequenas propriedades rurais e reflorestamentos de eucaliptos da SAIV;

- a área não pertence a unidade de conservação ambiental. 


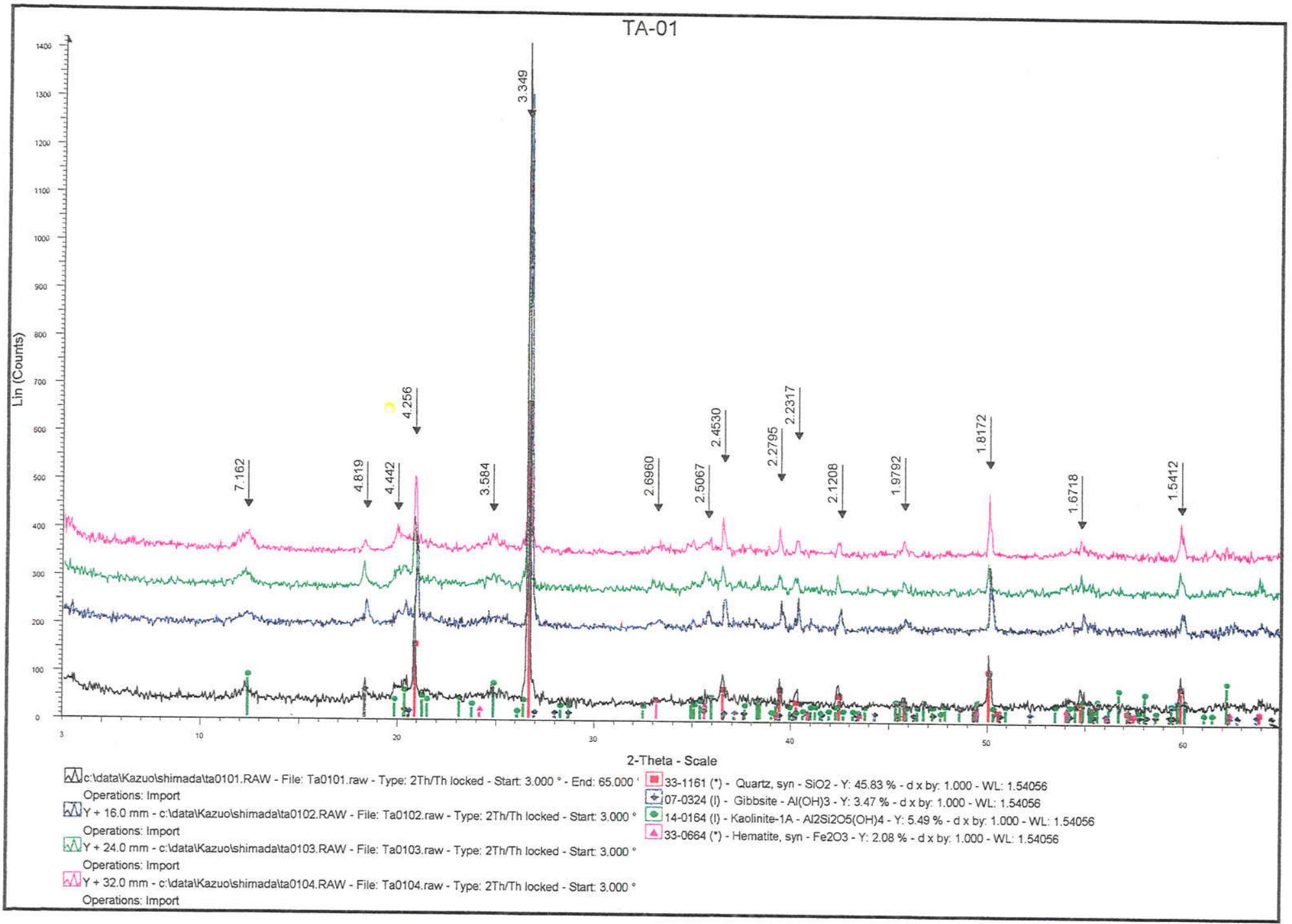

Figura 7.8 - Difratogramas de raios-X das amostras 01 a 04 do furo TA-01, na cobertura sedimentar avermelhada. 
Em função dos resultados obtidos, o prospecto 3 foi considerado como merecedor de trabalhos exploratórios adicionais; porém, como segunda prioridade em relação ao prospecto 2 , que apresenta o conjunto mais favorável de dados.

Tendo em vista a proximidade das ocorrências em relação à FCV-2, a SAIV considera o estudo da futura utilização da cobertura sedimentar nessa unidade, cujo processo envolve matérias-primas e parâmetros operacionais diferentes daqueles da FCV-1.

As Figuras 7.9A a F apresentam ilustrações fotográficas dos prospectos 1 e 3 , e as Figuras 7.10A a G mostram o mesmo tipo de ilustrações do prospecto 2.

\subsubsection{Prospecto 4 - Sienito de Piedade}

Na área da intrusiva sienítica de Piedade, o prospecto mais distante da FCV-1 (cerca de $35 \mathrm{~km}$ ), verificou-se que a rocha ocorre num morrote de encostas abruptas e pequena área superficial, inferior a $1 \mathrm{~km}^{2}$. A posição da intrusiva no contexto geológico regional é mostrada no mapa geológico da Figura 3.1 .

O solo que a capeia, amarelado a marrom, observado ao longo de uma estrada que corta a área no sentido $\mathrm{N}-\mathrm{S}$, é pouco espesso, raramente superior a $1 \mathrm{~m}$, passando diretamente à rocha alterada. Esta, é compacta, de coloração rosada a amarelada, mantendo a estrutura original da rocha (alterita com estrutura preservada). No solo, são comuns os blocos centimétricos de magnetita e métricos de material silicificado extremamente duro.

Pelas dimensões superficiais da intrusiva e pelas características do material de alteração, conclui-se que o potencial volumétrico do mesmo é pequeno.

Constatou-se, também, que área é coberta por mata secundária já bem desenvolvida na sua metade sul, onde passa, como impedimento adicional, uma linha de transmissão de energia elétrica. A metade norte é ocupada por cultivo de hortaliças e chácaras de lazer. Em relação aos títulos minerários, a área encontrava-se livre

Considerando os aspectos geológicos e de uso do solo desfavoráveis, decidiu-se pelo descarte da área sem trabalhos adicionais. 

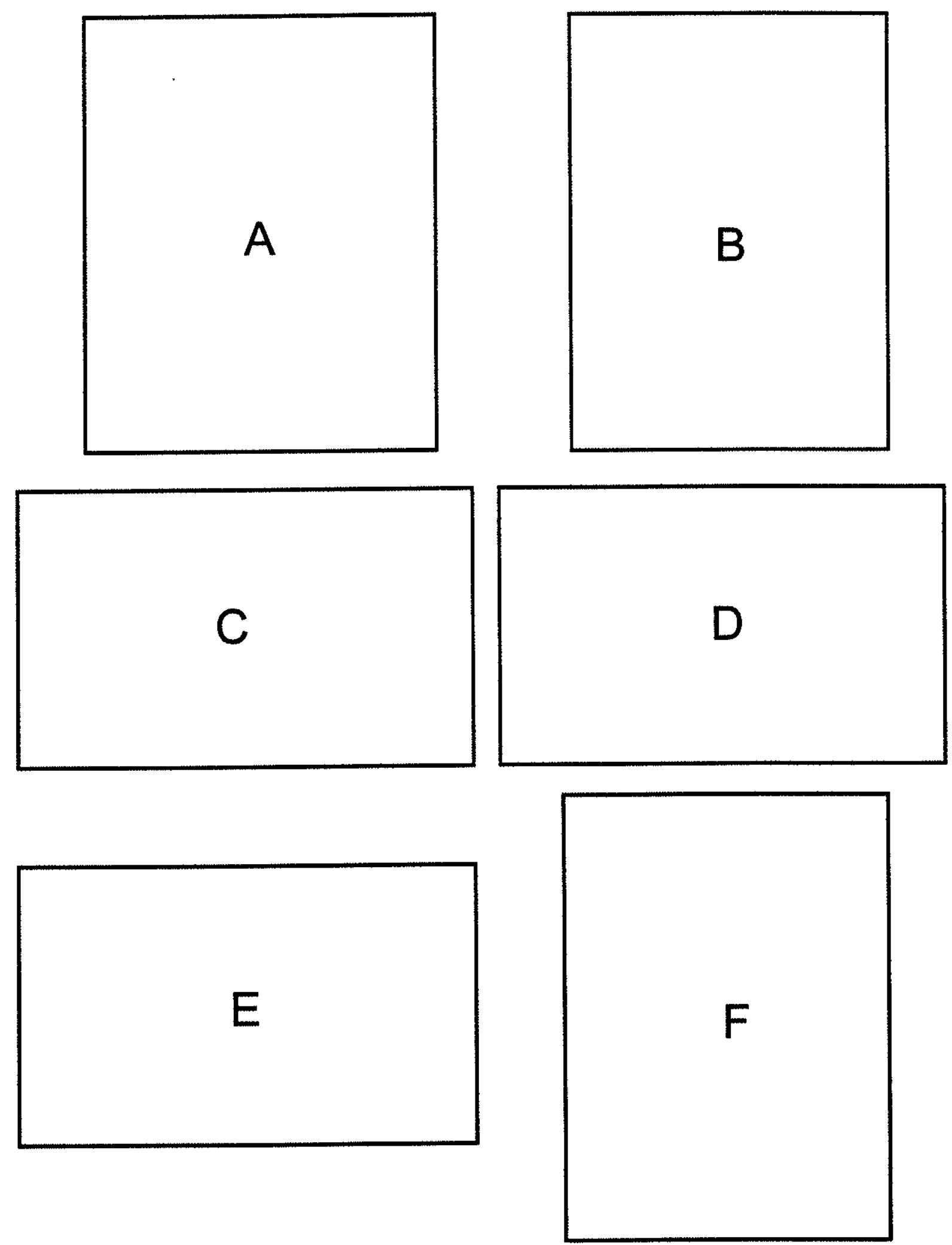

Figura 7.9 - A) Aspecto do perfil intempérico da metabásica de Alumínio; B) Produto intempérico avermelhado sobre filitos na área de Alumínio; C) Aspecto da "argila ferruginosa" na parte NE da Mina 1 - Salto de Pirapora; D) Detalhe de corte na "argila ferruginosa" da Mina 1; E) Aspecto superficial da cobertura sedimentar avermelhada a NW da Mina 1; F) Execução de furo de trado na cobertura sedimentar. 

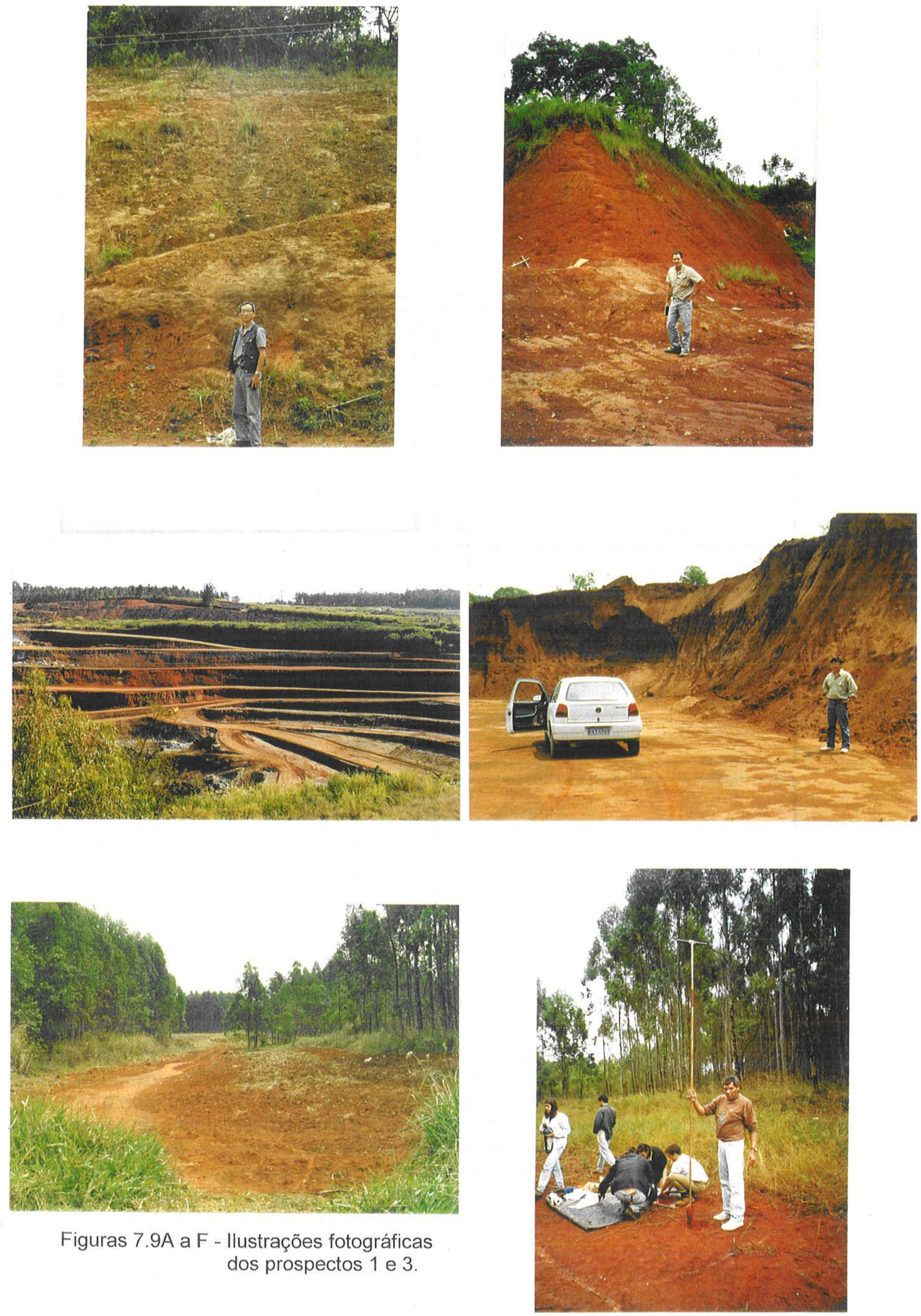

Figuras 7.9A a F - Ilustrações fotográficas dos prospectos 1 e 3 . 
LEGENDAS DAS FIGURAS 7.10A A G
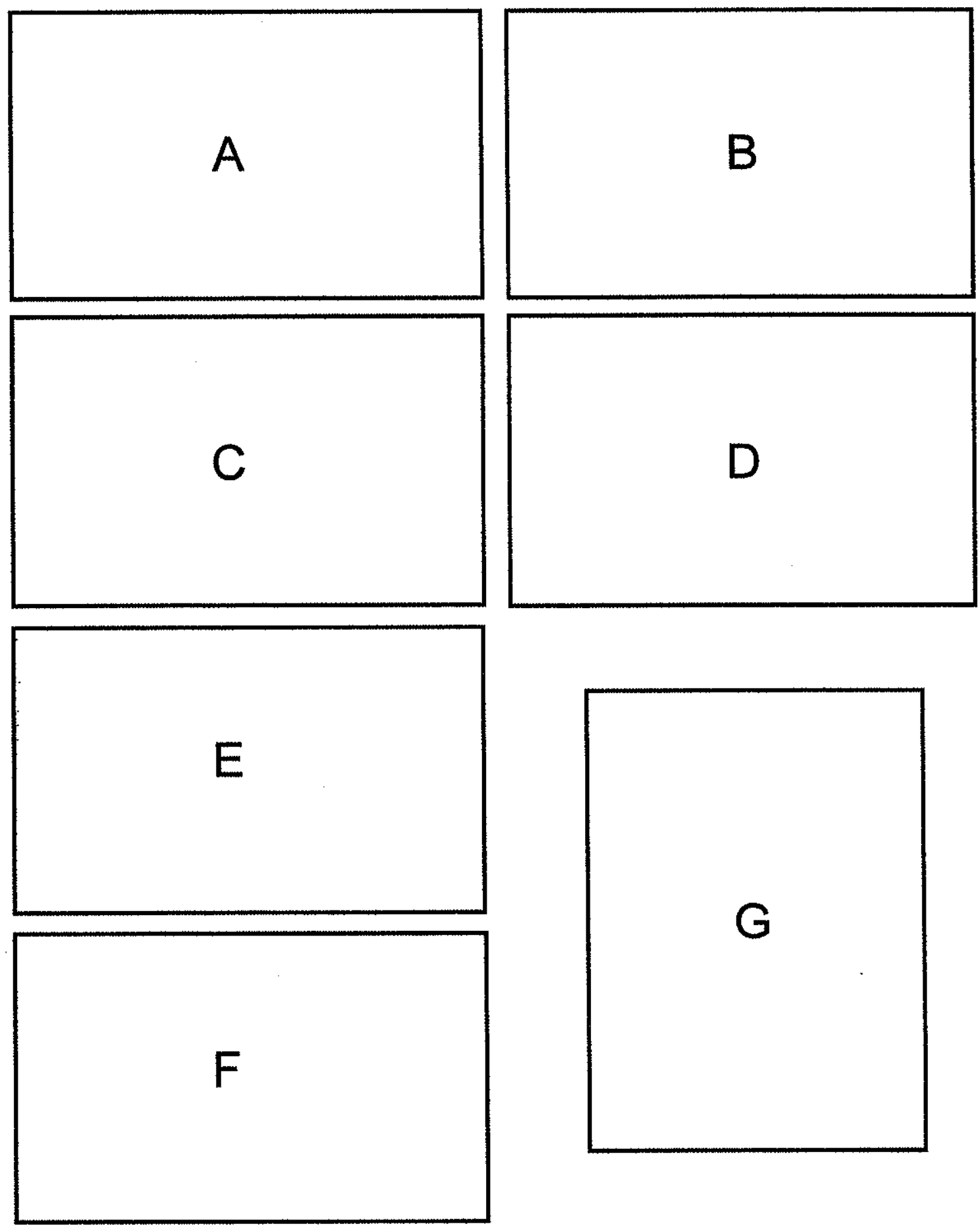

Figura 7.10 - A) Aspecto superficial do Maciço Granítico São Francisco, em cotas abaixo de $900 \mathrm{~m} ; \mathrm{B}$ ) Aspecto superficial do solo típico do granito, próximo ao ponto GSF 53; C) Couraça ferruginosa (ferricrete) sobre o granito (ponto GSF 53); D) Formigas trazendo material laterítico à superfície através de capeamento argiloso amarelado. Area da Fazenda Ventania, próximo ao furo GSF 42T; E) Execução de furo de trado na área da Fazenda Ventania; F) Trado mecanizado utlizado na fase inicial dos trabalhos prospectivos; $G$ ) Couraça ferruginosa na borda oeste da área da Fazenda Ventania (ponto 20). 

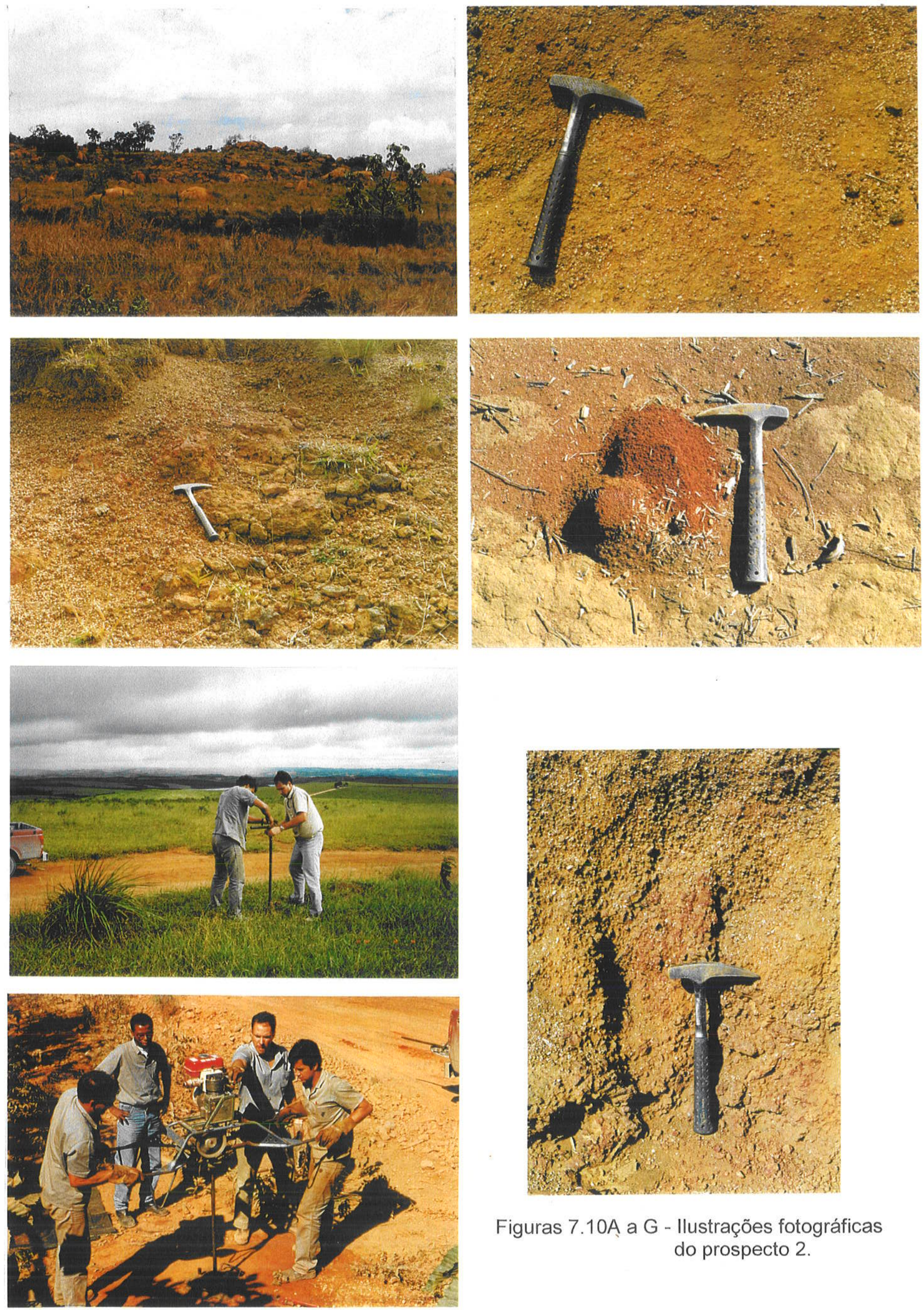

Figuras 7.10A a G - Ilustrações fotográficas do prospecto 2 . 


\subsection{PROSPECÇÃO TÁTICA}

Esta fase dos trabalhos foi dirigida ao prospecto 2, selecionado como o mais promissor em função dos resultados obtidos na primeira fase. Na prospecção tática, foram realizadas atividades de campo e de laboratório, envolvendo sondagem complementar a trado, caracterização do material amostrado e cálculo preliminar de reservas.

\subsubsection{Sondagem}

No prospecto 2, os trabalhos de campo da segunda etapa de prospecção foram realizados com a execução de $143 \mathrm{~m}$ de sondagem em 38 furos de trado (furos GSF-6T a 43T), utilizando-se o trado mecanizado da SAIV nos furos GSF 6T a 22T. Os demais furos foram realizados com o uso do trado manual Eijekelcamp.

Os furos foram identificados com piquetes numerados e suas posições foram lançadas em cartas topográficas 1:10.000, com o auxílio do GPS, sendo posteriormente localizados com precisão pela equipe de topografia da FCV-1.

A distribuição dos furos não obedeceu a uma malha sistemática, tendo caráter prospectivo e subordinada às condições de acesso aos locais da perfuração. Os furos de trado GSF 1T a 43T (incluindo os 5 furos da prospecção estratégica) e seus resultados analíticos encontram-se relacionados no Anexo 4.

Devido aos problemas operacionais do trado mecanizado, já descritos em 5.6.3, os furos executados por este equipamento foram rasos, não passando de $3 \mathrm{~m} \mathrm{e}$, excetuando os furos de borda do depósito, não atravessaram o perfil da laterita. Desta maneira, esses furos prestaram-se mais à delimitação da zona de ocorrência da laterita.

Os furos realizados com o trado manual, com profundidade máxima de $10,5 \mathrm{~m}$, atravessaram o perfil da laterita, à exceção de um furo que atingiu o lençol freático (GSF 31T) e daqueles que pararam em possíveis couraças de distribuição irregular na base do material (impenetrável nos furos GSF 32T, 34T, 35T, 38T, 41T e 43T).

Cada metro perfurado resultou em cerca de $10 \mathrm{~kg}$ de amostra, integralmente levada à FCV, onde foram secas ao ar livre a quarteadas para a obtenção das alíquotas para análise. 
O perfil da laterita apresenta pouca variação nos furos. Geralmente, os furos apresentam, do topo para a base:

- um solo com matéria orgânica, marrom claro a amarelado, de aproximadamente 0,5 m a $1 \mathrm{~m}$;

- o solo passa gradualmente a um material avermelhado, argiloso e plástico até cerca de $3 \mathrm{~m}$;

- abaixo desse horizonte, o material perde progressivamente a plasticidade, tornando-se mais compacto, com coloração vermelha intensa. Ao ser cortado pelo trado, apresentase granulado e solto, a ponto de cair da concha durante a manobra para recuperação;

- nódulos ferruginosos milimétricos são comuns a partir de $3 \mathrm{~m}$ de profundidade, aumentando em profundidade;

- grãos angulosos milimétricos de quartzo estão presentes em maior ou menor quantidade em todo o perfil, com maior abundância na parte inferior dos mesmos, principalmente nos furos de borda do depósito;

- a passagem para o saprolito do granito é marcada pelo aumento brusco na quantidade de grãos angulosos de quartzo e alteração na cor do material, o qual pode passar a amarelado ou avermelhado mais claro, com manchas brancas de caulinita. Aparentemente, ocorrem localmente couraças compactas na base da laterita, de penetração impossível com o trado.

A profundidade máxima atingida, de 10,5 m (furos GSF 34T e 35T), leva a crer que a espessura da laterita não ultrapasse em muito os $10 \mathrm{~m}$. A Figura 7.11 apresenta um perfil geológico típico de furo de trado na área, mostrando também a variação dos teores de $\mathrm{SiO}_{2}, \mathrm{Al}_{2} \mathrm{O}_{3}$ e $\mathrm{Fe}_{2} \mathrm{O}_{3}$ ao longo do mesmo. A Figura 7.12 apresenta o mapa de localização do furos de sondagem e os limites dos três altos que contêm os depósitos lateríticos, que receberam a denominação de Alvos 1, 2 e 3. A Figura 7.13 apresenta perfis geológicos do prospecto 2. A Figura 7.14 apresenta a fotografia aérea do Alvo 1. A Figura 7.15 apresenta ilustrações fotográficas do prospecto 2

As zonas de borda do depósito laterítico, em cotas mais baixas, revelam concentrações de nódulos ferruginosos, sempre contendo grãos angulosos de quartzo indicando que houve migração lateral e descendente do ferro. 


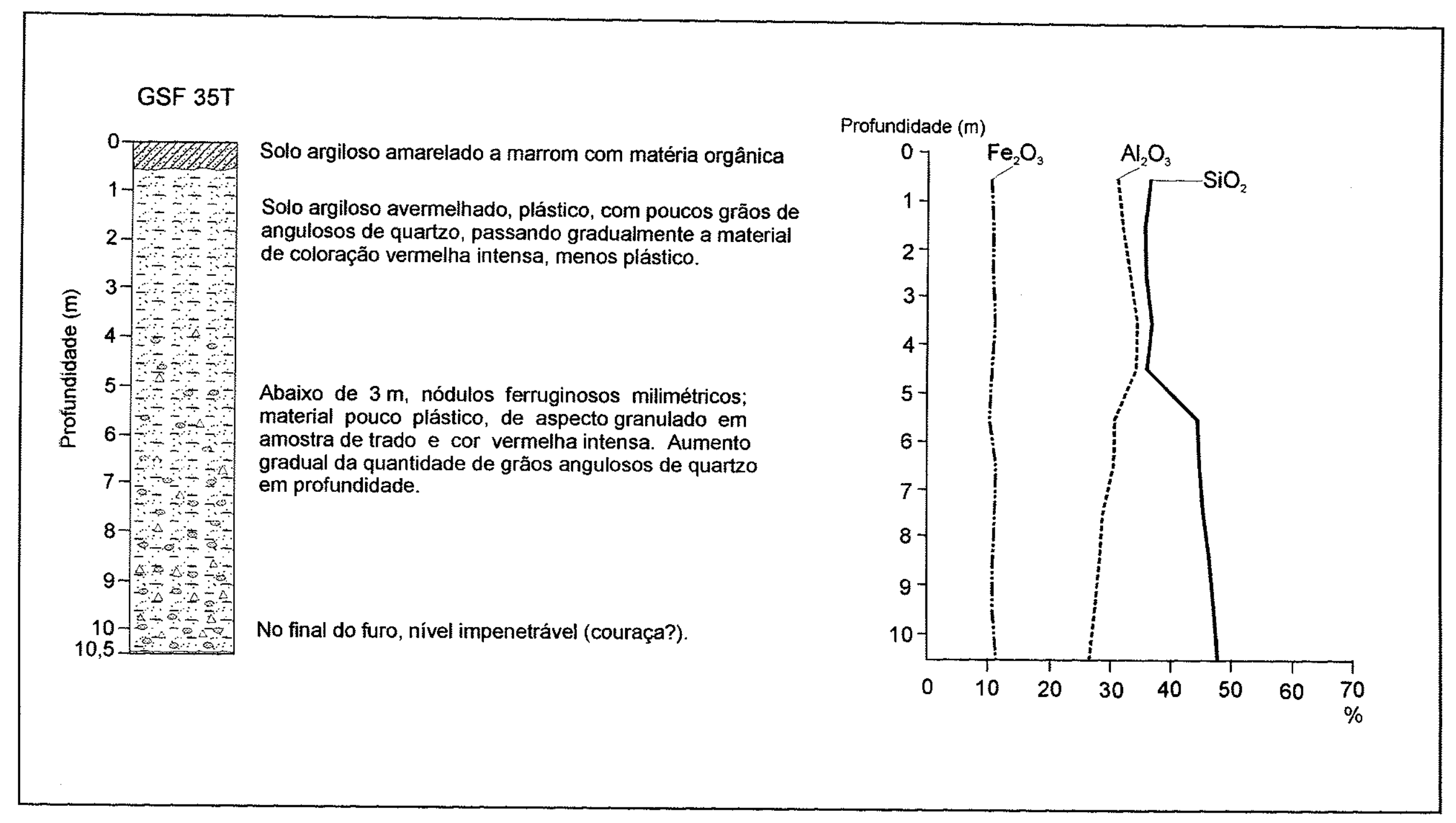

Figura 7.11 - Perfis geológico e de teores de $\mathrm{SiO}_{2}, \mathrm{Al}_{2} \mathrm{O}_{3}$ e $\mathrm{Fe}_{2} \mathrm{O}_{3}$ do furo GSF 35T. 


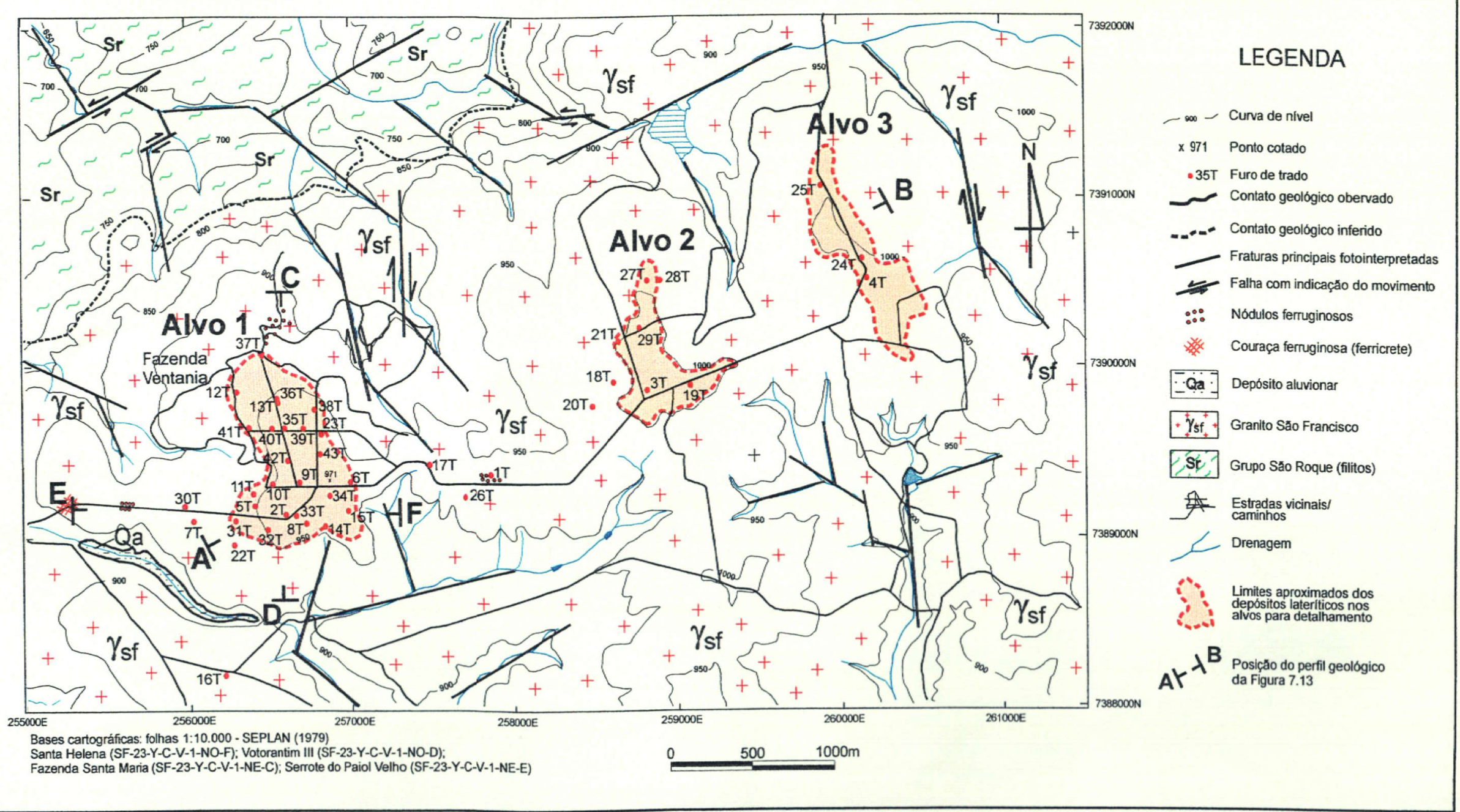

Figura 7.12 - Mapa de localização dos furos de trado e dos alvos para detalhamento no prospecto 2 - Setor do Maciço Granítico São Francisco. 


\section{SW}

NE
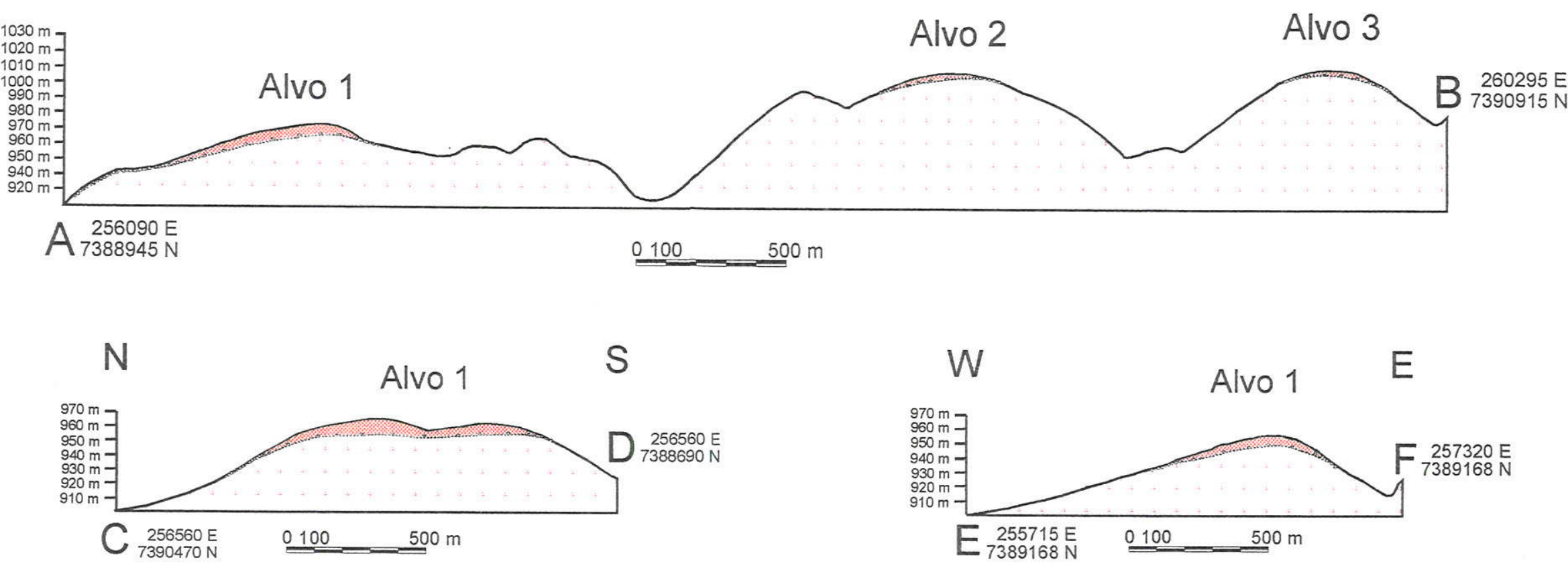

Laterita caulinítica vermelha, não compacta, com nódulos ferruginosos nas bordas e na base.

Granito São Francisco: monzogranitos porfiróides róseos, com texturas rapakivi e anti-rapakivi locais

Figura 7.13 - Perfis geológicos do prospecto 2 - Setor do Maciço Granítico São Francisco. 


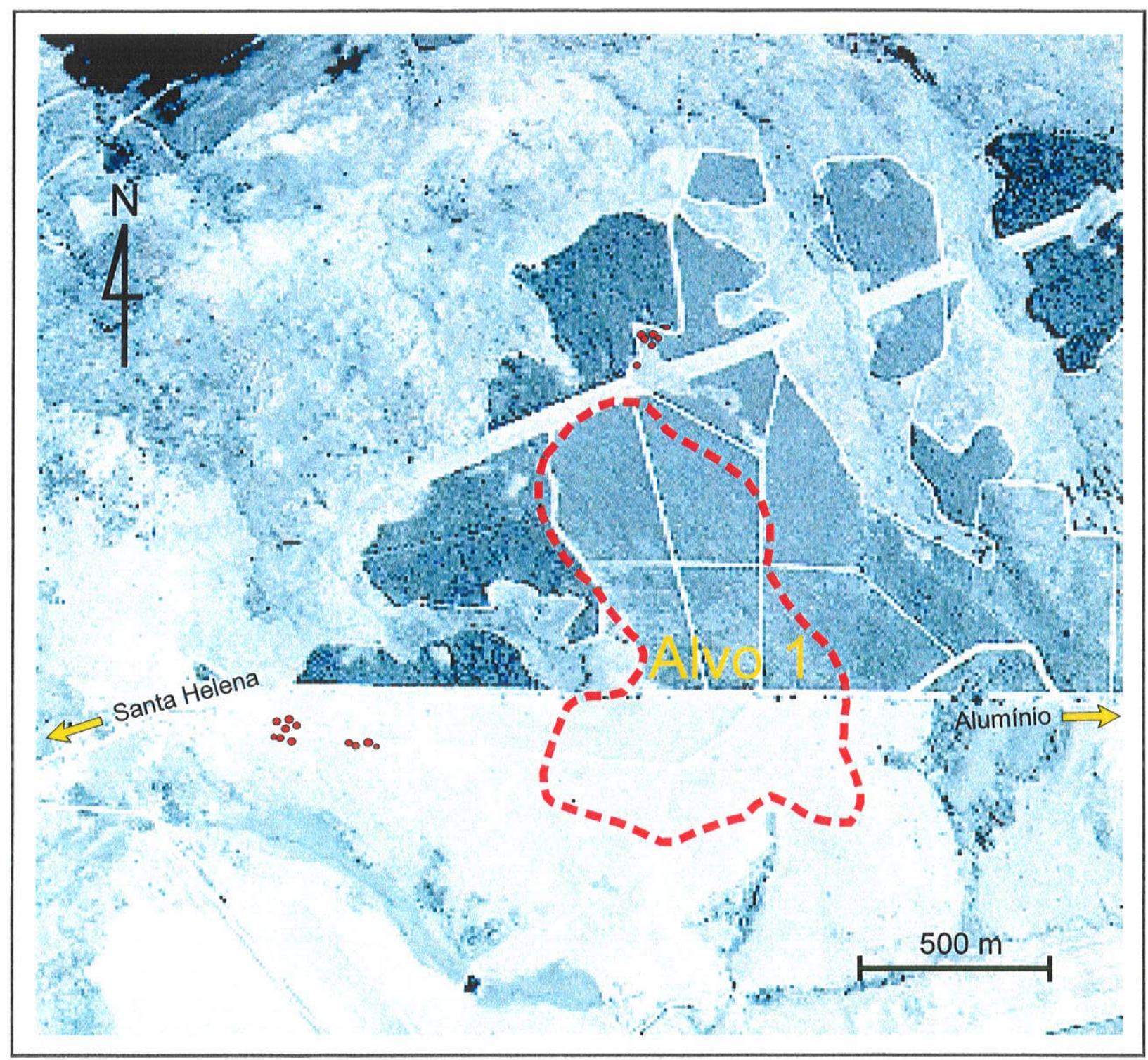

LEGENDA

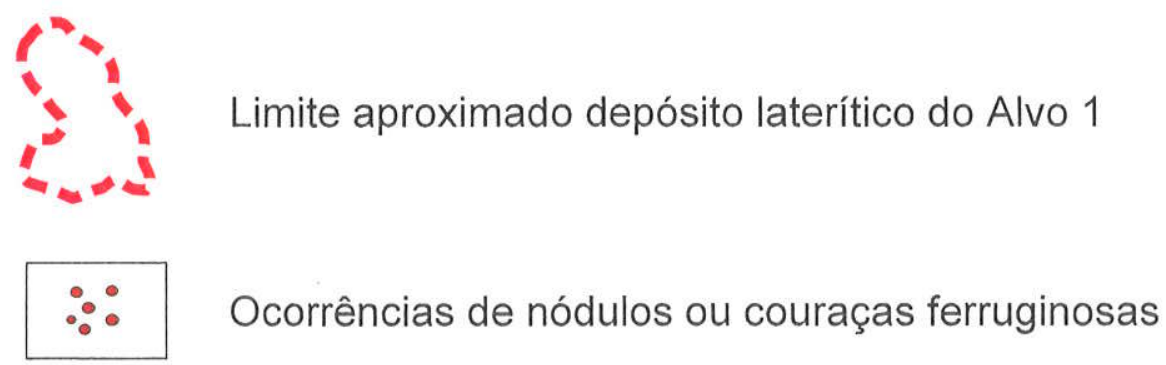

Figura 7.14 - Fotografia aérea do Alvo 1 do prospecto 2: Fazenda Ventania. 

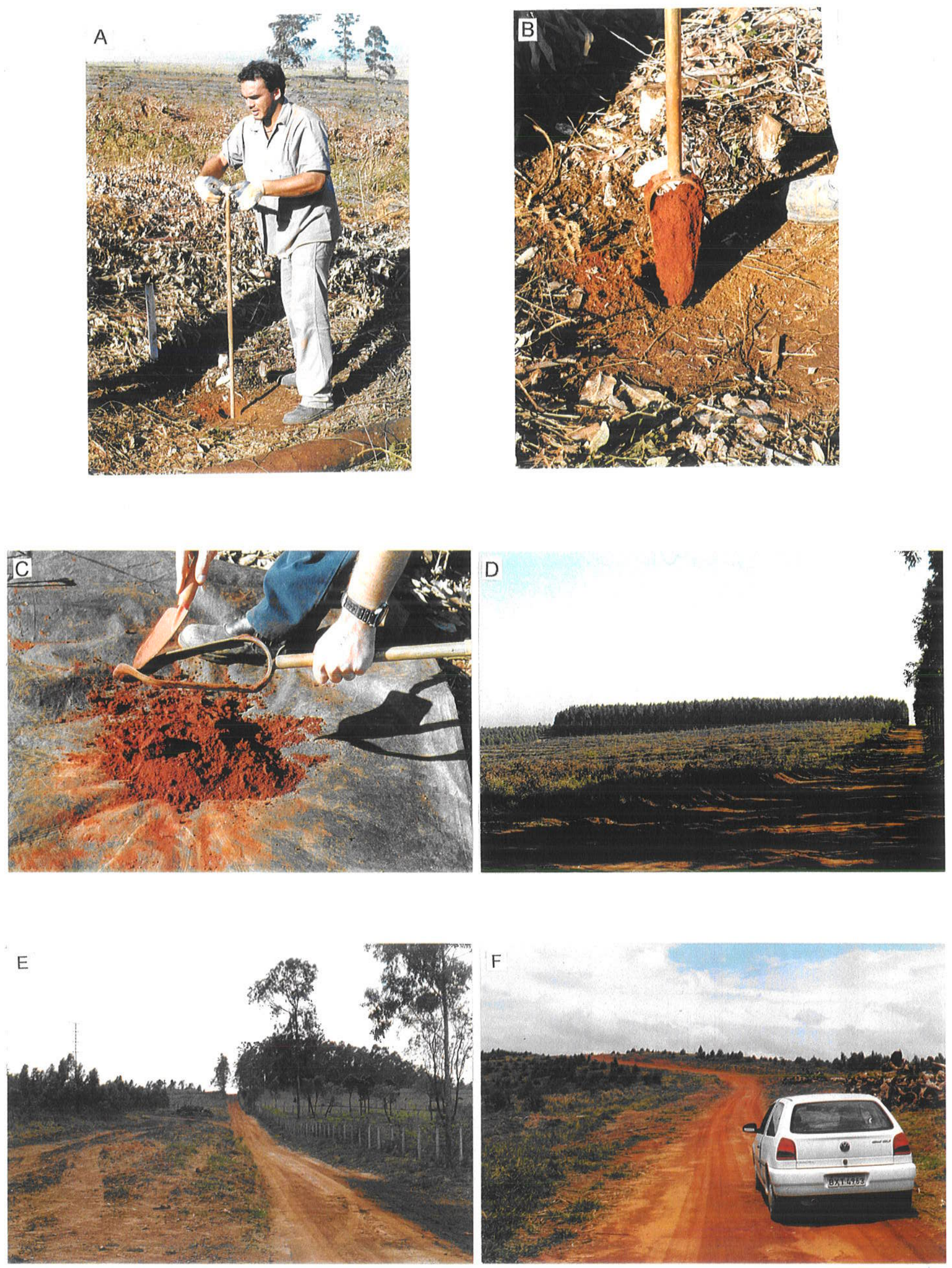

Figura 7.15 - Prospecto 2: A, B e C) Detalhes da sondagem a trado; D) Vista do furo GSF 42T para NW no alto mais a W; E) Vista de SW para NE do segundo alto; F) Vista de $\mathrm{N}$ para $\mathrm{S}$ do alto mais a $\mathrm{E}$. 


\subsubsection{Caracterização dos materiais amostrados}

\section{Análises químicas}

Em relação às análises, foi novamente enfrentado o problema da lentidão da via úmida ou clássica. Desta maneira, apenas as amostras dos furos GSF 6T a 13T foram analisadas por via úmida no laboratório da $\mathrm{FCV}$-1, para $\mathrm{SiO}_{2}, \mathrm{Al}_{2} \mathrm{O}_{3}, \mathrm{Fe}_{2} \mathrm{O}_{3}, \mathrm{CaO}$ e $\mathrm{MgO}$ e perda ao fogo. As demais, por espectrofotometria de plasma ICP no laboratório Nomos Análises Minerais, para $\mathrm{SiO}_{2}, \mathrm{Al}_{2} \mathrm{O}_{3}, \mathrm{Fe}_{2} \mathrm{O}_{3}, \mathrm{CaO}, \mathrm{MgO}, \mathrm{K}_{2} \mathrm{O}, \mathrm{MnO}_{2}, \mathrm{TiO}_{2}, \mathrm{P}_{2} \mathrm{O}_{5}$, $\mathrm{Cr}_{2} \mathrm{O}_{3}$ e perda ao fogo, conforme os resultados analíticos apresentados no Anexo 4. As médias para as amostras analisadas por via úmida foram:

\begin{tabular}{ccccccc}
$\mathrm{SiO}_{2}$ & $\mathrm{Al}_{2} \mathrm{O}_{3}$ & $\mathrm{Fe}_{2} \mathrm{O}_{3}$ & $\mathrm{CaO}$ & $\mathrm{MgO}$ & $\mathrm{Ki}$ & $\mathrm{P} . \mathrm{F}$. \\
\hline 40,35 & 27,70 & 11,39 & 0,57 & 0,02 & 1,73 & 16,53
\end{tabular}

As médias para as amostras analisadas espectrofotometria de plasma ICP foram:

\begin{tabular}{cccccccccccc}
$\mathrm{SiO}_{2}$ & $\mathrm{Al}_{2} \mathrm{O}_{3}$ & $\mathrm{Fe}_{2} \mathrm{O}_{3}$ & $\mathrm{CaO}$ & $\mathrm{MgO}$ & $\mathrm{K}_{2} \mathrm{O}$ & $\mathrm{MnO}_{2}$ & $\mathrm{TiO}_{2}$ & $\mathrm{P}_{2} \mathrm{O}_{5}$ & $\mathrm{Cr}_{2} \mathrm{O}_{3}$ & $\mathrm{Ki}$ & $\mathrm{P} . \mathrm{F}$. \\
\hline 45,16 & 26,01 & 10,94 & 0,13 & 0,09 & 0,20 & 0,02 & 1,54 & 0,20 & 0,02 & 1,79 & 14,94
\end{tabular}

Os resultados permitem observar que, com o aprofundamento dos furos, houve elevação nos teores médios de $\mathrm{Al}_{2} \mathrm{O}_{3}$ e ligeiro decréscimo da sílica. A média das espessuras passou a $4,85 \mathrm{~m}$, com os mais profundos situados no primeiro alto topográfico a partir de Santa Helena, no local denominado Fazenda Ventania.

\section{Caracterização dos tipos de laterita}

Com os resultados das análises dos materiais amostrados nas duas etapas da prospecção, procurou-se estudar preliminarmente os tipos de laterita que ocorrem nos prospectos estudados. Para tanto, os resultados de $\mathrm{SiO}_{2}, \mathrm{Al}_{2} \mathrm{O}_{3}$ e $\mathrm{Fe}_{2} \mathrm{O}_{3}$ dos materiais argilosos foram lançados no diagrama de Schellmann (1981) da Figura 7.16A. Nele, nota-se que as amostras do prospecto 1 distribuem-se principalmente nos campos das lateritas silicosa e caulinítica, tendendo a laterita, enquanto as amostras do prospecto 2 distribuem-se nos mesmos campos da silicosa, da laterita e da caulinítica, com predominância na caulinítica. As amostras da da cobertura sedimentar avermelhada situam-se nos campos da laterita silicosa e da laterita. 
No prospecto 2, foi também confeccionado um diagrama triangular para ilustrar a evolução geoquímica da laterita a partir do granito (Figura 7.16B), onde foram lançados os resultados analíticos de $\mathrm{SiO}_{2}, \mathrm{Al}_{2} \mathrm{O}_{3}$ e $\mathrm{Fe}_{2} \mathrm{O}_{3}$ do granito são, do saprolito do granito e da laterita.

Os dados de análise do granito fresco foram obtidos em Godoy (1989). As amostras de saprolito, cinco no total, foram coletadas num corte de estrada a cerca de $1500 \mathrm{~m}$ a oeste do Alvo 1 (Fazenda Ventania). Seus resultados analíticos, obtidos por via úmida no laboratório da FCV-1, encontram-se na Tabela 7.5 a seguir.

Tabela 7.5 - Resultados analíticos de amostras de saprolito do Granito São Francisco.

\begin{tabular}{|l|c|c|c|}
\hline Amostra & $\mathrm{SiO}_{2}$ & $\mathrm{Al}_{2} \mathrm{O}_{3}$ & $\mathrm{Fe}_{2} \mathrm{O}_{3}$ \\
\hline GSF 01SP & 69,38 & 19,84 & 2,21 \\
\hline SPSF-1 & 74,87 & 15,81 & 1,65 \\
\hline SPSF-2 & 69,60 & 18,51 & 2,58 \\
\hline SPSF-3 & 56,90 & 28,18 & 2,44 \\
\hline SPSF-4 & 72,02 & 18,14 & 1,88 \\
\hline Médias & 68,55 & 20,10 & 2,15 \\
\hline
\end{tabular}

\section{Estimativa do teor de areia (sílica livre) por elutriação}

Para conhecimento aproximado do conteúdo de sílica livre, principalmente sob a forma de grãos de quartzo, relevante no processo de fabricação do cimento, amostras selecionadas foram tratadas pelo processo conhecido como elutriação (Yamamoto, no prelo), no Laboratório de Preparação de Amostras do DGE/IG-USP.

No tratamento das amostras, deu-se ênfase àquelas dos furos de trado no depósito mais a oeste no prospecto 1 (Fazenda Ventania). Adicionalmente foram tratadas amostra de furos dos demais depósitos do prospecto da área do Granito São Francisco e, também, da "argila ferruginosa", do saprolito do granito e da cobertura sedimentar avermelhada.

Para as amostras da laterita dos Alvos 1, 2 e 3, a média do conteúdo de areia é de $16,29 \%$, para um teor médio de sílica total de $41,94 \%$. Na amostra da "argila ferruginosa" essa relação é de $31,54 \%$ para $60,56 \%$; no saprolito do granito, de 56,09 

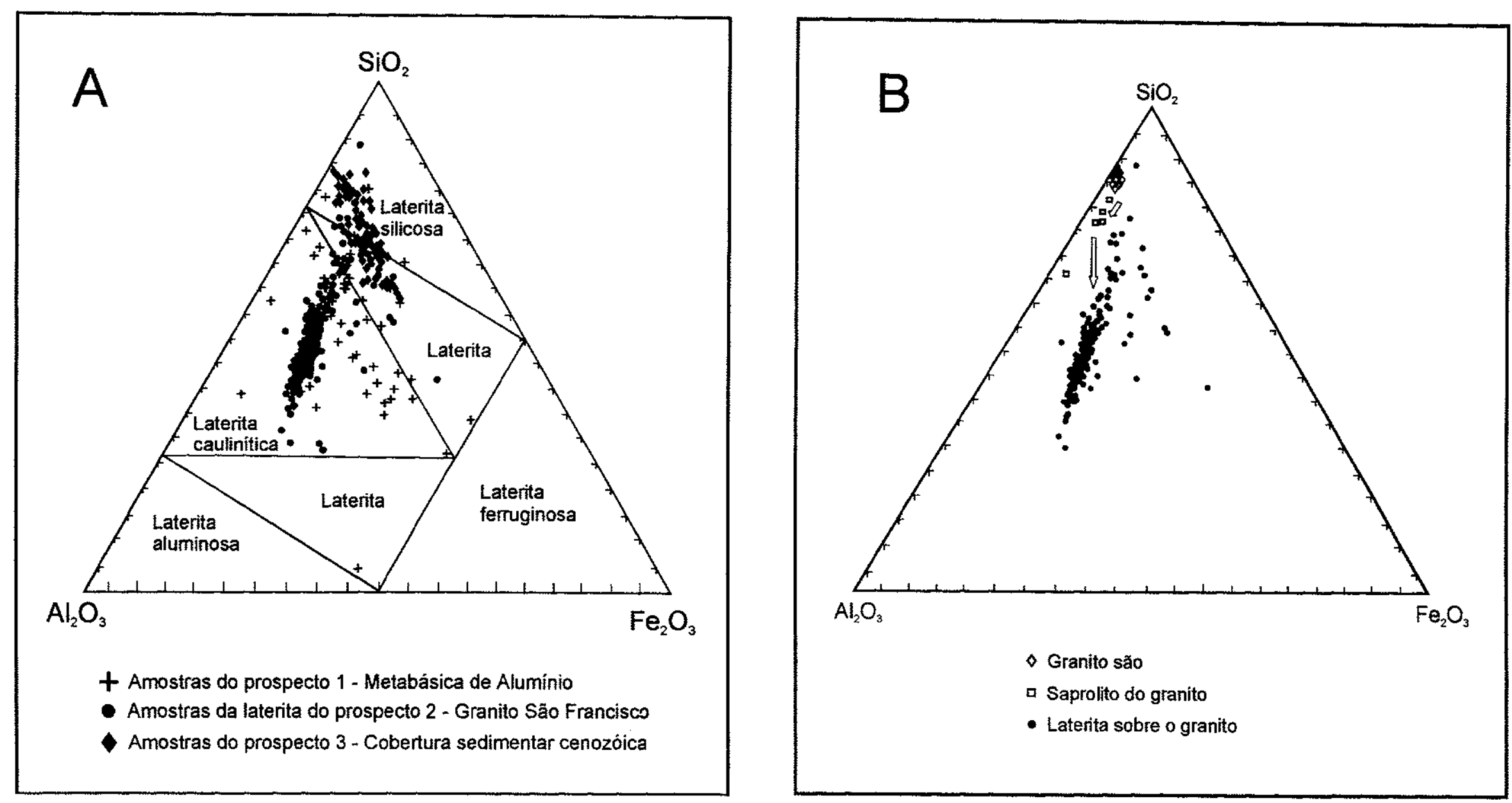

Figura 7-16 - A) Posições das amostras da área de estudo no diagrama de Schellmann (1981);

B) Evolução geoquímica da lateritização no prospecto 2 . 


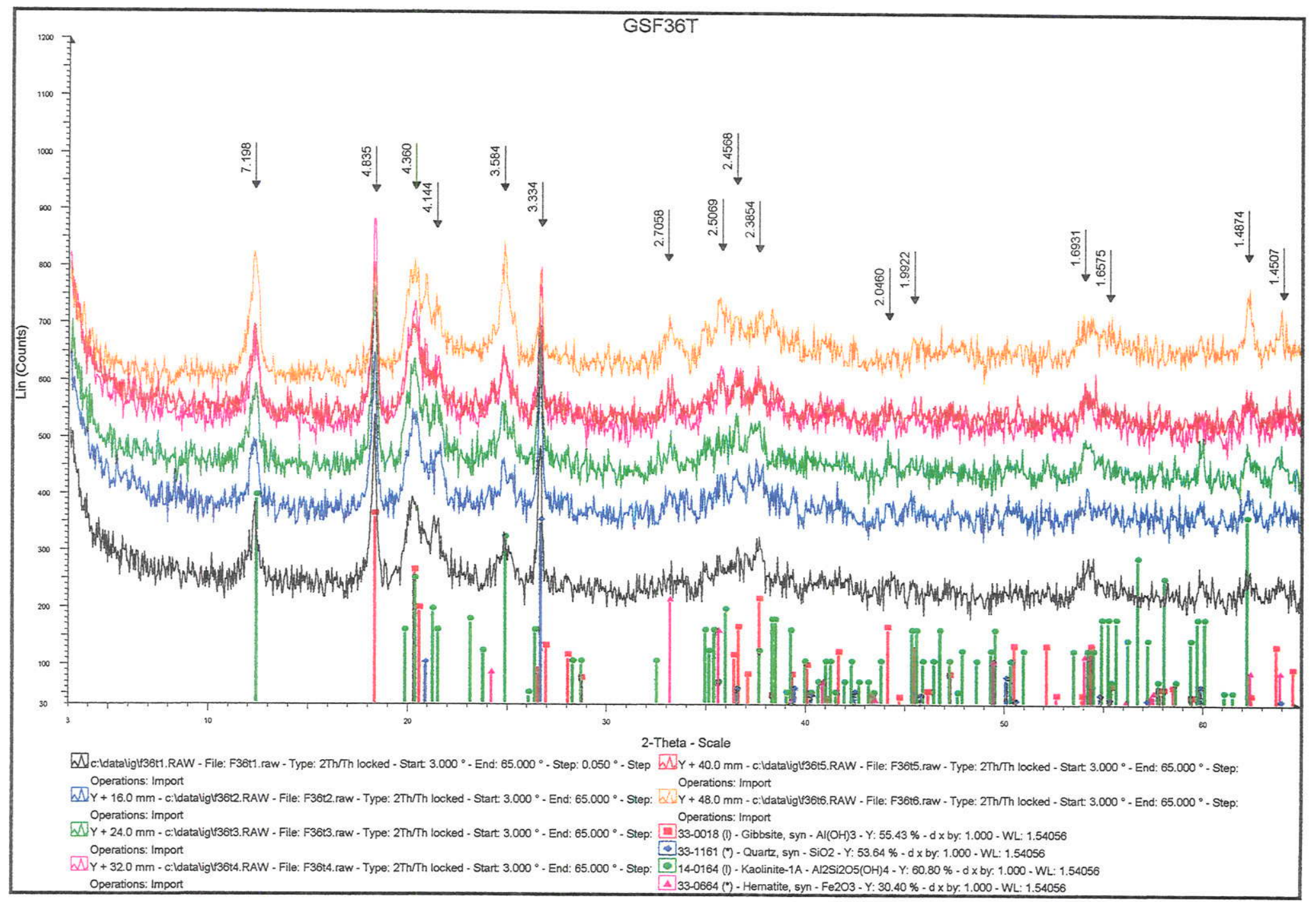

Figura 7.17 - Difratogramas de raios-X das amostras do furo GSF 36T. 
$\%$ para $69,38 \%$ e, na cobertura sedimentar, de $20,36 \%$ para $43,72 \%$. Todos os resultados obtidos encontram-se no Anexo 5.

\section{Identificação mineralógica por difratometria de raios-X}

No prospecto 2, foram escolhidas as amostras dos furos GSF 25T, 29T, 36T e 42T para a difratometria de raios- $X$. $O$ primeiro situa-se no alto mais a leste, o segundo no central e os demais naquele mais a oeste. As amostras para difratometria foram reduzidas abaixo da malha 150 e manualmente prensadas em suporte adequado. Os parâmetros operacionais do equipamento constam do difratograma.

Os difratogramas mostraram que a mineralogia das amostras praticamente não varia entre os furos e ao longo dos mesmos, apresentando como constituintes principais quartzo, caulinita, hematita e gibbsita. Os picos deste último são intensos, evidenciando a concentração de alumínio e comprovando o processo de lateritização. Para efeito ilustrativo, a Figura 7.17 apresenta os difratogramas das amostras do furo GSF 36T. As amostras dos demais furos citados apresentaram difratogramas semelhantes.

\section{Separação e identificação de minerais pesados}

Minerais pesados foram separados e qualitativamente identificados nas amostras compostas dos furos GSF 34T, GSF 42T, TA-01 e TA-02, além de amostras SPSF-1 e SPSF-2 do saprolito do Granito Säo Francisco, visando o conhecimento das fontes dos materiais estudados. A Figura 7.18 apresenta as fotomicrografias dos minerais pesados das amostras estudadas.

$\mathrm{Na}$ amostras da laterita da Fazenda Ventania (furos GSF 34T e 42T), a assembléia de minerais pesados é típica do granito, com zircão, turmalina, monazita, cassiterita e algum rutilo. Os minerais apresentam-se, em sua maioria, angulosos a subangulosos, evidenciando pouco ou nenhum transporte, constituindo forte evidência da origem da laterita a partir do granito.

Nas amostras do saprolito do granito, utilizadas para comparação, destacam-se zircão, turmalina, monazita, cassiterita e raras hornblendas. $O$ zircão, em prismas biterminados, apresenta-se freqüentemente zonado ou com inclusões fluidas. Grãos de quartzo com impregnações ferruginosas tiveram suas densidades aumentadas, tendo sido concentrados com os pesados. 


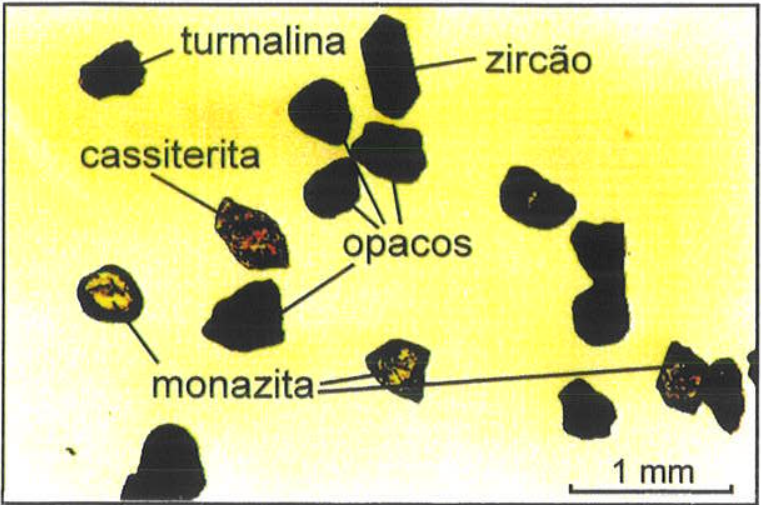

A - amostra do furo GSF 34T.

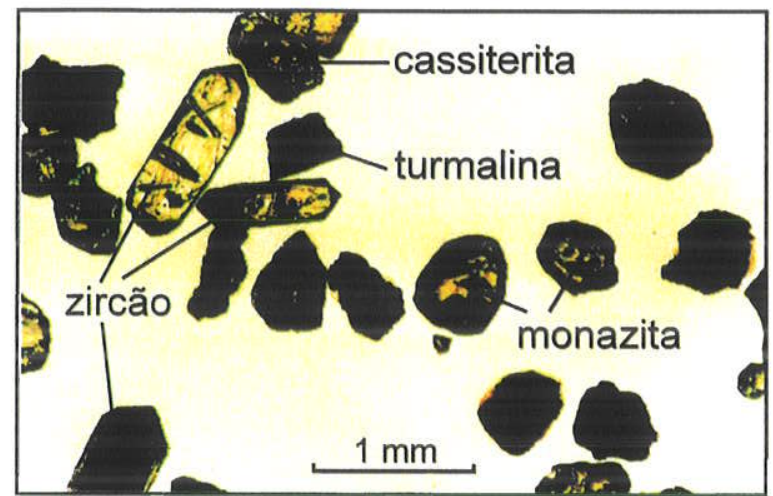

C - Amostra do saprolito do granito São Francisco (SPSF-1).

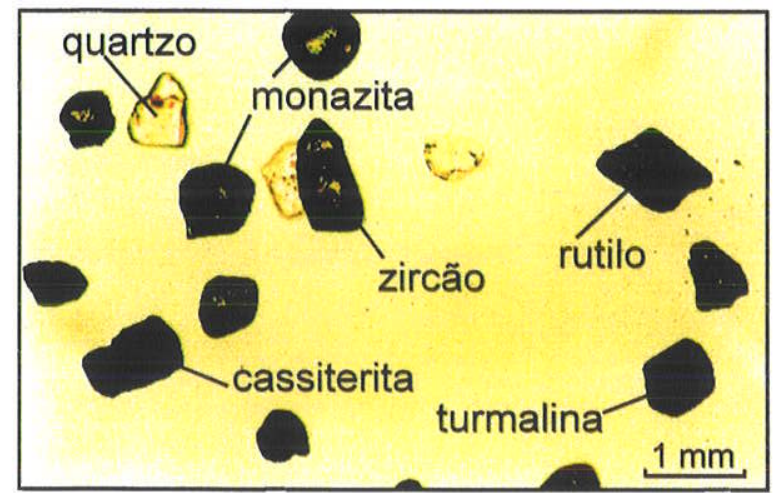

E - Amostra da cobertura sedimentar avermelhada (Furo TA-01).

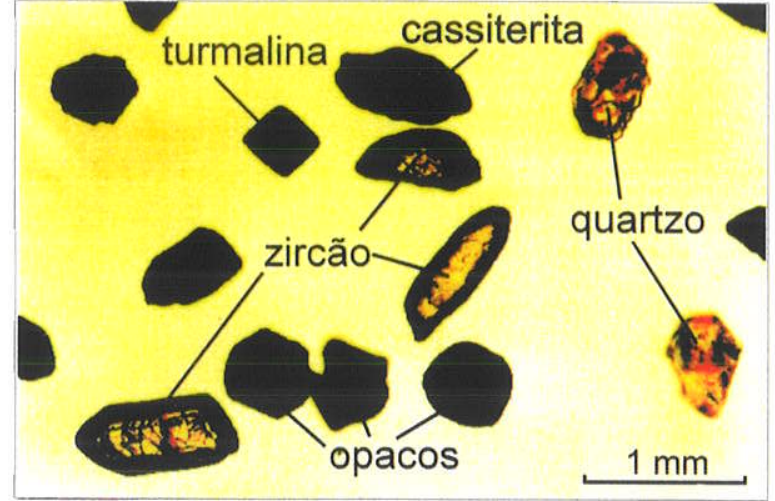

B - Amostra do furo GSF-42T

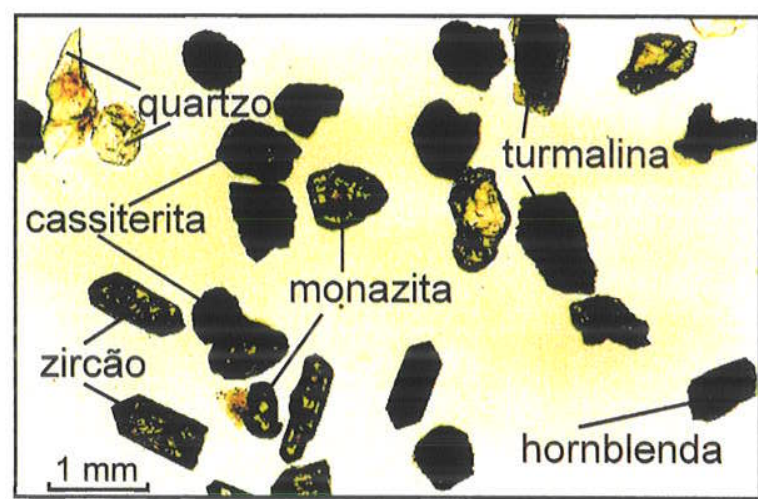

D - Amostra do saprolito do granito São Francisco (SPSF-2).

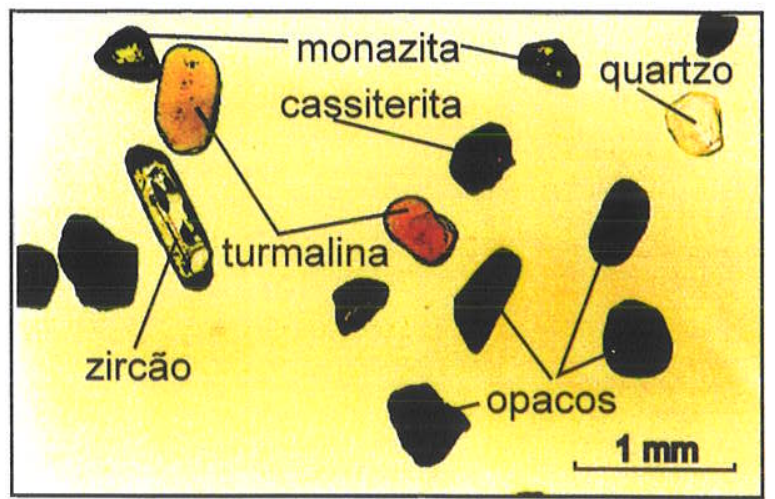

F - Amostra da cobertura sedimentar avermelhada (Furo TA-02).

Figura 7.18 - Fotomicrografias de concentrados de minerais pesados. 
Nas amostras dos furos TA-01 e TA-02, da cobertura sedimentar avermelhada, nota-se também zircão, turmalina, monazita e cassiterita, evidenciando contribuição granítica; porém, os grãos apresentam-se geralmente arredondados, indicando transporte. Como acessórios, comparecem epidoto, rutilo e sillimanita, indicando contribuição metamórfica.

\section{Microscopia eletrônica de varredura (MEV)}

Amostras dos furos GSF 29T (3-4 m e 4-5 m), GSF 31T (3-4 m) e GSF 42T (0-1 $\mathrm{m}$ ) foram examinadas nos microscópios eletrônicos de varredura (MEV) do Instituto de Geociências - USP e do LCT-EPUSP, visando o conhecimento da morfologia dos minerais constituintes na fração argila e, também, do quartzo, para comparação com o quartzo do saprolito do granito e verificação de feiçōes de corrosão.

Os minerais principais: caulinita, gibbsita e hematita revelaram-se de dificil individualização ao MEV. Somente na amostra GSF 29T (4-5m) foi possível ver vagas formas hexagonais mal formadas da caulinita, em cristais de dimensões nanométricas (Figura 7.19A). Nas demais amostras, os minerais formam agregados micronodulares, sendo impossivel a individualização nos aumentos utilizados, da ordem de 40.000 vezes (Figuras 7.19B e D). Apesar das sucessivas tentativas, não foi possivel conseguir nitidez focal em aumentos maiores. Análises qualitativas pontuais através do EDS revelam presença de $\mathrm{Al}, \mathrm{Si}, \mathrm{O}$ e $\mathrm{Fe}$ nesses agregados micronodulares. Zonas aluminosas, identificadas na amostra GSF 31 T $(3-4 \mathrm{~m})$ através do EDS, mostraram-se como manchas escuras sobre uma massa aluminos-ferruginosa-silicosa (Figura 7.19C).

Os grãos de quartzo, apresentando maiores dimensões, permitiram a visualização de imagens nítidas. A Figura 7.20 compara grãos do saprolito do granito (Figuras 7.20A, C e E) com os da laterita (Figuras 7.20B, D e F). Os últimos apresentam, freqüentemente, feições de corrosão, evidenciando a lixiviação da sílica, inclusive sob a forma de quartzo, no processo de lateritização.

\section{Granulometria}

Amostras dos furos GSF $35 T$ e $42 T$ foram escolhidas para análise granulométrica. As amostras do furo GSF $35 T$ foram submetidas à análise granulométrica convencional, por peneiramento e pipetagem, segundo o método 


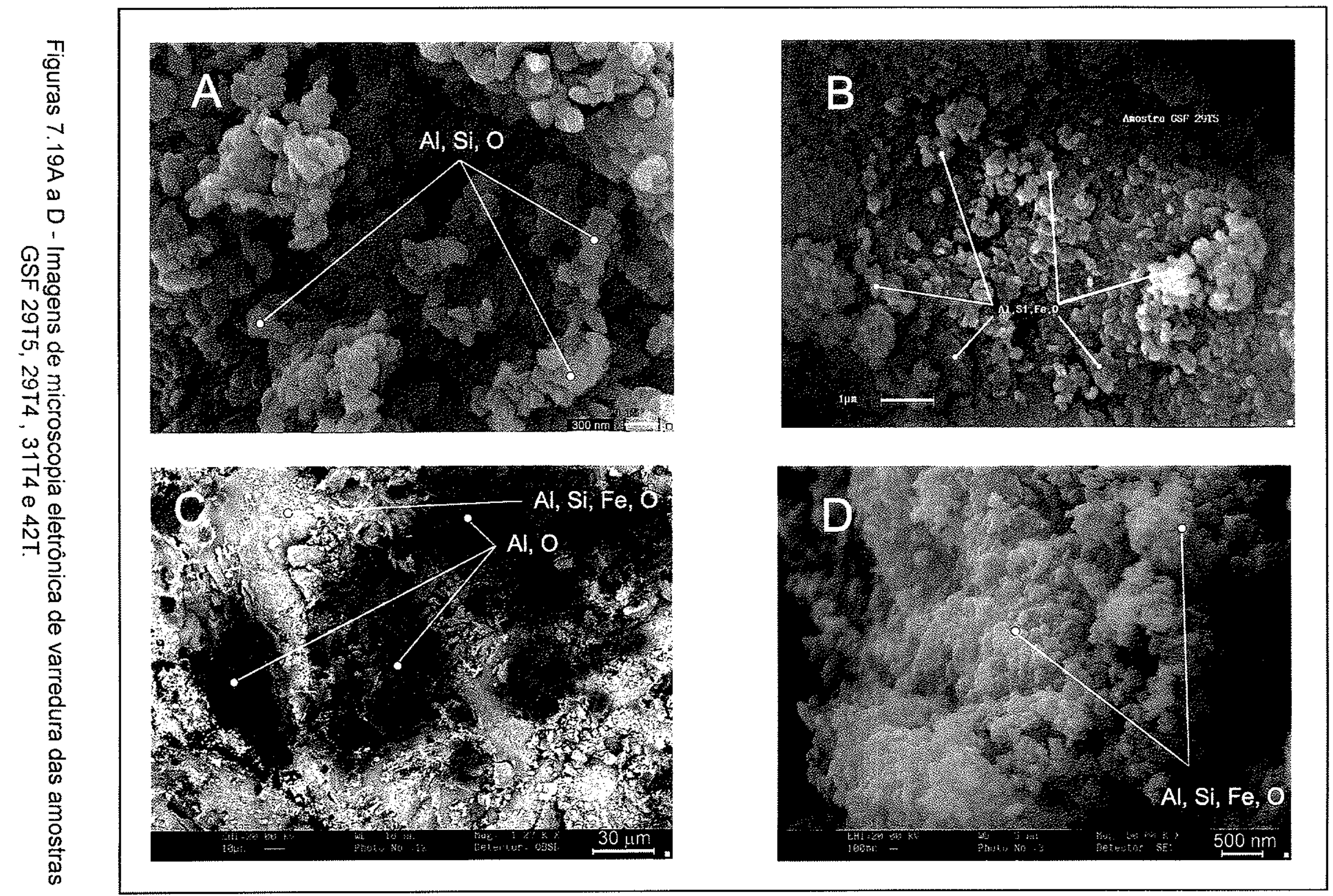

Figura 7.19 - A) Amostra GSF 29T5: cristais nanométricos e mal formados de caulinita); B) Amostra GSF 29T4: agregados micronodulares contendo $\mathrm{Al}, \mathrm{Fe}, \mathrm{Si}$ e O; C) Amostra GSF 31T4: zonas aluminosas (escuras) em massa alumino - ferrugino sa - silicosa; D) Amostra GSF 42T: agregado micronodular contendo $\mathrm{Al}$, $\mathrm{Fe}, \mathrm{Si}$ e O. 


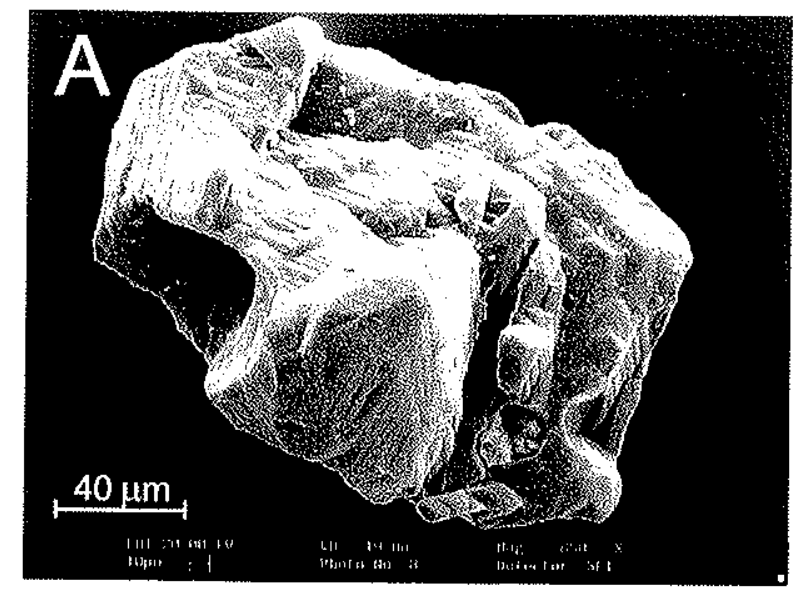

A: grão de quartzo do saprolito do Granito São Francisco, com moldes de outros minerais.

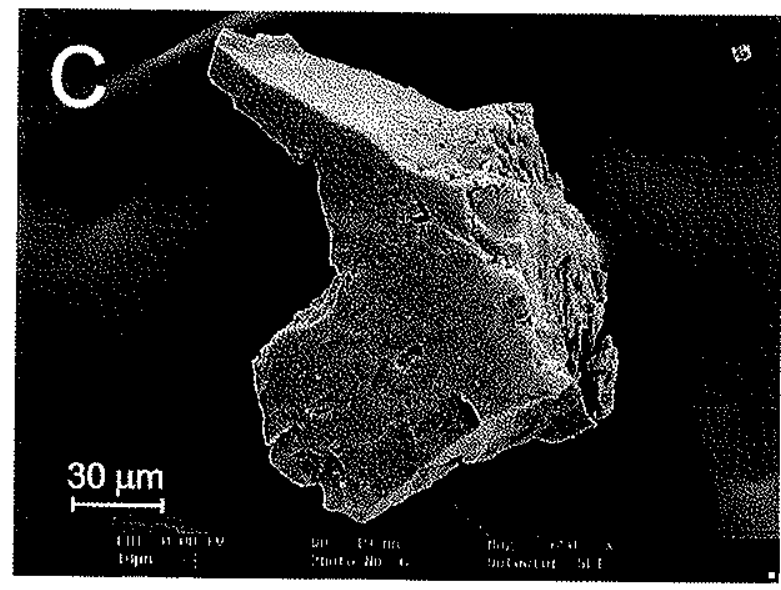

C: grão de quartzo do saprolito do granito, exibindo poros.

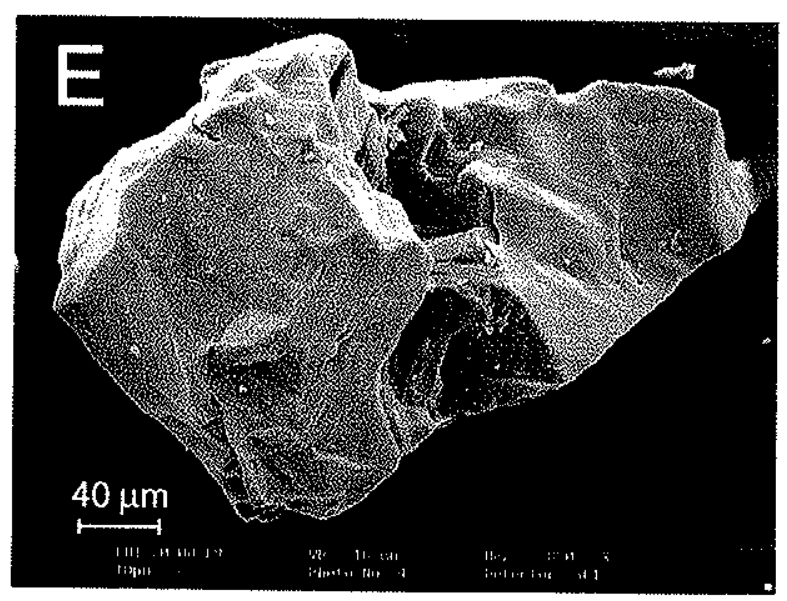

E: grão de quartzo do saprolito do granito, sem evidências de dissolução.

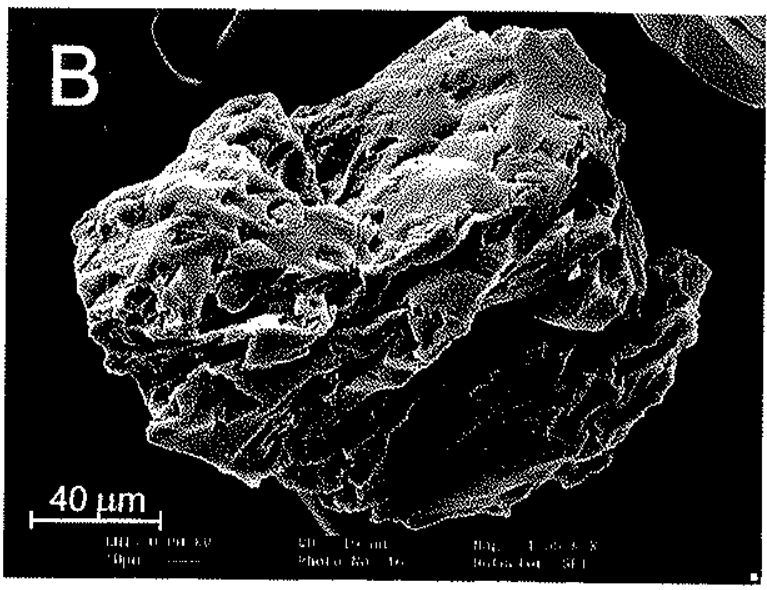

B: grão de quartzo da laterita sobre o granito, mostrando evidências de dissolução ao longo de fissuras.

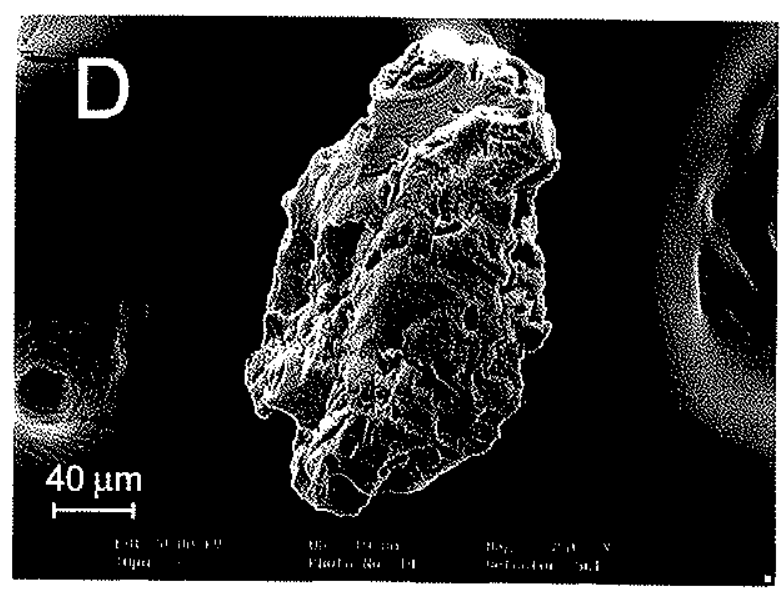

D: grão de quartzo da laterita, exibindo aumento de porosidade no início da dissolução.

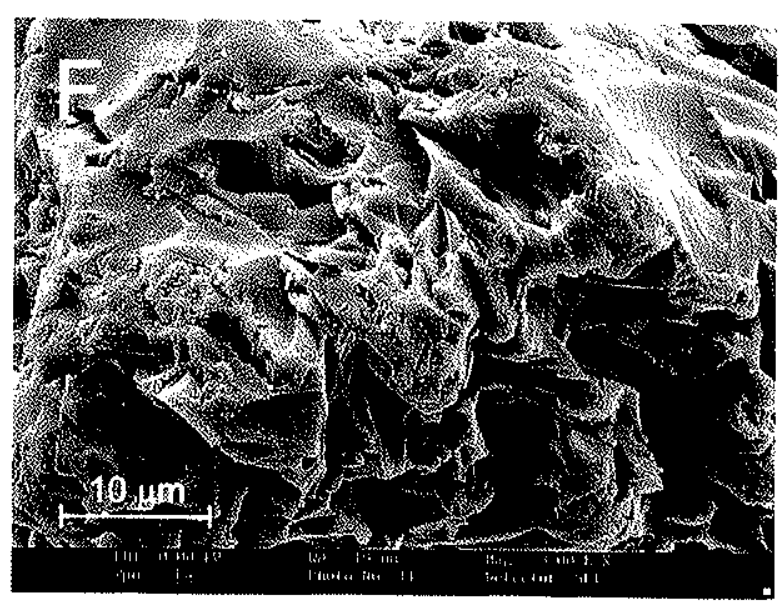

F: detalhe de grão de quartzo da laterita exibindo feições de dissolução.

Figura 7.20 - Imagens de microcopia eletrônica de varredura (elétrons secundários), de grãos de quartzo do saprolito do granito e da laterita do prospecto 2. 
descrito em Suguio (1973). Não mostraram variações significativas na granulometria ao longo do perfil, e a curva granulométrica da amostra composta do furo mostra, também, que há pouca variação em relação às amostras individuais. Apenas nas amostras da base do furo nota-se um ligeiro aumento da porcentagem das partículas mais grossas, acima de $2 \mathrm{~mm}$, que representam 2,05\% da massa total. No geral, as partículas têm diâmetros inferiores a $4 \mathrm{~mm}$, com a fração 1 - $4 \mathrm{~mm}$ representando $6,08 \%$. Predominam as frações mais finas, com $94,51 \%$ de silte e argila, com diâmetro inferior a $62 \mu \mathrm{m}$. Os Anexos $6 \mathrm{~A}$ e $6 \mathrm{~B}$ apresentam, respectivamente, as curvas granulométricas da amostra GSF $35 \mathrm{~T} 2$ e da amostra composta do furo (11 amostras), ilustrando a similaridade das curvas.

A predominância de partículas finas torna as análises granulométricas pelo método convencional muito demoradas, motivo pelo qual se optou pela combinação do peneiramento com a via instrumental nas amostras do furo GSF 42T. Foi utilizado o analisador a laser Mastersizer Microplus Ver. 2.17, marca Malvem, do LCTEPUSP/Minas, que analisa volumetricamente a distribuição granulométrica.

O peneiramento das partículas acima de $1 \mathrm{~mm}$ mostrou que, em média, as mesmas representam cerca de $8,45 \%$ da massa das amostras. Nota-se que há uma concentração no intervalo de 1 a 2,38 mm, com uma média de $93,97 \%$ no furo GSF 42T. As partículas acima de $4 \mathrm{~mm}$ representam apenas $2,51 \%$ das amostras, estando ausentes em 4 delas. $O$ Anexo $6 \mathrm{C}$ apresenta os dados do peneiramento.

A análise instrumental das frações abaixo de $1 \mathrm{~mm}$ mostra que, no furo estudado, nas amostras dos 3 metros superiores, as partículas situam-se no intervalo de 0,05 a $100 \mu \mathrm{m}$, com predominância entre 20 e $45 \mu \mathrm{m}$. Nas amostras entre 4 e $10 \mathrm{~m}$, com exceção do intervalo de 6 a $8 \mathrm{~m}$, onde há similaridade com os $3 \mathrm{~m}$ iniciais, as partículas distribuem-se mais amplamente, indo aproximadamente de 0,05 a $555 \mu \mathrm{m}$. Observa-se que esta distribuição é semelhante à da farinha de clínquer da FCV-1. O Anexo 6D apresenta as curvas granulométricas instrumentais do furo GSF 42T.

\subsubsection{Identificação de alvos para detalhamento - cálculo preliminar de reservas}

A prospecção permitiu identificar três depósitos de material laterítico nos domínios do prospecto 2, denominados Alvos 1,2 e 3 , indicados no mapa da Figura 7.12 . 
No Alvo 1, de maior expressão superficial e onde foi feita a maioria dos furos, foi efetuado um cálculo preliminar de reservas com base nos furos de trado. Para tanto, utilizou-se o método dos triângulos (Popoff 1996), já descrito em 5.8.2 e baseado no princípio das variações graduais entre duas estações de amostragem adjacentes. A Figura 7.21 apresenta os 24 triângulos considerados no cálculo. $O$ resumo do cálculo preliminar de reserva encontra-se no Anexo 7 .

Para o cálculo da tonelagem in situ, o peso específico do material foi determinado em $1,63 \mathrm{~g} / \mathrm{cm}^{3}$ como média obtida para três corpos de prova indeformados. Chegou-se a uma área superficial de $442.051 \mathrm{~m}^{2}$, encerrando um volume total de $2.269 .809 \mathrm{~m}^{3}$, equivalente a $3.699 .789 \mathrm{t}$. Os teores médios (\%) de $\mathrm{SiO}_{2}, \mathrm{Al}_{2} \mathrm{O}_{3}$, $\mathrm{Fe}_{2} \mathrm{O}_{3}, \mathrm{MgO}$ e $\mathrm{TiO}_{2}$, ponderados pelos volumes dos prismas de seção triangular, são:

\begin{tabular}{ccccc}
$\mathrm{SiO}_{2}$ & $\mathrm{Al}_{2} \mathrm{O}_{3}$ & $\mathrm{Fe}_{2} \mathrm{O}_{3}$ & $\mathrm{MgO}$ & $\mathrm{TiO}_{2}$ \\
\hline 42,56 & 29,02 & 11,22 & 0,06 & 1,44
\end{tabular}

Os outros dois alvos da área, indicados na Figura 7.12, têm dimensões reduzidas em relação ao primeiro, e os dados de sondagem dos mesmos não são ainda suficientes para um cálculo semelhante. Os dados disponiveis de sondagem indicam também espessuras menores para esses alvos; porém, com laterita de características físicas, químicas e mineralógicas similares às do Alvo 1 .

As áreas superficiais estimadas para os Alvos 2 e 3 são, respectivamente, de $340.000 \mathrm{~m}^{2}$ e $360.000 \mathrm{~m}^{2}$. Considerando uma espessura média de $2,5 \mathrm{~m}$, pode-se inferir uma reserva somada de $2.852 .500 \mathrm{t}$ para os mesmos, totalizando um potencial de cerca de $6.550 .000 \mathrm{t}$ para os três alvos. 


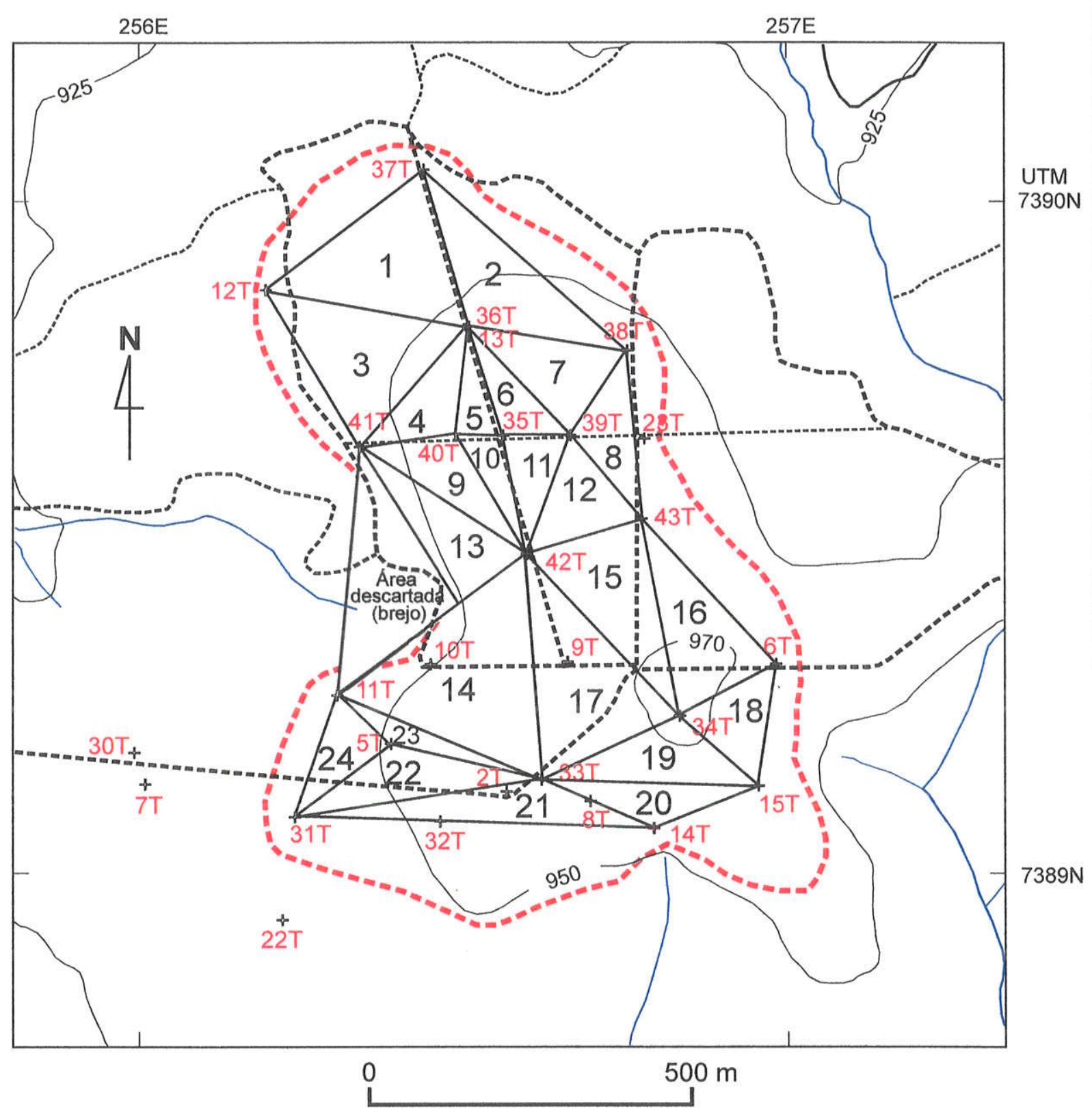

LEGENDA

15 Triângulo com furos de trado nos vértices

$+{ }^{43 T} \quad$ Furo de trado

Limite aproximado do depósito laterítico

g950 Curva de nível

..... Estrada não pavimentada

$\perp$ Drenagem

Figura 7.21 - Triângulos considerados no cálculo de reserva do Alvo 1 - Fazenda Ventania. 


\section{CAPÍTULO 8}

\section{TESTES DE PRODUÇÃO DE CLÍNQUER}

Os resultados da sondagem a trado, da caracterização da laterita e do cálculo preliminar de reserva justificaram a realização de testes de produção de clínquer em escala piloto com o uso da laterita do Alvo 1- Fazenda Ventania e das rochas encaixantes das minas Pastinho e Baltar subterrânea.

Inicialmente, foi escolhido o local do Alvo 1 para a lavra do material a ser utilizado nos testes, no qual foram estudadas em detalhe as propriedades da laterita. Em seguida, foram realizadas simulações computacionais da composição da farinha, para definição das combinações e proporções ótimas. Estas, foram utilizadas na orientação da composição dos depósitos de rocha carbonática e de argila destinados aos testes, conduzidos nos fornos $W 1$ e W2, sem alteração dos demais parâmetros operacionais. Os resultados técnicos dos testes foram então avaliados pela equipe do laboratório da FCV-1, segundo procedimentos usuais e normatizados pela ABNT e dentro dos critérios estabelecidos pela certificação ISO 9002.

A seguir, são sintetizados os detalhes envolvidos nos testes.

\subsection{LAVRA EXPERIMENTAL}

A Figura 8.1 ilustra em detalhes o local, situado na parte centro norte do Alvo 1, dentro de um polígono delimitado pelos furos de trado GSF 40T, 50T, 51T e 52T. Os três últimos furos já fazem parte da malha sistemática de sondagem $(50 \mathrm{~m} \times 50 \mathrm{~m}) \mathrm{em}$ execução pela equipe da DM/FCV-1, como parte do trabalho de avaliação do depósito laterítico. As coordenadas UTM e as cotas dos furos, bem como os resultados analíticos, estão compondo um banco de dados para futuro tratamento, modelagem e planejamento de lavra através do programa Datamine, de uso corrente na FCV-1.

Para o cálculo dos teores médios do bloco de lavra, foram considerados apenas os $4 \mathrm{~m}$ superiores nos furos $40 \mathrm{~T}$ e $50 \mathrm{~T}$ e $3 \mathrm{~m}$ nos furos $51 \mathrm{~T}$ e $52 \mathrm{~T}$, embora a espessura total deva se aproximar dos $10 \mathrm{~m}$ no local, visto que a lavra foi planejada para os $3 \mathrm{~m}$ superiores. Dados dos demais intervalos dos três últimos furos ainda não estavam disponiveis na ocasião. 


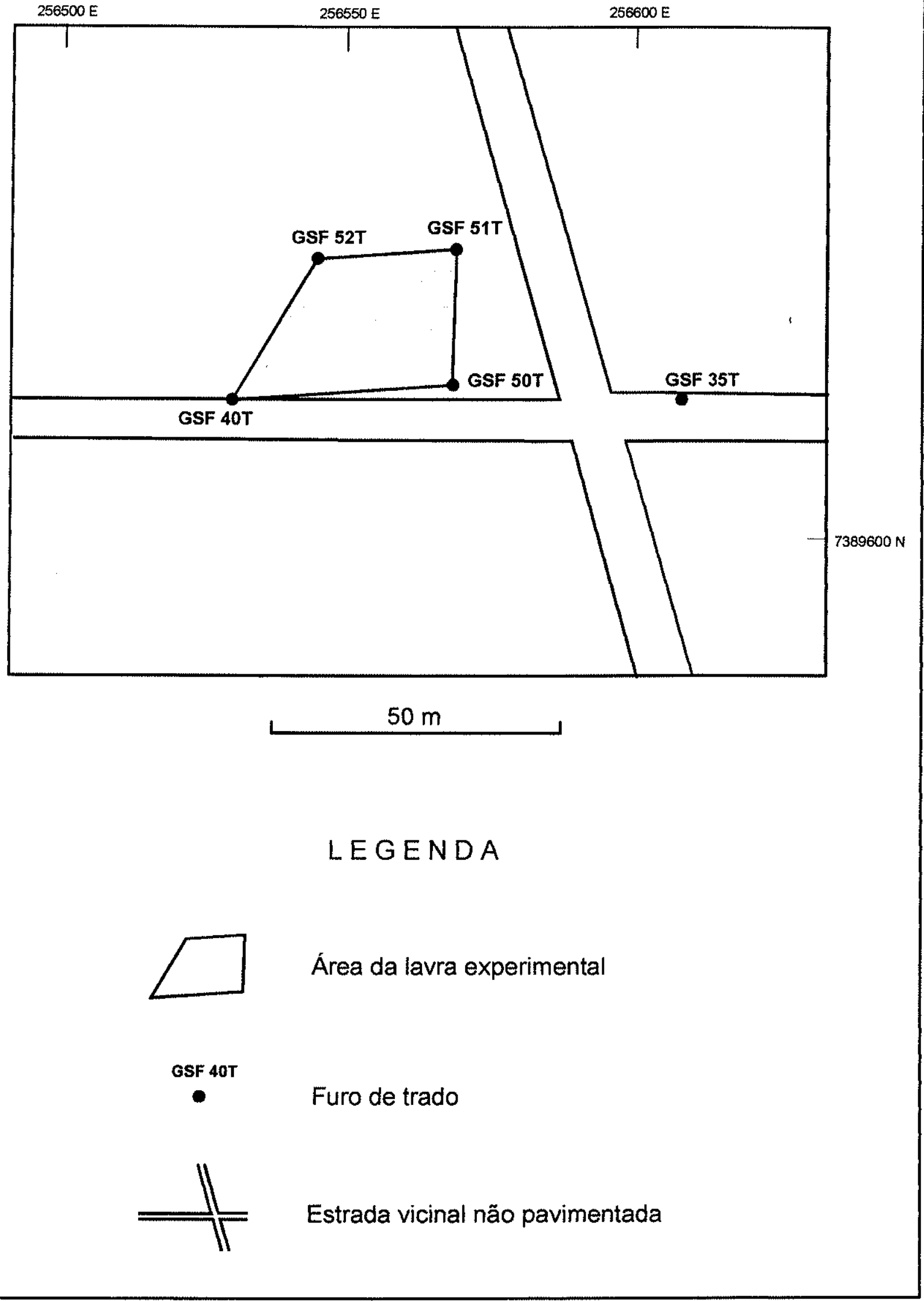

Figura 8.1 - Área da lavra experimental no Alvo 1. 
Nesse mesmo local, após a escavação do material, foram coletados os corpos de prova indeformados para a determinação do seu peso específico. A laterita apresenta peso específicos in natura e in situ de $1,63 \mathrm{~g} / \mathrm{cm}^{3}$, e in situ seco de 1,35 $\mathrm{g} / \mathrm{cm}^{3}$. No material escavado (empolado), o peso específico, com umidade natural, é de $1,20 \mathrm{~g} / \mathrm{cm}^{3}$; no empolado seco, é de $1,07 \mathrm{~g} / \mathrm{cm}^{3}$.

A Tabela 8.1 a seguir apresenta os dados médios parciais dos furos citados, bem como os dados médios calculados para o bloco de lavra experimental.

Tabela 8.1 - Dados médios dos furos GSF 40T, 50T, 51T e 52T.

\begin{tabular}{|c|c|c|c|c|c|c|c|}
\hline Furo & espessura $(\mathrm{m})$ & $\mathrm{CaO} \%$ & $\mathrm{SiO}_{2} \%$ & $\mathrm{Al}_{2} \mathrm{O}_{3} \%$ & $\mathrm{Fe}_{2} \mathrm{O}_{3} \%$ & $\mathrm{MgO} \%$ & $\mathrm{~K}_{2} \mathrm{O} \%$ \\
\hline $40 \mathrm{~T}$ & 4,0 & 0,01 & 44,46 & 28,19 & 9,22 & 0,04 & 0,14 \\
\hline $50 \mathrm{~T}$ & 4,0 & 0,37 & 34,05 & 35,34 & 11,87 & 0,07 & 0,13 \\
\hline $51 \mathrm{~T}$ & 3,0 & 0,34 & 30,39 & 36,39 & 12,42 & 0,07 & 0,13 \\
\hline $52 \mathrm{~T}$ & 3,0 & 0,28 & 30,84 & 36,07 & 12,42 & 0,05 & 0,13 \\
\hline Médias & 3,7 & 0,24 & 35,55 & 33,68 & 11,35 & 0,06 & 0,13 \\
\hline
\end{tabular}

$\mathrm{Na}$ ocasião das análises das amostras dos furos 50T a 52T, o laboratório da FCV-1 já havia estabelecido a curva de calibração do espectrômetro de fluorescência de raios- $X$ para a laterita, realizada com base em dados de análises feitas no laboratório da $A B C P$ por via úmida.

Para a realização dos dois testes, foram lavrados cerca de 1.000 t da laterita, através dos seguintes procedimentos:

- corte dos eucaliptos, destinados à Votocel - Votorantim Celulose, também situada na cidade homônima;

- remoção do solo superficial $(0,5 \mathrm{~m})$ por trator de esteira e estocagem do mesmo para posterior recomposição do terreno;

- escavação do material através de pá carregadeira mecânica;

- carregamento e transporte em caminhões basculantes para o pátio de estocagem e secagem prévia na FCV-1. 
Como a laterita do Alvo 1 apresenta umidade média de $21,7 \%$ ao ser escavada, demanda uma secagem natural antes da utilização. Caso contrário, causaria entupimentos no britador de martelos usado na cominuição dos torrões, o mesmo utilizado para a argila da mina do Lago. Em rotina de produção, será necessário um galpão coberto para essa secagem prévia, tendo sido iniciada a sua construção imediatamente após os testes.

\subsection{SIMULAÇÕES COMPUTACIONAIS DA COMPOSIÇÃO DA FARINHA}

$\mathrm{Na}$ etapa seguinte de preparação dos testes, foram realizadas simulações computacionais da composição da farinha, conforme o método descrito em 5.8.4, com o objetivo de definir as proporção ideal de cada componente da farinha. Foram estudadas as opções possiveis de combinação dos componentes das matérias-primas, chegandose à escolha da alternativa mais adequada aos objetivos deste estudo. Os resultados das simulações são sintetizados nas Tabelas 8.2 e 8.3 .

Os teores utilizados nas simulações foram obtidos a partir de análises de controle nos materiais já extraídos. A partir desses dados, foram compostos os depósitos de metacalcário e de argila utilizados nos testes, dando um total de $15.362 \mathrm{t}$ para o Teste 1 e 15.490 t para o Teste 2, suficientes para cerca de $42 \mathrm{~h}$ de operação cada.

\subsection{TESTES DE PRODUÇÃO DE CLÍNQUER}

Os técnicos da FCV-1 julgaram os dados das simulações suficientemente confiáveis para a execução dos testes em escala piloto, realizados no segundo semestre de 1998, tendo sido os mesmos conduzidos em condições de produção, tanto em termos volumétricos de matérias-primas, como dos parâmetros operacionais do processo. Assim, a parte industrial do teste seguiu os procedimentos ilustrados no fluxograma da Figura 2.7, sem a adição dos corretivos.

As farinhas dos Testes 1 e 2 (amostras FT-01 e FT-02A) foram submetidas à identificação mineralógica por difração de raios-X (Figura 8.2), com difratogramas comparados ao da farinha sem o uso da laterita (FN-01). São observadas diferenças nas intensidades dos picos correspondentes à mica e à caulinita, provavelmente devido à heterogeneidade do material da mina do Lago, contendo quantidades variáveis de 
Tabela 8.2 - Sintese da simulação da composição da farinha para o Teste 1 de produção de clínquer (teores em \%)

\begin{tabular}{|c|c|c|c|c|c|c|c|c|c|c|c|}
\hline ROCHAS CARBONÁTICAS & Massa (t) & $\%$ & $\mathrm{CaO}$ & $\mathrm{SiO}_{2}$ & $\mathrm{Al}_{2} \mathrm{O}_{3}$ & $\mathrm{Fe}_{2} \mathrm{O}_{3}$ & $\mathrm{MgO}$ & $\mathrm{K}_{2} \mathrm{O}$ & MA & MS & FSC \\
\hline Metacalcário mina Pastinho & 9.070 & $64,36 \%$ & 49,37 & 4,80 & 0,89 & 0,69 & 1,45 & 0,34 & 1,29 & 3,04 & 330,48 \\
\hline Metacalcário Baltar subterrânea & 1.690 & $11,99 \%$ & 50,00 & 4,60 & 0,95 & 0,67 & 1,42 & 0,78 & 1,42 & 2,84 & 346,34 \\
\hline Metadolomito alto cálcio Pastinho & 2.455 & $17,42 \%$ & 30,10 & 17,20 & 1,82 & 1,25 & 15,90 & 0,26 & 1,46 & 5,60 & 58,88 \\
\hline Cálcio-silicática Baltar subterrânea & 877 & $6,22 \%$ & 9,05 & 47,50 & 5,98 & 6,20 & 2,68 & 1,00 & 0,96 & 3,90 & 6,28 \\
\hline Pré-homo rocha carbonática (A) & 14.092 & $100,00 \%$ & 43,58 & 9,04 & 1,27 & 1,05 & 3,87 & 0,33 & 1,21 & 3,91 & 158,52 \\
\hline Metas pré-homo & 14.092 & $100,00 \%$ & 43,56 & & & & $<4,00$ & $<2,00$ & 1,20 & 3,90 & $158-162$ \\
\hline ARGILA & Massa $(t)$ & $\%$ & $\mathrm{CaO}$ & $\mathrm{SiO}_{2}$ & $\mathrm{Al}_{2} \mathrm{O}_{3}$ & $\mathrm{Fe}_{2} \mathrm{O}_{3}$ & $\mathrm{MgO}$ & $\mathrm{K}_{2} \mathrm{O}$ & MA & MS & FSC \\
\hline Argila da mina do Lago & 790 & $62,20 \%$ & 0,34 & 65,40 & 15,80 & 8,35 & 0,62 & 3,21 & 1,89 & 2,71 & 0,16 \\
\hline Laterita do Alvo 1 - Faz. Ventania & 480 & $37,80 \%$ & 0,03 & 38,97 & 32,90 & 11,95 & 0,05 & 0,13 & 2,75 & 0,87 & 0,02 \\
\hline Bauxita & 0 & $0,00 \%$ & 0,00 & 15,77 & 43,15 & 9,10 & 0,00 & 0,00 & 4,74 & 0,30 & 0,00 \\
\hline Minério de ferro & 0 & $0,00 \%$ & 8,82 & 3,93 & 1,86 & 73,79 & 0,00 & 0,00 & 0,03 & 0,05 & 14,42 \\
\hline Pre-homo argila obtida (B) & 1.270 & $100,00 \%$ & 0,22 & 55,41 & 22,26 & 9,71 & 0,40 & 2,05 & 2,29 & 1,73 & 0,12 \\
\hline Limites especificados na argila & & & & $55-65$ & & & & & & & \\
\hline COMPOSIÇÃO DA FARINHA & Massa (t) & $\%$ & $\mathrm{CaO}$ & $\mathrm{SiO}_{2}$ & $\mathrm{Al}_{2} \mathrm{O}_{3}$ & $\mathrm{Fe}_{2} \mathrm{O}_{3}$ & $\mathrm{MgO}$ & $\mathrm{K}_{2} \mathrm{O}$ & MA & MS & FSC \\
\hline Metacalcário pré-homo $(\mathrm{A})$ & 14.092 & $91,73 \%$ & 43,58 & 9,04 & 1,27 & 1,05 & 3,87 & 0,33 & 1,21 & 3,91 & 158,52 \\
\hline Argila pré-homo (B) & 1.270 & $8,27 \%$ & 0,22 & 55,41 & 22,26 & 9,71 & 0,40 & 2,05 & $\frac{1,21}{2,29}$ & 1,73 & 0,12 \\
\hline Farinha obtida & 15.362 & $100,00 \%$ & 39,99 & 12,88 & 3,00 & 1,76 & 3,58 & 0,47 & 1,70 & 2,70 & 98,17 \\
\hline Limites especificados na farinha & & & & & & & $<4,00$ & $<2,00$ & $1,40-2,00$ & $2,40-3,00$ & $98-102$ \\
\hline \multicolumn{12}{|l|}{$\mathrm{MA}=\mathrm{Al}_{2} \mathrm{O}_{3} / \mathrm{Fe}_{2} \mathrm{O}_{3}$} \\
\hline \multicolumn{12}{|c|}{$\mathrm{MS}=\mathrm{SiO}_{2} /\left(\mathrm{Al}_{2} \mathrm{O}_{3}+\mathrm{Fe}_{2} \mathrm{O}_{3}\right)$} \\
\hline \multicolumn{12}{|c|}{$\mathrm{FSC}=100 \cdot \mathrm{CaO} /\left(2,8 \cdot \mathrm{SiO}_{2}+1,18 \cdot \mathrm{Al}_{2} \mathrm{O}_{3}+0,65 \cdot \mathrm{Fe}_{2} \mathrm{O}_{3}\right)$} \\
\hline
\end{tabular}


Tabela 8.3 - Sintese da simulação da composição da farinha para o Teste 2 de produção de clínquer (teores em \%)

\begin{tabular}{|c|c|c|c|c|c|c|c|c|c|c|c|}
\hline ROCHAS CARBONÁTICAS & Massa $(t)$ & $\%$ & $\mathrm{CaO}$ & $\mathrm{SiO}_{2}$ & $\mathrm{Al}_{2} \mathrm{O}_{3}$ & $\mathrm{Fe}_{2} \mathrm{O}_{3}$ & $\mathrm{MgO}$ & $\mathrm{K}_{2} \mathrm{O}$ & MA & MS & FSC \\
\hline Metacalcário mina Pastinho & 9.120 & $64,41 \%$ & 49,51 & 4,50 & 0,78 & 0,72 & 1,35 & 0,23 & 1,08 & 3,00 & 353,94 \\
\hline Metacalcário Baltar subterrânea & 1.700 & $12,01 \%$ & 50,05 & 4,30 & 0,95 & 0,67 & 1,42 & 0,19 & 1,42 & 2,65 & 368,11 \\
\hline Metadolomito alto cálcio Pastinho & 2.420 & $17,09 \%$ & 29,84 & 16,54 & 1,73 & 1,28 & 15,88 & 0,14 & 1,35 & 5,50 & 60,67 \\
\hline Cálcio-silicática Baltar subterrânea & 920 & $6,50 \%$ & 8,97 & 46,56 & 5,88 & 6,15 & 2,54 & 1,00 & 0,96 & 3,87 & 6,35 \\
\hline Pré-homo rocha carbonática $(\mathrm{A})$ & 14.160 & $100,00 \%$ & 43,58 & 8,75 & 1,18 & 1,08 & 3,75 & 0,24 & 1,09 & 3,86 & 163,83 \\
\hline Metas pré-homo & 14.092 & $100,00 \%$ & 43,56 & & & & $<4,00$ & $<2,00$ & 1,20 & 3,90 & 158-162 \\
\hline ARGILA & Massa $(t)$ & $\%$ & $\mathrm{CaO}$ & $\mathrm{SiO}_{2}$ & $\mathrm{Al}_{2} \mathrm{O}_{2}$ & $\mathrm{Fe}_{2} \mathrm{O}$ & m? & 10 & & & \\
\hline Argila da mina do Lago & 850 & $63,91 \%$ & 0,32 & 64.95 & $\frac{1400}{1400}$ & 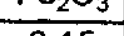 & Migu & $\mathrm{K}_{2} \mathrm{O}$ & MA & MS & FSC \\
\hline Laterita do Alvo 1 - Faz. Ventania & 480 & $36,09 \%$ & 0,02 & 37.84 & $\frac{14,98}{3265}$ & 8,15 & 0,61 & 3,12 & 1,84 & 2,81 & 0,16 \\
\hline Bauxita & 0 & $0,00 \%$ & 0,00 & $\frac{1,07}{15,77}$ & 32,65 & 11,84 & 0,05 & 0,11 & 2,76 & 0,85 & 0,01 \\
\hline Minério de ferro & 0 & $0,00 \%$ & 8,82 & & 43,15 & 9,10 & 0,00 & 0,00 & 4,74 & 0,30 & 0,00 \\
\hline Pre-homo argila obtida (B) & 1.330 & $100,00 \%$ & 0,21 & 3,93 & 1,86 & 73,79 & 0,00 & 0,00 & 0,03 & 0,05 & 14,42 \\
\hline Limites especificados na argila & & & 0,27 & $\frac{55,17}{55-65}$ & 21,36 & 9,48 & 0,41 & 2,03 & 2,25 & 1,79 & 0,11 \\
\hline & & & & & & & & & & & \\
\hline COMPOSIÇÃO DAFARINHA & Massa (t) & $\%$ & $\mathrm{CaO}$ & $\mathrm{SiO}_{2}$ & $\mathrm{Al}_{2} \mathrm{O}_{3}$ & $\mathrm{Fe}_{2} \mathrm{O}_{3}$ & $\mathrm{MgO}$ & $\mathrm{K}_{2} \mathrm{O}$ & MA & MS & FSC \\
\hline Metacalcário pré-homo $(A)$ & 14.160 & $91,41 \%$ & 43,58 & 8,75 & 1,18 & 1,08 & 3,75 & 0,24 & 1,09 & 3,86 & 163,83 \\
\hline Argila pré-homo (B) & 1.330 & $8,59 \%$ & 0,21 & 55,17 & 21,36 & 9,48 & 0,41 & 2,03 & 2,25 & 1,79 & 0,11 \\
\hline Farinha obtida & 15.490 & $100,00 \%$ & 39,86 & 12,74 & 2,92 & 1,80 & 3,46 & 0,39 & 1,62 & 2,70 & 98,97 \\
\hline Limites especificados na farinha & & & & & & & $<4,00$ & $<2,00$ & $1,40-2,00$ & $2,40-3,00$ & $98-102$ \\
\hline \multicolumn{12}{|l|}{$\mathrm{MA}=\mathrm{Al}_{2} \mathrm{O}_{3} / \mathrm{Fe}_{2} \mathrm{O}_{3}$} \\
\hline \multicolumn{12}{|l|}{$\mathrm{MS}=\mathrm{SiO}_{2} /\left(\mathrm{Al}_{2} \mathrm{O}_{3}+\mathrm{Fe}_{2} \mathrm{O}_{3}\right)$} \\
\hline \multicolumn{12}{|c|}{$\mathrm{FSC}=100 \cdot \mathrm{CaO} /\left(2,8 \cdot \mathrm{SiO}_{2}+1,18 \cdot \mathrm{Al}_{2} \mathrm{O}_{3}+0,65 \cdot \mathrm{Fe}_{2} \mathrm{O}_{3}\right)$} \\
\hline
\end{tabular}




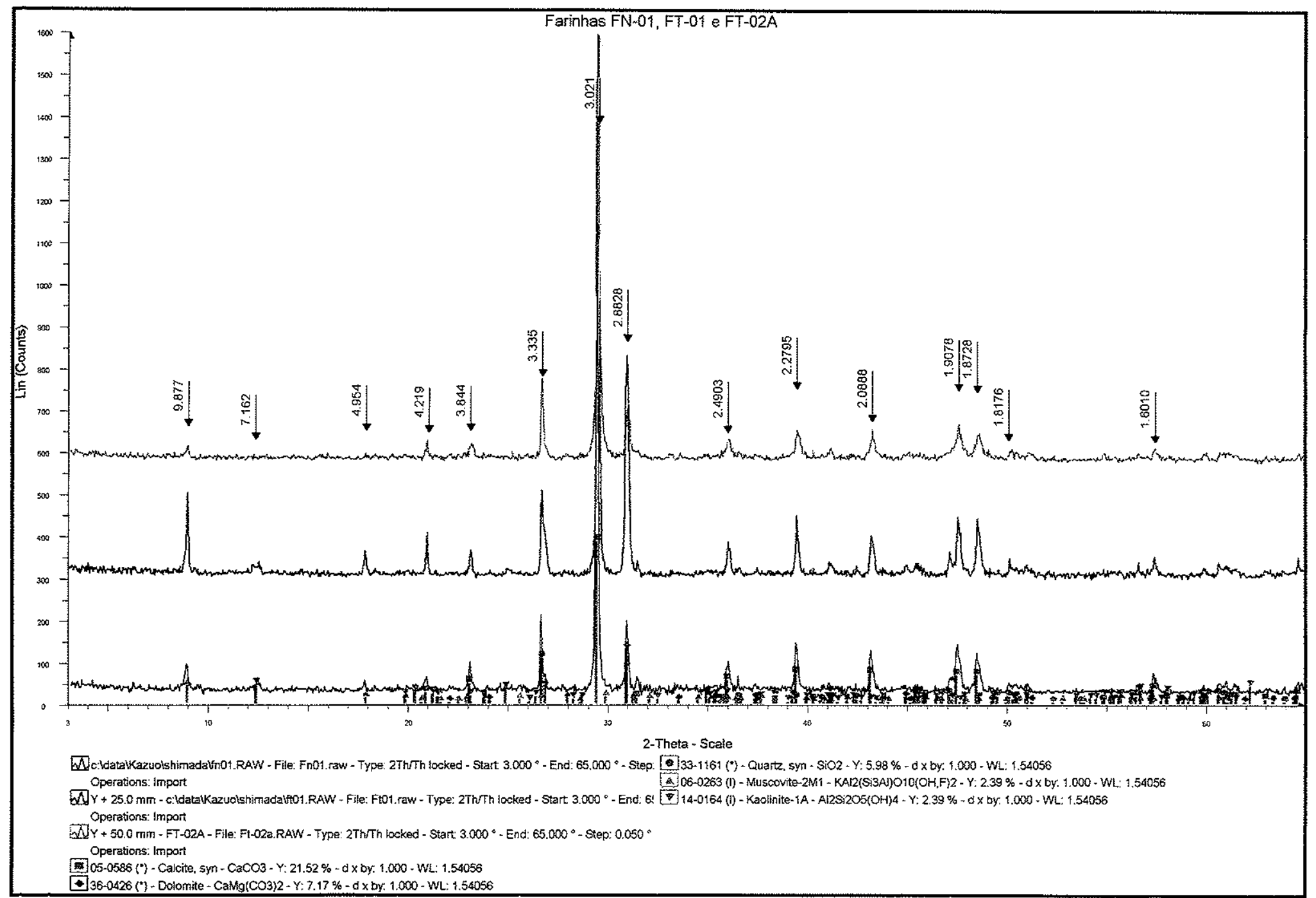

Figura 8.2 - Difratogramas de raios-X das farinhas FN-01 (normal), FT-01 e FT-02A (com a laterita do Alvo 1 - Fazenda Ventania).

Onde se lê Muscovite, leia-se Mica (variedade não precisada). 
blocos de rocha em diferentes graus de alteração, implicando em variações na sua mineralogia.

As granulometrias das farinhas normal e dos testes são bastante similares, com as partículas predominantemente no intervalo aproximado de $0,1 \mu \mathrm{m}$ a $480 \mu \mathrm{m}$. $\mathrm{O}$ Anexo 8 apresenta as curvas granulométricas instrumentais das farinhas FN-01 e FT01. As partículas acima de $480 \mu \mathrm{m}$ não foram detectadas pelo analisador Malvern, embora estivessem dentro dos limites operacionais do equipamento, possivelmente devido ao efeito pepita inerente à pequena alíquota utilizada na análise, mas, sabe-se que a retenção na malha 100 situa-se em torno de $2,7 \%$.

Durante os testes, foram feitas análises de controle da farinha e do clínquer em intervalos de $2 \mathrm{~h}$, totalizando 21 lotes de amostra para cada teste. Caso ocorressem variações nos parâmetros químicos fora das especificações, seriam realizadas pequenas correções através da adição de corretivos. Estes, não foram necessários no Teste 1, mas, no Teste 2, ocorreu e elevação do MA para 2,06 numa das alimentações, de 740 t de matéria-prima, demandando a adição de 1,38 t de minério de ferro, representando $0,3 \%$ dos $46 \mathrm{t}$ de argila participante, muito aquém dos $14,6 \mathrm{t}$ que seriam necessários sem a participação da laterita. Essa variação pode ter ocorrido em razão da pré-homogeneização insuficiente, visto que as simulações indicaram não haver necessidade de correção.

O clínquer produzido nos dois testes foi, após a aprovação da sua qualidade, foi inserido no circuito de moagem e o cimento resultante normalmente comercializado. Os resultados da avaliação dos testes são apresentados e analisados no capitulo seguinte.

As Figuras $8.3 \mathrm{~A}$ a $8.3 \mathrm{H}$ apresentam ilustrações fotográficas da lavra experimental e dos testes de produção. 


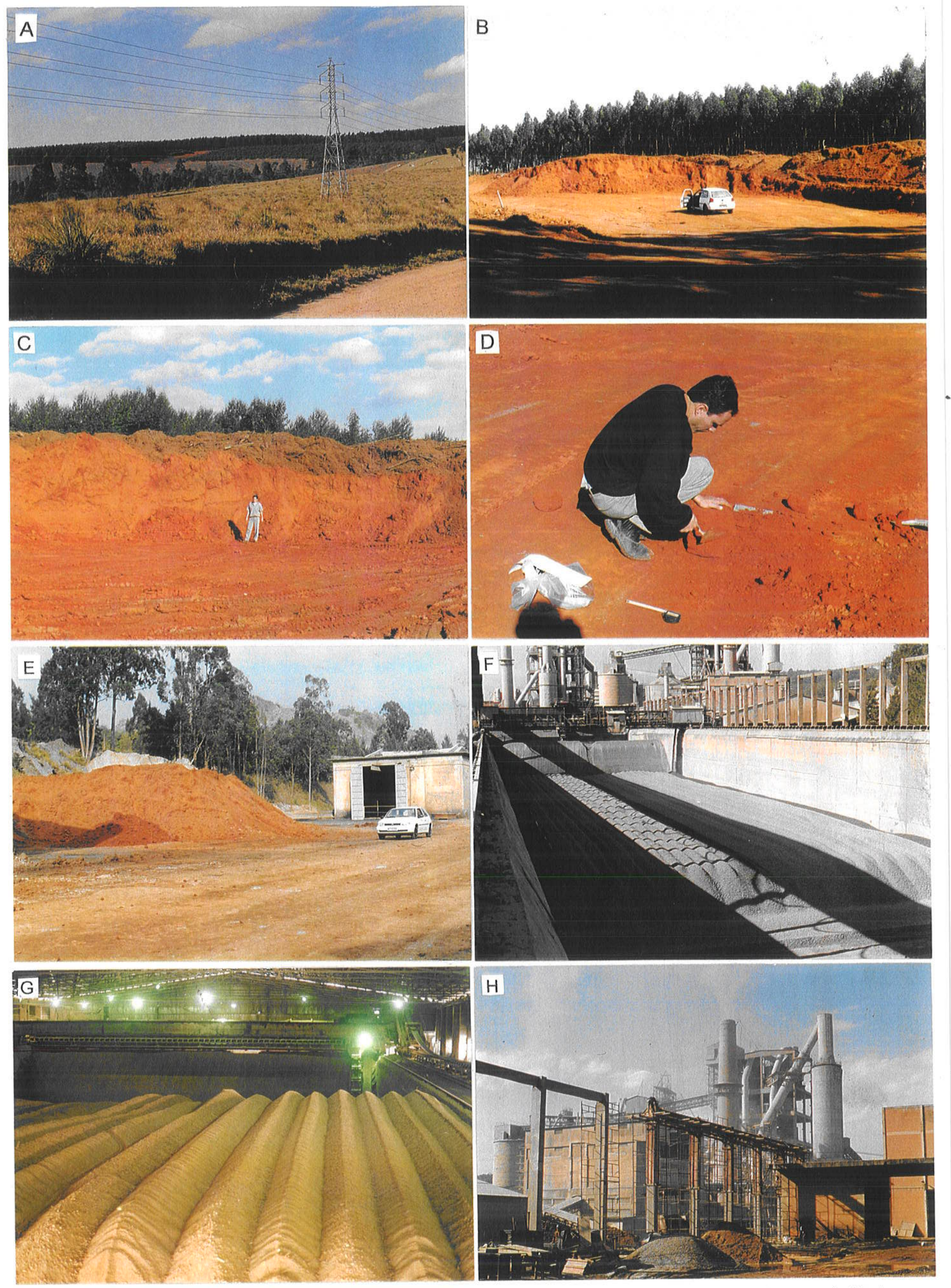

Figura 8.3 - A) Vista do local da lavra experimental no Alvo 1 - Fazenda Ventania, a partir das proximidades do ponto 21; B e C) Detalhes do local da lavra; D) Corte de blocos para determinação do peso específico; E) Depósito do material na fábrica; F e G) Pré-homogeneização de metacalcário e de argila do forno $2 ; \mathrm{H}$ ) Construção do galpão para estocagem da laterita. 


\section{CAPÍTULO 9}

\section{AVALIAÇÃO DOS RESULTADOS}

\subsection{AVALIAÇÃO TÉCNICA}

\subsubsection{Vida útil da reserva de laterita}

Considerando apenas a reserva preliminarmente calculada do Alvo 1 - Fazenda Ventania, estimando uma recuperação de $85 \%$ na lavra e considerando os níveis de consumo de matérias-primas mostrados nas simulações (Tabelas 8.2 e 8.3), pode-se fazer a seguinte projeção da vida útil da reserva:

- reserva preliminar calculada do Alvo 1: $3.669 .789 \mathrm{t}$

- reserva recuperável ( $85 \%): 3.119 .321 \mathrm{t}$

- consumo anual previsto da laterita: $100.375 \mathrm{t}$ (275 t/dia)

- vida útil da reserva: 31,07 anos

Assim, apenas o Alvo 1 encerra material suficiente para superar largamente a meta de 25 anos para vida útil da argila alternativa. As informações disponíveis sobre o depósito, de geometria lenticular e sem variações acentuadas de espessura, permitem dizer que essa perspectiva de vida útil não será grandemente alterada com os resultados da avaliação sistemática em andamento.

\subsubsection{Resultados dos testes de produção de clínquer}

Os resultados dos testes de produção, avaliados pela equipe do laboratório da FCV-1, constaram de:

- análises químicas das farinhas e dos clínqueres, realizadas em intervalos $2 \mathrm{~h}$ durante a realização dos testes;

- cálculo dos módulos MA, MS e do FSC;

- peneiramento das farinhas na malha 100;

- determinação do peso específico do clínquer (PL = peso por litro); 
- granulometria e microscopia óptica de clínquer;

- ensaios de resistência à compressão do cimento resultante a 3,7 e 28 dias, nos períodos de janeiro-maio/99 e junho-setembro/99;

- finura do cimento por peneiramento na malha 325.

Paralelamente, foram realizadas, como procedimento não rotineiro na indústria, a difratometria de raios-X e a microscopia eletrônica de varredura (MEV) dos clínqueres. A primeira prestou-se à comparação da mineralogia do clínquer produzido sem o uso da laterita com aqueles dos testes. As imagens MEV visaram o estudo morfológico tridimensional dos componentes do clínquer.

As Tabelas 9.2 e 9.3 resumem os resultados de análise química, cálculo de MA, MS e FSC, peneiramento das farinhas e determinação do $P L$, todos dentro das especificações.

A granulometria dos clínqueres obtidos nos dois testes é apresentada na Tabela 9.1 a seguir:

Tabela 9.1 - Granulometria dos clínqueres dos testes 1 e 2.

\begin{tabular}{|c|c|c|c|c|c|c|}
\hline Teste & $\begin{array}{c}\mathrm{RP} 25,0 \\
\%\end{array}$ & $\begin{array}{c}\mathrm{RP} 19,1 \\
\%\end{array}$ & $\begin{array}{c}\mathrm{RP} 9,5 \\
\%\end{array}$ & $\begin{array}{c}\mathrm{RP} 4,7 \\
\%\end{array}$ & $\begin{array}{c}\mathrm{RP} 2,4 \\
\%\end{array}$ & $\begin{array}{c}\text { Passante } \\
\text { em 2,4 mm }\end{array}$ \\
\hline 1 & 14,2 & 18,7 & 34,9 & 20,8 & 7,9 & 3,5 \\
\hline 2 & 14,5 & 18,6 & 35,2 & 20,7 & 7,2 & 3,8 \\
\hline
\end{tabular}

$R P 25,0=$ retido na malha $25,0 \mathrm{~mm}, R P 19,1=$ retido na malha $19,1 \mathrm{~cm}, \ldots$

As Figuras 9.1A a 9.1D apresentam fotomicrografias de uma amostra de clínquer fabricado sem o uso da laterita, para efeito de comparação com as fotomicrografias do clínquer do Teste 1 das Figuras 9.2A a 9D e 9.3A a 9.3D. Não foram fotografadas as seções do clínquer do Teste 2 por serem similares às do Teste 1.

Os clínqueres dos testes foram considerados de qualidade regular na avaliação microscópica, apresentando dimensões médias dos cristais de alita e belita respectivamente em torno de $29,2 \mu \mathrm{m}$ e $15 \mu \mathrm{m}$. Os últimos encontram-se dispersos ou formam zonas indefinidas com dimensão média de $210 \mu \mathrm{m}$. Os cristais de alita 
Tabela 9.2 - Síntese dos resultados analíticos e de resistência do cimento do Teste 1

\begin{tabular}{|c|c|c|c|c|c|c|c|c|c|c|c|c|c|c|}
\hline \multicolumn{15}{|c|}{ Dados médios de análise de farinha e do clínquer do forno $W 1$ (teores em \%) } \\
\hline Forno W1 & Período & $\mathrm{CaO}$ & $\mathrm{SiO}_{2}$ & $\mathrm{Al}_{2} \mathrm{O}_{3}$ & $\mathrm{Fe}_{2} \mathrm{O}_{3}$ & $\mathrm{MgO}$ & $\mathrm{SO}_{3}$ & $\mathrm{~K}_{2} \mathrm{O}$ & MA & MS & FSC & $\# 100^{\star}$ & $g / 1$ & $\%$ cal livre \\
\hline \multirow[t]{2}{*}{ Farinha } & Antes do Teste 1 & 40,88 & 12,84 & 3,18 & 1,76 & 3,22 & 0,56 & 0,69 & 1,81 & 2,60 & 100,08 & 2,70 & - & - \\
\hline & No Teste 1 & 40,29 & 12,83 & 3,18 & 1,84 & 3,53 & 0,59 & 0,72 & 1,73 & 2,56 & 98,58 & 2,76 & $\because$ & - \\
\hline \multirow[t]{2}{*}{ Clínquer } & Antes do Teste 1 & 63,01 & 20,34 & 5,01 & 2,53 & 4,96 & 1,77 & 108 & 198 & & & & & 1,36 \\
\hline & No Teste 1 & 62,70 & 20,21 & 5,07 & 2,63 & 5,41 & 2,16 & 1,07 & 1,90 & $\frac{2,10}{2,62}$ & $\frac{97,68}{97,54}$ & $\overline{-}$ & $\frac{1.160}{1.185}$ & $\frac{1,36}{0,93}$ \\
\hline \multicolumn{15}{|c|}{ Dados médios de análise de farinha e do clínquer do forno $W 2$} \\
\hline Forno W2 & Período & $\mathrm{CaO}$ & $\mathrm{SiO2}$ & $\mathrm{Al} 2 \mathrm{O3}$ & $\mathrm{Fe} 2 \mathrm{O}$ & $\mathrm{MgO}$ & $\mathrm{SO3}$ & $\mathrm{K} 2 \mathrm{O}$ & MA & MS & $\mathrm{FSC}$ & $\# 100^{*}$ & $\mathrm{~g} / \mathrm{I}$ & $\%$ cal livre \\
\hline \multirow[t]{2}{*}{ Farinha } & Antes do Teste 1 & 40,54 & 12,85 & 3,11 & 1,82 & 3,42 & 0,52 & 0,70 & 1,71 & 2,61 & 99,28 & 2,80 & $=$ & - \\
\hline & No Teste 1 & 40,71 & 12,67 & 3,07 & 1,59 & 3,51 & 0,60 & 0,65 & 1,93 & 2,72 & 101,44 & 2,57 & $=$ & - \\
\hline \multirow[t]{2}{*}{ Clínquer } & Antes do Teste 1 & 62,76 & 20,20 & 5,08 & 2,53 & 4,84 & 1,75 & 1.02 & 201 & 265 & 9776 & - & 1175 & 152 \\
\hline & No Teste 1 & 61,40 & 20,07 & 4,91 & 2,41 & 5,59 & 1,99 & 1,01 & $\frac{2,01}{2,04}$ & $\frac{2,0}{2,74}$ & $\frac{2+, 10}{96,61}$ & - & $\frac{1.110}{1.182}$ & $\frac{1,52}{1,62}$ \\
\hline \multicolumn{15}{|c|}{ - porcentagem retida na malha $100 \#$} \\
\hline \multicolumn{15}{|c|}{ Resistência mecânica do cimento antes e depois do Teste 1} \\
\hline \multirow[t]{2}{*}{ Cimento } & \multirow[t]{2}{*}{ Período } & \multicolumn{3}{|c|}{ Resistência } & Finura & & & & & & & & & \\
\hline & & 3 dias & 7 dias & 28 dias & \#325*夫 & & & & & & & & & \\
\hline \multirow[t]{2}{*}{$C P \|-E-32$} & Antes do Teste 1 & 21,97 & 27,25 & 35,07 & 14,55 & & & & & & & & & \\
\hline & No Teste 1 & 22,79 & 27,15 & 35,52 & 13,51 & & & & & & & & & \\
\hline \multirow{2}{*}{ CP II-E-40 } & Antes do Teste 1 & 3038 & 3710 & 4552 & 1.34 & & & & & & & & & \\
\hline & No Teste 1 & 30,73 & 37,64 & 45,79 & 1,04 & & & & & & & & & \\
\hline & & & Ia III & $325 \#$ & & & & & & & & & & \\
\hline
\end{tabular}


Tabela 9.3 - Sintese dos resultados analíticos e de resistência do cimento do Teste 2

\begin{tabular}{|c|c|c|c|c|c|c|c|c|c|c|c|c|c|c|}
\hline \multicolumn{15}{|c|}{ Dados médios de análise de farinha e clínquer do forno W1 (teores em \%) } \\
\hline Forno W1 & Periodo & $\mathrm{CaO}$ & $\mathrm{SiO}_{2}$ & $\mathrm{Al}_{2} \mathrm{O}_{3}$ & $\mathrm{Fe}_{2} \mathrm{O}_{3}$ & $\mathrm{MgO}$ & $\mathrm{SO}_{3}$ & $\mathrm{~K}_{2} \mathrm{O}$ & MA & MS & FSC & $\# 100^{*}$ & $g / l$ & $\%$ cal livre \\
\hline \multirow[t]{2}{*}{ Farinha } & Antes do Teste 2 & 40,88 & 12,84 & 3,18 & 1,76 & 3,22 & 0,56 & 0,69 & 1,81 & 2,60 & 100,08 & 2,70 & - & - \\
\hline & No Teste 2 & 40,55 & 12,92 & 3,01 & 1,64 & 3,47 & 0,54 & 0,69 & 1,84 & 2,78 & 99,40 & 2,76 & - & - \\
\hline \multirow[t]{2}{*}{ Clínquer } & Antes do Teste 2 & 63,01 & 20,34 & 5,01 & 2,53 & 4,96 & 1,77 & 1,08 & 1.98 & 270 & 9768 & - & 1160 & 136 \\
\hline & No Teste 2 & 62,66 & 20,42 & 4,98 & 2,50 & 5,37 & 2,05 & 1,08 & 1,99 & 2,73 & 96,88 & - & 1.186 & 1,03 \\
\hline \multicolumn{15}{|c|}{ Dados médios de análise de farinha e clínquer do forno $W 2$} \\
\hline Forno W2 & Período & $\mathrm{CaO}$ & $\mathrm{SiO} 2$ & $\mathrm{Al203}$ & Fe203 & $\mathrm{MgO}$ & $\mathrm{SO} 3$ & $\mathrm{~K} 2 \mathrm{O}$ & MA & MS & FSC & $\# 100^{\star}$ & $g / l$ & $\%$ cal livre \\
\hline \multirow[t]{2}{*}{ Farinha } & Antes do Teste 2 & 40,54 & 12,85 & 3,11 & 1,82 & 3,42 & 0,52 & 0,70 & 1,71 & 2,61 & 99,28 & 2,80 & - & - \\
\hline & No Teste 2 & 40,39 & 12,95 & 3,02 & 1,75 & 3,53 & 0,66 & 0,66 & 1,73 & 2,71 & 98,61 & 2,57 & - & - \\
\hline \multirow{2}{*}{ Clínquer } & Antes do Teste 2 & 62,76 & 20,20 & 5.08 & 253 & 484 & 175 & 102 & 201 & 265 & 9776 & & 1175 & 152 \\
\hline & No Teste 2 & 60,83 & 19,94 & 4,85 & 2,61 & 5,64 & $\frac{1,10}{2.08}$ & $\frac{1,02}{1.00}$ & $\frac{2,01}{186}$ & $\frac{2,60}{267}$ & $\frac{91,16}{96,17}$ & - & $\frac{1.1 / 5}{1191}$ & $\frac{1,52}{1,15}$ \\
\hline \multicolumn{15}{|c|}{ * - porcentagem retida na malha $100 \#$} \\
\hline \multicolumn{15}{|c|}{ Resistência mecânica do cimento antes e depois do Teste 2} \\
\hline \multirow[t]{2}{*}{ Cimento } & \multirow[t]{2}{*}{ Período } & \multicolumn{3}{|c|}{ Resistência } & Finura & & & & & & & & & \\
\hline & & 3 dias & 7 dias & 28 dias & $\# 325^{\star \star}$ & & & & & & & & & \\
\hline \multirow[t]{2}{*}{ CP II-E-32 } & Antes do Teste 2 & 21,97 & 27,25 & 35,07 & 14,55 & & & & & & & & & \\
\hline & No Teste 2 & 22,81 & 27,32 & 35,51 & 13,38 & & & & & & & & & \\
\hline \multirow{2}{*}{$C P \|-E-40$} & Antes do Teste ? & 3038 & 3712 & 4552 & 131 & & & & & & & & & \\
\hline & No Teste 2 & 30,72 & 37,58 & 45,37 & 1,61 & & & & & & & & & \\
\hline & & & & & & & & & & & & & & \\
\hline
\end{tabular}



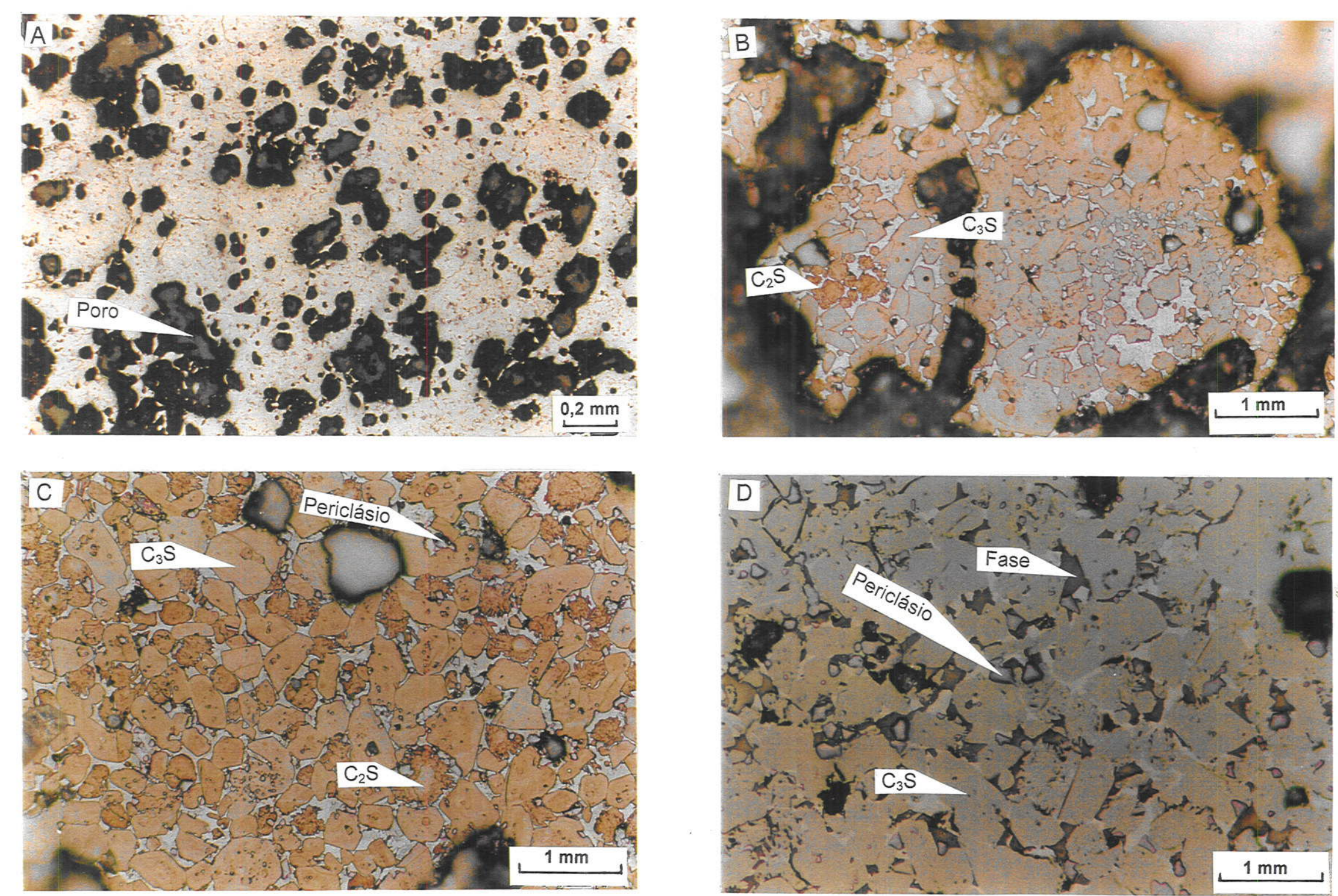

Figura 9.1 - Fotomicrografias de clínquer produzido sem o uso da laterita da Fazenda Ventania: A) Aspecto geral, mostrando a porosidade (sem ataque químico); B) Cristais de $\mathrm{C}_{3} \mathrm{~S}$ justapostos, poros e aglomerado de $\mathrm{C} 2 \mathrm{~S}$ à esquerda (ataque com $\mathrm{HNO}_{3}$ ); C) Cristais de $\mathrm{C}_{2} \mathrm{~S}$ digitados e em início de digitação, em meio a cristais de $\mathrm{C}_{3} \mathrm{~S}$ e periclásio (ataque com $\mathrm{HNO}_{3}$ ); D) Fase cristalizada, cristais de $\mathrm{C}_{3} \mathrm{~S}$ e periclásio (ataque com $\mathrm{HNO}_{3}$ ). 

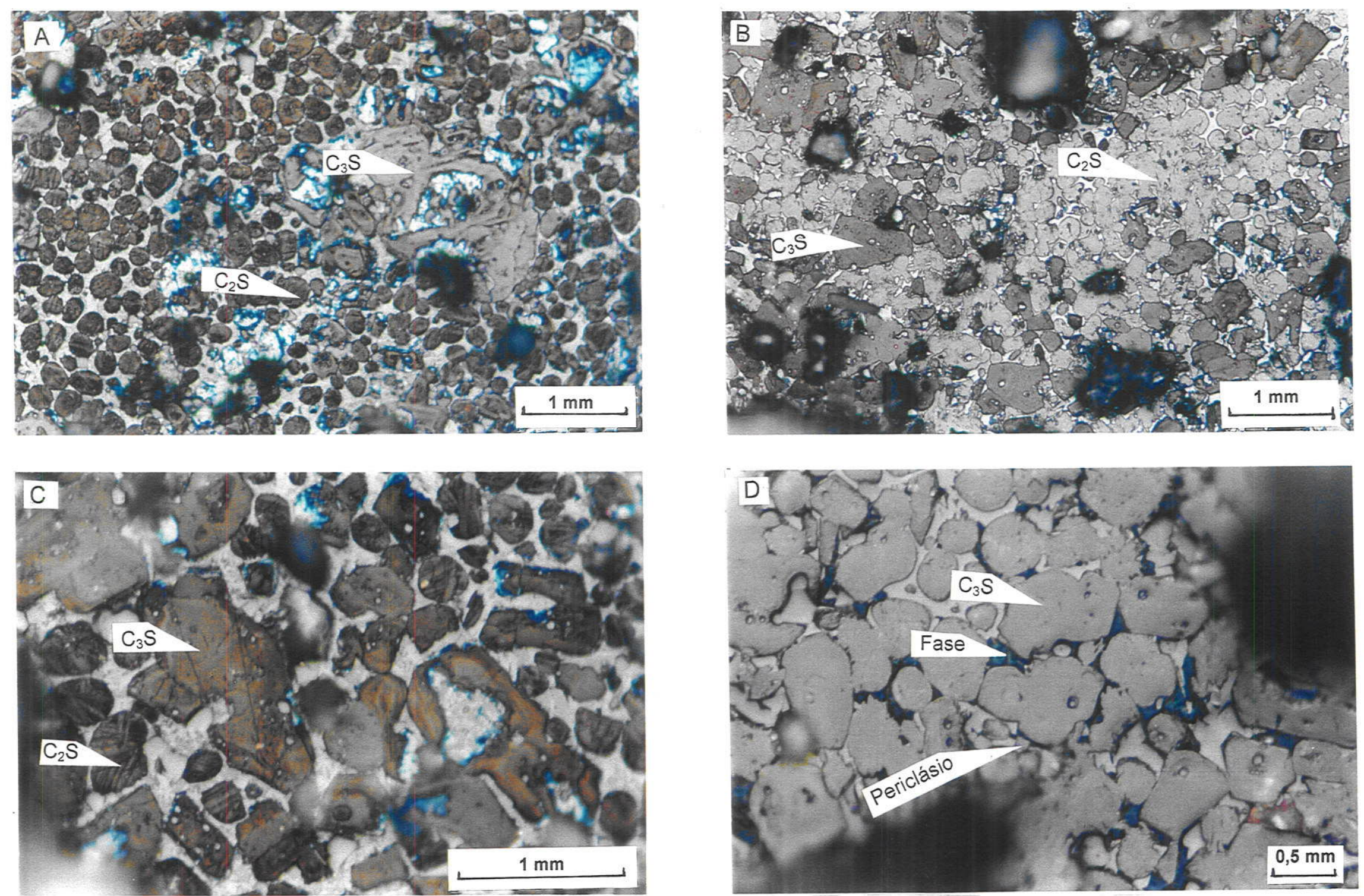

Figura 9.2 - Fotomicrografias de clínquer produzido com o uso da laterita da Fazenda Ventania: A) Cristais arredondados de $\mathrm{C}_{2} \mathrm{~S}$ e cristais de C3S corroídos (ataque c/ sílica gel + álcool etílico); B) Cristais xenomóficos de $\mathrm{C}_{2} \mathrm{~S}$ (claros) em meio a cristais de $\mathrm{C}_{3} \mathrm{~S}$ e poros (ataque com $\mathrm{HNO}_{3}+$ álcool etílico); C) Cristais de $\mathrm{C}_{3} \mathrm{~S}$ corroídos e $\mathrm{C} 2 \mathrm{~S}$ arredondados (ataque $\mathrm{c} /$ sílica gel + álcool etílico) ; D) Fase intersticial cristalizada (azul) entre cristais de $\mathrm{C}_{3} \mathrm{~S}$ e periclásio (ataque $\mathrm{C} / \mathrm{KOH}+$ sacarose). 

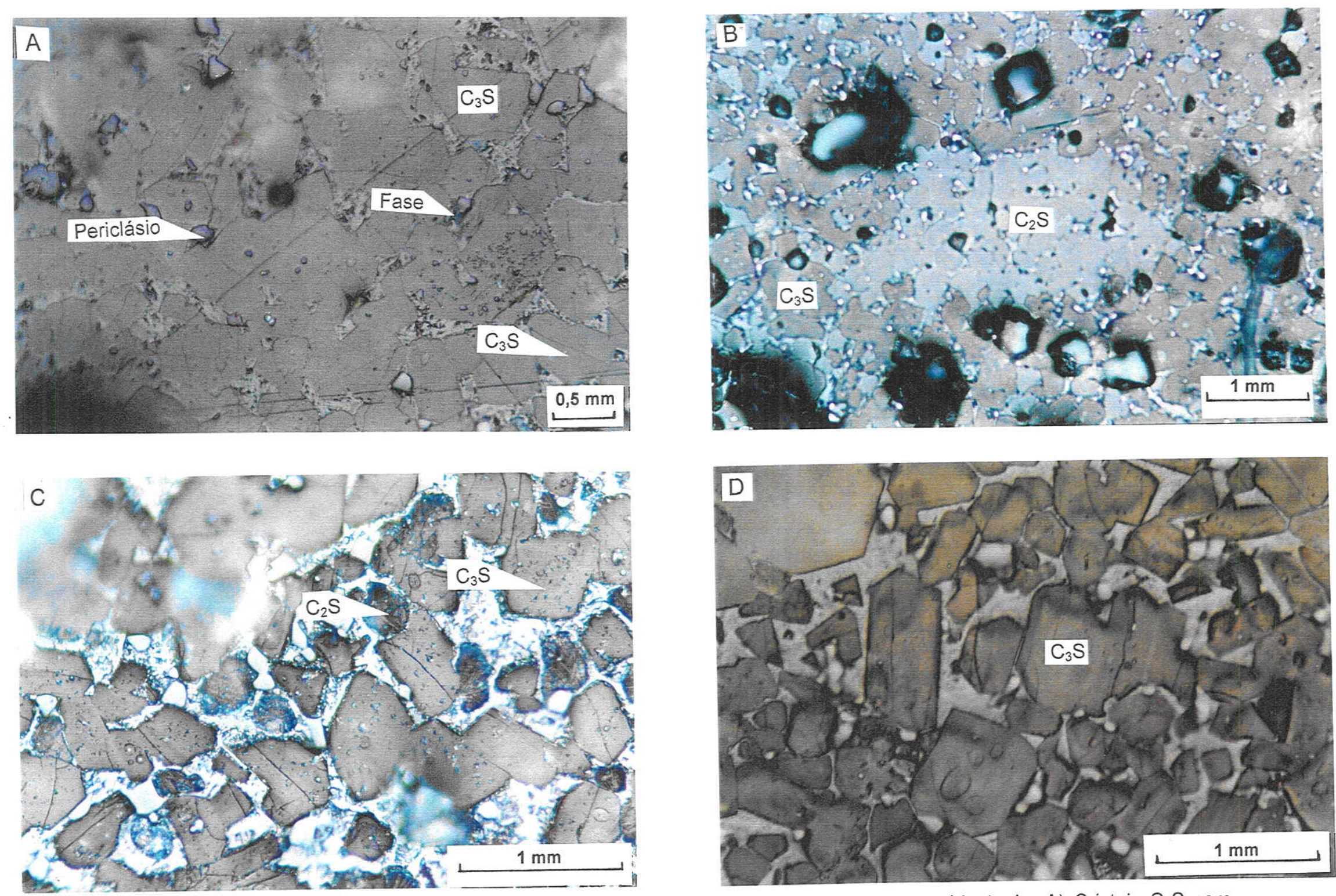

Figura 9.3 - Fotomicrografias de clínquer produzido com o uso da laterita da Fazenda Ventania: A) Cristais $\mathrm{C}_{3} \mathrm{~S}$ com inclusões de periclásio e fase intersticial (ataque $\mathrm{c} / \mathrm{KOH}+$ sacarose); $\mathrm{B}$ ) Cristais $\mathrm{C}_{2} \mathrm{~S}$ (claros) em meio cristais de $\mathrm{C}_{3} \mathrm{~S}$ e poros (ataque $\mathrm{C} / \mathrm{KOH}+$ sacarose); C) Cristais de $\mathrm{C}_{3} \mathrm{~S}$ e cristais xenomórficos de $\mathrm{C} 2 \mathrm{~S}$ (ataque $\mathrm{c} /$ sílica gel + álcool etílico); D) Cristais de $\mathrm{C}_{3} \mathrm{~S}$ (ataque $\mathrm{c} / \mathrm{HNO}_{3}$ ). 
apresentam-se subidiomórficos e pseudohexagonais, com bordas retilíneas e em início de digitação. A belita ocorre em cristais arredondados e em início de digitação. Cristais de cal livre são pouco freqüentes, apresentando dimensão média de $12 \mu \mathrm{m}$. $\mathrm{O}$ periclásio comparece disperso e freqüente, em cristais idiomórficos e pseudohexagonais, com dimensão média de $15 \mu \mathrm{m}$. A fase intersticial apresenta-se cristalizada, com $\mathrm{C}_{4} \mathrm{AF}$ em maior proporção. $\mathrm{O}$ grau de cristalização dos componentes indica resfriamento de normal a lento.

A Tabela 9.4 apresenta as porcentagens dos componentes dos clínqueres calculadas pela análise microscópica quantitativa:

Tabela 9.4 - Porcentagem dos componentes dos clínqueres calculada pela microscopia quantitativa

\begin{tabular}{|c|c|c|c|c|c|c|c|}
\hline Teste & $\mathrm{C}_{3} \mathrm{~S}$ & $\mathrm{C}_{2} \mathrm{~S}$ & $\mathrm{C}_{3} \mathrm{~A}$ & $\mathrm{C}_{4} \mathrm{AF}$ & $\mathrm{MgO}$ & Cal livre & Porosidade \\
\hline 1 & 66,0 & 15,5 & 7,6 & 5,6 & 1,9 & 3,3 & 20,5 \\
\hline 2 & 65,3 & 16,6 & 7,8 & 5,3 & 2,0 & 2,9 & 19,7 \\
\hline
\end{tabular}

As Figuras 9.4A e 9.4B apresentam imagens de MEV do clínquer do Teste 1, mostrando cristais desenvolvidos dos seus componentes. Espectros qualitativos EDS não puderam ser realizados em alguns pontos das amostras devido, na ocasião, a problemas no equipamento, motivo pelo qual os componentes desses pontos são identificados acompanhados de sinal de interrogação.

A Figura 9.5 apresenta os difratogramas de raios- $X$ dos clínqueres dos testes e, também, de um clínquer dito normal, sem o uso da laterita, onde não são observadas variações significativas na mineralogia.

Embora a resistência do cimento nos dois testes atendesse às especificações, optou-se por realizar uma avaliação mais completa, em dois períodos de 4 meses após os dois testes. O primeiro, de janeiro a maio/99, sem o uso da laterita. No segundo, de junho a setembro/99, com o uso rotineiro da laterita no processo. Os dados médios mensais obtidos para esses periodos mostram que a resistência do cimento praticamente não sofreu alterações, atendendo às especificações das normas ABNT citadas na Tabela 2.6 . 


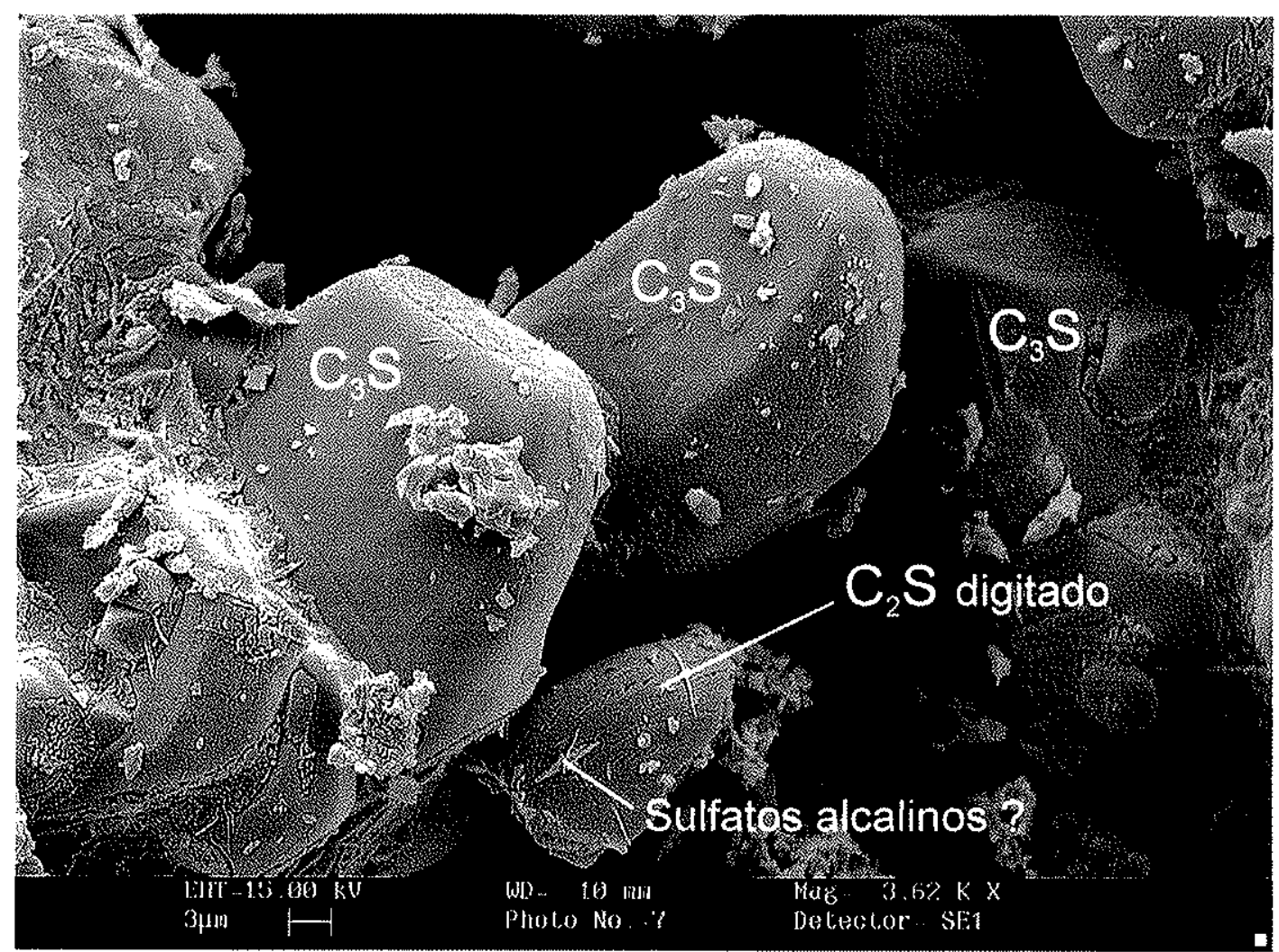

A: Imagem com elétrons secundários de cristais de $\mathrm{C}_{3} \mathrm{~S}$ e de $\mathrm{C}_{2} \mathrm{~S}$ digitado no clínquer do Teste 1.

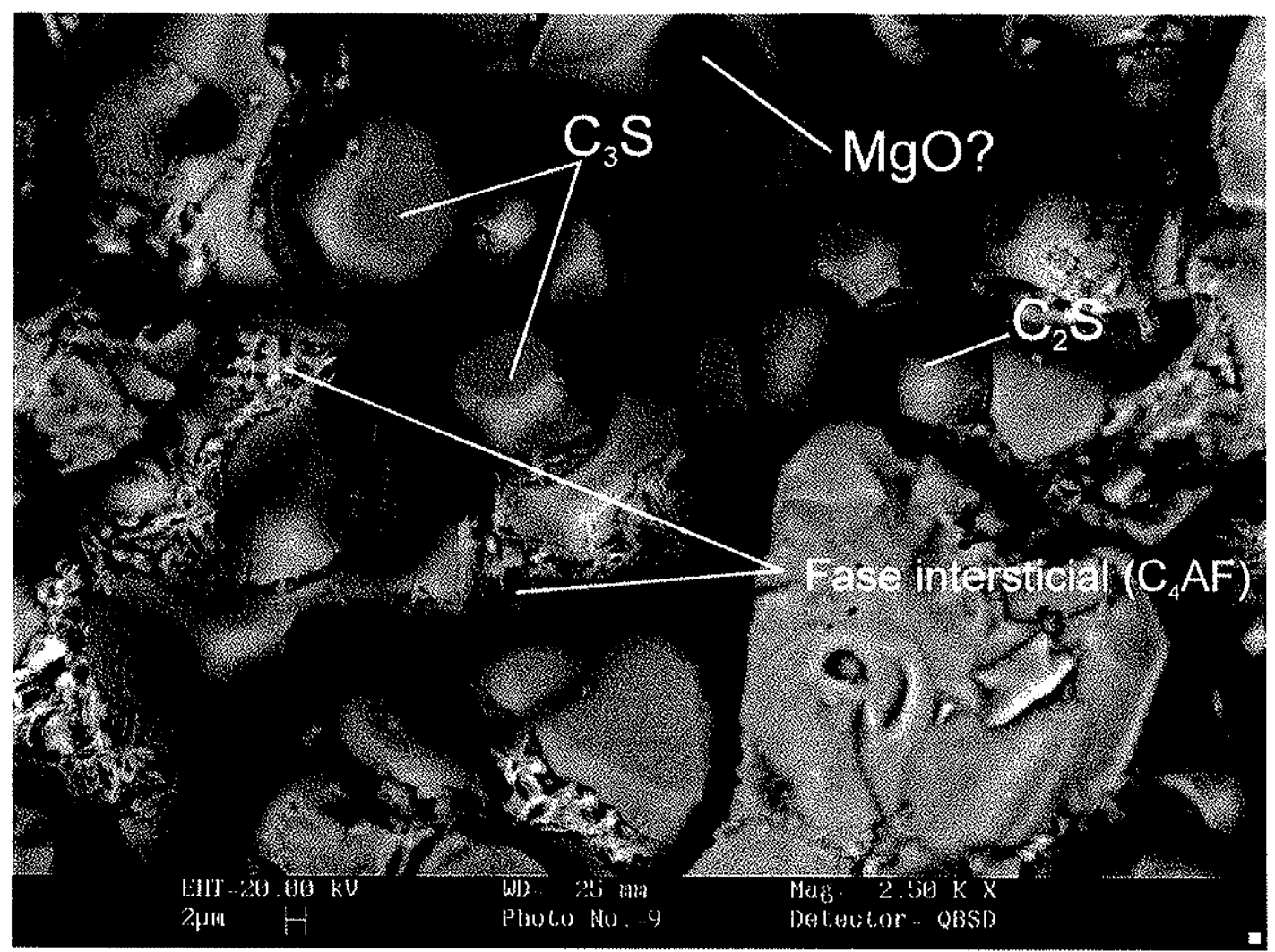

B: Imagem com elétrons retroespalhados do clínquer do Teste 1, mostrando a fase intersticial entre os cristais de $\mathrm{C}_{3} \mathrm{~S}$ (hexagonais) e $\mathrm{C}_{2} \mathrm{~S}$ (arredondados).

Figura 9.4 - Imagens de microscopia eletrônica de varredura (MEV) de amostra de clínquer do Teste 1 com o uso da laterita. 


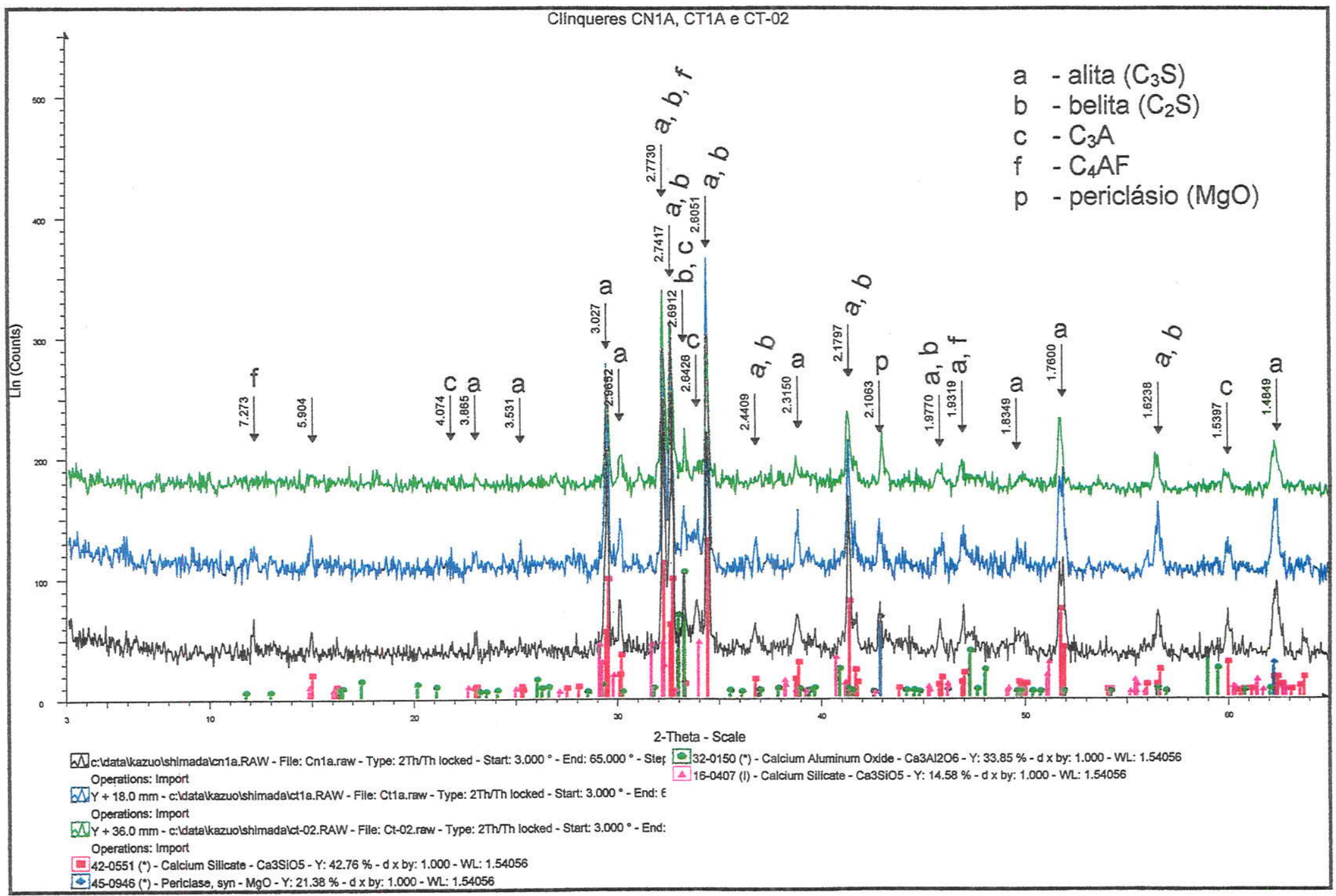

Figura 9.5 - Difratogramas dos clínqueres CN1A (normal), CT1A e CT-02 (com o uso da laterita do Alvo 1 - Fazenda Ventania). 
A tabela 9.5 apresenta as médias mensais dos resultados dos ensaios de compressão a 3, 7 e 28 dias dos cimento CP II-32 e CP II-40, e a Figura 9.6 apresenta os gráficos correspondentes.

As composições dos cimentos em termos de porcentagens de clínquer, escória e calcário aditivo (filler) não foram divulgadas pela FCV-1.

Tabela 9.5 - Resistência à compressão dos cimentos CP \|-32 e CP \|l-40 a 3, 7 e 28 dias, no periodo de janeiro - setembro/99.

\begin{tabular}{|c|c|c|c|}
\hline CP II-32 & Resistência & Resistência & Resistência \\
\hline Mês & 3 dias (Mpa) & 7 dias (Mpa) & 28 dias (Mpa) \\
\hline Jan/99 & 23,53 & 28,45 & 35,78 \\
\hline Fev/99 & 22,39 & 27,40 & 0,00 \\
\hline Mar/99 & 22,41 & 27,71 & 35,40 \\
\hline Abr/99 & 20,74 & 27,04 & 34,59 \\
\hline Mai/99 & 19,80 & 25,62 & 33,86 \\
\hline Médias & 21,77 & 27,24 & 27,93 \\
\hline Jun/99 & 22,44 & 28,05 & 35,59 \\
\hline Jul/99 & 22,49 & 28,02 & 35,91 \\
\hline Ago/99 & 22,79 & 25,59 & 36,29 \\
\hline Set/99 & 21,74 & 26,72 & 34,36 \\
\hline Médias & 22,37 & 27,10 & 35,54 \\
\hline CP $\|-40$ & Resistência & Resistência & Resistência \\
\hline Mês & 3 dias (Mpa) & 7 dias (Mpa) & 28 dias (Mpa) \\
\hline Jan/99 & 30,05 & 36,51 & 45,30 \\
\hline Fev/99 & 30,66 & 37,47 & 45,60 \\
\hline Mar/99 & 30,49 & 36,73 & 45,10 \\
\hline Abr/99 & 30,24 & 37,44 & 45,60 \\
\hline Mai/99 & 30,42 & 37,38 & 46,00 \\
\hline Médias & 30,37 & 37,11 & 45,52 \\
\hline Jun/99 & 30,89 & 37,69 & 45,70 \\
\hline Jul/99 & 30,57 & 37,45 & 45,90 \\
\hline Ago/99 & 31,01 & 38,10 & 45,60 \\
\hline Set/99 & 30,41 & 37,34 & 46,00 \\
\hline Médias & 30,72 & 37,65 & 45,80 \\
\hline
\end{tabular}

\subsubsection{Moabilidade da farinha e do clínquer}

Dados sobre o consumo energético específico, em $\mathrm{KWh} /$ tonelada, na moagem da farinha e do clínquer, permitiriam a avaliação das moabilidades da farinha e do clínquer nos dois períodos acima citados; porém, não foram divulgados pela FCV-1. 

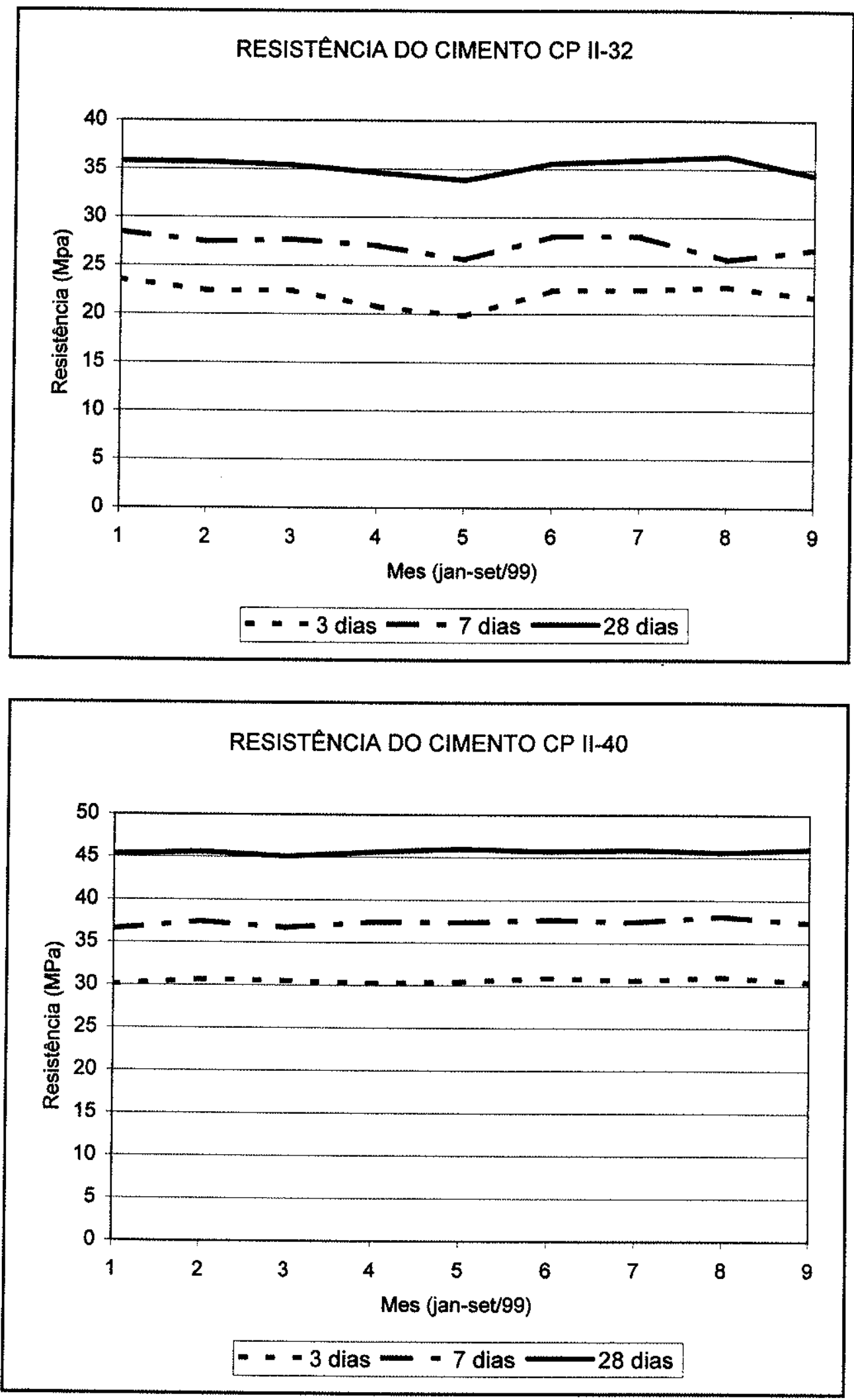

Figura 9.6 - Resistência à compressão dos cimentos CP \|-32 e CP \|-40 antes do uso da laterita do Alvo 1 - Fazenda Ventania (janeiro-maio/99) e com o uso da mesma (junho-setembro/99). 
Sabe-se apenas que não houve variação significativa nas moabilidades na comparação dos dois períodos.

\subsubsection{Consumo de metadolomito de alto cálcio da mina Pastinho e da cálcio- silicática xistosa da mina Baltar subterrânea}

Cálculos realizados a partir dos dados das simulações da farinha das Tabelas 8.2 e 8.3 mostram que a mistura dessas rochas ao metacalcário representa redução significativa nos volumes de rocha destinados aos bota-foras, bem como uma substancial economia no volume lavrado de metacalcário puro.

A mina Pastinho produziu, no período outubro/98 a outubro/99, cerca de $1.000 .000 \mathrm{t}$ de bota-fora, principalmente composto por metadolomitos $e$, secundariamente, por metarenito e filito carbonático. A tendência é de redução nesse volume com a cava se aproximando da sua configuração final.

A mina Baltar subterrânea, onde a lavra se processa dentro do corpo de metacalcário, produz uma média de $26.000 \mathrm{t}$ anuais de bota-fora, composto pelas cálcio-silicáticas maciça, bandada e xistosa. As duas primeiras não são utilizáveis na mistura com o metacalcário devido ao elevado teor de sílica sob a forma de quartzo.

As rochas potencialmente aproveitáveis são estocadas em pilhas separadas do bota-fora efetivamente estéril.

As simulações indicaram que pode haver uma participação importante do metadolomito de alto cálcio $(15,80 \%)$ e da cálcio-silicática xistosa $(5,82 \%)$ na composição da farinha. Isso representa, em termos anuais, cerca de $517.000 \mathrm{t}$ do primeiro e $183.264 \mathrm{t}$ da segunda. Como a quantidade produzida desta última não chega a esse valor, conclui-se que a mesma será consumida na totalidade, com a conseqüente elevação da participação do metadolomito para cerca de 570.000 t, o que representa cerca de $57 \%$ da massa total de bota-fora da mina Pastinho.

O filito carbonático, embora utilizável na proporção de $6,84 \%$ na farinha, combinado com $11,78 \%$ do metadolomito de alto cálcio, foi desconsiderado devido ao pequeno volume produzido e aos melhores resultados da combinação do metadolomito com a cálcio-silicática xistosa. 


\subsection{AVALIAÇÃO ECONÔMICA}

Por uma questão de sigilo industrial, a FCV-1 não autoriza a divulgação dos números absolutos sobre a redução de custos proporcionada pela substituição dos corretivos pela laterita do Alvo 1. Assim os resultados da avaliação econômica, realizada pelas equipes de mineração e de processo da FCV-1, são aqui apresentados apenas em porcentagens.

Estudos econômicos realizados para os fornos W1, W2 e W3 funcionando em plena capacidade produtiva, mostraram que a redução média no custo da matéria-prima argila com o uso da laterita em substituição aos corretivos é de $45,62 \%$. Isso representa uma redução de $1,56 \%$ no custo de produção do clínquer que, convertida em toneladas anuais de clínquer, significam cerca de $37.580 \mathrm{t}$, suficientes para a fabricação de cerca de $50.000 \mathrm{t}$ de cimento.

A porcentagem de redução acima considera ainda 0 uso de pequenas quantidades de minério de ferro na correção de eventuais desvios, como aquele citado em 8.3. Observa-se que esse corretivo pode ser substituído por certos resíduos industriais menos onerosos, como a lama de aciaria, e a FCV-1 já os aplica em seu processo. A bauxita, o corretivo mais oneroso, é integralmente substituída pela laterita do Alvo 1, que passou a ser denominado mina Ventania pela equipe da Divisão de Mineração da FCV-1.

A economia resultante da utilização do metadolomito de alto cálcio e da cálciosilicática xistosa não foi quantificada, visto que o benefício se traduz em ganhos de difícil quantificação em termos econômicos, como o ganho ambiental pela redução do volume de bota-fora e a otimização da lavra do metacalcário. 


\section{CAPÍTULO 10}

\section{CONCLUSÕES}

Os estudos realizados demonstraram, antes de tudo, a importância e o impacto da aplicação de conhecimentos geológicos fundamentais na solução de um problema industrial. Problema este enfrentado pela FCV-1 por 63 anos, desde a sua implantação em 1936. Tentativas, sem sucesso, de busca de materiais argilosos alternativos haviam sido feitas ao longo desse período; porém, restritas aos domínios dos metamorfitos do Grupo São Roque.

A abordagem metodológica, fundamentada em conhecimentos sobre a geologia regional, dos processos de alteração superficial das rochas, das técnicas de exploração mineral e do processo de fabricação do cimento Porland, utilizando métodos e materiais em grande parte simples, mostrou-se apropriada, podendo ser adaptada e aplicada em situações similares.

Destaca-se, também, a necessidade e a importância do detalhado conhecimento da geologia dos distritos mineiros onde se situam as unidades industriais, através de uma visão geológica mais ampla, não limitada aos detalhes das minas. A SAIV, ciente da importância desse conhecimento, tem desenvolvido trabalhos nesse sentido em estreita colaboração com universidades e outras instituições de pesquisa. com evidentes benefícios para as suas unidades industriais. O estudo aqui apresentado é um bom exemplo dessa colaboração.

O conjunto de dados da avaliação técnica mostrou que o depósito laterítico do Alvo 1 - Fazenda Ventania atende às especificações técnicas quanto às propriedades físicas, químicas e mineralógicas do material, bem como aos demais condicionantes apresentados em 5.3.2.

Os cimentos CP \|-32 e CP II-40, produzidos com o uso da laterita do Alvo 1 em substituição integral da bauxita e parcial do minério de ferro, têm qualidades equivalentes às dos anteriormente fabricados, mantidos constantes os parâmetros operacionais do processo. 
O cimento tipo CP || representa, segundo dados de SNIC (1998), 78,02\% do total de cimento produzido no Brasil em 1996-1997. Este fato, aliado ao aumento expressivo do consumo após 1994 que, embora em ritmo menos acelerado, mantém o crescimento, tem obrigado as indústrias do setor a pesados investimentos para a ampliação da capacidade produtiva, evidenciando a importância da redução de custos na fabricação. Devido ao alto grau de desenvolvimento tecnológico alcançado no processo de fabricação, as reduções têm sido geralmente traduzidas em porcentagens numericamente pequenas, mas, que assumem grande importância no cenário altamente competitivo do cimento. Assim, a redução mostrada na avaliação econômica pode ser considerada relevante para a FCV-1 como um todo e muito expressiva para a sua Divisão de Mineração.

Complementando a otimização do processo de fabricação, o aproveitamento do metadolomito de alto cálcio da mina Pastinho e da cálcio-silicática xistosa da mina Baltar subterrânea, misturadas aos metacalcários das duas minas, representam redução importante no volume de rocha destinado aos bota-foras de estéril, significando ganho ambiental e racionalização da utilização das reservas de metacalcário puro.

Adicionalmente, os resultados da prospecção produziram desdobramentos positivos até mesmo não relacionados à FCV-1 ou de importância futura para a mesma. O prospecto 3 - cobertura sedimentar avermelhada revelou-se potencialmente interessante para a FCV-2, em Salto de Pirapora, motivo pelo qual a sua equipe técnica já realiza um detalhamento exploratório na área. O prospecto 1 - Metabásica de Alumínio também não foi descartado pela FCV-1, que requereu autorização de pesquisa em parte de sua área, considerando o aproveitamento futuro dos seus materiais intempéricos.

Concluindo, pode-se afirmar que os objetivos do estudo aqui apresentado foram plenamente atingidos. 


\section{REFERÊNCIAS BIBLIOGRÁFICAS}

ABCP - Associação Brasileira de Cimento Portland. 1984. Curso de microscopia de clínquer de cimento portland. São Paulo, $86 \mathrm{p}$.

Amaral, G.; Bushee, J.; Cordani, U. G.; Kawashita, K.; Reynolds, J. H. 1967. Potassium-argon ages of alkaline rocks from Southern Brazil. Geochimica et Cosmochimica Acta, 31:117-142.

Annels, A. E. 1991. Mineral deposit evaluation - a practical approach. London, Chapman \& Hall. $436 \mathrm{p}$.

Bardossy, G. \& Aleva, G. J. J. 1990. Lateritic bauxites. Amsterdam, Elsevier. 624 p. (Developments in Economic Geology 27).

Beljavskis, P. 1981. Avaliação das ocorrências de bauxita na região de Nazaré Paulista. São Paulo, IPT, 78 p. (Relatório n. 15.849).

Beljavskis, P.; Juliani, C.; Uchoa, M. L. de A.; Perosa, P. T. Y.; Tanno, L. C.; Martins, F. A. 1984. Prospecção de bauxita na Serra do Itaberaba e Pedra Branca, São Paulo. Ciência da Terra, 10:20 - 24.

Bergmann, M. 1988. Caracterização estratigráfica e estrutural da seqüencia vulcanosedimentar do Grupo São Roque, região de Pirapora do Bom Jesus(SP). Instituto de Geociências, Universidade de São Paulo, São Paulo, Dissertação de Mestrado, $164 p$.

Bergmann, M. 1992. Litoestratigrafia e paleoambiente do Grupo São Roque na região do sinclinório de Pirapora (SP) - revisão. In: SBG, Congresso Brasileiro de Geologia, 37, São Paulo, Boletim de Resumos Expandidos, 1:282-283.

Bettencourt, J. S. 1972. Mapa geológico da região de Santa Helena e Salto de Pirapora (1:25.000). (Cópia heliográfica, inédita).

Bigarella, J. J. 1956. Contribuição ao estudo dos calcários do Estado do Paraná. Boletim, Instituto de Biologia e Pesquisa Tecnológica, Curitiba, n. 37, 83 p.

Birot, P. 1981. Les processus d'érosion à la surface des continents. Paris, Masson Editeurs, $607 \mathrm{p}$. 
Bjornberg, A. J. S., Gandolfi, N., Paraguassu, A. B. 1971. Basculamentos tectônicos modernos no Estado de São Paulo. In: SBG, Congresso Brasileiro de Geologia, 25, São Paulo, Anais, 2:159-174.

Bogue, R. H. 1947. The chemistry of Portland cement. New York, Reinhold Publishing. $572 p$.

Boulangé, B. \& Carvalho, A. 1997. The bauxite of Porto Trombetas. In: Carvalho, A.; Boulange, B.; Melfi, A.J.; Lucas, Y. (Eds.). Brazilian Bauxites. São Paulo, USP/ ORSTROM, p. 55-73.

Braga, M. O. 1973. Microscopia quantitativa de clínqueres e cimentos portland. Revista de Engenharia, Lisboa, 418:125-135 (Separata).

Campos Neto, M. C. 1985. Evolução do Pré-Cambriano paulista e regiões adjacentes (mesa redonda). In: SBG, Simpósio Regional de Geologia, 5, São Paulo, Atas, p. 561-586.

Campos Neto, M. C.; Bergmann, M.; Siga Jr., O.; Figueiredo, M. C. H. 1990. Geologia da Folha Pilar do Sul, 1:25.000. São Paulo, IG-USP/PRO-MINÉRIO, v.1 (Relatório).

Campy, M. \& Macaire, J. J. 1989. Géologie des formations superficielles Géodinamique - faciès - utilisation. Paris, Masson Editeurs, $433 \mathrm{p}$.

Candlot, E. 1906. Ciments et Chaux Hydrauliques. 3 ed. Paris, Librairie Polytechnique Ch. Béranger Editeur, $531 \mathrm{p}$.

Carneiro, C. D. R.; Coutinho, J. M. V.; Suemitsu, A. ; Rodrigues, E. P. 1984. Relações geométricas e temporais de eventos magmáticos no Grupo São Roque, a partir da descoberta de rochas metavulcânicas e da aplicação de critérios estruturais. In: SBG, Congresso Brasileiro de Geologia, 33, Rio de Janeiro, Anais, p. 3196-3211.

Centurione, S. L. 1993. Influência das características das matérias-primas no processo de sinterização do clínquer Portland. Instituto de Geociências, Universidade de São Paulo, São Paulo, Dissertação de Mestrado, 155 p.

Chatterjee, A. K. - 1979a - Phase composition, microstructure, quality and burning of portland cement clinkers: a review of phenomenological interrelations, part 1. London, World Cement, v. 10, n 4, p. $124-135$. 
Chatterjee, A. K. - 1979b - Phase composition, microstructure, quality and burning of portland cement clinkers: a review of phenomenological interrelations, part 2 . London, World Cement, v. 10, $n^{\circ} 5$, p. $165-73$.

Christensen, N. H. 1981. Modelling the clinker reaction. World Cement, London, 12(5): 238-247.

Cordani, U. G.; Gomes, C. B.; Girardi, V. A. V. 1963. Rochas cálcio-silicatadas da região de Perus, SP. Anais da Academia Brasileira de Ciências, 35:361-372.

Cordani, U. G.; Melcher, G. C. ; Almeida, F. F. M. 1967. Outline of Precambrian geochronology of South America. Canadian Journal of Earth Sciences, 5:629-632.

Coutinho, J. M. V. 1972 - Petrologia do Pré-Cambriano em São Paulo e arredores. Boletim Instituto de Geociências-Universidade de São Paulo, 1:5-99.

Coutinho, J. M. V. 1980. Mapa geológico da região metropolitana de São Paulo 1:100.000. São Paulo, EMPLASA.

Couto, J. G. P. 1984. Algumas considerações sobre a evolução tectônica/metalogenética dos continentes sul americano e africano no Proterozóico (formação de bacias rifteanas) e os efeitos de uma tríplice colisão cratônica na região sul do Estado de Minas Gerais e áreas adjacentes dos Estados do Rio de Janeiro e São Paulo (Brasil). In: SBG, Congresso Brasileiro de Geologia, 33, Rio de Janeiro, Anais, 2:3044-3055.

CPRM - Companhia de Pesquisa de Recursos Minerais 1972. Projeto calcário para cimento - relatório final. São Paulo, CPRM, v.1.

CPRM - Companhia de Pesquisa de Recursos Minerais. 1998. Mapa Geológico da Folha de São Paulo - 1:250.000.

Duda, W. H. (1985). Cement data book - v. 1: International process engineering in the cement industry. Berlim, Wiesbaden, Bauerverlag Gmbh., $636 \mathrm{p}$.

Dunhan, R. J. 1962. Classification of carbonate rocks according to depositional texture. Memoir, American Association of Petroleum Geologists, 1:108-121.

Felissíssimo Junior, J. 1967. Carbonatitos do Estado de São Paulo. Anais da Academia Brasileira de Ciências. Suplemento, 40:93-115. 
Ferrari, J. A. 1996. Deriva continental e sucessão paleoclimática: simulação da evolução das paisagens lateriticas da América do Sul e da África. Instituto Astronômico e Geofísico, Universidade de São Paulo, São Paulo, Tese de Doutoramento, 111p.

Figueiredo, M. C. H.; Bergmann, M.; Penalva, F. e Tassinari, C. C. G. 1982. Ocorrência de pillow-lavas no Grupo São Roque, Estado de São Paulo. Ciências da Terra, 2:68.

Formoso, M.; Dani, N; Valeton, I. 1997. The bauxite of Lages District. In: Carvalho, A.; Boulangé, B.; Melfi, A.J.; Lucas,Y. (Eds.). Brazilian Bauxites. São Paulo, USP/ ORSTROM. p. $273-308$.

Franco, R. R. 1958. Contribuição ao conhecimento das rochas termometamórficas da Série São Roque. Boletim da Faculdade de Filosofia, Ciências e Letras. Universidade de São Paulo. Série Mineralogia, 189:1-81.

Frascá, M. H. B. de O. 1992. Petrografia e geoquímica de rochas carbonáticas précambrianas do Estado de São Paulo. Instituto de Geociências, Universidade de São Paulo, São Paulo, Dissertação de Mestrado, 168p.

Fúlfaro, V. J. \& Suguio, K. 1974. O Cenozóico paulista: gênese e idade. In: SBG, Congresso Brasileiro de Geologia, 28, Porto Alegre, Anais, 3:91-101.

Godoy, A. M. 1989. Caracterização faciológica, petrográfica e geoquímica dos maciços Sorocaba e São Francisco - SP. Instituto de Geociências, Universidade de São Paulo, São Paulo, Tese de Doutoramento, 220p.

Gomà, F. 1979. El cemento portland y otros aglomerantes. Barcelona, Editores Técnicos Asociados, $487 \mathrm{p}$.

Gomes, J. F. C. 1956. Jazida de bauxita de Curututu, SP. Revista da Escola de Minas, Universidade Federal, Ouro Preto, 20(2):47 - 157.

Goraieb, C. L.; Almeida, A. dos S.; Cuchierato, G. 1998. Novos depósitos bauxíticos associados a rochas graníticas no sul de Minas Gerais. In: SBG, Congresso Brasileiro de Geologia, 40, Belo Horizonte, Anais, p. 153. 
Gouda, G. R. 1978. Influence des matières premières de cimenterie sur la consommation de combustibles. Ciments, Bétons, Plâtres, Chaux. Paris, 712:151154.

Grubb, P. L. C. 1983. Weathering and leaching patterns associated with some gibbsitic soils in Southern Africa. in: Augustitis, S.S. (Ed.). Leaching and diffusion in rocks and their weathering products. Atenas, Theophrastus Publications, $562 \mathrm{p}$.

Hackspacher, P. C.; Morales, N.; Zanardo, A.; Godoy, A. M.; Oliveira, M. A. F.; Arthur, A. C. 1992a. A tectônica transcorrente - transpressiva brasiliana da Folha São Roque(SP). In: SBG, Congresso Brasileiro de Geologia, 37, São Paulo, Boletim de Resumos Expandidos, 2:348-349.

Hackspacher, P. C.; Godoy, A. M.; Oliveira, M. A. F. 1992b. Geologia da Folha Pirapora (SP), 1:25.000. In: SBG, Congresso Brasileiro de Geologia, 37, São Paulo, Boletim de Resumos Expandidos, 2:127-128.

Hackspacher, P. C.; Oliveira, M. A.; Godoy, A. M. 1992c. Geologia dos Grupos Serra de Itaberaba e São Roque na Folha Cabreúva, SP, 1:50.000. In: SBG, Congresso Brasileiro de Geologia, 37, São Paulo, Boletim de Resumos Expandidos, 2:124-125.

Hackspacher, P. C. 1994. Tectônica transtensiva/transpressiva e alojamento de rochas plutônicas, a exemplo da Folha Cabreúva (SP) 1:50.000. Instituto de Geociências e Ciências Exatas - UNESP, Rio Claro, Tese de Livre-Docência, 203 p.

Hasui, Y. ; Penalva F.; Hennies, W. T. 1969. Geologia do Grupo São Roque. In: SBG, Congresso Brasileiro de Geologia, 23, Salvador, Anais, p. 101-134.

Hasui, Y. \& Hama, M. 1972. Geocronologia do Grupo São Roque pelo método potássio - argônio. Revista Brasileira de Geociências, 2:18-24.

Hasui, Y. \& Oliveira, M. A. F. 1984. Província Mantiqueira - Setor Central. In: Almeida, F.F.M. de \& Hasui, Y. (coords.). O Pré-Cambriano do Brasil. São Paulo, Edgard Blücher, p. $308-344$.

Hasui, Y. \& Sadowski, G. R. 1976. Evolução geológica do pré-cambriano na região sudeste do Estado de São Paulo. Revista Brasileira de Geociências, 6:(3):180-200. 
Hasui, Y.; Almeida, F. F. M. de; Neves, B. B. de B. 1978. As estruturas Brasilianas. In: SBG, Congresso Brasileiro de Geologia, 30, Recife, Anais, 6:2423-2437.

Hasui, Y.; Carneiro, C. D. R.; Bistrichi, C. A. 1980. Estruturas e Tectônica do PréCambriano de São Paulo e Paraná. Anais da Academia Brasileira de Ciências, 52(1):61-76.

Hasui, Y.; Dantas, A. S. L.; Carneiro, C. D. R.; Bistrichi C. A. 1981. O Embasamento Pré-Cambriano e Eopaleozóico em São Paulo. In: Mapa Geológico do Estado de São Paulo - texto explicativo. São Paulo, IPT/PRO-MINÉRIO, 1:12-45.

Hennies, W. T.; Hasui, Y.; Penalva, F. 1967. O falhamento transcorrente de Taxaquara. In: SBG, Congresso Brasileiro de Geologia, 21, Curitiba, Anais, p. 159-168.

Hernalsteens, C. M. de O. \& Lapa, R. P. 1988. Bauxita de Porto Trombetas, Oriximiná, Pará. In: Schobbenhaus,C. \& Coelho, C.E.S. (Coords.). Principais depósitos minerais do Brasil, v. 3, metais básicos não ferrosos, ouro e alumínio. Brasilia, Departamento Nacional da Produção Mineral - Companhia Vale do Rio Doce, p. $621-639$.

IG - SMA - Instituto Geológico - Secretaria do Meio Ambiente. 1990a. Mapeamento geológico da Folha Salto de Pirapora (SP), Escala 1:50.000. São Paulo, 76p. (Relatório Técnico).

IG - SMA - Instituto Geológico - Secretaria do Meio Ambiente. 1990b. Subsídios do meio físico-geológico ao planejamento do município de Sorocaba (SP). São Paulo, 2 v. (Relatório Técnico).

Johansen, V. 1977. Cocción de clínquer de cemento Portland em hornos rotatórios. Materiales de Construction, Madrid, 166-167: 85-101.

Juliani, C. 1993. Geologia, petrogênese e aspectos metalogenéticos dos Grupos Serra do Itaberaba e São Roque na região das Serras do Itaberaba e da Pedra Branca, NE da cidade São Paulo, SP. Instituto de Geociências, Universidade de São Paulo, São Paulo, Tese de Doutoramento, 803 p.

Juliani, C. \& Beljavskis, P. 1995. Revisão litoestratigráfica da faixa São Roque/Serra do Itaberaba (SP). Revista do Instituto Geológico, São Paulo, 16(1/2):33-58. 
Kihara, Y. 1973. Estudo mineralógico de clínquer de cimento Portland. Instituto de Geociências, Universidade de São Paulo, São Paulo, Dissertação de Mestrado 72 p.

Kihara, Y. \& Valarelli, J. V. 1975. Estudo de clínqueres de cimento Portland brasileiros por microscopia óptica. Revista Brasileira de Tecnologia, 6:207-16.

Kihara, Y; Battagin, A. F.; Marciano Jr., E.; Shuzukawa, J.K. 1983. Aptidão à clinquerização de farinhas de cimento; fator de controle e qualidade do cimento. São Paulo, ABCP (ET-48).

Kihara, Y.; Battagin, A. F.; Zampieri, V. A.; Centurione, S. L.; Pecchio, M. 1990. A microscopia do clínquer portland e seus benefícios tecnológicos. In: ABCP, Congresso Brasileiro de Cimento, 2, São Paulo, Anais, 1:241-264.

King, L. E. 1956. A geomorfologia do Brasil Central. Revista Brasileira de Geografia, 18(2): $147-265$.

Knecht, T. 1943a. Estaurolita da Série São Roque. O IGG, São Paulo, 1(2):165-168.

Knecht, T. 1943b. Notícia sobre a gênese de algumas ocorrências de bauxita no Município de Mogi das Cruzes. Revista do Instituto Geográfico e Geológico, São Paulo, 1(1):32-39.

Knecht, T. 1944. Sillimanita no km 20 da Via Anhanguera. O IGG, São Paulo, 2(2):129132.

Knecht, T. 1950. Ocorrências minerais do Estado de São Paulo. São Paulo, Instituto Geográfico e Geológico, $144 \mathrm{p}$.

Knecht, T. 1960. Notas preliminares sobre novas ocorrências de rochas alcalinas no Estado de São Paulo. Boletim da Sociedade Brasileira de Geologia, 9(1):71 - 76.

Krauskopf, K. B. 1972. Introdução à geoquímica. São Paulo, Poligono/EDUSP. $2 v$.

Lea, F. M. 1970. The chemistry of cement and concrete. 3 ed. Glasgow, Edward Arnold, $726 \mathrm{p}$. 
Long, G. R. 1982. Clinker quality characterization by reflected light techniques. In: International Cement Microscopy Association, International Conference on Cement Microscopy, 14, Nevada, Proceedings, p. 92-109.

Magalhães, F. S. et al. 1995. Levantamento geológico-estrutural e geotécnico do maciço rochoso da mina de Salto (Salto de Pirapora, SP). Escola de Engenharia de São Carlos, Universidade de São Paulo (Relatório da Disciplina SGS 812 Levantamento Geológico-Geotécnico de Maciços Rochosos).

McFarlane, M. J. 1976. Laterite and landscape. London, Academic Press. 151 p.

Melfi, A. J. 1993. Geoquímica de superfície. Instituto de Geociências, Universidade de São Paulo, São Paulo (Resumo de curso de pós - graduação).

Melfi, A. J. 1994. Lateritas e processos de lateritização. São Paulo, Escola de Engenharia de São Carlos/Universidade de São Paulo, Departamento de Geotecnia. (Transcrição de aula inaugural).

Melfi, A. J. 1997. Brazilian bauxite deposits: a review. In: Carvalho, A.; Boulangé, B.; Melfi, A.J. ; Lucas, Y. (Eds.). Brazilian Bauxites. São Paulo, USP/ORSTROM. p. 3 $-22$.

Melfi, A. J.; Trescases, J. J.; Carvalho, A.; Oliveira, S. M. B; Ribeiro Filho, E.; Formoso, M.L.L. 1988. The lateritic ore deposits of Brasil. Science Géologique, Bulletin, 41(1):5-36.

Melo, M. S. de \& Ponçano, W. L. 1983. Gênese, distribuição e estratigrafia dos depósitos cenozóicos no Estado de São Paulo. Monografias IPT, 9:1-74.

Melo, M. S. de. 1995. A formação Rio Claro e depósitos associados: sedimentação neocenozóica na depressão periférica paulista. Instituto de Geociências, Universidade de São Paulo, São Paulo, Tese de Doutoramento, 144 p.

Miller, F. M. (1981). Microscopy as an aid in evaluation of mix burnability and clinker formation. Ciments, Bétons, Plastres, Chaux. Paris, 731:213 - 218.

Nahon, D. B. 1991. Introduction to the petrology of soils and chemical weathering. New York, John Wiley \& Sons. $313 \mathrm{p}$. 
Oliveira, M. A. F.; Zanardo, A.; Arthur, A. C.; Godoy, A. M.; Andrade, F. R. M. D.; Negri, F. de A.; Morales, N.; Machado, P. R.; Hackspacher, P. C.; Galembeck, T. M. B. 1991. Mapa geológico em 1:50.000 da folha São Roque. Instituto de Geociências e Ciências Exatas - UNESP (Rio Claro) - Secretaria da Ciência, Tecnologia e Desenvolvimento Econômico (Pró-Minério).

Oliveira, M. A. F.; Godoy, A. M.; Zanardo, A.; Arthur, A. C.; Hackspacher, P. C.; Morales, N. 1992. Geologia da Folha São Roque (SP). In: SBG, Congresso Brasileiro de Geologia, 37, São Paulo, Boletim de Resumos Expandidos, 2:26-127.

Oliveira, S. M. B. \& Toledo, M. C. M. de. 1997. The bauxite of Nazare Paulista and associated deposits. In: A. Carvalho, A.; Boulangé,B.; Melfi, A.J. \& Lucas,Y. (Eds.). Brazilian Bauxites. São Paulo, USP/ORSTROM, p. 209-224.

Pedro, G. 1964. Contribution à l'étude experimentale de l'altération géochimique des roches cristallines. Institut National de la Recherche Agronomique, Paris, Thèse, $345 \mathrm{p}$.

Pedro, G. 1969. A alteração das rochas em condições superficiais (perimorfismo) caracterização dos processos fundamentais. Noticia Geomorfológica, Campinas, 9(17):3 -14 (Tradução de A. J. Melfi).

Pedro, G, \& Melfi, A. J. 1983. The superficial alteration in tropical region and the lateritisation phenomena. In: IGCP-129/IAGC, International Seminar on Lateritization Processes, 2, São Paulo, Proceedings, IAG-USP, p. 3-13.

Petri, S. \& Fúlfaro, V. J. 1983. Geologia do Brasil (Fanerozóico). São Paulo, Ed. T. A. Queiroz /EDUSP, $631 \mathrm{p}$.

Pliskin, L. 1993. La fabrication du ciment. Paris, Ciments Français/ Editions Eyrolles, $213 p$.

Popoff, C. C. 1966. Computing reserves of mineral deposits: principles and conventional methods. Washington, Bureau of Mines. 113 p. (I.C. 8283).

Ratti, G. 1994. Análises químicas na engenharia mineral. Escola Politécnica, Universidade de São Paulo, São Paulo, Tese de Doutoramento, 83 p. 
Ross, J. L. S. \& Moroz, I. C. - 1997 - Mapa geomorfológico do Estado de São Paulo. Laboratório de Geomorfologia, Depto. de Geografia FFCLH-USP/Laboratório de Cartografia Geotécnica - Geologia Aplicada-IPT/FAPESP - Fundação de Amparo à Pesquisa de São Paulo. v. 1 (Relatório) e v. 2 (mapa).

Samama, J. C. 1986. Ore fields and continental weathering. New York, Hutchinson Ross, $326 \mathrm{p}$.

Santos, P. de S. 1992. Ciência e tecnologia de argilas. São Paulo, Edgard Blücher, 3v.

Schellmann, W. 1981. Considerations on the definition and classification of laterites. In: IGCP-129/IAGC, International Seminar on Lateritization Processes, Trivandrum, 1979, Proceedings, Balkema, Rotterdam, p. 1-10.

Schellmann, W. 1983. A new definition of laterite. Natural Resources and Development, 18:7-21. Tubingen.

Schwertmann, U. 1983. The role of aluminium in iron oxide systems. In: IGCP129/IAGC, Intemational Seminar on Lateritization Processes, 2, São Paulo, Proceedings, IAG-USP, p. 65-68.

Setzer, J. 1960. Identificação de sills de diabásio decompostos. Boletim da Sociedade Brasileira de Geologia, 9:(1):63 - 70.

SFIC - Syndicat Français de I'Industrie Cimentière. 1998. Rapport Exercice 1997. Paris, Paris, SFIC, $25 \mathrm{p}$.

Shimada, H. 1983. Contribution à l'étude des gisements latéritiques d'or du Brésil. Nancy, Ecole Nationale Supérieure de Géologie Appliquée et de la Prospection Minière, 36 p. (Mémoire de stage).

Sígolo, J. B. 1979. Geologia dos depósitos residuais bauxíticos de Lavrinhas, SP e sua viabilidade econômica. Instituto de Geociências, Universidade de São, Paulo São Paulo, Dissertação de Mestrado, $190 \mathrm{p}$.

Sígolo, J. B. 1988. As formações bauxíticas do Maciço Alcalino de Passa Quatro, MG: sua evolução micromorfológica, geoquímica e as implicações do relevo. Instituto de Geociências, Universidade de São Paulo, São Paulo, São Paulo, Tese de Doutoramento, 208p. 
Sígolo, J. B. \& Boulangé, B. 1997. The bauxites of the Passa Quatro alkaline massif. In: Carvalho, A.; Boulangé, B.; Melfi, A.J. \& Lucas, Y. (Eds.). Brazilian Bauxites. São Paulo, USP/ORSTROM, p. $255-272$.

Silva, M. L. M. C. E. \& Oliveira, S. M. B. de. 1989. Ferruginous bauxite from Nazaré Paulista: geochemical evolution. Académie Yugoslave des Sciences et des Arts, Travaux Comité International pour l'Etude des Bauxites, de l'Alumine et de l'Aluminium, Zagreb, 19(22):147 - 158.

Silva, P. C. F. da. 1997. Ambientes de sedimentação e tectônica do Grupo São Roque na região entre Pilar do Sul e Votorantim, SP. Instituto de Geociências, Universidade de São, Paulo São Paulo, Dissertação de Mestrado, 127p.

SNIC - Sindicato Nacional da Indústria do Cimento. 1998. Sindicato Nacional da Indústria do Cimento - 45 anos - 1953-1998. Rio de Janeiro, 78 p.

Soares, P. C. 1988. Tectônica colisional em torno de Bloco Paraná, Brasil. In: SBG, Congresso Brasileiro de Geologia, 35/Congresso Latino - Americano de Geologia, 7, Belém, Anais, 1:63-79.

Souza, S. C. A. de. 1997. Anfibolitos ortoderivados do Complexo Itapira e do Bloco São Roque nas folhas: Cabreúva, Sorocaba, Itu e São Roque (SP). Petrografia, litoquímica, química mineral e termobarometria. Instituto de Geociências e Ciências Exatas da Universidade Estadual de São Paulo, Rio Claro, Dissertação de Mestrado, 137p.

Suguio, K. 1973. Introdução à Sedimentologia. São Paulo, Edgard Blücher/ EDUSP. $317 p$.

Tardy, Y. 1986. Le cycle de l'eau. Paris, Masson, 338 p.

Tardy, Y. 1992. Diversity end terminology of lateritic profiles. In: Martini, I.P. \& Chesworth, W. (Eds.). Weathering, soils \& paleosols. Amsterdam, Elsevier, 618 p. (Developments in Earth Surface Processes 2).

Tardy, Y. 1993. Pétrologie des latérites et des sols tropicaux. Paris, Masson, 256 p. 
Tardy, Y.; Kobilsek, B.; Paquet, H. 1991. Mineralogical composition and geographical destribution of African and Brazilian periatlantic laterites - the influence of continental drift and tropical paleoclimates during past 150 million years and implications for India and Australia. Joumal of African Earth Sciences, 12(1/2):283 -295.

Tardy, Y. \& Roquin, C. 1992. Geochemistry and evolution of lateritic landscapes. In: Martini, I.P. \& Chesworth, W. (Eds.). Weathering, soils \& paleosols. Amsterdam, Elsevier, 618 p. (Developments in Earth Surface Processes 2).

Tassinari, C. C. G.; Kawashita, K. e Kikuchi, R. K. P. de. 1985. Estudo geocronológico nos metaconglomerados do Grupo São Roque, SP. In: SBG, Simpósio Regional de Geologia, 5, São Paulo, Atas, 1:201-208.

Tavares, R. 1997. O clima local de Sorocaba. Instituto de Geografia, Universidade de São Paulo, São Paulo, Dissertação de Mestrado, 205 p.

Taylor, H. F. W. 1997. Cement chemistry. London, Thomas Tilford, $459 \mathrm{p}$.

Theisen, K. 1992. The influence of raw mix bumability on cement clinker. World Cement, London, 23(8):17-23.

Thomas, M. F. 1994. Geomorphology in the tropics - a study of weathering and denudation in low latitudes. Chichester, John Wiley, $460 \mathrm{p}$.

Toledo-Groke, M. C. de. 1981. Evolução geoquímica, mineralógica e micromorfológica no processo de bauxitização: estudo comparativo dos depósitos de Mogi das Cruzes, Curucutu e Lavrinhas, SP, associados a diferentes tipos litológicos. Instituto de Geociências, Universidade de São, Paulo São Paulo, Dissertação de Mestrado, $106 \mathrm{p}$.

Toledo-Groke, M. C. de \& Melfi, A. J. 1982. Aspectos micromorfológicos da evolução bauxítica de rochas básicas e alcalinas no Estado de São Paulo. In: SBG, Congresso Brasileiro de Geologia, 32, Salvador, Anais, 2:702 - 713

Turner, F. J. 1981. Metamorphic Petrology. 2 ed., Washington, Hemisphere, 524 p.

Ulbrich, H. H. G. J. \& Gomes, C. de B. 1981. Alkaline rocks from continental Brazil. Earth Science Reviews, Amsterdam, 17:135-154. 
Van Schmus, W. R.; Tassinari, C. C. G. e Cordani, U. G. 1986. Estudo geocronológico da parte inferior do Grupo São Roque. In: SBG, Congresso Brasileiro de Geologia, 34, Goiânia, Anais, 3:1399-1405.

Von Landsberg, D. 1992. The history of lime production and use forn early times to the industrial revolution. Zement - Kalk - Gips, Wiesbaden, 4(8):199-203.

Wernick, E. e Galembeck, T. M. B. 1986. Caracterização do plutonismo granitóide do ciclo Brasiliano no Estado de São Paulo através do método da tipologia do zircão. In: SBG, Congresso Brasileiro de Geologia, 34, Goiânia, Anais, 3:1360-1384.

Wernick, E.; Oliveira, M. A. F.; Kawashita, K.; Cordani, U. G.; Delhal, J. 1976. Estudo geocronológico pelo método $\mathrm{Rb}-\mathrm{Sr}$ em rochas do bloco Jundiaí e regiões adjacentes. Revista Brasileira de Geociências, 50(3):125-135.

Wolter, A. 1985. Influence of the kiln system on the clinker properties. Zement - KalkGips, Wiesbaden, 37(12):327-329.

Yamamoto, J. K. (no prelo). A simple and practical device for wet elutriation of sediments. Journal of Sedimetology Research .

Zampieiri, V. A. 1993. Cimento portland aditivado com pozolanas de argilas calcinadas: fabricação, hidratação e desempenho mecânico. Instituto de Geociências, Universidade de São Paulo, São Paulo, Tese de Doutoramento, 233 p. 
ANEXO 1

RESULTADOS ANALITICOS DE AMOSTRAS DE ROCHA DA MINA PASTINHO 
ANEXO 1 - RESULTADOS ANALITICOS DE AMOSTRAS DE ROCHA DA MINA PASTINHO

(Análise de $\mathrm{K}_{2} \mathrm{O}$ e $\mathrm{Na}_{2} \mathrm{O}$ por via úmida e dos demais óxidos por fluorescência de raios-X; teores em \%)

\begin{tabular}{|c|c|c|c|c|c|c|c|c|c|c|c|c|c|}
\hline NR & Litologia & Amostra & $\mathrm{CaO}$ & $\mathrm{SiO}_{2}$ & $\mathrm{Al}_{2} \mathrm{O}_{3}$ & $\mathrm{Fe}_{2} \mathrm{O}_{3}$ & MgO & $\mathrm{K}_{2} \mathrm{O}$ & $\mathrm{Na}_{2} \mathrm{O}$ & P.F. & MS & MA & FSC \\
\hline 1 & Mcal & 4932 & 49,84 & 1,88 & 0,46 & 1,92 & 2,50 & 0,13 & 0,10 & 43,01 & 0,79 & 0,24 & 706,40 \\
\hline 2 & Filca & $4933 A$ & 22,05 & 36,10 & 5,11 & 3,06 & 12,34 & 1,66 & 0,09 & 25,86 & 4,42 & 1,67 & 20,20 \\
\hline 3 & Fil ca & $4933 B$ & 16,40 & 33,08 & 5,33 & 3,01 & 10,74 & 2,23 & 0,09 & 27,81 & 3,97 & 1,77 & 16,30 \\
\hline 4 & Mdol ac & 4934 & 33,88 & 2,46 & 0,25 & 0,43 & 22,35 & 0,02 & 0,06 & 44,49 & 3,62 & 0,57 & 454,60 \\
\hline 5 & Mcal & 4935 & 48,54 & 2,32 & 0,34 & 1,16 & 4,21 & - & - & - & 1,55 & 0,57 & 454,60 \\
\hline 6 & Fil ca & 4936 & 14,44 & 44,52 & 9,73 & 3,15 & 9,64 & 3,66 & 0,12 & 19,94 & 3,46 & 3,09 & 10,40 \\
\hline 7 & Mcal & 4938 & 54,18 & 1,87 & 0,45 & 0,20 & 0,58 & 0,11 & 0,08 & 42,94 & 2,88 & 2,25 & 918,77 \\
\hline 8 & Mdol sil & 4939 & 20,62 & 45,71 & 4,18 & 2,45 & 12,33 & 1,26 & 0,07 & 24,80 & 6,89 & 1,71 & 15,33 \\
\hline 9 & Mdol ac & 4941 & 34,07 & 0,80 & 0,36 & 0,30 & 24,28 & 0,03 & 0,08 & 45,48 & $\overline{1,21}$ & 1,20 & $1.191,34$ \\
\hline 10 & Fil ca & 4943 & 12,99 & 51,35 & 10,67 & 3,02 & 8,02 & 4,22 & 0,11 & 18,94 & 3,75 & 3,53 & 8,20 \\
\hline 11 & Mdol ac & 4944 & 33,93 & 1,45 & 0,63 & 0,35 & 23,50 & 0,17 & 0,07 & 45,33 & 1,48 & 1,80 & 674,43 \\
\hline 12 & Mdol ac & $4944 A$ & 33,81 & 0,29 & 0,34 & 0,43 & 23,12 & - & - & - & 0,38 & 0,79 & $2.265,02$ \\
\hline 13 & Mcal & 4945 & 49,50 & 6,63 & 1,49 & 0,59 & 1,02 & 0,50 & 0,08 & 40,40 & 3,19 & 2,53 & 239,06 \\
\hline 14 & Mcal & 4946 & 51,98 & 3,37 & 0,76 & 0,63 & 0,27 & - & - & - & 2,42 & 1,21 & 483,88 \\
\hline 15 & Mcal sil & $4947 \mathrm{~A}$ & 41,39 & 13,78 & 3,37 & 0,76 & 1,76 & 2,04 & 0,09 & 36,32 & 3,34 & 4,43 & 96,13 \\
\hline 16 & Mdol ac & 4947B & 31,71 & 3,86 & 0,95 & $0, \overline{43}$ & 21,91 & 0,45 & 0,11 & 44,42 & 2,80 & 2,21 & 259,74 \\
\hline 17 & Mdol ac & 4949 & 31,97 & 3,20 & 0,96 & 0,63 & 21,45 & 0,38 & 0,00 & 43,78 & 2,01 & 1,52 & 304,41 \\
\hline 18 & Mcal dol & 4951 & 47,47 & 2,61 & 0,62 & 0,53 & 4,33 & 0,11 & 0,00 & 43,10 & 2,27 & 1,17 & 566,19 \\
\hline 19 & Mcal & 4952 & 51,22 & 3,84 & 0,57 & 0,33 & 1,62 & 0,18 & 0,06 & 41,88 & 4,27 & 1,73 & 440,07 \\
\hline 20 & Mcal sil & 4953 & 42,86 & 8,14 & 1,18 & 0,69 & 3,80 & 0,44 & 0,00 & 39,27 & 4,35 & 1,71 & 173,99 \\
\hline 21 & Mdol sil & 4954 & 19,99 & 23,06 & 3,22 & 2,25 & 14,79 & 0,91 & 0,11 & 33,37 & 4,22 & 1,43 & 28,63 \\
\hline 22 & Mdol sil & $4954 \mathrm{~A}$ & 20,10 & 23,05 & 3,14 & 2,05 & 14,72 & 0,85 & 0,07 & 32,84 & 4,44 & 1,53 & 28,89 \\
\hline 23 & Mdol sil & 4955 & 21,63 & 24,32 & 1,87 & 1,53 & 12,41 & 0,64 & 0,07 & 33,44 & 7,15 & 1,22 & 30,34 \\
\hline 24 & Mcal & 4956 & 50,70 & 5,96 & 0,57 & 0,36 & 1,12 & 0,17 & 0,08 & 40,82 & 6,41 & 1,58 & 288,16 \\
\hline 25 & Mdol sil & 4958 & 19,23 & 26,57 & 2,99 & 1,96 & 14,33 & 0,97 & 0,06 & 33,09 & 5,37 & 1,53 & 24,28 \\
\hline 26 & Mdol sil & 4962 & 21,27 & 23,26 & 2,18 & 1,85 & 14,59 & $0, \overline{87}$ & 0,06 & 35,28 & 5,77 & 1,18 & 30,87 \\
\hline 27 & Mcal & 4963 & 52,64 & 3,90 & 0,50 & 0,36 & 0,38 & 0,18 & - & 41,39 & 4,53 & 1,39 & 448,23 \\
\hline 28 & Mcal & 64 & 50,99 & 5,11 & 0,79 & 0,48 & 1,11 & 0,19 & - & 41,74 & 4,02 & 1,65 & 327,86 \\
\hline 29 & Mcal & 65 & 53,61 & 1,78 & 0,39 & 0,25 & 0,40 & 0,12 & - & 42,17 & 2,78 & 1,56 & 956,18 \\
\hline 30 & Mcal & 4966 & 52,77 & 1,87 & 0,42 & 0,61 & 0,98 & 0,09 & - & 41,98 & 1,82 & 0,69 & 861,12 \\
\hline 31 & Mcal sil & 4967 & 39,50 & 14,74 & 1,56 & 0,64 & 3,00 & 0,61 & 0,00 & 35,96 & 6,70 & 2,44 & 90,74 \\
\hline
\end{tabular}


ANEXO 1 - RESULTADOS ANALÍTICOS DE AMOSTRAS DE ROCHA DA MINA PASTINHO

(Análise de $\mathrm{K}_{2} \mathrm{O}$ e $\mathrm{Na}_{2} \mathrm{O}$ por via úmida e dos demais óxidos por fluorescência de raios-X; teores em \%)

\begin{tabular}{|c|c|c|c|c|c|c|c|c|c|c|c|c|c|}
\hline NR & Litologia & Amostra & $\mathrm{CaO}$ & $\mathrm{SiO}_{2}$ & $\mathrm{Al}_{2} \mathrm{O}_{3}$ & $\mathrm{Fe}_{2} \mathrm{O}_{3}$ & $\mathrm{MgO}$ & $\overline{\mathrm{K}_{2} \mathrm{O}}$ & $\mathrm{Na}_{2} \mathrm{O}$ & P.F. & MS & MA & $\overline{F S C}$ \\
\hline 32 & Mdol sil & $4967 \mathrm{~A}$ & 22,84 & 20,46 & 3,07 & 1,63 & 13,50 & - & - & - & 4,35 & 1,88 & 36,86 \\
\hline 33 & Mcal sil & 4968 & 34,24 & 13,75 & 2,08 & 1,43 & 5,99 & 0,79 & 0,02 & 36,46 & 3,92 & 1,45 & 81,75 \\
\hline 34 & Mdol sil & 4969 & 20,31 & 22,71 & 2,96 & 1,99 & 14,03 & - & - & - & 4,59 & 1,49 & 29,70 \\
\hline 35 & Mcal & 4970 & 54,08 & 1,18 & 0,28 & 0,19 & 0,46 & 0,03 & 0,00 & 42,98 & 2,51 & 1,47 & $1.439,10$ \\
\hline 36 & Mcal & $4971 \mathrm{~A}$ & 53,60 & 2,21 & 0,49 & 0,27 & 0,96 & - & - & - & 2,91 & 1,81 & 772,15 \\
\hline 37 & Mcal & 4972 & 54,05 & 1,38 & 0,34 & 0,21 & 0,46 & - & - & - & 2,51 & 1,62 & $1.227,93$ \\
\hline 38 & Mcal & 4973 & 53,68 & 1,34 & 0,32 & 0,23 & 0,80 & - & - & - & 2,44 & 1,39 & $1.254,47$ \\
\hline 39 & Mcal & $4973 A$ & 53,67 & 0,61 & 0,22 & 0,23 & 0,89 & - & - & $=$ & 1,36 & 0,96 & $2.535,07$ \\
\hline 40 & Mdol sil & 4974 & 25,83 & 14,77 & 0,55 & 0,66 & 16,04 & - & - & - & 12,21 & 0,83 & 60,87 \\
\hline 41 & Mdol sil & 4975 & 22,75 & 16,12 & 1,90 & 2,73 & 14,25 & 0,23 & 0,06 & 36,98 & 3,48 & 0,70 & 46,28 \\
\hline 42 & Mcal & 4976 & 54,48 & 1,27 & 0,35 & 0,17 & 0,33 & - & - & - & 2,44 & 2,06 & $1.335,46$ \\
\hline 43 & Mcal & 4977 & 50,90 & 2,46 & 0,66 & 0,47 & 1,47 & & & & 2,18 & 1,40 & 638,46 \\
\hline 44 & Mcal sil & 4978 & 47,49 & 6,42 & 1,38 & 0,66 & 2,46 & - & - & - & 3,15 & 2,09 & 237,05 \\
\hline 45 & Mcal sil & 4979 & 49,77 & 6,11 & 1,18 & 0,73 & 0,95 & - & - & - & 3,20 & 1,62 & 262,29 \\
\hline 46 & Mcal sil & 4980 & 41,87 & 7,20 & 2,26 & 1,22 & 4,01 & - & - & $=$ & 2,07 & 1,85 & 177,27 \\
\hline 47 & Mcal & 4981 & 50,76 & 3,51 & 0,72 & 0,37 & 1,02 & - & - & - & 3,22 & 1,95 & 464,92 \\
\hline 48 & Mcal & 4982 & 51,62 & 5,48 & 0,49 & 0,32 & 0,51 & - & - & - & 6,77 & 1,53 & 320,02 \\
\hline$\overline{49}$ & Mcal & 4983 & 47,70 & 5,88 & 1,00 & 0,48 & 1,50 & - & - & - & 3,97 & 2,08 & 265,65 \\
\hline 50 & Mcal sil & 4984 & 30,48 & 16,56 & 2,10 & 1,29 & 8,42 & - & $=$ & - & 4,88 & 1,63 & 61,35 \\
\hline 51 & Mcal & $4984 \mathrm{~A}$ & 51,62 & 3,90 & 0,70 & 0,46 & 0,94 & - & $=$ & - & 3,36 & 1,52 & 428,56 \\
\hline 52 & Mcal sil & 4985 & 43,59 & 10,17 & 0,74 & 0,56 & 4,10 & - & - & - & 7,82 & 1,32 & 146,70 \\
\hline 53 & Mdol sil & 4986 & 20,19 & 24,72 & 1,89 & 1,49 & 13,82 & - & $=$ & - & 7,31 & 1,27 & 27,88 \\
\hline 54 & Mdol sil & $4986 \mathrm{~A}$ & 24,61 & 15,36 & 1,71 & 1,44 & 14,55 & - & $=$ & $=$ & 4,88 & 1,19 & 53,54 \\
\hline 55 & Mdol sil & 4987 & 24,79 & 13,20 & 1,86 & 1,49 & 15,69 & $=$ & - & - & 3,94 & 1,25 & 61,78 \\
\hline 56 & Mcal sil & $4988 \mathrm{~A}$ & 42,98 & 9,11 & 1,07 & 0,58 & 4,03 & $=$ & - & - & 5,52 & 1,84 & 158,32 \\
\hline 57 & Mcal & 4988B & 50,15 & 5,88 & 0,89 & 0,52 & 1,00 & $=$ & - & - & 4,17 & 1,71 & 280,92 \\
\hline 58 & Mdol sil & 4990 & 19,80 & 29,54 & 0,78 & 1,14 & 12,71 & - & - & - & 15,39 & 0,68 & 23,47 \\
\hline 59 & Mdol ac & 4992 & 31,90 & 3,46 & 1,29 & 0,79 & 15,86 & $=$ & - & $=$ & 1,66 & 1,63 & 272,10 \\
\hline 60 & Mdol ac & 4993 & 32,78 & 1,11 & 0,61 & 0,72 & 17,92 & - & - & - & 0,83 & 0,85 & 763,07 \\
\hline 61 & Mdol ac & 4994 & 32,64 & 0,94 & 0,45 & 0,43 & 18,35 & - & - & - & 1,07 & 1,05 & 948,15 \\
\hline 62 & Mdol ac & 4997 & 30,94 & 2,19 & 0,81 & 0,81 & 17,63 & - & - & $=$ & 1,35 & 1,00 & 406,34 \\
\hline
\end{tabular}


ANEXO 1 - RESULTADOS ANALÍTICOS DE AMOSTRAS DE ROCHA DA MINA PASTINHO

(Análise de $\mathrm{K}_{2} \mathrm{O}$ e $\mathrm{Na}_{2} \mathrm{O}$ por via úmida e dos demais óxidos por fluorescência de raios-X; teores em \%)

\begin{tabular}{|c|c|c|c|c|c|c|c|c|c|c|c|c|c|}
\hline NR & Litologia & Amostra & $\mathrm{CaO}$ & $\mathrm{SiO}_{2}$ & $\overline{\mathrm{Al}_{2} \mathrm{O}_{3}}$ & $\mathrm{Fe}_{2} \mathrm{O}_{3}$ & $\mathrm{MgO}$ & $\mathrm{K}_{2} \mathrm{O}$ & $\mathrm{Na}_{2} \mathrm{O}$ & P.F. & MS & MA & FSC \\
\hline 63 & Mdol sil & 4998 & 25,43 & 8,92 & 3,72 & 4,06 & 12,35 & - & - & - & 1,15 & 0,92 & 79,46 \\
\hline 64 & Mdol ac & 4999 & 30,07 & 4,33 & 1,47 & 2,08 & 17,83 & - & - & - & 1,22 & 0,71 & 197,69 \\
\hline 65 & Mar sil & 5000 & 8,70 & 55,62 & 11,55 & 2,96 & 4,60 & 4,18 & 0,03 & $=$ & 3,83 & 3,90 & 5,08 \\
\hline 66 & Mdol sil & 5001 & 25,89 & 9,54 & 1,61 & 4,64 & 15,54 & - & - & - & 1,53 & 0,35 & 81,86 \\
\hline 67 & Mdol ac & 5002 & 31,01 & 2,18 & 0,80 & 2,89 & 17,85 & $=$ & - & - & 0,59 & 0,28 & 347,39 \\
\hline 68 & Mdol ac & $5002 A$ & 31,91 & 2,32 & 0,81 & 0,54 & 20,24 & E & - & $=$ & 1,72 & 1,50 & 408,96 \\
\hline 69 & Mcal & $5002 B$ & 51,38 & 3,30 & 0,79 & 0,85 & 1,22 & - & - & $=$ & 2,01 & 0,93 & 479,08 \\
\hline 70 & Mdol sil & $5002 \mathrm{C}$ & 30,19 & 7,21 & 2,93 & 1,34 & 12,24 & - & - & - & 1,69 & 2,19 & 123,14 \\
\hline 71 & Mdol sil & $5002 D$ & 29,73 & 6,43 & 1,30 & 0,64 & 19,14 & $=$ & $=$ & $=$ & 3,31 & 2,03 & 148,99 \\
\hline 72 & Mdol ac & $5002 E$ & 29,53 & 4,92 & 1,71 & 0,71 & 18,88 & $=$ & - & - & 2,03 & 2,41 & 181,66 \\
\hline 73 & Mdol ac & 5003 & 33,12 & 4,39 & 1,83 & 0,51 & 18,63 & $=$ & $=$ & $=$ & 1,88 & 3,59 & 224,04 \\
\hline 74 & Mdol ac & 5004 & 30,96 & 4,77 & 2,30 & 0,63 & 20,76 & $=$ & - & $=$ & 1,63 & 3,65 & 187,87 \\
\hline 75 & Mcal sil & 5005 & 47,43 & 8,36 & 2,32 & 1,07 & 0,86 & - & $=$ & - & 2,47 & 2,17 & 176,71 \\
\hline 76 & Mdol ac & 5006 & 30,49 & 5,64 & 2,12 & 0,76 & 20,27 & - & - & $=$ & 1,96 & 2,79 & 162,29 \\
\hline 77 & Mdol ac & 5007 & 30,81 & 5,21 & 1,79 & 0,86 & 20,61 & $=$ & - & - & 1,97 & 2,08 & 178,51 \\
\hline 78 & Mdol ac & 5008 & 33,05 & 4,58 & 1,34 & 0,62 & 18,84 & - & - & - & 2,34 & 2,16 & 223,19 \\
\hline 79 & Mdol ac & 5009 & 31,56 & 4,05 & 1,16 & 0,51 & 22,48 & - & $=$ & - & 2,43 & 2,27 & 242,02 \\
\hline 80 & Mcal & 5010 & 49,66 & 4,97 & 1,16 & 0,51 & 1,68 & - & - & - & 2,98 & 2,27 & 318,00 \\
\hline 81 & Mdol sil & 5011 & 36,10 & 11,18 & 1,45 & 0,85 & 7,81 & - & - & - & 4,86 & 1,71 & 107,54 \\
\hline 82 & Mcal & 5012 & 50,53 & 3,41 & 0,53 & 0,29 & 1,53 & - & - & - & 4,16 & 1,83 & 487,65 \\
\hline 83 & Mcal & 5013 & 51,06 & 5,14 & 0,56 & 0,48 & 0,50 & $=$ & - & - & 4,94 & 1,17 & 332,32 \\
\hline 84 & Mcal & 5014 & 50,27 & 5,28 & 0,92 & 0,50 & 0,76 & - & - & - & 3,72 & 1,84 & 310,41 \\
\hline 85 & Mcal sil & 5015 & 48,95 & 7,80 & 0,93 & 0,63 & 0,91 & - & $=$ & - & 5,00 & 1,48 & 209,66 \\
\hline 86 & Mdol sil & 5016 & 25,72 & 18,04 & 1,83 & 1,43 & 15,06 & - & $=$ & - & 5,53 & 1,28 & 47,98 \\
\hline 87 & Mdol sil & 5017 & 18,50 & 27,91 & 5,54 & 2,09 & 12,83 & - & $=$ & - & 3,66 & 2,65 & 21,50 \\
\hline 88 & Mdol sil & 5018 & 27,81 & 19,16 & 1,73 & 1,18 & 12,29 & - & - & $=$ & 6,58 & 1,47 & 49,26 \\
\hline 89 & Mdol sil & 5019 & 16,86 & 22,71 & 5,32 & 3,44 & 16,84 & - & - & - & 2,59 & 1,55 & 23,38 \\
\hline 90 & Mdol sil & 5020 & 21,09 & 20,58 & 4,62 & 2,49 & 16,32 & - & - & - & 2,89 & 1,86 & 32,60 \\
\hline 91 & Mdol sil & 5021 & 24,01 & 21,08 & 2,10 & 1,79 & 14,71 & - & - & - & 5,42 & 1,17 & 38,31 \\
\hline 92 & Mdol sil & 5022 & 19,98 & 25,95 & 3,24 & 2,12 & 15,14 & - & - & - & 4,84 & 1,53 & 25,66 \\
\hline 93 & Mdol sil & 5023 & 19,04 & 28,69 & 3,93 & 2,37 & 14,30 & - & - & - & 4,55 & 1,66 & 22,01 \\
\hline
\end{tabular}


ANEXO 1 - RESULTADOS ANALÍTICOS DE AMOSTRAS DE ROCHA DA MINA PASTINHO

(Análise de $\mathrm{K}_{2} \mathrm{O}$ e $\mathrm{Na}_{2} \mathrm{O}$ por via úmida e dos demais óxidos por fluorescência de raios- $\mathrm{X}$; teores em \%)

\begin{tabular}{|c|c|c|c|c|c|c|c|c|c|c|c|c|c|}
\hline NR & Litologia & Amostra & $\mathrm{CaO}$ & $\mathrm{SiO}_{2}$ & $\mathrm{Al}_{2} \mathrm{O}_{3}$ & $\mathrm{Fe}_{2} \mathrm{O}_{3}$ & $\mathrm{MgO}$ & $\mathrm{K}_{2} \mathrm{O}$ & $\mathrm{Na}_{2} \mathrm{O}$ & P.F. & MS & MA & FSC \\
\hline 94 & Mdol sil & 5024 & 21,22 & 27,01 & 2,50 & 1,75 & 14,43 & - & - & - & 6,36 & 1,43 & 26,62 \\
\hline 95 & $\overline{\text { Mdol sil }}$ & 5025 & 19,57 & 39,90 & 7,64 & 3,56 & 11,65 & - & - & - & 3,56 & 2,15 & 15,90 \\
\hline 96 & Mdol sil & 5026 & 32,31 & 14,77 & 1,89 & 0,95 & 7,27 & - & - & - & 5,20 & 1,99 & 73,09 \\
\hline 97 & Mdol sil & 5027 & 20,05 & 45,56 & 4,25 & 1,77 & 10,03 & - & - & - & 7,57 & 2,40 & 14,99 \\
\hline 98 & Mdol sil & 5028 & 19,28 & 45,86 & 4,09 & 2,03 & 10,76 & - & - & $=$ & 7,49 & 2,01 & 14,33 \\
\hline 99 & Mdol sil & 5029 & 26,19 & 11,78 & 3,86 & 1,59 & 14,48 & - & - & - & 2,16 & 2,43 & 67,90 \\
\hline 100 & Mdol sil & 5030 & 24,74 & 25,29 & 2,13 & 1,33 & 9,26 & - & - & - & 7,31 & 1,60 & 33,35 \\
\hline 101 & Mdol sil & $5031 \mathrm{~A}$ & 24,34 & 22,34 & 3,96 & 1,98 & 8,61 & - & - & - & 3,76 & 2,00 & 35,53 \\
\hline 102 & Mdol sil & $5031 \mathrm{~B}$ & 18,78 & 42,45 & 9,71 & 3,43 & 9,84 & - & $=$ & - & 3,23 & 2,83 & 14,17 \\
\hline 103 & Mdol sil & 5032 & 16,56 & 40,09 & 7,64 & 3,48 & 10,62 & $=$ & $=$ & - & 3,61 & 2,20 & 13,41 \\
\hline 104 & Mdol sil & 5033 & 26,32 & 9,51 & 4,35 & 1,89 & 15,54 & - & E & - & 1,52 & 2,30 & 79,78 \\
\hline 105 & Mcal & 5034 & 57,65 & 0,50 & 0,23 & 0,16 & 0,30 & - & $=$ & - & 1,28 & 1,44 & $3.247,16$ \\
\hline 106 & Mar sil & 5035 & 0,46 & 57,48 & 26,62 & 4,58 & 2,02 & $=$ & $=$ & - & 1,84 & 5,81 & 0,24 \\
\hline 107 & Mdol ac & 5036 & 28,44 & 6,49 & 1,28 & 1,15 & 16,78 & - & 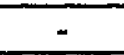 & - & 2,67 & 1,11 & 139,21 \\
\hline 108 & Mdol ac & 5037 & 31,14 & 2,54 & 0,99 & 1,33 & 17,18 & $=$ & - & - & 1,09 & 0,74 & 340,53 \\
\hline 109 & Mdol ac & 5038 & 26,69 & 7,13 & 3,54 & 0,70 & 1,56 & - & $=$ & - & 1,68 & 5,06 & 108,51 \\
\hline 110 & Mdol ac & 5039 & 34,08 & 0,74 & 0,44 & 0,46 & 16,55 & - & - & $=$ & 0,82 & 0,96 & $1.179,16$ \\
\hline 111 & Mdol ac & 5047 & 30,88 & 2,81 & 1,22 & 0,47 & 17,67 & - & 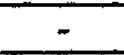 & $=$ & 1,66 & 2,60 & 321,23 \\
\hline 112 & Mdol ac & 5048 & 32,47 & 1,31 & 0,63 & 0,39 & 18,12 & - & - & - & 1,28 & 1,62 & 696,05 \\
\hline 113 & Mdol ac & 5049 & 29,36 & 7,17 & 3,14 & 1,68 & 15,68 & - & - & $=$ & 1,49 & 1,87 & 118,04 \\
\hline 114 & Mar sil & 5050 & 5,99 & 49,20 & 22,40 & 4,65 & 2,50 & - & - & - & 1,82 & 4,82 & 3,58 \\
\hline 115 & Mdol sil & $5051 \mathrm{~A}$ & 25,90 & 18,08 & 1,53 & 0,67 & 15,36 & - & $=$ & - & 8,22 & 2,28 & 48,99 \\
\hline 116 & Mcal sil & $5051 \mathrm{~B}$ & 45,42 & 10,10 & 2,43 & 0,83 & 0,99 & $=$ & - & - & 3,10 & 2,93 & 143,34 \\
\hline 117 & Mcal sil & 5052 & 36,79 & 15,94 & 4,39 & 0,81 & 1,63 & - & - & - & 3,07 & 5,42 & 73,08 \\
\hline 118 & Mcal sil & 5053 & 44,75 & 10,25 & 2,29 & 0,66 & 0,72 & - & - & - & 3,47 & 3,47 & 140,59 \\
\hline 119 & Mcal sil & 5054 & 49,15 & 6,66 & 1,53 & 0,72 & 0,31 & $=$ & - & - & 2,96 & 2,13 & 234,93 \\
\hline 120 & Mdol ac & $5054 \mathrm{~B}$ & 29,37 & 4,70 & 1,77 & 0,55 & 17,74 & - & - & - & 2,03 & 3,22 & 188,20 \\
\hline 121 & Mcal sil & 5055 & 44,67 & 8,68 & 2,36 & 0,49 & 0,64 & - & - & - & 3,05 & 4,82 & 162,99 \\
\hline 122 & Mdol ac & $5055 \mathrm{~B}$ & 29,47 & 4,03 & 1,99 & 0,75 & 17,26 & - & - & - & 1,47 & 2,65 & 208,72 \\
\hline 123 & Mcal sil & 5056 & 31,69 & 24,75 & 3,58 & 1,01 & 0,93 & - & - & - & 5,39 & 3,54 & 42,72 \\
\hline 124 & Mdol ac & $5056 \mathrm{~B}$ & 30,08 & 3,51 & 1,26 & 0,68 & 17,93 & - & $=$ & - & 1,81 & 1,85 & 255,85 \\
\hline
\end{tabular}


ANEXO 1 - RESULTADOS ANALÍTICOS DE AMOSTRAS DE ROCHA DA MINA PASTINHO

(Análise de $\mathrm{K}_{2} \mathrm{O}$ e $\mathrm{Na}_{2} \mathrm{O}$ por via úmida e dos demais óxidos por fluorescência de raios-X; teores em \%)

\begin{tabular}{|c|c|c|c|c|c|c|c|c|c|c|c|c|c|}
\hline NR & Litologia & Amostra & $\mathrm{CaO}$ & $\mathrm{SiO}_{2}$ & $\mathrm{Al}_{2} \mathrm{O}_{3}$ & $\mathrm{Fe}_{2} \mathrm{O}_{3}$ & MgO & $\mathrm{K}_{2} \mathrm{O}$ & $\mathrm{Na}_{2} \mathrm{O}$ & P.F. & MS & MA & FSC \\
\hline 125 & Mdol ac & 5057 & 30,68 & 2,56 & 1,12 & 0,54 & 18,17 & - & - & $\sim$ & 1,54 & 2,07 & 347,04 \\
\hline 126 & Mdol ac & 5058 & 32,00 & 1,24 & 0,59 & $0, \overline{42}$ & 18,73 & $=$ & $=$ & $=$ & 1,23 & 1,40 & 720,53 \\
\hline 127 & Mdol sil & 5059 & 23,46 & 21,58 & 2,22 & 1,58 & 14,22 & $=$ & - & - & 5,68 & 1,41 & 36,62 \\
\hline 128 & Mdol sil & 5060 & 20,48 & 23,69 & 5,00 & 1,46 & 13,64 & - & - & - & 3,67 & 3,42 & 27,99 \\
\hline 129 & Mcal dol & 5062 & 31,32 & 32,36 & 2,85 & 1,36 & 10,19 & $=$ & $=$ & $=$ & 7,69 & 2,10 & 33,02 \\
\hline 130 & Mcal & 5063 & 48,85 & 3,86 & 0,43 & 0,32 & 2,37 & - & - & - & 5,15 & 1,34 & 423,92 \\
\hline 131 & Mdol sil & 5065 & 26,03 & 17,41 & 1,33 & 1,51 & 14,90 & - & - & - & 6,13 & 0,88 & 50,74 \\
\hline 132 & Mdol ac & 5066 & 35,84 & 2,00 & 0,71 & 0,40 & 16,34 & - & - & - & 1,80 & 1,78 & 535,10 \\
\hline 133 & Mcal sil & 5067 & 46,64 & 7,60 & 1,63 & 0,66 & 1,98 & $=$ & - & - & 3,32 & 2,47 & 197,36 \\
\hline 134 & Mdol ac & 5068 & 32,65 & 1,00 & 0,41 & 0,33 & 18,98 & - & - & - & 1,35 & 1,24 & 933,31 \\
\hline 135 & Mar sil & 5070 & 11,53 & 54,35 & 12,49 & 3,39 & 7,98 & - & $=$ & $=$ & 3,42 & 3,68 & 6,82 \\
\hline 136 & Mdol ac & 5071 & 32,72 & 2,25 & 0,77 & 0,44 & 16,76 & $=$ & - & - & 1,86 & 1,75 & 436,58 \\
\hline 137 & Mar sil & 5072 & 36.06 & 43,22 & 3,72 & 1,46 & 0,56 & - & - & - & 8,34 & 2,55 & 0,00 \\
\hline 138 & Mar sil & 5073 & 6,35 & 92,11 & 5,52 & 4,93 & 2,12 & - & - & - & 8,81 & 1,12 & 2,37 \\
\hline 139 & Mar sil & 5074 & 6,28 & 64,28 & 14,68 & 5,02 & 3,30 & - & - & - & 3,26 & 2,92 & 3,13 \\
\hline 140 & Mar sil & 5075 & 11,70 & 47,30 & 13,04 & 5,60 & 6,09 & - & - & - & 2,54 & 2,33 & 7,72 \\
\hline 141 & Mdol ac & 5076 & 27,25 & 6,90 & 2,15 & 6,86 & 12,20 & - & $=$ & $=$ & 0,77 & 0,31 & 103,55 \\
\hline 142 & Mar sil & 5077 & 3,96 & 82,02 & 4,36 & 3,26 & 3,01 & - & - & $=$ & 10,76 & 1,34 & 1,67 \\
\hline 143 & Mcal & 5080 & 49,35 & 5,39 & 1,19 & 0,61 & 1,37 & - & $=$ & $=$ & 2,99 & 1,95 & 292,14 \\
\hline 144 & Mcal & 5082 & 54,99 & 0,63 & 0,08 & 0,10 & 0,55 & - & - & - & 3,50 & 0,80 & $2.859,00$ \\
\hline 145 & Mcal sil & 5083 & 45,76 & 8,22 & 1,38 & 1,35 & 2,21 & - & $=$ & $=$ & 3,01 & 1,02 & 179,30 \\
\hline 146 & Mcal sil & 5084 & 44,01 & 10,79 & 2,50 & 0,68 & 0,89 & - & $\because$ & - & 3,39 & 3,68 & 130,97 \\
\hline 147 & Mdol ac & 5085 & 32,85 & 4,60 & 0,94 & 0,55 & 16,26 & $=$ & - & - & 3,09 & 1,71 & 228,97 \\
\hline 148 & Mcal & 5086 & 50,25 & 4,34 & 0,52 & 0,45 & 1,26 & $=$ & - & - & 4,47 & 1,16 & 384,82 \\
\hline 149 & Mcal & 5087 & 50,04 & 4,66 & 0,86 & 0,70 & 0,90 & - & - & - & 2,99 & 1,23 & 344,68 \\
\hline 150 & Mcal & 5088 & 53,39 & 2,15 & 0,31 & 0,24 & 0,57 & - & $=$ & - & 3,91 & 1,29 & 816,14 \\
\hline 151 & Mcal & 5089 & 51,81 & 4,30 & 0,55 & 0,52 & 0,40 & - & - & - & 4,02 & 1,06 & 397,71 \\
\hline 152 & Mdol sil & 5090 & 27,51 & 17,17 & 0,80 & 1,39 & 13,52 & $=$ & - & - & 7,84 & 0,58 & 55,10 \\
\hline 153 & Mcal & 5091 & 55,30 & 0,77 & 0,17 & 0,13 & 0,22 & - & 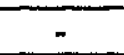 & - & 2,57 & 1,31 & $2.265,37$ \\
\hline 154 & Mcal & 5092 & 52,08 & 2,73 & 0,38 & 0,39 & 0,81 & $=$ & - & - & 3,55 & 0,97 & 624,02 \\
\hline 155 & Fil ca & 5093 & 11,16 & 49,03 & 15,69 & 5,89 & 2,68 & - & - & - & 2,27 & 2,66 & 6,99 \\
\hline
\end{tabular}


ANEXO 1 - RESULTADOS ANALITICOS DE AMOSTRAS DE ROCHA DA MINA PASTINHO

(Análise de $\mathrm{K}_{2} \mathrm{O}$ e $\mathrm{Na}_{2} \mathrm{O}$ por via úmida e dos demais óxidos por fluorescência de raios- $\mathrm{X}$; teores em \%)

\begin{tabular}{|c|c|c|c|c|c|c|c|c|c|c|c|c|c|}
\hline NR & Litologia & Amostra & $\mathrm{CaO}$ & $\mathrm{SiO}_{2}$ & $\mathrm{Al}_{2} \mathrm{O}_{3}$ & $\mathrm{Fe}_{2} \mathrm{O}_{3}$ & MgO & $\mathrm{K}_{2} \mathrm{O}$ & $\mathrm{Na}_{2} \mathrm{O}$ & P.F. & MS & MA & FSC \\
\hline 156 & Mdol ac & 5095 & 31,13 & 7,23 & 1,51 & 1,07 & 16,74 & - & - & - & 2,80 & 1,41 & 137,01 \\
\hline 157 & Mar sil & $5096 \mathrm{~B}$ & 23,09 & 44,93 & 2,22 & 3,11 & 11,06 & $=$ & - & - & 8,43 & 0,71 & 17,70 \\
\hline 158 & Fil ca & $5096 \mathrm{~A}$ & 3,06 & 63,75 & 21,67 & 2,75 & 2,53 & - & $=$ & - & 2,61 & 7,88 & 1,49 \\
\hline 159 & Mdol sil & 5097 & 22,38 & 22,24 & 3,46 & 1,19 & 14,45 & - & - & - & 4,78 & 2,91 & 33,34 \\
\hline 160 & Mdol ac & 5098 & 29,65 & 3,64 & 1,55 & 1,42 & 17,33 & - & - & $=$ & 1,23 & 1,09 & 229,06 \\
\hline 161 & Mar sil & 5100 & 0,39 & 66,86 & 23,78 & 4,11 & 1,52 & - & $=$ & - & 2,40 & 5,79 & 0,18 \\
\hline 162 & Mdol sil & 5103 & 23,46 & 24,03 & 1,48 & 1,32 & 11,65 & - & - & - & 8,58 & 1,12 & 33,57 \\
\hline 163 & Mdol sil & 5104 & 33,64 & 12,94 & 1,05 & 0,67 & 9,09 & - & - & - & 7,52 & 1,57 & 88,74 \\
\hline 164 & Mcal & 5105 & 52,71 & 3,96 & 0,81 & 0,36 & 0,60 & - & - & $=$ & 3,38 & 2,25 & 429,31 \\
\hline 165 & Mcal & 5106 & 53,80 & 2,00 & 0,32 & 0,27 & 0,37 & - & - & - & 3,39 & 1,19 & 874,36 \\
\hline 166 & Mcal & 5107 & 54,82 & 0,87 & 0,16 & 0,15 & 0,06 & - & - & - & 2,81 & 1,07 & $2.013,74$ \\
\hline 167 & Mdol sil & 5109 & 19,02 & 42,71 & 9,41 & 4,01 & 6,74 & - & $=$ & $=$ & 3,18 & 2,35 & 14,27 \\
\hline 168 & Mdol sil & 5110 & 25,93 & 25,88 & 5,92 & 2,39 & 3,92 & - & - & $=$ & 3,11 & 2,48 & 32,01 \\
\hline 169 & Mdol sil & 5111 & 21,34 & 32,16 & 6,72 & 4,17 & 13,58 & $=$ & $=$ & - & 2,95 & 1,61 & 21,19 \\
\hline 170 & Mdol sil & 5112 & 19,82 & 27,74 & 4,57 & 2,02 & 12,77 & - & - & - & 4,21 & 2,26 & 23,49 \\
\hline 171 & Mdol sil & 5113 & 21,66 & 25,12 & 3,18 & 1,89 & 11,18 & - & - & - & 4,95 & 1,68 & 28,76 \\
\hline 172 & Mdol sil & 5114 & 22,27 & 36,84 & 2,82 & 1,90 & 12,19 & - & - & $=$ & 7,81 & 1,48 & 20,68 \\
\hline 173 & Mdol sil & 5115 & 27,12 & 40,50 & 4,65 & 2,61 & 8,07 & - & - & - & 5,58 & 1,78 & 22,49 \\
\hline 174 & Mdol sil & 5116 & 18,64 & 27,80 & 4,61 & $2, \overline{71}$ & 14,22 & - & - & - & 3,80 & 1,70 & 21,92 \\
\hline 175 & Mdol sil & 5117 & 21,70 & 22,25 & 3,34 & 2,37 & 15,89 & - & - & - & 3,90 & 1,41 & 32,01 \\
\hline 176 & Mdol sil & 5118 & 27,33 & 9,17 & 2,90 & 2,11 & 15,93 & - & - & - & 1,83 & 1,37 & 89,70 \\
\hline 177 & Mdol sil & 5119 & 19,80 & 27,05 & 3,16 & 2,25 & 14,67 & - & - & - & 5,00 & 1,40 & 24,47 \\
\hline 178 & Mdol sil & 5120 & 19,66 & 26,43 & 3,98 & 2,15 & 14,23 & - & - & - & 4,31 & 1,85 & 24,54 \\
\hline 179 & Mdol sil & 5121 & 20,30 & 26,30 & 3,11 & 2,51 & 14,25 & $=$ & - & - & 4,68 & 1,24 & 25,72 \\
\hline 180 & Mdol sil & 5122 & 20,14 & 25,41 & 4,60 & 1,74 & 12,86 & - & - & - & 4,01 & 2,64 & 25,92 \\
\hline 181 & Mdol sil & 5123 & 25,56 & 19,29 & 2,53 & 1,89 & 13,08 & - & - & $=$ & 4,36 & 1,34 & 43,90 \\
\hline 182 & Mdol sil & 5124 & 24,60 & 16,73 & 3,17 & 1,95 & 15,08 & - & - & - & 3,27 & 1,63 & 47,44 \\
\hline 183 & Mdol sil & 5125 & 23,91 & 35,89 & 3,42 & 2,06 & 13,87 & - & - & - & 6,55 & 1,66 & 22,59 \\
\hline 184 & Mdol sil & 5126 & 18,94 & 25,20 & 4,72 & 3,04 & 16,04 & - & $=$ & - & 3,25 & 1,55 & 24,25 \\
\hline 185 & Mdol sil & 5127 & 21,15 & 24,24 & 3,94 & 2,08 & 13,64 & - & - & - & 4,03 & 1,89 & 28,63 \\
\hline 186 & Mdol sil & 5128 & 19,41 & 26,60 & 4,70 & 1,99 & 12,80 & - & - & - & 3,98 & 2,36 & 23,87 \\
\hline
\end{tabular}


ANEXO 1 - RESULTADOS ANALÍTICOS DE AMOSTRAS DE ROCHA DA MINA PASTINHO

(Análise de $\mathrm{K}_{2} \mathrm{O}$ e $\mathrm{Na}_{2} \mathrm{O}$ por via úmida e dos demais óxidos por fluorescência de raios- $\mathrm{X}$; teores em \%)

\begin{tabular}{|c|c|c|c|c|c|c|c|c|c|c|c|c|c|}
\hline NR & Litologia & Amostra & $\mathrm{CaO}$ & $\mathrm{SiO}_{2}$ & $\mathrm{Al}_{2} \mathrm{O}_{3}$ & $\mathrm{Fe}_{2} \mathrm{O}_{3}$ & $\mathrm{MgO}$ & $\mathrm{K}_{2} \mathrm{O}$ & $\mathrm{Na}_{2} \mathrm{O}$ & P.F. & MS & MA & FSC \\
\hline 187 & Mdol sil & 5129 & 24,11 & 20,17 & 2,11 & 1,52 & 15,39 & - & - & - & 5,56 & 1,39 & 40,21 \\
\hline 188 & Mcal & 5130 & 50,15 & 5,71 & 0,59 & 0,42 & 1,16 & $=$ & - & - & 5,65 & 1,40 & 295,74 \\
\hline 189 & Mcal & 5131 & 53,42 & 1,02 & 0,23 & 0,19 & 0,25 & $=$ & - & - & 2,43 & 1,21 & $1.643,24$ \\
\hline 190 & Mcal & 5132 & 51,99 & 2,87 & 0,42 & 0,39 & 0,52 & - & - & - & 3,54 & 1,08 & 591,80 \\
\hline 191 & Mcal & 5133 & 54,05 & 1,34 & 0,22 & 0,20 & 0,24 & $=$ & $=$ & $=$ & 3,19 & 1,10 & $1.305,05$ \\
\hline 192 & Mcal & 5134 & 53,20 & 2,03 & 0,16 & 0,19 & 0,57 & - & $=$ & - & 5,80 & 0,84 & 887,21 \\
\hline 193 & Mdol sil & 5135 & 33,88 & 20,76 & 4,22 & 0,73 & 1,50 & - & - & - & 4,19 & 5,78 & 53,29 \\
\hline 194 & Mdol sil & 5136 & 27,66 & 14,64 & 1,21 & 0,73 & 16,06 & - & - & $=$ & 7,55 & 1,66 & 64,48 \\
\hline 195 & Mdol ac & 5137 & 29,69 & 4,83 & 0,95 & 0,57 & 18,35 & - & - & - & 3,18 & 1,67 & 197,73 \\
\hline 196 & Mdol ac & 5138 & 30,47 & 2,57 & 1,11 & 0,55 & 18,47 & $=$ & - & $=$ & 1,55 & 2,02 & 343,78 \\
\hline 197 & Mdol ac & 5139 & 31,01 & 3,54 & 0,97 & 0,73 & 18,17 & - & $=$ & $=$ & 2,08 & 1,33 & 268,92 \\
\hline 198 & Mcal & 5140 & 53,60 & 1,24 & 0,32 & 0,19 & 0,64 & - & - & - & 2,43 & 1,68 & $1.349,07$ \\
\hline 199 & Mcal & 5141 & 54,15 & 1,35 & 0,18 & 0,40 & 0,34 & - & - & - & 2,33 & 0,45 & $1.273,40$ \\
\hline 200 & Mcal & 5142 & 50,57 & 3,25 & 0,72 & 0,58 & 1,11 & $=$ & $E$ & $=$ & 2,50 & 1,24 & 489,71 \\
\hline 201 & Mcal & 5143 & 52,69 & 3,38 & 0,24 & 0,31 & 0,57 & - & - & - & 6,15 & 0,77 & 529,62 \\
\hline 202 & Mcal & 5144 & 52,74 & 2,54 & 0,26 & 0,31 & 0,45 & - & $=$ & $=$ & 4,46 & 0,84 & 692,10 \\
\hline 203 & Mcal sil & 5145 & 44,94 & 12,69 & 0,81 & 0,78 & 2,56 & - & $=$ & - & 7,98 & 1,04 & 121,48 \\
\hline 204 & Mdol ac & 5146 & 32,04 & 2,63 & 1,43 & 0,48 & 18,13 & - & - & - & 1,38 & 2,98 & 342,18 \\
\hline 205 & Mcal sil & 5147 & 25,63 & 24,99 & 7,15 & 1,54 & 3,43 & - & - & - & 2,88 & 4,64 & 32,28 \\
\hline 206 & Mcal sil & 5148 & 47,56 & 8,16 & 2,16 & 1,09 & 0,69 & - & - & - & 2,51 & 1,98 & 182,19 \\
\hline 207 & Mcal sil & 5149 & 48,19 & 7,24 & 1,71 & 1,11 & 0,48 & $=$ & - & - & 2,57 & 1,54 & 209,42 \\
\hline 208 & Mdol sil & 5150 & 19,77 & 25,10 & 4,74 & 2,44 & 14,99 & - & - & - & 3,50 & 1,94 & 25,52 \\
\hline 209 & Mdol sil & 5151 & 20,28 & 25,71 & 3,45 & 2,42 & 15,09 & $\because$ & - & - & 4,38 & 1,43 & 26,12 \\
\hline 210 & Mdol sil & 5152 & 23,21 & 23,21 & 3,33 & 2,12 & 13,64 & $=$ & - & - & 4,26 & 1,57 & 33,02 \\
\hline 211 & Mdol sil & 5253 & 20,95 & 26,57 & 2,78 & 2,10 & 14,49 & - & $=$ & $=$ & 5,44 & 1,32 & 26,51 \\
\hline 212 & Mdol sil & 5154 & 22,51 & 21,91 & 2,96 & 1,89 & 13,72 & $=$ & $=$ & - & 4,52 & 1,57 & 34,07 \\
\hline 213 & Mdol sil & 5155 & 18,55 & 28,33 & 3,39 & 4,02 & 12,99 & - & - & - & 3,82 & 0,84 & 21,59 \\
\hline 214 & Mdol sil & 5156 & 18,83 & 25,71 & 4,83 & 2,29 & 15,34 & - & - & - & 3,61 & 2,11 & 23,78 \\
\hline 215 & Mdol sil & 5157 & 21,95 & 25,19 & 2,60 & 1,81 & 14,18 & $=$ & - & $=$ & 5,71 & 1,44 & 29,35 \\
\hline 216 & Mdol sil & 5158 & 22,97 & 20,24 & 3,28 & 1,90 & 14,14 & - & $=$ & $=$ & 3,91 & 1,73 & 37,18 \\
\hline 217 & Mdol sil & 5159 & 21,84 & 23,12 & 2,84 & 1,99 & 14,42 & - & - & - & 4,79 & 1,43 & 31,48 \\
\hline
\end{tabular}


ANEXO 1 - RESULTADOS ANALITICOS DE AMOSTRAS DE ROCHA DA MINA PASTINHO

(Análise de $\mathrm{K}_{2} \mathrm{O}$ e $\mathrm{Na}_{2} \mathrm{O}$ por via úmida e dos demais óxidos por fluorescência de raios-X; teores em \%)

\begin{tabular}{|c|c|c|c|c|c|c|c|c|c|c|c|c|c|}
\hline$\overline{N R}$ & Litologia & Amostra & $\mathrm{CaO}$ & $\mathrm{SiO}_{2}$ & $\overline{\mathrm{Al}_{2} \mathrm{O}_{3}}$ & $\mathrm{Fe}_{2} \mathrm{O}_{3}$ & $\mathrm{MgO}$ & $\mathrm{K}_{2} \mathrm{O}$ & $\mathrm{Na}_{2} \mathrm{O}$ & P.F. & MS & MA & FSC \\
\hline 218 & Mdol sil & 5160 & 22,78 & 23,61 & 2,19 & 1,68 & 14,48 & - & - & - & 6,10 & 1,30 & 32,64 \\
\hline 219 & Mdol sil & 5161 & 33,09 & 11,11 & 1,46 & 1,08 & 10,24 & - & - & - & 4,37 & 1,35 & 98,68 \\
\hline 220 & Mdol sil & 5162 & 25,09 & 17,22 & 1,92 & 1,63 & 15,04 & - & - & - & 4,85 & 1,18 & 48,68 \\
\hline 221 & Mdol sil & 5163 & 25,97 & 17,02 & 1,42 & 1,48 & 15,51 & - & - & - & 5,87 & 0,96 & 51,64 \\
\hline 222 & Mdol sil & 5164 & 21,90 & 25,00 & 2,23 & 1,45 & 14,13 & - & - & - & 6,79 & 1,54 & 29,77 \\
\hline 223 & Mdol sil & 5165 & 25,19 & 17,76 & 1,64 & 1,51 & 15,42 & - & - & $=$ & 5,64 & 1,09 & 47,85 \\
\hline 224 & Mdol sil & 5166 & 24,02 & 19,91 & 2,17 & 1,47 & 15,27 & - & - & - & 5,47 & 1,48 & 40,53 \\
\hline 225 & Mdol sil & 5167 & 25,36 & 15,98 & 1,96 & 1,55 & 15,35 & - & - & - & 4,55 & 1,26 & 52,76 \\
\hline 226 & Mdol sil & 5168 & 23,30 & 22,14 & 2,33 & 1,89 & 14,13 & - & - & - & 5,25 & 1,23 & 35,32 \\
\hline 227 & Mdol sil & 5169 & 23,25 & 19,36 & 2,99 & 2,02 & 15,39 & - & $=$ & $=$ & 3,86 & 1,48 & 39,37 \\
\hline 228 & Mdol sil & 5170 & 23,67 & 23,34 & 2,38 & 1,86 & 13,39 & - & - & $=$ & 5,50 & 1,28 & 34,12 \\
\hline 229 & Mdol sil & 5171 & 17,48 & 29,60 & 3,85 & 1,64 & 12,40 & - & - & $=$ & 5,39 & 2,35 & 19,75 \\
\hline 230 & Mdol sil & 5172 & 19,31 & 25,03 & 4,10 & 2,83 & 16,09 & - & - & - & 3,61 & 1,45 & 25,16 \\
\hline 231 & Mdol sil & 5173 & 17,66 & 27,75 & 5,71 & 2,46 & 14,69 & - & - & $=$ & 3,40 & 2,32 & 20,53 \\
\hline 232 & Mdol sil & 5174 & 25,25 & 15,36 & 2,40 & 1,60 & 15,85 & - & - & - & 3,84 & 1,50 & 53,86 \\
\hline 233 & Mdol sil & 5175 & 23,71 & 18,89 & 2,82 & 1,60 & 16,42 & 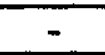 & - & - & 4,27 & 1,76 & 41,41 \\
\hline 234 & Mcal & 5176 & 50,88 & 4,55 & 0,55 & 0,38 & 1,30 & $=$ & - & - & 4,89 & 1,45 & 373,13 \\
\hline 235 & Mcal & 5177 & 54,32 & 1,31 & 0,19 & 0,19 & 0,17 & - & $=$ & - & 3,45 & 1,00 & $1.352,69$ \\
\hline 236 & Mcal sil & 5178 & 46,41 & 7,62 & 0,77 & 2,80 & 1,54 & - & - & - & 2,13 & 0,28 & 192,86 \\
\hline 237 & Mdol sil & 5179 & 26,27 & 16,64 & 2,02 & 1,31 & 14,82 & $=$ & - & - & 5,00 & 1,54 & 52,72 \\
\hline 238 & Mcal sil & 5180 & 48,32 & 7,95 & 1,18 & 0,83 & 0,88 & - & $=$ & - & 3,96 & 1,42 & 199,74 \\
\hline 239 & Mcal & 5181 & 51,72 & 4,52 & 0,45 & 0,33 & 0,34 & - & - & - & 5,79 & 1,36 & 385,93 \\
\hline 240 & Mcal & 5182 & 51,69 & 3,46 & 0,75 & 0,66 & 0,60 & - & - & - & 2,45 & 1,14 & 469,82 \\
\hline 241 & Mcal & 5183 & 50,59 & 4,98 & 0,51 & 0,50 & 0,81 & - & $\overline{-}$ & - & 4,93 & 1,02 & 340,20 \\
\hline 242 & Mcal & 5184 & 51,71 & 3,86 & $\overline{0,41}$ & 0,33 & 0,76 & - & - & - & 5,22 & 1,24 & 449,41 \\
\hline 243 & Mcal & 5185 & 51,12 & 3,51 & 0,29 & 0,32 & 1,00 & - & - & $=$ & 5,75 & 0,91 & 492,57 \\
\hline 244 & Mcal & 5186 & 50,50 & 3,47 & 0,35 & 0,32 & 1,80 & - & - & $=$ & 5,18 & 1,09 & 488,54 \\
\hline 245 & Mcal & 5187 & 52,94 & 2,52 & 0,25 & 0,32 & 0,41 & - & - & - & 4,42 & 0,78 & 700,36 \\
\hline 246 & Mcal & 5188 & 50,55 & 3,76 & 0,54 & 0,41 & 0,96 & - & - & - & 3,96 & 1,32 & 442,19 \\
\hline 247 & Mcal & 5189 & 48,36 & 7,51 & 0,74 & 0,73 & 1,58 & - & F & - & 5,11 & 1,01 & 216,13 \\
\hline 248 & Mcal & 5191 & 53,88 & 1,70 & 0,23 & 0,21 & 0,24 & - & - & - & 3,86 & 1,10 & $1.042,59$ \\
\hline
\end{tabular}


ANEXO 1 - RESULTADOS ANALÍTICOS DE AMOSTRAS DE ROCHA DA MINA PASTINHO

(Análise de $\mathrm{K}_{2} \mathrm{O}$ e $\mathrm{Na}_{2} \mathrm{O}$ por via úmida e dos demais óxidos por fluorescência de raios- $\mathrm{X}$; teores em \%)

\begin{tabular}{|c|c|c|c|c|c|c|c|c|c|c|c|c|c|}
\hline NR & Litologia & Amostra & $\mathrm{CaO}$ & $\mathrm{SiO}_{2}$ & $\mathrm{Al}_{2} \mathrm{O}_{3}$ & $\mathrm{Fe}_{2} \mathrm{O}_{3}$ & MgO & $\overline{\mathrm{K}_{2} \mathrm{O}}$ & $\mathrm{Na}_{2} \mathrm{O}$ & P.F. & MS & MA & FSC \\
\hline 249 & Mcal & 5192 & 53,04 & 2,60 & 0,36 & 0,23 & 0,52 & - & - & - & 4,41 & 1,57 & 675,30 \\
\hline 250 & Mcal & 5193 & 53,89 & 2,53 & 0,43 & 0,21 & 0,17 & - & $=$ & $=$ & 3,95 & 2,05 & 697,34 \\
\hline 251 & Mcal & 5194 & 53,67 & 1,37 & 0,18 & 0,16 & 0,10 & - & - & - & 4,03 & 1,13 & $1.292,51$ \\
\hline 252 & Mcal sil & 5195 & 46,59 & 8,92 & 1,90 & 2,15 & 0,43 & - & $=$ & - & 2,20 & 0,88 & 162,81 \\
\hline 253 & Mcal sil & 5196 & 46,31 & 11,03 & 1,08 & 0,90 & 1,18 & - & - & - & 5,57 & 1,20 & 141,43 \\
\hline 254 & Mcal & 5197 & 51,95 & 3,34 & 0,43 & 0,39 & 0,52 & - & $=$ & - & 4,07 & 1,10 & 513,70 \\
\hline 255 & Mcal sil & 5198 & 30,38 & 20,18 & 2,92 & 1,32 & 3,09 & - & $=$ & - & 4,76 & 2,21 & 49,96 \\
\hline 256 & Mcal & 5199 & 50,66 & 4,02 & 0,83 & 0,57 & 0,95 & - & - & - & 2,87 & 1,46 & 401,88 \\
\hline 257 & Mcal & 5200 & 53,23 & 2,43 & 0,41 & 0,30 & 0,36 & - & - & - & 3,42 & 1,37 & 711,36 \\
\hline 258 & Mcal sil & 5180 & 48,32 & 7,95 & 1,18 & 0,83 & 0,88 & - & - & $=$ & 3,96 & 1,42 & 199,74 \\
\hline 259 & Mcal & 5181 & 51,72 & 4,52 & 0,45 & 0,33 & 0,34 & - & - & - & 5,79 & 1,36 & 385,93 \\
\hline 260 & Mcal & 5182 & 51,69 & 3,46 & 0,75 & 0,66 & 0,60 & - & 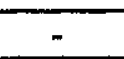 & - & 2,45 & 1,14 & 469,82 \\
\hline 261 & Mcal & 5183 & 50,59 & 4,98 & 0,51 & 0,50 & 0,81 & - & - & - & 4,93 & 1,02 & 340,20 \\
\hline 262 & Mcal & 5184 & 51,71 & 3,86 & 0,41 & 0,33 & 0,76 & - & - & - & 5,22 & 1,24 & 449,41 \\
\hline 263 & Mcal & 5185 & 51,12 & 3,51 & 0,29 & 0,32 & 1,00 & - & - & - & 5,75 & 0,91 & 492,57 \\
\hline 264 & Mcal & 5486 & 50,50 & 3,47 & 0,35 & 0,32 & 1,80 & - & - & - & 5,18 & 1,09 & 488,54 \\
\hline 265 & Mcal & 5187 & 52,94 & 2,52 & 0,25 & 0,32 & 0,41 & - & - & - & 4,42 & 0,78 & 700,36 \\
\hline 266 & Mcal & 5188 & 50,55 & 3,76 & 0,54 & 0,41 & 0,96 & - & - & - & 3,96 & 1,32 & 442,19 \\
\hline 267 & Mcal sil & 5189 & 48,36 & 7,51 & 0,74 & 0,73 & 1,58 & - & - & - & 5,11 & 1,01 & 216,13 \\
\hline 268 & Mcal & 5190 & 52,81 & 3,26 & 0,28 & 0,24 & 0,57 & - & - & - & 6,27 & 1,17 & 549,28 \\
\hline 269 & Mcal & 5201 & 51,25 & 5,32 & 0,46 & 0,39 & 0,45 & - & - & - & 6,26 & 1,18 & 326,59 \\
\hline 270 & Mcal & 5202 & 51,10 & 4,97 & 0,46 & 0,38 & 0,32 & - & 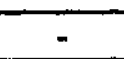 & $=$ & 5,92 & 1,21 & 347,48 \\
\hline 271 & Mcal & 5203 & 51,45 & 3,73 & 0,54 & 0,43 & 0,71 & - & - & - & 3,85 & 1,26 & 452,88 \\
\hline 272 & Mcal sil & 5204 & 45,63 & 8,08 & 1,23 & 1,17 & 2,72 & - & - & - & 3,37 & 1,05 & 183,73 \\
\hline 273 & Mcal & 5205 & 53,77 & 2,12 & 0,11 & 0,14 & 0,19 & - & - & - & 8,48 & 0,79 & 873,34 \\
\hline 274 & Mcal sil & 5206 & 38,76 & 17,81 & 0,95 & 0,49 & 2,68 & $\overline{-}$ & - & - & 12,37 & 1,94 & 75,54 \\
\hline 275 & Mcal sil & 5207 & 50,84 & 6,66 & 0,23 & 0,28 & 0,31 & - & 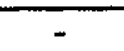 & - & 13,06 & 0,82 & 266,16 \\
\hline 276 & Mcal sil & 5208 & 33,23 & 14,02 & 2,67 & 1,17 & 6,70 & - & - & - & 3,65 & 2,28 & 76,98 \\
\hline 277 & Mcal & 5209 & 51,08 & 5,20 & 0,47 & 0,36 & 0,89 & - & $=$ & - & 6,27 & 1,31 & 332,80 \\
\hline 278 & Mcal & 5210 & 49,13 & 5,17 & 0,97 & 0,67 & 1,67 & 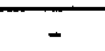 & - & - & 3,15 & 1,45 & 305.99 \\
\hline 279 & Mcal sil & 5211 & 28,92 & 16,86 & 1,64 & 1,06 & 7,61 & - & - & - & 6,24 & 1,55 & 58,03 \\
\hline
\end{tabular}


ANEXO 1 - RESULTADOS ANALÍTICOS DE AMOSTRAS DE ROCHA DA MINA PASTINHO

(Análise de $\mathrm{K}_{2} \mathrm{O}$ e $\mathrm{Na}_{2} \mathrm{O}$ por via úmida e dos demais óxidos por fluorescência de raios-X; teores em \%)

\begin{tabular}{|c|c|c|c|c|c|c|c|c|c|c|c|c|c|}
\hline NR & Litologia & Amostra & $\mathrm{CaO}$ & $\mathrm{SiO}_{2}$ & $\mathrm{Al}_{2} \mathrm{O}_{3}$ & $\mathrm{Fe}_{2} \mathrm{O}_{3}$ & $\mathrm{MgO}$ & $\mathrm{K}_{2} \mathbf{O}$ & $\mathrm{Na}_{2} \mathrm{O}$ & P.F. & MS & MA & FSC \\
\hline 280 & Mcal sil & 5212 & 18,51 & 22,06 & 5,66 & 1,57 & 11,56 & - & - & - & 3,05 & 3,61 & 26,65 \\
\hline 281 & Mcal sil & 5213 & 22,08 & 17,59 & 1,18 & 1,34 & 11,79 & - & $=$ & $=$ & 6,98 & 0,88 & 42,86 \\
\hline 282 & Mdol sil & 5214 & 26,58 & 15,44 & 1,82 & 1,45 & 12,50 & - & - & - & 4,72 & 1,26 & 57,38 \\
\hline 283 & Mcal & 5215 & 51,85 & 3,80 & 0,45 & 0,35 & 0,68 & $=$ & $=$ & $=$ & 4,75 & 1,29 & 454,88 \\
\hline 284 & Mdol sil & 5216 & 24,51 & 18,36 & 2,34 & 1,56 & 15,40 & - & - & - & 4,71 & 1,50 & 44,42 \\
\hline 285 & Mdol sil & 5217 & 23,62 & 39,46 & 3,95 & 2,09 & 9,76 & - & - & - & 6,53 & 1,89 & 20,27 \\
\hline 286 & Mdol sil & 5218 & 21,38 & 48,84 & 3,19 & 1,72 & 9,61 & - & - & - & 9,95 & 1,85 & 15,10 \\
\hline 287 & Mcal sil & 5219 & 46,27 & 10,24 & 1,37 & 1,01 & 1,72 & $=$ & - & $=$ & 4,30 & 1,36 & 149,52 \\
\hline 288 & Mcal & 5220 & 50,47 & 5,71 & 0,46 & 0,48 & 0,90 & - & - & - & 6,07 & 0,96 & 299,65 \\
\hline 289 & Mcal & 5221 & 54,18 & 1,79 & 0,25 & 0,21 & 0,15 & - & - & - & 3,89 & 1,19 & 995,32 \\
\hline 290 & Mcal & 5222 & 53,48 & 2,59 & 0,25 & 0,24 & 0,32 & $=$ & $=$ & $=$ & 5,29 & 1,04 & 694,27 \\
\hline
\end{tabular}

Fil ca = filito carbonático; Mcal = metacalcário; Mcal dol = metacalcário dolomítico; Mcal sil = metacalcário silicoso; Mdol ac = metadolomito de alto cálcio Mdol sil = metadolomito silicoso; Mar sil = metarenito silicoso 
ANEXO 1 (Continuação)

RESULTADOS ANALÍTICOS DE AMOSTRAS DE CANALETA DA MINA PASTINHO (Análise por fluorescência de raios-X; teores em \%)

\begin{tabular}{|c|c|c|c|c|c|c|c|c|c|c|}
\hline NR & Litologia & Amostra & $\mathrm{CaO}$ & $\mathrm{SiO}_{2}$ & $\mathrm{Al}_{2} \mathrm{O}_{3}$ & $\mathrm{Fe}_{2} \mathrm{O}_{3}$ & $\mathrm{MgO}$ & MS & MA & FSC \\
\hline \multicolumn{11}{|c|}{ CANALETA 1} \\
\hline 1 & $\mathrm{Fil} \mathrm{ca}$ & 4943 & 12,99 & 51,35 & 10,67 & 3,02 & 8,02 & 3,75 & 3,53 & 8,20 \\
\hline 2 & Mdol ac & $4943+3$ & 32,13 & 1,81 & 0,47 & 0,33 & 18,85 & 2,26 & 1,42 & 550,44 \\
\hline 3 & Mdol ac & $4943+6$ & 31,01 & 2,33 & 0,91 & 0,50 & 18,34 & 1,65 & 1,82 & 391,40 \\
\hline 4 & Mdol ac & $4943+9$ & 30,10 & 3,75 & 1,80 & 0,73 & 17,48 & 1,48 & 2,47 & 229,80 \\
\hline 5 & Mdol ac & $4943+12$ & 35,72 & 3,03 & 0,91 & 0,43 & 15,52 & 2,26 & 2,12 & 363,11 \\
\hline 6 & Mdol ac & $4943+15$ & 31,48 & 1,97 & 0,85 & 0,43 & 18,39 & 1,54 & 1,98 & 463,04 \\
\hline 7 & Mdol ac & $4943+18$ & 32,88 & 0,60 & 0,34 & 0,35 & 19,03 & 0,87 & 0,97 & $1.424,18$ \\
\hline 8 & Mdol ac & $4943+21$ & 32,01 & 1,35 & 0,70 & 0,43 & 18,55 & 1,19 & 1,63 & 655,20 \\
\hline 9 & Mdol ac & $4943+24$ & 32,24 & 1,25 & 0,61 & 0,41 & 18,48 & 1,23 & 1,49 & 718,63 \\
\hline 10 & Mdol ac & $4943+27$ & 32,04 & 1,47 & 0,68 & 0,48 & 18,62 & 1,27 & 1,42 & 612,57 \\
\hline 11 & Mdol ac & 4944 & 33,93 & 1,45 & 0,63 & 0,35 & 23,50 & 1,48 & 1,80 & 674,43 \\
\hline 12 & Mdol ac & $4944+3$ & 32,69 & 2,89 & 1,42 & 0,52 & 17,20 & 1,49 & 2,73 & 323,48 \\
\hline 13 & Mdol ac & $4944+6$ & 33,55 & 2,17 & 0,83 & 0,48 & 17,99 & 1,66 & 1,73 & 455,38 \\
\hline 14 & Mdol ac & $4944+9$ & 34,39 & 0,79 & 0,47 & 0,37 & 18,58 & 0,94 & 1,27 & $1.143,63$ \\
\hline 15 & Mdol ac & $4944+12$ & 30,96 & 2,36 & 0,80 & 0,95 & 16,75 & 1,35 & 0,84 & 378,97 \\
\hline 16 & Ndol ac & $4944+15$ & 34,39 & 1,95 & 0,76 & 0,63 & 17,22 & 1,40 & 1,21 & 508,25 \\
\hline 17 & Mdol ac & $4944+18$ & 34,60 & 2,79 & 0,82 & 0,41 & 16,59 & 2,27 & 2,00 & 382,49 \\
\hline 18 & Mdol ac & $4944+21$ & 34,47 & 0,79 & 0,43 & 0,29 & 18,00 & 1,10 & 1,48 & $1.185,39$ \\
\hline 19 & Mdol ac & $4944+24$ & 34,27 & 1,61 & 0,56 & 0,42 & 41,00 & 1,64 & 1,33 & 629,75 \\
\hline 20 & Mdol ac & $4944+27$ & 32,52 & 4,05 & 1,99 & 0,49 & 18,29 & 1,63 & 4,06 & 232,17 \\
\hline 21 & Mdol ac & $4944 \mathrm{~A}$ & 33,81 & 0,29 & 0,34 & 0,43 & 23,12 & 0,38 & 0,79 & $2.265,02$ \\
\hline 22 & Mdol ac & $4944 A+3$ & 34,11 & 1,74 & 0,70 & 0,69 & 17,14 & 1,25 & 1,01 & 554,95 \\
\hline 23 & Mdol ac & $4944 A+6$ & 35,32 & 0,55 & 0,18 & 0,23 & 18,21 & 1,34 & 0,78 & $1.857,09$ \\
\hline 24 & Mdol ac & $4944 A+9$ & 34,18 & 0,99 & 0,48 & 0,41 & 18,22 & 1,11 & 1,17 & 948,15 \\
\hline 25 & Mdol ac & $4944 A+12$ & 30,83 & 4,50 & 2,07 & 0,59 & 16,95 & 1,69 & 3,51 & 199,86 \\
\hline 26 & Mdol ac & $4944 A+15$ & 31,51 & 4,43 & 1,84 & 0,44 & 17,48 & 1,94 & 4,18 & 212,03 \\
\hline 27 & Mdol ac & $4944 A+18$ & 30.59 & 5,22 & 1.92 & 0.48 & 17,30 & 2,18 & 4,00 & 177,92 \\
\hline 28 & Mdol ac & $4944 A+21$ & 33,56 & 2,30 & 0,70 & 0,35 & 18,11 & 2,19 & 2,00 & 447,85 \\
\hline 29 & Mdol ac & $4944 A+24$ & 33,56 & 2,45 & 0,94 & 0,55 & 16,52 & 1,64 & 1,71 & 403,04 \\
\hline 30 & Mcal sil & $4944 A+27$ & 29,28 & 22,26 & 5,76 & 1,29 & 2,29 & 3.16 & 4,47 & 41,85 \\
\hline 31 & Mdol ac & $4944 A+30$ & 36,78 & 4,57 & 0,88 & 0,51 & 10,71 & 3,29 & 1,73 & 259,64 \\
\hline 32 & Mcal & $4944 A+33$ & 49,00 & 3,45 & 0,76 & 0,57 & 1,88 & 2,59 & 1,33 & 448,42 \\
\hline 33 & Mdol ac & $4944 A+36$ & 34,69 & 2,76 & 1,08 & 0,62 & 16,17 & 1,62 & 1,74 & 368,83 \\
\hline 34 & Mdol ac & $4944 A+39$ & 34,31 & 1,10 & 0,39 & 0,56 & 18,03 & 1,16 & 0,70 & 878,80 \\
\hline 35 & Mcal & $4944 A+42$ & 51,10 & 3,66 & 0,81 & 0,52 & 0,83 & 2,75 & 1,56 & 442,74 \\
\hline 36 & Mcal & $4944 A+45$ & 49,93 & 5,49 & 1,26 & 0.62 & 0,68 & 2,92 & 2,03 & 289,25 \\
\hline 37 & Mcal sil & 4945 & 49,50 & 6,63 & 1,49 & 0,59 & 1,02 & 3,19 & 2,53 & 239,06 \\
\hline 38 & Mcal sil & $4945+3$ & 43,65 & 6,29 & 1,58 & 0,55 & 3,36 & 2,95 & 2,87 & 220,08 \\
\hline 39 & Mdol sil & $4945+6$ & 22,45 & 28,56 & 7,63 & 1,71 & 2,96 & 3,06 & 4,46 & 24,92 \\
\hline 40 & Mcal sil & $4945+9$ & 44,56 & 7,76 & 2,15 & 0,83 & 1,47 & 2,60 & 2,59 & 179,64 \\
\hline 41 & Mcal sil & $4945+12$ & 42,02 & 11,27 & 3,17 & 0,86 & 0,86 & 2,80 & 3,69 & 117,19 \\
\hline 42 & Mcal & $4945+15$ & 49,40 & 5,55 & 1,57 & 0,99 & 0,47 & 2,17 & 1,59 & 273,90 \\
\hline 43 & Mcal & $4945+18$ & 49,96 & 5,34 & 1,35 & 0.83 & 0,37 & 2,45 & 1,63 & 292,43 \\
\hline 44 & Mcal sil & $4945+21$ & 47,81 & 7,52 & 2,02 & 0,86 & 0,43 & 2,61 & 2,35 & 199,22 \\
\hline 45 & Mcal & 4946 & 51,98 & 3,37 & 0,76 & 0,63 & 0.27 & 2,42 & 1,21 & 483,88 \\
\hline 46 & Mcal & $4946+3$ & 50,16 & 4,58 & 1,07 & 0,95 & 0,31 & 2,27 & 1,13 & 341,13 \\
\hline 47 & Mical & $4946+6$ & 52,88 & 2,61 & 0,70 & 0,56 & 0,32 & 2.07 & 1,25 & 622,26 \\
\hline 48 & Mcal sil & $4946+9$ & 38,23 & 13,76 & 4,25 & 0,89 & 0,76 & 2,68 & 4,78 & 86,65 \\
\hline 49 & Mcal sil & $4946+12$ & 37,58 & 14,84 & 4,45 & 0,97 & 0,96 & 2,74 & 4,59 & 79,23 \\
\hline 50 & Mcal sil & $4946+15$ & 47,69 & 7,56 & 2,14 & 1,10 & 0,37 & 2,33 & 1,95 & 195,39 \\
\hline 51 & Mcal sil & $4946+18$ & 49,24 & 5,95 & 1,56 & 1,11 & 0,44 & 2,23 & 1,41 & 256,16 \\
\hline 52 & Mcal sil & $4946+21$ & 40,88 & 12,46 & 3,57 & 0,75 & 0,83 & 2.88 & 4,76 & 103,26 \\
\hline 53 & Mcal sil & $4946+24$ & 42,81 & 10,15 & 3,11 & 0,71 & 0,69 & 2,66 & 4,38 & 131,52 \\
\hline 54 & Mcal sil & $4946+27$ & 44,72 & 10,37 & 2,12 & 0,63 & 0,52 & 3,77 & 3,37 & 139.98 \\
\hline 55 & Mcal sil & $4946+30$ & 49,03 & 6,61 & 1,39 & 0,56 & 0,62 & 3,39 & 2,48 & 239,03 \\
\hline 56 & Mcal sil & $4946+33$ & 43,59 & 9,29 & 2,25 & 0,56 & 1,29 & 3,31 & 4,02 & 150,15 \\
\hline 57 & Mcal sil & $4946+36$ & 41,77 & 11,92 & 2,43 & 0,63 & 1,43 & 3,90 & 3,86 & 113,96 \\
\hline
\end{tabular}


ANEXO 1 (Continuação)

RESULTADOS ANALITICOS DE AMOSTRAS DE CANALETA DA MINA PASTINHO (Análise por fluorescência de raios-X; teores em \%)

\begin{tabular}{|c|c|c|c|c|c|c|c|c|c|c|}
\hline NR & Litologia & Amostra & $\mathrm{CaO}$ & $\mathrm{SiO}_{2}$ & $\mathrm{Al}_{2} \mathrm{O}_{3}$ & $\mathrm{Fe}_{2} \mathrm{O}_{3}$ & $\mathrm{MgO}$ & MS & MA & FSC \\
\hline 58 & Mcal sil & $4946+39$ & 42,68 & 10,89 & 2,19 & 0,61 & 1,55 & 3,89 & 3,59 & 127,51 \\
\hline \multirow[t]{4}{*}{59} & Mdol ac & $4947 \mathrm{~B}$ & 31,71 & 3,86 & 0,95 & 0,43 & 21,91 & 2,80 & 2,21 & 259,74 \\
\hline & & Médias & 37,89 & 6,15 & 1,71 & 0,66 & 10,73 & 2,59 & 2,57 & 192,74 \\
\hline & \multicolumn{2}{|c|}{ Média Mdol ac } & 33,14 & 2,29 & 0,89 & 0,48 & 18,70 & 1,67 & 1,86 & 426,89 \\
\hline & \multicolumn{2}{|c|}{ CANALETA 2} & & & & & & & & \\
\hline 1 & Mdol ac & 4934 & 33,88 & 2,46 & 0,25 & 0,43 & 22,35 & 3,62 & 0,58 & 454,00 \\
\hline 2 & Mar sil & $4934+3$ & 4,28 & 91,53 & 0,87 & 1,13 & 2,98 & 45,77 & 0,77 & 1,66 \\
\hline 3 & Mdol ac & $4934+6$ & 31,58 & 8,67 & 0.43 & 0,70 & 16,35 & 7,67 & 0,61 & 125,13 \\
\hline 4 & Mdol ac & $4934+9$ & 32,57 & 5,33 & 0,30 & 0,44 & 16,89 & 7,20 & 0,68 & 209,26 \\
\hline 5 & Mcal & $4934+12$ & 52,15 & 3,59 & 0,24 & 0,40 & 0,62 & 5,61 & 0,60 & 492,20 \\
\hline 6 & Mcal & $4934+15$ & 53,94 & 2,04 & 0.56 & 0,60 & 0,19 & 1,76 & 0,93 & 797,60 \\
\hline 7 & Mcal & $4934+21$ & 53,70 & 1.45 & 0,33 & 0,26 & 0,72 & 2,46 & 1,27 & $1.162,74$ \\
\hline 8 & Mcal & $4934+24$ & 53,82 & 1,60 & 0,29 & 0,33 & 0,51 & 2,58 & 0,88 & $1.068,56$ \\
\hline 9 & Mcal & $4934+27$ & 43,59 & 3,53 & 0,37 & 1,22 & 4,34 & 2,22 & 0,30 & 392,22 \\
\hline 10 & Mcal & 4935 & 48,54 & 2,32 & 0,34 & 1,16 & 4,21 & 1,55 & 0,29 & 634,41 \\
\hline 11 & Mcal & $4935+3$ & 54,45 & 1.07 & 0,29 & 0,25 & 0,44 & 1,98 & 1,16 & $1.555,40$ \\
\hline 12 & Mdol ac & $4935+6$ & 33,67 & 5,29 & 0,37 & 0,82 & 13,48 & 4,45 & 0,45 & 213,35 \\
\hline 13 & Mdol sil & $4935+9$ & 28,95 & 10,69 & 0,96 & 0,85 & 13,82 & 5,91 & 1,13 & 91,56 \\
\hline 14 & Mdol sil & $4935+12$ & 27,86 & 13,34 & 0,70 & 1,09 & 13,42 & 7,45 & 0,64 & 71,64 \\
\hline 15 & Mdol sil & $4935+15$ & 28,24 & 12,26 & 1,70 & 1,18 & 14,71 & 4,26 & 1,44 & 76,12 \\
\hline 16 & Mdol sil & $4935+18$ & 19,62 & 22,57 & 3,20 & 1,87 & 13,19 & 4,45 & 1,71 & 28,77 \\
\hline 17 & Mcal sil & $4935+21$ & 27,90 & 30,48 & 1,35 & 2,94 & 13,72 & 7,10 & 0,46 & 31,40 \\
\hline \multirow[t]{2}{*}{18} & Mcal sil & $4935+24$ & 24,34 & 20,65 & 0,84 & 2,28 & 14,34 & 6,62 & 0,37 & 40,37 \\
\hline & & Médias & 36,28 & 13,27 & 0,74 & 1,00 & 9,24 & 7,62 & $\mathbf{0 , 7 5}$ & 93,79 \\
\hline \multicolumn{3}{|c|}{ Médias Mdol ac + Mcal } & 41,66 & 2,91 & 0,31 & 0,53 & 6,06 & 3,49 & 0,59 & 469,76 \\
\hline & \multicolumn{2}{|c|}{ CANALETA 3} & & & & & & & & \\
\hline 1 & Mdol ac & 4997 & 30,94 & 2,19 & 0,81 & 0,81 & 17,63 & 1,35 & 1,00 & 406,34 \\
\hline 2 & Mdol ac & $4997+3$ & 28,96 & 5,33 & 0,83 & 2,31 & 16,58 & 1,70 & 0,36 & 166.39 \\
\hline 3 & Mdol ac & $4997+6$ & 29,02 & 6,83 & 2,40 & 3,00 & 15,44 & 1,26 & 0,80 & 121,39 \\
\hline 4 & Mdol sil & 4998 & 25,43 & 8,92 & 3,72 & 4,06 & 12,35 & 1,15 & 0,92 & 79,46 \\
\hline 5 & Mdol sil & $4998+3$ & 26,01 & 11,01 & 3,65 & 4,01 & 13,70 & 1,44 & 0,91 & 68,92 \\
\hline 6 & Mdol ac & $4998+6$ & 30,44 & 6,26 & 1,82 & 3,56 & 12,00 & 1,16 & 0,51 & 138,43 \\
\hline 7 & Mdol sil & $4998+9$ & 26,77 & 13,12 & 2,19 & 2,35 & 15,43 & 2,89 & 0,93 & 65,54 \\
\hline 8 & Mdol sil & $4998+12$ & 23,04 & 18,10 & 3,33 & 3,76 & 13,26 & 2,55 & 0,89 & 40,38 \\
\hline 9 & Mdol ac & 4999 & 30,07 & 4,33 & 1,47 & 2,08 & 17,83 & 1,22 & 0,71 & 197,69 \\
\hline 10 & Mdol sil & $4999+3$ & 23,05 & 17,92 & 3,86 & 2,06 & 14,30 & 3,03 & 1,87 & 41,11 \\
\hline 11 & Mdol ac & $4999+6$ & 29,19 & 6,13 & 1,68 & 4,38 & 15,15 & 1,01 & 0,38 & 132,72 \\
\hline 12 & Mdol sil & $4999+9$ & 24,86 & 33,29 & 2,71 & 3,39 & 12,99 & 5,46 & 0,80 & 25,21 \\
\hline 13 & Mdol ac & $4999+12$ & 26.57 & 9,43 & 1,88 & 1,46 & 16,40 & 2,82 & 1,29 & 89,85 \\
\hline 14 & Mdol sil & $4999+15$ & 14,85 & 57,41 & 4,78 & 4,21 & 8,12 & 6,39 & 1,14 & 8,78 \\
\hline 15 & Mdol sil & $4999+18$ & 14,67 & 35,35 & 13,96 & 5,68 & 7,97 & 1,80 & 2,46 & 12,31 \\
\hline 16 & Mar sil & $4999+21$ & 11,45 & 55,22 & 11,27 & 4,33 & 6,69 & 3,54 & 2,60 & 6,71 \\
\hline 17 & Mar sil & $4999+24$ & 4,90 & 77,58 & 12,42 & 3,14 & 3,81 & 4,99 & 3,96 & 2,09 \\
\hline 18 & Mar sil & 5000 & 8,70 & 55,62 & 11,55 & 2,96 & 4,60 & 3,83 & 3,90 & 5,08 \\
\hline 19 & Mar sil & $5000+3$ & 6,56 & 80,12 & 8,65 & 3,17 & 4,53 & 6,78 & 2,73 & 2,77 \\
\hline 20 & Mar sil & $5000+6$ & 1,63 & 70,83 & 18,94 & 3,87 & 2,76 & 3,11 & 4,89 & 0,73 \\
\hline 21 & Mdol sil & $5000+9$ & 21,65 & 36,26 & 4,68 & 4,49 & 10,78 & 3,95 & 1,04 & 19,69 \\
\hline 22 & Mdoi sil & $5000+12$ & 11,47 & 57,43 & 9,48 & 3,57 & 7,48 & 4,40 & 2,66 & 6,58 \\
\hline 23 & Mdol sil & $5000+15$ & 19,13 & 22,53 & 4,13 & 3,70 & 11,66 & 2,88 & 1,12 & 27,19 \\
\hline \multirow[t]{4}{*}{24} & Mdol ac & 5001 & 25,89 & 9,54 & 1,61 & 4,64 & 15,54 & 1,53 & 0,35 & 81,86 \\
\hline & & Médias & 20,64 & 29,20 & 5,49 & 3,37 & 11,54 & 3,29 & 1,63 & 22,82 \\
\hline & \multicolumn{2}{|c|}{ Média Mdol ac } & 28,89 & 6,26 & 1,56 & 2,78 & 15,82 & 1,44 & 0,56 & 136,48 \\
\hline & \multicolumn{2}{|c|}{ CANALETA 4} & & & & & & & & \\
\hline 1 & \begin{tabular}{|l|} 
Mdol ac \\
\end{tabular} & 5047 & 30,88 & 2,81 & 1,22 & 0,47 & 17.67 & 1,66 & 2,60 & 321,23 \\
\hline 2 & Mdol ac & $5047+3$ & 29.52 & 4,10 & 1,25 & 0,57 & 17,88 & 2,25 & 2,19 & 221,53 \\
\hline 3 & Mdol sil & 5135 & 33,88 & 20,76 & 4,22 & 0,73 & 1,50 & 4,19 & 5,78 & 53,29 \\
\hline 4 & $\mathrm{Mdol}$ ac & $5135+3$ & 29,81 & 4,25 & 0,90 & 0,53 & 18,08 & 2,97 & 1,70 & 224,03 \\
\hline 5 & Mdol ac & $5135+6$ & 27,37 & 8,41 & 1,55 & 0,63 & 17,20 & 3,86 & 2,46 & 106,14 \\
\hline 6 & Mdol ac & 5136 & 29,88 & 1,27 & 1,27 & 0,61 & 17,72 & 0,68 & 2,08 & 548,15 \\
\hline
\end{tabular}


ANEXO 1 (Continuação)

RESULTADOS ANALITICOS DE AMOSTRAS DE CANALETA DA MINA PASTINHO

(Análise por fluorescência de raios-X; teores em \%)

\begin{tabular}{|c|l|c|c|c|c|c|c|c|c|c|}
\hline NR & Litologia & Amostra & $\mathrm{CaO}$ & $\mathrm{SiO}_{2}$ & $\mathrm{Al}_{2} \mathrm{O}_{3}$ & $\mathrm{Fe}_{2} \mathrm{O}_{3}$ & $\mathrm{MgO}$ & $\mathrm{MS}$ & $\mathrm{MA}$ & FSC \\
\hline 7 & Mdol ac & $5136+3$ & 30,40 & 3,47 & 0,81 & 0,51 & 18,11 & 2,63 & 1,59 & 276,28 \\
\hline 8 & Mdol ac & 5137 & 29,69 & 4,83 & 0,95 & 0,57 & 18,35 & 3,18 & 1,67 & 197,73 \\
\hline & & Médias & $\mathbf{3 0 , 1 8}$ & $\mathbf{6 , 2 4}$ & $\mathbf{1 , 5 2}$ & $\mathbf{0 , 5 8}$ & $\mathbf{1 5 , 8 1}$ & $\mathbf{2 , 9 7}$ & $\mathbf{2 , 6 3}$ & $\mathbf{1 5 3 , 7 0}$ \\
\hline & & Media Mdol ac & $\mathbf{2 9 , 6 5}$ & $\mathbf{4 , 1 6}$ & $\mathbf{1 , 1 4}$ & $\mathbf{0 , 5 6}$ & $\mathbf{1 7 , 8 6}$ & $\mathbf{2 , 4 6}$ & $\mathbf{2 , 0 4}$ & $\mathbf{2 2 1 , 9 8}$ \\
\hline & CANALETA 5 & & & & & & & & \\
\hline 1 & Mcal & 5086 & 50,25 & 4,34 & 0,52 & 0,45 & 1,26 & 4,47 & 1,16 & 384,82 \\
\hline 2 & Mcal & $5086+5$ & 53,93 & 1,42 & 0,17 & 0,19 & 0,41 & 3,94 & 0,89 & $1.254,16$ \\
\hline 3 & Mcal & $5086+10$ & 54,50 & 1,05 & 0,21 & 0,20 & 0,34 & 2,56 & 1,05 & $1,642,65$ \\
\hline 4 & Mcal & $5086+15$ & 54,73 & 1,02 & 0,26 & 0,33 & 0,18 & 1,73 & 0,79 & $1,620,53$ \\
\hline 5 & Mcal & $5086+20$ & 54,39 & 1,28 & 0,17 & 0,21 & 0,13 & 3,37 & 0,81 & $1,387,11$ \\
\hline 6 & Mcal & $5086+25$ & 52,34 & 2,81 & 0,38 & 0,35 & 0,64 & 3,85 & 1,09 & 612,60 \\
\hline 7 & Mcal & $5086+30$ & 51,30 & 2,57 & 0,40 & 0,41 & 1,42 & 3,17 & 0,98 & 646,54 \\
\hline 8 & Mcal sil & $5086+35$ & 47,43 & 9,57 & 1,08 & 0,75 & 0,84 & 5,23 & 1,44 & 166,08 \\
\hline 9 & Mcal & $5086+40$ & 51,28 & 4,47 & 0,55 & 0,45 & 0,46 & 4,47 & 1,22 & 381,05 \\
\hline 10 & Mcal & $5086+45$ & 50,88 & 7,14 & 0,18 & 0,24 & 0,23 & 17,00 & 0,75 & 249,90 \\
\hline 11 & Mcal & $5086+50$ & 54,55 & 1,38 & 0,19 & 0,19 & 0,15 & 3,63 & 1,00 & $1.295,20$ \\
\hline 12 & Mcal & $5086+55$ & 50,97 & 4,30 & 0,61 & 0,42 & 1,13 & 4,17 & 1,45 & 391,09 \\
\hline 13 & Mcal & $5086+60$ & 49,35 & 4,72 & 0,89 & 0,63 & 1,02 & 3,11 & 1,41 & 336,27 \\
\hline 14 & Mcal & $5086+65$ & 49,57 & 4,96 & 0,83 & 0,56 & 1,38 & 3,57 & 1,48 & 325,45 \\
\hline 15 & Mcal & $5086+70$ & 54,34 & 1,95 & 0,30 & 0,20 & 0,22 & 3,90 & 1,50 & 914,20 \\
\hline 16 & Mcal & $5086+75$ & 53,21 & 2,83 & 0,42 & 0,30 & 0,45 & 3,93 & 1,40 & 617,67 \\
\hline 17 & Mcal & 5087 & 50,04 & 4,66 & 0,86 & 0,70 & 0,90 & 2,99 & 1,23 & 344,68 \\
\hline
\end{tabular}


ANEXO 2

RESULTADOS ANALÍTICOS DAS AMOSTRAS SUPERFICIAIS DA

PROSPECÇÃO ESTRATÉGICA 
ANEXO 2 - RESULTADOS ANALÍTICOS DAS AMOSTRAS SUPERFICIAIS DA PROSPECÇÃO ESTRATÉGICA Amostras da área da metabásica de Alumínio e de seu entorno (análise via úmida)

\begin{tabular}{|c|c|c|c|c|c|c|}
\hline Amostra & Substrato & $\mathrm{SiO}_{2}(\%)$ & $\mathrm{Al}_{2} \mathrm{O}_{3}(\%)$ & $\mathrm{Fe}_{2} \mathrm{O}_{3}(\%)$ & $\mathrm{CaO}(\%)$ & $\mathrm{MgO}(\%)$ \\
\hline MB-01 & Filito & 49,10 & 21,56 & 11,38 & 1,01 & 0,60 \\
\hline MB-02 & Filito & 54,72 & 18,89 & 10,16 & 1,12 & 0,32 \\
\hline MB-03 & Filito & 51,88 & 20,02 & 11,70 & 0,78 & 0,32 \\
\hline MB-04 & Filito & 50,52 & 20,60 & 12,34 & 1,01 & 0,08 \\
\hline MB-05 & Filito & 52,60 & 19,93 & 11,46 & 0,78 & 0,32 \\
\hline MB-06 & Filito & 56,14 & 11,17 & 19,49 & 1,01 & n.d. \\
\hline MB-07 & Metassiltito & 55,08 & 17,28 & 11,10 & 1,01 & n.d. \\
\hline $\mathrm{MB}-08$ & Metassiltito & 42,80 & 19,82 & 16,87 & 0,96 & 0,16 \\
\hline MB-09 & Metabásica & 51,58 & 15,40 & 15,83 & 1,12 & 0,08 \\
\hline $\mathrm{MB}-10$ & Metabásica & 29,47 & 14,37 & 40,72 & 0,30 & 0,18 \\
\hline $\mathrm{MB}-11$ & Metabásica & 32,78 & 26,72 & 23,56 & 0,15 & 0,19 \\
\hline $\mathrm{MB}-12$ & Metabásica & 56,77 & 20,01 & 10,04 & 0,22 & 0,16 \\
\hline MB-13 & Metassiltito & 60,14 & 17,74 & 8,80 & 0,36 & 0,13 \\
\hline $\mathrm{MB}-14$ & Metassiltito & 31,36 & 19,61 & 29,95 & 0,20 & 0,20 \\
\hline $\mathrm{MB}-15$ & Metabásica & 22,50 & 19,67 & 40,08 & 0,22 & 0,11 \\
\hline $\mathrm{MB}-16$ & Metabásica & 38,11 & 23,78 & 23,33 & 0,22 & 0,21 \\
\hline $\mathrm{MB}-17$ & Filito & 45,70 & 29,06 & 9,62 & 0,24 & 0,08 \\
\hline $\mathrm{MB}-18$ & Metabásica & 40,27 & 26,43 & 14,93 & 0,34 & 0,04 \\
\hline $\mathrm{MB}-19$ & Metassiltito & 57,05 & 18,77 & 10,11 & 0,48 & 0,31 \\
\hline $\mathrm{MB}-20$ & Metassiltito & 73,29 & 11,01 & 7,77 & 0,41 & 0,05 \\
\hline MB-21 & Metassiltito & 48,75 & 24,52 & 11,42 & 0,17 & 0,05 \\
\hline $\mathrm{MB}-22$ & Metassiltito & 52,92 & 24,18 & 8,74 & 0,79 & 0,06 \\
\hline $\mathrm{MB}-23$ & Metabásica & 44,00 & 10,28 & 7,31 & 0,68 & 0,38 \\
\hline \multirow[t]{4}{*}{ MB-24 } & Metassiltito & 43,50 & 25,35 & 12,20 & 1,01 & n.d. \\
\hline & Média da alteração da metabásica & 39,44 & 19,58 & 21,98 & 0,41 & 0,17 \\
\hline & Média da alteração de filito & 51,37 & 20,16 & 12,92 & 0,76 & 0,20 \\
\hline & Média da alteração de metassiltito & 51,65 & 19,81 & 13,00 & 0,60 & 0,14 \\
\hline
\end{tabular}


Anexo 2-continuação

Amostras da área da metabásica de Alumínio (Análise por espectrofotometria de plasma ICP)

\begin{tabular}{|c|c|c|c|c|c|c|c|c|c|c|c|c|c|}
\hline Amostra & Substrato & $\mathrm{SiO}_{2}(\%)$ & $\mathrm{Al}_{2} \mathrm{O}_{3}(\%)$ & $\mathrm{Fe}_{2} \mathrm{O}_{3}(\%)$ & $\mathrm{CaO}(\%)$ & $\mathrm{MgO}(\%)$ & $\mathrm{CrO}_{2}(\%)$ & $\mathrm{K}_{2} \mathrm{O}(\%)$ & $\mathrm{MnO}_{2}(\%)$ & $\mathrm{P}_{2} \mathrm{O}_{5}(\%)$ & $\mathrm{TiO}_{2}(\%)$ & $\mathrm{ZrO}_{2}(\%)$ & PF (\%) \\
\hline MB-25 & Metabásica & 42,86 & 13,41 & 16,05 & 9,18 & 12,22 & 0,05 & 0,28 & 0,33 & 0,17 & 1,00 & 0,03 & 3,92 \\
\hline $\mathrm{MB}-26$ & Mefassiltito & 61,65 & 17,01 & 8,25 & 0,35 & 0,55 & 0,02 & 2,07 & 0,08 & 0,09 & 1,02 & 0,07 & 8,41 \\
\hline MB-27 & Metabásica & 52,74 & 20,47 & 11,55 & 0,20 & 0,44 & 0,03 & 1,87 & 0,09 & 0,22 & 1,33 & 0,07 & 10,70 \\
\hline MB-28 & Metabásica & 46,26 & 19,92 & 11,47 & 0,40 & 0,45 & 0,03 & 1,90 & 0,10 & 0,29 & 1,19 & 0,06 & 17,25 \\
\hline $\mathrm{MB}-29$ & Metabásica & 56,45 & 18,41 & 10,01 & 0,14 & 0,58 & 0,02 & 2,46 & 0,18 & 0,12 & 1,19 & 0,06 & 9,80 \\
\hline MB-30 & Metabásica & 55,93 & 18,88 & 10,41 & 0,18 & 0,48 & 0,02 & 1,44 & 0,06 & 0,19 & 1,41 & 0,08 & 10,35 \\
\hline $\mathrm{MB}-31$ & Metabásica & 35,42 & 19,15 & 28,51 & 0,06 & 0,09 & 0,00 & 0,15 & 0,48 & 0,30 & 2,39 & 0,03 & 12,67 \\
\hline $\mathrm{MB}-32$ & Metabásica & 32,95 & 21,58 & 26,59 & 0,46 & 0,21 & 0,00 & 0,15 & 0,40 & 0,19 & 2,20 & 0,03 & 14,56 \\
\hline $\mathrm{MB}-33$ & Metabásica & 46,28 & 18,86 & 14,60 & 0,89 & 1,27 & 0,03 & 1,16 & 0,29 & 0,21 & 1,26 & 0,10 & 14,21 \\
\hline $\mathrm{MB}-34$ & Metabásica & 27,98 & 24,64 & 26,73 & 0,19 & 0,26 & 0,01 & 0,14 & 0,26 & 0,24 & 2,58 & 0,06 & 16,38 \\
\hline MB-35 & Metabásica & 59,99 & 18,26 & 6,56 & 0,14 & 0,52 & 0,02 & 1,62 & 0,02 & 0,12 & 1,17 & 0,07 & 10,90 \\
\hline MB-36 & Metabásica & 40,73 & 17,76 & 19,01 & 3,13 & 2,40 & 0,00 & 0,42 & 0,37 & 0,25 & 1,45 & 0,04 & 13,93 \\
\hline MB-37 & Granito & 69,74 & 17,97 & 1,83 & 0,15 & 0,16 & 0,01 & 3,01 & 0,27 & 0,22 & 0,17 & 0,02 & 5,85 \\
\hline MB-38 & Filito & 43,10 & 23,95 & 14,37 & 0,09 & 0,33 & 0,01 & 0,73 & 0,02 & 0,19 & 1,73 & 0,11 & 14,62 \\
\hline MB-39 & Filito & 60,85 & 23,32 & 1,53 & 0,14 & 0,17 & 0,01 & 0,70 & 0,01 & 0,20 & 1,53 & 0,16 & 10,75 \\
\hline $\mathrm{MB}-40$ & Granito & 37,09 & 23,84 & 17,54 & 0,32 & 0,25 & 0,04 & 0,42 & 0,29 & 0,37 & 1,73 & 0,04 & 17,41 \\
\hline $\mathrm{MB}-41$ & Metabásica & 31,48 & 23,00 & 27,07 & 0,11 & 0,15 & 0,00 & 0,12 & 0,29 & 0,21 & 2,32 & 0,04 & 14,59 \\
\hline MB-42 & Metabásica & 33,88 & 24,00 & 23,51 & 0,23 & 0,31 & 0,01 & 0,15 & 0,25 & 0,17 & 1,58 & 0,03 & 15,28 \\
\hline MB-43 & Filito & 46,73 & 23,26 & 9,50 & 0,25 & 0,26 & 0,01 & 1,02 & 0,04 & 0,19 & 1,98 & 0,16 & 15,95 \\
\hline MB-44 & Granito & 57,49 & 22,41 & 5,10 & 0,56 & 0,20 & 0,00 & 1,46 & 0,02 & 0,19 & 0,76 & 0,07 & 11,32 \\
\hline MB-45 & Filito & 54,59 & 23,25 & 4,56 & 0,51 & 0,25 & 0,01 & 0,57 & 0,03 & 0,14 & 1,52 & 0,17 & 13,97 \\
\hline MB-46 & Metabásica & 31,96 & 32,49 & 14,00 & 0,22 & 0,24 & 0,02 & 0,73 & 0,02 & 0,22 & 1,89 & 0,14 & 17,38 \\
\hline MB-47 & Metabásica & 30,07 & 24,48 & 26,26 & 0,38 & 0,20 & 0,00 & 0,26 & 0,39 & 0,25 & 2,32 & 0,02 & 14,79 \\
\hline MB-48 & Metassiltito & 50,28 & 14,51 & 21,74 & 0,25 & 0,12 & 0,00 & 0,12 & 0,36 & 0,46 & 1,59 & 0,13 & 9,91 \\
\hline MB-49 & Filito & 45,34 & 26,67 & 11,09 & 0,13 & 0,47 & 0,02 & 3,05 & 0,07 & 0,11 & 1,17 & 0,08 & 11,15 \\
\hline MB-50 & Filito & 37,02 & 25,18 & 18,52 & 0,22 & 0,34 & 0,03 & 0,28 & 0,31 & 0,10 & 1,39 & 0,06 & 15,88 \\
\hline MB-51 & Filito & 36,56 & 25,08 & 18,49 & 0,35 & 1,39 & 0,09 & 0,35 & 0,33 & 0,16 & 1,03 & 0,02 & 15,68 \\
\hline MB-52 & Metabásica & 34,76 & 20,31 & 25,65 & 0,30 & 0,43 & 0,00 & 0,12 & 0,30 & 0,20 & 2,00 & 0,03 & 15,17 \\
\hline Média & metabásica & 41,48 & 21,18 & 18,20 & 0,88 & 1,19 & 0,02 & 0,85 & 0,23 & 0,22 & 1,73 & 0,06 & 13,34 \\
\hline Média & metassiltito & 55,97 & 15,76 & 15,00 & 0,30 & 0,34 & 0,01 & 1,10 & 0,22 & 0,28 & 1,31 & 0,10 & 9,16 \\
\hline Média & filito & 46,16 & 23,61 & 13,27 & 0,25 & 0,46 & 0,02 & 1,29 & 0,18 & 0,16 & 1,12 & 0,06 & 12,83 \\
\hline Média & granito & 50,73 & 21,90 & 8,65 & 1,01 & 0,77 & 0,01 & 0,68 & 0,11 & 0,20 & 1,62 & 0,13 & 13,65 \\
\hline
\end{tabular}


Anexo 2 - continuação

Amostras de solo do prospecto 2 - Setor do Maciço Granítico São Francisco (análise via úmida)

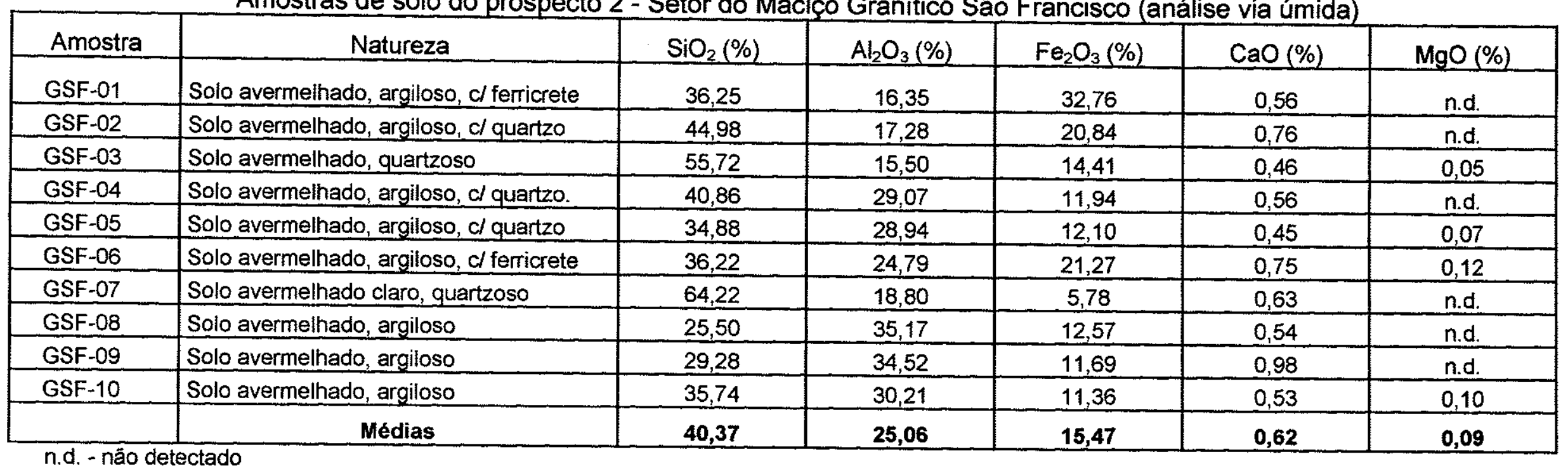

Amostras da cobertura sedimentar avermelhada (análise via úmida)

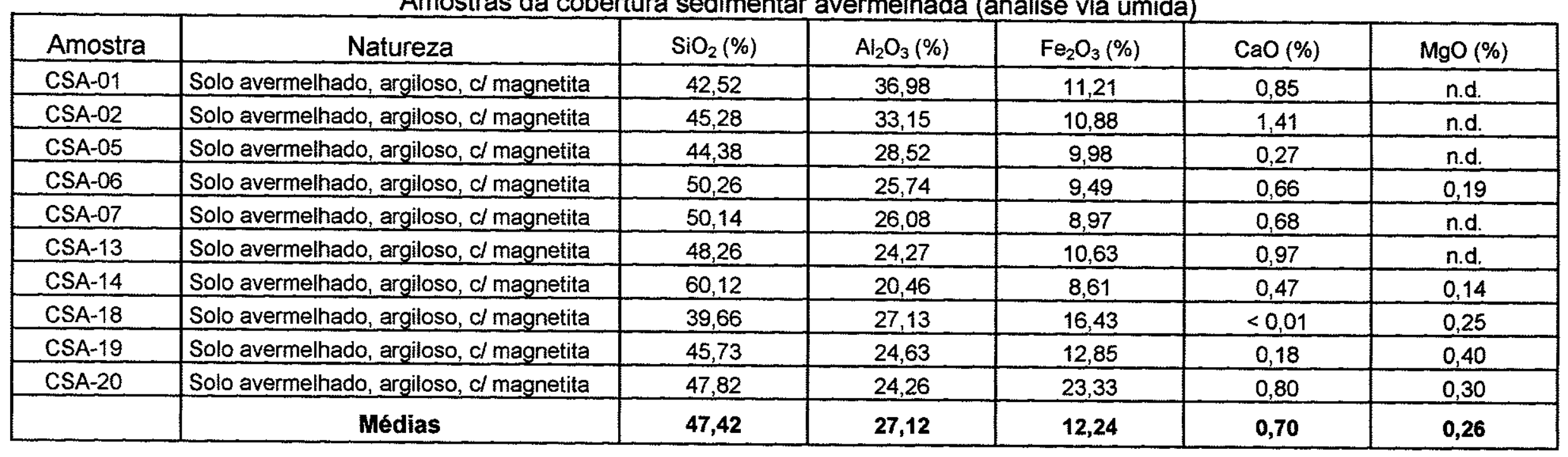


Anexo 2 - continuação

Amostras da "argila ferruginosa" do NW da Mina 1 - Salto de Pirapora (análise via úmida)

\begin{tabular}{|l|l|c|c|c|c|c|}
\hline Amostra & \multicolumn{1}{|c|}{ Natureza } & $\mathrm{SiO}_{2}(\%)$ & $\mathrm{Al}_{2} \mathrm{O}_{3}(\%)$ & $\mathrm{Fe}_{2} \mathrm{O}_{3}(\%)$ & $\mathrm{CaO}(\%)$ & $\mathrm{MgO}(\%)$ \\
\hline AFE-01 & $\begin{array}{l}\text { Solo avermelhado, areno-argiloso, cl } \\
\text { magnetita }\end{array}$ & 62,40 & 15,40 & 13,51 & 0,85 \\
\hline AFE-02 & $\begin{array}{l}\text { Solo avermelhado, areno-argiloso, cl } \\
\text { magnetita }\end{array}$ & 61,72 & 15,17 & 11,94 & 0,16 \\
\hline AFE-03 & $\begin{array}{l}\text { Solo avermelhado, areno-argiloso, cl } \\
\text { magnetita }\end{array}$ & 66,78 & 15,43 & 10,45 & 0,24 & 0,20 \\
\hline AFE-04 & $\begin{array}{l}\text { Solo avermelhado, areno-argiloso, cl } \\
\text { magnetita }\end{array}$ & 66,42 & 15,51 & 10,86 & 0,14 \\
\hline AFE-05 & $\begin{array}{l}\text { Solo avermelhado, areno-argiloso, cl } \\
\text { magnetita }\end{array}$ & 52,22 & 16,53 & 12,18 & 0,17 \\
\hline & Médias & $\mathbf{6 1 , 9 1}$ & $\mathbf{1 5 , 6 1}$ & $\mathbf{1 1 , 7 9}$ & $\mathbf{0 , 4 2}$ & 0,20 \\
\hline
\end{tabular}


ANEXO 3

RESULTADOS ANALITICOS DOS FUROS DE TRADO

NO

EXTREMO NE DA MINA 1 
ANEXO 3 - RESULTADOS ANALÍTICOS DOS FUROS DE TRADO NO EXTREMO NW DA MINA 1 (Análise por via úmida)

\begin{tabular}{|c|c|c|c|c|c|c|c|}
\hline NR & Furo trado & Amostra & $\mathrm{SiO}_{2}$ & $\mathrm{Al}_{2} \mathrm{O}_{3}$ & $\mathrm{Fe}_{2} \mathrm{O}_{3}$ & $\mathrm{CaO}$ & MgO \\
\hline 1 & $652 / 1$ & $1(0-1 \mathrm{~m})$ & 63,42 & 15,04 & 13,15 & 0,58 & 0,16 \\
\hline 2 & $652 / 1$ & $2(1-2 m)$ & 60,27 & 15,71 & 11,49 & 0,46 & 0,20 \\
\hline 3 & $652 / 1$ & $3(2-3 m)$ & 65,87 & 15,34 & 10,54 & 0,42 & 0,18 \\
\hline 4 & $652 / 1$ & $4(3-4 m)$ & 67,24 & 15,15 & 10,68 & 0,41 & 0,17 \\
\hline 5 & $652 / 1$ & $5(4-5 m)$ & 53,22 & 16,35 & 12,81 & 0,32 & 0,20 \\
\hline 6 & $652 / 1$ & $6(5-6 m)$ & 54,69 & 17,40 & 7,45 & 0,64 & 0,30 \\
\hline 7 & $652 / 1$ & $7(6-7 \mathrm{~m})$ & 71,43 & 15,78 & 4,38 & 0,30 & 0,20 \\
\hline 8 & $652 / 1$ & $8(7-8 m)$ & 71,45 & 15,53 & 5,36 & 0,69 & 0,19 \\
\hline 9 & $652 / 1$ & $9(8-9 m)$ & 48,02 & 15,86 & 16,12 & 0,27 & 0,15 \\
\hline 10 & $652 / 1$ & $10(9-10 \mathrm{~m})$ & 70,60 & 15,28 & 8,38 & 0,28 & 0,16 \\
\hline 11 & $653 / 1$ & $1(0-1 \mathrm{~m})$ & 65,15 & 14,48 & 13,93 & 0,61 & 0,12 \\
\hline 12 & $653 / 1$ & $2(1-2 m)$ & 62,52 & 14,41 & 15,89 & 0,62 & 0,10 \\
\hline 13 & $653 / 1$ & $3(2-3 m)$ & 54,27 & 15,02 & 16,67 & 0,42 & 0,11 \\
\hline 14 & $653 / 1$ & $4(3-4 m)$ & 48,65 & 15,02 & 16,67 & 0,31 & 0,11 \\
\hline 15 & $653 / 1$ & $5(4-5 m)$ & 55,02 & 15,38 & 15,42 & 0,57 & 0,15 \\
\hline 16 & $653 / 1$ & $6(5-6 m)$ & 51,75 & 16,09 & 13,54 & 0,42 & 0,18 \\
\hline 17 & $653 / 1$ & $7(6-7 \mathrm{~m})$ & 58,99 & 15,84 & 7,15 & 0,71 & 0,24 \\
\hline 18 & $653 / 1$ & $8(7-8 m)$ & 69,73 & 16,06 & 4,05 & 0,33 & 0,25 \\
\hline 19 & $653 / 1$ & $9(8-9 m)$ & 70,86 & 15,93 & 3,95 & 0,64 & 0,31 \\
\hline 20 & $653 / 1$ & $10(9-10 \mathrm{~m})$ & 66,41 & 16,55 & 4,84 & 0,30 & 0,28 \\
\hline 21 & $654 / 1$ & $1(0-1 \mathrm{~m})$ & 61,16 & 14,36 & 17.13 & 0,45 & 0,10 \\
\hline 22 & $654 / 1$ & $2(1-2 m)$ & 56,02 & 14,35 & 19,59 & 0,32 & 0,08 \\
\hline 23 & $654 / 1$ & $3(2-3 m)$ & 55,96 & 14,27 & 19,31 & 0,23 & 0,07 \\
\hline 24 & $654 / 1$ & $4(3-4 m)$ & 49,53 & 14,59 & 20,50 & 0,28 & 0,07 \\
\hline 25 & $654 / 1$ & $5(4-5 m)$ & 54,14 & 14,93 & 18,57 & 0,20 & 0,10 \\
\hline 26 & $654 / 1$ & $6(5-6 m)$ & 68,31 & 15,21 & 9,85 & 0,18 & 0,15 \\
\hline 27 & $654 / 1$ & $7(6-7 m)$ & 64,94 & 12,98 & 6,80 & 0,31 & 0,31 \\
\hline 28 & $654 / 1$ & $8(7-8 m)$ & 76,27 & 15,66 & 2,87 & 0,15 & 0,23 \\
\hline 29 & $654 / 1$ & $9(8-9 m)$ & 68,01 & 14,43 & 3,71 & 0,25 & 0,36 \\
\hline 30 & $654 / 1$ & $10(9-10 m)$ & 77,14 & 15,03 & 1,82 & 0,18 & 0,21 \\
\hline 31 & $654 / 2$ & $1(0-1 \mathrm{~m})$ & 54.93 & 15,14 & 17,18 & 1,07 & 0,13 \\
\hline 32 & $654 / 2$ & $2(1-2 m)$ & 59,12 & 14,76 & 16,68 & 0,75 & 0,11 \\
\hline 33 & $654 / 2$ & $3(2-3 m)$ & 58,27 & 14,89 & 16,82 & 0,45 & 0,09 \\
\hline 34 & $654 / 2$ & $4(3-4 m)$ & 58,62 & 15,00 & 16,47 & 0,28 & 0,09 \\
\hline 35 & $654 / 2$ & $5(4-5 m)$ & 61,39 & 15,17 & 14,29 & 0,24 & 0,11 \\
\hline 36 & $654 / 2$ & $6(5-6 m)$ & 56,51 & 16,12 & 13,06 & 0,24 & 0,16 \\
\hline 37 & $654 / 2$ & $7(6-7 m)$ & 73,26 & 15,67 & 6.21 & 0,21 & 0,16 \\
\hline 38 & $654 / 2$ & $8(7-8 m)$ & 78,82 & 15,53 & 3,82 & 0,18 & 0,18 \\
\hline 39 & $654 / 2$ & $9(8-9 m)$ & 67,45 & 14,85 & 3,91 & 0,45 & 0,37 \\
\hline 40 & $654 / 2$ & $10(9-10 \mathrm{~m})$ & 59,38 & 15,98 & 13,67 & 0,19 & 0,22 \\
\hline 41 & $655 / 2$ & $1(0-1 \mathrm{~m})$ & 53,84 & 14,72 & 17,97 & 0,31 & 0,07 \\
\hline 42 & $655 / 2$ & $2(1-2 m)$ & 51,04 & 14,82 & 19,19 & 0,36 & 0,07 \\
\hline 43 & $655 / 2$ & $3(2-3 m)$ & 52,22 & 14,88 & 19,29 & 0,63 & 0,11 \\
\hline 44 & $655 / 2$ & $4(3-4 m)$ & 51,84 & 14,81 & 19,13 & 1,31 & 0,15 \\
\hline 45 & $655 / 2$ & $5(4-5 m)$ & 54,59 & 14,71 & 19,47 & 0,73 & 0,11 \\
\hline 46 & $655 / 2$ & $6(5-6 m)$ & 54,85 & 14,80 & 18,74 & 0,31 & 0,09 \\
\hline 47 & $655 / 2$ & $7(6-7 m)$ & 53,82 & 15,07 & 18,67 & 0,31 & 0,10 \\
\hline 48 & $655 / 2$ & $8(7-8 m)$ & 58,51 & 15,00 & 15,59 & 0,35 & 0,11 \\
\hline 49 & $655 / 2$ & $9(8-9 m)$ & 60,31 & 14,98 & 14,44 & 0,26 & 0,11 \\
\hline 50 & $655 / 2$ & $10(9-10 \mathrm{~m})$ & 61,34 & 15,03 & 14,60 & 0,31 & 0,11 \\
\hline 51 & $656 / 1$ & $1(0-1 \mathrm{~m})$ & 50,87 & 15,35 & 18,25 & 0,63 & 0,12 \\
\hline 52 & $656 / 1$ & $2(1-2 m)$ & 54,42 & 14,52 & 19,99 & 0,61 & 0,08 \\
\hline
\end{tabular}


ANEXO 3 - RESULTADOS ANALITICOS DOS FUROS DE TRADO NO EXTREMO NW DA MINA 1

(Análise por via úmida)

\begin{tabular}{|c|c|c|c|c|c|c|c|}
\hline NR & Furo trado & Amostra & $\mathrm{SiO}_{2}$ & $\mathrm{Al}_{2} \mathrm{O}_{3}$ & $\mathrm{Fe}_{2} \mathrm{O}_{3}$ & $\mathrm{CaO}$ & $\mathrm{MgO}$ \\
\hline 53 & $656 / 1$ & $3(2-3 m)$ & 56,22 & 14,45 & 19,42 & 0,62 & 0,07 \\
\hline 54 & $656 / 1$ & $4(3-4 m)$ & 55,39 & 14,49 & 20,00 & 0,37 & 0,07 \\
\hline 55 & $656 / 1$ & $5(4-5 m)$ & 61,14 & 14,73 & 16,69 & 0,28 & 0,08 \\
\hline 56 & $656 / 1$ & $6(5-6 m)$ & 66,01 & 14,99 & 12,18 & 0,29 & 0,09 \\
\hline 57 & $656 / 1$ & $7(6-7 m)$ & 74,88 & 14,97 & 6,80 & 0,55 & 0,11 \\
\hline 58 & $656 / 1$ & $8(7-8 m)$ & 83,92 & 14,55 & 4,18 & 0,29 & 0,10 \\
\hline 59 & $656 / 1$ & $9(8-9 m)$ & 78,31 & 15,06 & 5,27 & 0,40 & 0,12 \\
\hline 60 & $658 / 1$ & $1(0-1 m)$ & 61,40 & 14,09 & 15,00 & 0,38 & 0,21 \\
\hline 61 & $658 / 1$ & $2(1-2 m)$ & 60,03 & 15,25 & 15,77 & 0,24 & 0,28 \\
\hline 62 & $658 / 1$ & $3(2-3 m)$ & 62,57 & 15,41 & 12,94 & 0,30 & 0,25 \\
\hline 63 & $658 / 1$ & $4(3-4 m)$ & 70,81 & 13,60 & 8,09 & 0,51 & 0,10 \\
\hline 64 & $658 / 1$ & $5(4-5 m)$ & 66,74 & 14,97 & 9.47 & 0,51 & 0,10 \\
\hline 65 & $658 / 1$ & $6(5-6 m)$ & 70,96 & 12,38 & 9,52 & 0,97 & 0,15 \\
\hline 66 & $658 / 1$ & $7(6-7 m)$ & 73,68 & 12,05 & 7,60 & 0,68 & 0,26 \\
\hline 67 & $658 / 1$ & $8(7-8 m)$ & 75,46 & 10,75 & 6,91 & 0,55 & 0,13 \\
\hline 68 & $658 / 1$ & $9(8-9 m)$ & 72,86 & 12,21 & 7,70 & 0,53 & 0,17 \\
\hline 69 & $658 / 1$ & $10(9-10 \mathrm{~m})$ & 68,76 & 12,86 & 10,24 & 0,71 & 0,41 \\
\hline 70 & $658 / 2$ & $1(0-1 \mathrm{~m})$ & 52,87 & 16,30 & 15,44 & 0,56 & 0,14 \\
\hline 71 & $658 / 2$ & $2(1-2 m)$ & 52,19 & 16,38 & 15,67 & 0,47 & 0,12 \\
\hline 72 & $658 / 2$ & $3(2-3 m)$ & 51,45 & 16,76 & 16,47 & 0,39 & 0,09 \\
\hline 73 & $658 / 2$ & $4(3-4 m)$ & 52,46 & 16,56 & 15,99 & 0,41 & 0,11 \\
\hline 74 & $658 / 2$ & $5(4-5 m)$ & 50,99 & 16,55 & 15,93 & 0,38 & 0,09 \\
\hline 75 & $658 / 2$ & $6(5-6 m)$ & 51,85 & 16,79 & 16,20 & 0,43 & 0,12 \\
\hline 76 & $658 / 2$ & $7(6-7 m)$ & 51,71 & 16,19 & 14,48 & 0,55 & 0,11 \\
\hline 77 & $658 / 2$ & $8(7-8 m)$ & 53,32 & 16,79 & 15,17 & 0,40 & 0,11 \\
\hline 78 & $658 / 2$ & $9(8-9 m)$ & 53,95 & 15,48 & 14,68 & 0,39 & 0,12 \\
\hline 79 & $658 / 2$ & $10(9-10 \mathrm{~m})$ & 53,14 & 16,62 & 15,03 & 0,40 & 0,12 \\
\hline 80 & $658 / 3$ & $1(0-1 \mathrm{~m})$ & 55,12 & 15,95 & 10,31 & 0,31 & 0,09 \\
\hline 81 & $658 / 3$ & $2(1-2 m)$ & 55,93 & 15,82 & 9,80 & 0,28 & 0,08 \\
\hline 82 & $658 / 3$ & $3(2-3 m)$ & 55,68 & 15,86 & 9,48 & 0,27 & 0,08 \\
\hline 83 & $658 / 3$ & $4(3-4 m)$ & 55,58 & 16,03 & 9,97 & 0,28 & 0,10 \\
\hline 84 & $658 / 3$ & $5(4-5 m)$ & 54,20 & 15,96 & 11,34 & 0,28 & 0,09 \\
\hline 85 & $658 / 3$ & $6(5-6 \mathrm{~m})$ & 51,26 & 18,45 & 10,02 & 0,31 & 0,13 \\
\hline 86 & $658 / 3$ & $7(6-7 \mathrm{~m})$ & 58,11 & 17,08 & 6,24 & 0,36 & 0,11 \\
\hline 87 & $658 / 3$ & $8(7-8 m)$ & 60,60 & 15,68 & 6,34 & 0,40 & 0,11 \\
\hline 88 & $658 / 3$ & $9(8-9 m)$ & 53,65 & 16,72 & 8,21 & 0,34 & 0,13 \\
\hline \multicolumn{3}{|c|}{ Médias dos furos } & 60,56 & 15,21 & 12,44 & 0,43 & 0,15 \\
\hline \multicolumn{3}{|c|}{ Desvio Padrao } & 8,42 & 1,17 & 5,16 & 0,20 & 0,07 \\
\hline
\end{tabular}


ANEXO 4

RESULTADOS ANALÍTICOS DOS FUROS DE TRADO

NO

PROSPECTO 2 
ANEXO 4 - RESULTADOS ANALITICOS DAS AMOSTRAS DOS FUROS DE TRADO NO PROSPECTO 2

(GSF 1T a 13T - via úmida; 14T a 43T - plasma ICP; teores em \%)

\begin{tabular}{|c|c|c|c|c|c|c|c|c|c|c|c|c|c|c|}
\hline Nr. Campo & Intervalo & $\mathrm{Ki}$ & $\mathrm{SiO}_{2}$ & $\mathrm{Al}_{2} \mathrm{O}_{3}$ & $\mathrm{Fe}_{2} \mathrm{O}_{3}$ & $\mathrm{CaO}$ & $\mathrm{MgO}$ & $\mathrm{K}_{2} \mathrm{O}$ & $\mathrm{MnO}_{2}$ & $\mathrm{TiO}_{2}$ & $\mathrm{P}_{2} \mathrm{O}_{5}$ & $\mathrm{Cr}_{2} \mathrm{O}_{3}$ & $\mathrm{PF}$ & SOMA \\
\hline GSF $01 T 1$ & $0-1 \mathrm{~m}$ & 2,20 & 36,02 & 16,34 & 32,96 & 0,57 & 0,00 & & & & & & 12,38 & 98,27 \\
\hline GSF $01 T 2$ & $1-2 \mathrm{~m}$ & 2,60 & 44,98 & 17,28 & 20,84 & 0,76 & 0,00 & & & & & & 10,40 & 94,26 \\
\hline GSF $01 T 3$ & $2-3 \mathrm{~m}$ & 3,59 & 55,72 & 15,50 & 14,41 & 0,46 & 0,05 & & & & & & 8,47 & 94,61 \\
\hline GSF 02T1 & $0-0,3 \mathrm{~m}$ & 0,79 & 27,97 & 35,22 & 13,20 & 0,03 & 0,10 & & & & & & 22,63 & 99,15 \\
\hline GSF $02 T 2$ & $0,3-0,6 \mathrm{~m}$ & 0,76 & 26,71 & 35,01 & 13,19 & 0,01 & 0,09 & & & & & & 22,74 & 97,75 \\
\hline GSF 02T3 & $0,6-0,9 \mathrm{~m}$ & 0,75 & 26,18 & 34,90 & 13,35 & $<0,01$ & 0,10 & & & & & & 21,71 & 96,24 \\
\hline GSF $02 T 4$ & $0,9-1,2 \mathrm{~m}$ & 0,77 & 27,38 & 35,67 & 13,44 & $<0,01$ & 0,09 & & & & & & 22,46 & 99,04 \\
\hline GSF $02 T 5$ & $1,2-1,5 \mathrm{~m}$ & 0,60 & 20,08 & 33,63 & 14,34 & 0,01 & 0,08 & & & & & & 22,02 & 90,16 \\
\hline GSF $03 T 1$ & $0-1 \mathrm{~m}$ & 1,27 & 35,94 & 28,35 & 5,99 & 0,45 & 0,00 & & & & & & 20,43 & 91,16 \\
\hline GSF 04T1 & $0-1 \mathrm{~m}$ & 1,34 & 37,06 & 27,70 & 12,50 & 0,38 & 0,01 & & & & & & 18,34 & 95,99 \\
\hline GSF $04 T 2$ & $1-2 \mathrm{~m}$ & 1,24 & 36,84 & 29,61 & 12,31 & 0,36 & 0,06 & & & & & & 16,64 & 95,82 \\
\hline GSF 05T1 & $0-1 \mathrm{~m}$ & 1,67 & 43,90 & 26,25 & 9,56 & 0,56 & 0,05 & & & & & & 15,62 & 95,94 \\
\hline GSF $05 T 2$ & $1-2 \mathrm{~m}$ & 1,79 & 44,84 & 25,03 & 10,06 & 0,92 & 0,00 & & & & & & 15,23 & 96,08 \\
\hline GSF $05 T 3$ & $2-3 \mathrm{~m}$ & 1,64 & 42,20 & 25,69 & 10,14 & 0,54 & 0,12 & & & & & & 17,27 & 95,96 \\
\hline GSF $05 T 4$ & $3.4 \mathrm{~m}$ & 2,11 & 48,01 & 22,80 & 10,54 & 0,90 & 0,00 & & & & & & 12,94 & 95,19 \\
\hline GSF 05T5 & $4-5 m$ & 4,34 & 64,68 & 14,90 & 12,23 & 0,40 & 0,03 & & & & & & 6,95 & 99,19 \\
\hline GSF $06 T 1$ & $0.1 \mathrm{~m}$ & 1,06 & 33,08 & 31,25 & 12,62 & 0,52 & 0,00 & & & & & & 19,60 & 97,07 \\
\hline GSF $06 \mathrm{~T} 2$ & $1-2 m$ & 0,91 & 29,88 & 32,87 & 12,65 & 0,48 & 0,00 & & & & & & 19,46 & 95,34 \\
\hline GSF 07T1 & $0-1 \mathrm{~m}$ & 1,50 & 41,36 & 27,56 & 11,41 & 1,06 & 0,00 & & & & & & 16,18 & 97,57 \\
\hline GSF 07T2 & $1-2 m$ & 1,45 & 41,96 & 28,88 & 11,31 & 0,45 & 0,04 & & & & & & 16,18 & 98,82 \\
\hline GSF 07T3 & $2-3 m$ & 1,43 & 40,30 & 28,21 & 11,12 & 0,37 & 0,00 & & & & & & 15,83 & 95,83 \\
\hline GSF 08T1 & $0-1 \mathrm{~m}$ & 0,88 & 29,00 & 32,96 & 12,28 & 0,50 & 0,00 & & & & & & 21,43 & 96,17 \\
\hline GSF 0812 & $1-2 m$ & 0,73 & 25,60 & 35,27 & 12,59 & 0,52 & 0,00 & & & & & & 21,63 & 95,61 \\
\hline GSF 0813 & $2-3 m$ & 0,64 & 23,40 & 36,46 & 13,46 & 0,58 & 0,26 & & & & & & 21,75 & 95,91 \\
\hline GSF 09T1 & $0-1 \mathrm{~m}$ & 1,05 & 32,39 & 30,95 & 12,72 & 0,57 & 0,00 & & & & & & 20,21 & 96,84 \\
\hline GSF 0972 & $1-2 m$ & 1,06 & 32,74 & 30,92 & 11,59 & 0,50 & 0,00 & & & & & & 19,13 & 94,88 \\
\hline GSF 09T3 & $2-3 m$ & 0,85 & 29,26 & 34,42 & 11,89 & 1,01 & 0,00 & & & & & & 19,92 & 96,50 \\
\hline GSF $10 T 1$ & $0.1 \mathrm{~m}$ & 1,32 & 37,64 & 28,54 & 11,02 & 0,45 & 0,04 & & & & & & 18,86 & 96,55 \\
\hline GSF 10T2 & $1-2 m$ & 1,19 & 35,60 & 30,01 & 11,46 & 0,54 & 0,00 & & & & & & 17,53 & 95,14 \\
\hline GSF $10 T 3$ & $2-3 m$ & 1,18 & 36,88 & 31,16 & 12,02 & 0,59 & 0,00 & & & & & & 16,55 & 97,20 \\
\hline
\end{tabular}


ANEXO 4 - RESULTADOS ANALITICOS DAS AMOSTRAS DOS FUROS DE TRADO NO PROSPECTO 2

(GSF 1T a 13T - via úmida; 14T a 43T - plasma ICP; teores em \%)

\begin{tabular}{|c|c|c|c|c|c|c|c|c|c|c|c|c|c|c|}
\hline Nr. Campo & Intervalo & $\mathrm{Ki}$ & $\mathrm{SiO}_{2}$ & $\mathrm{Al}_{2} \mathrm{O}_{3}$ & $\mathrm{Fe}_{2} \mathrm{O}_{3}$ & $\mathrm{CaO}$ & $\mathrm{MgO}$ & $\mathrm{K}_{2} \mathrm{O}$ & $\mathrm{MnO}_{2}$ & $\mathrm{TiO}_{2}$ & $\mathrm{P}_{2} \mathrm{O}_{5}$ & $\mathrm{Cr}_{2} \mathrm{O}_{3}$ & PF & SOMA \\
\hline GSF $11 T 1$ & $0-1 m$ & 3,28 & 53,40 & 16,26 & 15,98 & 0,53 & 0,00 & & & & & & 10,43 & 96,60 \\
\hline GSF $11 T 2$ & $1-2 m$ & 4,94 & 69,42 & 14,04 & 7,38 & 0,49 & 0,00 & & & & & & 6,70 & 98,03 \\
\hline GSF $12 T 1$ & $0-1 \mathrm{~m}$ & 4,10 & 64,70 & 15,78 & 7,45 & 0,49 & 0,00 & & & & & & 9,08 & 97,50 \\
\hline GSF $12 T 2$ & $1-2 m$ & 2,66 & 55,14 & 20,73 & 8,71 & 0,50 & 0,00 & & & & & & 11,42 & 96,50 \\
\hline GSF $13 T 1$ & $0.1 \mathrm{~m}$ & 2,73 & 54,82 & 20,06 & 8,77 & 0,65 & 0,00 & & & & & & 12,09 & 96,39 \\
\hline GSF 14T1 & $0.1 \mathrm{~m}$ & 1,48 & 41,38 & 28,02 & 10,34 & 0,03 & 0,13 & 0,17 & 0,02 & 1,69 & 0,09 & 0,02 & 16,94 & 98,83 \\
\hline GSF $14 T 2$ & $1-2 \mathrm{~m}$ & 1,70 & 45,37 & 26,68 & 10,21 & 0,10 & 0,10 & 0,21 & 0,02 & 1,58 & 0,26 & 0,01 & 14,77 & 99,31 \\
\hline GSF $14 T 3$ & $2.3 m$ & 3,49 & 63,32 & 18,16 & 7,23 & 0,09 & 0,08 & 0,33 & 0,01 & 0,84 & 0,16 & 0,01 & 9,24 & 99,47 \\
\hline GSF $15 T 1$ & $0.1 \mathrm{~m}$ & 1,50 & 41,73 & 27,89 & 10,43 & 0,12 & 0,12 & 0,20 & 0,02 & 1,65 & 0,21 & 0,02 & 16,94 & 99,33 \\
\hline GSF $15 T 2$ & $1-2 m$ & 1,51 & 42,37 & 28,12 & 10,31 & 0,10 & 0,11 & 0,19 & 0,02 & 1,66 & 0,16 & 0,01 & 16,19 & 99,24 \\
\hline GSF 16T1 & $0.1 \mathrm{~m}$ & NA & NA & $\mathrm{NA}$ & NA & NA & NA & NA & $\mathrm{NA}$ & NA & $\mathrm{NA}$ & NA & NA & NA \\
\hline GSF 17T1 & $0.1 \mathrm{~m}$ & 2,28 & 48,29 & 21,20 & 14,81 & 0,13 & 0,06 & 0,18 & 0,05 & 1,55 & 0,27 & 0,01 & 12,72 & 99,27 \\
\hline GSF $17 \mathrm{~T} 2$ & $1-2 m$ & 1,95 & 45,16 & 23,15 & 17,14 & 0,17 & 0,10 & 0,36 & 0,06 & 1,59 & 0,34 & 0,01 & 11,24 & 99,32 \\
\hline GSF 18T1 & $0.1 \mathrm{~m}$ & 1,39 & 39,91 & 28,63 & 10,89 & 0,12 & 0,10 & 0,13 & 0,02 & 1,69 & 0,17 & 0,02 & 17,63 & 99,31 \\
\hline GSF $18 T 2$ & $1-2 m$ & 1,31 & 38,96 & 29,78 & 10,77 & 0,16 & 0,09 & 0,14 & 0,02 & 1,76 & 0,23 & 0,02 & 17,39 & 99,32 \\
\hline GSF 19T1 & $0.1 \mathrm{~m}$ & 1,55 & 42,02 & 27,17 & 10,39 & 0,14 & 0,12 & 0,17 & 0,03 & 1,55 & 0,21 & 0,01 & 17,31 & 99,12 \\
\hline GSF $19 T 2$ & $1-2 m$ & 1,72 & 45,10 & 26,17 & 10,23 & 0,19 & 0,10 & 0,18 & 0,02 & 1,61 & 0,22 & 0,01 & 14,93 & 98,76 \\
\hline GSF $20 T 1$ & $0.1 \mathrm{~m}$ & 1,83 & 46,52 & 25,42 & 9,71 & 0,18 & 0,07 & 0,13 & 0,02 & 1,44 & 0,17 & 0,01 & 15,63 & 99,30 \\
\hline GSF $20 T 2$ & $1.2 \mathrm{~m}$ & 1,65 & 44,05 & 26,77 & 10,79 & 0,21 & 0,09 & 0,16 & 0,02 & 1,63 & 0,22 & 0,02 & 15,29 & 99,25 \\
\hline GSF $20 T 3$ & $2-3 m$ & 1,40 & 40,91 & 29,29 & 11,22 & 0,12 & 0,05 & 0,15 & 0,02 & 1,71 & 0,12 & 0,01 & 15,39 & 98,99 \\
\hline GSF 21T1 & $0-1 \mathrm{~m}$ & 1,90 & 47,94 & 25,21 & 9,51 & 0,13 & 0,09 & 0,21 & 0,01 & 1,51 & 0,15 & 0,02 & 14,47 & 99,25 \\
\hline GSF $21 T 2$ & $1.2 \mathrm{~m}$ & 1,52 & 43,31 & 28,56 & 10,46 & 0,13 & 0,10 & 0,22 & 0,02 & 1,68 & 0,12 & 0,02 & 14,72 & 99,34 \\
\hline GSF $22 T 1$ & $0.1 \mathrm{~m}$ & 2,23 & 50,70 & 22,70 & 10,17 & 0,06 & 0,10 & 0,17 & 0,01 & 1,26 & 0,28 & 0,02 & 13,93 & 99,40 \\
\hline GSF $22 \mathrm{~T} 2$ & $1-2 m$ & 1,82 & 45,85 & 25,24 & 12,25 & 0,07 & 0,09 & 0,23 & 0,01 & 1,35 & 0,17 & 0,02 & 14,15 & 99,43 \\
\hline GSF $23 T 1$ & $0.1 \mathrm{~m}$ & 1,52 & 41,95 & 27,61 & 10,59 & $<0,01$ & 0,04 & 0,12 & 0,01 & 1,55 & 0,22 & 0,02 & 17,17 & 99,28 \\
\hline GSF $23 \mathrm{~T} 2$ & $1-2 m$ & 1,64 & 44,99 & 27,46 & 10,75 & $<0,01$ & 0,03 & 0,14 & 0,01 & 1,59 & 0,22 & 0,02 & 14,17 & 99,38 \\
\hline GSF 24T1 & $0-1 \mathrm{~m}$ & 1,11 & 35,97 & 32,30 & 12,54 & $<0,01$ & 0,04 & 0,14 & 0,02 & 1,78 & 0,23 & 0,01 & 16,26 & 99,29 \\
\hline GSF $24 T 2$ & $1-2 m$ & 1,73 & 46,93 & 27,16 & 11,61 & $<0,01$ & 0,05 & 0,23 & 0,02 & 1,41 & 0,15 & 0,02 & 11,74 & 99,32 \\
\hline GSF $25 T 1$ & $0-1 \mathrm{~m}$ & 0,93 & 31,22 & 33,54 & 12,35 & $<0,01$ & 0,03 & 0,10 & 0,01 & 1,86 & 0,28 & 0,01 & 19,88 & 99,28 \\
\hline GSF $25 T 2$ & $1-2 m$ & 0,94 & 32,15 & 34,25 & 12,57 & $<0,01$ & 0,02 & 0,11 & 0,01 & 1,93 & 0,12 & 0,01 & 18,15 & 99,32 \\
\hline
\end{tabular}


ANEXO 4 - RESULTADOS ANALITICOS DAS AMOSTRAS DOS FUROS DE TRADO NO PROSPECTO 2

(GSF 1T a 13T - via úmida; 14T a 43T - plasma ICP; teores em \%)

\begin{tabular}{|c|c|c|c|c|c|c|c|c|c|c|c|c|c|c|}
\hline Nr. Campo & Intervalo & $\mathrm{Ki}$ & $\mathrm{SiO}_{2}$ & $\mathrm{Al}_{2} \mathrm{O}_{3}$ & $\mathrm{Fe}_{2} \mathrm{O}_{3}$ & $\mathrm{CaO}$ & $\mathrm{MgO}$ & $\mathrm{K}_{2} \mathrm{O}$ & $\mathrm{MnO}_{2}$ & $\mathrm{TiO}_{2}$ & $\mathrm{P}_{2} \mathrm{O}_{5}$ & $\mathrm{Cr}_{2} \mathrm{O}_{3}$ & $\mathrm{PF}$ & SOMA \\
\hline GSF $25 T 3$ & $2-3 m$ & 0,93 & 32,28 & 34,62 & 12,62 & $<0,01$ & 0,03 & 0,11 & 0,01 & 1,91 & 0,18 & 0,01 & 17,53 & 99,30 \\
\hline GSF $25 T 4$ & $3-4 m$ & 0,85 & 30,76 & 36,13 & 13,11 & $<0,01$ & 0,02 & 0,11 & 0,01 & 1,94 & 0,16 & 0,01 & 16,97 & 99,22 \\
\hline GSF $25 T 5$ & $4-5 \mathrm{~m}$ & 1,00 & 34,71 & 34,71 & 12,58 & $<0,01$ & 0,02 & 0,16 & 0,02 & 1,90 & 0,18 & 0,01 & 15,05 & 99,34 \\
\hline GSF $26 T 1$ & $0-1 \mathrm{~m}$ & 1,53 & 43,17 & 28,25 & 10,91 & $<0,01$ & 0,08 & 0,30 & 0,03 & 1,61 & 0,15 & 0,02 & 14,74 & 99,26 \\
\hline GSF 2612 & $1-2 m$ & 1,41 & 42,42 & 30,00 & 11,47 & $<0,01$ & 0,07 & 0,48 & 0,05 & 1,76 & 0,21 & 0,02 & 12,87 & 99,35 \\
\hline GSF $26 T 3$ & $2-3 m$ & NA & $\mathrm{NA}$ & NA & NA & NA & NA & NA & $\mathrm{NA}$ & NA & $\mathrm{NA}$ & $\mathrm{NA}$ & NA & NA \\
\hline GSF 27T1 & $0-1 \mathrm{~m}$ & 1,46 & 42,17 & 28,86 & 10,85 & 0,02 & 0,04 & 0,22 & 0,02 & 1,57 & 0,19 & 0,01 & 15,33 & 99,28 \\
\hline GSF $27 T 2$ & $1-2 m$ & 1,27 & 39,87 & 31,44 & 12,08 & $<0,01$ & 0,05 & 0,34 & 0,04 & 1,75 & 0,20 & 0,01 & 13,57 & 99,35 \\
\hline GSF $27 T 3$ & $2.3 m$ & 1,53 & 44,40 & 28,95 & 11,80 & $<0,01$ & 0,06 & 0,46 & 0,04 & 1,64 & 0,20 & 0,02 & 11,81 & 99,38 \\
\hline GSF $28 T 1$ & $0-1 \mathrm{~m}$ & NA & $\mathrm{NA}$ & NA & $\mathrm{NA}$ & $\mathrm{NA}$ & NA & $\mathrm{NA}$ & NA & NA & $\mathrm{NA}$ & NA & NA & NA \\
\hline GSF $29 T 1$ & $0.1 \mathrm{~m}$ & 1,06 & 34,36 & 32,34 & 11,49 & $<0,01$ & 0,04 & 0,14 & 0,02 & 1,81 & 0,18 & 0,01 & 18,87 & 99,26 \\
\hline GSF 29T2 & $1-2 m$ & 1,02 & 34,71 & 33,87 & 11,65 & $<0,01$ & 0,05 & 0,13 & 0,02 & 1,92 & 0,10 & 0,02 & 16,89 & 99,36 \\
\hline GSF $29 T 3$ & $2-3 m$ & 0,87 & 31,45 & 36,14 & 12,25 & $<0,01$ & 0,09 & 0,15 & 0,02 & 2,02 & 0,23 & 0,01 & 16,98 & 99,34 \\
\hline GSF $29 T 4$ & $3-4 m$ & 1,15 & 38,37 & 33,25 & 11,09 & $<0,01$ & 0,07 & 0,21 & 0,02 & 1,84 & 0,13 & 0,01 & 14,33 & 99,32 \\
\hline GSF $29 T 5$ & $4-5 m$ & 1,35 & 41,78 & 30,92 & 12,08 & $<0,01$ & 0,04 & 0,46 & 0,04 & 1,77 & 0,19 & 0,01 & 12,04 & 99,33 \\
\hline GSF $30 T 1$ & $0.1 \mathrm{~m}$ & NA & $\mathrm{NA}$ & NA & NA & $\mathrm{NA}$ & NA & NA & $\mathrm{NA}$ & NA & $\mathrm{NA}$ & NA & NA & NA \\
\hline GSF $31 T 1$ & $0-1 \mathrm{~m}$ & 1,38 & 39,41 & 28,64 & 10,84 & $\geq 0,01$ & 0,04 & 0,13 & 0,01 & 1,55 & 0,22 & 0,01 & 18,40 & 99,25 \\
\hline GSF $31 T 2$ & $1-2 m$ & 1,33 & 39,27 & 29,42 & 12,47 & 0,10 & 0,03 & 0,12 & 0,03 & 1,54 & 0,12 & 0,02 & 16,16 & 99,28 \\
\hline GSF $31 T 3$ & $2-3 m$ & 1,20 & 36,17 & 30,09 & 14,59 & $<0,01$ & 0,02 & 0,14 & 0,06 & 1,56 & 0,13 & 0,01 & 16,50 & 99,27 \\
\hline GSF $32 T 1$ & $0-1 \mathrm{~m}$ & 1,20 & 37,03 & 30,79 & 11,10 & $<0,01$ & 0,02 & 0,10 & 0,02 & 1,76 & 0,20 & 0,02 & 18,20 & 99,24 \\
\hline GSF $32 T 2$ & $1.2 \mathrm{~m}$ & 1,16 & 36,51 & 31,60 & 11,59 & 0,04 & 0,03 & 0,15 & 0,02 & 1,83 & 0,22 & 0,01 & 17,25 & 99,25 \\
\hline GSF $32 T 3$ & $2-3 m$ & 1,09 & 35,52 & 32,52 & 11,77 & 0,04 & 0,04 & 0,14 & 0,02 & 1,84 & 0,16 & 0,01 & 17,19 & 99,25 \\
\hline GSF $32 T 4$ & $3-4 m$ & 1,08 & 34,33 & 31,90 & 14,82 & $<0,01$ & 0,04 & 0,16 & 0,02 & 1,77 & 0,12 & 0,01 & 16,07 & 99,24 \\
\hline GSF $33 T 1$ & $0.1 \mathrm{~m}$ & 0,93 & 31,23 & 33,72 & 11,78 & $<0,01$ & 0,04 & 0,09 & 0,02 & 1,93 & 0,28 & 0,01 & 20,14 & 99,24 \\
\hline GSF $33 T 2$ & $1-2 m$ & 0,99 & 33,48 & 33,81 & 11,85 & $<0,01$ & 0,03 & 0,12 & 0,01 & 1,92 & 0,19 & 0,01 & 17,80 & 99,22 \\
\hline GSF $33 T 3$ & $2-3 m$ & 0,98 & 33,83 & 34,41 & 11,75 & $<0,01$ & 0,03 & 0,12 & 0,02 & 1,99 & 0,22 & 0,01 & 16,94 & 99,32 \\
\hline GSF $33 T 4$ & $3.4 \mathrm{~m}$ & 0,85 & 30,97 & 36,49 & 12,22 & $<0,01$ & 0,02 & 0,12 & 0,02 & 2,08 & 0,11 & 0,01 & 17,27 & 99,31 \\
\hline GSF $33 T 5$ & $4-5 m$ & 0,92 & 32,75 & 35,51 & 11,94 & $<0,01$ & 0,03 & 0,11 & 0,02 & 2,11 & 0,09 & 0,01 & 16,84 & 99,41 \\
\hline GSF 33T6 & $5-6 m$ & 1,12 & 37,55 & 33,50 & 11,13 & $<0,01$ & 0,05 & 0,13 & 0,02 & 1,93 & 0,20 & 0,01 & 14,83 & 99,35 \\
\hline GSF $34 T 1$ & $0-1 \mathrm{~m}$ & 1,15 & 36,21 & 31,59 & 11,33 & $<0,01$ & 0,02 & 0,10 & 0,02 & 1,83 & 0,25 & 0,01 & 17,96 & 99,32 \\
\hline
\end{tabular}


ANEXO 4 - RESULTADOS ANALITICOS DAS AMOSTRAS DOS FUROS DE TRADO NO PROSPECTO 2

(GSF 1T a 13T - via úmida; 14T a 43T - plasma ICP; teores em \%)

\begin{tabular}{|c|c|c|c|c|c|c|c|c|c|c|c|c|c|c|}
\hline Nr. Campo & Intervalo & $\mathrm{Ki}$ & $\mathrm{SiO}_{2}$ & $\mathrm{Al}_{2} \mathrm{O}_{3}$ & $\mathrm{Fe}_{2} \mathrm{O}_{3}$ & $\mathrm{CaO}$ & $\mathrm{MgO}$ & $\mathrm{K}_{2} \mathrm{O}$ & $\mathrm{MnO}_{2}$ & $\mathrm{TiO}_{2}$ & $\mathrm{P}_{2} \mathrm{O}_{5}$ & $\mathrm{Cr}_{2} \mathrm{O}_{3}$ & $\mathrm{PF}$ & SOMA \\
\hline GSF $34 T 2$ & $1-2 m$ & 1,10 & 36,02 & 32,61 & 11,61 & $<0,01$ & 0,05 & 0,11 & 0,02 & 1,89 & 0,21 & 0,01 & 16,79 & 99,32 \\
\hline GSF $34 T 3$ & $2-3 m$ & 0,97 & 33,65 & 34,73 & 12,09 & $<0,01$ & 0,03 & 0,12 & 0,02 & 1,93 & 0,14 & 0,01 & 16,55 & 99,27 \\
\hline GSF $34 T 4$ & $3-4 m$ & 0,94 & 32,97 & 35,00 & 12,15 & $<0,01$ & 0,03 & 0,11 & 0,02 & 1,91 & 0,18 & 0,01 & 16,87 & 99,25 \\
\hline GSF $34 T 5$ & $4.5 \mathrm{~m}$ & 0,92 & 32,70 & 35,62 & 12,37 & $<0,01$ & 0,02 & 0,11 & 0,02 & 1,94 & 0,21 & 0,02 & 16,27 & 99,28 \\
\hline GSF $34 T 6$ & $5.6 \mathrm{~m}$ & 1,01 & 35,29 & 34,79 & 12,09 & $<0,01$ & 0,03 & 0,16 & 0,02 & 1,93 & 0,17 & 0,01 & 14,86 & 99,35 \\
\hline GSF 34T7 & $6-7 \mathrm{~m}$ & 1,41 & 43,35 & 30,65 & 10,89 & $<0,01$ & 0,03 & 0,27 & 0,03 & 1,68 & 0,01 & 0,01 & 12,44 & 99,36 \\
\hline GSF $34 T 8$ & $7-8 m$ & 1,51 & 44,64 & 29,53 & 11,32 & $<0,01$ & 0,04 & 0,38 & 0,05 & 1,64 & 0,18 & 0,01 & 11,56 & 99,35 \\
\hline GSF $34 T 9$ & $8.9 \mathrm{~m}$ & 1,48 & 43,75 & 29,62 & 12,12 & $<0,01$ & 0,06 & 0,46 & 0,05 & 1,72 & 0,21 & 0,01 & 11,36 & 99,36 \\
\hline GSF 34 T 10 & $9.10 m$ & 1,67 & 46,80 & 28,04 & 11,37 & $<0,01$ & 0,05 & 0,40 & 0,04 & 1,65 & 0,15 & 0,01 & 10,86 & 99,37 \\
\hline GSF $34 T 11$ & $10-10,5 \mathrm{~m}$ & 2,92 & 59,00 & 20,23 & 10,51 & $<0,01$ & 0,03 & 0,37 & 0,03 & 1,18 & 0,23 & 0,02 & 7,80 & 99,40 \\
\hline GSF $35 T 1$ & $0.1 \mathrm{~m}$ & 1,19 & 37,19 & 31,18 & 10,65 & $<0,01$ & 0,03 & 0,09 & 0,01 & 1,78 & 0,07 & 0,01 & 18,39 & 99,40 \\
\hline GSF $35 T 2$ & $1-2 m$ & 1,14 & 36,87 & 32,37 & 11,01 & $<0,01$ & 0,03 & 0,13 & 0,01 & 1,82 & 0,18 & 0,01 & 16,96 & 99,39 \\
\hline GSF $35 T 3$ & $2-3 m$ & 1,09 & 36,46 & 33,40 & 11,05 & $<0,01$ & 0,03 & 0,14 & 0,01 & 1,84 & 0,04 & 0,01 & 16,38 & 99,36 \\
\hline GSF $35 T 4$ & $3-4 m$ & 2,99 & 30,97 & 36,49 & 12,22 & $<0,01$ & 0,02 & 0,12 & 0,02 & 2,08 & 0,11 & 0,01 & 17,27 & 99,31 \\
\hline GSF $35 T 5$ & $4-5 m$ & 1,06 & 36,30 & 34,25 & 10,84 & $<0,01$ & 0,02 & 0,13 & 0,02 & 1,95 & 0,29 & 0,02 & 15,67 & 99,49 \\
\hline GSF $35 T 6$ & $5-6 m$ & 1,43 & 43,66 & 30,52 & 10,43 & $<0,01$ & 0,03 & 0,22 & 0,02 & 1,71 & 0,20 & 0,01 & 12,64 & 99,44 \\
\hline GSF $35 T 7$ & $6-7 \mathrm{~m}$ & 1,44 & 43,72 & 30,30 & 11,35 & $<0,01$ & 0,06 & 0,42 & 0,04 & 1,73 & 0,19 & 0,01 & 11,58 & 99,40 \\
\hline GSF $35 T 8$ & $7-8 \mathrm{~m}$ & 1,57 & 45,29 & 28,87 & 11,22 & $<0,01$ & 0,06 & 0,45 & 0,04 & 1,70 & 0,09 & 0,01 & 11,68 & 99,41 \\
\hline GSF $35 T 9$ & $8-9 m$ & 1,65 & 46,31 & 28,06 & 11,12 & $<0,01$ & 0,08 & 0,50 & 0,04 & 1,70 & 0,28 & 0,01 & 11,32 & 99,42 \\
\hline GSF $35 T 10$ & $9-10 m$ & 1,70 & 47,36 & 27,85 & 11,07 & $<0,01$ & 0,07 & 0,53 & 0,04 & 1,66 & 0,23 & 0,01 & 10,60 & 99,42 \\
\hline GSF $35 T 11$ & $10-10,5 \mathrm{~m}$ & 1,75 & 47,59 & 27,21 & 11,35 & $<0,01$ & 0,08 & 0,55 & 0,03 & 1,64 & 0,25 & 0,01 & 10,74 & 99,45 \\
\hline GSF $36 T 1$ & $0.1 \mathrm{~m}$ & 1,49 & 41,21 & 27,63 & 10,27 & $<0,01$ & 0,08 & 0,14 & 0,02 & 1,52 & 0,03 & $<0,01$ & 18,37 & 99,27 \\
\hline GSF $36 \mathrm{~T} 2$ & $1-2 m$ & 1,45 & 41,33 & 28,57 & 10,84 & 0,05 & 0,12 & 0,16 & 0,02 & 1,54 & 0,15 & $<0,01$ & 16,30 & 99,08 \\
\hline GSF $36 T 3$ & $2-3 m$ & 1,23 & 38,33 & 31,13 & 11,39 & $<0,01$ & 0,08 & 0,16 & 0,01 & 1,72 & $-0,01$ & $<0,01$ & 16,12 & 98,93 \\
\hline GSF $36 T 4$ & $3-4 m$ & 1,20 & 38,07 & 31,65 & 11,42 & $<0,01$ & 0,05 & 0,14 & 0,02 & 1,70 & 0,02 & $<0,01$ & 16,25 & 99,32 \\
\hline GSF $36 T 5$ & $4-5 \mathrm{~m}$ & 2,59 & 44,34 & 29,32 & 11,30 & 0,05 & 0,07 & 0,31 & 0,02 & 1,63 & 0,02 & $<0,01$ & 13,88 & 100,94 \\
\hline GSF $36 T 6$ & $5.6 m$ & 1,57 & 45,16 & 28,85 & 10,72 & $<0,01$ & 0,08 & 0,26 & 0,02 & 1,50 & 0,11 & 0,01 & 12,39 & 99,10 \\
\hline GSF $37 T 1$ & $0.1 \mathrm{~m}$ & 3,56 & 58,45 & 16,41 & 13,10 & $<0,01$ & 0,05 & 0,19 & $<0,01$ & 0,68 & 0,03 & $<0,01$ & 10,41 & 99,32 \\
\hline GSF $37 T 2$ & $1-2 m$ & 3,06 & 54,27 & 17,71 & 17,05 & $<0,01$ & 0,04 & 0,24 & $<0,01$ & 0,70 & 0,14 & $<0,01$ & 9,60 & 99,75 \\
\hline GSF $37 T 3$ & $2-3 m$ & 3,69 & 66,33 & 18,00 & 6,06 & $<0,01$ & 0,05 & 0,29 & $<0,01$ & 0,44 & $<0,01$ & $<0,01$ & 7,89 & 99,06 \\
\hline
\end{tabular}


ANEXO 4 - RESULTADOS ANALITICOS DAS AMOSTRAS DOS FUROS DE TRADO NO PROSPECTO 2 (GSF 1T a 13T - via úmida; 14T a 43T - plasma ICP; teores em \%)

\begin{tabular}{|c|c|c|c|c|c|c|c|c|c|c|c|c|c|c|}
\hline Nr. Campo & Intervalo & $\mathrm{Ki}$ & $\mathrm{SiO}_{2}$ & $\mathrm{Al}_{2} \mathrm{O}_{3}$ & $\mathrm{Fe}_{2} \mathrm{O}_{3}$ & $\mathrm{CaO}$ & $\mathrm{MgO}$ & $\mathrm{K}_{2} \mathrm{O}$ & $\mathrm{MnO}_{2}$ & $\mathrm{TiO}_{2}$ & $\mathrm{P}_{2} \mathrm{O}_{5}$ & $\mathrm{Cr}_{2} \mathrm{O}_{3}$ & $\mathrm{PF}$ & SOMA \\
\hline GSF $38 \mathrm{~T} 1$ & $0-1 \mathrm{~m}$ & 2,77 & 57,16 & 20,63 & 8,48 & $<0,01$ & 0,04 & 0,13 & 0,10 & 0,96 & 0,17 & $<0,01$ & 11,51 & 99,18 \\
\hline GSF $38 T 2$ & $1-2 m$ & 2,65 & 55,82 & 21,07 & 10,30 & $<0,01$ & 0,05 & 0,16 & $<0,01$ & 0,97 & 0,07 & $<0,01$ & 10,49 & 98,93 \\
\hline GSF $38 T 3$ & $2-3 m$ & 2,60 & 46,89 & 18,03 & 22,84 & $<0,01$ & 0,04 & 0,26 & $<0,01$ & 0,80 & $<0,01$ & $<0,01$ & 10,18 & 99,04 \\
\hline GSF $39 T 1$ & $0.1 \mathrm{~m}$ & 1,28 & 37,66 & 29,31 & 11,04 & $<0,01$ & 0,08 & 0,12 & 0,01 & 1,60 & 0,12 & 0,01 & 19,06 & 99,01 \\
\hline GSF 3912 & $1-2 m$ & 1,49 & 42,14 & 28,23 & 9,79 & $<0,01$ & 0,03 & 0,12 & 0,01 & 1,51 & $<0,01$ & 0,01 & 17,46 & 99,30 \\
\hline GSF 3913 & $2-3 m$ & 1,30 & 39,30 & 30,34 & 10,54 & $<0,01$ & 0,07 & 0,13 & 0,01 & 1,62 & $<0,01$ & $<0,01$ & 16,93 & 98,94 \\
\hline GSF $39 T 4$ & $3-4 m$ & 1,48 & 42,27 & 28,59 & 9,53 & $<0,01$ & 0,03 & 0,12 & 0,01 & 1,50 & 0,08 & $<0,01$ & 17,25 & 99,38 \\
\hline GSF $39 T 5$ & $4.5 \mathrm{~m}$ & 1,27 & 39,31 & 30,87 & 10,34 & $<0,01$ & 0,04 & 0,13 & 0,01 & 1,62 & 0,15 & $<0,01$ & 18,56 & 101,03 \\
\hline GSF $39 T 6$ & $5.6 m$ & 1,60 & 44,17 & 27,58 & 9,28 & $<0,01$ & 0,05 & 0,13 & 0,02 & 1,43 & $<0,01$ & $<0,01$ & 16,22 & 98,88 \\
\hline GSF $39 T 7$ & $6.7 \mathrm{~m}$ & 1,77 & 48,72 & 27,60 & 7,63 & $<0,01$ & 0,08 & 0,19 & 0,01 & 1,40 & 0,07 & $<0,01$ & 13,46 & 99,16 \\
\hline GSF 40T1 & $0.1 \mathrm{~m}$ & 1,68 & 45,10 & 26,90 & 8,79 & $<0,01$ & 0,03 & 0,12 & 0,01 & 1,38 & 0,10 & $<0,01$ & 16,50 & 98,93 \\
\hline GSF 40T2 & $1-2 m$ & 1,54 & 44,03 & 28,51 & 9,30 & $<0,01$ & 0,06 & 0,16 & 0,01 & 1,47 & 0,40 & $<0,01$ & 15,06 & 99,00 \\
\hline GSF $40 T 3$ & $2-3 m$ & 1,41 & 42,04 & 29,87 & 9,80 & $<0,01$ & 0,04 & 0,13 & 0,10 & 1,54 & 0,07 & $<0,01$ & 15,50 & 99,09 \\
\hline GSF 40T4 & $3-4 m$ & 1,70 & 46,67 & 27,47 & 9,00 & $<0,01$ & 0,04 & 0,14 & 0,01 & 1,39 & 0,06 & $<0,01$ & 14,57 & 99,35 \\
\hline GSF 40T5 & $4.5 \mathrm{~m}$ & 1,95 & 50,55 & 25,98 & 8,64 & $<0,01$ & 0,05 & 0,12 & 0,02 & 1,30 & 0,03 & $<0,01$ & 12,26 & 98,95 \\
\hline GSF $40 T 6$ & $5.6 m$ & 2,11 & 52,44 & 24,82 & 9,07 & $<0,01$ & 0,07 & 0,40 & 0,03 & 1,28 & 0,02 & $<0,01$ & 11,17 & 99,30 \\
\hline GSF $40 T 7$ & $6.7 \mathrm{~m}$ & 2,13 & 51,97 & 24,44 & 9,45 & $<0,01$ & 0,07 & 0,40 & 0,04 & 1,33 & 0,01 & $<0,01$ & 11,12 & 98,83 \\
\hline GSF $40 T 8$ & $7-8 m$ & 2,34 & 53,62 & 22,93 & 9,65 & $<0,01$ & 0,08 & 0,43 & 0,04 & 1,37 & 0,15 & $<0,01$ & 11,09 & 99,36 \\
\hline GSF $40 T 9$ & $8.9 \mathrm{~m}$ & 2,68 & 56,63 & 21,12 & 8,74 & $<0,01$ & 0,08 & 0,45 & 0,03 & 1,25 & 0,01 & $<0,01$ & 10,63 & 98,94 \\
\hline GSF 41T1 & $0.1 \mathrm{~m}$ & 3,12 & 56,79 & 18,20 & 7,55 & $<0,01$ & 0,08 & 0,19 & 0,10 & 1,13 & $<0,01$ & $<0,01$ & 15,10 & 99,14 \\
\hline GSF $41 T 2$ & $1-2 m$ & 2,04 & 49,80 & 24,46 & 10,53 & $<0,01$ & 0,06 & 0,29 & 0,01 & 1,26 & $<0,01$ & $<0,01$ & 12,73 & 99,14 \\
\hline GSF $41 T 3$ & $2-3 m$ & 1,80 & 44,33 & 24,57 & 17,26 & $<0,01$ & 0,10 & 0,17 & $<0,01$ & 1,28 & $<0,01$ & 0,01 & 11,55 & 99,27 \\
\hline GSF $42 T 1$ & $0.1 \mathrm{~m}$ & 1,47 & 40,94 & 27,79 & 10,33 & $<0,01$ & 0,08 & 0,13 & 0,01 & 1,57 & 0,04 & $<0,01$ & 18,31 & 99,20 \\
\hline GSF $42 T 2$ & $1-2 m$ & 1,33 & 40,48 & 30,34 & 10,52 & 0,02 & 0,05 & 0,18 & 0,01 & 1,64 & $<0,01$ & 0,01 & 18,15 & 101,40 \\
\hline GSF $42 T 3$ & $2-3 m$ & 1,23 & 39,22 & 31,91 & 10,81 & $<0,01$ & 0,06 & 0,22 & 0,02 & 1,61 & 0,16 & $<0,01$ & 15,40 & 99,41 \\
\hline GSF $42 T 4$ & $3-4 m$ & 1,34 & 41,55 & 30,99 & 10,74 & $<0,01$ & 0,05 & 0,23 & 0,02 & 1,67 & $<0,01$ & $<0,01$ & 14,56 & 99,81 \\
\hline GSF $42 T 5$ & $4-5 m$ & 1,22 & 39,77 & 32,72 & 12,12 & 0,20 & 0,11 & 0,36 & 0,04 & 1,71 & 0,07 & 0,01 & 12,63 & 99,74 \\
\hline GSF 42T6 & $5.6 m$ & 1,86 & 53,95 & 29,03 & 11,66 & $<0,01$ & 0,09 & 0,42 & 0,05 & 1,61 & $<0,01$ & $<0,01$ & 2,05 & 98,86 \\
\hline GSF $42 T 7$ & $6-7 \mathrm{~m}$ & 1,54 & 44,94 & 29,22 & 11,86 & $<0,01$ & 0,09 & 0,49 & 0,05 & 1,61 & $<0,01$ & $<0,01$ & 11,52 & 99,78 \\
\hline GSF $42 T 8$ & $7-8 m$ & 1,54 & 44,58 & 29,02 & 11,54 & $<0,01$ & 0,11 & 0,51 & 0,05 & 1,58 & 0,19 & 0,01 & 12,16 & 99,75 \\
\hline
\end{tabular}


ANEXO 4 - RESULTADOS ANALITICOS DAS AMOSTRAS DOS FUROS DE TRADO NO PROSPECTO 2

(GSF 1T a 13T - via úmida; 14T a 43T - plasma ICP; teores em \%)

\begin{tabular}{|c|c|c|c|c|c|c|c|c|c|c|c|c|c|c|}
\hline Nr. Campo & Intervalo & $\mathrm{Ki}$ & $\mathrm{SiO}_{2}$ & $\mathrm{Al}_{2} \mathrm{O}_{3}$ & $\mathrm{Fe}_{2} \mathrm{O}_{3}$ & $\mathrm{CaO}$ & $\mathrm{MgO}$ & $\mathrm{K}_{2} \mathrm{O}$ & $\mathrm{MnO}_{2}$ & $\mathrm{TiO}_{2}$ & $\mathrm{P}_{2} \mathrm{O}_{5}$ & $\mathrm{Cr}_{2} \mathrm{O}_{3}$ & $\mathrm{PF}$ & SOMA \\
\hline GSF 42T9 & $8.9 \mathrm{~m}$ & 1,68 & 46,28 & 27,62 & 11,51 & $<0,01$ & 0,14 & 0,59 & 0,05 & 1,61 & 0,10 & 0,01 & 11,66 & 99,57 \\
\hline GSF $42 T 10$ & $9-10 m$ & 1,58 & 46,75 & 29,54 & 10,80 & $<0,01$ & 0,14 & 0,59 & 0,04 & 1,47 & 0,17 & $<0,01$ & 11,19 & 100,69 \\
\hline GSF $43 T 1$ & $0-1 \mathrm{~m}$ & 1,45 & 40,34 & 27,78 & 10,44 & $<0,01$ & 0,10 & 0,12 & 0,02 & 1,51 & $<0,01$ & 0,01 & 18,61 & 98,93 \\
\hline GSF $43 T 2$ & $1-2 m$ & 1,32 & 39,66 & 30,08 & 10,65 & $<0,01$ & 0,06 & 0,18 & 0,01 & 1,64 & 0,13 & $<0,01$ & 16,62 & 99,03 \\
\hline GSF $43 T 3$ & $2.3 \mathrm{~m}$ & 1,34 & 40,07 & 29,90 & 10,52 & $<0,01$ & 0,04 & 0,12 & 0,03 & 1,64 & 0,04 & $<0,01$ & 17,32 & 99,68 \\
\hline GSF $43 T 4$ & $3-4 m$ & 1,25 & 38,64 & 30,98 & 10,54 & $<0,01$ & 0,05 & 0,13 & 0,01 & 1,67 & 0,04 & $<0,01$ & 17,00 & 99,06 \\
\hline \multirow[t]{3}{*}{ GSF $43 T 5$} & $4.5 \mathrm{~m}$ & 1,34 & 40,08 & 29,96 & 11,18 & $<0,01$ & 0,08 & 0,14 & 0,02 & 1,62 & $<0,01$ & $<0,01$ & 15,88 & 98,96 \\
\hline & MÉDIAS & 1,58 & 42,40 & 28,92 & 11,22 & 0,11 & 0,06 & 0,22 & 0,03 & 1,60 & 0,16 & 0,01 & 14,71 & 99,33 \\
\hline & Desv pad & 0,75 & 8,66 & 5,15 & 2,77 & 0,27 & 0,04 & 0,13 & 0,02 & 0,29 & 0,08 & 0,00 & 3,58 & 1,61 \\
\hline \multicolumn{6}{|c|}{$N A=$ não analisada } & & & & & & & & & \\
\hline
\end{tabular}


ANEXO 5

RESULTADOS DA DETERMINAÇÃO DO TEOR DE AREIA POR ELUTRIAÇÃO 
ANEXO 5

RESULTADOS DA DETERMINAÇÃO DO TEOR DE AREIA POR ELUTRIAÇÃO

\begin{tabular}{|c|c|c|c|c|c|c|}
\hline & Amostra & $\begin{array}{c}\text { Peso } \\
\operatorname{seco}(g) \\
\end{array}$ & $\begin{array}{c}\text { Peso } \\
\text { areia }(g) \\
\end{array}$ & $\begin{array}{c}\% \text { areia } \\
\text { (Quartzo) }\end{array}$ & $\begin{array}{c}\mathrm{SiO}_{2}{ }^{*} \\
\text { Total }(\%)\end{array}$ & Observação \\
\hline 1 & GSF $25 \mathrm{~T} 1$ & 93,63 & 16,89 & 18,04 & 31,22 & Alvo 3 \\
\hline 2 & GSF $25 T 2$ & 93,57 & 17,89 & 19,12 & 32,15 & \\
\hline 3 & GSF $25 T 3$ & 93,39 & 12,11 & 12,97 & 32,28 & \\
\hline 4 & GSF $25 T 4$ & 93,63 & 11,69 & 12,49 & 30,76 & \\
\hline 5 & GSF 25T5 & 93,09 & 10,15 & 10,90 & 34,71 & \\
\hline 6 & GSF 28T1 & 92,99 & 29,25 & 31,45 & N. A. & solo arenoso, típico de granito \\
\hline 7 & GSF 29T1 & 93,41 & 11,15 & 11,94 & 34,36 & Alvo 2 \\
\hline 8 & GSF $29 T 2$ & 92,97 & 14,89 & 16,02 & 34,71 & \\
\hline 9 & GSF $29 T 3$ & 93,25 & 10,92 & 11,71 & 31,45 & \\
\hline 10 & GSF 29T4 & 91,02 & 10,27 & 11,28 & 38,37 & \\
\hline 11 & GSF 29T5 & 91,66 & 11,56 & 12,61 & 41,78 & \\
\hline 12 & GSF 31T1 & 332,31 & 54,05 & 16,26 & 39,41 & Alvo 1 \\
\hline 13 & GSF $31 T 2$ & 207,25 & 58,98 & 28,46 & 39,27 & \\
\hline 14 & GSF31T3 & 361,56 & 80,36 & 22,23 & 36,17 & \\
\hline 15 & GSF $32 \mathrm{~T} 1$ & 272,81 & 83,14 & 30,48 & 37,03 & \\
\hline 16 & GSF $32 T 2$ & 260,48 & 46,36 & 17,80 & 36,51 & \\
\hline 17 & GSF 32 T3 & 272,50 & 44,44 & 16,31 & 35,52 & \\
\hline 18 & GSF 32T4 & 294,93 & 53,47 & 18,13 & 34,33 & \\
\hline 19 & GSF $33 T 1$ & 202,45 & 28,05 & 13,86 & 31,23 & \\
\hline 20 & GSF $33 T 2$ & 283,93 & 36,20 & 12,75 & 33,48 & \\
\hline 21 & GSF 33 T3 & 203,57 & 29,23 & 14,36 & 33,83 & \\
\hline 22 & GSF $33 T 4$ & 265,43 & 30,75 & 11,58 & 30,97 & \\
\hline 23 & GSF 33T5 & 281,45 & 31,80 & 11,30 & 32,75 & \\
\hline 24 & GSF 33 T6 & 295,05 & 30,40 & 10,30 & 37,55 & \\
\hline 25 & GSF 34T1 & 92,93 & 16,18 & 17,41 & 36,21 & \\
\hline 26 & GSF $34 T 2$ & 91,94 & 16,07 & 17,48 & 36,02 & \\
\hline 27 & GSF $34 T 3$ & 91,73 & 13,82 & 15,07 & 33,65 & \\
\hline 28 & GSF 34T4 & 98,30 & 10,62 & 10,80 & 32,97 & \\
\hline 29 & GSF $34 T 5$ & 88,02 & 10,50 & 11,93 & 32,70 & \\
\hline 30 & GSF 34 T6 & 93,03 & 9,12 & 9,80 & 35,29 & \\
\hline 31 & GSF $34 T 7$ & 89,84 & 9,12 & 10,15 & 43,35 & \\
\hline 32 & GSF 34 T8 & 92,05 & 7,34 & 7,97 & 44,64 & \\
\hline 33 & GSF 34 T9 & 307,25 & 37,33 & 12,15 & 43,75 & \\
\hline 34 & GSF $34 \mathrm{~T} 10$ & 261,09 & 34,12 & 13,07 & 46,80 & \\
\hline 35 & GSF $34 T 11$ & 303,24 & 124,53 & 41,07 & 59,00 & fundo de furo/saprolito \\
\hline 36 & GSF 35T1 & 234,87 & 43,37 & 18,47 & 37,19 & \\
\hline 37 & GSF $35 \mathrm{~T} 2$ & 236,40 & 46,06 & 19,48 & 36,87 & \\
\hline 38 & GSF $35 T 3$ & 247,47 & 34,10 & 13,78 & 36,46 & \\
\hline 39 & GSF $35 T 4$ & 223,73 & 28,69 & 12,82 & 39,46 & \\
\hline 40 & GSF $35 T 5$ & 228,02 & 28,31 & 12,42 & 36,30 & \\
\hline 41 & GSF $35 T 6$ & 224,94 & 28,31 & 12,59 & 43,66 & \\
\hline 42 & GSF $35 T 7$ & 291,69 & 33,69 & 11,55 & 43,72 & \\
\hline 43 & GSF 35T8 & 244,50 & 28,89 & 11,82 & 45,29 & \\
\hline 44 & GSF 35T9 & 245,16 & 27,83 & 11,35 & 46,31 & \\
\hline
\end{tabular}


ANEXO 5

RESULTADOS DA DETERMINAÇÃO DO TEOR DE AREIA POR ELUTRIAÇÃO

\begin{tabular}{|c|c|c|c|c|c|c|}
\hline & Amostra & $\begin{array}{c}\text { Peso } \\
\operatorname{seco}(g)\end{array}$ & $\begin{array}{c}\text { Peso } \\
\text { areia (g) }\end{array}$ & $\begin{array}{c}\% \text { areia } \\
\text { (Quartzo) }\end{array}$ & $\begin{array}{c}\mathrm{SiO}_{2}{ }^{*} \\
\text { Total (\%) }\end{array}$ & Observação \\
\hline 1 & GSF 25T1 & 93,63 & 16,89 & 18,04 & 31,22 & Alvo 3 \\
\hline 2 & GSF 25T2 & 93,57 & 17,89 & 19,12 & 32,15 & \\
\hline 3 & GSF $25 T_{3}$ & 93,39 & 12,11 & 12,97 & 32,28 & \\
\hline 4 & GSF 25T4 & 93,63 & 11,69 & 12,49 & 30,76 & \\
\hline 5 & GSF $25 T 5$ & 93,09 & 10,15 & 10,90 & 34,71 & \\
\hline 6 & GSF 28T1 & 92,99 & 29,25 & 31,45 & N. A. & solo arenoso, típico de granito \\
\hline 7 & GSF 29T1 & 93,41 & 11,15 & 11,94 & 34,36 & Alvo 2 \\
\hline 8 & GSF 29T2 & 92,97 & 14,89 & 16,02 & 34,71 & \\
\hline 9 & GSF 29T3 & 93,25 & 10,92 & 11,71 & 31,45 & \\
\hline 10 & GSF 29T4 & 91,02 & 10,27 & 11,28 & 38,37 & \\
\hline 11 & GSF 29T5 & 91,66 & 11,56 & 12,61 & 41,78 & \\
\hline 12 & GSF $31 T 1$ & 332,31 & 54,05 & 16,26 & 39,41 & Alvo 1 \\
\hline 13 & GSF $31 T 2$ & 207,25 & 58,98 & 28,46 & 39,27 & \\
\hline 14 & GSF31T3 & 361,56 & 80,36 & 22,23 & 36,17 & \\
\hline 15 & GSF 32T1 & 272,81 & 83,14 & 30,48 & 37,03 & \\
\hline 16 & GSF $32 T 2$ & 260,48 & 46,36 & 17,80 & 36,51 & \\
\hline 17 & GSF 32 T3 & 272,50 & 44,44 & 16,31 & 35,52 & \\
\hline 18 & GSF $32 \mathrm{~T} 4$ & 294,93 & 53,47 & 18,13 & 34,33 & \\
\hline 19 & GSF 33T1 & 202,45 & 28,05 & 13,86 & 31,23 & \\
\hline 20 & GSF $33 T 2$ & 283,93 & 36,20 & 12,75 & 33,48 & \\
\hline 21 & GSF $33 T 3$ & 203,57 & 29,23 & 14,36 & 33,83 & \\
\hline 22 & GSF $33 T 4$ & 265,43 & 30,75 & 11,58 & 30,97 & \\
\hline 23 & GSF $33 T 5$ & 281,45 & 31,80 & 11,30 & 32,75 & \\
\hline 24 & GSF 33 T6 & 295,05 & 30,40 & 10,30 & 37,55 & \\
\hline 25 & GSF $34 \mathrm{~T} 1$ & 92,93 & 16,18 & 17,41 & 36,21 & \\
\hline 26 & GSF $34 \mathrm{~T} 2$ & 91,94 & 16,07 & 17,48 & 36,02 & \\
\hline 27 & GSF $34 \mathrm{T3}$ & 91,73 & 13,82 & 15,07 & 33,65 & \\
\hline 28 & GSF $34 T 4$ & 98,30 & 10,62 & 10,80 & 32,97 & \\
\hline 29 & GSF 34 T5 & 88,02 & 10,50 & 11,93 & 32,70 & \\
\hline 30 & GSF 34 T6 & 93,03 & 9,12 & 9,80 & 35,29 & \\
\hline 31 & GSF 34T7 & 89,84 & 9,12 & 10,15 & 43,35 & \\
\hline 32 & GSF 34 T8 & 92,05 & 7,34 & 7,97 & 44,64 & \\
\hline 33 & GSF 34 T9 & 307,25 & 37,33 & 12,15 & 43,75 & \\
\hline 34 & GSF $34 T 10$ & 261,09 & 34,12 & 13,07 & 46,80 & \\
\hline 35 & GSF $34 T 11$ & 303,24 & 124,53 & 41,07 & 59,00 & fundo de furo/saprolito \\
\hline 36 & GSF $35 T 1$ & 234,87 & 43,37 & 18,47 & 37,19 & \\
\hline 37 & GSF $35 T 2$ & 236,40 & 46,06 & 19,48 & 36,87 & \\
\hline 38 & GSF $35 T 3$ & 247,47 & 34,10 & 13,78 & 36,46 & \\
\hline 39 & GSF 35T4 & 223,73 & 28,69 & 12,82 & 39,46 & \\
\hline 40 & GSF 35T5 & 228,02 & 28,31 & 12,42 & 36,30 & \\
\hline 41 & GSF 35T6 & 224,94 & 28,31 & 12,59 & 43,66 & \\
\hline 42 & GSF $35 T 7$ & 291,69 & 33,69 & 11,55 & 43,72 & \\
\hline 43 & GSF 35 T8 & 244,50 & 28,89 & 11,82 & 45,29 & \\
\hline 44 & GSF 35 T9 & 245,16 & 27,83 & 11,35 & 46,31 & \\
\hline
\end{tabular}


ANEXO 5

RESULTADOS DA DETERMINAÇÃO DO TEOR DE AREIA POR ELUTRIAÇÃO

\begin{tabular}{|c|c|c|c|c|c|c|}
\hline & Amostra & $\begin{array}{c}\text { Peso } \\
\operatorname{seco}(g)\end{array}$ & $\begin{array}{c}\text { Peso } \\
\text { areia (g) }\end{array}$ & $\begin{array}{c}\% \text { areia } \\
\text { (Quartzo) }\end{array}$ & $\begin{array}{c}\mathrm{SiO}_{2}{ }^{*} \\
\text { Total }(\%)\end{array}$ & Observação \\
\hline 45 & GSF $35 T 10$ & 271,60 & 30,10 & 11,08 & 47,36 & \\
\hline 46 & GSF $35 T 11$ & 256,54 & 35,83 & 13,97 & 47,59 & \\
\hline 47 & GSF $36 \mathrm{~T} 1$ & 94,80 & 18,21 & 19,21 & 41,21 & \\
\hline 48 & GSF $36 \mathrm{~T} 2$ & 92,41 & 17,43 & 18,86 & 41,33 & \\
\hline 49 & GSF $36 \mathrm{~T} 3$ & 92,82 & 15,55 & 16,75 & 38,33 & \\
\hline 50 & GSF $36 \mathrm{~T} 4$ & 91,94 & 14,81 & 16,11 & 38,07 & \\
\hline 51 & GSF 36 T5 & 92,34 & 12,50 & 13,54 & 44,34 & \\
\hline 52 & GSF 36 T6 & 95,47 & 17,52 & 18,35 & 45,16 & \\
\hline 53 & GSF 37T1 & 104,11 & 40,33 & 38,74 & 58,45 & borda $\mathrm{N}$ do Alvo 1 \\
\hline 54 & GSF $37 T 2$ & 101,63 & 45,37 & 44,64 & 54,27 & borda $\mathrm{N}$ do Alvo 1 \\
\hline 55 & GSF $37 T 3$ & 99,41 & 42,50 & 42,75 & 66,33 & borda $\mathrm{N}$ do Alvo 1 \\
\hline 56 & GSF $38 \mathrm{~T} 1$ & 272,49 & 97,88 & 35,92 & 57,16 & borda NE do Alvo 1 \\
\hline 57 & GSF $38 T 2$ & 249,75 & 93,80 & 37,56 & 55,82 & borda NE do Alvo 1 \\
\hline 58 & GSF $38 \mathrm{~T} 3$ & 184,73 & 43,51 & 23,55 & 46,89 & borda NE do Alvo 1 \\
\hline 59 & GSF 39T1 & 277,46 & 50,85 & 18,33 & 37,66 & \\
\hline 60 & GSF 39T2 & 212,70 & 38,27 & 17,99 & 42,14 & \\
\hline 61 & GSF $39 T 3$ & 173,50 & 27,74 & 15,99 & 39,30 & \\
\hline 62 & GSF $39 \mathrm{~T} 4$ & 180,15 & 30,29 & 16,81 & 42,27 & \\
\hline 63 & GSF $39 T 5$ & 194,50 & 27,80 & 14,29 & 39,31 & \\
\hline 64 & GSF 39T6 & 161,78 & 20,40 & 12,61 & 44,17 & \\
\hline 65 & GSF $39 T 7$ & 152,29 & 23,04 & 15,13 & 48,72 & \\
\hline 66 & GSF 40T1 & 212,19 & 36,27 & 17,09 & 45,10 & \\
\hline 67 & GSF 40T2 & 145,91 & 24,86 & 17,04 & 44,03 & \\
\hline 68 & GSF $40 T 3$ & 215,78 & 25,28 & 11,72 & 42,04 & \\
\hline 69 & GSF $40 T 4$ & 149,91 & 15,21 & 10,15 & 46,67 & \\
\hline 70 & GSF 40T5 & 189,13 & 18,75 & 9,91 & 50,55 & \\
\hline 71 & GSF 40T6 & 212,33 & 17,72 & 8,35 & 52,44 & \\
\hline 72 & GSF $40 T 7$ & 160,58 & 15,00 & 9,34 & 51,97 & \\
\hline 73 & GSF 40T8 & 181,03 & 16,82 & 9,29 & 53,62 & \\
\hline 74 & GSF 40T9 & 189,36 & 20,24 & 10,69 & 56,63 & \\
\hline 75 & GSF $41 T 1$ & 92,31 & 21,04 & 22,79 & 56,79 & borda W do Alvo 1 \\
\hline 76 & GSF 41T2 & 92,80 & 20,27 & 21,84 & 49,80 & borda $W$ do Alvo 1 \\
\hline 77 & GSF 41T3 & 95,61 & 9,41 & 9,84 & 44,33 & borda $W$ do Alvo 1 ; ferricrete \\
\hline 78 & GSF 42T1 & 88,42 & 15,46 & 17,48 & 40,94 & \\
\hline 79 & GSF $42 T 2$ & 86,77 & 14,11 & 16,26 & 40,48 & \\
\hline 80 & GSF $42 \mathrm{T3}$ & 86,88 & 14,22 & 16,37 & 39,32 & \\
\hline 81 & GSF 42T4 & 89,27 & 8,72 & 9,77 & 41,55 & \\
\hline 82 & GSF 42 T5 & 91,72 & 9,05 & 9,87 & 39,77 & \\
\hline 83 & GSF 42T6 & 92,94 & 11,37 & 12,23 & 53,95 & \\
\hline 84 & GSF $42 T 7$ & 92,96 & 8,64 & 9,29 & 44,94 & \\
\hline 85 & GSF 42T8 & 93,19 & 8,76 & 9,40 & 44,58 & \\
\hline 86 & GSF 42T9 & 93,03 & 10,67 & 11,47 & 46,28 & \\
\hline 87 & GSF $42 T 10$ & 92,68 & 8,17 & 8,82 & 46,75 & \\
\hline 88 & GSF 43T1 & 153,35 & 26,02 & 16,97 & 40,34 & \\
\hline
\end{tabular}


ANEXO 5

RESULTADOS DA DETERMINAÇÃO DO TEOR DE AREIA POR ELUTRIAÇÃO

\begin{tabular}{|c|c|c|c|c|c|c|}
\hline & Amostra & $\begin{array}{c}\text { Peso } \\
\operatorname{seco}(g)\end{array}$ & $\begin{array}{c}\text { Peso } \\
\text { areia }(g)\end{array}$ & $\begin{array}{c}\% \text { areia } \\
\text { (Quartzo) }\end{array}$ & $\begin{array}{c}\mathrm{SiO}_{2}{ }^{*} \\
\text { Total (\%) }\end{array}$ & Observação \\
\hline 89 & GSF 43T2 & 214,73 & 33,43 & 15,57 & 39,66 & \\
\hline 90 & GSF 43 T3 & 216,16 & 32,68 & 15,12 & 40,07 & \\
\hline 91 & GSF $43 T 4$ & 210,81 & 29,47 & 13,98 & 38,64 & \\
\hline \multirow[t]{2}{*}{92} & GSF 4375 & 183,80 & 22,75 & 12,38 & 40,08 & \\
\hline & Médias & 169,77 & 28,15 & 16,29 & 41,94 & \\
\hline \multicolumn{6}{|c|}{ Amostra da superFicial "argila ferruginosa" da Mina 1} & \\
\hline 93 & AFE-01 & 93,79 & 29,58 & 31,54 & 62,40 & \\
\hline \multicolumn{6}{|c|}{ Amostra do saprolito do Granito São Francisco } & \\
\hline 94 & GSF 01SP & 118,23 & 66,32 & 56,09 & 69,38 & \\
\hline \multicolumn{6}{|c|}{ Amostra do furo TA-01 (0-1m) - Cobertura sedimentar avermelhad } & \\
\hline 95 & TA-01/1 & 93,37 & 19,01 & 20,36 & 43,72 & \\
\hline
\end{tabular}




\section{ANEXO 6 (A a D)}

CURVAS E TABELAS GRANULOMÉTRICAS

DA

LATERITA DO PROSPECTO 2 - SETOR DO MACIÇO GRANÍTICO SÃO FRANCISCO

ANEXOS 6A E 6B - CURVAS GRANULOMÉTRICAS DO FURO GSF 35T

ANEXO 6C - TABELA GRANULOMÉTRICA DA FRAÇÃO > $1 \mathrm{~mm}$ DO FURO GSF 42T

ANEXO 6D - CURVAS GRANULOMÉTRICAS INSTRUMENTAIS DAS AMOSTRAS DOS FUROS GSF 25T E GSF 42T 
ANEXOS 6A E 6B - CURVAS GRANULOMÉTRICAS DE AMOSTRAS DO FURO GSF 35T.

$\%$ acumulada

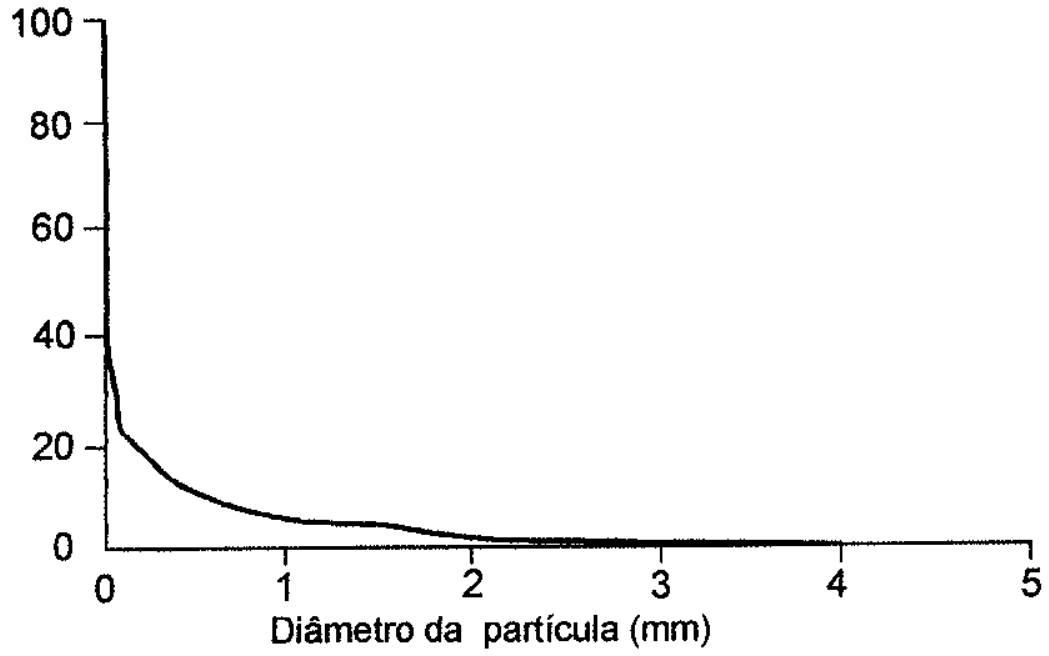

6 A -Curva granulométrica da amostra GSF $35 \mathrm{~T} 2$

$\%$ acumulada

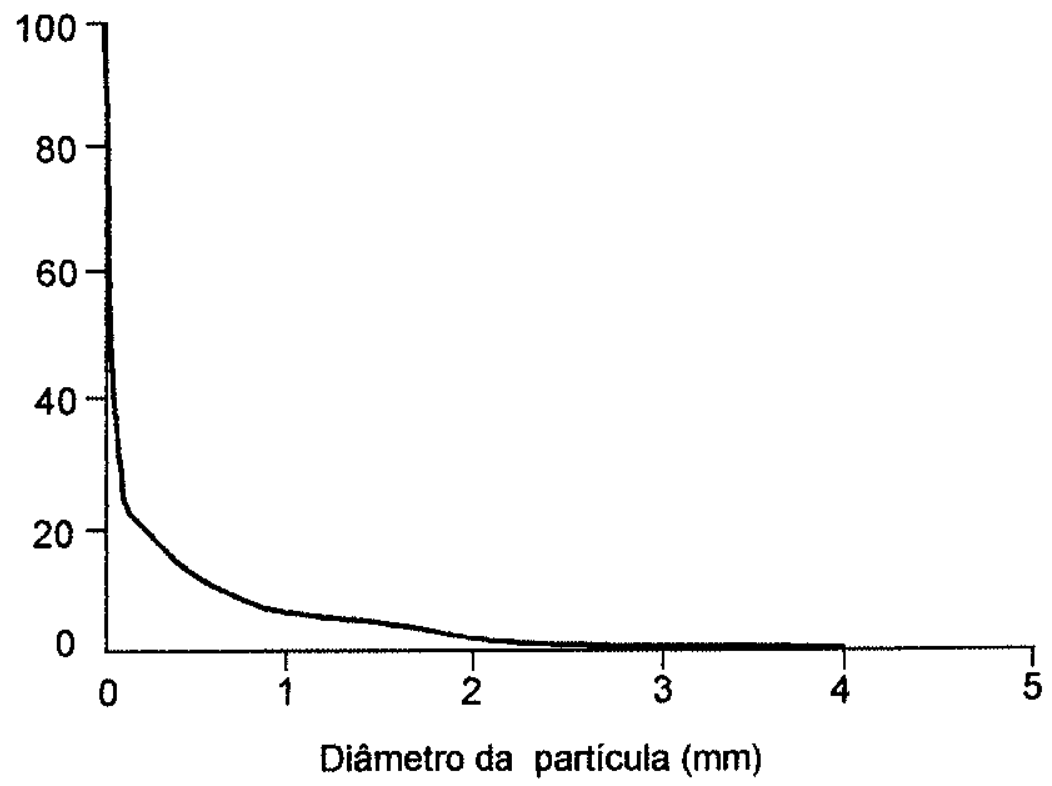

6B - Curva granulométrica de amostra composta do furo GSF 35T 
ANEXO 6C - GRANULOMETRIA DAS PARTICULAS ACIMA DE $1 \mathrm{~mm}$ NAS AMOSTRAS DO FURO GSF $42 T$

(Por peneiramento)

\begin{tabular}{|c|c|c|c|c|c|c|}
\hline Amostra & $\begin{array}{c}\text { massa }(\mathrm{g}) \\
\mathrm{D}>4 \mathrm{~mm}\end{array}$ & $\begin{array}{c}\text { massa (g) } \\
4 \mathrm{~mm}<\mathrm{D}<2,38 \mathrm{~mm}\end{array}$ & $\begin{array}{c}\text { massa (g) } \\
2,38 \mathrm{~mm}<\mathrm{D}<1,68 \mathrm{~mm}\end{array}$ & $\begin{array}{c}\text { massa (g) } \\
1,68 \mathrm{~mm}<D<1 \mathrm{~mm}\end{array}$ & $\begin{array}{c}\text { total da } \\
\text { massa> } 1 \mathrm{~mm}\end{array}$ & massa amostra \\
\hline GSF42T1 & 0,17 & 0,45 & 1,12 & 3,14 & 4,88 & $\frac{\% \text { massa amostra }}{69,91}$ \\
\hline$\%$ & $3,48 \%$ & $9,22 \%$ & $22,95 \%$ & $64,34 \%$ & $100,00 \%$ & $6,98 \%$ \\
\hline GSF42T2 & 0,31 & 0,69 & 2,01 & 6,48 & 9,49 & 128,24 \\
\hline$\%$ & $3,27 \%$ & $7,27 \%$ & $21,18 \%$ & $68,28 \%$ & $100,00 \%$ & $7,40 \%$ \\
\hline GSF 42T3 & 0,17 & 0,30 & 2,17 & 5,13 & 7,77 & 107,92 \\
\hline$\%$ & $2,19 \%$ & $3,86 \%$ & $27,93 \%$ & $66,02 \%$ & $100,00 \%$ & $7,20 \%$ \\
\hline GSF42T4 & 0,25 & 0,18 & 1,04 & 5,53 & 7,00 & 86,42 \\
\hline$\%$ & $3,57 \%$ & $2,57 \%$ & $14,86 \%$ & $79,00 \%$ & $100,00 \%$ & $8,10 \%$ \\
\hline GSF42T5 & - & 0,22 & 1,39 & 7,68 & 9,29 & 138,66 \\
\hline$\%$ & - & 2,37 & 14,96 & 82,67 & 100,00 & $6,70 \%$ \\
\hline GSF42T6 & 0,04 & 0,41 & 2,69 & 7,87 & 11,01 & 119,67 \\
\hline$\%$ & $0,36 \%$ & $3,72 \%$ & $24,43 \%$ & $71,48 \%$ & $100,00 \%$ & $9,20 \%$ \\
\hline GSF42T7 & 0,13 & 0,50 & 1,36 & 3,95 & 5,94 & 62,53 \\
\hline$\%$ & $2,19 \%$ & $8,42 \%$ & $22,90 \%$ & $66,50 \%$ & $100,00 \%$ & 9,50 \\
\hline GSF42T8 & - & 0,17 & 0,50 & 3,88 & 4,55 & 42,52 \\
\hline$\%$ & $=$ & 3,74 & 10,99 & 85,27 & $100,00 \%$ & $10,70 \%$ \\
\hline GSF42T9 & - & 0,15 & 1,15 & 4,05 & 5,35 & 42,46 \\
\hline$\%$ & - & 2,80 & 21,50 & 75,70 & $100,00 \%$ & $12,60 \%$ \\
\hline GSF 42T10 & $=$ & 0,15 & 0,74 & 4,97 & 5,86 & 43,41 \\
\hline$\%$ & - & 2,56 & 12,63 & 84,81 & $100,00 \%$ & $13,50 \%$ \\
\hline Médias (g) & 0,18 & 0,32 & 1,42 & 5,27 & 7,11 & 84,17 \\
\hline$\%$ médias & $2,51 \%$ & $4,53 \%$ & $19,92 \%$ & $74,05 \%$ & & \\
\hline$\%$ acumulada & $2,51 \%$ & $7,03 \%$ & $26,95 \%$ & $100,00 \%$ & & $8,45 \%$ \\
\hline
\end{tabular}


ANEXO 6D

CURVAS GRANULOMÉTRICAS INSTRUMENTAIS DAS AMOSTRAS DO FURO GSF 42T

(FRAÇÃO ABAIXO DE $1 \mathrm{~mm}$ ) 


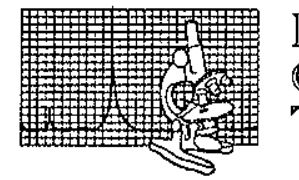

IL Laboratörio de Caracterização Tecnológica - Departamento de Engenharia de Minas $\mathbb{C}$ Escola Polltécnica da Universidade de Sāo Paulo

Av. Prof. Melo Mordes, 2373 - 05508 -900 SōoPado-SP TEL: (011) 818.5787e 818-5551. FAX (011) 818.5787

\section{EXPLICAÇÕES DOS PARÂMETROS FORNECIDOS PELO MALVERN}

\section{Dados do Equipamento Utilizado}

Equipamento:

Marca:

Principio de Funcionamento:

Medida:

Faixa ótima de operação:
Droplet and Particle Analyser

MALVERN série 2.600

difraçăo de raios laser medida por "conventional Fourier optics" distribuiçăo de particulas em volume

1 a 1.000 micrômetros precisão $\pm 4 \%$ relativos

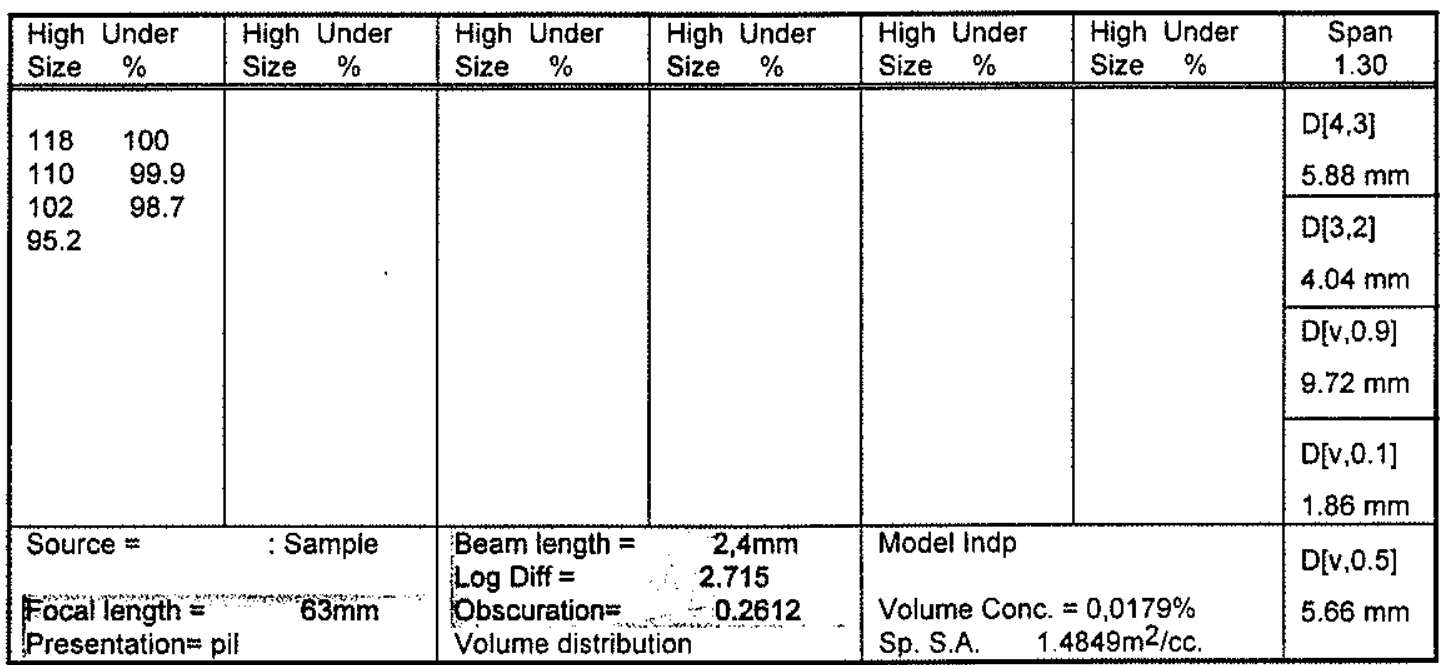

High Size

Under \%

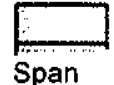

$\mathrm{D}[4,3]$

$D[3,2]$

$D[v, 0.9]$

$D[v, 0.5]$

$D[v, 0.1]$

Sp. S.A

Model Indp

Volume Conc.

Volume distribution
= limite superior do intervalo de diámetro das particulas (em micrómetros)

$=$ porcentagem passante no diámetro limite superior do intervalo

= parâmetros operacionais

$=(D[v, 0.9]+D[v, 0.1]) / D[v, 0.5]$

= média da distribuição do tamanho de particula medido pelo seu volume (em micrómetros)

= média da distribuiçăo do tamanho de particulas medido pelo sua superficie (em micrômetros)

= diâmetro (em micrómetros) no qual $90 \%$ das particulas passam (tamanho medido por volume)

= diâmetro (em micrómetros) no qual 50\% das particulas passam (tamanho medido por volume)

= diâmetro (em micrómetros) no qual 10\% das particulas passam (tamanho medido por volume)

= área de superficie especifica aparente $\mathrm{em}^{2} / \mathrm{cm}^{3}$

= modelo estatistico da distribuiçăo adotado

= concentraçăo volumétrica de particulas na suspensăo analisada (em porcentagem)

= base da distribuição granulométrica (tipo de medida = distribuição em volume) 


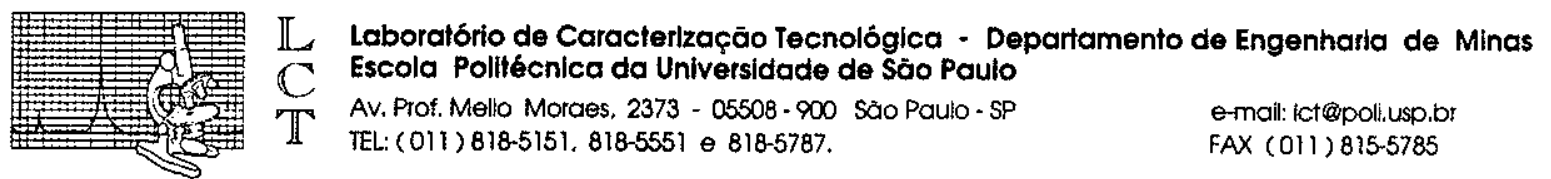

RESULTADOS DE ANÁLISE DE TAMANHO DE PARTICULLAS

Histórico: Certificado: $1225 / 99$

Sampie File: $1225-99$

Sample Path: C:ISIZERSDATAI

Amostra: AMOSTRA:GSF42T1

CLIENTE:FABRICA DE CIMENTO VOTORAN

Meio de Dispersäo: AGUA Veloc. bomba:2500

Dispersante: Ultrassom:
Medida:

Análise: Fĩ 7 de May de 1999 21:25

Fonte de Resultados: Média
Run Number: 11

Record Number: 12

Range Lens: 300RF mm
Presentation: 3TJD
Analysis Model: Polydisperse
Modifications: None
Tipo de Distributicn: Volume
Diâmetros Médios:
D $[4,3]=22.28 \mathrm{\mu m}$

Obscuration: $17.8 \%$

Residual: $1.878 \%$ $\begin{array}{ll}\text { Beam Length: } 14.30 \mathrm{~mm} & \text { Sampler: } \\ \text { [Particie R.1. }=(2.5935,1.0000) ; & \text { Dispersant R.I. }=1.3300 \text { ] }\end{array}$

Resultados Estatisticos

$\begin{array}{ll}\text { Concentracáo }=0.0013 \% \mathrm{Vol} & \text { Densidade }=2.650 \mathrm{~g} / \mathrm{cm} 3 \\ D(v, 0.1)=1.52 \mu \mathrm{m} & D(v, 0.5)=20.07 \mu \mathrm{m} \\ D(3,2]=3.73 \mu \mathrm{m} & \text { Span }=2.243 \mathrm{E}+00\end{array}$

Area Superf. Espec. $=0.6057 \mathrm{~m} 2 / \mathrm{g}$

$D(v, 0.9)=46.55 \mu \mathrm{m}$

Uniformictade $=7.130 \mathrm{E}-01$

Diam.Inferior $(\mu \mathrm{m})$ No Intervalo \% Diam.Super. $(\mu \mathrm{m})$ Acum.Abaixo \% Diam.Inferior $(\mu \mathrm{m})$ No Intervalo \% Diam.Super. $(\mu \mathrm{m})$ Acum.Abaixo \%

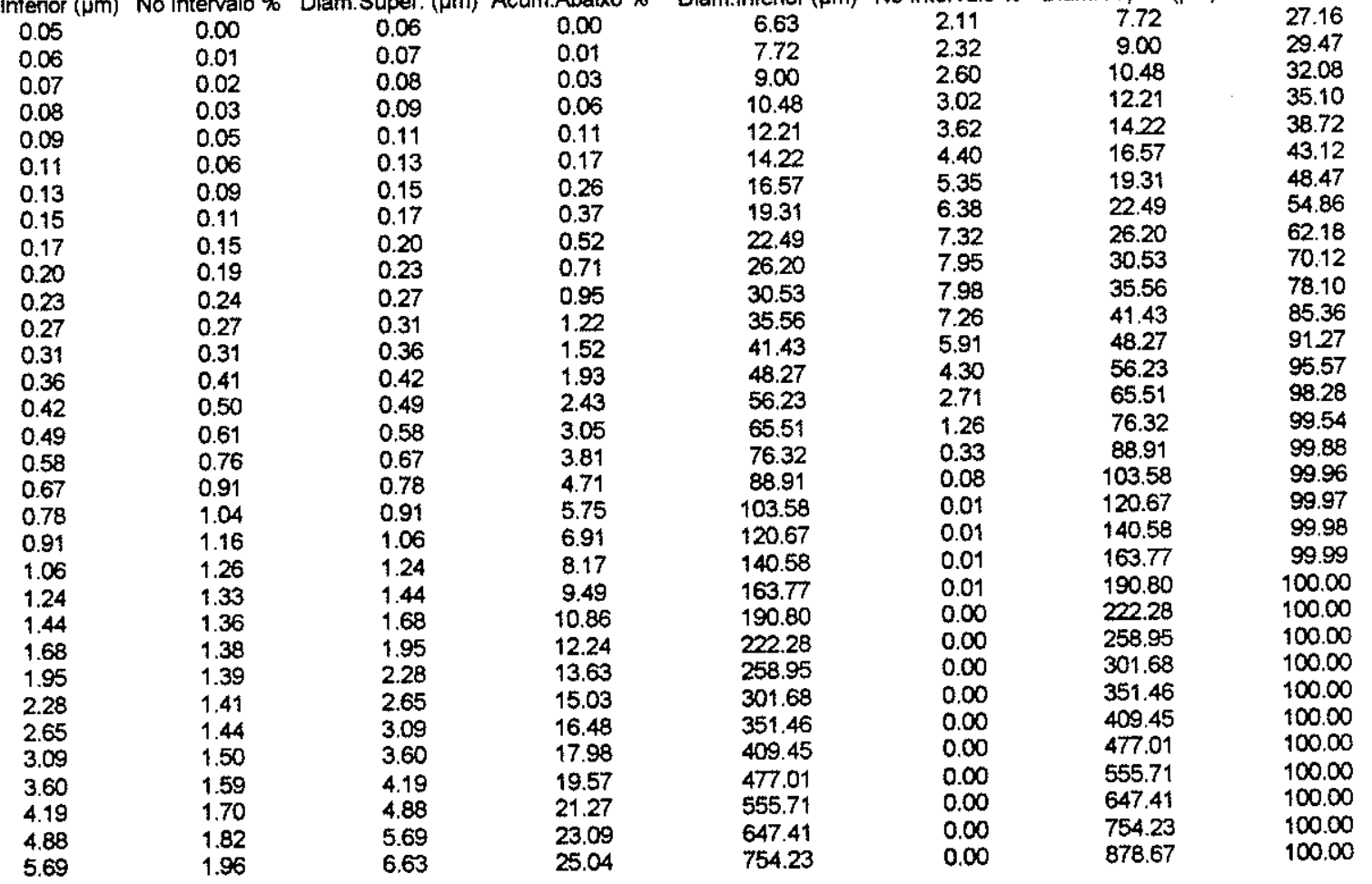

10

Volume (\%) 100

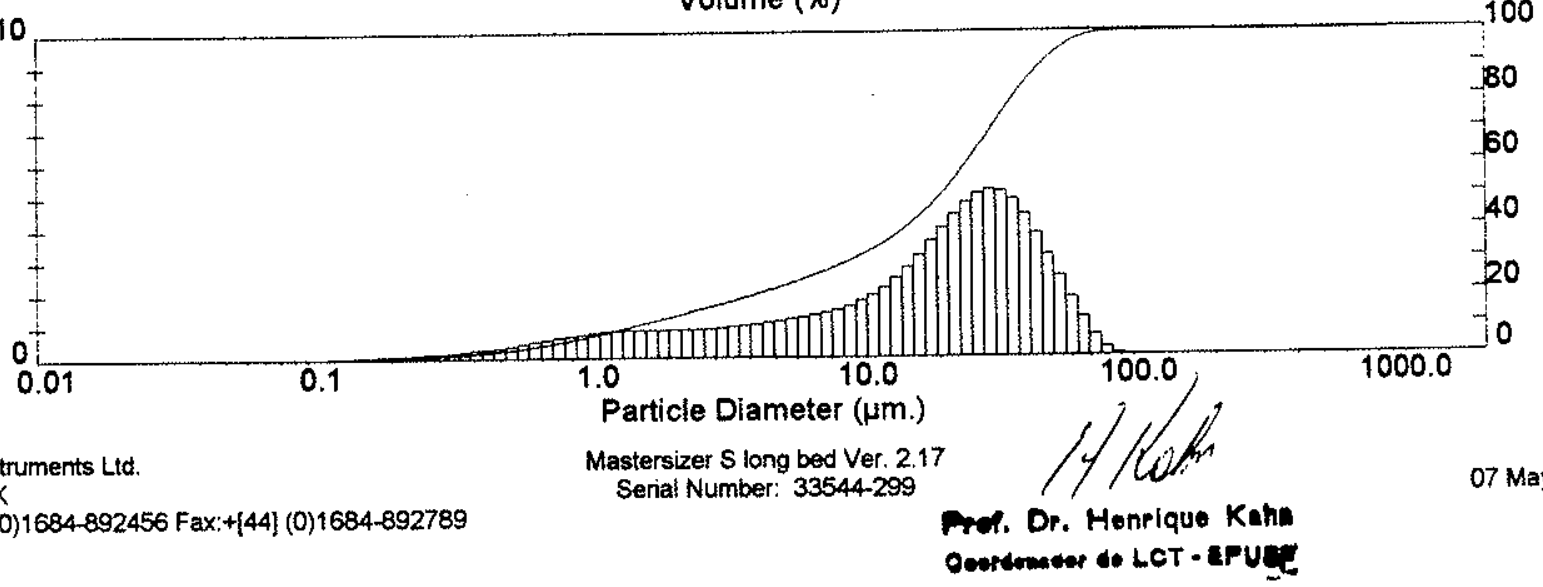

p. 10

Makvern Instruments Ltd

Malvem, UK

Tel: $=+[44](0) 1684-892456$ Fax $+\{44](0) 1684-892789$ 


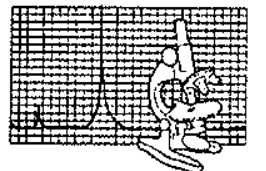

I. Laboratório de Caracterização Tecnotógica - Departamento de Engenharia de Minas (C) Escola Polltécnica da Universidade de São Paulo

TT Av. Prof. Mello Moraes, 2373 - 05508 - 900 Sáo Paulo-SP TEL: (OI1) 818-5151, 818-5551 e 818-5787.

omall: ict@poli.usp.tor FAX (011) 815-5785

\section{RESULTADOS DE ANÁLISE DE TAMANHO DE PARTÍCULAS}

Histórico: Certificado: $1226 / 99$

Sample File: $1226-99$

Sample Path: C:ISIZERSLDATAI

Amostra: AMOSTRA:GSF42T2 CLIENTE:FABRICA DE CIMENTO VOTORAN

Mejo de Dispersão: ÁGUA Veloc. bomba:2500

Dispersante:

Ultrassom:
Detalhes da Amostra

Run Number: 22

Record Number: 12
Medida:

Análise: Fri 7 de May de 1999 20:41

Fonte de Resultados: Média
Range Lens: $300 \mathrm{RF} \mathrm{mm}$ Presentation: 3TJD Analysis Model: Polydisperse

Modifications: None

Tipo de Distribution: Volume Diámetros Médios: $D[4,3\}=9.22 \mu \mathrm{m}$
Beam Length: $14.30 \mathrm{~mm}$

Detalhes do Sistema (Particle R.I. $=(2.5935,1.0000)$ i
Dispersant R.I. $=\begin{aligned} & \text { Sampler: } \\ & 1.33001\end{aligned}$
Obscuration: $12.6 \%$

Residual: $3.263 \%$
Diaminferior ( $\mu$ m) No intervalo $\%$
0.05
0.06

0.06
0.07

0.08

0.09

0.11

0.13

0.15

0.17
0.20

0.20
0.23

0.27

0.31
0.36

0.36
0.42

0.42
0.49

0.58

0.67

0.78

0.91

1.06

1.24

1.44

1.68

1.95

2.28

2.65

3.09

3.60

4.19

4.88

5.69

0.00
0.01
0.03
0.06
0.09
0.13
0.18
0.23
0.30
0.38
0.46
0.51
0.57
0.74
0.92
1.13
1.45
1.78
2.12
2.44
2.71
2.90
3.00
3.01
2.95
2.85
2.73
2.64
2.60
2.64
2.81
3.14

10

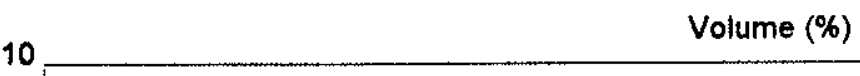

Resultados Estatisticos
Abaixo

0.00

0.05

0.11

0.20

0.33

0.50

0.74

1.03

1.41

1.87

2.38

2.95

3.69

4.61

5.74

7.20

8.98

11.10

13.53

16.24

19.14

22.13

25.14

28.08

30.93

33.66

36.30

38.90

41.54

44.35

47.48
Area Superf. Espec. $=1.1192 \mathrm{~m} 2 / \mathrm{g}$

$D(v, 0.9)=20.79 \mu \mathrm{m}$

Uniformidade $=8.994 \mathrm{E}-01$
Densidade $=2.650 \mathrm{~g} / \mathrm{cm} 3$
$D(v, 0.5)=7.38 \mu \mathrm{m}$

Span $=2.701 \mathrm{E}+00$

Diam.Super. ( $\mu \mathrm{m})$ Acum.Abaixo $\%$

Diam.Inferior $(\mu m)$ No Intervaio \% Diam.Super.

$7.72 \quad 51.14$

$\begin{array}{ll}6.63 & 3.65 \\ 7.72 & 4.37\end{array}$

9.00

10.48

12.21

14.22

16.57

19.31

22.49

26.20

30.53

35.56

41.43

48.27

56.23

65.51

76.32

88.91

103.58

120.67

140.58

163.77

190.80

222.28

258.95

301.68

351.46

409.45

477.01

555.71

647.41

754.23

5.24
6.12

6.12
6.80

7.01

6.54

5.36

3.76

2.33

1.10

0.23

0.00

0.00

0.00

0.00

0.00

0.00

0.00

0.00

0.00

0.00

0.00

0.00

0.00

0.00

0.00

0.00

0.00

0.00

0.00

9.00

12.21

12.21
14.22

16.57

19.31

22.49

26.20

30.53

35.56

41.43

48.27

56.23

65.51

76.32

88.91

103.58

120.67

140.58

163.77

190.80

222.28

258.95

301.68

351.46

409.45

477.01

555.71

647.41

754.23

0.00

878.67

55.51

66.86
73.67

80.68

87.22

92.58

96.34

98.67

99.77

100.00

100.00

100.00

100.00

100.00

100.00

100.00

100.00

100.00

100.00

100.00

100.00

100.00

100.00

100.00

100.00

100.00

100.00

100.00

100.00

100.00

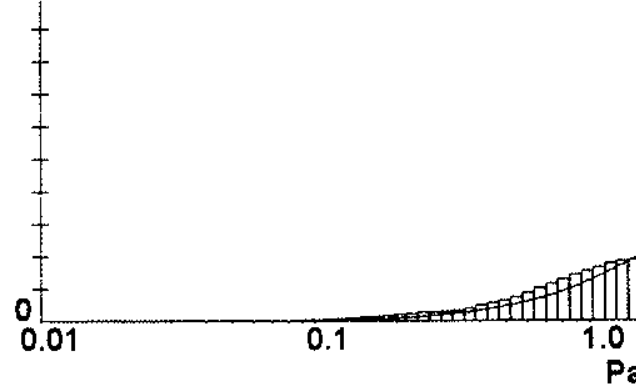

(2)

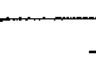

Particle Diameter ( $\mu \mathrm{m}$.

Ver. 2.17 


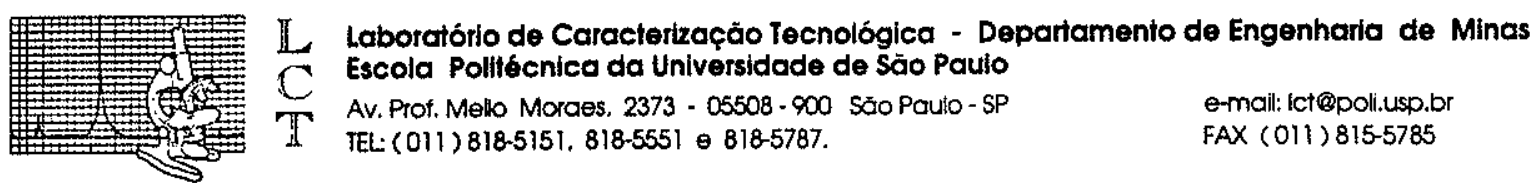

\section{RESULTADOS DE ANÁLISE DE TAMANHO DE PARTIICULAS}

\begin{tabular}{|c|c|c|}
\hline $\begin{array}{l}\text { fistórico: Certificado: } 122699 \\
\text { Sample file: } 1227-99 \\
\text { Sampie Path: C:ISIZERSDATAI }\end{array}$ & $\begin{array}{l}\text { Detalhes da Amostra } \\
\text { Run Number: } 11 \\
\text { Record Number: } 24\end{array}$ & $\begin{array}{l}\text { Medida: } \\
\text { Análise: Fri } 7 \text { de May de } 1999 \text { 21:20 } \\
\text { Fonte de Resultados: Média }\end{array}$ \\
\hline
\end{tabular}

Sampie Path: C:ISIZERSLATAI

Amostra: AMOSTRA:GSF42T3

CLIENTE:FABBRICA DE CIMENTO VOTORAN

Meio de Dispersáo: AGUA Veloc. bomba:2500

Dispersante:

Ultrassom:

Fonte de Resultados: Média

Range Lens: $300 R F \mathrm{~mm}$
Presentation: 3TJD
Aralysis Model: Polydisperse
Modifications: None

Beam Length: $14.30 \mathrm{~mm}$ Sampler: (Particle R.L. $=(2.5935,1.0000) ; \quad$ Dispersant R.I. $=1.3300$ ]

Obscuration: $24.1 \%$ Modifications: None

Tipo de Distribution: Votume

Diâmetros Médios:

$D[4,3]=12.57 \mu \mathrm{m}$

$\begin{array}{ll} & \text { Resultados Estatisticos } \\ \text { Concentracato }=0.0011 \% \text { Vol } & \text { Densidade }=2.650 \mathrm{~g} / \mathrm{cm} 3 \\ D(V, 0.1)=0.78 \mu \mathrm{m} & D(v, 0.5)=8.75 \mu \mathrm{m} \\ D[3,2]=2.23 \mu \mathrm{m} & \mathrm{Span}=3.331 \mathrm{E}+00\end{array}$

Area Superf. Espec $=1.0174 \mathrm{m2} / \mathrm{g}$

$D(v, 0.9)=20.92 \mu \mathrm{m}$

Uniformidade $=1.111 \mathrm{E}+\infty$

Diam

\begin{tabular}{|c|c|c|c|c|c|c|c|}
\hline $\begin{array}{l}\text { ferior }(\mu \mathrm{m}) \\
0.05\end{array}$ & $\begin{array}{c}\text { No intervalo } \% \\
0.00\end{array}$ & $\begin{array}{l}\text { Sham.super. } \\
0.06\end{array}$ & 0.00 & 6.63 & 2.98 & 7.72 & 47.31 \\
\hline 0.06 & 0.00 & 0.07 & 0.00 & 7.72 & 3.33 & 9.00 & 50.64 \\
\hline 0.07 & 0.00 & 0.08 & 0.00 & 9.00 & 3.78 & 10.48 & 54.42 \\
\hline 0.08 & 0.00 & 0.09 & 0.00 & 10.48 & 4.29 & 12.21 & 58.71 \\
\hline 0.09 & 0.00 & 0.11 & 0.00 & 12.21 & 4.84 & 14.22 & 63.55 \\
\hline 0.11 & 0.02 & 0.13 & 0.02 & 14.22 & 5.34 & 16.57 & 68.89 \\
\hline 0.13 & 0.04 & 0.15 & 0.07 & 16.57 & 5.70 & 19.31 & 74.59 \\
\hline 0.15 & 0.09 & 0.17 & 0.16 & 19.31 & 5.77 & 22.49 & 80.36 \\
\hline 0.17 & 0.16 & 0.20 & 0.32 & 22.49 & 5.46 & 2620 & 8582 \\
\hline 0.20 & 0.28 & 0.23 & 0.60 & 26.20 & 4.75 & 30.53 & 90.58 \\
\hline 0.23 & 0.44 & 0.27 & 1.04 & 30.53 & 3.77 & 65 & 94.55 \\
\hline 0.27 & 0.57 & 0.31 & 1.61 & 35.56 & 2.73 & का.43 & 97.08 \\
\hline 0.31 & 0.73 & 0.36 & 2.35 & 41.43 & 1.73 & 48.27 & 9880 \\
\hline 0.36 & 1.01 & 0.42 & 3.36 & 48.27 & 0.81 & 56.23 & 99.62 \\
\hline 0.42 & 1.27 & 0.49 & 4.63 & 56.23 & 0.19 & 65.51 & 99.80 \\
\hline 0.49 & 1.52 & 0.58 & 6.15 & 65.51 & 0.01 & 76.32 & 99.82 \\
\hline 0.58 & 1.85 & 0.67 & 8.00 & 76.32 & 0.01 & 88.91 & 9982 \\
\hline 0.67 & 2.11 & 0.78 & 10.11 & 88.91 & 0.01 & 103.58 & 99.84 \\
\hline 0.78 & 2.30 & 0.91 & 12.42 & 103.58 & 0.02 & 120.67 & 99.86 \\
\hline 0.91 & 2.46 & 1.06 & 14.88 & 120.67 & 0.04 & 140.58 & 99.90 \\
\hline 1.06 & 2.56 & 1.24 & 17.44 & 140.58 & 0.04 & 163.77 & 99.94 \\
\hline 1.24 & 2.50 & 4.44 & 20.04 & 163.77 & 0.03 & 190.80 & 99.97 \\
\hline 1.44 & 2.57 & 1.68 & 22.61 & 190.80 & 0.02 & 222.28 & 99.99 \\
\hline 1.68 & 2.50 & 1.95 & 25.11 & 222.28 & 0.01 & 258.95 & 100.00 \\
\hline 1.95 & 2.41 & 2.28 & 27.52 & 258.95 & 0.00 & 301.68 & 100.00 \\
\hline 2.28 & 2.34 & 2.65 & 29.86 & 301.68 & 0.00 & 351.46 & 100.00 \\
\hline 2.65 & 2.29 & 3.09 & 32.15 & 351.46 & 0.00 & 409.45 & 100.00 \\
\hline 3.09 & 2.27 & 3.60 & 34.42 & 409.45 & 0.00 & 477.01 & 100.00 \\
\hline 3.60 & 2.30 & 4.19 & 36.72 & 477.01 & 0.00 & 555.71 & 100.00 \\
\hline 4.19 & 2.38 & 4.88 & 39.10 & 555.71 & 0.00 & 647.41 & 100.00 \\
\hline 4.88 & 2.52 & 5.69 & 41.61 & 647.41 & 0.00 & 754.23 & 100.00 \\
\hline 5.69 & 2.71 & 6.63 & 44.33 & 754.23 & 0.00 & 878.67 & 100.00 \\
\hline
\end{tabular}

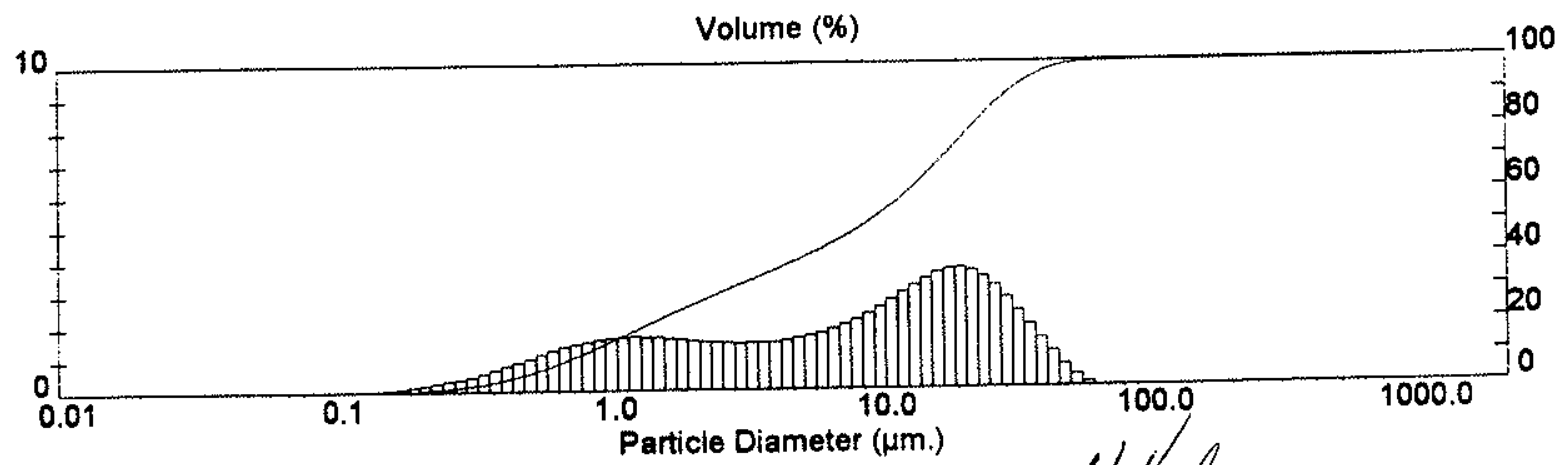

Matvem instruments Ltd.

Malvern, UK

Tel: $:+[44](0) 1684-892456$ Fax:+[44] (0)1684-892789
Particle Diameter ( $\mu \mathrm{m}$.)

Mastersizer S long bed Ver. 2.17 Serial Number: $33544-299$

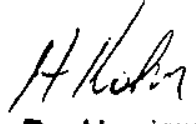

Aree. Dr. Henrique Kahs

07 May 99 p. 9 


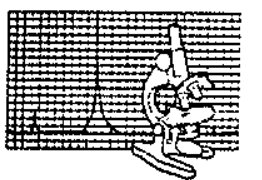

IL Laboratório de Caracterizaçăo Tecnológica - Departamento de Engenharia de Minas C Escola Polltécnica da Universidade de Sāo Paulo

TT Av. Prot. Mello Motaes, 2373 - 05508-900 Sảo Paulo-SP TEL: (011) 818-5151, 818-5551 e 818-5787.

O-mali: lct@poti.usp.br FAX (011) 815-5785

\section{RESULTADOS DE ANÁLISE DE TAMANHO DE PARTÍCULAS}

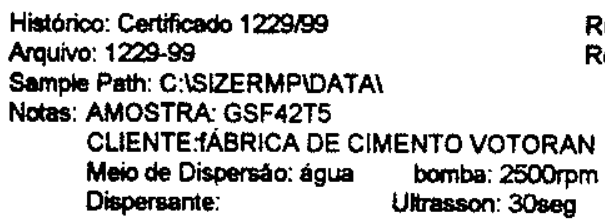

Record Number: 21
Run Number:
Medicta:

Analise: Wed 5 de May de 1999 11:43

Fonte de Resultados: Média
Sampler:

Presentation: 5 UHD

Analysis Model: Polydisperse Modifications: None

\section{Tipo de Distribuiç̧o: Volume}

Dismetros Medios:

$D[4,3]=50.70 \mu \mathrm{m}$
Resultados Estatisticos
Concentraçáo * $0.0178 \%$ Vol Densidade $=2.650 \mathrm{~g} / \mathrm{cm} 3$

$D(v, 0.1)=1.45 \mu \mathrm{m}$

$D[3,2]=4.17 \mu \mathrm{m}$ $0(v, 0.5)=1732 \mu \mathrm{m}$ Span $=8.493 E+\infty$
Detalhes do Sistema

[Particle R.1. $=(3.1255,0.1000) ; \quad$ Dispersant R.I. $=1.3300]$
Measured Beam Obscuration: $31.3 \%$

Residual: $0.305 \%$

\author{
Area Superf,Espec, $=0.5428 \mathrm{~m} 2 / \mathrm{g}$ \\ $D(v, 0.9)=148.55 \mathrm{um}$ \\ Uniformidade $=2.626 E+\infty$
}

Diam.Inferior (um) No intervalo \% Diam Super $(\mu \mathrm{m})$ Acum Abaixo\%

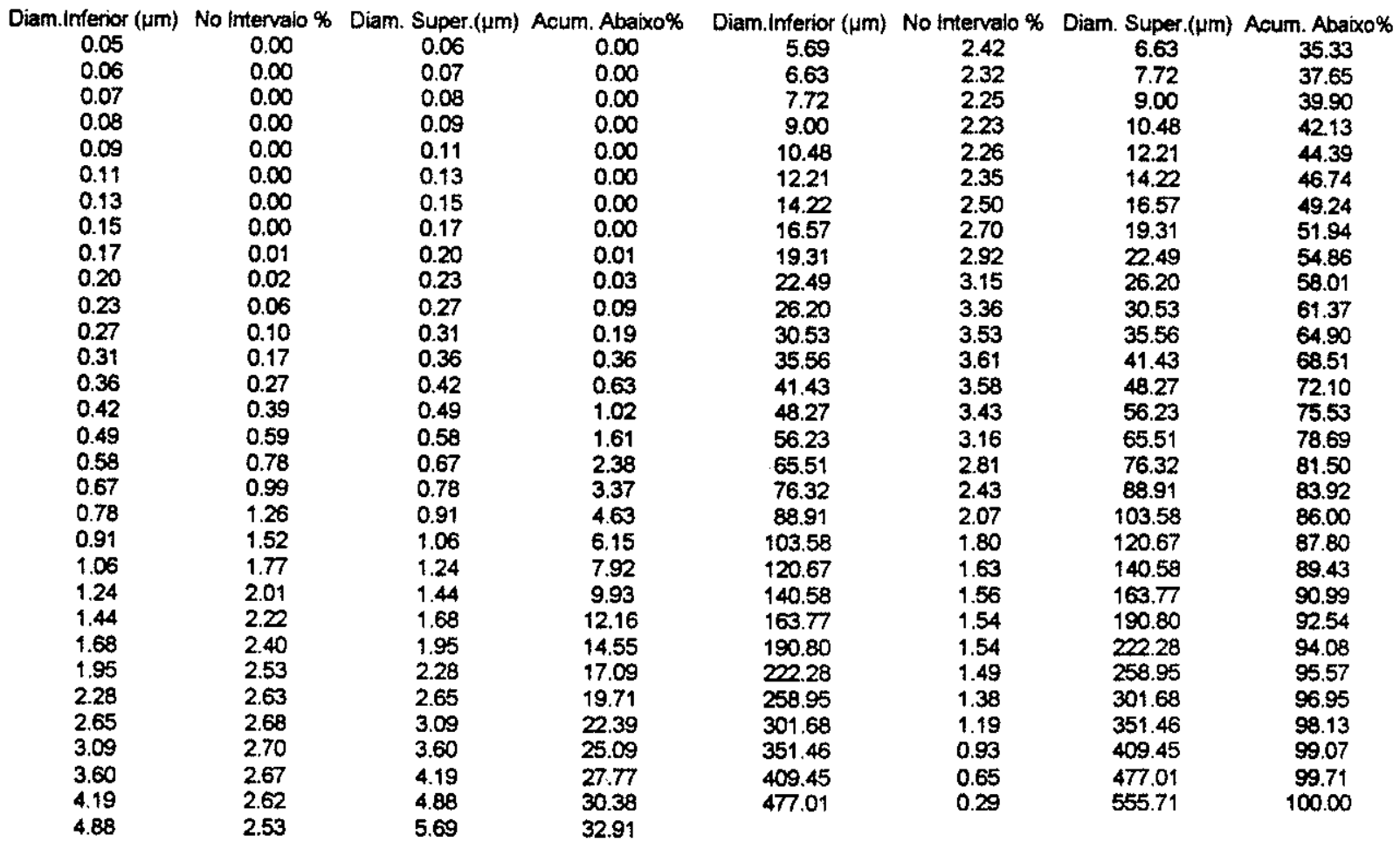

Volume (\%)

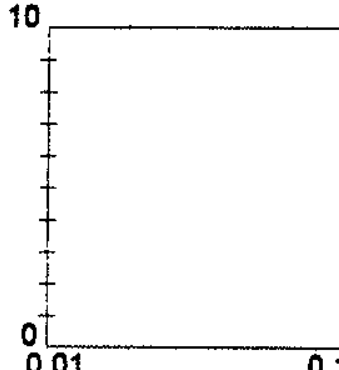
100

SAAL - South American Application Laboratory A LCT-EPUSP, Malvem and Altmann co-operation

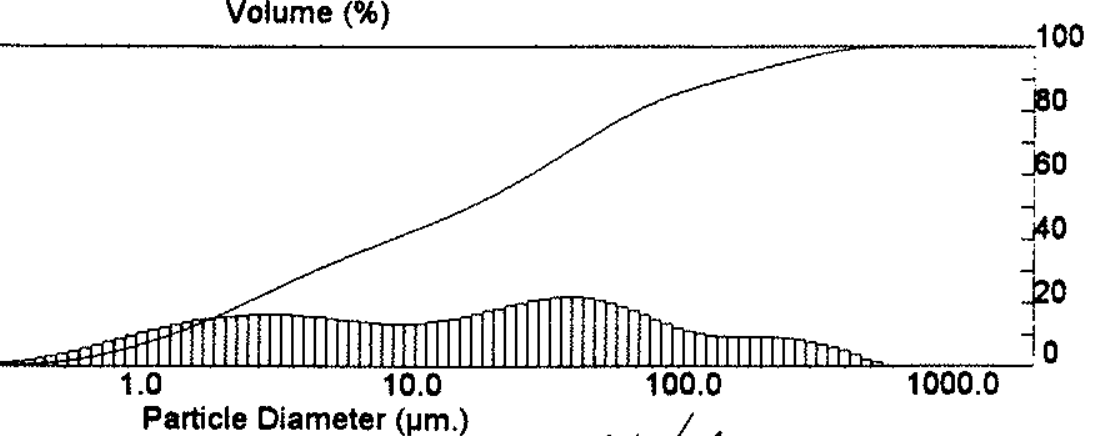




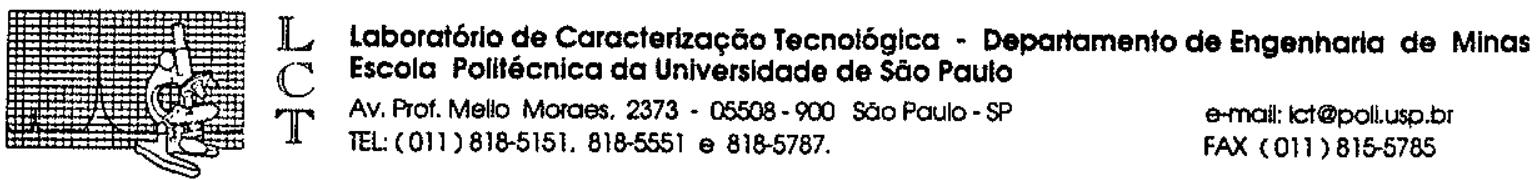

\section{RESULTADOS DE ANÁLISE DE TAMANHO DE PARTICULAS}

Historico: Certificado 123099
Arquivo: 1230-99
Sample Path: C:LIZIERMPLATAI
Notas: AMOSTRA: GSF42T6
CLIENTE:AABRICA DE CIMENTO VOTORAN
Meio de Dispersáo: água bomba: 2500rpm
Dispersante:

Detaines da Amostra

coord Number: 14
Medida:

Andilise: Wed 5 de May de 1999 12:50

Fonte de Resultados: Média
Sampler:

Presentation: 5UHD

Analysis Model: Polydisperse Modifications: None

Tipo de Distribuiçăo: Volume

Diametros Médios:

$D[4,3]=41.06 \mu \mathrm{m}$

\section{Detalhes do Sistema}

Particle R.I. $=(3.1255,0.1000) ; \quad$ Dispersant R.I $=1.3300]$

Concentracăo $=0.0151 \% \mathrm{Vd} \quad$ Densidade $=2.650 \mathrm{~g} / \mathrm{cm} 3$

$D(v, 0.1)=1.50 \mu \mathrm{m} \quad D(v, 0.5)=21.96 \mu \mathrm{m}$

$D[3,2]=4.52 \mu \mathrm{m}$
Span $=4.364 E+00$
Measured Beam Obscuration: $24.1 \%$

Residual: $0.497 \%$

Diam.Inferior ( $\mu \mathrm{m})$ No Intervalo \% Diam. Super.(um) Acum. Abaixo\% Unitomiciade $=1.555 \mathrm{E}+\infty$

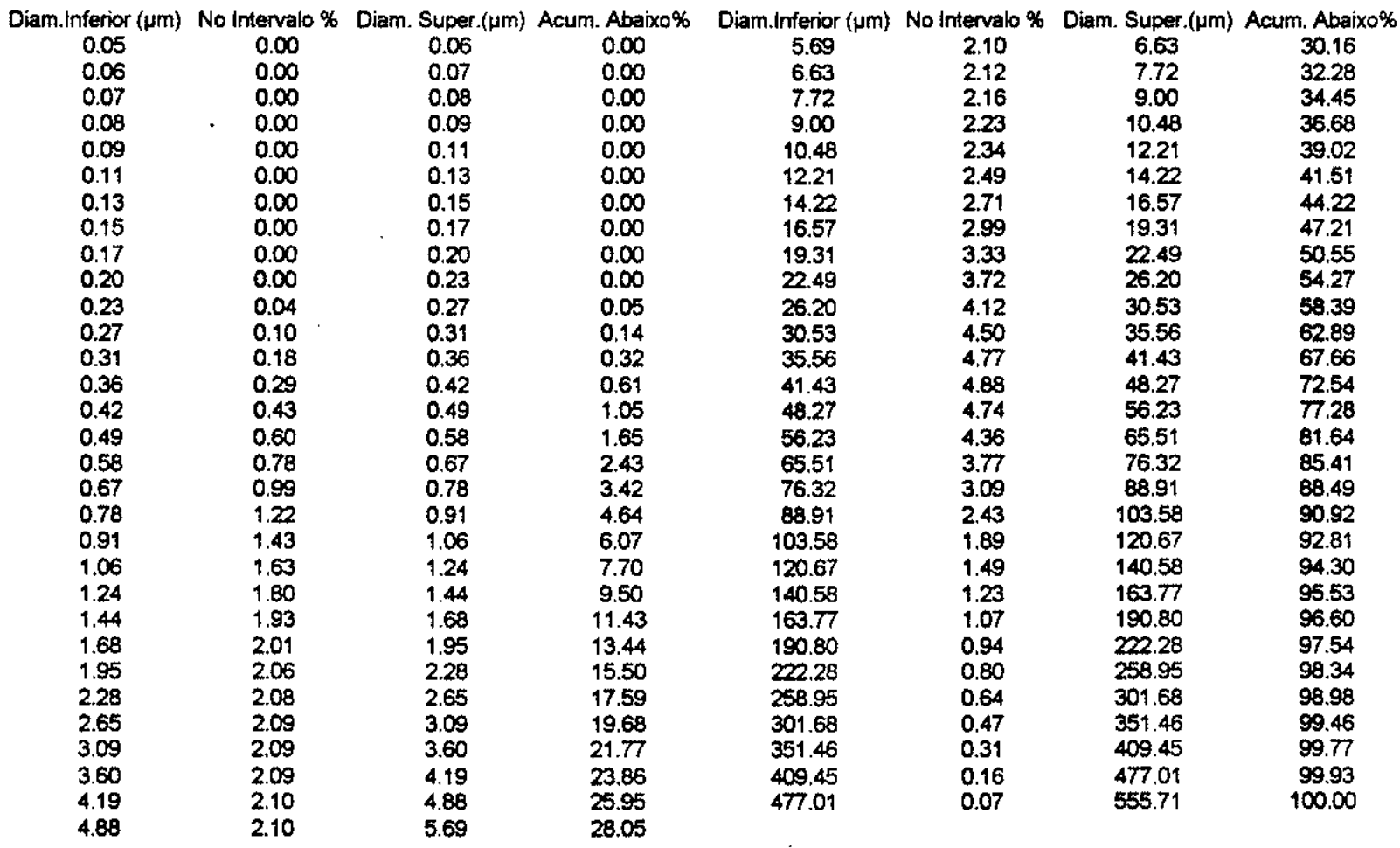

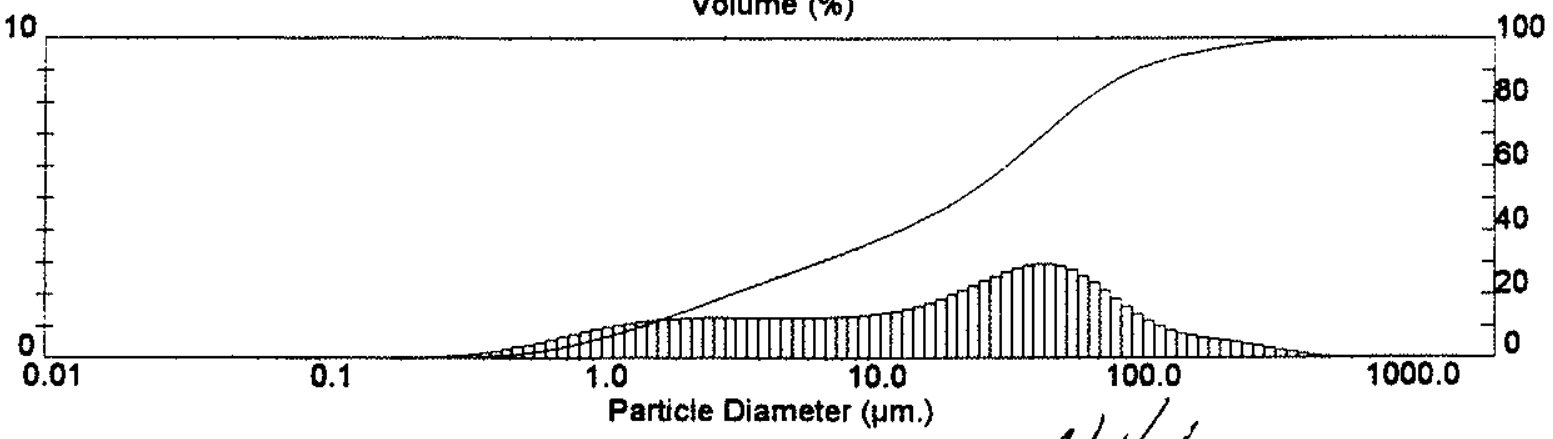




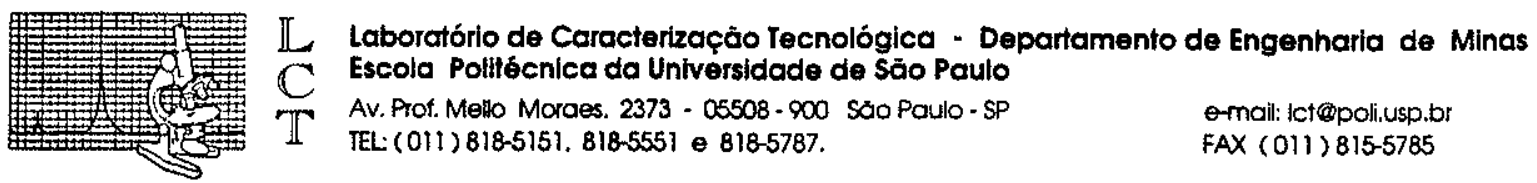

\section{RESULTADOS DE ANÁLISE DE TAMANHO DE PARTICULAS}

\begin{tabular}{lll} 
& \multicolumn{1}{c}{ Detalhes da Amostra } & Medida: \\
Histórico: Certificado: $1231 / 99$ & Run Number: 11 & Análise: Fri 7 de May de 1999 17:49 \\
Sample File: $1231-99$ & Record Number: 12 & Fonte de Resultados: Média
\end{tabular}

Sample Path: C:ISIZERSIDATA

CLIENTE:FABRICA DE CIMENTO VOTORAN

Meio de Dispersá: AGUA Veloc. bomba:2500

Dispersante: Ulitrassom:

Range Lens: 300RF mm Presentation: 3TJD

Analysis Model: Polydisperse

Modifications: None

Tipo de Distribution: Volume
Diámetros Medios:
D $\{4,3]=3.10 \mu \mathrm{m}$

Obscuration: $11.1 \%$

Residual: $2.825 \%$
Resultados Estatisticos

$\begin{array}{ll}\text { Resultados Estatisticos } \\ \text { Concentraça }=0.0002 \% \text { Vol } & \text { Densidade }=2.650 \mathrm{~g} / \mathrm{cm} 3 \\ D(v, 0.1)=0.29 \mu \mathrm{m} & D(v, 0.5)=1.96 \mu \mathrm{m} \\ D[3,2]=0.79 \mu \mathrm{m} & \text { Span }=3.730 \mathrm{E}+00\end{array}$

$\operatorname{Span}=3.730 E+\infty$
Area Superf. Espec. $=2.8623 \mathrm{~m} 2 / \mathrm{g}$

$D(v, 0.9)=7.59 \mu \mathrm{m}$

Uniformidade $=1.158 E+\infty$

Diam.Inferior $(\mu \mathrm{m})$ No intervalo \% Diam.Super. $(\mu \mathrm{m})$ Acum Abaixo $\%$

$\begin{array}{ll}0.05 & 0.04 \\ 0.06 & 0.1 \\ 0.07 & 0.23 \\ 0.08 & 0.08\end{array}$

0.04
0.11
0.23
0.39
0.57

0.09

8.13

0.15

0.17

0.20

0.23

0.27

0.36

0.42
0.49

0.58

0.58
0.67

0.78

0.91

1.06

1.24
1.44

1.68

1.95

2.65

3.09

3.60

4.19

4.88

0.39
0.57

8.76

1.17

1.38

1.59

1.74

1.77

1.81

2.02

2.21

2.45

2.84

3.23

3.60

3.93

4.18

4.32

4.36

4.32

4.26

4.23

4.28

4.41

4.62

4.81

4.89

4.73

$0.06 \quad 0.04$

$\begin{array}{ll}0.06 & 0.04 \\ 0.07 & 0.15 \\ 0.08 & 0.38\end{array}$

0.09

0.11

$8: 15^{3}$

0.17

0.20

0.23

0.27

0.31

0.36

0.42

0.49

0.58

0.67

0.78

0.91

1.06

1.24

1.44

1.68

1.95
2.28

2.65

3.09

3.60

4.19

4.88

5.69

6.63

Diam.Inferior ( $\mu m)$ No intervalo \% Diam.Super. $(\mu m)$ Acum.Abaixo \%

0.77

1.33

3.89

4.22

5.60

7.18

8.93

10.70

12.51

14.52

16.73

19.19

22.02

25.25

28.85

32.78

36.96

41.28

45.64

49.96

54.22

58.45

62.72

67.14

71.76

76.57

81.46

86.19

$6.63 \quad 4.26$

7.72

9.00

10.48

12.21

14.22

19.31

22.49

26.20

30.53

35.56

41.43

48.27

56.23

65.51

76.32

88.91

103.58

120.67

140.58

163.77

190.80

222.28

258.95

301.68

351.46

409.45

477.01

555.71

647.41

754.23
4.26
3.51

2.66

1.83

1.10

$8: 45$

0.00

0.00

0.00

0.00

0.00

0.00

0.00

0.00

0.00

0.00

0.00

0.00

0.00

0.00

0.00

0.00

0.00

0.00

0.00

0.00

0.00

0.00

0.00

0.00

$\begin{array}{rr}7.72 & 90.45 \\ 9.00 & 93.96 \\ 10.48 & 96.62 \\ 12.21 & 98.45 \\ 14.22 & 99.55 \\ 16.57 & 100.00 \\ 19.31 & 100.00 \\ 22.49 & 100.00 \\ 26.20 & 100.00 \\ 30.53 & 100.00 \\ 35.56 & 100.00 \\ 41.43 & 100.00 \\ 48.27 & 100.00 \\ 56.23 & 100.00 \\ 65.51 & 100.00 \\ 76.32 & 100.00 \\ 88.91 & 100.00 \\ 103.58 & 100.00 \\ 120.67 & 100.00 \\ 140.58 & 100.00 \\ 163.77 & 100.00 \\ 190.80 & 100.00 \\ 222.28 & 100.00 \\ 258.95 & 100.00 \\ 301.68 & 100.00 \\ 351.46 & 100.00 \\ 409.45 & 100.00 \\ 477.01 & 100.00 \\ 555.71 & 100.00 \\ 647.41 & 100.00 \\ 754.23 & 100.00 \\ 878.67 & 100.00 \\ & \end{array}$
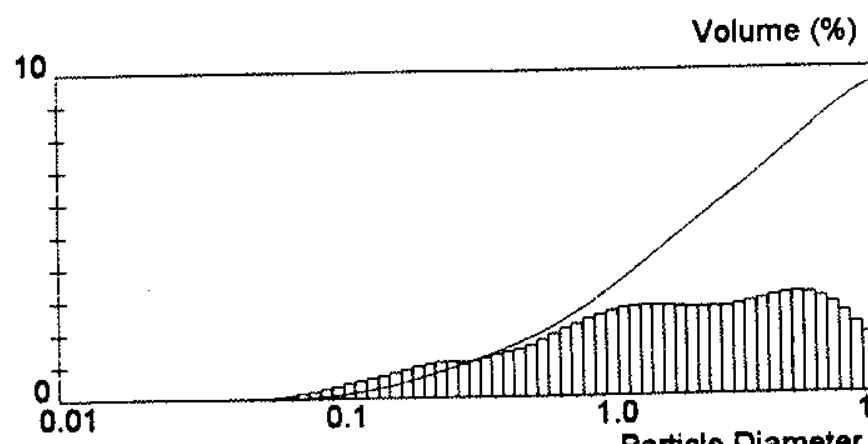

Matvem tnstruments Lid.

Matvern. UK

Tel: $=+[44]$ (0)1684-892456 Fax:+[44] (0)1684-892789

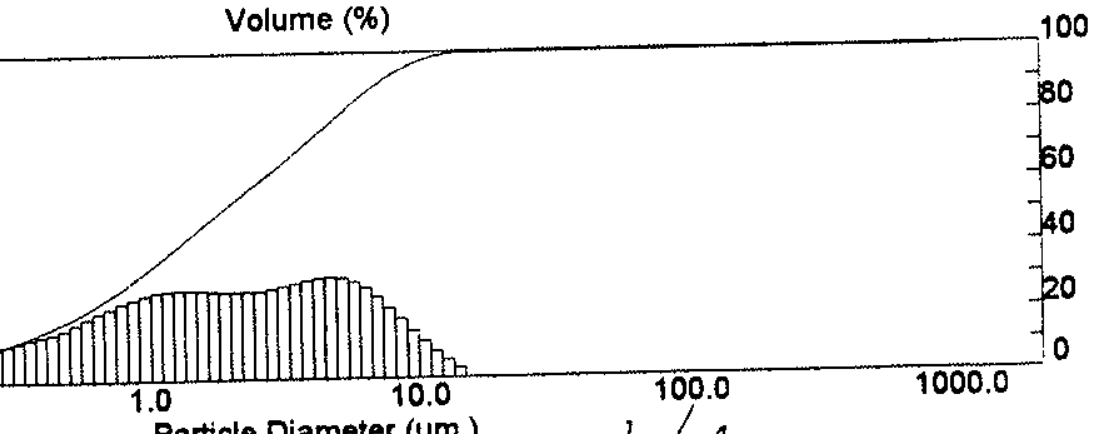
Senial Number: 33544290

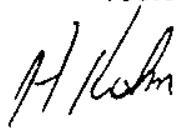




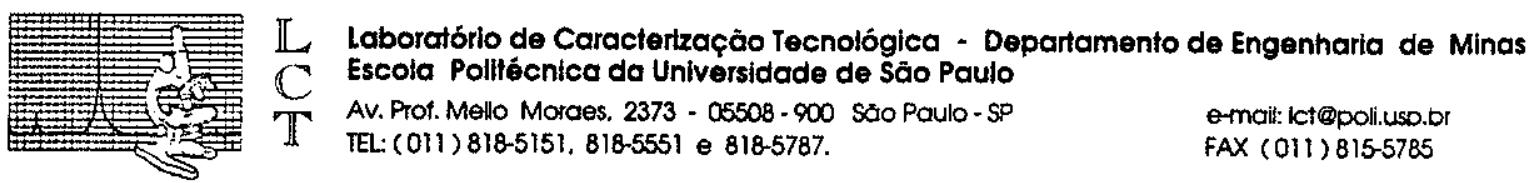

RESULTADOS DE ANÁLISE DE TAMANHO DE PARTÍCULAS

\begin{tabular}{lll}
\multicolumn{2}{c}{ RESULTADOtalhes da Amostra } & Medida: : \\
Histónico: Certificado: 1232199 & Run Number: 12 & Análise: Fri 7 de May de 1999 17:36 \\
Sample File: 1232.99 & Record Number: 22 & Fonte de Resultados: Media
\end{tabular}

Semple Path: C:ISIZERSLATAI

Amostra: AMOSTRA:GSF42T8

CLIENTE.FABRICA DE CIMENTO VOTORAN

Meio de Dispersa: ÁGUA Veloc. bomba:2500

Dispersante:

Uitrassom:

Análise: Fri 7 de May de 1999 17:36

Range Lens: $300 \mathrm{RF} \mathrm{mm}$

Presentation: 3TJD

Analysis Model: Polydisperse

Modifications: None

Beam Length: $14.30 \mathrm{~mm}$.

Obscuration: $10.6 \%$

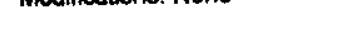

Tipo de Distribution: Volume

Diametros Médios:

$D[4,3]=13.02 \mu \mathrm{m}$

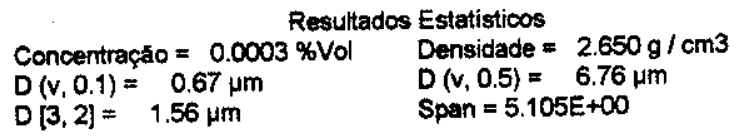

Area Superf. Espec. $=1.4509 \mathrm{~m} 2 / \mathrm{g}$

$D(v, 0.9)=35.20 \mu \mathrm{m}$

Uniformidade $=1.559 \mathrm{E}+00$

Diam

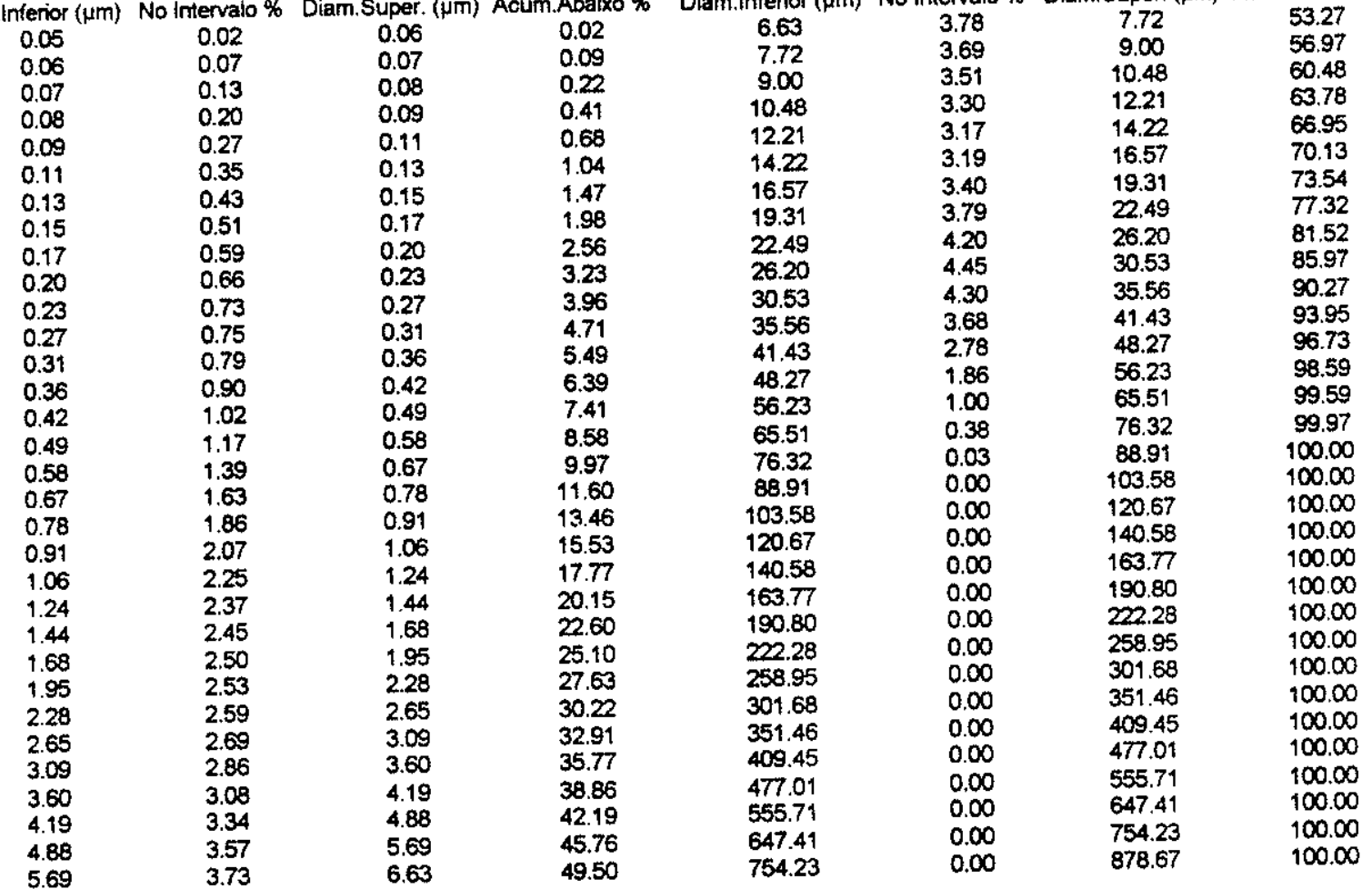

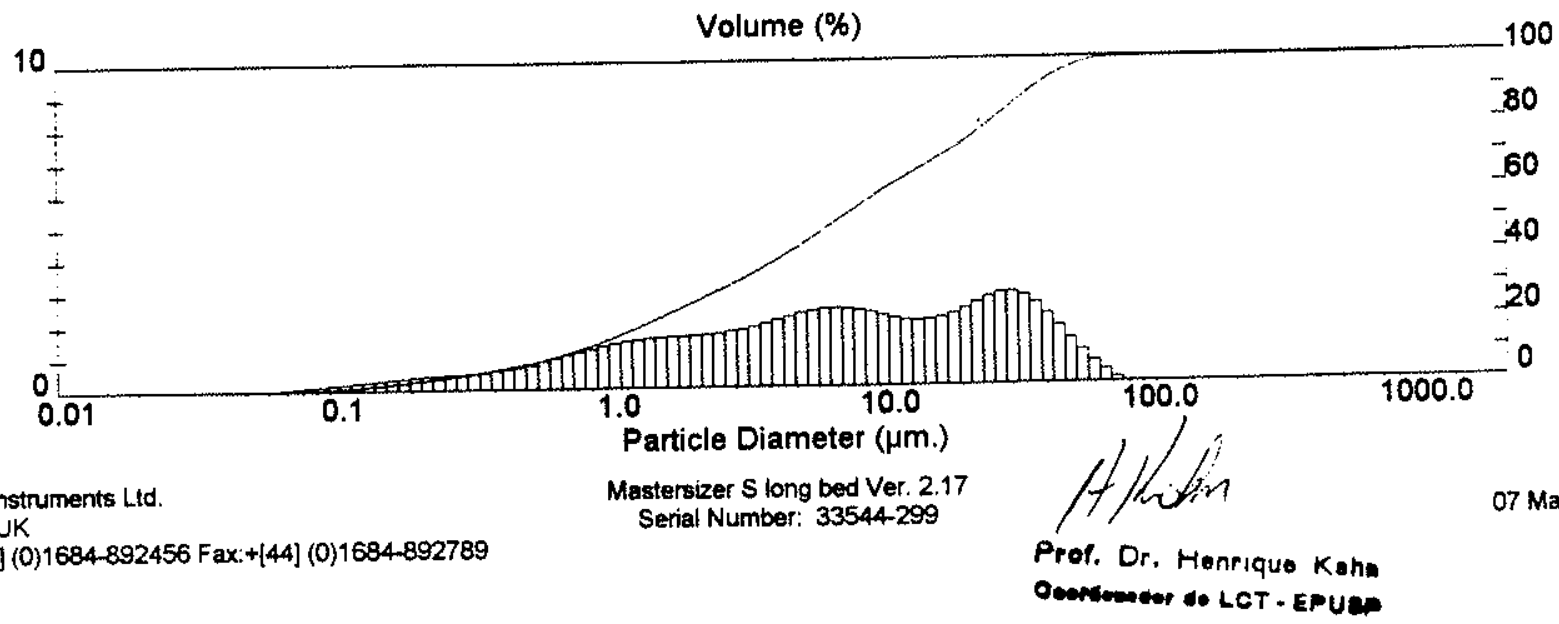

Matvern instuments Lid.

Matvern. UK

Tel: $=+[44](0) 1684-892456$ Fax: $+[44](0) 1684-892789$
07 May 99 17:

Residual: $2.657 \%$

98.59

99.97

100.00

$\infty$

$\infty .00$

$\infty .00$

$\infty .00$

100

60

$-40$

20

0 


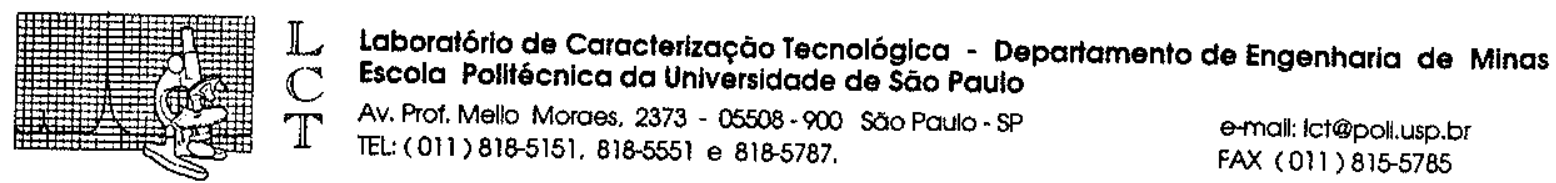

RESULTADOS DE ANÁLISE DE TAMANHO DE PARTÍCULAS

Detalines da Amostra

\author{
Historico: Certificado 1233/90 \\ Run Number: 11
}

Arquivo: $1233-99$

Run Number: 11

Sample Path: C:LSIZERMPDATA

Notas: AMOSTRA: GSF42TO

CLIENTE,fÁBRICA DE CIMENTO VOTORAN

Meio de Dispersáo: água bomba: $2500 \mathrm{pm}$

Dispersante:

Uttrasson: $30 \mathrm{seg}$

Detalhes do Sistema

Sampler:

Presentation: 5UHD

Analysis Model: Polydisperse

Modifications: None

[Particle R.I. $=(3.1255,0.1000) ; \quad$ Dispersant R.I. $=1.3300]$

\begin{tabular}{lll} 
& \multicolumn{3}{c}{ Resultados Estatisticos } \\
Tipo de Distribuiçá: Volume & Concentraça $=0.0155 \%$ Vol & Densidade $=2.650 \mathrm{~g} / \mathrm{cm} 3$ \\
DiÂmetros Médios: & $D(v, 0.1)=1.43 \mu \mathrm{m}$ & $D(v, 0.5)=16.59 \mu \mathrm{m}$ \\
$D[4,3]=36.45 \mu \mathrm{m}$ & $D[3,2]=4.16 \mu \mathrm{m}$ & Span $=4.931 \mathrm{E}+\infty$
\end{tabular}

Medida:

Análise: Wed 5 de May de 1999 10:56

Fonte de Resultados: Média FAX (011) 815-5785

Diam.Inferior ( $\mu m)$ No Intervalo\% Diam. Super.( $\mu m)$ Acum. Abaixo\%

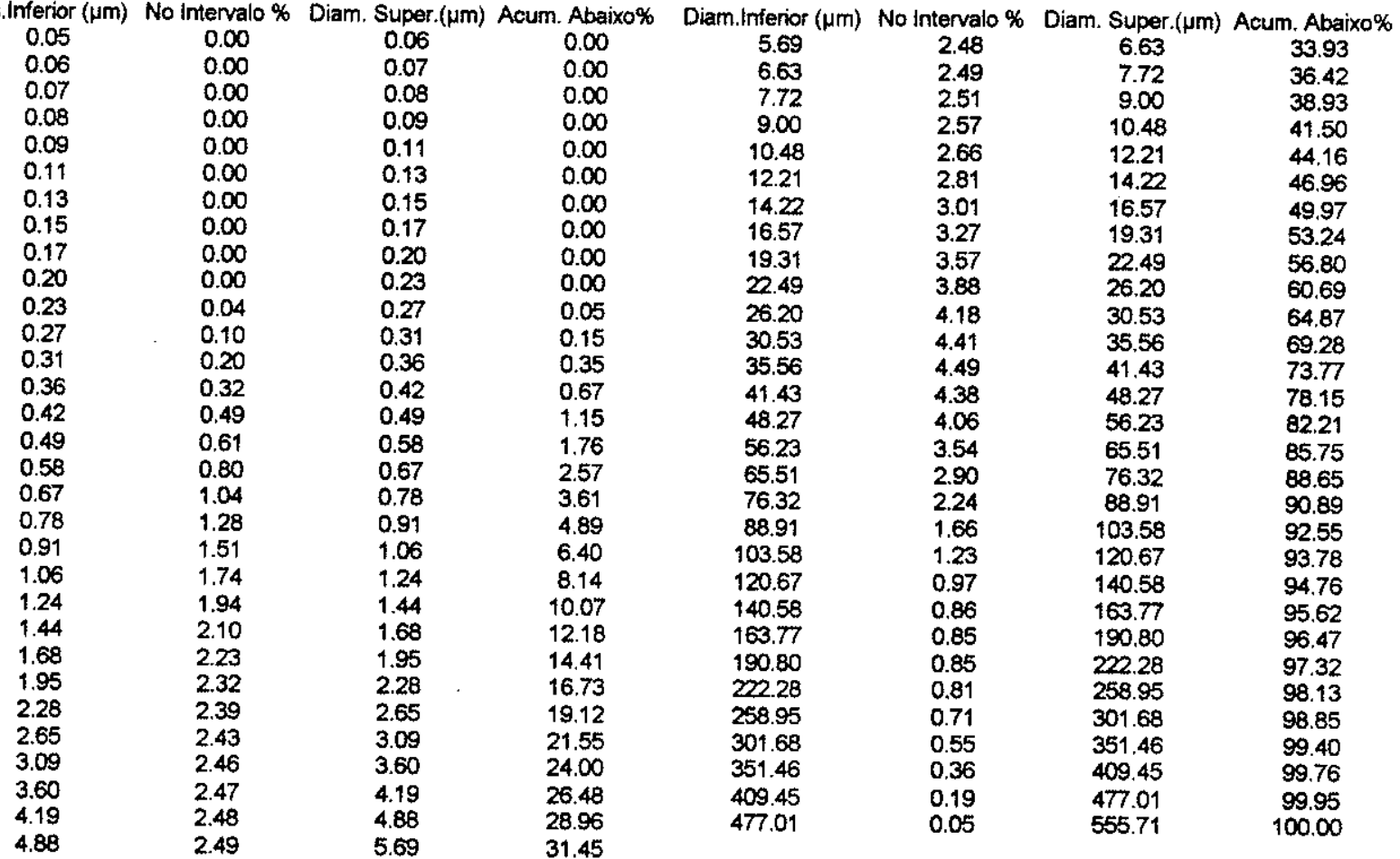

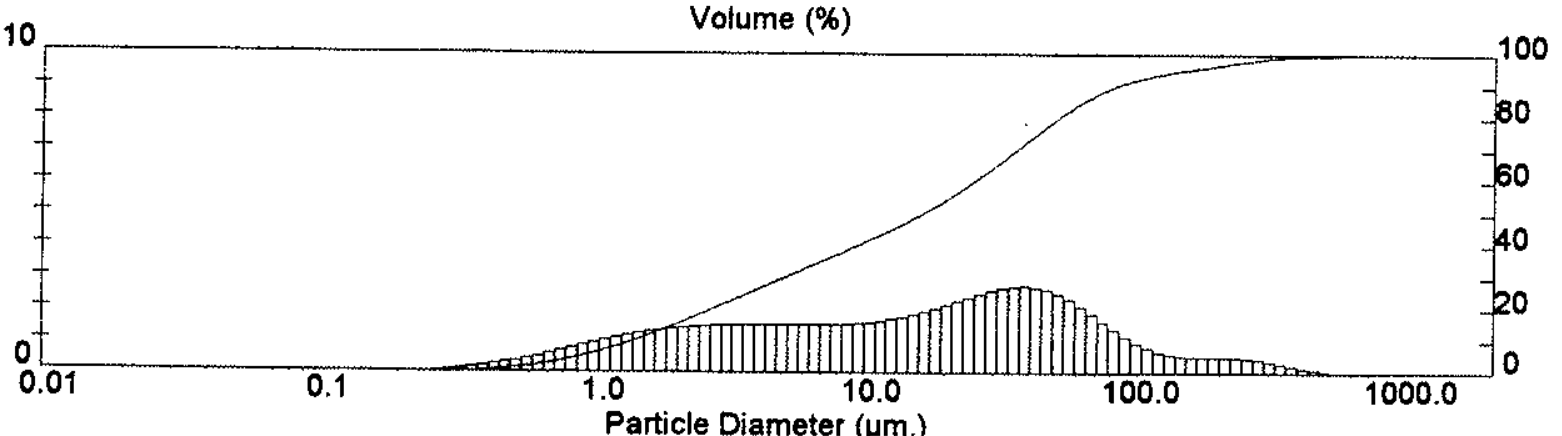

SAAL - South American Application Laboratory A LCT-EPUSP, Matvem and Altmann co-operation
Mastersizer Microplus Ver. 217 Serial Number: 3385042
Measured Beam Obscuration: $28.1 \%$

Residuat: $0.496 \%$

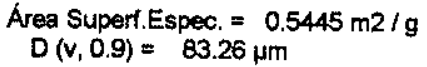




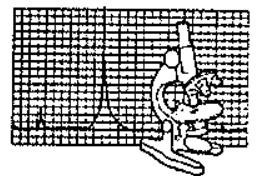

Laboratório de Caracterização Tecnológica - Departamento de Engenharia de Minas Escola Politécnica da Universidade de Sáo Paulo

Av. Prot. Melio Moraes, 2373 - 05508 - 900 Sáo Paulo - SP TEL: (011) 818-5151, 818-5551 \& 818-5787.

e-mall: ict@poli,usp.b FAX ( 011 ) 815-5785

\section{RESULTADOS DE ANÁLISE DE TAMANHO DE PARTICULAS}

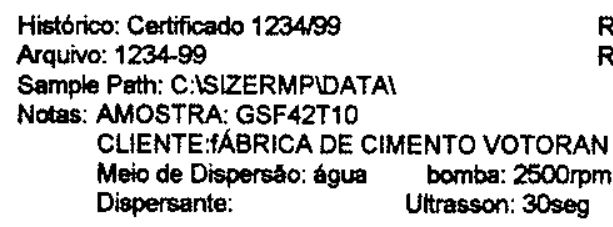

mber: 10

Record Number: 11
Medida:

Análise: Wed 5 de May de 1999 10:46 Fonte de Resultados: Média
Sampler:

Presentation: 5UHD

Analysis Model: Polydisperse Modifications: None
Detalhes to Sistema

[Particle R.I. $=(3.1255,0.1000) ; \quad$ Dispersant R.I. $=1.3300]$

Tipo de Distribuiça: Volume Diámetros Médios:

$D[4,3]=55.55 \mu \mathrm{m}$

\author{
Resultados Estatisticos \\ Concentraçáo $=0.0072 \% \mathrm{Vol} \quad$ Densidade $=2.650 \mathrm{~g} / \mathrm{cm} 3$ \\ $D(v, 0.1)=1.76 \mu \mathrm{m}$ \\ $D[3,2]=5.20 \mu \mathrm{m}$
}

Measured Beam Obscuration: $12.1 \%$

Residual: $0.456 \%$

Diam.Inferior $(\mu \mathrm{m})$ No intervalo\% Diam. Super.( $\mu m)$ Acum. Abaixo\% Diam.Inferior $(\mu m)$ No intervalo \% Diam. Super. $(\mu m)$ Acum. Abaixo\%

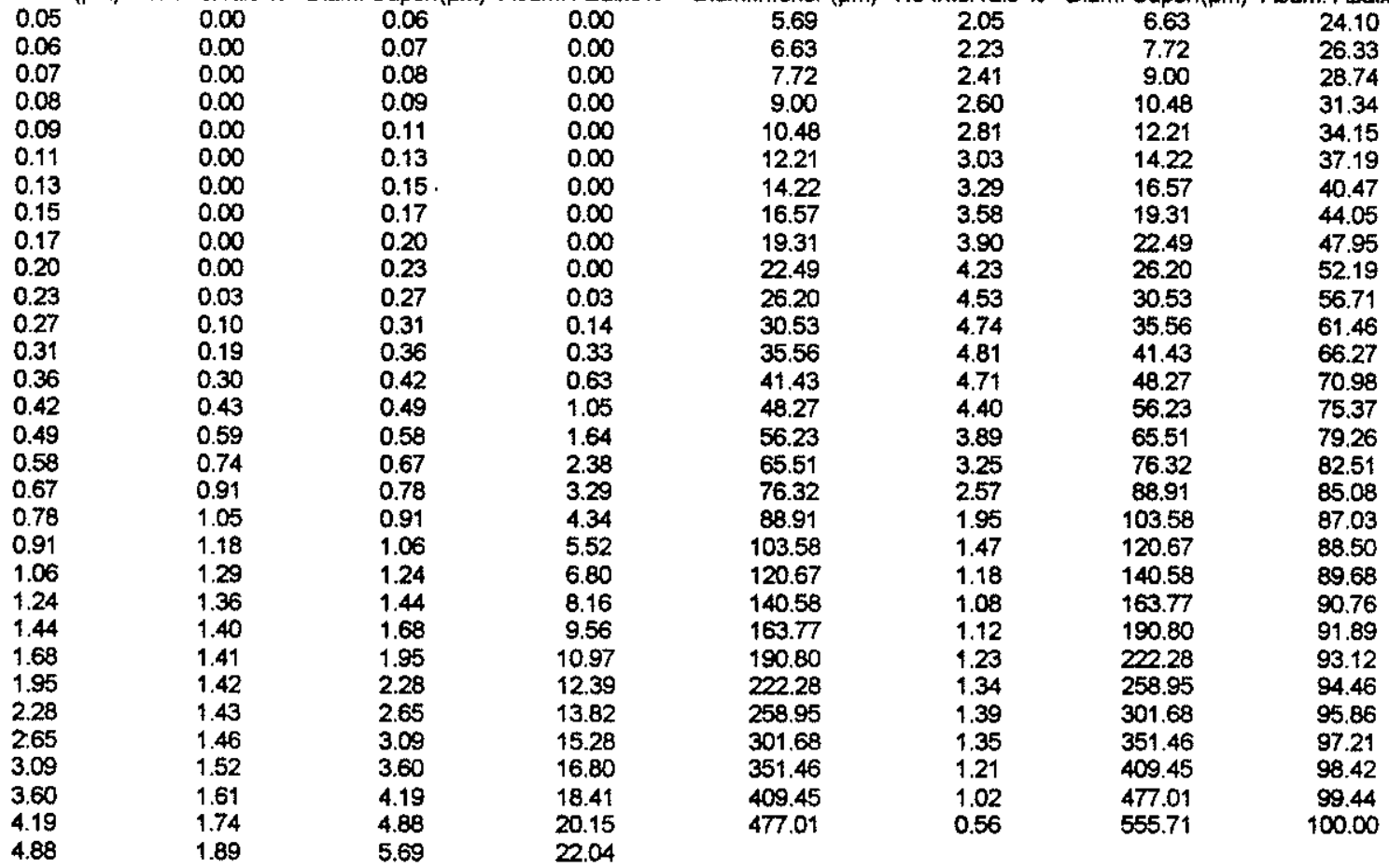

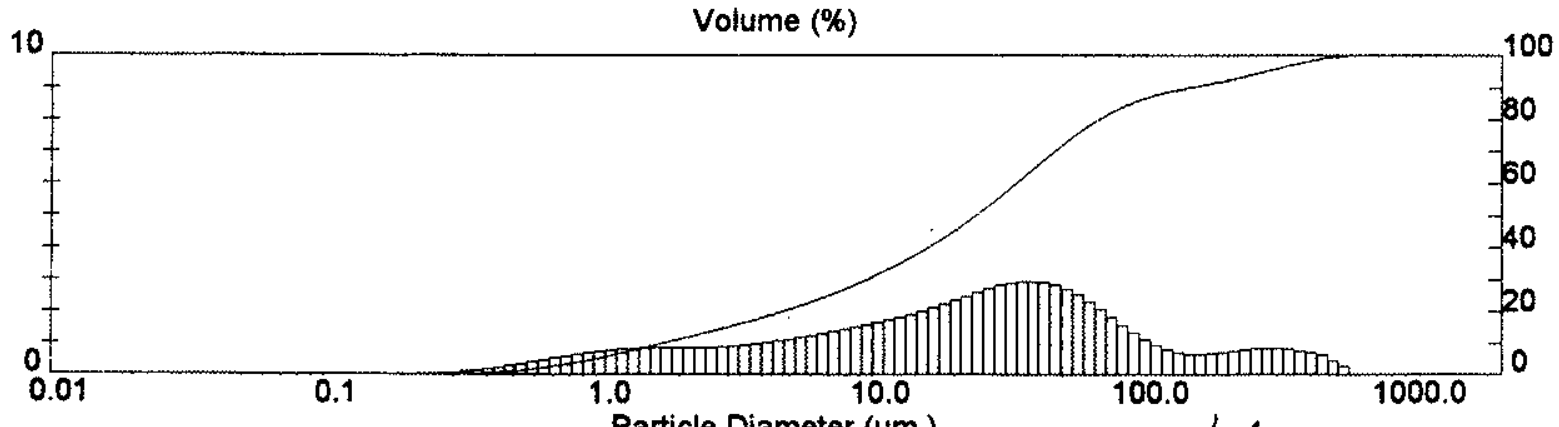

Particle Diameter ( $\mu \mathrm{m}$.)

SAAL - South American Application Laboratory A LCT-EPUSP, Malvern and Atrnann co-operation
Mastersizer Microplus Ver. 2.17 Serial Number: $33850-42$

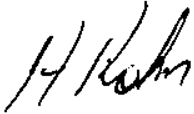

p. 1

Pret. Or. Henrlque Kahn 
ANEXO 7

RESUMO DO CÁLCULO PRELIMINAR DE RESERVA DO

ALVO 1 - FAZENDA VENTANIA 
ANEXO 7 - RESUMO DO CÁLCULO PRELIMINAR DE RESERVA DO ALVO 1 - FAZENDA VENTANIA

(Descontados $0,5 \mathrm{~m}$ superior de solo para recomposição do terreno)

\begin{tabular}{|c|c|c|c|c|c|c|c|c|c|c|c|}
\hline Triângulo & Furos & $\begin{array}{l}\text { Área } \\
\left(\mathrm{m}^{2}\right) \\
\end{array}$ & $\begin{array}{l}\text { Espessura } \\
\text { média (m) }\end{array}$ & $\begin{array}{c}\begin{array}{c}\text { Volume } \\
\text { in situ }\left(m^{3}\right)\end{array} \\
\end{array}$ & $\begin{array}{c}\text { Tonelagem } \\
\text { (p.e. }=1,63)\end{array}$ & $\begin{array}{l}\text { Teor médio } \\
\mathrm{SiO}_{2}(\%) \\
\end{array}$ & $\begin{array}{l}\text { Teor médio } \\
\mathrm{Al}_{2} \mathrm{O}_{3}(\%)\end{array}$ & $\begin{array}{c}\text { Teor médio } \\
\mathrm{Fe}_{2} \mathrm{O}_{3}(\%)\end{array}$ & $\begin{array}{c}\text { Teor médio } \\
\mathrm{MgO}(\%)\end{array}$ & $\begin{array}{c}\text { Teor médio } \\
\mathrm{K}_{2} \mathrm{O}(\%)\end{array}$ & $\begin{array}{c}\text { Teor médio } \\
\mathrm{TiO}_{2}(\%)\end{array}$ \\
\hline 1 & $12-36-37$ & 29.213 & 3,20 & 93.482 & 152.375 & 49,44 & 24,19 & 10,72 & 0,06 & 0,18 & 1,04 \\
\hline 2 & $36-37-38$ & 24.750 & 3,50 & 86.625 & 141.199 & 48,65 & 24,11 & 11,95 & 0,07 & 0,21 & 1,18 \\
\hline 3 & $12-36-41$ & 31.250 & 3,20 & 100.000 & 163.000 & 46,88 & 25,56 & 10,64 & 0,07 & 0,15 & 1,21 \\
\hline 4 & $36-40-41$ & 17.500 & 5,50 & 96.250 & 156.888 & 46,61 & 26,48 & 10,19 & 0,07 & 0,22 & 1,42 \\
\hline 5 & $35-36-40$ & 8.050 & 8,00 & 64.400 & 104.972 & 44,55 & 28,56 & 10,22 & 0,06 & 0,28 & 1,57 \\
\hline 6 & $35-36-39$ & 12.600 & 7,30 & 91.980 & 149.927 & 41,44 & 29,89 & 10,59 & 0,06 & 0,22 & 1,64 \\
\hline 7 & $36-38-39$ & 23.100 & 4,80 & 110.880 & 180.734 & 43,65 & 27,48 & 10,96 & 0,07 & 0,15 & 1,44 \\
\hline 8 & $38-39-43$ & 15.125 & 4,50 & 68.063 & 110.942 & 43,48 & 27,40 & 10,88 & 0,05 & 0,16 & 1,44 \\
\hline 9 & $40-41-42$ & 12.400 & 6,80 & 84.320 & 137.442 & 46,94 & 27,16 & 9,96 & 0,06 & 0,31 & 1,46 \\
\hline 10 & $35-40-42$ & 6.000 & 9,30 & 55.800 & 90.954 & 44,70 & 28,89 & 10,12 & 0,05 & 0,33 & 1,58 \\
\hline 11 & $35-39-42$ & 4.675 & 8,70 & 40.673 & 66.296 & 42,47 & 29,44 & 10,34 & 0,05 & 0,30 & 1,64 \\
\hline 12 & $39-42-43$ & 13.500 & 6,80 & 91.800 & 149.634 & 42,32 & 29,52 & 10,13 & 0,07 & 0,20 & 1,59 \\
\hline $13^{*}$ & $11-41-42$ & 21.750 & 4,50 & 97.875 & 159.536 & 47,49 & 25,68 & 10,67 & 0,06 & 0,30 & 1,32 \\
\hline 14 & $11-33-42$ & 53.200 & 5,50 & 292.600 & 476.938 & 42,29 & 29,76 & 11,68 & 0,06 & 0,26 & 1,56 \\
\hline 15 & $34-42-43$ & 25.125 & 8,00 & 201.000 & 327.630 & 40,87 & 30,79 & 10,90 & 0,07 & 0,28 & 0,95 \\
\hline 16 & $06-34-43$ & 22.400 & 5,30 & 118.720 & 193.514 & 38,08 & 31,49 & 11,53 & 0,04 & 0,18 & 1,51 \\
\hline 17 & $33-34-42$ & 28.050 & 8,30 & 232.815 & 379.488 & 39,36 & 31,85 & 11,70 & 0,06 & 0,27 & 1,75 \\
\hline 18 & $06-15-34$ & 9.750 & 4,30 & 41.925 & 68.338 & 38,05 & 31,62 & 11,67 & 0,04 & 0,20 & 1,49 \\
\hline 19 & $15-33-34$ & 10.213 & 5,60 & 57.193 & 93.224 & 37,22 & 32,53 & 12,40 & 0,04 & 0,20 & 1,82 \\
\hline 20 & 14-15-33 & 10.600 & 2,80 & 29.680 & 48.378 & 37,52 & 31,41 & 12,68 & 0,04 & 0,11 & 1,85 \\
\hline 21 & $14-31-33$ & 24.300 & 3,20 & 77.760 & 126.749 & 36,49 & 31,39 & 13,14 & 0,02 & 0,10 & 1,81 \\
\hline 22 & $05-31-33$ & 17.400 & 3,80 & 66.120 & 107.776 & 37,97 & 30,41 & 12,64 & 0,02 & 0,09 & 1,28 \\
\hline 23 & $05-11-33$ & 17.100 & 3,50 & 59.850 & 97.556 & 41,80 & 28,12 & 12,43 & 0,02 & 0,06 & 1,00 \\
\hline 24 & $05-11-31$ & 4.000 & 2,50 & 10.000 & 16.300 & 46,29 & 25,97 & 12,73 & 0,01 & 0,08 & 0,66 \\
\hline Total & & 442.051 & & 2.269 .809 & 3.699 .789 & & & & & & \\
\hline \multicolumn{3}{|c|}{ Médias } & 5,37 & & & $42,56^{\star *}$ & $29,02^{\star *}$ & $11,22^{* \star}$ & $0,06^{\star \star}$ & $0,22^{\star \star}$ & $1,44^{* \star}$ \\
\hline
\end{tabular}


ANEXO 8

CURVAS GRANULOMÉTRICAS INSTRUMENTAIS DAS AMOSTRAS DE FARINHA FN-01 (SEM O USO DA LATERITA) E FT-01 (TESTE 1) 


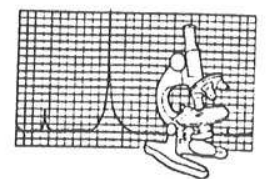

L Laboratório de Caracterização Tecnológica - Departamento de Engenharia de Minas

C Escola Pollitécnica da Universidade de São Paulo

"T Av. Prof. Mello Moraes, 2373 - 05508 - 900 São Paulo - SP TEL: (011) 818-5151, 818-5551 e 818-5787.

RESULTADOS DE ANÁLISE DE TAMANHO DE PARTÍCULAS

FAX (011) 815-5785

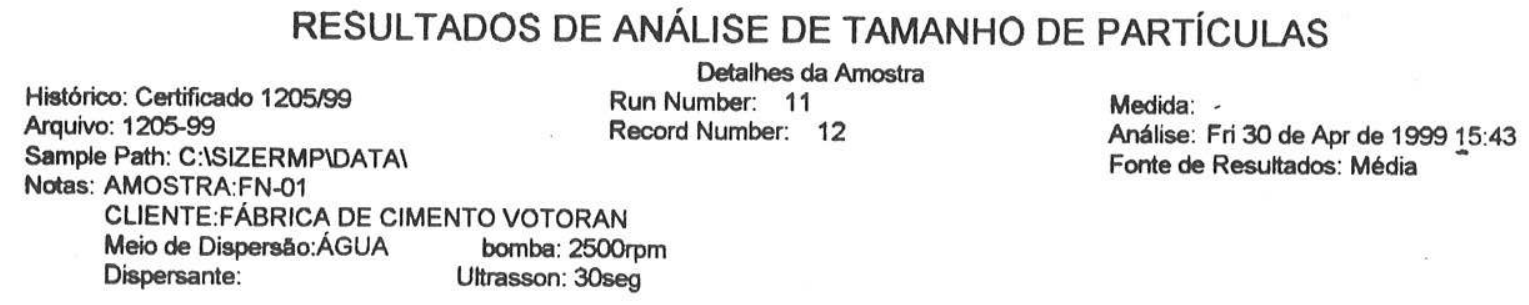

Sampler:

Detalhes do Sistema

Presentation: $50 \mathrm{HD}$

Analysis Model: Polydisperse

Modifications: None

[Particle R.I. $=\left(\begin{array}{ll}1.5295,0.1000\end{array}\right) ; \quad$ Dispersant R.I $\left.=1.3300\right]$

Resultados Estatisticos

Tipo de Distribuiçăo: Volume Diâmetros Médios:

$D[4,3]=27.45 \mu \mathrm{m}$

Concentraçăo $=0.0103 \%$ Vol

Densidade $=2.650 \mathrm{~g} / \mathrm{cm} 3$ $D(v, 0.1)=0.60 \mu \mathrm{m}$

$D[3,2]=1.90 \mu \mathrm{m}$
Measured Beam Obscuration: $18.1 \%$

Residual: $0.391 \%$

Área Superf.Espec. $=1.1940 \mathrm{~m} 2 / \mathrm{g}$ $D(v, 0.9)=74.04 \mu \mathrm{m}$

Uniformidade $=2.146 \mathrm{E}+\infty$

Diam.Inferior $(\mu \mathrm{m})$ No Intervalo \% Diam. Super. $(\mu \mathrm{m})$ Acum. Abaixo\% Diam.Inferior $(\mu \mathrm{m})$ No Intervalo \% Diam. Super. $(\mu \mathrm{m})$ Acum. Abaixo\% 0.05

$0.00 \quad 0.06 \quad 0.00$

$0.06 \quad 0.00$

$0.07 \quad 0.01$

$\begin{array}{ll}0.08 & 0.02 \\ 0.09 & 0.05\end{array}$

$0.09 \quad 0.05$

$0.11 \quad 0.10$

$\begin{array}{ll}0.13 & 0.19 \\ 0.15 & 0.33\end{array}$

$\begin{array}{ll}0.17 & 0.53\end{array}$

$\begin{array}{ll}0.20 & 0.79\end{array}$

$\begin{array}{ll}0.23 & 1.06\end{array}$

$\begin{array}{ll}0.27 & 1.27 \\ 0.31 & 1.36\end{array}$

$\begin{array}{ll}0.36 & 1.36\end{array}$

$0.42 \quad 1.33$

$0.49 \quad 1.30$

$0.58 \quad 1.24$

$0.67 \quad 1.24$

$0.78 \quad 1.30$

$\begin{array}{ll}0.91 & 1.39 \\ 1.06 & 1.48\end{array}$

$1.24 \quad 1.58$

$1.44 \quad 1.65$

$\begin{array}{ll}1.68 & 1.69\end{array}$

$1.95 \quad 1.75$

$2.28 \quad 1.82$

$\begin{array}{ll}2.65 & 1.91 \\ 3.09 & 2.04\end{array}$

$3.60 \quad 2.22$

$4.19 \quad 2.42$

$\begin{array}{ll}4.88 & 2.63\end{array}$

$\begin{array}{lr}0.07 & 0.01 \\ 0.08 & 0.02 \\ 0.09 & 0.04 \\ 0.11 & 0.09 \\ 0.13 & 0.19 \\ 0.15 & 0.38 \\ 0.17 & 0.71 \\ 0.20 & 1.25 \\ 0.23 & 2.04 \\ 0.27 & 3.10 \\ 0.31 & 4.37 \\ 0.36 & 5.74 \\ 0.42 & 7.09 \\ 0.49 & 8.42 \\ 0.58 & 9.72 \\ 0.67 & 10.96 \\ 0.78 & 12.20 \\ 0.91 & 13.51 \\ 1.06 & 14.89 \\ 1.24 & 16.37 \\ 1.44 & 17.96 \\ 1.68 & 19.61 \\ 1.95 & 21.30 \\ 2.28 & 23.06 \\ 2.65 & 24.87 \\ 3.09 & 26.78 \\ 3.60 & 28.83 \\ 4.19 & 31.05 \\ 4.88 & 33.46 \\ 5.69 & 36.09 \\ & \end{array}$

$5.69 \quad 2.84$

6.63

7.72

9.00

10.48

12.21

14.22

16.57

19.31

22.49

26.20

30.53

35.56

41.43

48.27

56.23

65.51

76.32

88.91

103.58

120.67

140.58

163.77

190.80

222.28

258.95

301.68

351.46

409.45

477.01

2.84
3.06
3.27
3.47
3.65
3.80
3.89
3.92
3.86
3.71
3.49
3.22
2.94
2.67
2.41
2.16
1.93
1.72
1.53
1.37
1.24
1.10
0.93
0.74
0.54
0.34
0.13
0.00
0.00
0.00

6.63

$\begin{array}{ll}7.72 & 41.98\end{array}$

$9.00 \quad 45.25$

$10.48 \quad 48.72$

$12.21 \quad 52.37$

$14.22 \quad 56.17$

$16.57 \quad 60.07$

$19.31 \quad 63.99$

$22.49 \quad 67.84$

$26.20 \quad 71.55$

$30.53 \quad 75.03$

$35.56 \quad 78.26$

$\begin{array}{ll}41.43 & 81.20\end{array}$

$48.27 \quad 83.86$

$56.23 \quad 86.27$

$\begin{array}{ll}65.51 & 88.43\end{array}$

$76.32 \quad 90.37$

$88.91 \quad 92.09$

$103.58 \quad 93.62$

$120.67 \quad 94.99$

$140.58 \quad 96.22$

$163.77 \quad 97.32$

$190.80 \quad 98.26$

$222.28 \quad 99.00$

$258.95 \quad 99.53$

$301.68 \quad 99.87$

$351.46 \quad 100.00$

$409.45 \quad 100.00$

$477.01 \quad 100.00$

$10 \quad$ Volume (\%)

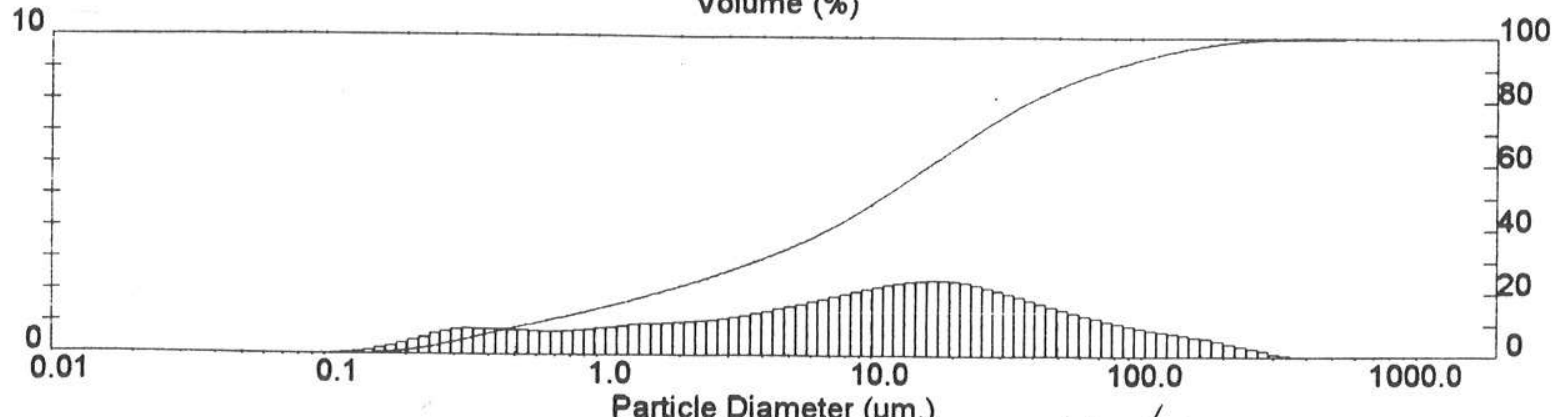

SAAL - South American Application Laboratory A LCT-EPUSP, Malvern and Altmann co-operation

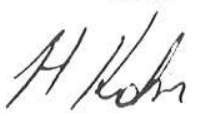

Ppof. Dr. Henrique Kahn

Sopploender do LCT - EPUEP. p. 9

30 Apr 99 15:45 


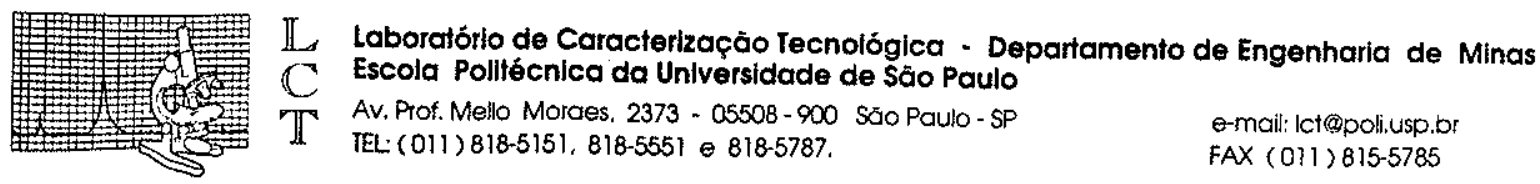

RESULTADOS DE ANÁLISE DE TAMANHO DE PARTICULAS

Run Number: 11

Historico: Certificado 120699
Arquivo: $1206-99$

Sample Path: C:ISIZERMPIDATAI

Record Number: 12

Medida:

Notas: AMOSTRA:FT 01

CLIENTE:FÁBRICA DE CIMENTO VOTORAN

Meio de Dispersso:ÁGUA bomba: $2500 \mathrm{~mm}$

Dispersante:

Ultrasson: $30 \mathrm{seg}$

Detalhes do Sistema

Sampler:

Presentation: 5OHD

[Particle R.I. $=(1.5295,0.1000) ; \quad$ Dispersant R.I $=1.3300]$

[Particle R.I. $=(1.5295,0.1000) ; \quad$ Dispersant R.I $=1.3300$ ]

Madifications: None

Measured Beam Obscuration: $26.9 \%$

Residual: $0.305 \%$

Tipo de Distribuiça: Volume

Diametros Médios:

Resultados Estatisticos

$\mathrm{D}[4,3]=27.56 \mu \mathrm{m}$

$\begin{array}{ll}\text { Concentraça }=0.0151 \% \mathrm{Vol} & \text { Densidade }=2.650 \mathrm{~g} / \mathrm{cm} 3 \\ D(v, 0.1)=0.54 \mu \mathrm{m} & D(v, 0.5)=10.34 \mu \mathrm{m} \\ D(3,2]=1.80 \mu \mathrm{m} & \mathrm{Span}=7.054 \mathrm{E}+\infty\end{array}$

Area Super.Espec. $=1.2549 \mathrm{~m} 2 / \mathrm{g}$

$D(v, 0.9)=73.46 \mu \mathrm{m}$

Uniformidade $=2.336 \mathrm{E}+\infty 0$

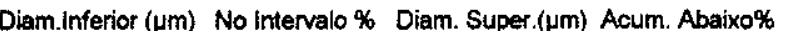
$7.054 E+\infty$

Abaixo\%

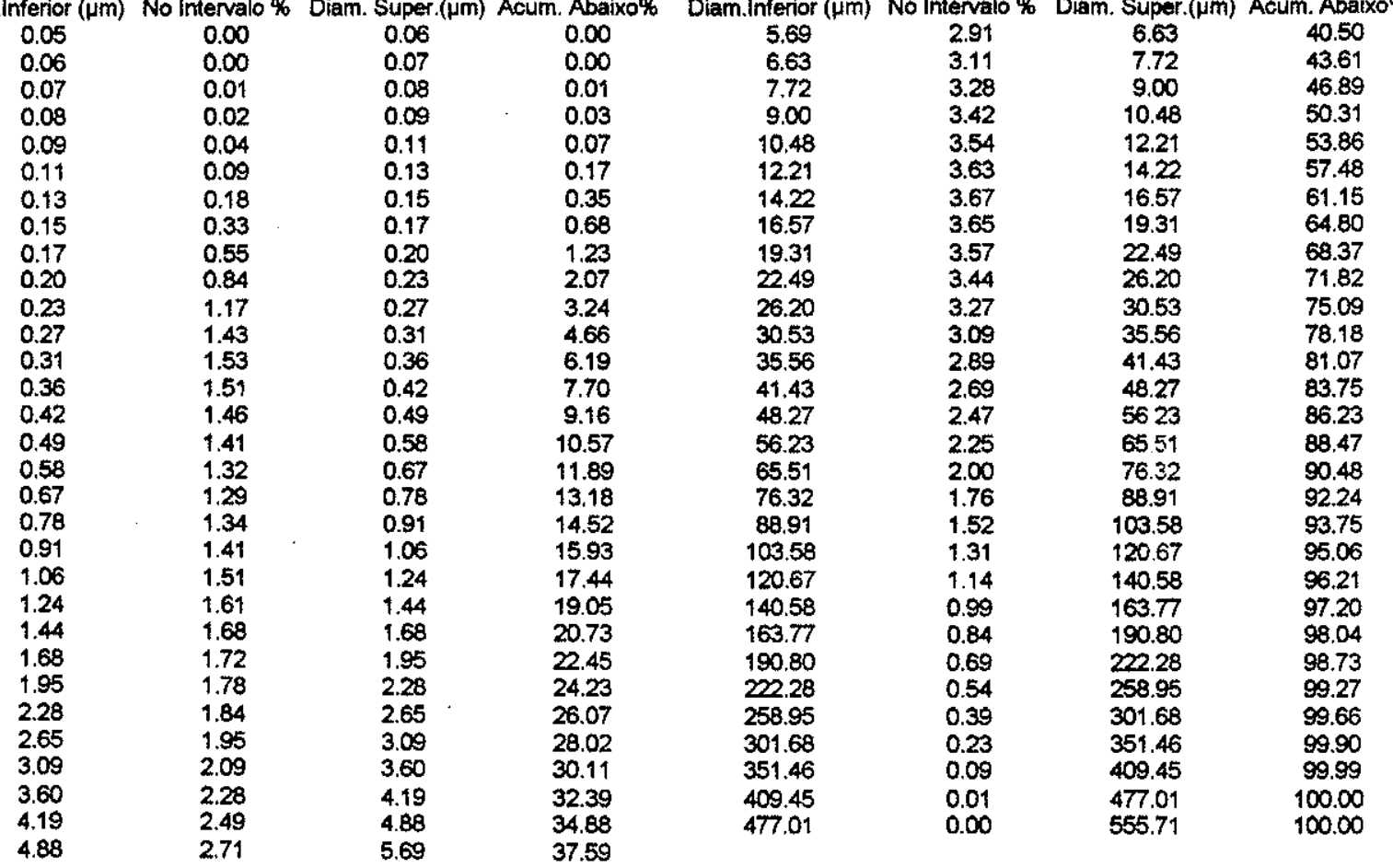

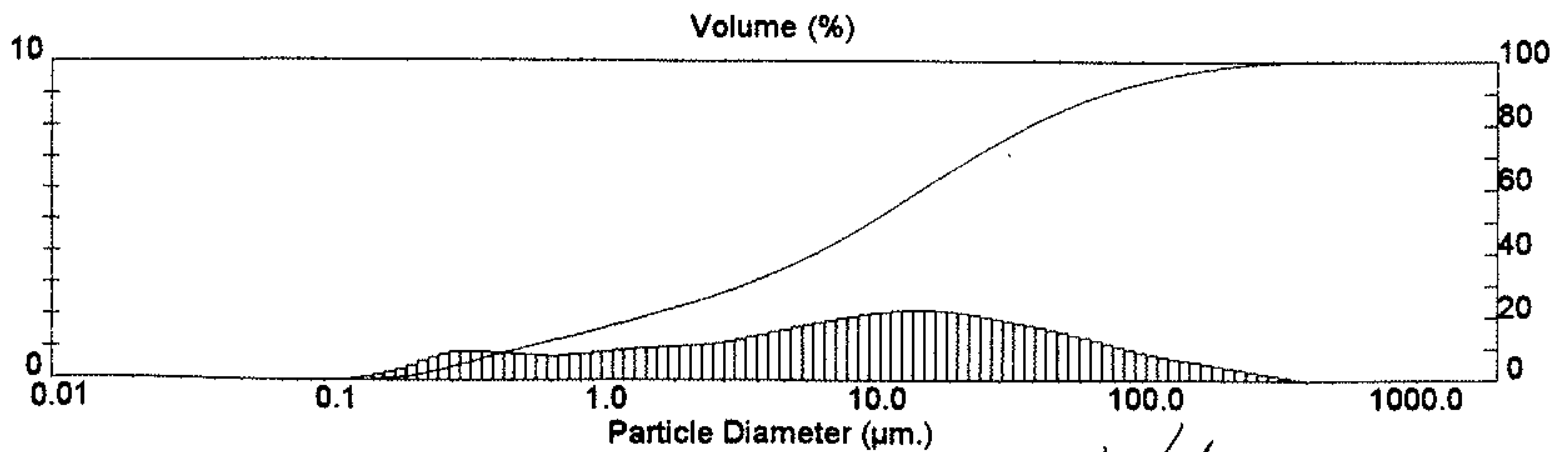

SAAL - South American Application Laboratory A LCT-EPUSP, Malvem and Altmann co-operation
Particle Diameter ( $\mathrm{\mu m}$. )

Mastersizer Microplus Ver. 2.17 Serial Number: $33850-42$

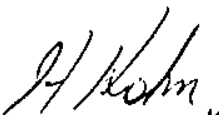

Prof. Dr. Henrique Kahn 